\author{
Universidade de São Paulo \\ Faculdade de Filosofia, Letras e Ciências Humanas \\ Departamento de História \\ Programa de Pós-Graduação em História Econômica
}

\title{
CRESCIMENTO, FLUTUAÇÕES E ENDIVIDAMENTO EXTERNO NA ECONOMIA DOS ESTADOS UNIDOS: 1980-2000
}

\author{
Tese apresentada ao Programa de Pós- \\ Graduação em História Econômica do \\ Departamento de História da Faculdade de \\ Filosofia, Letras e Ciências Humanas da \\ Universidade de São Paulo, como requisito \\ para a obtenção do título de Doutor em \\ História Econômica.
}

Aluno: Vitor Eduardo Schincariol

Orientador: Prof. Dr. Wilson do Nascimento Barbosa

São Paulo 


\section{Resumo}

Este trabalho buscar explicar como o endividamento externo da economia norte-americana, a partir do início da década de (19)80, atenuou (e atenua ainda hoje) as decorrências macroeconômicas advindas da tendência para a estagnação do produto interno bruto. Segundo o argumento usado aqui, tal tendência para a estagnação origina-se da queda ao longo do tempo da parcela da acumulação produtiva sobre o produto. A tendência é explicada por um crescente diferencial no desempenho das taxas de lucro intersetoriais na economia, no qual as desvantagens para os setores industriais podem ser explicadas por suas mais elevadas razões capital/produto e conseqüentes menores taxas de lucro. Tal é intensificado por (a) pelo comportamento dos preços relativos, os quais conhecem uma queda maior dos preços dos bens industriais face a outros preços na economia; e (b) pelos crescentes déficits comerciais em bens. Particularmente, a tendência ao declínio foi intensificada pelas crises do petróleo (1974-1979) e pela política de juros altos no fim da década de (19)70 e meados de (19)80. O crescimento da financeirização surge assim como a outra face da moeda do movimento de diminuição da acumulação produtiva.

Em segundo lugar, além de se tentar abordar as causas das flutuações em tendência decrescente do produto no período, tentou-se demonstrar como, em meio às flutuações do produto, o nível de endividamento correlacionou-se com a economia norte-americana no sentido de funcionar como elemento estabilizador. Dentro disto, buscou-se mostrar como a recuperação das taxas de lucro industriais, a partir do final da década de (19)80, e em meados da de (19)90, não levaram à queda da dívida externa. Isto se deu porque o nível de crescimento do setor industrial não logrou levar a economia a um patamar de crescimento que tornasse possível prescindir da dívida externa. Isto significava que a acumulação produtiva continuava insuficiente como mecanismo que permitisse uma diminuição do endividamento externo, principalmente devido às dificuldades relativas das taxas das de lucro industriais e das perdas no comércio exterior em bens tangíveis, não contornadas completamente pelo crescimento visto no período. Isto mostra que para sustentar os níveis de investimento e consumo, sem auxílio do endividamento externo, um volume muito maior de investimento teria de estar ocorrendo, o que não é possível pela queda relativa das taxas de lucro nos setores produtivos.

Argumenta-se, assim, que o endividamento externo atenuou mas não solucionou fundamentalmente a continuidade da queda do investimento produtivo ao longo do tempo, processo que teria conduzido a economia a ainda menores taxas de crescimento na ausência do papel hegemônico do dólar na economia mundial.

Palavras-chave: Estados Unidos; economia dos Estados Unidos; política econômica; finanças internacionais; crescimento econômico; ambiente macroeconômico contemporâneo; crises econômicas; história econômica. 


\section{Abstract}

This work aims to explain how the external indebtedness of the U.S. economy since the 1980s attenuated and still attenuates the macroeconomic effects originated from the tendency of the gross domestic product to stagnate. This tendency comes from the fall of the productive accumulation in its relation to the national product, explained by the growing disadvantages of the industrial profit rates when compared to the financial ones. These disadvantages can be explained mainly by the bigger capital/product rates in the industrial sectors, lowering its rates of profit. This is intensified by (a) the performance of the relative prices, which shows an ongoing fall in goods prices and a increase in nongoods prices, and (b) by the increasing trade deficits, stressing domestic production. Particularly, these tendencies were intensified by the oil crisis and the high interest rates of the middle 1970s. The growing participation of the financial sectors in the national economy is the other face of this tendency of the productive accumulation to fall.

Moreover, this work intended to discuss how the external indebtedness is correlated to the instability of the economy, showing how, during all the period, the external indebtedness worked as a mechanism of stabilization. The work then tried to describe this process of stabilization. After this, the work intended to explain why the absolute rise of the industrial rates of profit, since the middle 1980s, was not able to diminish the rate of the external indebtedness. This occurred because the financial rates of profit expanded still more rapidly, expressing the persistence of the above mentioned different performances between productive and non-productive sectors in the U.S. economy. It explains why the increase in profitability of productive capital during the 1990s continued insufficient to conduct the economy to smaller degrees of external indebtedness. This is the specific conclusion of chapter 9, which tries to demonstrate how a faster process of accumulation of capital did not take to a lesser external debt during the middle 1990s. It occurred because that process of economic growth needed a still more vigorous rate of productive investment to make possible a fall in external indebtedness.

Hence, the conclusion that emerges is that only a much more stronger process of productive accumulation would be able to diminish the external indebtedness process - a not easy process, given the poorest domestic performance of industrial sectors in face of the other domestic sectors and in face of the international ones. That is, the external indebtedness attenuated but did not solve the occurrence of a falling rate of productive accumulation. So, this fall of the rate of profit in industrial sectors would have conducted the economy to a still more fragile degree of investment and consumption if there was not the hegemonic role of dollar in the international economy, which permits the above mentioned strategy of external indebtedness.

Keywords: United States; U.S. economy; international finance; economic growth; contemporary macroeconomic conditions; economic policy; economic crisis; economy history. 
Índice

Resumo, p.2.

Abstract, p.3.

Índice geral, p.4.

Tabelas e Gráficos, p.7.

Siglas, p.13.

Agradecimentos, p.14.

\section{I: Teoria}

1. Introdução, p.19

1.1. O panorama internacional a partir de (19)70

1.2. Periodização e colocação do problema

1.2.1. O papel determinante da acumulação produtiva

1.2.2. O endividamento externo

1.3. Proposta do trabalho e hipóteses

1.4. Justificativas

1.5. Pressupostos teórico-metodológicos

1.6. Estrutura dos capítulos

\section{Desaceleração e taxa de lucro, p.46}

2.1.Introdução

2.2.Algumas opiniões

2.3.Ainda a lei tendencial

2.4. A centralidade da relação capital/produto

2.5. Uma digressão: algumas opiniões divergentes

\section{Demanda efetiva e endividamento externo, p. 74}

3.1. Introdução

3.2. A reprodução simples do capital social

3.3. A reprodução ampliada do capital social

3.4. Lógica do endividamento externo

3.4.1. Método e hierarquia das variáveis

3.4.2. Endividamento externo e agregados macroeconômicos: seu papel na manutenção da demanda efetiva e na ampliação da capacidade de financiamento da economia

\section{II: Mudanças estruturais}

\section{Uma análise de dados, p.97}

4.1. A queda das massas de lucro no setor manufatureiro

4.2. Taxas de lucro no setor manufatureiro

4.3. Um cálculo alternativo de taxa de lucro na manufatura e taxas de lucro setoriais

4.4. Impactos do petróleo, produtividade e investimento estrangeiro direto

4.5. Destinos da poupança internacional

4.6. Preços relativos e importações

4.7. Relação investimento-poupança

4.8. Propensão a investir e propensão a consumir

4.9. A posição única dos Estados Unidos e do dólar na economia mundial 


\section{III: Conjunturas}

5. Antecedentes: balanço de pagamentos e Acordo de Bretton Woods, p.153

5.1. Introdução

5.2. O panorama no pós-1945 e a conferência de Bretton Woods

5.3. O crescimento do pós-guerra

5.4. Transformações nos anos (19)70

5.5.Desaceleração e a opção pelo endividamento externo

6. A primeira administração Reagan (1981-1984), p.177

6.1. Introdução

6.2. O conturbado panorama econômico

6.3. O Reaganomics e o Program for Economic Recovery

6.4. As contradições do Programa

6.5. A posição de Paul Volcker sobre a condução da política econômica

6.6. A recuperação em 1983 e 1984

6.7. Análise empírica

6.7.1. O desempenho da economia durante o Programa para Recuperação Econômica

6.7.2. As contas do governo federal e a indústria de guerra

6.7.3. O papel do endividamento externo

6.8. Lógica do endividamento

\section{A segunda administração Reagan (1985-1988), p.228}

7.1. Introdução

7.2. A continuação do Reaganomics

7.3. O acordo do Plaza de 1985

7.4. O Balanced Budget and Emergency Deficit Control Act de 1985

7.5. O aumento do endividamento externo em 1986

7.6. O acordo do Louvre em 1987 e a crise acionária

7.7. Fim da administração Reagan

7.8. Uma análise de dados

7.9. Conclusão

\section{A administração Bush (1989-1992), p.278}

8.1. Introdução

8.2. Um novo presidente republicano

8.3. O Financial Institutions Reform Recovery and Enforcement Act (FIRREA) de 1989

8.4. O Omnibus Budget Reconciliation Act de 1990

8.5. A crise de 1990-1991

8.6. Uma recuperação tardia para evitar a derrota republicana

8.7. Uma análise de dados

8.8. Um balanço

\section{A primeira administração Clinton (1993-1996), p.326}

9.1. Introdução

9.2. O contexto da vitória do governo democrata

9.3. O problema da "nova economia"

9.4. A readequação da indústria de guerra

9.5. A política econômica 
9.6. Uma checagem empírica

9.7. A permanência das dificuldades

10. Um comentário final: a brecha entre PIB e PNB e a economia na última década (20002009), p.377

10.1. Uma última análise empírica

10.2. PIB x PNB

10.3. A economia entre 2000 e 2008

IV: Conclusão

11. Considerações finais, p. 390

Apêndice: sobre as fontes, p.397.

Fontes e Bibliografia, p.399 


\section{Tabelas e Gráficos}

Na seqüência em que aparecem nos capítulos.

Capitulo 1. Introdução.

Gráfico 1. Estados Unidos. Crescimento do PIB (em \%). 1947-2004.

Tabela 1. Estados Unidos. PIB per capita e $1^{\text {a }}$ diferença de crescimento de PIB per capita. 1960-2005.

Gráfico 2. Estados Unidos. Crescimento (1 ${ }^{\text {a }}$ diferença) de PIB per capita. 1965-2005.

Gráfico 3. Estados Unidos. Lucros do setor manufatureiro depois de pagos os impostos. 1956-2000.

Gráfico 4. Estados Unidos. Lucros do setor de serviços depois de pagos os impostos. 1953-2000.

Gráfico 5. Estados Unidos. Lucros do setor financeiro depois de pagos os impostos. 1970-2000.

Gráfico 6. Estados Unidos. Lucros deflacionados (1980) nos setores manufatureiros, de serviços e financeiros. 1971-2001.

Gráfico 7. Estados Unidos. Ativos estrangeiros totais na economia dos Estados Unidos e PIB dos Estados Unidos. 1976-2000.

Gráfico 8. Estados Unidos. Resultados líquidos em conta de capitais e conta corrente do Balanço de Pagamentos. 1960-2004.

Gráfico 9. Estados Unidos. Bonds e Ações de corporações norte-americanas detidos por estrangeiros e investimento bruto doméstico privado. 1976-2004.

Gráfico 10. Estados Unidos. Porcentagem (\%) da dívida federal detida por estrangeiros (oficiais e privados). 1970-2003.

Capítulo 2. Desaceleração e taxa de lucro.

Gráfico 1. Estados Unidos. Composição setorial do PIB. Setores selecionados. 1975-2004. Em porcentagem (\%).

Tabela 1. Estados Unidos. Relação da poupança líquida com a poupança total. 1970-2005. Em bilhões de dólares correntes.

\section{Capítulo 3. Demanda efetiva e endividamento externo}

Gráfico 1. Estados Unidos. Ativos estrangeiros totais na economia dos Estados Unidos e PIB dos Estados Unidos. 1976-2004.

Gráfico 2. Estados Unidos. Bonds e Ações de corporações norte-americanas detidos por estrangeiros, e investimento bruto doméstico privado. 1976-2004.

Gráfico 3. Estados Unidos. Porcentagem (\%) da dívida federal detida por estrangeiros (oficiais e privados). 1970-2003.

Gráfico 4. Estados Unidos. Poupança líquida das famílias, como porcentagem da renda disponível. $1972-$ 2005.

Gráfico 5. Estados Unidos. Saldos de balança comercial (bens e serviços). Em milhões de dólares correntes. 1980-2005. Fonte: BEA.

\section{Capitulo 4. Uma análise de dados}

Gráfico 1. Estados Unidos. Média móvel (três anos) dos lucros no setor manufatureiro feita a partir dos lucros deflacionados pelo dólar de 1980. 1956-2000.

Tabela 1. Estados Unidos. Setores manufatureiros. Equações de tendência estimadas para cada setor obtidas a partir de seus lucros deflacionados. 1948-1974.

Gráfico 2. Estados Unidos. Relação entre o capital fixo e os salários, no setor manufatureiro e nos serviços. 1970-2000.

Gráfico 3. Estados Unidos. Relação entre o capital constante e os salários, no setor manufatureiro. 19482000.

Gráfico 4. Estados Unidos. Proxy de taxa de lucro e mais-valia no setor manufatureiro. 1948-1996.

Tabela 2. Estados Unidos. Lucros não distribuídos, gastos com salários e capital fixo, e taxa de lucro, por setor econômico (em \%).

Tabela 3. Estados Unidos. Taxas de lucro setoriais.

Gráfico 5. Proxies de taxa de lucro em diferentes setores da economia norte-americana. Em porcentagem (\%).

Gráfico 6. Estados Unidos. Outras proxies de taxa de lucro no setor manufatureiro: produção bruta menos lucros, divididos pelo capital e por salários, e incluindo e excluindo impostos pagos. 
Gráfico 7. Mudanças (\% face ao período anterior) na produtividade, produção e salários reais nos setores não-agrícolas. 1959-1979.

Gráfico 8. Estados Unidos. Variações da produção nos setores não-agrícolas e dos salários reais por hora. 1970-2004.

Gráfico 9. Estados Unidos. Lucros deflacionados (1980) nos setores manufatureiros, de serviços e financeiros. 1971-2001. Em milhões de dólares.

Tabela 4. Estados Unidos. Preços para a produção por níveis de processamento (1982=100); ganhos médios por hora e ganhos semanais médios, em dólares correntes divididos pelo índice de preços ao consumidor para salários urbanos (onde, para o deflator, $1982=1$ ). 1976-1984.

Tabela 5. Preços para a produção por setor industrial em setores selecionados. $1982=100$. 1976-1984.

Gráfico 10. Estados Unidos. Investimento Direto Estrangeiro dos Estados Unidos no exterior e Investimento Estrangeiro Direto (IED) do exterior nos Estados Unidos. 1980-2000. Em bilhões de dólares correntes.

Gráfico 11. Países selecionados. Investimentos em formação de capital fixo, em porcentagem do PIB. 1970-2004.

Tabela 6. Poupança, investimento e empréstimos líquidos. Países selecionados. Em \% do Produto nacional Bruto (Gross Domestic Product). 1984-2007.

Gráficos 12, 13 e 14. Estados Unidos. Poupança líquida e investimento líquido doméstico, entre 1950 e 1972, 1973 e 1986, e 1986 e 2002. Em bilhões de dólares correntes. Fonte: NIPA-BEA.

Tabela 7. Poupança e investimentos, e empréstimos líquidos. Grupos de países selecionados. Em \% do Produto nacional Bruto (Gross Domestic Product). 1984-2007.

Gráfico 15. Estados Unidos. Mudanças nos preços ao consumidor (de Dezembro a Dezembro) para mercadorias e serviços. Para todos os consumidores urbanos. Em porcentagem (\%).

Tabela 8. Estados Unidos. Mudanças nos preços ao consumidor (de Dezembro a Dezembro) para mercadorias e serviços. Para todos os consumidores urbanos. Em porcentagem (\%).

Tabela 9. Estados Unidos. Índices de preços selecionados. 1982-1984 $=100$.

Tabela 10. Estados Unidos. Gastos de consumo pessoais. 1970-2000. Em bilhões de dólares.

Gráfico 16. Estados Unidos. Relação de bens tangíveis importados sobre a importação de serviços e relação da exportação de bens tangíveis exportados sobre a exportação de serviços.

Gráfico 17. Estados Unidos. Relação da poupança bruta em t com o consumo de capital fixo em t-1. 1948-2006.

Gráfico 18. Estados Unidos. Relação dos lucros no tempo t com os gastos com capital fixo das empresas domésticas em t-1. 1945-2006.

Tabela 11. Estados Unidos. Investimento em capital fixo e poupança doméstica bruta. Em bilhões de dólares. 1945-2004.

Tabela 12. Estados Unidos. Consumo das famílias e investimentos privados. Em bilhões de dólares correntes. 1980-2004.

Gráfico 19. Estados Unidos. Produto interno bruto e tendência estimada. Em bilhões de dólares.

Gráfico 20. Estados Unidos. Produto Interno Bruto desagregado. Em bilhões de dólares correntes.

Tabela 13. Estados Unidos. Investimentos em capital fixo e produto interno bruto. Em bilhões de dólares.

Tabela 14. Estados Unidos. Renda disponível e consumo pessoal. Em bilhões de dólares.

Gráfico 21. Estados Unidos. Relação entre consumo pessoal e investimentos em capital fixo. Calculado a partir de bilhões de dólares correntes.

\section{Capítulo 5. Antecedentes: balanço de pagamentos e Acordo de Bretton Woods}

Gráfico 1. Salários nos Estados Unidos, 1929-1945.

Gráfico 2. Estados Unidos. Gastos do governo federal discriminados: defesa e não-defesa.

Gráfico 3. Estados Unidos. Balanço de Pagamentos entre 1960-1969.

Gráfico 4. Estados Unidos. Médias de crescimento do produto interno bruto por década (\%).

Tabela 1. Estados Unidos. Balanço de Pagamentos. 1951-1961.

Tabela 2. Estados Unidos. Balanço de Pagamentos. 1961-1967.

Gráfico 5. Estados Unidos. Investimento estrangeiro direto norte-americano no exterior e investimento estrangeiro direto nos Estados Unidos. 1960-1980.

Gráfico 6. Estados Unidos. Poupança bruta doméstica e investimento bruto doméstico. 1940-1970.

Tabela 3. Estados Unidos, Japão e Alemanha (ocidental). Produção industrial. 1960-1980.

Tabela 4. Estados Unidos, Japão e Alemanha (ocidental). Exportações. 1965-1977.

Gráfico 7. Estados Unidos. Ativos estrangeiros totais na economia dos Estados Unidos e PIB dos Estados Unidos. 1976-2004.

Gráfico 8. Estados Unidos. Empréstimos líquidos do exterior e exportações líquidas. Em bilhões de dólares. Fonte: BEA.

Gráfico 9. Países selecionados. Médias decenais de crescimento do produto (\%). 1970-2000. 
Gráfico 1. Estados Unidos. Variações trimestrais do PNB. 1978-1980.

Gráfico 2. Estados Unidos. Gastos do governo federal: defesa e não-defesa. 1981-1984.

Gráfico 3. Estados Unidos. Orçamento do governo federal: impostos sobre lucros corporativos e impostos de renda. 1981-1984.

Tabela 2. Estados Unidos. Déficits do governo federal. 1981-1983.

Gráfico 4. Estados Unidos. Variações trimestrais do PNB (em \%). 1980-1984.

Tabela 3. Estados Unidos. Balanço de Pagamentos. Contas Selecionadas: conta de capitais (1), balanço em rendas (2) e balança comercial (3). 1979-1984.

Gráfico 5. Japão (iene - eixo esquerdo) e Alemanha (marco - eixo direito). 1979-1984.

Gráfico 6. Estados Unidos. Resultados líquidos de Conta de Capitais (ativos norte-americanos em mãos de estrangeiros menos ativos norte-americanos no exterior) e Conta Corrente de Balanço de Pagamentos. 1979-1984.

Gráfico 7. Estados Unidos. (1) Novas empresas abertas por ano, (2) falências, em números absolutos, de empresas com capital menor que 100 mil dólares e (3) com capital superior a 100 mil dólares, e taxa de falências. 1979-1986.

Gráfico 8. Estados Unidos. Lucros no setor manufatureiro, financeiro e de serviços, depois de cobrados os impostos, deflacionados pelo dólar de 1980. 1979-1984.

Tabela 3. Estados Unidos. 1978-1984. Utilização de capacidade instalada na indústria, em \%.

Tabela 4. Estados Unidos, dados selecionados, 1978-1984. (1) Índices de Preço ao Consumidor de acordo com as principais categorias de gastos, 1978-1979.

Gráfico 9. Estados Unidos, dados selecionados. 1978-1984. Variações anuais (\%).

Tabela 5. Estados Unidos. Exportações e importações por área, em milhões de dólares correntes. 19811984.

Gráfico 10. Estados Unidos. Exportações e importações de mercadorias. Em milhões de dólares correntes. 1979-1984.

Tabela 6. Estados Unidos. Poupança do governo (déficits com sinal negativo). 1979-1984.

Tabela 7. Estados Unidos. Receitas do governo federal - impostos de renda sobre indivíduos e empresas, em bilhões de dólares correntes. 1950-1980.

Gráfico 11. Estados Unidos. Impostos recebidos pelo governo federal e PNB. Calculado a partir de séries em bilhões de dólares correntes. 1940-1979.

Tabela 8. Consumo das Famílias e Renda Disponível em bilhões de dólares correntes, e resultados da regressão (I) do consumo em função do investimento. 1984-1979.

Tabela 9. Estados Unidos. Despesas e receitas do governo federal. 1980-1984. Em bilhões de dólares correntes. 1980-1984.

Tabela 10. Estados Unidos. (1) Gastos com defesa do governo federal; (2) gastos com defesa vezes o multiplicador da renda $(5,88)$ calculado; (3) renda disponível. 1981-1984.

Gráfico 12. Estados Unidos. Renda disponível e gastos multiplicados a partir de gastos do governo federal com despesas militares. 1980-1984.

Gráfico 13. Estados Unidos. Aumento do déficit do governo federal financiado localmente (aumento do déficit federal menos aumento da dívida em mãos de estrangeiros) e base monetária. Em bilhões de dólares de 1980. 1981-1984.

Tabela 11. Estados Unidos. Agregados Monetários e relação de M3 sobre M1. 1978-1988.

Tabela 12. Estados Unidos. Investimento doméstico bruto e líquido, empréstimos líquidos (do exterior) para o investimento doméstico bruto, e poupança agregada. 1980-1984.

Tabela 13. Estados Unidos. Preços históricos das ações. 1976-1984.

Tabela 14. Estados Unidos. Discriminação dos papéis emitidos pelos Estados Unidos a estrangeiros. 1980-1984.

Tabela 15. Estados Unidos. Crédito remanescente aos consumidores e PNB. 1960-1989.

Tabela 16. Estados Unidos. Investimentos privados fixos não-residenciais. 1976-1984.

Tabela 17. Estados Unidos. (a) Investimento bruto privado não-doméstico verificado e (b) estimado, a partir da função-investimento. 1981-1984.

Gráfico 13. Estados Unidos. Investimentos privados não-residenciais e tendência estimada (investimentos em função do tempo). 1976-1984.

Tabela 18. Estados Unidos. Empréstimos por setores. Famílias - hipotecas (casas) e crédito ao consumo , corporações e setores financeiros. 1972-1984.

Gráfico 14. Estados Unidos. Ativos estrangeiros nos Estados Unidos menos ativos dos Estados Unidos no exterior, e saldo em conta corrente do Balanço de Pagamentos. 1960-2004.

Gráfico 15. Estados Unidos. Proxy de taxa de lucro no setor manufatureiro. 1978-1985.

Tabela 19. Estados Unidos. Dados selecionados. 1976-1984.

Gráfico 16. Estados Unidos. Porcentagem (\%) da dívida federal detida por estrangeiros (oficiais e privados). 1970-2003.

Capítulo 7. A segunda administração Reagan (1985-1988) 
Tabela 1. Estados Unidos. Variações semestrais e anuais do PNB (\%). 1985-1988.

Tabela 2. Estados Unidos. Taxas de juros selecionadas e déficits fiscais do governo federal. 1985.

Tabela 3. Estados Unidos. Ativos de estrangeiros nos Estados Unidos (I), PNB (II), ativos estrangeiros sobre PNB (III) e variação da atração de ativos estrangeiros sobre o PNB (IV). 1981-1988.

Tabela 4. Estados Unidos. Variações mensais (\%) dos índices de preços ao consumidor. 1985-1986.

Tabela 5. Estados Unidos. Exportações e importações de bens e serviços. I/E = importações/exportações. 1985-1986.

Tabela 6. Estados Unidos. Exportações e importações de bens e serviços. E/I = importações/exportações. 1989-1988.

Tabela 7. Estados Unidos. Dados Selecionados. 1987.

Gráfico 1. Estados Unidos. Taxa de câmbio do dólar face ao iene e ao marco. 1980-1990.

Tabela 8. Estados Unidos. Compras do governo federal em bens e serviços. 1985-1988.

Tabela 9. Estados Unidos. Compras do governo federal em bens e serviços. 1908-1988.

Tabela 10. Estados Unidos. Déficits fiscais e investimentos privados, resultados previstos em função do tempo e resíduos. 1985-1988.

Gráfico 2. Estados Unidos. Resíduos das regressões de déficits fiscais (Y1) e investimentos privados (Y2) em função do tempo (X1). 1985-1989.

Tabela 11. Estados Unidos. Dados selecionados. 1981-1986.

Gráfico 3. Estados Unidos. Plotagem de ajuste de linha. Variável X (gastos com defesa) e variável Y (investimentos privados não-residenciais). 1981-1988.

Tabela 12. Estados Unidos. Salários e produção - variação anual (\%). Setores não-agrícolas. 1981-1988.

Gráfico 4. Estados Unidos. Proxy de taxa de lucro no setor manufatureiro. 1985-1990.

Tabela 13. Estados Unidos. Utilização de capacidade ociosa e número de empresas falidas. 1981-1988.

Tabela 14. Estados Unidos. Taxas de juros selecionadas. 1981-1988.

Tabela 15. Estados Unidos. Taxas de crescimento anuais das exportações e importações da Europa ocidental e Japão. 1981-1988.

Gráfico 5. Estados Unidos. Exportações e importações de bens e serviços. 1985-1988.

Tabela 16. Estados Unidos. Lucros nos setores manufatureiros e exportações de bens e serviços. 19601990.

Tabela 17. Estados Unidos. Lucros nos setores manufatureiros e exportações do setor manufatureiro. 1981-1988.

Tabela 18. Estados Unidos. Estrutura do endividamento externo. 1985-1988.

Gráfico 6. Estados Unidos. Resíduos de poupança agregada líquida e de empréstimos externos. 19851988.

Tabela 19. Estados Unidos. Poupança agregada líquida e empréstimos externos, e resíduos em função do tempo. 1985-1988.

Tabela 20. Estados Unidos. Arrecadação do governo, renda e consumo das famílias, e importações. 19841988.

Tabela 21. Estados Unidos. Consumo de bens duráveis e ativos estrangeiros na economia. 1981-1988.

Tabela 22. Estados Unidos. Empréstimos das famílias - hipotecas. 1981-1988.

Tabela 23. Estados Unidos. Dados selecionados. Títulos do Tesouro (3 meses) e Federal Funds Rate (taxa de desconto do Fed). 1987.

Tabela 24. Estados Unidos. Índices selecionados. 1981-1987.

Gráfico 7. Estados Unidos. Ganhos por ação em relação ao preço das ações (earnings/price ratio). Standard\&Poor's composite index. 1980-1990.

Tabela 25. Estados Unidos. Dados observados: lucros nas empresas do setor financeiro, na do setor manufatureiro e PNB. 1981-1988.

Capitulo 8. A administração Bush (1989-1992)

Tabela 1. Estados Unidos. Variações trimestrais do PIB (\%). 1989-1990.

Tabela 2. Estados Unidos. Índice de Preços ao Consumidor para todos os itens (\%). 1986-1993.

1988-1992.

Tabela 3. Estados Unidos. Taxas de juros selecionadas (\%). 1988-1992.

Gráfico 1. Estados Unidos. Preços de importação do petróleo. 1974-1999.

Tabela 4. Estados Unidos. Taxas de desemprego entre trabalhadores brancos e negros (em \%).

Tabela 4. Estados Unidos. Taxas de desemprego entre trabalhadores brancos e negros (em \%). 19891992.

Tabela 5. Estados Unidos. Recebimentos, gastos, gastos com defesa e déficits do governo federal, em porcentagem do PIB e em bilhões de dólares correntes. 1989-1992.

Tabela 6. Estados Unidos. Orçamento do governo federal: recebimentos e gastos discriminados. Em milhões de dólares correntes. 1989-1992. 
Gráfico 2. Estados Unidos. Resíduos de déficits orçamentários federais (Y1) em função do tempo (X) e resíduos de investimentos líquidos em capital fixo privado (Y2) em função do tempo (Y). 1989-1992.

Tabela 7. Estados Unidos. Déficits orçamentários federais (Y1) em função do tempo (X) e resíduos, e investimentos líquidos em capital fixo privado (Y2) em função do tempo (Y) e seus resíduos. 1989-1992.

Tabela 8. Estados Unidos. Renda disponível e consumo das famílias, e investimento líquido privado em capital fixo. 1991-1992.

Gráfico 3. Estados Unidos. Resíduos de investimentos líquidos em capital fixo (Y) em função do tempo (Y). 1980-1992.

Gráfico 4. Estados Unidos. Variação (\%) dos meios de pagamento. 1980-1989.

Tabela 9. Estados Unidos. Endividamento de setores selecionados. 1987-1993.

Tabela 10. Estados Unidos. Crédito a hipotecas por tipo de instituição. 1986-1990.

Gráfico 5. Estados Unidos. Investimentos em capital fixo privados (com exceção dos investimentos em residências) e investimentos em capital fixo privados em forma de residências. 1980-1992.

Tabela 11. Estados Unidos. Dados selecionados de renda e salário. 1989-1992.

Tabela 12. Estados Unidos. Índice de preços ao produtor por grupos majoritários de tipos de produção. 1988-1992.

Tabela 13. Estados Unidos. Índice de preços ao produtor por estágio de processamento. 1985-1993.

Gráfico 6. Estados Unidos. Proxy de taxa de lucro no setor manufatureiro. 1974-1995.

Gráfico 7. Estados Unidos. Exportações e importações de bens e serviços. 1989-1993.

Gráfico 8. Estados Unidos. Taxa de câmbio do dólar em relação ao marco e ao iene. 1980-2000.

Gráfico 9. Estados Unidos. Variação de produtividade (Output per hour - nonfarm business), em (\%). 1980-1994.

Tabela 14. Estados Unidos. Estrutura do endividamento externo. Em bilhões de dólares correntes. 19891990.

Tabela 15. Estados Unidos. Dados selecionados. 1976-1984. Em bilhões de dólares.

Gráfico 10. Estados Unidos. Resíduos de poupança agregada doméstica em função do tempo e de ativos estrangeiros na economia norte-americana (dívida externa), em base trimestral. Em bilhões de dólares correntes. 1989-1990.

Tabela 16. Estados Unidos. Poupança agregada doméstica e ativos estrangeiros na economia norteamericana, em base trimestral. Em bilhões de dólares 1989-1990.

Tabela 17. Estados Unidos. Poupança agregada doméstica e ativos estrangeiros na economia norteamericana, em base trimestral. Em bilhões de dólares 1989-1990.

Tabela 18. Estados Unidos. Trabalhadores por setores. Em milhares de pessoas. 1980-1992.

Gráfico 11. Estados Unidos. Valor real adicionado na indústria, em (\%). 1980-1992.

\section{Capítulo 9. A primeira administração Clinton (1993-1996)}

Tabela 1. Estados Unidos. Principais empresas norte-americanas produtoras de artigos bélicos, suas sedes (cidade e estado), número de empregados e faturamento em dólares em 2008.

Tabela 2. Mudanças nas taxas marginais de impostos de renda sob o OBRA93 para indivíduos casados vivendo juntos.

Tabela 3. Estados Unidos. Dados selecionados. 1993-1996.

Gráfico 1. Estados Unidos. Variações trimestrais (\%) do Produto Interno Bruto. 1993-1996.

Tabela 4. Estados Unidos. Orçamento do governo federal: impostos sobre os lucros corporativos e sobre as famílias, e impostos indiretos sobre as empresas; orçamento destinado à defesa e déficits orçamentários. 1996-1993.

Tabela 5. Estados Unidos. Aumentos anuais de empréstimos por setor e dívida remanescente de tais setores em fim de período. 1990-1996.

Tabela 6. Estados Unidos. PIB, investimentos privados em capital fixo não-residenciais, e poupança das empresas. 1993-1996.

Gráfico 2. Estados Unidos. Investimentos em setores selecionados. 1990-2001.

Gráfico 3. Estados Unidos. Contribuição (em \%) de cada setor para as variações em porcentagem da taxa total de investimento privado não-residencial. 1980-2001.

Gráfico 4. Estados Unidos. Variação anual (\%) da produção por hora dos salários reais, nos setores nãoagrícolas. 1980-2002.

Gráfico 5. Estados Unidos. Gastos pessoais reais com consumo por tipo de produto, em números-índices $(2000=100) .1989-2006$.

Tabela 7. Estados Unidos. Lucros setoriais: setores financeiros (inclui bancos da Reserva Federal), nãofinanceiros, e dentre estes os da manufatura. 1993-1996.

Gráfico 6. Estados Unidos. Relação entre os lucros não distribuídos e o consumo de capital fixo, para as empresas domésticas norte-americanas. 1993-1996.

Tabela 8. Estados Unidos. Estrutura do endividamento externo. Em bilhões de dólares correntes. 19931996. 
Gráfico 7. Estados Unidos. Endividamento líquido com o exterior. Em bilhões de dólares. Resultados positivos indicam haveres líquidos contra o exterior.

Gráfico 87. Estados Unidos. Resíduos de poupança agregada líquida e de empréstimos externos. Em bilhões de dólares correntes. 1993-1996. Fonte: Economic Report of the President de 1997 e 1998.

Tabela 9. Estados Unidos. Poupança agregada doméstica e ativos estrangeiros na economia norteamericana, em base trimestral. 1993-1996. Fonte: Economic Report of the President, 1997 e 1998.

Tabela 10. Estados Unidos. Poupança bruta total, poupança das famílias, saldo em balança comercial e saldo em conta corrente. 1993-1996.

Tabela 11. Estados Unidos. Investimentos privados não-residenciais e ativos estrangeiros nos Estados Unidos. 1993-1996. Em bilhões de dólares correntes.

Gráfico 9. Estados Unidos. Saldos líquidos em transações de bens e serviços com Canadá, México e outros países da América Latina. Fonte: BEA.

Gráfico 10. Estados Unidos. Fluxos de Investimento Estrangeiro Direto. 1989-1997. Em bilhões de dólares correntes.

Tabela 12. Estados Unidos. Investimento Estrangeiro Direto com países selecionados. Em bilhões de dólares. Fonte: BEA.

Tabela 13. Estados Unidos. Lucros corporativos financeiros e não-financeiros, e a relação entre eles. Em bilhões de dólares. 1964-2004.

Capitulo 10. Um comentário final: a brecha entre PIB e PNB e a economia na última década (20002009)

Gráfico 1. Estados Unidos. Rendas recebidas do exterior menos rendas enviadas ao exterior (saldo líquido em rendas). Em milhões de dólares correntes.

Tabela 1. Estados Unidos. PIB, resultado de rendas líquidas com o exterior, e PNB, calculado pela soma de PIB e rendas líquidas. PIB e PNB em bilhões dólares. Rendas em milhões de dólares.

Tabela 2. Estados Unidos. Variações percentuais de PIB e PNB.

Gráfico 2. Estados Unidos. Rendas recebidas do exterior menos rendas enviadas ao exterior (saldo líquido em rendas).

Tabela 3. Estados Unidos. PIB, resultado de rendas líquidas com o exterior, e PNB, calculado pela soma de PIB e rendas líquidas. PIB e PNB em bilhões dólares. Rendas em milhões de dólares.

Tabela 4. Estados Unidos. Variações percentuais de PIB e PNB.

Tabela 5. Estados Unidos. População, PIB, PIB per capita e dívida externa acumulada com o exterior no fim de período. População em milhares, PIB per capita em dólares, e PIB e dívida em bilhões de dólares correntes.

Tabela 6. Estados Unidos. Lucros da indústria e lucros do setor financeiro (inclui bancos da Reserva Federal) em relação aos lucros totais da renda nacional.

Gráfico 3. Estados Unidos. Gastos agregados como porcentagens do PIB. 2000-2006.

Tabela 7. Estados Unidos. Contas selecionadas do orçamento federal. Em bilhões de dólares correntes. Gráfico 4. Estados Unidos. Base monetária. Em bilhões de dólares. Fonte: Economic Report of the President de 2009. 


\section{Siglas}

BEA - Bureau of Economic Analysis

BLS - Bureau of Labor Statistics

BID - Banco Interamericano de Desenvolvimento

BIRD - Banco Mundial

BIS - Bank for International Settlements

BUNDESBANK - Banco Central da Alemanha

CEPAL - Comissão Econômica para a América Latina

CPI-U - United States Consumer Price Index

Fed - Federal Reserve

CIA - Central Intelligence Agency

FEA - Faculdade de Economia, Administração e Ciências Contábeis da Universidade de São Paulo

FRASER - Federal Reserve Archival System for Economic Research

FMI - Fundo Monetário Internacional

FFLCH - USP - Faculdade de Filosofia, Letras e Ciências Humanas da Universidade de São Paulo

GATT - General Agreements of Trade and Tariffs

GPO - Service of the U.S. Government Printing Office

INPC - Índice Nacional de Preços ao Consumidor

IPEA - Instituto de Pesquisa Econômica Aplicada

NASDAQ - National Association of Securities Dealers Automated Quotations

NEPHE - Núcleo de Economia Política e História Econômica do Departamento de História da FFLCH-USP

NIPA - National Income and Product Accounts (Tabelas de Contas Nacionais fornecidas pelo BEA)

OCDE - Organização para Cooperação e Desenvolvimento Econômico

OIT - Organização Internacional do Trabalho

OMC - Organização Mundial do Comércio

ONU - Organização das Nações Unidas

OTAN - Organização do Tratado do Atlântico Norte

PIB - Produto Interno Bruto

PNB - Produto Nacional Bruto

REPHE - Revista de Economia Política e História Econômica do NEPHE

UE - União Europeia 
URSS - União das Repúblicas Socialistas Soviéticas

UNCTAD - United Nations Conference on Trade and Development

\section{Agradecimentos}

Aos funcionários e professores do Departamento de História da Faculdade de Filosofia, Letras e Ciências Humanas da Universidade de São Paulo, que possibilitaram, mediante o Programa de Pós-Graduação em História Econômica, a realização deste trabalho de tese. Igualmente, aos funcionários das Bibliotecas da FEA-USP e FFLCH-USP.

Ao Bureau of Economic Analysis (BEA), Bureau of Labor Statistics (BLS), à Reserva Federal e ao Departamento de Comércio do governo norte-americano, pela ampla disponibilização de seus dados via internet e, inclusive, disponibilização gratuita doméstica em vias impressas, quando socilitado.

Aos professores na Universidade de São Paulo: Prof. Jorge Luis da Silva Grespan; Prof. Lincoln Secco; Prof. José Mao Rodrigues Junior; Prof. ${ }^{a}$ Leda Paulani. Aos colegas de trabalho do Departamento de Ciências Sociais da Universidade Federal de São Carlos: Prof. Eduardo Garuti Noronha; Profa. Maria do Socorro Sousa Braga; Prof. Thales Haddad Novaes de Andrade; Profa. Vera Alves Cepeda; Prof. Marcos Pazzanese Duarte Lanna. Aos colegas de trabalho na Universidade Federal de Alagoas, especialmente os professores da Faculdade de Economia, Administração e Ciências Contábeis (FEAC): Prof. Fábio Guedes Gomes; Prof. Ana Maria Rita Millani; Prof. Luiz Antonio Palmeira Cabral; Prof. Marcio Jorge Porangaba Costa; Prof. Cícero Péricles de Oliveira Carvalho; Prof. Dilson José Sena Pereira; Prof. André Lages; Prof. Francisco Rosário.

Aos meus alunos das Universidades Federais de São Carlos e de Alagoas, pelas discussões e debates dentro e fora de aula, que sem dúvida fazem parte do processo de maturação intelectual das ideias da tese. E, em especial, aos alunos de nosso grupo de estudos de teoria econômica no Departamento de Economia da FEAC-UFAL.

À Editora LCTE, especialmente à Carla de Mello Arruda, pela atenção e cuidado em minhas publicações, assim como do NEPHE.

Aos amigos pesquisadores do NEPHE: Felipe Pereira Loureiro; Luiz Eduardo Simões de Souza; Mariana Mendonça de Gusmão; Irinéia Maria Franco dos Santos; Fátima Previdelli; Marcos Cordeiro Pires; e Muryatan Santana Barbosa; cujas contribuições em forma de leituras, sugestões, caminhos de abordagem, e críticas, foram importantes.

Aos meus familiares, especialmente meus pais, Sandra e José Antonio, e minha irmã Camila. A meu tio Mauricio, por sua ajuda e presença. A todos meus amigos, dentro e fora da Universidade de São Paulo, e em especial a Rodrigo Ramos da Silva, Danilo Koshimizu, Sérgio de Oliveira, Gilberto Francisco da Silva, Anselmo Araújo, Virgilio de Paula Bassanelli, Lucas Viani, Ezequiel Ipar e Mariana de Gainza.

Ao meu orientador, professor Wilson do Nascimento Barbosa, por sua atenção, orientação, ajuda, e paciência para com os erros deste pesquisador. O nome do professor Wilson honra este trabalho de doutoramento. Sou grato por sua grande capacidade de fornecer caminhos, abordagens 
certeiras e orientação em campos distintos como o da teoria e história econômica, o da estatística e da economia internacional.

Evidentemente, isento todos meus colegas de trabalho e pesquisa pelos erros da tese, e em especial o professor Wilson.

Por fim, agradeço profundamente a Maria Cecilia Ipar. Seu companheirismo e carinho durante este período de escrita da tese foram responsáveis por uma travessia muito mais feliz do que a que teria havido sem ela. A ela dedico com carinho este trabalho. 
Para Cecilia. 
"A fronteira que se poderia traçar atualmente entre os homens, no que diz respeito à importância de seus conhecimentos, deveria ser determinada menos pela extensão de sua formação científica do que por certos sinais em sua atitude que exprimem sua posição diante das lutas sociais. Aquele que possui as intuições decisivas vê chegarem até eles, por si mesmos, os conhecimentos tirados de outros campos quando a necessidade se faz sentir.”

Max Horkheimer, A propósito da querela do racionalismo na filosofia contemporânea, 1934.

"Para proceder à análise dos problemas atuais não é possível que esperemos até que os modelos sejam devidamente formulados, até que se escolham meticulosamente os elementos que os integram e que se faça o diagnóstico preciso de suas ações recíprocas. Temos, portanto, que empregar métodos imperfeitos, porém eficazes. De todos os modos, é provável que os métodos simplificados nos ajudem a conseguir uma interpretação da natureza dos problemas reais, sob condição de que se compreenda devidamente sua índole. Porque se não se compreende, é indubitável que constituirão um obstáculo.”

Joan Robinson, Ensaios sobre a teoria do crescimento econômico, 1962. 
Teoria 


\section{Introdução}

\subsection{O panorama internacional a partir de (19)70}

$\mathrm{N}$ os últimos trinta anos (1973-2003), um conjunto de transformações alterou radicalmente o cenário em que se desenrolaria a subseqüente história econômica internacional. As crises do petróleo (1973 e 1979) colocaram fim aos baixos preços deste insumo e aceleraram, nos centros econômicos mundiais (Estados Unidos, Japão e Europa ocidental) mudanças tecnológicas que culminaram na assim chamada “Terceira Revolução Industrial”. A recessão que se seguiu, incrementada pela brusca elevação dos juros nos Estados Unidos em 1979, colocou fim ao "Consenso Keynesiano" ou ao "padrão de acumulação fordista", desencadeando a estagnação econômica e a elevação do desemprego. Era o fim de um determinado arranjo político-econômico ao qual se atribuía o sucesso dos “Trinta [anos] Gloriosos", entre o fim da Segunda Guerra Mundial e a primeira crise do petróleo (1945-1973).

O "arranjo virtuoso" de crescimento econômico e elevação do consumo tinha sua expressão máxima na difusão do pensamento keynesiano, aceito pelas elites internacionais devido às vicissitudes da guerra-fria. A existência de um campo avesso ao capitalismo, representado pela União Soviética e seus aliados, fortalecia politicamente os trabalhadores e tornava as burguesias mundiais mais propensas às reformas sociais. Com o fim deste "regime de acumulação" específico do capitalismo posterior à Segunda Grande Guerra Mundial, elevou-se o desemprego e facilitou-se um ataque frontal aos direitos trabalhadores. Nos anos (19)70, a crise provocara uma combinação de inflação mais estagnação, o que não era previsto nos modelos tradicionais da teoria keynesiana. Assim, o keynesianismo tornou-se desacreditado.

Estes ataques aos trabalhadores foram iniciados pelas políticas de Thatcher na Inglaterra e Reagan nos Estados Unidos, além do Chile de Pinochet, em sua versão ditatorial. Os acontecimentos eram indicativos de que as elites da Europa ocidental e Estados Unidos notavam que os imperativos de ordem política de maximizar o crescimento em favor das coletividades poderiam ser abandonados, à medida que o desemprego crescia e que a União Soviética se aproximava cada vez mais politicamente dos Estados Unidos. As políticas recessivas adotadas para controlar a inflação levaram a um desempenho econômico irregular nos Estados Unidos e na Europa ocidental nos anos (19)80, com o desemprego mantendo-se alto e a concentração de renda se elevando.

Neste ínterim, ganhou terreno a difusão de uma nova perspectiva do pensamento liberal - agora chamado de neoliberal. Se o liberalismo clássico de Adam Smith criticava a intromissão do Estado monárquico na nascente economia industrial capitalista do fim do século XVIII, o pensamento neoliberal criticava o intervencionismo keynesiano e o Estado de Bem Estar Social. 
O neoliberalismo, à medida que ganhava forças, mostrava uma modificação dos interesses dos grupos econômicos e políticos dominantes no Ocidente. Com a elevação do desemprego e com o declínio da "ameaça socialista" - pelas sucessivas aproximações e mesmo capitulações da União Soviética no cenário externo nos anos (19)70 e oitenta - a aliança com os trabalhadores, no sistema capitalista da Europa ocidental e Estados Unidos, perdeu importância.

Neste cenário, as estratégias de acumulação de capital dos monopólios e oligopólios capitalistas alteraram-se em favor de (1) um maior rearranjo em torno de áreas de integração econômica (a União Europeia, o Nafta, o Mercosul e outros); (2) de uma pressão por abertura de mercados periféricos; (3) da financeirização dos lucros, que se tornou cada vez mais uma saída para a queda da acumulação nos setores manufatureiros, e para o limite do crescimento do setor de serviços nas economias. A financeirização cresceu e se desenvolveu em ramos variados, tal como visto no enorme volume atingido de transações no mercado cambial, de bônus, de ações e dos assim chamados mercados de derivativos.

$\mathrm{O}$ crescimento das atividades de finanças internacionais, facilitado pelas novas técnicas de comunicação ancoradas na microeletrônica, tinha suas raízes: (1) nos déficits no balanço de pagamentos norte-americano na década de (19)50 e (19)60, que levaram a uma elevação da "liquidez" nos mercados financeiros internacionais, explicados pela necessidade de pôr fim à escassez de dólares no contexto de auxílio à Europa ocidental no pós-guerra, e depois pela intervenção armada no Vietnã; e (2) pela reciclagem dos "petrodólares", seguida da crise do petróleo. Criava-se assim o mercado de "eurodólares", que eram dólares possuídos por outras nações, que não os Estados Unidos, e depositados em bancos nos próprios Estados Unidos. Esse conjunto de transformações foi chamado posteriormente de época da globalização.

Neste contexto, diminuíram os setores da economia com desempenho dinâmico, com exceção dos da microeletrônica, que se difundiu por toda a estrutura econômica, com forte impacto no plano da produtividade do trabalho. Neste setor, onde a pesquisa e propriedade estiveram sempre restritas a alguns poucos oligopólios, o número de inovações tecnológicas foi bastante alto, num processo onde a oferta moldou a demanda pela rápida obsolescência dos bens fabricados. Conseqüentemente houve forte concorrência entre os fabricantes e um grande barateamento de bens, finais ou de produção, o que contribuiu para neutralizar as pressões inflacionárias na economia mundial.

No entanto, se a cadeia de tecnologias e bens da microeletrônica, que representam a “Terceira Revolução Industrial”, se difundiu por toda a economia, não se pode dizer que seus resultados, do ponto de vista do crescimento econômico mundial, foram similares aos da fase anterior do "regime de acumulação fordista" capitaneado pelo automóvel, a chamada "Segunda Revolução Industrial". Com exceção da China, os resultados foram de diminuição do crescimento na maior parte do mundo, do ponto de vista do crescimento econômico.

Celso Furtado e Raul Prebisch, à sua época, chamaram atenção para a elevação da participação dos países periféricos do sistema capitalista na produção e renda mundiais, no intervalo entre a Crise de 1929 e a Segunda Guerra Mundial (1939-45). Tais resultados 
prolongaram-se até meados a década de (19)60, no período em que as transformações assinaladas acima começaram a precipitar-se. Porém, a política dos centros econômicos, encabeçada pelos Estados Unidos e sua "diplomacia do dólar forte" com enormes elevações de juros, minou o crescimento que se verificava cada vez mais difícil. A crise da dívida externa, com a elevação dos juros na economia dos Estados Unidos; a adoção de políticas de ajuste do Fundo Monetário Internacional; a conexão das políticas econômicas à lógica financeira e a abertura total de seus mercados financeiros aos fluxos de capitais dos centros econômicos; todas estas políticas determinaram o bloqueio da industrialização periférica a partir dos anos (19)80.

Deste quadro recessivo mais geral, poucas exceções escaparam. Estas exceções eram a dos países de "desenvolvimento a convite" pelos Estados Unidos, como a Coreia do Sul, ou de regimes avessos à interferência direta capitalista, como a China. Nestes ambientes, a acumulação pôde se dar pela tomada de mercados externos previamente ocupados mediante larga exploração de mão-de-obra local barata e disciplinada. A América Latina, a África e a maior parte dos países asiáticos situados fora do eixo dinâmico no leste asiático estagnaram ou regrediram social e economicamente. A maior fatia do crescimento do produto mundial se deu pela integração comercial, produtiva e financeira entre as três regiões desenvolvidas - América do Norte, Europa ocidental, Japão e depois a China. Elevaram-se as disparidades entre o "centro" e o resto da "periferia", entendida como a soma das nações latino-americanas, a África e os países do Leste Europeu recém convertidos à economia capitalista, com o fím do socialismo em 1990-1991.

O fim do campo socialista mundial marcou o último desdobramento fundamental na caracterização desta nova ordem econômica. Ele representou a abertura de novos mercados para o capital ocidental, centrados na Europa Oriental e na ex-União Soviética. Os resultados econômicos desta integração foram pífios, tal como elevação dos fluxos imigratórios, desnacionalização da economia, elevação das disparidades sociais e regressão da capacidade industrial. O desaparecimento do socialismo representou a consolidação dos Estados Unidos como única potência mundial, com ampliação de suas margens de atuação do ponto de vista econômico, político e militar. Mas sua própria economia não apresentava resultados satisfatórios desde o fim dos anos (19)70.

\subsection{Periodização e colocação do problema}

\subsubsection{O papel determinante da acumulação produtiva}

Como pôde a economia norte-americana crescer relativamente menos nos últimos trinta anos, face aos "trinta gloriosos" (1945-73) ao mesmo tempo em que todas as variáveis macroeconômicas - déficits fiscais, poupança das famílias, níveis de endividamento dos agentes - apresentaram o melhor desempenho que poderiam ter tido? O já velho problema da "senilidade" da economia norte-americana norteou então este trabalho. A resposta não pode ser 
encontrada sem uma investigação sobre o papel do setor industrial e assim da acumulação produtiva, responsável em última instância pelo crescimento.

O processo de queda relativa do valor do setor industrial no produto é fato conhecido e que não levanta por si mesmo suspeita ou dúvida alguma. Está discutido na literatura ${ }^{1} \mathrm{e}$ refletido nas Contas Nacionais. Por si mesmo, é um truísmo afirmar que na medida em que a participação do setor industrial diminui face ao produto, as taxas de crescimento têm de ser menores, dada justamente a centralidade do papel da indústria. Em última instância, todo crescimento expressa-se como acumulação produtiva. Daí que, num momento dado, quanto menores são as taxas de lucro no setor industrial, menores serão as taxas de crescimento do produto. De fato, como se observa para os Estados Unidos, quanto mais se avança no tempo, maiores terão de ser as taxas de lucro industriais para que a economia continue crescendo às mesmas taxas de antes. Isto é, naturalmente as taxas de crescimento terão de ser menores. E se as taxas de lucro caem, esta "tendência à reprodução simples" se vê ainda mais aguçada.

$\mathrm{O}$ debate sobre o estancamento da economia norte-americana já existia desde os anos (19)30, e reapareceu com força a partir da crise de $1973 .{ }^{2}$ Com efeito, a tendência para a estagnação ou para a queda da taxa de lucros nos setores industriais durante os últimos aproximadamente trinta anos (1973-2006) - face aos setores onde a relação entre insumos e capital fixo (capital constante, na linguagem marxista) e salários (capital variável, na linguagem marxista) tende a ser menor - e assim do crescimento da economia norte-americana a partir dos anos (19)70, já foi indicado por muitos autores, sob diferentes perspectivas teóricas. De fato, o comportamento do produto interno bruto dos Estados Unidos mostrou uma tendência de estagnação a partir do período referido, onde cada recuperação se deu com variações cíclicas cada vez menores. Visto no longo prazo, a partir dos anos (19)70 até o presente momento (2008), a economia tem crescido cada vez menos, com grande crescimento das massas de lucro nos setores financeiros, a indicar as cadentes oportunidades relativas no restante dos setores, tal como se vê no gráfico abaixo. Este comportamento se intensificou a partir da década de (19)90, a ponto de a massa de lucros no setor financeiro já ter ultrapassado a dos setores industriais no fim do período (ver gráfico abaixo).

\footnotetext{
${ }^{1}$ Ver por exemplo: KRUGMAN, Paul. Pop internationalism; WALLERSTEIN, Immanuel. Decline of American Power; RATNER, Sidney, SOLTOW, James, SYLLA, Richard, The Evolution of the American Economy; KENNEDY, Paul. Preparing for the twenty-first century. BERNSTEIN, Michael, ADLER, David. Understanding American Economic Decline; ARRIGHI, Giovani. O longo século XX e Adam Smith em Pequim.

${ }^{2}$ Cf. ROLL, Eric, Historia de las doctrinas económicas, pp. 467-475.
} 
Gráfico 1. Estados Unidos. Crescimento do PIB (em \%). 1947-2004.

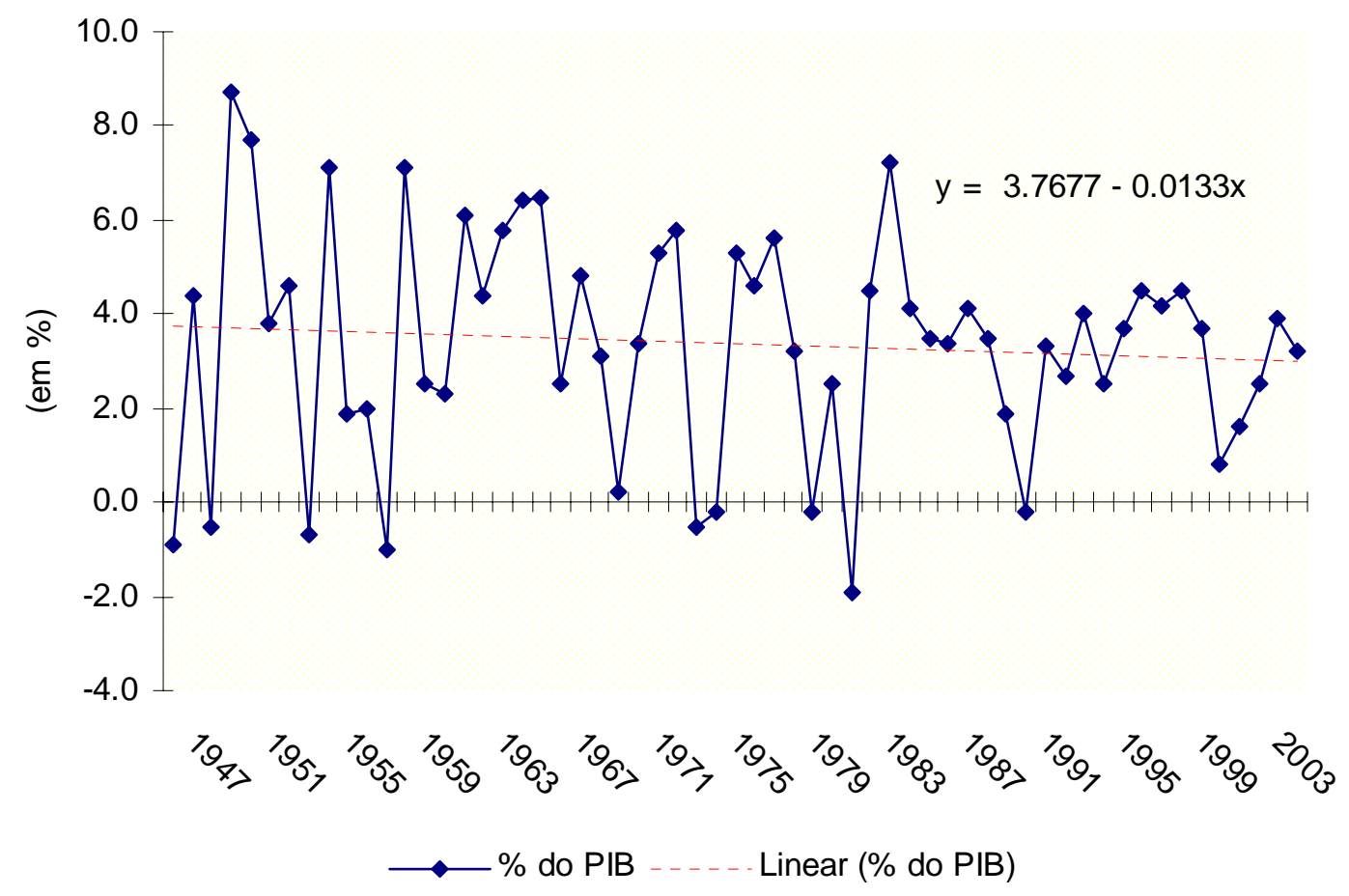

Fonte: NIPA-BEA. Seção I, Domestic Product and Income, Tabela 1.1.1., Percent Change From Preceding Period in Real Gross Domestic Product. ${ }^{3}$

Em termos de variação do PIB, pode-se observar que o crescimento do Produto Interno Bruto entre 1985 e 2005 somou 118,6\% de variação, contrastando com 194\% entre 1964 e 1984. As médias do crescimento do PIB foram 9,2\% entre 1964 e 1984 e 5,6\% entre 1985 e 2005. O sinal negativo no regressor "b" da equação regressional para os dados de PIB em função do tempo $(y=a+b x)$ gera outra forma de ver tal tendência declinante. Este padrão de flutuações do PIB pode ser verificado também na distribuição do PIB per capita. O passo sempre mais ascendente de crescimento do PIB per capita inverteu-se a partir de 1975, opostamente ao que se verificava desde 1965. No gráfico abaixo, nota-se uma ligeira interrupção desta tendência decrescente durante a segunda metade da década de (19)90. Ela é retomada, porém, no início da primeira década do século atual.

\footnotetext{
${ }^{3}$ Como explicado no Apêndice, todos os dados do Bureau of Economic Analysis podem ser obtidos em www.bea.gov.
} 
Tabela 1. Estados Unidos. PIB per capita (PIB dividido pelo número de habitantes) e $1^{\text {a }}$ diferença de crescimento de PIB per capita (tempo 2 dividido por tempo 1). 1960-2005. Em dólares correntes.

\begin{tabular}{ccc}
\hline$(1)$ & $(2)$ & $(3)$ \\
Anos & PIB per capita & $\begin{array}{c}\text { Variação de PIB per capita } \\
\left(\mathrm{T}_{2} \div \mathrm{T}_{1}\right)\end{array}$ \\
1960 & 2913 & $\ldots$ \\
1965 & 3700 & 1,27 \\
1970 & 5064 & 1,36 \\
1975 & 7585 & 1,49 \\
1980 & 12249 & 1,61 \\
1985 & 17697 & 1,44 \\
1990 & 23200 & 1,31 \\
1995 & 27752 & 1,19 \\
2000 & 34762 & 1,25 \\
2005 & 39925 & 1,14 \\
\hline
\end{tabular}

Fonte: Calculado pelo autor a partir dos dados de população e Produto Interno Bruto do BEA. Os dados de PIB são os mesmos do gráfico 1. Os dados de população foram obtidos na Tabela B-34 do Apêndice Estatístico do Economic Report of the President de 2006, intitulada "Population by Age and Group, 1929-2005". 4

Gráfico 2. Estados Unidos. Crescimento ( $1^{\text {a }}$ diferença) de PIB per capita, em dólares correntes. 1965-2005.

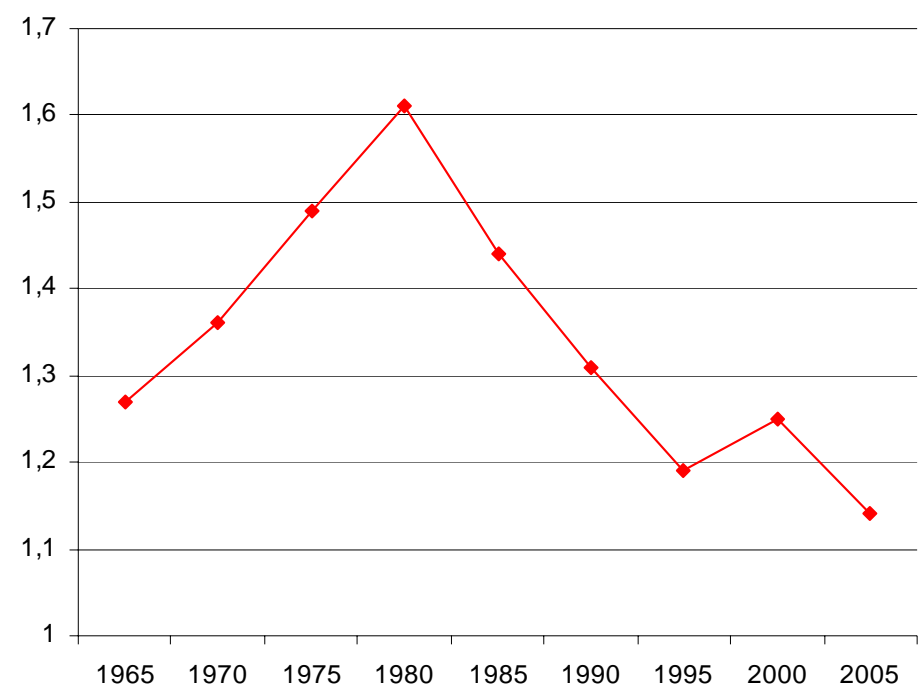

Fonte: coluna 3 da tabela 1.

Assim, não se pode desconectar a pressão negativa nas taxas de lucro industriais, variável determinante dos movimentos da economia, da diminuição do crescimento do produto. A tendência ascendente das massas de lucro no setor manufatureiro herdada dos anos (19)50 deu lugar a uma grande queda de tais massas a partir dos anos (19)70. Tal como se vê no gráfico abaixo (feito com a série deflacionada para lucros do setor manufatureiro a partir do dólar de 1980), os seguintes sub-períodos podem ser traçados para o comportamento das taxas de lucro

\footnotetext{
${ }^{4}$ A partir daqui, todas as referências às tabelas do Economic Report of the President dão como implícito que se trata das tabelas do Apêndice Estatístico presente no fim de cada volume.
} 
do setor manufatureiro: (i) tendência ascendente (1955-1976), (ii) crise entre 1977 e 1985, e (iii) recuperação parcial entre 1986 e 2001, sem nunca recompor as perdas reais acumuladas no período anterior -; (iv) nova queda a partir de 2001.

Gráfico 3. Estados Unidos. Lucros do setor manufatureiro depois de pagos os impostos. 19562000. Em milhões de dólares de 1980.

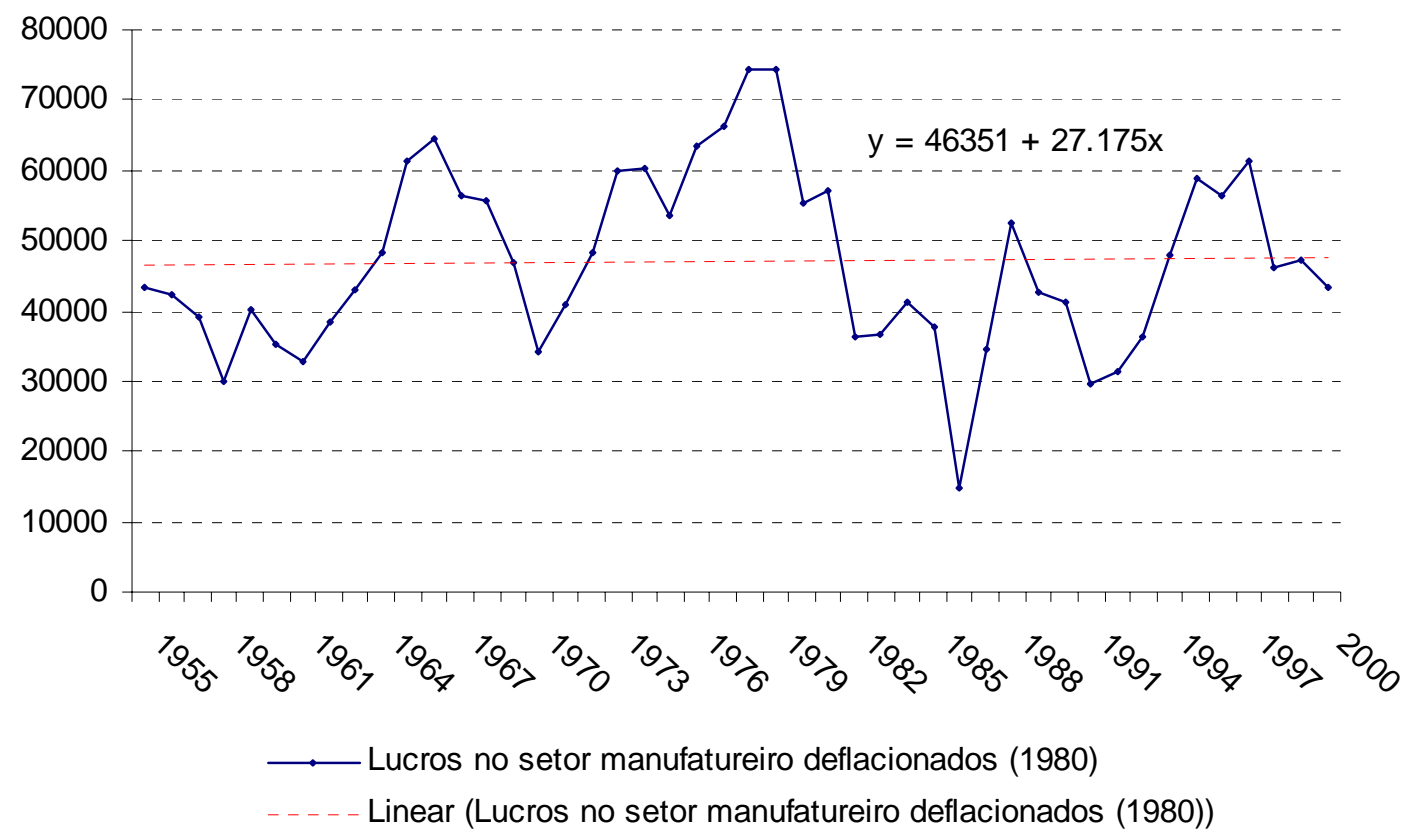

Fonte dos dados deflacionados: NIPA-BEA. Seção 6: Income and Employment by Industry. Tabelas: 6.19: Corporate profits after tax by industry. Fonte do deflator: dados fornecidos pelo calculador automático (inflation calculator) fornecido pelo BLS em seu endereço eletrônico, especificamente no link Consumer Price Index. Ver http://www.bls.gov/cpi/.

Por outro lado, o comportamento do setor de serviços deixa ver um desempenho diferente: um crescimento maior do que o referente ao setor industrial, e a formação de uma bolha nos anos (19)90. Abaixo estão plotadas as massas de lucros no setor de serviços norteamericano entre 1953 e 2000, deflacionadas pelo dólar de 1980. Está também traçada a linha de tendência, calculada pela regressão da série em função do tempo. Em primeiro lugar, vê-se que o regressor " $b$ " da equação regressional é significativamente maior que o regressor da equação de lucros manufatureiros, o que indica um crescimento mais rápido de maiores lucros no setor de serviços. Tal mostra o declínio relativo do setor industrial. Em segundo lugar, tal como no setor manufatureiro, as massas de lucros caíram entre 1973 e 1988. O desempenho do setor no agregado esteve em queda durante todos os anos (19)80, deixando para trás a o desempenho expansivo das décadas anteriores; em 1989, chegou a atingir o valor de apenas 6 bilhões, em dólares de 1980. Em terceiro lugar, desde 1994, os lucros passaram a crescer vertiginosamente, num comportamento que rompe bruscamente com o passado. Acumulou-se média de lucros entre 1990 e 1999 de 16 bilhões (em dólares de 1980), contra a média de 6 bilhões na década anterior. 
A partir de 2000, o setor passou a amargar prejuízo agregado de 700 milhões de dólares, prejuízos que seriam aprofundados após 2001. A queda das massas de lucros em 2001 foi proporcional à ascensão vertiginosa, numa típica bolha. Tal permite afirmar que os anos (19)90 parecem "nunca ter existido" (Brenner). ${ }^{5} \mathrm{O}$ crescimento da lucratividade do setor assemelhouse a um "castelo de cartas": o desempenho do setor não tinha criado as bases para uma ascensão consolidada dos lucros no longo prazo. Os lucros registrados eram fictícios, não tinham base na própria estrutura econômica real subjacente. Após 2001 o setor de serviços ia juntar-se ao setor manufatureiro em sua dificuldade para novas elevações da lucratividade e expansão do capital.

Gráfico 4. Estados Unidos. Lucros do setor de serviços depois de pagos os impostos. 19532000. Em milhões de dólares de 1980.

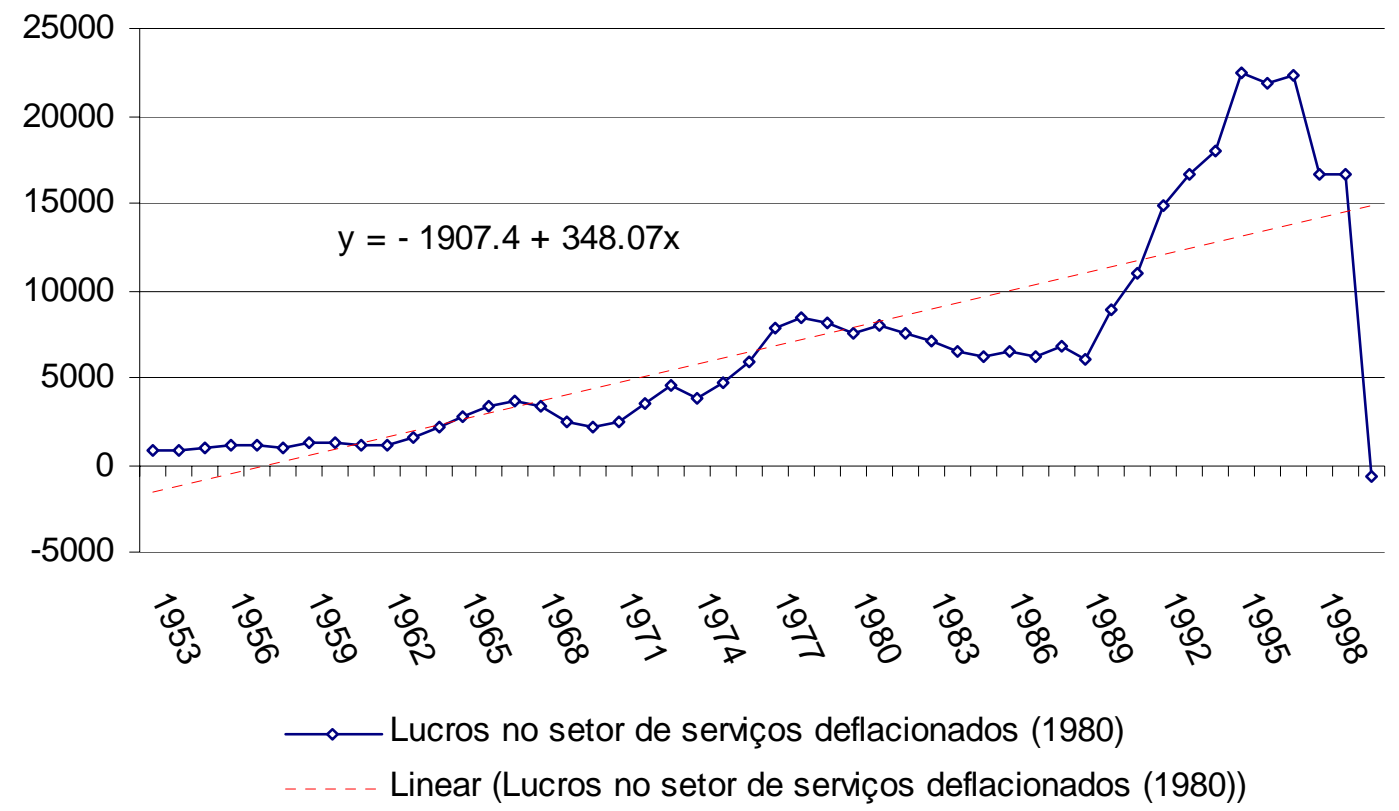

Fonte dos dados deflacionados: NIPA-BEA. Seção 6: Income and Employment by Industry. Tabelas: 6.19: Corporate profits after tax by industry. Fonte do deflator: dados fornecidos pelo calculador automático (inflation calculator) fornecido pelo BLS em seu endereço eletrônico, especificamente no link Consumer Price Index. Ver http://www.bls.gov/cpi/.

Por sua vez, os setores financeiros e imobiliários da economia (Bancos do Federal Reserve, Comerciais e de Investimento, Fundos Mútuos, Agências de Crédito, Seguradoras) tiveram um desempenho econômico bem menos irregular que os setores de serviços e da manufatura. O valor do regressor " $b$ " na equação regressional acusa o maior crescimento das três séries. Como se pode ver a partir do próximo gráfico, após uma grande tendência cadente dos lucros entre o fim dos anos (19)70 e início da segunda década de (19)80, o setor como um todo redesperta da crise e retomada lucratividade crescente. A tendência da série é francamente ascendente, contrariamente às séries de lucro do setor manufatureiro e não-manufatureiro.

${ }^{5}$ O Boom e a Bolha, cap. 1. 
Gráfico 5. Estados Unidos. Lucros do setor financeiro depois de pagos os impostos. 1970-2000. Em milhões de dólares de 1980.

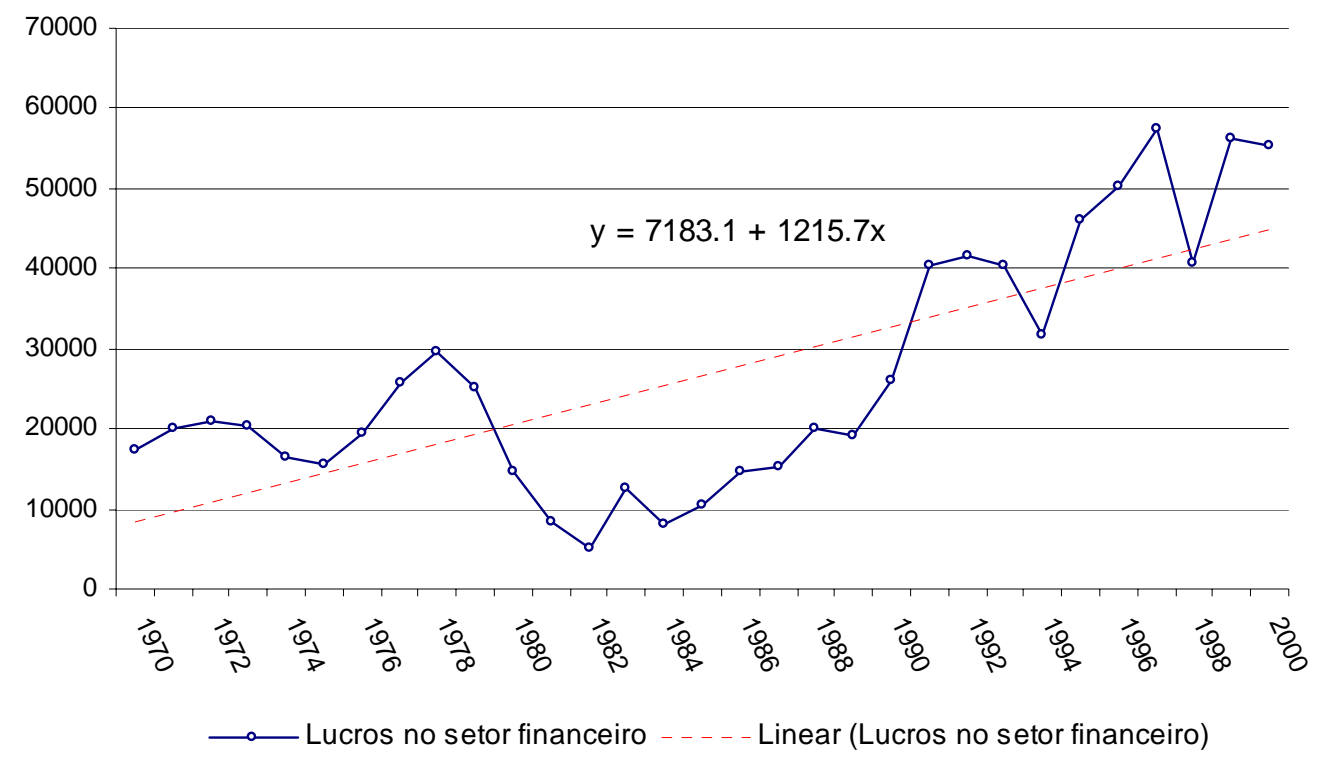

Fonte dos dados deflacionados: NIPA-BEA. Seção 6: Income and Employment by Industry. Tabelas: 6.19: Corporate profits after tax by industry. Fonte do deflator: dados fornecidos pelo calculador automático (inflation calculator) fornecido pelo BLS em seu endereço eletrônico, especificamente no link Consumer Price Index. Ver http://www.bls.gov/cpi/ .

Gráfico 6. Estados Unidos. Lucros deflacionados nos setores manufatureiros, de serviços e financeiros. 1971-2001. Em milhões de dólares de 1980.

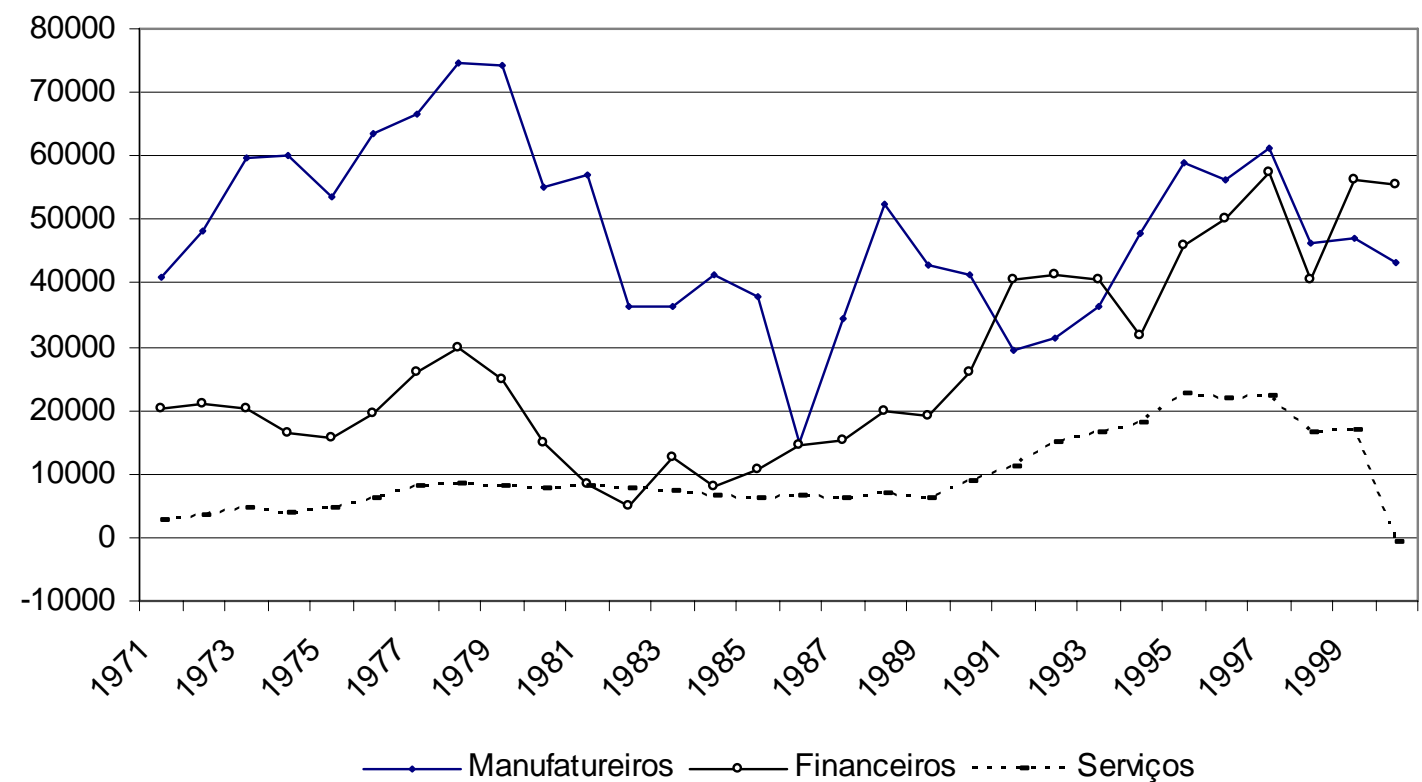

Fonte dos dados deflacionados: NIPA-BEA. Seção 6: Income and Employment by Industry. Tabelas: 6.19: Corporate profits after tax by industry. Fonte do deflator: dados fornecidos pelo calculador automático (inflation calculator) fornecido pelo BLS em seu endereço eletrônico, especificamente no link Consumer Price Index: ver http://www.bls.gov/cpi/. 
A figura acima traz juntas as mesmas três séries de lucros, deflacionados pelo dólar de 1980, para efeitos comparativos de seus respectivos desempenhos, onde se torna clara a discrepância acima assinalada.

\subsubsection{Endividamento externo}

Com efeito, este processo de diminuição relativa da massa de lucros nos setores manufatureiros e de serviços tomados em conjunto foi acompanhado pelo endividamento externo da economia dos Estados Unidos. Como mostra o gráfico 7 abaixo, a quantidade de haveres estrangeiros contra os Estados Unidos elevou-se mais rápido do que o PIB entre 1976 e 2004, e ultrapassou o próprio PIB neste ano. Este é outro aspecto que diferencia o período que aqui se vai analisar do momento estudado por Steindl, em Maturidade e Estagnação no Capitalismo Americano (1952). Até fins dos anos (19)70, o país fora credor líquido em relação ao exterior pelo menos desde a Primeira Guerra Mundial (1914-1918). A partir de 1980, tornouse importador líquido de capitais. Tratou-se de fato de uma mudança histórica do comportamento das contas externas do país. O aporte de capitais tornou-se cada vez mais amplo e serviu para financiar parte dos gastos do governo, dos investimentos e do consumo das famílias. Como comentou Duncan:

"Os déficits em conta corrente dos Estados Unidos estão se aproximando de 5\% do PIB e estão acelerando. É somente questão de tempo antes que se torne impossível para os Estados Unidos continuar aumentando seu endividamento em relação ao resto do mundo a uma taxa de 5\% do PIB ao ano. Neste ponto, os países com superávits no balanço de pagamentos serão forçados a converterem seus excedentes em dólar em suas próprias moedas, causando uma brusca apreciação destas moedas e um grande declínio no valor do dólar. Esta mudança vai ajudar a restaurar o equilíbrio no balanço de pagamentos dos Estados Unidos, mas vai também jogar os principais exportadores em recessão assim que suas exportações para os Estados Unidos colapsarem." 6

Neste sentido, elencam-se as questões: o que está por detrás do comportamento citado dos lucros auferidos e do PIB? Que relações isto guarda com a posição externa da economia? E quais impactos o endividamento externo exerceu na estrutura econômica?

\footnotetext{
6 "The U.S. current account deficit is approaching 5\% of GPD and accelerating. It is only a matter of time before it will become impossible for the United States to continue increasing its indebteness to the rest of the world at the rate of 5\% of GPD per year. At that point, the countries with balance of payments surpluses will be forced to convert their dollar surpluses into their own currencies, causing a sharp appreciation in their currencies and a sharp decline in the value of dollar. That shift will help restore equilibrium to the U.S. balance of payments, but also it will throw the major exporting nations into recession as their exports to the United States collapse.” Richard Duncan, The Dollar Crisis, p.63-64.
} 
Gráfico 7. Estados Unidos. Ativos estrangeiros totais na economia dos Estados Unidos e PIB dos Estados Unidos. 1976-2000. Em bilhões de dólares correntes.

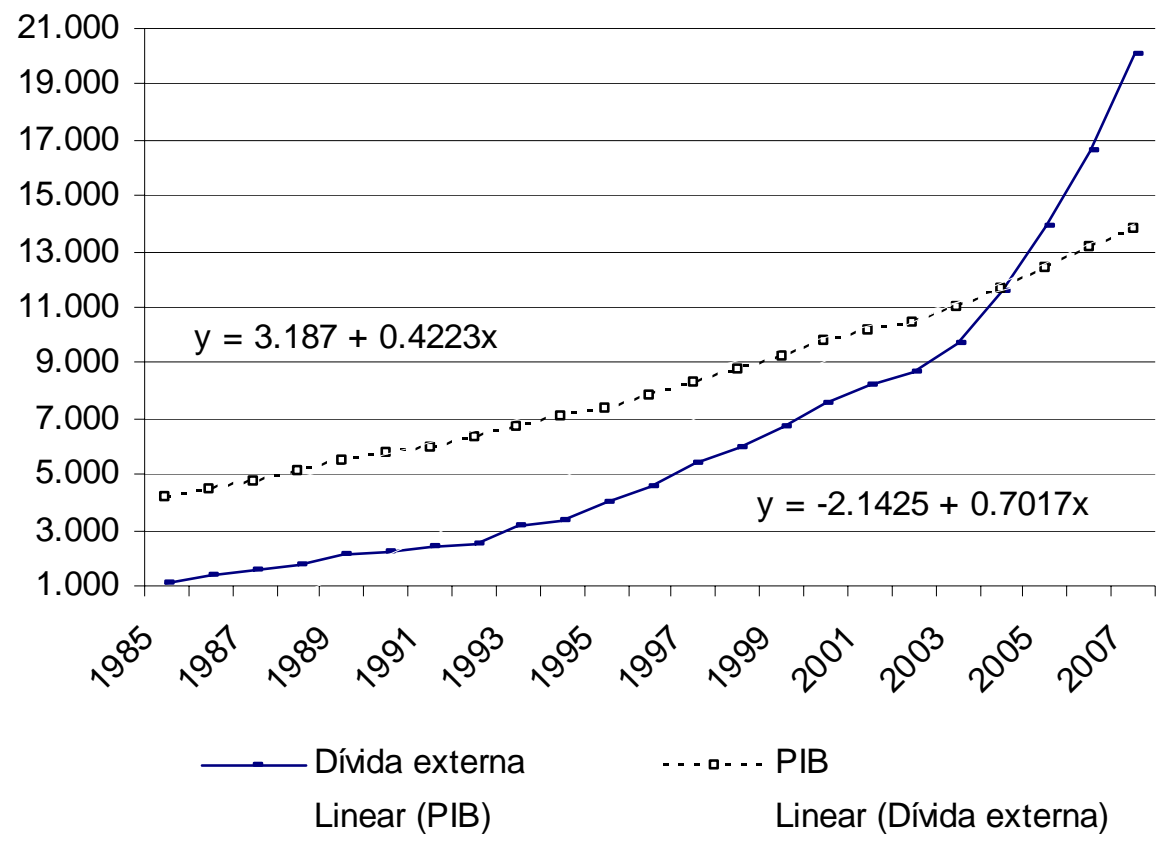

Fonte: apêndice estatístico do Economic Report of the President, vários anos (1984-2008). ${ }^{7}$ Para PIB: Tabela B-1, Gross Domestic Product, 1959-2007; para Ativos Estrangeiros totais na economia dos Estados Unidos: International Investment Position of the United States at yearend, vários anos.

Quando se fala de capitais recebidos e remetidos por um país, leva-se em consideração a seguinte divisão básica: a) recebimentos ou exportação de investimento direto estrangeiro; b) recebimentos ou remessas de empréstimos bancários a governos e agentes privados; c) recebimento de capitais ou contribuição com capitais a instituições não-privadas que concedem financiamentos a governos e empresas. Ou seja, um processo de captação de recursos externos implica, no limite, em: (1) aumento a capacidade de financiamento da economia; ${ }^{8}$ (2) maior demanda efetiva. O endividamento externo da economia define-se por um maior resultado no ingresso de recursos pela conta de capitais face aos resultados da conta corrente do balanço de pagamentos; quando a conta corrente, e, em geral, os resultados comerciais, são negativos, eles são compensados pela atração de recursos do exterior. Esta diferença chama-se de endividamento externo, e pode ser de curto, médio ou longo prazo. Os investimentos diretos não fazem parte, por definição, do endividamento externo, porque contribuem para a taxa de investimento doméstico a partir de recursos estrangeiros, sendo assim são contabilizados seus ingressos na conta de capitais.

\footnotetext{
${ }^{7}$ A partir daqui, quando se mencionar em tabelas e gráficos o documento Economic Report of the President como fonte, subenterder-se-ão as tabelas de seu Apêndice Estatístico, no fim do documento, salvo menção em contrário (menção de página no meio do documento).

8 "O dinheiro mais barato torna o investimento mais fácil". ROBINSON, Joan. The second crisis of economic theory. In: American Economic Review, v.62, n. 1/2, Março de 1972, p.4. ("Cheap money makes investment easier.")
} 
A figura abaixo mostra os resultados de endividamento externo líquido da economia norte-americana. Ela mostra a contraposição entre os resultados totais de conta corrente do B.P. (negativos desde 1982) com os resultados de conta de capitais, que cresceram mais do que estes resultados negativos na conta corrente. Se os resultados de conta corrente, e em especial os comerciais, são negativos, os resultados de conta de capital devem ser positivos. Isto expressa que o mundo está financiando diretamente as importações norte-americanas, e, indiretamente, o consumo e investimento norte-americano. Este aumento dos resultados positivos na conta de capital dos Estados Unidos se dão pelo aumento da posse de títulos denominados em dólar pelo mundo, principalmente ações e títulos do Tesouro norte-americano. A posse de ativos produtivos do mundo nos Estados Unidos pode ser considerado também como um componente do endividamento externo se se observa que a entrada deste tipo de investimento direto nos Estados Unidos implica num aumento dos recursos em conta de capital, que permite com que o nível de importações aumente no mesmo montante. A diferença entre papéis denominados em dólar e investimentos diretos em forma de ativos produtivos reside em seus diferentes graus de liquidez.

Gráfico 8. Estados Unidos. Endividamento líquido com o exterior. 1970-2006. Em bilhões de dólares. Resultados positivos haveres líquidos contra o exterior.

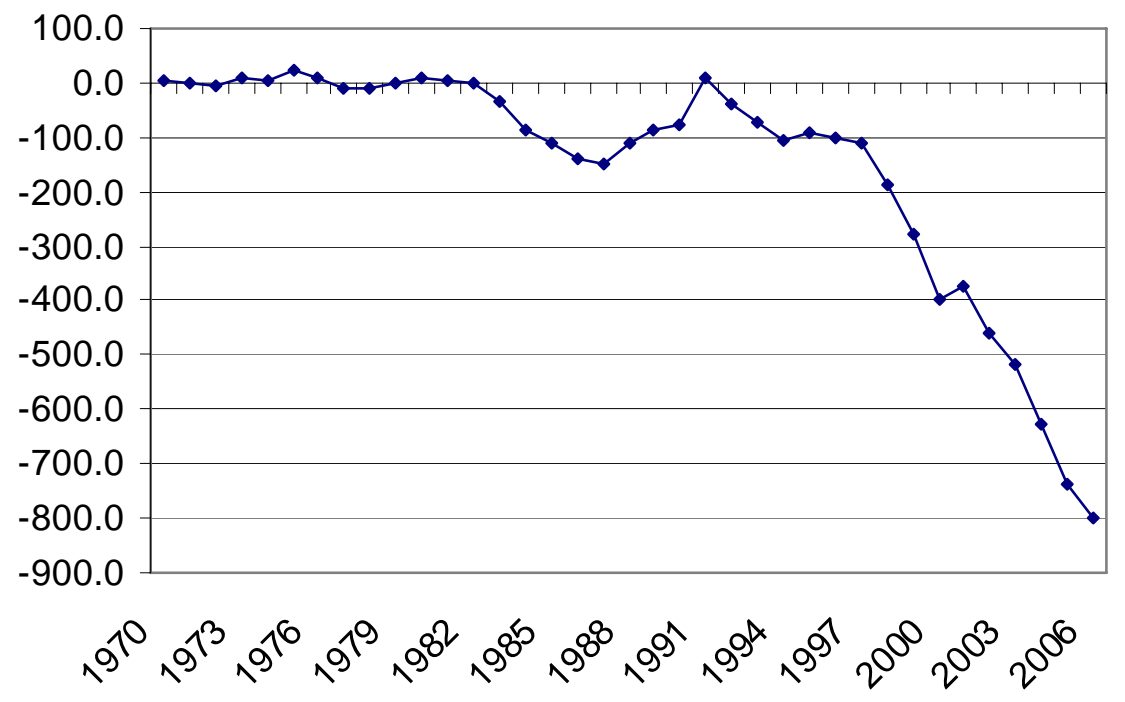

Fonte: NIPA-BEA. Seção 4, Foreign Transactions, Tabela 4.1, Foreign Transactions in the National Income and Product Accounts.

Assim, se se exclui o investimento direto produtivo, o endividamento externo norteamericano consiste (i) na emissão de títulos da dívida externa do governo federal; (ii) na captação pelas empresas norte-americanas de recursos na economia mundial, via emissão de ações e bonus (títulos que pagam juros); e (iii) na atração de recursos pelo sistema financeiro, também mediante empréstimos ao exterior. Na medida em que os bancos re-emprestam às famílias e às empresas, há um entrelaçamento entre (1) a dívida externa dos bancos, (2) a dívida externa do governo federal e (3) a dívida interna dos agentes que alavancam recursos nos 
bancos. O endividamento externo reúne então uma ampla gama de benefícios macroeconômicos: por parte do governo, permite-se ampliar sua capacidade de gastos, face a uma determinada base de arrecadação doméstica; a emissão de papéis corporativos ao exterior permite, em termos macroeconômicos, uma maior taxa de investimento relativa, sem pressionar o nível de consumo; e os haveres em dólar depositados pelo mundo no sistema financeiro norteamericano permitem, por sua vez, uma ampliação da capacidade de financiamento, principalmente do consumo das famílias.

Com efeito, foram os Estados Unidos, entre 1945 até o fim dos anos 19(70), a grande fonte de poupança da economia capitalista mundial, com grande colocação de investimentos diretos em outros países, como se nota a partir dos sinais negativos para as contas de capital nas duas tabelas. Os resultados líquidos do balanço de pagamentos também eram negativos, pela desproporção entre o resultado da conta de capitais (negativa) e da conta corrente (positiva). Neste momento os déficits foram financiados com reservas de ouro previamente acumuladas e endividamento com instituições financeiras internacionais, como mostra a tabela seguinte. As remessas de capital em forma de "auxílios não-militares" também contribuíam para tornar negativa a conta de capitais. Os investimentos diretos dos Estados Unidos no exterior eram em média cinco vezes maiores do que os investimentos diretos de outros países em seu território.

Após os anos (19)70, a situação externa dos Estados Unidos modificou-se estruturalmente, como se vê no gráfico acima. O país ingressou na situação de devedor líquido de capitais e importador líquido de mercadorias. Isto se traduziu na consolidação de déficits na conta corrente e em saldos positivos na conta de capitais do balanço de pagamentos (indicando sua posição de receptores líquidos de capital), processo que inverteu a situação precedente das duas contas do balanço de pagamentos entre 1945 e 1970. Quer dizer: ao longo dos anos (19)70, (19)70 e 19(90), o trajeto da poupança dos Estados Unidos indo ao exterior para financiar ali a compra de suas futuras exportações de bens e serviços deu lugar a uma nova situação, onde os Estados Unidos deixavam aos poucos de investir localmente cada vez maior parte seus recursos, repassando esta tarefa aos investidores de fora, que assim iniciaram reciclagem de seus saldos de exportação com o deficitário (comercialmente) Estados Unidos.

Longe de estabilizar-se, o endividamento externo cresceu e continua crescendo. Os ativos produtivos e financeiros detidos por agentes não-norte-americanos, no presente e com promessa de pagamento futuro, somavam já em 2004 praticamente todo o PIB. O objetivo deste trabalho é investigar então como o crescimento da economia no período se relacionou com tamanha inversão da posição externa do país. O crescimento da dívida diante do PIB pode ser visto a partir das duas equações de regressão estimadas no gráfico 7 acima. Ambas foram traçadas sobre PIB e dívida em bilhões de dólares correntes. Os coeficientes angulares de dívida e PIB, que medem o crescimento anual de ambos, são respectivamente 0,7017 e 0,4223 . Os ativos nos Estados Unidos em posse de estrangeiros ultrapassaram todo o Produto Interno Bruto de 2004. 
Isto pode ser notado quando se analisam as séries de investimento doméstico bruto, investimento doméstico líquido e empréstimos líquidos ao exterior para financiamento da taxa de investimentos. Segundo informa o Economic Report of the President de 2006, o investimento líquido em porcentagem do PIB é decrescente no longo prazo, com financiamento cada vez maior do exterior. O investimento líquido médio em porcentagem do PIB passou de $9 \%$ em 1959 para 8\% em 1970 e 1980, e para apenas 6\% nos anos (19)90. Seu financiamento desde fora do país chegou a mais de 70\% em 2004 (estava em 5\% em 1980). (Ver também gráfico abaixo.)

Em termos mais agregados, o gráfico na seqüência mostra os resultados de balanço de pagamentos desde os anos (19)60 até 2004. Indicam-se as variações reais, isto é, deflacionadas, das contas do balanço de pagamentos. Na primeira série, resultados de conta de capitais, vê-se o saldo entre a entrada e saída de recursos financeiros dos Estados Unidos, nas formas acima estabelecidas ( $a, b$ e c). A segunda série indica os saldos em conta corrente do balanço de pagamentos. Em primeiro lugar, nota-se que até aproximadamente 1982 os resultados de conta corrente do balanço de pagamentos superavam a conta de capitais. Os Estados Unidos foram assim exportadores líquidos de capital até aproximadamente (19)80. Durante as três décadas que sucedem 1945, os saldos positivos na balança comercial e o recebimento de lucros de suas corporações no exterior mais que compensaram as exportações de capital e remessas de lucro, royalties e outros pagamentos a partir de sua própria economia ao exterior.

A situação se inverte a partir de 1984, justamente quando o produto passava a crescer novamente, após a crise entre 1980 e 1982, na administração de Ronald Reagan (1981-1989). Entre 1982 e 1986 o hiato entre os saldos de conta de capital e conta corrente do B.P. elevou-se bruscamente, para diminuir até 1990. A partir deste ano, já na administração de George Bush (1989-1992) a discrepância entre a tomada de recursos no exterior e aqueles produzidos principalmente pelos saldos de exportações de bens e serviços elevou-se sem tendência de reversão.

\subsection{Proposta do trabalho e hipóteses}

Este trabalho busca então investigar o comportamento da economia norte-americana entre 1980 e 2004, enfatizando a relação entre o endividamento externo da economia e o comportamento dos agregados domésticos, à luz das seguintes questões: (1) por que se iniciou o endividamento externo da economia?; (2) por que se mantém?; (3) como o endividamento afetou o desempenho da referida economia? A proposta é investigar como o endividamento externo da economia norte-americana neutralizou as decorrências macroeconômicas estagnativas oriundas da tendência para a queda da taxa de lucros desde a década de (19)70.

A partir disto, afirma-se que a crise dos anos (19)70, aguçando a tendência para a queda dos lucros no setor industrial - com relação aos outros setores da economia - conduziu ao endividamento externo como uma resposta de caráter estabilizador da referida crise. Este 
movimento inicial rumo ao endividamento externo foi propiciado pelo então recente papel modificado do dólar no mundo, depois da crise do padrão de Bretton Woods: após a eliminação do ouro como divisa significativa sob o conceito das reservas internacionais, tal expediente do endividamento externo da economia norte-americana foi facilitado. Sendo instituído o dólar como única divisa de reserva, praticamente impôs-se à economia internacional a possibilidade quase ilimitada do endividamento externo norte-americano em sua própria moeda. Este expediente já era este existente antes da crise de Bretton Woods, mas não era utilizado sob forma sistêmica justamente porque o desempenho econômico do país mostrava-se muito mais satisfatório (maiores taxas de lucro conduzindo a maiores taxas de acumulação produtiva e maior produção relativa de excedente etc.).

Argumenta-se que a partir daí toda a estrutura econômica adequou-se ao endividamento externo, e que tal ajudou a postergar o processo de estagnação do crescimento ao qual a economia tendia, explicado pela referida queda relativa da acumulação produtiva, originada pela tendência para a queda da lucratividade, e aguçado pelo comportamento dos preços relativos desfavoráveis à indústria e pelos déficits comerciais (seção 4.7 a seguir). No entanto, observa-se que o endividamento externo não eliminou completamente a tendência à desaceleração, ocasionada por uma relação capital/produto no setor industrial norte-americano não bloqueada em sua tendência ascendente mesmo na presença do endividamento externo (seção 3.4. do capítulo 3). Quer dizer, o endividamento externo realmente compensou a baixa na taxa de investimentos produtivos com aportes de recursos adicionais de investimentos e de consumo ao longo do tempo, constituindo-se assim uma fonte de demanda efetiva adicional, direta ou indireta.

É verdade que o endividamento externo possibilitou baratear em parte os investimentos corporativos, com (i) aumento de emissões de ações para o exterior e (ii) aumento do financiamento dos investimentos domésticos mediante os recursos externos depositados no sistema financeiro local - ambos expedientes permitindo taxas de juros mais baixas do que as que haveriam se o endividamento externo não existisse. Do mesmo modo, o endividamento externo permitiu a queda relativa dos investimentos industriais com aumento do consumo do governo e das famílias financiados com recursos vindos de fora da economia. Porém, o endividamento externo não possibilitou uma reativação da taxa de lucro nos setores produtivos ${ }^{9}$ tal que conduzisse a uma elevação relativa dos investimentos industriais. Ou, o que é o mesmo, uma elevação da parcela do rendimento nacional em forma de investimentos produtivos. O endividamento externo apareceu assim, de forma resumida, como uma

\footnotetext{
${ }^{9}$ Os setores produtivos são assumidos, neste trabalho, como sendo os setores responsáveis pela produção física, ou material, de mercadorias: dentro da terminologia das Contas Nacionais norte-americana, considera-se o setor manufatureiro (manufacturing) o setor produtivo mais importante. Além dele, o setor de mineração (mining), e transportes (transportation), são considerados como setores produtivos - no caso do segundo, porque mantém o valor das mercadorias produzidas (de acordo com a definição de Marx em $O$ Capital, volume II). Os setores de comércio (trade), finanças (finance) e serviços (services) são considerados improdutivos. Os setores agrícolas são considerados produtivos, mas, dada sua posição dependente das induções dos setores industriais no processo geral de acumulação de capital, não ganham ênfase no estudo.
} 
compensação da queda dos investimentos industriais com aumento da capacidade de financiamento do consumo das famílias e dos gastos do governo. Representou uma fonte de demanda efetiva adicional e de barateamento dos recursos ao consumo e aos investimentos.

Assim, o crescimento a partir da década de (19)80 deu-se cada vez mais com a atração de capitais externos para a sustentação de parte crescente do volume de consumo e investimento. Expediente este que passou a ser cada vez mais necessário e aceito pelas autoridades - ainda que no discurso oficial já se percebessem as decorrências de manter-se sempre uma taxa de investimento maior do que a de poupança. Caso contrário, níveis de investimento e consumo mais baixos teriam de ter se dado, com menores níveis de crescimento. De fato, tamanha é a queda relativa do setor industrial nos Estados Unidos, por um lado; e tamanha foi a adequação do comportamento dos agentes à dívida, por outro, que mesmo quando a taxa de lucro nos setores industriais se recuperou da crise dos (19)70, passando a subir, o mecanismo de endividamento externo não foi suprimido. Continuou atuando, na verdade, com cada vez mais força. Isso indica que a economia teve parte crucial de crescimento às custas da dívida, portanto.

Sugere-se então a tese geral de que o endividamento externo da economia norteamericana compensou a tendência para o declínio, a partir da qual se têm as seguintes hipóteses a ela subjacentes.

1) Tendência para o declínio do crescimento do produto norte-americano para o periodo 1980-2004. Esta atribuir-se-ia primeiramente ao diferencial progressivo das taxas de lucro nos setores produtivos face a outros setores, processo que ocasiona uma mudança na estrutura da composição setorial do PIB.

Nos setores produtivos se dão as maiores taxas de relação entre capital e produto, ou de trabalho morto face ao vivo. Isto conduziu à diversificação da economia, com surgimento de muitos setores onde a produção física não é predominante, mas refletiu-se numa queda gradual da variação do produto. Porém, a crise das taxas de lucro no setor manufatureiro nos anos (19)70 aguçou este processo estrutural, e, pela sua rapidez, teria engendrado a necessidade do endividamento, mediante a política do dólar forte, para que a economia não ingressasse em longos anos de retração, pela queda dos investimentos corporativos e assim da demanda agregada global. Os choques do petróleo nos anos (19)70, em conjunção com as altas taxas de juros que lhe seguiram, provocaram uma rápida queda das taxas de lucro nos setores produtores, o que foi respondido por uma renovação do padrão produtivo. Tal esforço de renovação produtiva (a chamada Terceira Revolução Industrial), que visava a substituição do petróleo e seus derivados, teria conduzido as empresas pioneiras a uma compensação das perdas anteriores, mas na medida em que se generalizaram teriam levado a menores taxas de lucro globais (capítulo 2, seção 2.4.).

A reestruturação produtiva pós-fordista teria diminuído então os níveis de dependência do petróleo, mas agravado a disparidade entre o capital morto e vivo. A recente retomada 
ascendente dos preços do petróleo (2000 em diante) apenas tornou pior uma posição dos lucros que, ao longo dos anos (19)80, havia ganhado certo fôlego com a queda dos preços deste insumo. O capital produtivo tendeu a deslocar-se para áreas onde os gastos com capital variável fossem mais compensadores (leste-asiático, México etc.). (Capítulo 4, nas seções 4.2. e 4.3.)

2) Fatores adicionais teriam acentuado a sugerida diminuição da acumulação produtiva a partir dos impactos da crise do petróleo: (i) queda da participação da indústria no PIB, devido ao processo de diminuição de longo prazo dos custos na fabricação dos bens industriais, que teria provocado uma mudança nos preços relativos em favor dos serviços, como fator de mudança na pauta de consumo das famílias; (ii) substituição da produção doméstica por déficits comerciais crescentes; (iii) exportação de capital produtivo a outras nações. (Para (i), ver capítulo 2, seção 2.4; para (ii), capítulo 4, seção 4.6; e para (ii), capítulo 4, seção 4.4.)

Quanto a (i), a queda relativa dos preços dos manufaturados, explicada pelo processo de mecanização e automação dos processos industriais, teria conduzido a um aumento dos gastos das famílias em forma de serviços ao longo do tempo. Por sua vez, quanto a (ii), o aumento dos déficits comerciais, resultados do aumento do endividamento externo, outra pressão adicional sobre a produção doméstica teria surgido, na medida em que a importação de bens cresceu mais rapidamente do que a de serviços e bens intangíveis. Quanto a (iii), a exportação de capital teria sido estimulada pela queda da taxa de lucro industrial nos Estados Unidos ao longo do tempo. Os Estados Unidos exportariam capital produtivo porque este poderia ser aplicado mais lucrativamente em outros países.

Assim, ter-se-ia tornado cada vez mais difícil para o setor industrial norte-americano imprimir ao produto as taxas de crescimento verificadas entre 1950 e 1970, mesmo depois da recuperação da taxa de lucro após 1987. Isto porque esta recuperação teria sido relativa, quando comparada com o desempenho dos outros setores, cujos lucros cresceram muito mais rapidamente. Tal teria agravado ainda mais o problema do endividamento, porque se necessitou endividar cada vez mais externamente para que a economia mantivesse uma mesma taxa de crescimento, explicada - mesmo que a taxa de lucro na indústria se mantenha crescente - pela queda relativa dos impactos em valor da produção industrial no produto. Sugere-se que o endividamento teria levado a economia a obter um nível de investimentos, de gastos, e de capacidade de financiamento maiores do que os propiciados pelo nível de investimento produtivo doméstico, dada a taxa de lucros.

3) Queda da propensão a investir e financeirização. As cadentes oportunidades de investimento produtivo ano após ano explicariam a (i) queda da propensão a investir ao longo do tempo e (ii) a financeirização dos gastos por toda a economia, na medida em que as inversões produtivas fossem cada vez menos atrativas. De fato, quanto a (ii), não se pode compreender a "bolha" dos anos (19)90 sem uma perspectiva que deixasse ver a financeirização 
dos próprios ativos produtivos (Chesnais). ${ }^{10}$ (Para (i) e (ii), ver seção 4.8 do capítulo 4, e para (iii) novamente a seção 4.3.) Quer dizer, os Estados Unidos teriam se tornado importadores de capital para financiamento dos gastos e investimentos com depreciação, mas não abandonaram a exportação de capital manufatureiro.

Neste sentido, o caso é que ao mesmo tempo em que importariam capital para manter o consumo e os investimentos (em forma principalmente de depreciação do capital), os Estados Unidos estariam exportando capital produtivo, para áreas onde os custos são menores em termos de fator trabalho, de acordo com a lógica de atuação das empresas transnacionais. Esta estabeleceria as atuais condições da Divisão Internacional do Trabalho. Com efeito, no que toca a (i), o comportamento ruim dos lucros na maior parte dos setores e a queda da propensão a investir permitiriam compreender a necessidade da contribuição do financiamento externo aos investimentos e consumo domésticos.

Gráfico 9. Estados Unidos. Bonds e Ações de corporações norte-americanas detidos por estrangeiros e investimento bruto doméstico privado. Em dólares correntes. 1976-2004.

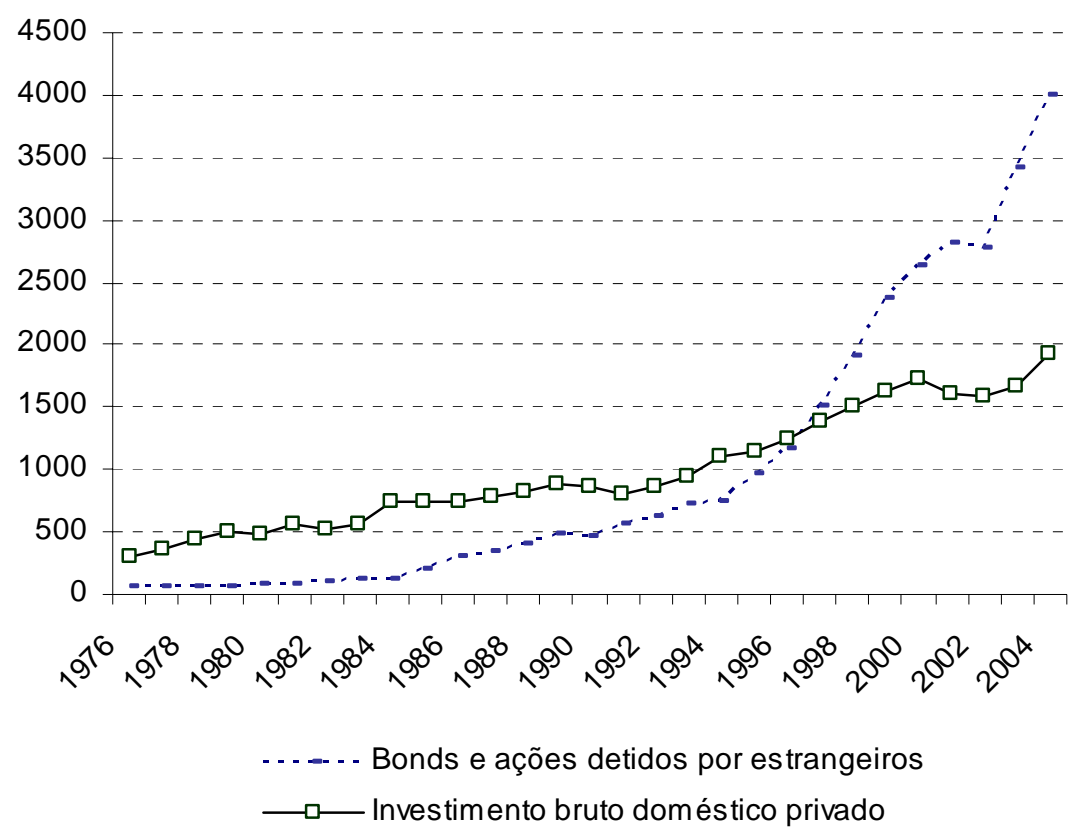

Fonte: Economic Report of the President, vários números. Para bonds e ações, foram utilizadas as Tabelas International Investment Position of the United States at year-end, na seção International Statistics (linhas Corporate Bonds and other bonds e Corporate Stocks). Para investimento bruto doméstico privado, foi utilizada a primeira tabela, B-1, do apêndice estatístico de 2006, Gross Domestic Product, 1959-2005.

Quanto às firmas privadas domésticas, se os lucros têm comportamento estagnativo, isto é, a taxa de poupança das corporações (na expressão de Kalecki) tem tendência cadente, as disparidades entre (i) a necessidade de expansão do capital e (ii) a lucratividade subjacente teriam se tornado cada vez mais amplas, explicando a recorrência ao financiamento externo da economia. O fato de que uma economia financia crescentemente parte de seus investimentos

${ }^{10}$ Cf. CHESNAIS, François, A finança mundializada, 2005. 
locais com recursos do exterior, expresso no aumento do endividamento externo global da economia, indicaria que ela recebe do exterior recursos adicionais para tais investimentos e consumo. Dada uma queda constante da taxa de lucro, um menor volume de recursos iria ser invertido, e indiretamente consumido; o endividamento externo seria deste modo uma fonte adicional de financiamento e demanda efetiva. Com menor crescimento da taxa de lucro nos setores produtivos, as empresas não investem tanto como numa situação onde a taxa de lucros fosse maior.

Daí, na situação realmente existente do comportamento menos dinâmico dos lucros, o volume de investimentos ao longo do tempo, assim como o volume de consumo das famílias (que depende do nível de investimentos) seria menor. Este impasse, no caso dos Estados Unidos, estaria sendo rompido pela captação de recursos externos. Estes representariam uma adição ao volume de investimentos e consumo gerados pelos investimentos correntes, assim como uma adição ao volume de recursos que podem financiar mais consumo e investimento futuros. Não se vai negar que, em termos keynesianos, o investimento pode financiar-se a si mesmo. Porém, não se pode negar que o aumento do endividamento externo facilita os mecanismos de financiamento dos investimentos privados, do consumo das famílias e mesmo dos gastos públicos, representando uma fonte adicional de demanda efetiva, particularmente no caso das compras do governo federal. (Ver seção 3.4 do capítulo 3.)

4) Papel contracíclico do endividamento externo. Dado que a poupança doméstica poder-se-ia definir como a poupança agregada menos o nível de aporte de recursos estrangeiros num momento dado, poder-se-ia arrolar outra hipótese: a de que, durante as flutuações negativas, o montante da poupança externa aumentaria na poupança doméstica total (do qual aquela faz parte), para contrabalançar a flutuação. A poupança agregada contém o endividamento externo, por definição. Principalmente por parte do governo, sugere-se que durante todas as flutuações do período ora considerado, o nível de captações no exterior teria aumentado, durante as baixas cíclicas. O mesmo teria ocorrido com os setores privados. Isto porque, dada uma contração doméstica no mercado de capitais, seria mais fácil às firmas e ao governo aumentarem o volume de captações de estrangeiros, devido ao aumento das dificuldades relativas surgidas no mercado local - principalmente no que toca à escassez relativa das fontes de financiamento durante a baixa. (Para esta hipótese, ver especificamente os itens "papel do endividamento" em cada um dos capítulos 6,7,8 e 9, na parte referente à análise empírica.)

Quais seriam as vantagens deste mecanismo? Ocorre que quando o cômputo da poupança externa aumenta na poupança agregada, pressionar-se-ia relativamente menos a capacidade de financiamento local, assim como a capacidade de consumo e de investimento. $\mathrm{O}$ expediente evitaria assim diminuições relativas da utilização da capacidade instalada no médio e longo prazo. Particularmente para a atuação do governo, dado um volume de investimentos produtivos em queda e uma ascendente expansão do produto, surge um hiato crescente entre as 
necessidades fiscais do governo federal e a capacidade dos agentes domésticos em financiá-las. Dada a queda dos investimentos produtivos, isto se reflete nas contas do governo, estimulando a emissão de papéis ao exterior para manter seus gastos correntes, e rolar a própria dívida, sem precisar elevar no curto prazo a arrecadação local. Como o produto tende no longo prazo à "reprodução simples", o papel do governo federal em incorrer em déficits tem sido cada vez mais marcante, chegando a notáveis patamares na crise de 2008-2009.

Gráfico 10. Estados Unidos. Porcentagem (\%) da dívida federal detida por estrangeiros (oficiais e privados). 1970-2003.

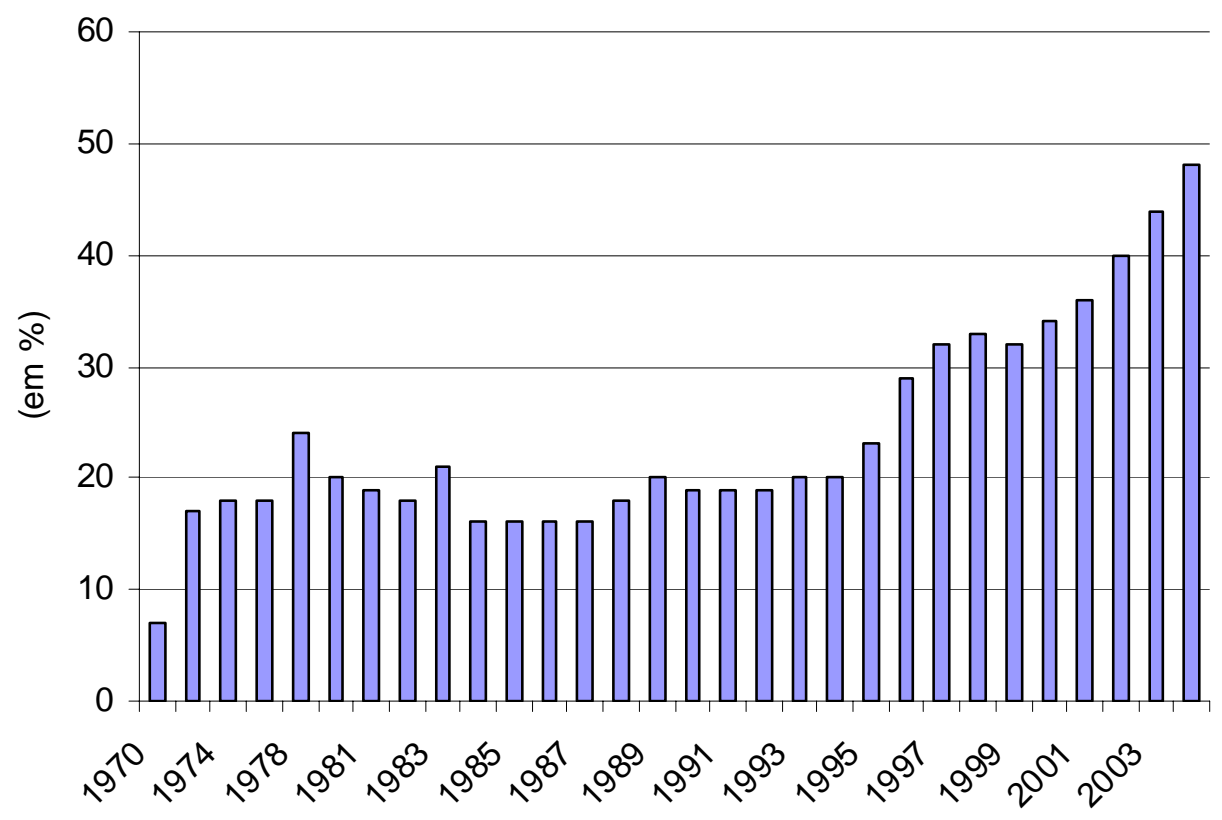

Fonte: Economic Report of the President, vários números. A tabela é International Investment Position of the United States at year-end, na seção International Statistics. Calculados a partir das linhas "Government Securities" e "Other U.S. government liabilities" na sub-seção "Foreign official assets in the United States" (Ativos oficiais estrangeiros nos Estados Unidos) e da linha "U.S. Treasury Securities" na sub-seção "Other Foreign Assets" (Ativos privados estrangeiros nos Estados Unidos).

A contrapartida seria o aumento do endividamento, particularmente do governo, como um dos componentes do endividamento externo global, como se vê no gráfico 10. A tendência cumulativa desta estratégia, mostrada na figura acima, sugeriria a crescente dificuldade em combinar a continuação dos gastos do governo - com base numa arrecadação meramente doméstica - e o próprio desempenho da economia. E isso não poderia ser diferente num ambiente onde o capital exerce forte influência sobre a política econômica no sentido de evitar aumentos nos tributos sobre os lucros, e onde a tendência para a estagnação força o governo a favorecer o consumo, mediante mais déficits orçamentários.

5) Insuficiência dos impactos positivos das novas tecnologias. Os gastos com novas tecnologias e capital fixo estariam sendo insuficientes, por si mesmos, como fatores 
compensadores das tendências estagnativas. Antes, agravariam-na no longo prazo, quando estivessem universalizadas. Mesmo as inversões nos setores pioneiros mais lucrativos não teriam sido suficientes para impulsionar a economia a patamares de variação do produto maiores do que no período anterior à crise dos anos (19)70. Kalecki observou que um dos efeitos do progresso técnico sobre o crescimento é que ele mantém elevados os incentivos a investir. ${ }^{11}$ Sem dúvida, o progresso técnico esteve sempre presente ao longo do período referido, mas sem impedir o que Kalecki classificou como uma impossibilidade de "tomar-se por suposto o crescimento auto-sustentado da economia capitalista". Como ele observou em outro momento, o progresso técnico "não assegura uma satisfatória utilização do equipamento a longo prazo". ${ }^{12}$ (Para esta hipótese, ver especificamente o capítulo 9.) O processo não tem sido suficiente para compensar os outros desestímulos às inversões produtivas domésticas, e pode-se mesmo dizer que, dada a exportação de capital produtivo a partir dos Estados Unidos, seus impactos estimulantes acabam por se dar mais fora do que dentro da economia norte-americana.

6) Centralidade da indústria de guerra. Como afirma Joan Robinson, "a coisa mais conveniente para um governo é gastar é em armamentos". ${ }^{13}$ A influência do complexo industrial-militar nas políticas do governo determina que as políticas do governo, facilitadas pelo endividamento externo, manipulem as inversões no setor da economia de guerra como elemento anticíclico. Tal presença e influência do setor militar nas políticas do governo, muito anterior ao endividamento externo da economia (datando principalmente da Segunda Guerra Mundial [1939-1945]), explica porque as políticas do Estado norte-americano assumiriam, nestas condições do endividamento externo da economia, a feição de políticas militaristas. A influência do complexo industrial-militar na sociedade torna saídas militares politicamente mais aceitáveis, onde o apelo ao nacionalismo e à "segurança nacional" contra supostos inimigos estrangeiros é o primeiro mote de qualquer administração no poder. Ela tem ainda a vantagem de suspender as "condições normais" das regras do jogo (Joan Robinson), de predomínio dos setores civis, dadas pelos limites do mercado consumidor doméstico. Os saques ao exterior e a necessidade constante das inversões no setor da economia de guerra, que somam quase $40 \%$ dos gastos do governo federal, explicam assim, nas condições do endividamento externo, a continuidade do corte imperialista da política econômica norte-americana. O resultado é a manutenção da importância do setor de economia de guerra na renda local. (Ver especificamente a análise empírica feita nos capítulos 6,7 e 10, para utilização da indústria de guerra como elemento anticíclico.)

\footnotetext{
${ }^{11}$ Um teorema sobre o progresso técnico, p.120. Em: Kalecki - Coleção Grandes Cientistas Sociais (Jorge Miglioli org.).

${ }^{12}$ KALECKI, Michal. As equações marxistas de reprodução e a economia moderna. In: Crescimento e Ciclo das Economias Marxistas, p.8.

${ }^{13}$ The second crisis in economic theory. In: American Economic Review, v.62, n.1/2, Março de 1972, p.6. ("The most convenient thing for a government to spend is on armaments.")
} 
Portanto, o rompimento da lógica do endividamento externo não se daria, neste ínterim, sem forte diminuição no ritmo de atividade, de utilização da capacidade instalada. Quer dizer, o apelo ao endividamento externo seria uma resposta à queda das taxas de lucro em muitos setores industriais, e do conseqüente menor crescimento da economia, funcionando como um fator contra-balanceador que diminui os impactos do crescimento tendencialmente menor para todos agentes. O governo federal (i), com gastos cada vez maiores em armamentos nos anos (19)80, viu-se premido entre seus gastos e capacidade de recolhimento interno dos recursos necessários para tal. A tomada de recursos de fora da economia norte-americana viria como uma resposta a este hiato (ver seções empíricas dos capítulos 6, 7, 8, 9 e 10). Por sua vez (ii), a emissão de ações e bônus externos teria permitido um financiamento mais rápido e barato, que substituiria em parte a necessidades dos próprios lucros internos como meios de alavancarem investimentos. A taxa de poupança das empresas, para Kalecki a variável determinante da função-investimento, pôde assim beneficiar do crédito abundante vindo de fora do país - na ausência de uma taxa de poupança doméstica adequada para financiar os investimentos que permitiram o produto crescer à velocidade de fato verificada. Quanto às famílias (iii), o crédito abundante permitiria um enorme nível de endividamento paralelo a patamares baixíssimos de poupança. Pressionar o consumo das famílias em nível máximo teria permitido aos setores manufatureiros e nãomanufatureiros lograrem taxas de utilização da capacidade instalada que na ausência do endividamento teriam sido muito menores - afetando conseqüentemente o desempenho da taxa de investimentos.

$\mathrm{Na}$ ausência do endividamento, os fatores explicativos da persistência da estagnação teriam então atuado com muito mais força. $\mathrm{O}$ endividamento externo consistiria numa "fuga para frente", mantendo de modo cada vez mais dependente o consumo e investimentos presentes com base na emissão de papéis cada vez mais rápida, para pagamento num momento futuro. Isto se verificaria, portanto, pelo crescimento da dívida numa velocidade mais rápida do que o crescimento do próprio Produto Interno Bruto, tal como observado acima.

\subsection{Justificativas}

O estudo histórico-econômico dos agregados pode levar a perspectivas mais abrangentes e objetivas do que a análise do curto-prazo podem trazer. Indagar sobre o crescimento econômico contemporâneo norte-americano, enfatizando as contrapartidas para os agregados domésticos não só da política econômica local mas também das relações comerciais e financeiras com o resto do mundo, pode esclarecer aspectos até então obscurecidos por análises parciais, que não levem em conta os interesses da maioria dos trabalhadores, ou que sequer os leve em conta, explicita ou implicitamente.

Já se demonstrou urbi et orbi como as políticas patrocinadas pelos Estados Unidos na América Latina e outras regiões nos anos 19(90), sob a roupagem da globalização, repercutiram em conseqüências sócio-econômicas bastante negativas para estas, com perda do controle das 
variáveis macroeconômicas, colocação de capital no exterior, desnacionalizações, e um crescimento sem precedentes do desemprego. Isso chegou a levar à ruptura do tecido social em muitas localidades. Abordar o modelo acumulativo norte-americano é de interesse à análise social e ao debate contemporâneo, podendo contribuir para questões-chave sobre a política econômica atual e sobre o modo pelo qual o Brasil tem se inserido na economia mundial, dado que as políticas que os Estados Unidos patrocinaram para a América Latina não são de modo geral seguidas por este país. Quer dizer, os Estados Unidos não praticam o superávit da balança comercial; não praticam superávits de contas públicas; o Estado investe maciçamente no fomento de novas tecnologias e no militarismo; a economia norte-americana, ainda a maior do planeta, mantêm cada vez mais sua reprodução com recursos advindos de países muito mais pobres; etc.. Ora, justamente, se a economia norte-americana cresce menos mas cresce com recursos do restante da economia mundial, isto não denota então uma aproximação entre eles e a periferia, mas sim uma maior transferência indireta de custos à última

Como escreveu Joseph Stiglitz sobre sua participação na administração dos Estados Unidos nos anos (19)90, durante o governo Clinton:

Especialmente estranho era o contraste entre os paliativos do governo Clinton para o exterior e as batalhas travadas internamente. Em nosso próprio país, defendíamos nossa Seguridade Social pública contra a privatização, enaltecendo seus baixos custos de transação, a renda segura que propiciava, como ela havia praticamente eliminado a pobreza entre os idosos. No exterior, incentivávamos a privatização. Internamente, argumentávamos energicamente que o Fed deveria dirigir sua atenção para o crescimento e o desemprego, bem como para a inflação - com um presidente eleito cuja plataforma se apoiava na criação de empregos, era o mínimo que podíamos fazer. No exterior, instávamos os bancos centrais a se concentrarem exclusivamente na inflação. ${ }^{14}$

Assim, é de importância fundamental à América Latina a construção de estudos comparativos com economias que vêm apresentando resultados superiores. Eles permitem: a) compreender melhor os processos econômicos internos a estas economias, por contraposição, e b) compreender melhor o modo pelo qual estas economias têm se inserido no ambiente internacional, assim como (c) os impactos a partir desta inserção. Uma questão central para a qual conduz este estudo é: são justificáveis as crescentes colocações de capital numa economia que já é imensamente mais rica que muitos dos países periféricos juntos, que ajudam a sustentar este processo de endividamento externo? A partir desta e outras indagações, a leitura do discurso oficial das autoridades internacionais e a contraposição deste discurso com as práticas efetivas reais certamente representam ganhos e lições para futuras recomposições da posição da América Latina e do Brasil no cenário econômico mundial.

${ }^{14}$ STIGLITZ, Joseph. Os exuberantes anos 90, p.51. 


\subsection{Pressupostos teórico-metodológicos}

A base teórica deste trabalho apoia-se numa perspectiva marxista de interpretação estrutural do movimento econômico, tomando-se a obra de Kalecki como uma tradução para a linguagem da moderna macroeconomia dos postulados do campo marxista. Adota-se também a terminologia keynesiana e robinsoniana para a interpretação das flutuações conjunturais e das inter-relações entre os agregados, sempre quando ela efetivamente não entre em contradição com o quadro teórico marxista adotado, nem com suas conclusões, mas sim contribuindo para enriquecê-lo. ${ }^{15}$ Evidentemente, buscou-se evitar o enfrentamento de problemas colocados pelos "neokeynesianos", mantendo-se o "núcleo duro" da metodologia macroeconômica original para fins de análise do comportamento da economia sob um determinado tipo de política econômica. Deste modo, citando Eric Roll, a adoção desta perspectiva de interpretação enquadrar-se-ia dentro das análises contemporâneas que "conservam muito da teoria keynesiana", ${ }^{16}$ aqui adotadas quando elas podem auxiliar as inferências da teoria marxista.

Quanto à metodologia de abordagem dos agregados, combinaram-se os seguintes ramos de enfoque do trabalho do historiador econômico: (a) análise de séries cronológicas; (b) contabilidade nacional; (c) processamento econométrico empírico de modelos, além da (d) análise macroeconômica dos agregados da contabilidade nacional, sob os referidos marcos teóricos. Destacam-se nestes procedimentos o exame das principais fontes oficiais existentes, sendo elas os Economic Report of the President (vários anos), os Federal Reserve Flow of Funds Accounts, as tabelas do Bureau of Economic Analysis, além do World Economic Outlook da OCDE e outros documentos do Fundo Monetário Internacional.

Particularmente, as seguintes pressuposições nortearam a abordagem do período de estudo para a economia dos Estados Unidos:

(1) As sucessivas elevações do Produto Interno Bruto dos Estados Unidos não poderiam ser enfocadas sem que considere a participação da poupança externa na (a) contribuição para a taxa de investimento doméstica e (b) para financiar suas importações. Tal posição privilegiada é tributária da vantagem do poder liberatório do dólar na economia internacional, nascido das transformações iniciadas a partir da década de (19)70 (fim do padrão dólar-ouro).

(2) Tal posição destacada da economia norte-americana permite uma condução autônoma das políticas monetárias e fiscais domésticas e possibilita contornar os efeitos negativos do comportamento instável das taxas de lucro e do crescente poder das instituições financeiras em se assegurar do excedente econômico;

\footnotetext{
${ }^{15}$ Não se comparte, particularmente, da leitura que Joan Robinson faz da lei da tendência para a queda da taxa de lucro marxista no capítulo "A taxa decrescente de lucro" de sua obra Economia Marxista.

${ }^{16}$ Historia de las Doctrinas Económicas, p.559.
} 
(3) A atuação internacional dos Estados Unidos se dá nas condições de hegemonia de uma única superpotência, onde as "potências de segunda ordem", e a periferia capitalista, têm para com ela laços de dependência. Esta relação "hegemônica" compõe o elemento fundamental para a compreensão dos destinos do excedente econômico mundial atual. A recente política econômica externa norte-americana combina assim traços da exportação de capital e a abertura de novos mercados, típicos do imperialismo, com uma nova política de atração da poupança mundial que vem financiar seus investimentos e seus gastos domésticos, que estaria de acordo com a relação de forças existente entre uma superpotência que impõe o uso de sua moeda ao restante das economias nacionais.

(4) O crescimento da economia norte-americana no período poderia ser enquadrado então dentro de um modelo de crescimento baseado na dívida externa, cujas principais características seriam: (a) déficits comerciais consolidados com o exterior, como resultado da contínua atração de recursos, expressa no superávit da conta de capitais; (b) déficits fiscais do governo federal, permitidos pelo endividamento externo e necessários como elementos de manutenção da demanda agregada; (c) o crescimento relativo e absoluto cada vez maior do consumo das famílias em detrimento dos investimentos em ampliação da capacidade como elemento de manutenção da demanda agregada, expressando os desestímulos ao crescimento do setor industrial; (d) queda consolidada da taxa de poupança das famílias no longo prazo, necessária como elemento de manutenção da capacidade instalada e pelo endividamento externo, com anuência da política econômica.

Logo, a hegemonia dos Estados Unidos expressou-se até o momento na capacidade de fazer o exterior aceitar o abandono do ouro como lastro do sistema financeiro internacional pela adoção pura e simples de papéis e ativos denominados em dólares. Os limites para que o exterior continue aceitando papéis denominados em dólar, no lugar de algum outro representante de valor internacional, podem ser talvez melhor conhecidos a partir das inferências deste estudo.

\subsection{Estrutura dos capitulos}

Uma palavra sobre a divisão dos capítulos. No próximo capítulo aborda-se o problema da lei tendencial da queda da taxa de lucro e suas decorrências para a interpretação do movimento de longo prazo da economia norte-americana. No capítulo 3, aborda-se a reprodução do capital social global, dada a lei tendencial da queda da taxa de lucro, e o endividamento externo da economia, mostrando-se como estão correlacionados. Segue-se no capítulo 4 uma análise empírica. 
Nos capítulos de abordagem histórica das sucessivas conjunturas, volta-se primeiramente à crise do Padrão de Bretton Woods (1971-73) e à construção - ou antes aprofundamento - do papel conferido ao dólar na economia mundial em 1945, expediente pelo qual os Estados Unidos puderam levar à frente a estratégia do endividamento externo como um indutor fundamental para seu desempenho doméstico. Nos capítulos dedicados às duas administrações de Reagan, investiga-se como as políticas econômicas lidaram com a crise vinda da década passada, e como foi crescendo a percepção das autoridades no que se refere à dependência dos Estados Unidos da poupança externa. No capítulo sobre o governo de George Bush (pai), verifica-se como, mesmo com a inversão do comportamento da taxa de lucro, que iniciava novo período ascendente, a economia não iria se comportar de modo estável.

A análise das conjunturas deste trabalho termina no primeiro governo Clinton. Aí se busca mostrar como as variações positivas do produto não puderam se dar sem um correlato aumento do endividamento externo. De fato, a aparente elevação da taxa de lucro na indústria para um patamar maior do que o período prévio ao da crise dos (19)70 não conduziu a um crescimento maior nem sustentado, à luz das variações históricas do produto, devido à (1) permanente ascensão dos lucros financeiros e (2) ao tipo de crescimento em que dita elevação se assentou - uma bolha no mercado acionário, tal como a literatura amplamente demonstrou. Buscou-se, deste modo, evitar incorrer nas análises que a literatura já fez de modo exaustivo dos outros aspectos do período Clinton: a formação da bolha, as fraudes empresariais, o processo de desregulamentação dos investimentos, o modo como o Fed permitiu a formação da bolha etc..

Para estes aspectos específicos já existe uma literatura abundante para a qual este trabalho não tem mais como contribuir. Respeitam-se com isso, ao mesmo tempo, os limites da investigação nele estabelecidos - o de ser um estudo a partir dos agregados macroeconômicos fundamentais. Evita-se assim que o trabalho aborreça o leitor com um aumento de seu volume devido a conclusões às quais já se chegou alhures, independentemente da orientação teórica que busque abordar tais fatos: o aumento do endividamento das famílias e empresas, as fraudes corporativas, o papel do Fed em inflar a bolha, assim como a bolha em si, não podem ser negados por nenhum autor. Contorna-se uma mera repetição da literatura, um perigo atribuído ao fato de que o tema da economia norte-americana é muito amplo e muito estudado na pesquisa internacional. Evita-se a infinidade de citações e repetições do que já se sabe, sem que se avance em nada em relação ao que outros já disseram.

Deste modo, a análise dos principais agregados referentes ao crescimento do primeiro governo Clinton, assim como o balanço feito na conclusão com a análise do perfil do endividamento externo nos últimos dez anos (2000-2009) permite comprovar as previsões traçadas para os capítulos anteriores, de modo que ela é suficiente para demonstrar parte das hipóteses deste estudo: a permanência da queda do investimento produtivo, o aumento ainda mais rápido do endividamento externo. Além disso, este autor, em conjunto com outros, analisou paralelamente, em diferentes trabalhos, o período mais recente do comportamento da 
economia norte-americana (2000-2009), chegando às mesmas conclusões derivadas deste trabalho. ${ }^{17}$

Fecha-se a análise empírica do trabalho com um comentário sobre a brecha entre PIB e PNB para os Estados Unidos, assim como sobre o comportamento dos principais agregados macroeconômicos da economia nos últimos dez anos (2000-2009). Na conclusão, retomam-se os resultados obtidos.

17 Alguns destes artigos foram reunidos no livro Ensaios sobre a economia dos Estados Unidos, 19802004 (ver bibliografia). 


\title{
Desaceleração e taxa de lucro
}

\begin{abstract}
"Se em uma comunidade potencialmente rica o incentivo para investir for fraco, a insuficiência de demanda efetiva a obrigará a reduzir sua produção real até que, a despeito de sua riqueza potencial, ela se torne tão pobre que os excedentes sobre o consumo diminuam até chegar ao nível correspondente de seu fraco incentivo a investir."

John Maynard Keynes, A Teoria Geral do Emprego, do Juro e da Moeda
\end{abstract}

\subsection{Introdução}

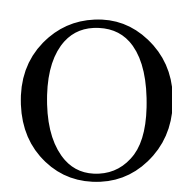

capítulo está estruturado sob a seguinte divisão: primeiramente se faz um comentário sobre diferentes perspectivas teóricas acerca do comportamento recente da economia norte-americana e sobre as causas da crise dos anos (19)70. O comentário da literatura é então complementado por uma apreciação teórica sobre (i) o papel da taxa de lucro nos setores manufatureiros, tomados como o setor decisivo para a obtenção do crescimento da economia. Prepara-se o terreno para a discussão, feita no capítulo seguinte, sobre as condições em que se pode dar a tendência à reprodução simples do capital social, com base na perspectiva de Michal Kalecki.

\subsection{Algumas opiniões}

O comportamento da economia norte-americana entre a década de (19)70 e o início do novo século XXI vem sendo estudado por muitos autores. Há entre muitos um diagnóstico pessimista, acerca das possibilidades de um crescimento maior, e do modo como a economia obteve seu crescimento recente efetivo com base em grande parte no endividamento externo. Basicamente, as duas variáveis centrais para tal diagnóstico pessimista seriam justamente (1) o fato de que a economia conheceu uma diminuição absoluta das massas de lucro auferidas na maior parte dos setores manufatureiros a partir da segunda metade da década de (19)70 até os anos (19)90; e (2) a transformação da economia em devedora do exterior, no mesmo período. É fundamentalmente este comportamento estrutural que se vai discutir neste capítulo, para apenas depois partir-se para a investigação das flutuações de curto e médio prazos. Estas não expressam diretamente a atuação da queda tendencial da acumulação produtiva na economia nacional, mas sim outros mecanismos macroeconômicos (política econômica, "choques exógenos" etc.).

Como se viu na introdução, de fato, depois de deflacionados seus valores, a maior parte dos setores manufatureiros norte-americanos apresentou diminuição absoluta dos lucros auferidos após 1975, quando tomado o período 1948-2000 como um todo. Como os setores 
industriais são os responsáveis diretos pelo crescimento da economia, a diminuição relativa e/ou absoluta dos lucros em seus setores indica menores possibilidades de inversão produtiva, o que conduziu a um crescimento menor. Por outro lado, o diagnóstico quase sempre comum entre os avaliadores é o de que o crescimento baseado na atração de recursos externos é insustentável no longo prazo, com uma crise no dólar avizinhando-se, e uma necessária reorganização dos parâmetros macroeconômicos, com ainda menor crescimento.

Immanuel Wallerstein é um dos autores mais conhecidos no estudo da economia mundial. São conhecidas suas opiniões de que a hegemonia norte-americana está em queda progressiva desde o fim da guerra do Vietnã (1959-1975), e do que os problemas enfrentados na ocupação do Iraque apenas espelham isto. De um ponto de vista econômico, ele assim caracteriza as raízes do declínio norte-americano, em seu artigo Entering global anarchy, publicado no volume 22 da New Left Review de Julho-Agosto de 2003:

"Declínio na lucratividade das empresas produtivas - especialmente aquelas que antes tinham sido as mais lucrativas - e uma conseqüente mudança de foco dos capitalistas da arena da produção para a da atividade especulativa financeira; uma fuga das indústrias cujos lucros estão declinando - pela desaparição de suas vantagens monopolísticas - das zonas principais para as periféricas dos países 'em desenvolvimento', onde os salários são mais baixos mesmo que os custos de transação sejam mais altos; uma significativa elevação nos níveis de desemprego mundiais, e portanto um esforço de pelos principais lugares [loci] de acumulação para exportar desemprego uns aos outros, em grande parte para minimizar falhas políticas." 18

Paul Kennedy, em 1993, no auge do que parecia ser a indestrutível hegemonia norteamericana, discutia abertamente a transição do poderio norte-americano inconteste para uma situação mais horizontal no mundo, na obra Preparing for the Twenty-First Century. Segundo ele, apesar de os padrões norte-americanos de vida necessariamente permanecerem ainda por um bom tempo como os mais elevados do mundo, era inevitável reconhecer que a economia mundial crescia mais rápido. $\mathrm{O}$ autor fez neste estudo um balanço dos pontos onde os Estados Unidos ainda tinham uma vantagem incontestável face aos outros países desenvolvidos, e dos pontos onde tal vantagem desaparecia. Segundo sua perspectiva teórica, porém, o destino do

\footnotetext{
18 "Decline in profitability of productive enterprises - especially those that had previously been most profiTabela - and a consequent shift in focus by capitalists from the arena of production to that of speculative financial activity; a flight of industries whose profits are declining - because their monopolistic advantages disappeared - from the core zones to semiperipheral 'developing countries', where wages are lower even if transactions costs are higher; a significant rise in world unemployment levels, and therefore an effort by the major loci of accumulation to 'export' unemployment to each other, in large part to minimize political fallout." Entering global anarchy, New Left Review, n.22, p.30.
} 
país dependia em primeiro lugar do tipo de condução política pela qual seria governado nos próximos anos:

"Resta ver, portanto, se as abordagens tradicionais vão levar o povo [norte]americano com sucesso ao século XXI, ou se elas vão pagar um alto preço por crer que as coisas podem continuar as mesmas em casa enquanto o mundo lá fora muda mais rapidamente do que nunca." 19

Richard Duncan, que estudou de perto a estrutura da dívida externa norte-americana, sob o ponto de vista do economista e não do historiador econômico, observou em The Dollar Crisis que...

"Os déficits em conta corrente dos Estados Unidos estão se aproximando de 5\% do PIB e estão acelerando. É somente questão de tempo antes que se torne impossível para os Estados Unidos continuar aumentando seu endividamento em relação ao resto do mundo a uma taxa de 5\% do PIB ao ano. Neste ponto, os países com superávits no balanço de pagamentos serão forçados a converter seus excedentes em dólar em suas próprias moedas, causando uma brusca apreciação destas moedas e um grande declínio no valor do dólar. Esta mudança vai ajudar a restaurar o equilíbrio no balanço de pagamentos dos Estados Unidos, mas vai também jogar os principais exportadores em recessão assim que suas exportações para os Estados Unidos colapsarem.” 20

Por sua vez, Jorge Beinstein, que buscou - em El capitalismo senil - La larga Crisis de la Economía Global - avaliar criticamente a situação da economia capitalista mundial contemporânea, observa a posição dos Estados Unidos também criticamente. Tal como Duncan, Beinstein sugere que o crescimento com base na dívida assenta-se numa possível deterioração do valor do dólar na economia internacional.

\footnotetext{
19 "It remains to be seen, therefore, wheter traditional approuches will carry the American people successfully into the twenty first century - or wheter they will pay a high price in assuming that things can stay the same at home while the world outside changes more swiftly than ever before." Preparing for the Twenty-First Century, p. 325.

20 "The U.S. current account deficit is approaching 5\% of GDP and accelerating. It is only a matter of time before it will become impossible for the United States to continue increasing its indebteness to the rest of the world at the rate of 5\% of GDP per year. At that point, the countries with balance of payments surpluses will be forced to convert their dollar surpluses into their own currencies, causing a sharp appreciation in their currencies and a sharp decline in the value of dollar. That shift will help restore equilibrium to the U.S. balance of payments, but also it will throw the major exporting nations into recession as their exports to the United States collapse." DUNCAN, Richard. The Dollar Crisis, p.63-64.
} 
"A sociedade americana, o Estado, os consumidores, as empresas, [que] dependem de forma crescente de mercadorias e fluxos monetários externos, parasitam sobre o sistema global através de um jogo duplo: por um lado o planeta sustenta o mercado norte-americano, motor da demanda mundial. Se ele chegasse a afundar, arrastaria ao desastre toda a economia internacional. Por outro lado, este escoramento do gigante enfermo amplia seus aspectos parasitários (dívidas, déficits, especulação financeira etc.), o que conduz a um irresistível horizonte de crise." ${ }^{21}$

Sob um ponto de vista pertinente aos interesses dos países subdesenvolvidos, Joseph Stiglitz observa criticamente a transferência de poupança destes países para os Estados Unidos, a troco de acumularem papéis denominados em dólar como meio de ampliação de suas reservas. Os recursos que poderiam ser aplicados domesticamente por tais países são convertidos em dólares para sustentar a taxa corrente de consumo norte-americana, o que é ocasionado pela estrutura viciada e desigual do arranjo monetário internacional. A desculpa da virtual queda das exportações periféricas em caso de quebra do dólar para manter-se o atual sistema não pode ser sustentada se confrontada à aplicação local dos excedentes que não fossem aos Estados Unidos.

“A gestão da crise de 1997 pelo FMI [na Ásia] expôs a divergência de interesses entre a Instituição - e, por extensão, dos Estados Unidos - e os países da região. Essas nações se perguntaram naturalmente: por que devemos pôr o dinheiro de nossas consideráveis reservas em países ocidentais que nos tratam tão mal, quando poderíamos manter as reservas na região, com cada um de nós sustentando a moeda dos outros? Precisamos de mais investimentos, e, se vamos emprestar para aumentar o consumo de alguém, por que não emprestar para sustentar o baixo nível de consumo de nosso povo, em vez do consumo perdulário dos Estados Unidos?" 22

Coerentemente, Stiglitz propõe a reforma do sistema monetário internacional, rumo a uma situação não dominada por uma nação específica, e conseqüentemente sem que houvesse um papel de predomínio de uma moeda nacional específica. Evidentemente, tal colocaria em xeque o desempenho da economia dos Estados Unidos, forçando um "ajuste" desagradavelmente recessivo, mas por outro lado liberaria recursos adicionais para inversões nos países periféricos.

Opiniões análogas podem ser encontradas nas obras de Paul Krugman (A desintegração americana) e Ravi Batra (Greenspan, a fraude). Mesmo Robert Solomon, que apresenta tendência à neutralidade apreciativa, cita o Banco para Compensações Internacionais (BIS -

${ }^{21}$ BEINSTEIN, Jorge. Capitalismo Senil, p.195.

${ }^{22}$ STIGLITZ, Joseph. Globalização, como dar certo, p.401. 
Bank for International Settlements), para afirmar que "não há paralelo para este fenômeno de uma moeda fortalecendo-se sempre, com base nos fluxos de capital sempre crescentes, e a conta corrente deteriorando-se constantemente." 23

Lance Taylor e John Eatwell também escreveram sobre o tema com um olhar pessimista. Em sua análise sobre a desregulação dos mercados financeiros internacionais, perguntaram:

"Mas durante quanto tempo poderão manter-se livres os Estados Unidos das pressões do mercado internacional? A situação atual data da decisão política, tomada pelos Estados Unidos em meados da década de (19)70, de adotar um enfoque 'passivo' da conta de capitais do balanço de pagamentos. Isto resultou num enorme acumulação de dívida externa durante os últimos trinta anos. [...] A estratégia de solicitação de empréstimos pelos Estados Unidos chegou a ser um importante elemento para manter alta a demanda no mundo. Se forçosamente tivesse que modificá-la, a mudança acarretaria graves conseqüências para estabilidade e o crescimento futuros da economia mundial." ${ }^{24}$

Alguns autores merecem um comentário mais demorado. Robert Brenner, em The Boom and the Bubble e The Economics of Global Turbulence, tenta estabelecer uma interpretação do que chamou de "longo declínio" a partir de 1973, e do crescimento da economia dos Estados Unidos entre 1994 e 2001, puxado pelos efeitos da bolha acionária. Brenner, mesmo politicamente próximo ao campo marxista, procura retomar a noção clássica da primazia do "excesso de capacidade instalada e produção excessiva de mercadorias", que pressionam para baixo os preços e assim os lucros. Não reconhece no crescimento da composição orgânica do capital nos anos (19)70 a raiz para a queda da taxa de lucro, mas sim atribui esta a um "excesso de capacidade instalada" no parque manufatureiro mundial e à pressão baixista que esta exerce nos preços, deprimindo os lucros. Assim, põe de lado a perspectiva de Marx de que não há nunca um "excesso de capital" absoluto, mas sim uma taxa de lucro média esperada abaixo da qual os investimentos se realizam com cada vez mais dificuldade. Taxa de lucro esta que não se estabelece mediante a concorrência entre os capitais - isto é, entre preços - mas entre os lucros e os salários.

Brenner constrói, em The Economics of Global Turbulence, uma tese explicativa alternativa à teoria liberal - a teoria do "supply side" -, de que foi o crescimento dos salários nas principais economias do mundo industrial o fator determinante da abertura da crise dos anos (19)70, período depois do qual ele chama de "longo declínio". Tece com isto uma tentativa de esboço teórico que desloca a explicação do problema fundamental posto por Marx - a queda da taxa de lucro como fruto do aumento da participação do valor do capital constante face ao

\footnotetext{
${ }^{23}$ Dinheiro em movimento, p.28.

${ }^{24}$ Finanzas globales en riesgo - un anális a favor de la regulación internacional, p.140.
} 
trabalho vivo no processo produtivo - para a primazia de um confronto "horizontal" entre as empresas, via preços. O que desemboca na tendência da queda da lucratividade agregada via circulação. Para Brenner, é impossível que a elevação sustentada dos salários cause a crise, porque sempre que os salários crescem, os investimentos baixam e uma taxa compensatória se estabelece de novo.

"A queda na lucratividade agregada que foi responsável pelo longo declínio foi o resultado não tanto da pressão vertical autônoma do capital pelo trabalho, mas sim da capacidade excedente e da superprodução que resultaram da competição intercapitalista horizontal intensificada." 25

Ora, como diria o próprio Ricardo, "se, por mais abundantes que sejam, os capitais puderem encontrar aplicação em um país, como se poderia afirmar que são abundantes em relação às suas possibilidades de aplicação?" ${ }^{26}$ Neste sentido, a perspectiva do "excesso de capital" de Brenner foi analisada criticamente por Anwar Shaikh, atualmente professor da New School University em Nova York. O texto Explaining the Global Economic Crisis (1999) ${ }^{27}$ refere-se especialmente à obra de Brenner, por isso ir-se-á comentá-lo aqui. Como argumenta este autor, Brenner não consegue, mesmo com um trabalho empírico bastante extenso, evitar as contradições que envolvem explicar a queda da taxa de lucro fora da relação trabalho/capital, mas sim primeiramente pela concorrência entre os capitalistas. Na verdade, Shaikh encontra pouca evidência de que tenha havido grande impacto nos preços, seja na economia norteamericana, seja nos outros países industriais, advindos do acirramento da competição intercapitalista, mostrando não haver correlação entre a tendência das séries de preços e da lucratividade. De fato, o argumento de Shaikh é o mais procedente do ponto de vista sistêmico: como pode a competição inter-capitalista reduzir as margens de lucro, se, globalmente, as mesmas empresas que venderão mais barato comprarão mais barato? Trata-se de uma crítica análoga à de Marx quanto à noção mercantilista de valor criado na esfera na circulação.

"Suponha-se uma mudança no salário real, mantendo-se as outras variáveis constantes, incluindo a tecnologia e as condições de trabalho. Desde o tempo de Ricardo e Marx sabemos que a taxa de lucro média vai cair. Em termos marxianos, tal aumento no salário real iria pressionar para baixo a taxa de mais-valia, deixando a composição orgânica do capital imutável, levando então à queda da taxa de lucro. Agora se considere a situação na qual os preços relativos de um setor caem independentemente de uma mudança em seus custos, por exemplo, devido à super-

\footnotetext{
25 "In my view, the fall in aggregate profitability that was responsible for the long downturn was the result of not so much an autonomous vertical squeeze by labor on capital, as of the over-capacity and over production which resulted from intensified, horizontal inter-capitalist competition." The Economics of Global Turbulence, p.8.

${ }^{26}$ Princípios de Economia Política e Tributação, p.198.

${ }^{27} \mathrm{O}$ texto pode ser encontrado em: http://homepage.newschool.edu/ AShaikh/
} 
competição. Daí, o impacto imediato seria diminuir a taxa de lucro deste setor, mantendo-se as outras variáveis constantes. Mas se tanto a tecnologia e os salários reais permanecessem constantes, tal iria difundir-se pelo sistema e não haveria nenhum efeito particular de longo prazo na taxa de lucro. De um ponto de vista sistêmico, a queda dos preços relativos em um setor não apenas diminui inicialmente sua própria lucratividade, mas também inicia imediatamente uma redução dos custos de seus compradores, incluindo ele mesmo. O segundo efeito contrabalança o primeiro; com um atraso dependente do tempo, os efeitos de custo tornar-se-ão lucros." 28

Ressalte-se como Shaikh, lançando mão de ampla verificação empírica das hipóteses de Brenner, chega a resultados completamente diferentes, sobre uma base estritamente marxista. $\mathrm{O}$ resumo da abordagem de Brenner é o de que "de modo técnico, como resultado da apropriação de fatias do mercado pelas empresas com custos menores, surgiu investimento em excesso, levando ao excesso de capacidade e de produção" ${ }^{29}$. A crítica a Brenner é a de que, numa visão marxista, a desaceleração - a queda das taxas de lucratividade a partir dos anos (19)70 - não pode ser explicada mediante uma guerra sistêmica de preços, fruto de intensiva aplicação de mudanças técnicas, que desemboca em resultados nulos para todos. Enquanto que, segundo a perspectiva de Brenner, as empresas que levam à frente maiores mudanças tecnológicas permanecem as mais lucrativas, numa visão marxista é apenas questão de tempo para que as mudanças tecnológicas sejam incorporadas pela maior parte das empresas, elevando a composição orgânica média dos capitais, e trazendo abaixo a taxa de lucro. Daí que as transformações oriundas da chamada "Terceira Revolução Industrial" possam impactar positivamente nas taxas de lucro das empresas que pioneiramente as aplicam no processo produtivo, mas que, num momento posterior de sua generalização, acabem pressionando para baixo as taxas de lucro. Isto porque, como dito, fazem crescer o valor do capital constante face ao variável, com eliminação relativa de trabalho vivo.

\footnotetext{
28 "Suppose we consider a change in real wages, all other things, including technology and working conditions, being held constant. Then we know from the time Ricardo and Marx that the general rate of profit would fall. In marxian terms, such a rise in the real wage would lower the rate of surplus value while leaving the organic composition unchanged, so that the general rate of profit would fall. Now consider a situation where a sector's relative price declines independently of a change in its costs, e.g. due to overcompetition. Then the immediate impact would be to lower the sector's own profit rate, other things being equal. But if both technology and real wages were unchanged, this would diffuse through the system and there would be no particular long term effect on the general rate of profit. From a systemic point of view, fall in a sector's relative price not only initially diminishes its own profitability, but also initially immediately reduces the costs of its buyers, including itself. The second effect counteracts the first, with a lag dependent on the time it takes cost effects to work through into profits." Explaining the global economic crisis, p. 12 .

29 "Technically speaking, as a result of the lower cost firm's appropriation of market share through the imposition of its lower cost price, over-investment leading to over-capacity and over-production has arisen in the line". The Economics of Global Turbulence, p.19.
} 
"A teoria marxiana requer apenas que um aumento na taxa de capital-produto quer dizer, uma queda na taxa nominal de produto por capital - explique a parte principal na queda temporal das taxas de lucro (dado ajuste de utilização de capacidade). E é exatamente o que [a pesquisa empírica] encontra." 30

\section{Como observou O'Connor:}

"A importância relativa da força viva de trabalho declinou e a do capital fixo (ou morto) aumentou. Estudos estatísticos mostram que o crescimento da produção agregada dos Estados Unidos é determinado, cada vez menos, pela expansão do insumo de trabalho e do estoque de capital físico e cada vez mais pela promoção da habilitação superior da mão-de-obra, pela melhoria da qualidade do capital físico e pelo aprimoramento da organização e do controle do trabalho." 31

Outra perspectiva globalizante muito conhecida do desempenho recente da economia norte-americana é a de Giovanni Arrighi, estabelecida em $O$ Longo Século XX, Adam Smith em Pequim, e outras obras. Nesta última obra, Arrighi endossa as críticas de Shaikh à tese de Brenner:

"Em sua crítica aos teóricos da oferta, Brenner compara a disposição destes em ver a economia mundial como mera soma de componentes nacionais com sua tentativa de buscar uma lógica própria para processos sistêmicos. Por mais que seja louvável, a análise não cumpre a promessa e concentra-se quase exclusivamente em três economias-Estados Nacionais (Japão, Alemanha e Estados Unidos). [Ao tratar o Sul global de forma superficial, ele tende a] deixar de lado um dos elementos mais dinâmicos da intensificação da concorrência, à qual ele atribui tanta importância." 32

Arrighi comenta ainda que, além de ignorar a economia dos países periféricos elemento essencial da concorrência capitalista mundial contemporânea - e os fatores políticos da análise histórico-econômica - o que transparece em O Boom e a Bolha-, Brenner empobrece sua análise ao dirigir o grosso de sua atenção apenas para o setor industrial, com menos atenção sobre os outros agregados. Ora, o setor industrial esteve ao longo do período perdendo cada vez mais importância no valor do PIB das economias industriais, e então uma verificação do

\footnotetext{
30 "The marxian theory requires only that a rise in the nominal capital-output ratio, i.e. a fall in the nominal outputcapital ratio, account for the bulk of the secular fall in (capacity utilization adjusted) profit rates. And this is exactly what one finds." SHAIKH, Anwar. Explaining the global economic crisis, p.27.

${ }^{31}$ USA: a crise do Estado capitalista, p.125.

${ }^{32}$ Adam Smith em Pequim, ps. 140-1.
} 
comportamento dos outros setores e séries far-se-ia mais importante. Como os setores de serviços não estão tão expostos à concorrência internacional, e constituem o grosso do emprego e do PIB das economias desenvolvidas, sua análise focada centralmente no comércio internacional perde peso.

Quanto à tese da "super-capacidade"...

"Brenner não apresenta nenhum indicador do seu conceito de 'supercapacidade e superprodução' comparável aos indicadores múltiplos de financeirização da economia não financeira [apresentado por Greta R. Krippner em "The finantialization of American Economy"]. No entanto, Anwar Shaikh apresenta dois indicadores de "utilização de capacidade instalada' na indústria norte-americana, um baseado em suas próprias medições e outro nas medições do Fed, que podemos adotar como indicadores invertidos e imperfeitos de supercapacidade. Durante o período de 1947 a 1995, ambos os indicadores mostram bastante flutuação, mas nenhuma tendência clara a longo prazo." 33

Porém, para Arrighi, o deslocamento da acumulação produtiva para fora dos Estados Unidos também se explica, no fundo, por uma "saturação de capitais", que é uma caracterização muito próxima, senão idêntica, que a de "excesso de capacidade instalada". Em sua narrativa de fundo "braudeliano", dá-se uma alternância entre os ciclos de acumulação financeira e produtiva, nos quais aquela sucede esta depois de um determinado momento de "saturação" da produção material. Estes ciclos marcariam a história do capitalismo desde seu surgimento no século XVI, e continuariam a manifestar as mesmas características deste então: aumento da produção, saturação da produção, e assim financeirização - e isto desde Gênova, passando-se pela Holanda, Inglaterra e depois os próprios Estados Unidos.

Similarmente, não é objetivo deste trabalho discutir esta tese, que não se enquadra dentro de uma perspectiva eminentemente marxista de análise, já que Arrighi não argumenta em termos de aumento da composição orgânica que leva à queda da taxa de lucro, mas sim em "saturação das oportunidades de investimento", um conceito smithiano, como origem da financeirização e da exportação de capital produtivo. Ele se vale de uma linguagem marxista, mas de modo eclético, aliando a ela uma perspectiva braudeliana, que remete, como vimos, a uma noção clássica de "saturação das oportunidades de investimento".

"O ponto de vista de nossa investigação foi a afirmação de Fernand Braudel de que as características essenciais do capitalismo histórico em sua longue durée - isto é, durante toda sua existência - foram a 'flexibilidade' e o 'ecletismo' do capital, e não as formas concretas assumidas por ele em diferentes lugares e épocas. [...] [Dada a fórmula DMD' de Marx], o capital

\footnotetext{
${ }^{33}$ Adam Smith..., p.150.
} 
dinheiro (D) significa liquidez, flexibilidade e liberdade de escolha. O capitalmercadoria (M) é o capital investido numa determinada combinação de insumoproduto, visando ao lucro; portanto, significa concretude, rigidez, e um estreitamento ou fechamento das opções. D' representa ampliação da liquidez, da flexibilidade e da liberdade de escolha. [...] A fórmula nos diz que, quando os agentes capitalistas não têm expectativa de aumentar sua própria liberdade de escolha, ou quando esta expectativa é sistematicamente frustrada, o capital tende a retornar a formas mais flexíveis de investimento - acima de tudo, à sua forma monetária.

[...] [Esta interpretação] está implícita na caracterização braudeliana da 'expansão financeira' como um sintoma da maturidade de determinado desenvolvimento capitalista" [grifo meu]. [...] Nas fases de expansão material, o capital monetário 'coloca em movimento' uma massa crescente de produtos (que inclui a força de trabalho e as dádivas da natureza, tudo transformado em mercadoria); nas fases de expansão financeira, uma massa crescente de capital monetário 'liberta-se' de sua forma mercadoria, e a acumulação prossegue através de acordos financeiros (como na fórmula abreviada de Marx, DD'). Juntas, estas duas épocas, ou fases, constituem um complexo ciclo sistêmico de acumulação (DMD').” 34

É subjacente a esta interpretação uma definição diferente da marxista, acerca do que é o sistema capitalista; para Fernand Braudel, o capitalismo tem início já no século XVI, e não se caracteriza pela separação do produtor e dos meios de produção ocorrida durante a Revolução Industrial. A própria noção de Revolução Industrial é contestada por ele. ${ }^{35} \mathrm{O}$ fato é que, como Arrighi se propôs a fazer um estudo que cobrisse toda a história do capitalismo, ele não se debruçou mais demoradamente sobre os Estados Unidos. Isto é: Arrighi não se concentra nas contas nacionais e no desempenho dos agentes desta economia, porque não foi objetivo dele focar atenção no desempenho dos Estados Unidos. E, especialmente, não aprofunda análise do problema do endividamento externo.

Importa explicar que, de um ponto de vista empírico, não há a priori impedimentos para a aceitação de que houve e continua havendo um deslocamento do capital produtivo dos Estados Unidos para outros países. Ou, nos termos de Arrighi, um "deslocamento do eixo dinâmico da economia mundial para a Ásia".

Esta abordagem de Arrighi merece, todavia, um comentário adicional. Não se trata de negar que houve, realmente, uma transferência da acumulação produtiva dos Estados Unidos em relação ao leste asiático, constatação que é correta. Ocorre simplesmente que os motivos alegados por Arrighi não são os mesmos que a perspectiva aqui adotada e aceita, não obstante

\footnotetext{
${ }^{34}$ ARRIGHI, Giovani. O Longo Século XX, p.5-6.

${ }^{35}$ Cf. Civilização Material, Economia e Capitalismo, Volume III, O tempo do mundo, capítulo 6.
} 
serem os resultados a que ele chega os mesmos que serão derivados a partir do estudo aqui feito: um crescimento relativamente menor da economia dos Estados Unidos, e uma maciça transferência de capital produtivo deste país para outras regiões do globo, onde, além de maiores taxas de lucro, haja um ambiente institucional e político que permita recebê-los com sucesso.

Fundamentalmente, as constatações de Arrighi estão corretas, do ponto de vista da dificuldade da continuidade da acumulação nos Estados Unidos, e em relação a como isto promove a exportação de capitais produtivos para o leste da Ásia. Porém, os Estados Unidos tornaram-se importadores líquidos de recursos, e não exportadores. É este fato que não aparece explicitado em sua obra. A resposta para a aparente contradição é que estes capitais suprem a lacuna deixada pela queda da demanda agregada oriunda da crise de lucratividade industrial e da conseqüente queda da acumulação produtiva, que conduz aos poucos à desaceleração cada vez mais forte. Ao caírem os lucros, a demanda efetiva tem de ser compensada pelo consumo das famílias e do Estado, nos quais o componente externo assume, desde a década de (19)80, uma importância cada vez maior. O capital externo não tem sido investido de modo diretamente produtivo em sua grande parte, portanto. Tem-se então sustentado cada vez mais a demanda agregada, num ambiente de queda dos lucros, a partir de recursos obtidos no exterior. $\mathrm{O}$ endividamento externo não seria necessário se a lucratividade corrente doméstica dos setores produtivos fossem relativamente crescente.

Tal como mostrou Jorge Grespan, a tendência para a queda da taxa de lucro, como exposta por Marx, apresenta contra-tendências que impedem que se trace a-priori seu movimento determinado. ${ }^{36}$ Porém, ainda que implicitamente (porque em $O$ Capital não se discute a economia em termos nacionais mas sim em termos abstratos), Marx tem a percepção de que os lucros tendem à saturação numa determinada economia nacional e de que, por conseqüência, o capital migra em escala geográfica mundial. "Se o capital é mandado para o exterior, isto não é feito porque não pode ser absolutamente aplicado domesticamente, mas porque pode ser aplicado a uma taxa mais alta de lucro no país estrangeiro". ${ }^{37}$ É que esta percepção fica obscurecida pela etapa específica de abordagem presente neste momento do Livro III, estritamente teórica.

Por isso, quando se aceita a noção de tendência para a queda da taxa de lucro, assume-se que, por mais "flexível", ou "dialética", que a tendência do capital possa assumir, pode-se afirmar que, numa perspectiva global, geográfica, o capital acaba deslocando-se - o que não impede, é claro, que, mesmo em escala "nacional", os "arcabouços" não possam ser rompidos periodicamente pelo movimento dialético. De fato, é isso que acaba ocorrendo, como na expansão dos anos (19)90. Mas não se pode negar que, a partir dos anos (19)80, tenha havido a tendência para que cada expansão industrial tenha se dado a ritmos cada vez menores, em âmbito nacional, tornando inevitável a acumulação mais rápida nas regiões do capitalismo internacional em que a composição orgânica do capital industrial é menor. Neste sentido, uma

\footnotetext{
${ }^{36}$ O Negativo do Capital, p. 260 e subseqüentes.

${ }^{37}$ Capital, V.III, p.251.
} 
visão torpe argumentaria que a ausência de uma necessidade da direção do movimento do capital na análise meramente teórica de Marx pode parecer enfraquecê-la, diante da análise histórica propriamente dita. $\mathrm{O}$ que é um erro, dados os limites objetivos da exposição teórica. $\mathrm{O}$ fato é que, enquanto a análise da crise pela teoria de Marx aceita a visão diacrônica, a visão de Arrighi praticamente reduz a crise contemporânea a uma versão revisitada das crises que atingem o capitalismo desde o século XVI. O enfoque da sociologia-histórica, que supostamente deveria conferir alguma especificidade ao momento atual, não ajuda a reduzir esta deficiência.

\subsection{Ainda a lei tendencial}

Desde o nascimento da economia como ciência, até o keynesianismo, as indagações sobre o "estado estacionário" sempre estiveram presentes na história do pensamento econômico. Somente a partir da "contra-revolução" neo-neo-clássica (1970) a maior parte do mainstream dos economistas norte-americanos começou a remover da teoria econômica as indagações mais fundamentais e as conclusões mais pessimistas. Como é de praxe, afinal, também nas outras áreas da produção de ciências sociais nos Estados Unidos. A boa tradição da economia, porém, nunca se furtou a uma posição mais crítica e realista.

Dentro das modalidades de crise - entendida aqui como incapacidade de o sistema continuar a mostrar aumento da acumulação e reprodução ampliada, e não crise como "estado terminal" ou de sublevação política - a noção de tendência de queda da taxa de lucros levando a uma desaceleração do crescimento econômico foi considerada, dentro da hierarquia sistêmica das crises para Marx, a mais importante. Para Marx, esta era de fato a "lei mais importante da economia política". É claro, contudo, que a noção tem uma trajetória que se confunde com a própria economia como ciência; não é uma percepção originalmente marxista, mas sim liberal. Adam Smith foi o primeiro a estabelecê-la, para depois iniciar um debate do qual toda a economia política do século XIX e XX, em suas diferentes vertentes, iria participar. Com isto, surgiram muitas explicações particulares sobre as pressões que levavam à queda da "lucratividade do capital."

Adam Smith a atribuía à crescente "oferta de capital" decorrente do crescimento econômico:

"O aumento do capital, que faz com que os salários cresçam, tende a fazer cair o lucro. Quando o estoque de muitos comerciantes ricos são postos no mesmo ramo, sua mútua competição irá naturalmente tender a fazer cair seu lucro; e quando houver um aumento semelhante em todos as atividades comerciais realizadas pela sociedade, a mesma competição deve produzir o mesmo efeito em todas." 38

38 "The increase of stock, which raises wages, tends to lower profit. When the stocks of many rich merchants are turned into the same trade, their mutual competition naturally tends to lower its profit; and 
David Ricardo imputou a tendência para a queda da taxa de lucros à agricultura. Referiu-se ao processo de crescente aumento dos preços dos gêneros alimentícios, dada a crescente dificuldade de cultivar terras cada vez mais improdutivas, que culminaria num aumento irresistível dos salários. Tal determinaria a queda da taxa de lucros.

"Somente se poderá acumular num país uma determinada quantidade de capital se o mesmo puder ser utilizado produtivamente, até que os salários aumentem tanto em conseqüência do aumento dos gêneros de primeira necessidade - reduzindo o que sobre como lucro do capital - que cesse o motivo para acumulação." 39

Stuart Mill admitiu também que o crescimento da população levava a uma maior exigência de terras cultiváveis, e de que as terras iam sendo cultivadas num sentido decrescente de produtividade, conduzindo isto a maiores salários e menores lucros. Estendeu então a noção de "estado estacionário" para o âmbito da própria acumulação de capital industrial. No item 4 do capítulo 4 de seus Principles of Political Economy, no capítulo intitulado "Of the tendency of the profits to a minumum", escreveu Mill que a tendência para o "estado estacionário" originase de uma produção extensa em volume e em tempo de existência, que tornam cada vez menos possível fazer novas adições ao volume de capital. Isto levaria à permanência da taxa de lucro num patamar mínimo que desestimularia novos investimentos. Ele previa para a Europa, que já conhecia um movimento acumulativo anterior ao dos Estados Unidos, uma saturação mais ou menos próxima, naquele momento, devido ao tamanho já alcançado pelo crescimento econômico de então. Os fatores contra-balanceadores de que fala o autor envolviam então o cultivo de novas áreas agrícolas e a exportação de capital para áreas de menor crescimento.

"Quando um país tem uma grande produção há muito tempo, e uma grande renda líquida de onde tirar poupança, e quando, portanto, os meios para fazer uma adição anual ao capital já existem há muito tempo (não tendo o país, como os Estados Unidos [América] uma grande reserva de terra fértil ainda inutilizada), é uma das características deste país que a taxa de lucro esteja habitualmente próxima do mínimo [a hand's breadth of the minimum], e que o país portanto esteja na iminência do estado estacionário. Com isto eu não quero dizer que este estado seja provavelmente alcançado em nenhum dos grandes países da Europa, ou que o capital ainda não forneça um lucro consideravelmente maior do que é meramente suficiente para induzir as pessoas deste país a poupar e investir. O que quero dizer é

when there is a like increase in stock in all the different trades carried on in the same society, the same competition must produce the same effect in them all." The Wealth of the Nations, p.37.

${ }^{39}$ Princípios de Economia Politica e Tributação, p.198. 
que requerer-se-ia apenas pouco tempo para reduzir os lucros ao mínimo se o capital continuasse a crescer sob as taxas atuais, e se não se apresentassem circunstâncias que fizessem a taxa de lucro se elevar no meio tempo. A expansão do capital iria cedo atingir seu limite, se este limite não fosse expandido e deixasse mais espaço." 40

Não é necessário demorar-se sobre a opinião de Keynes acerca da capacidade da economia capitalista de expandir-se indefinidamente, e de como isto influenciou toda a escola keynesiana. "Keynes não precisava de uma teoria da distriuição para o longo prazo, embora tivesse uma vaga ideia de uma queda da taxa de lucro em sua visão da civilização futura." ${ }^{41}$ Com efeito, a perspectiva da eficácia marginal decrescente do capital conduzia a uma posição descrédula sobre a capacidade de o sistema crescer sempre. O aumento da oferta das empresas que investem, conjugado com um aumento dos preços de seus insumos, causa um declínio da lucratividade. No longo prazo, o primeiro fator é mais importante, para Keynes. Nota-se a similitude da linguagem utilizada por Keynes com a linguagem clássica (“oferta de capital”).

"Quando o investimento, em dado tipo de capital, aumenta durante certo período, a eficiência marginal desse capital diminuiu à medida que o investimento aumenta, em parte, porque a renda prospectiva baixará conforme suba a oferta desse tipo de capital, e, em parte, porque a pressão sobre as fábricas produtoras daquele dado tipo de capital causará, normalmente, uma elevação de seu preço de oferta; sendo que o segundo destes fatores é, geralmente, o mais importante para estabelecer o equilíbrio no curto prazo, embora quanto mais longo for o período que se considere, maior importância adquire o primeiro fator." 42

Mas a natureza das perguntas da macroeconomia está fundamentalmente ligada ao curto e médio prazos e não a fatores que explicam movimentos de longa duração. A importância da volta à indagação sobre as origens do "estado estacionário", tal como definia a economia política clássica, está então na ênfase numa abordagem objetiva e estrutural que esteja além das

\footnotetext{
40 "When a country has long possessed a large production, and a large net income to make savings from, and when, therefore, the means have long existed of making a great annual addition to capital (the country not having, like America, a large reserve of fertile land still unused) it is one of the characteristics of such a country, that the rate of profit is habitually within, as it were, a hand's breadth of the minimum, and the country therefore on the very verge of the stationary state. By this I do not mean that this state is likely, in any of the great countries of Europe, to be soon actually reached, or that capital does not still yield a profit considerably greater than what is barely sufficient to induce the people of those countries to save and accumulate. My meaning is, that it would require but a short time to reduce profits to the minimum, if capital continued to increase at its present rate, and no circumstances having a tendency to raise the rate of profit occurred in the meantime. The expansion of capital would soon reach its ultimate boundary, if the boundary itself did not continually open and leave more space."

${ }^{41}$ ROBINSON, Joan. In: American Economic Review, v.62, n. 1/2, Março de 1972, p.8. ("Keynes did not need a theory of distribution for the long run though he had a vague idea of a falling rate of profit in his daydream of future civilization.")

${ }^{42}$ A teoria geral do emprego, do juro e da moeda, p.101-102.
} 
flutuações, abordagem esta que o enfoque da macroeconomia tendeu a perder de vista, pela atenção aos movimentos de curto prazo. Keynes buscou evitá-la na Teoria Geral, assim como Kalecki em sua obra. ${ }^{43}$ Quando se aproximaram dela, tendiam a vê-la como ocasionadas pela queda do investimento ou do consumo, advindas de desproporções conjunturais. Todavia, a história econômica, por definição, não pode deixar de indagar sobre tais fatores cuja atuação está no longo prazo, conectando-os com as flutuações mais curtas. Mesmo que Anwar Shaikh tenha abordado com muita precisão a lei tendencial nos trabalhos anteriormente citados, deve-se voltar a ela aqui, para tender estabelecer sua conexão com o problema do endividamento externo, tema do trabalho.

Contrariamente a Keynes, Marx e Engels tinham uma teoria clara da distribuição. A lei tendencial faz parte dela. A vantagem da abordagem teórica marxista reside neste fato, e isto permite com que ela se torne complementar à teoria keynesiana; ou antes o oposto. Neste sentido, é de interesse voltar atenção ao modo pelo qual ambos desenvolverem uma perspectiva explicativa particular do movimento tendencial entre lucros e salários, para depois atentar a ela com as ferramentas metodológicas da economia moderna: a macroeconomia, as contas nacionais e a econometria.

De fato, a importância da teoria de Marx e Engels reside em terem formulado a teoria do valor esboçada pelos economistas clássicos sob uma estrutura sistêmica coerente, destituída de contradições internas que Ricardo não conseguiu eliminar de todo. Ela é então um guia fundamental para a interpretação do movimento de longo prazo, que aqui julgamos mais objetivo do que outras teorias alternativas. A lei, que não pode ser compreendida sem a abordagem dialética, atribui-se à lógica de mecanização crescente do processo produtivo. Com ele, a base material da extração do excedente social - o fator trabalho - tende a diminuir, face ao crescente uso do capital constante, especialmente o fixo, no processo de produção. Como não é dado explorar máquinas, tal movimento conduz - desde que não atuem tendências em contrário - a uma queda da taxa de lucro agregada no sistema como um todo, o que expressa simplesmente que a relação social entre capital e trabalho se vê apertada. Isto porque, em termos de valor, há cada vez menos trabalho para ser explorado. Isto é, dá-se uma diminuição relativa da própria base da qual se extrai o excedente social, a mais-valia, o com a substituição do trabalho pelas máquinas - que não produzem valor. Produz valor apenas o trabalho cuja exploração é insuficiente. A interrupção do crescimento da taxa de lucro conduziria aos poucos a economia ao estado de reprodução simples, situação na qual as corporações deixam de ampliar a produção e financeirizam seus gastos. A lei, no entanto, é reversível, e ela mesma sujeita um processo cíclico. ${ }^{44}$

\footnotetext{
${ }^{43}$ Como explicou Joan Robinson, "Keynes estava preocupado principalmente com o curto prazo, aqui e agora, quando somente as expectativas de lucros futuros importavam para o argumento." ROBINSON, Joan. Ibid., p.8. ([Keynes] was concerned mainly with the short period, here and now, when only expectations of future profits come into the argument.")

${ }^{44}$ Cf. o artigo de BARBOSA, Wilson do Nascimento, "Uma teoria marxista dos ciclos econômicos", in: COGGIOLA, Osvaldo (org.). Marx e Engels na História (1996).
} 
Para dar-se a tendência, as corporações devem automatizar cada vez mais em conjunto seus processos produtivos, de modo que em escala sistêmica a base da qual se extrai mais-valia tenha de cair, se os preços dos elementos do capital constante não caírem numa medida suficiente para neutralizar este efeito. Quanto maior é a queda dos lucros industriais, maior é o indicativo de que o restante dos setores não responsáveis diretamente pela acumulação produtiva tornam-se mais lucrativos e sua participação no produto aumenta. Mas como tais setores não produzem bens, a taxa de crescimento da produção material da economia tende a ser menor. A dificuldade em substituir trabalho vivo por morto no processo de funcionamento dos setores fora dos setores produtivos leva a uma relação capital/trabalho menor, e assim a maiores taxas de lucro nestes setores não produtivos. Com o tempo, a economia diversifica-se e a participação do setor industrial cai, levando a um menor crescimento.

A tendência para a queda da taxa de lucro dá-se então quando cresce a participação em valor, no processo de produção, do chamado capital constante face ao chamado capital variável - ou trabalho morto em relação ao vivo - o que pressiona as taxas de lucro para baixo se os elementos do capital constante não tiverem seus preços rebaixados. A taxa de exploração sobre os trabalhadores cresce, mas cai a taxa de lucro. Se isto ocorre, a base em relação à qual se extrai a mais-valia torna-se relativamente menor a cada elevação de mecanização do processo produtivo. Com isso, os investimentos, ou a acumulação de capital, tendem a diminuir à medida que as firmas obtêm, a cada inversão adicional, lucros em relação ao capital adicional proporcionalmente menores do que na rodada anterior de investimentos.

No capítulo XIII do volume III de O Capital, "A lei como tal” [Das Gesetz als Solches, no original alemão], Marx argumenta como o aumento do capital constante face ao variável, mesmo quando empregado em condições de maior extração absoluta da massa de mais-valia, pode expressar-se numa queda da taxa de lucro. Veja-se isto com um exemplo apresentado pelo próprio Marx. Tenha-se uma diferenciação do processo de trabalho tal que o capital total num determinado ramo (ou mesmo na economia como um todo), passe de seis a dezoito milhões de unidades monetárias, com elevação do capital constante de quatro para quinze milhões, e com elevação absoluta dos gastos em salários de dois para três milhões:

$$
\begin{aligned}
& \text { I. } 4 \mathrm{cc}+2 \mathrm{cv}+2 \mathrm{mv} ; \mathrm{C}=6 \text {; taxa de lucro de } 33_{1 / 3} \% \\
& \text { II. } 15 \mathrm{cc}+3 \mathrm{cv}+3 \mathrm{mv} ; \mathrm{C}=18 \text {; taxa de lucro de } 16_{2 / 3} \%
\end{aligned}
$$

Dada uma determinada taxa de mais-valia, constante nas duas situações, enquanto a massa de mais-valia cresceu $50 \%$, a taxa de lucro caiu pela metade. Pode-se então afirmar que "o número de trabalhadores empregados pelo capital, e assim a massa absoluta de valor empregado por ele, e portanto a massa absoluta de mais-valia por ele absorvida, a massa de mais-valia produzida por ele, e assim a massa absoluta de lucro produzida por ele, podem, conseqüentemente, aumentar, e aumentar progressivamente, a despeito de uma progressiva 
queda na taxa de lucro". ${ }^{45}$ Destarte, a massa de lucros pode crescer mesmo diante de uma queda da taxa de lucros. Porém, mostrando-se cadente ao longo do tempo a taxa de lucro, a massa dos lucros irá cair, pela queda nos investimentos, devido ao não estímulo em continuar novas inversões.

Os investimentos corporativos dependem do movimento da taxa de lucro, tal como, no nível indireto, a renda dos trabalhadores e os impostos dependem dos investimentos. Os investimentos decrescem à medida que a taxa de lucro cai; numa visão keynesiana, os próprios lucros caem à medida que a oferta de capital cresce. Porém, como demonstrou Marx, o rebaixamento da taxa de investimentos nunca significa que o capital, ou os meios de produção, existem em "excesso", do ponto de vista das necessidades sociais. Eles existem em excesso apenas do ponto de vista de que, na economia capitalista, eles servem como capital. Daí nunca há tal excesso de capital - isto é, excesso de bens de produção e de demanda de trabalho - do ponto de vista absoluto, mas sempre relativo.

Se a taxa de lucro mostrar-se incapaz de apresentar tendência ascendente, cessará aos poucos a ampliação da acumulação de capital. O capital recusar-se-á cada vez mais a continuar investindo sob uma taxa de lucro que apresenta menores ganhos do que nas rodadas anteriores. Se a cada nova rodada de acumulação a taxa cai, cria-se um impedimento estrutural para que ela continue se dando. Isto não implica que a acumulação cessará totalmente, mas sim que ela cairá, face ao que poderia ocorrer caso a queda da taxa de lucro não se apresentasse. Por outro lado, este processo pode ser aguçado; por exemplo: se a taxa de mais-valia cair ao mesmo tempo em que se dá o aumento dos gastos com capital constante, a taxa de lucro cairá ainda mais. Exemplo:

$$
\begin{aligned}
& \text { I. } 1300 \mathrm{cc}+100 \mathrm{cv}+100 \mathrm{mv} ; \mathrm{C}=1400 \text {; taxa de lucro de } 0,07 \% \\
& \text { II. } 1400 \mathrm{cc}+120 \mathrm{cv}+100 \mathrm{mv} ; \mathrm{C}=1520 \text {; taxa de lucro de } 0,065 \%
\end{aligned}
$$

Isto é: processos pontuais, como um súbito aumento dos preços de componentes que entram no valor dos salários, ou mesmo nos custos do capital (como os juros, que neste caso entram como parte dos custos dos quais a mais-valia será deduzida), podem fazer cair a taxa de modo mais rápido do que durante a atuação "lenta e surda" do processo de crescimento da composição orgânica.

De fato, nesta situação, não é que o capital se recuse a investir porque não há lucro algum. É porque a taxa de lucros mostra-se tendencialmente menor, em proporção ao capital investido. Quando a inversão em capital adicional, $\mathrm{C}+\Delta \mathrm{C}$, não é capaz de render uma massa de lucros proporcional ao aumento $\Delta \mathrm{C}$, o investimento tornar-se-á cada vez mais

\footnotetext{
${ }^{45} \mathrm{Na}$ edição em inglês aqui utilizada: "The number of labourers employed by capital, hence the absolute mass of the labour set in motion by it, and therefore the absolute mass of surplus-labour absorved by it, the mass of the surplus-value produced by it, and therefore the absolute mass of profit produced by it, can, consequently, increase, and increase progressively, in spite of the progressive drop in the rate of profit.” MARX, Karl. Capital, V.III, The process of capitalist production as a whole, p.213.
} 
desinteressante, e sua queda, se não canalizada para algum outro tipo de gasto, trará abaixo o nível de emprego e da renda, e a arrecadação do Estado. Ao mesmo tempo, o consumo dos capitalistas tenderá a manter-se no mesmo patamar, porque os lucros, sem mais acumulação, serão os mesmos quando o capital era apenas C. De qualquer modo, quanto mais o excedente é invertido na forma de consumo, menor será no futuro a capacidade relativa de crescimento da economia. É somente neste sentido que há uma disponibilidade "absoluta" de capital acumulado. Cite-se o próprio Marx:

“A tão chamada 'pletora de capitais' sempre implica essencialmente uma pletora de capitais para a qual a queda da taxa de lucro não é compensada pela massa do lucro obtido [...]. O propósito do modo capitalista de produção, entretanto, é a autoexpansão do capital, isto é, apropriação da mais-valia, produção de mais-valia, de lucro. O capital cresceria a uma taxa frente à população em condições de trabalhar em que nem o tempo absoluto de trabalho suprido por esta população nem o mais-trabalho relativo poderiam ser expandidos para mais adiante (esta última não seria factível sob qualquer taxa no caso em que a demanda de trabalho por trabalho fosse tão forte que houvesse como conseqüência uma alta dos salários); a um ponto, entretanto, quando o capital aumentado produzisse tanto mais, ou menos, mais-valia do que quando o fazia antes de seu acréscimo, haveria então uma superprodução absoluta de capital. Isto é, o capital acrescido, $\mathrm{C}+\Delta \mathrm{C}$, não produziria mais, ou mesmo menos, lucro que o capital $\mathrm{C}$ antes de sua expansão a $\Delta C . " 46$

Se a taxa de lucro proporcional a um mesmo capital apresentar-se em constante queda, haverá acirramento da disputa entre os capitais, desvalorização de parte do capital excedente, e conseqüente queda dos salários. Como afirmou Barbosa, pode-se captar neste trecho de $O$ Capital uma teoria dos ciclos, na medida em que o rebaixamento dos salários reativa a taxa de lucro e a acumulação, causando uma nova expansão da acumulação. ${ }^{47} \mathrm{~A}$ tendência pode ser então engendrada por processos determinados, e revertida à frente, caso outros fatores sistêmicos ocorram. É o que ocorre entre o período 1973 a 1988, e que é em parte mudado entre 1987 e 2000.

\footnotetext{
46 "The so-called plethora of capital always applies essentially to a plethora of the capital for which the fall in the rate of profit is not compensated through the mass of profit [...]. The purpose of capitalist production, however, is self-expansion of capital, i.e., appropriation of surplus-labour, production of surplus value, of profit. As soon as capital would, therefore, have grown in such a ratio to the labouring population that neither the absolute working-time supplied by this population nor the relative surplus working-time, could be expanded any further (this last would be not feasible at any rate in the case when the demand for labour were so strong that there were a tendency for wages to rise); at a point therefore, when the increased capital produced just as much, or even less, surplus-value than it did before its increase, there would be absolute over-production of capital; i.e., the increased capital $\mathrm{C}+\Delta \mathrm{C}$ would produce no more, or even less, profit than capital C before its expansion by $\triangle \mathrm{C}$." MARX, Karl. Capital, V.III, The Process of Capitalist Production as a Whole, p.246.

47 "Uma teoria marxista dos ciclos econômicos", in: COGGIOLA, Osvaldo (org.). Marx e Engels na História (1996).
} 
A desvalorização do capital instalado e a conseqüente queda dos preços são a mera expressão de que o capital está encontrando dificuldades em continuar investimento a taxas de lucro crescentes. Não seria então o mero "excesso de capacidade instalada" o princípio que impediria que a economia se expandisse continuamente. A determinação explicativa residiria em uma esfera anterior: o desinteresse em se continuar investindo sob taxas de lucro decrescentes desestimula, simplesmente, a continuidade dos investimentos. Como este processo se dá com mais ênfase no setor manufatureiro, cai a acumulação nos setores manufatureiros, responsáveis, no limite, pelo crescimento real da economia. Cai a acumulação produtiva e dá-se menor crescimento ao longo do tempo.

Logo, para a teoria marxista, é primeiramente a relação entre o capital e os trabalho que determina o movimento estagnativo em questão, e não, ou pelo menos não num nível estruturalmente similar de explicação, a relação entre os capitais mediante uma guerra destrutiva de preços. De fato, se os preços caem, eles caem para todas as corporações, mantendo-se a situação posterior idêntica, de um ponto de vista relativo; mas se a taxa de lucros cai, as corporações são desestimuladas a investir, conjuntamente. Um princípio explicativo é exterior, outro interior. Se os salários crescem rapidamente, os lucros caem na mesma medida em que os salários crescem; se a mecanização do trabalho permite elevar a massa de lucros, leva mais à frente a uma queda da taxa de lucros. A disputa via preços e a desvalorização do capital entre os capitais concorrentes expressa tão-somente a impossibilidade de crescer continuamente a taxa de lucros.

Ressalte-se então que quando se dá o aumento da composição orgânica do capital, mesmo uma massa maior de lucros será calculada sob uma menor taxa de lucros, face ao capital total instalado:

"A queda da taxa de lucro seria acompanhada então por uma queda absoluta da massa dos lucros, dado que a massa de poder de trabalho empregado não poderia ser acrescida, assim como a taxa de mais-valia acrescida nas condições assumidas, resultando no fato de que a própria massa de mais-valia não poderia crescer. E a massa reduzida de lucro teria de ser recalculada face a um capital total maior. Mesmo assumindo que o capital empregado continua a expandir-se à mesma taxa, e que a massa de lucros mantém-se a mesma, esta massa seria ainda calculada em relação a um capital total maior, outrossim implicando uma queda da taxa de lucro. Se um capital total de 1.000 rendesse um lucro de 100, e depois de ser acrescido rendesse ainda 100, daí, no segundo caso, 1.000 renderiam apenas $66_{2 / 3}$. A auto-expansão do antigo capital, neste sentido, teria sido reduzida. O capital de 1.000 não renderia mais sob as novas circunstâncias que anteriormente um capital de $666_{2 / 3} . " 48$

${ }^{48}$ Capital, V.III, The Process of Capitalist Production as a Whole, p. 247. 
Neste ínterim, é interessante ressaltar que não é o nível de composição orgânica do capital por si mesmo que leva à exportação de capital, porque este é apenas uma abstração que não diz nada quando comparadas duas realidades nacionais distintas. $O$ que importa é o comportamento da taxa de lucro. Dado um determinado padrão tecnológico existente mais ou menos universal na economia capitalista mundial hoje, o que causa a exportação de capital produtivo a partir dos Estados Unidos não é uma composição orgânica do capital mais alta por si mesma, mas sim efetivamente uma taxa média de lucro relativa mais curta. Isto é, uma relação capital/salários mais apertada em níveis nacionais (no caso, o norte-americano). Não há assim um nível "absoluto" de níveis de composição orgânica do capital, mas sim um nível de taxa de lucro dado pela relação entre capital e trabalho, nível este que é o que baliza a comparação a níveis mundiais. Quando um mesmo padrão de coeficiente técnico do capital é levado, por exemplo, à China, a composição orgânica do capital muda radicalmente. Ela pode até aumentar, mas com um aumento ainda mais rápido da taxa de lucro. Assim, supondo uma taxa de salários na China dez vezes menor, em dólares, que nos Estados Unidos, para uma mesma produção em valor-trabalho, a taxa de lucro e a taxa de composição orgânica seriam as seguintes:

\section{EUA}

$3000 \mathrm{cc}+7000 \mathrm{cv}+7000 \mathrm{mv}$

Taxa de mais-valia: $7000 / 7000=100 \%$

Composição orgânica: $3000 / 7000=42 \%$

Taxa de lucro: $7000 / 10.000=70 \%$

\section{China}

$3000 \mathrm{cc}+700 \mathrm{cv}+13300 \mathrm{mv}$

Taxa de mais-valia: $13300 / 700=1900 \%$

Composição orgânica: $3000 / 700=428 \%$

Taxa de lucro: $359 \%$

Assim, não é uma alta composição orgânica do capital em si mesma que leva à exportação de capital. Ela é simplesmente uma expressão abstrata da relação do valor do capital constante face aos salários obtido em níveis nacionais, e não internacionais. A exportação de capital produtivo resulta de uma determinada relação entre (1) o nível de mecanização dado num determinado patamar do conhecimento tecnológico e (2) os salários, assumindo os casos onde a composição técnica do capital não pode ser muito distinta para empresas norteamericanas produzindo, por exemplo, na China e que antes produziam nos Estados Unidos. Boa parte das empresas que se dirigem ao Leste Asiático são empresas cujo nível técnico era adequado ao ambiente do país desenvolvido, mas que, face ao nível de salários, proporcionam 
uma taxa de lucro muito mais alta, ainda que isto apareça como uma também maior composição orgânica do capital. ${ }^{49}$

\subsection{A centralidade da relação capital/produto}

"De modo geral (fora certos casos incertos), na economia com a taxa de lucro menor, predominarão técnicas de produção mais mecanizadas." ${ }^{50}$ O que Robinson quer afirmar com isto? Que as economias tendem a substituir trabalho por máquinas se os salários são altos; se os salários são baixos, a taxa de lucro é alta e o grau de mecanização pequeno. Sob a perspectiva da divisão setorial, tal também se dá: a análise da taxa de lucro não pode ser feita então sem se levar em conta as diferentes relações de capital/produto nos vários setores da economia. Dentro disto, os setores mais mecanizados aparecem como os menos lucrativos, dada a ausência de total mobilidade e concorrência perfeitas. Assim, sendo os setores responsáveis pela produção física o eixo central da acumulação de capital e do crescimento econômico, a tendência à queda dos lucros se verifica aí com particular força, com dada sua tendência a apresentar maiores relações de capital/força de trabalho. Os setores manufatureiros envolvem maior capital constante face ao trabalho vivo; e, responsáveis diretos pelo crescimento material da economia - e assim efetivo -, induzem a um crescimento menor quando suas taxas deixam de apresentar resultados relativamente favoráveis, face aos outros setores domésticos, e face à economia internacional.

Assim, a mecanização não torna por si mesma menor a taxa de lucro. Trata-se do fato de que a relação entre mecanização e taxa de lucro é um processo contraditório. A mecanização eleva a taxa de lucro das firmas pioneiras, porque elas venderão mercadorias agora mais baratas pelo preço médio estabelecido no mercado. Mas quando a nova técnica se difunde para todos os concorrentes, os preços caem, e tais preços refletirão agora maiores relações de capital/trabalho. Por isso as economias, e os setores, com maior capital fixo, serão os menos lucrativos, no longo prazo.

Como se mostra no próximo capítulo, a alta utilização de capital constante, especialmente fixo, nos setores responsáveis pela produção física, face aos outros setores da economia, estimula os investimentos nos serviços e nos setores financeiros. No comércio, nos transportes, comunicações etc., geralmente se concentram menores massas (em valor e fisicamente) de capital constante face ao variável, especialmente fixo. Deste modo, há tendência de que os capitais migrem para outros setores econômicos, que empregarão relativamente mais trabalhadores e obterão taxas de lucro relativamente mais atrativas. Isto não significa dizer que não haja uma tendência para a equalização da taxa de lucro. Ela de fato deve existir, mas o resultado dela deve ser pensado em termos dinâmicos: as taxas de lucro se estabilizam depois que o movimento migratório a partir da indústria justamente fez diminuir a participação da

\footnotetext{
${ }^{49}$ Como o caso da siderúrgica alemã da ThyssenKrupp que foi comprada, desmontada, levada por transporte marítimo, e remontada na China por uma empresa chinesa, de que fala King no capítulo 1 de $A$ China Sacode o mundo.

${ }^{50}$ ROBINSON, Joan. Ensaios sobre a teoria do crescimento econômico capitalista, p.327.
} 
indústria no produto. As massas de lucro vão então espelhar a distribuição setorial a que se chega de acordo com os diferentes movimentos setoriais da taxa de lucro. E como o setor industrial cai em termos de valor no produto, há menor expansão da produção.

Neste movimento estará se dando um processo subjacente de diminuição relativa do crescimento da economia como um todo, à luz do que poderia estar ocorrendo se os setores manufatureiros continuassem a ser os carros-chefe dos investimentos. Quer dizer: isto não significa que a lei de tendência não atue nos setores que não os industriais. Significa apenas que este processo é mais aguçado pelo uso intensivo da maquinaria em condições de constante renovação da técnica para a produção de bens em massa, do que face aos processos onde a presença da mão-de-obra não pode ser eliminada com tanta rapidez (como no comércio, transportes, finanças, e atividades de serviço em geral). ${ }^{51} \mathrm{E}$ que isto conduz naturalmente à diminuição do crescimento. Ou, ainda: a taxa de lucro na manufatura pode estar crescendo, como resultado da atuação dos "fatores contrabalanceadores". Mas se as massas de lucro estão crescendo mais rapidamente nos outros setores da economia, a atuação "oculta" do peso da relação capital/produto estará atuando de qualquer modo. Estar-se-á obtendo menor crescimento, de qualquer modo, dada a relação desfavorável entre as taxas nos setores responsáveis pela acumulação produtiva e nos outros setores.

Marx assim resumiu este problema:

"Dado que o desenvolvimento da produtividade do trabalho ocorre muito desproporcionalmente nas várias linhas da indústria, e não desproporcionalmente em grau mas freqüentemente também em direções opostas, segue-se que a massa de lucro médio (= mais-valia) deve estar substancialmente abaixo do que se esperaria depois do desenvolvimento da produtividade nos mais avançados ramos da indústria." 52

\footnotetext{
${ }^{51}$ É neste sentido que a saturação de capitais num determinado ramo econômico é que leva a queda nas inversões relativas a ele, pondo na renovação das técnicas e novos produtos e no melhoramento do sistema de crédito uma importância central para compensar menores taxas de lucro, e na relação capitaltrabalho uma maneira de fazer com que esta taxa suba.

52 "Since the development of the productivity of labour proceeds very disproportionately in the various lines of industry, and not only disproportionately in degree but frequently also in opposite directions, it follows that the mass of average profit (=surplus-value) must be substantially below the level one would naturally expect after the development of the productiveness in the most advanced branches of industry." Capital, V.III, The Process of Capitalist Production as a Whole, p.255. Este é o sentido também do que afirmou Robinson no clássico texto "The production function and the theory of capital": "When competition is free and active, as we assume it to be, this process of competing away excess profits profits and raising sub-average profits is always completely successful, and at any moment a uniform rate of profit is ruling throughout the system" (p.97). "Aproximado" porque as condições aqui estudadas não são as de livre concorrência. De modo que: "the argument in terms of equilibrium rate of profit corresponding to a given ratio of capital to labour then cannot be applied without a great deal of complication." Presssupõe-se então que o equilíbrio acima referido incorpora a priori este elemento de complição: a concorrência entre os oligopólios acaba equilibrando a taxa de lucro entre eles (ainda que às custas dos capitais menores e dos trabalhadores) num ponto do tempo, mas não impede o movimento a transformação ao longo do tempo. Eis aí a importância da distinção epistemológica de Robinson, entre equilibrio e história, crucial aqui para a discussão de um tema caro à teoria marxista.
} 
Há um fator adicional, porém: a transformação setorial que conduz a uma queda cada vez maior da participação do setor industrial no produto pelo diferencial das taxas de lucro e também via atuação dos preços relativos, indica que a queda de sua participação representará uma dificuldade cada vez maior de o setor produtivo impulsionar o produto, mesmo sob taxas de lucro ascendentes. A mecanização intensa do processo de industrialização - tal como na agricultura - leva a um barateamento maior das mercadorias fabricadas face aos preços nos outros setores não produtivos, conduzindo ao longo do tempo os setores manufatureiros a quedas relativas cada vez maiores em participação de seu valor produzido no produto agregado nacional. Este conhece um aumento dos setores não-industriais, principalmente os serviços e os financeiros, no que se refere ao volume de emprego e à apropriação do valor produzido. Assim, a lei tendencial da queda da taxa de lucro no setor manufatureiro pode ser revertida, no interior do próprio setor manufatureiro. Porém, não bastará que suas taxas de lucro se mantenham constantes ou mesmo crescentes para que o setor industrial, e assim a economia, continue crescendo como antes. À medida que outros setores da economia apresentarem perspectivas maiores, fatalmente diminuirão os investimentos nele.

Logo, a centralidade dos setores industriais reside no fato de que, mesmo que sua participação no valor do produto possa cair, o crescimento material da economia depende de seu comportamento. A participação no valor do produto do setor de serviços (e financeiros) pode crescer à revelia do setor industrial, no qual este assume o papel subsidiário de ofertar mercadorias. O produto "aparece" como derivado do crescimento dos serviços. Mas nem os setores de serviços nem os financeiros podem criar renda e produção sem que o processo produtivo os ancore. Daí o comportamento da taxa de lucro neste setor ser decisivo, a explicar porque sua queda (relativa aos outros setores) se vê acompanhada do crescimento do endividamento externo.

Neste sentido, pode-se afirmar que, em primeiro lugar, a tendência para o crescimento da composição orgânica pode diminuir os investimentos na indústria, e por conseqüência a massa de lucros em tais setores. E, em segundo, que mesmo uma tendência estável da taxa de lucro nos setores industriais não pode impedir uma menor participação sua no produto, se a taxa de lucro em setores menos automatizados, não industriais, onde a queda dos custos seja menos rápida, se mostrar maior (o que, como se viu na introdução, e como se vê mais especificamente no capítulo seguinte, efetivamente ocorre). Estes dois processos conduzem a quedas relativas da participação da indústria no PIB, que por sua vez leva a quedas relativas do crescimento agregado da economia.

Ora, a relação entre o produto representado pelos serviços e pela produção de bens na

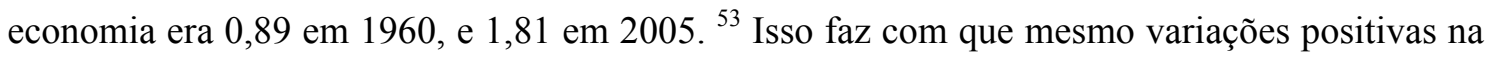
taxa de lucros no setor industrial se mostrem cada vez mais impotentes para exercer o mesmo impacto dinâmico no presente do que em relação ao passado. Assim, à medida que a produção material local vai sendo substituída pela produção do exterior, torna-se cada vez mais difícil

\footnotetext{
${ }^{53}$ Cf. a tabela B-8 do apêndice estatístico do Economic Report of the President de 2006.
} 
para o setor industrial impulsionar o produto sob o comportamento consuetudinário, mesmo mediante a própria recomposição de sua taxa de lucro.

Logo, mesmo após a recuperação das taxas de lucro desde 1987, a economia não se comportou de maneira a pôr de lado completamente a tendência à estagnação, e mesmo (como entre 2001 e 2007) quando a taxa de lucro industrial cresceu, não se pôde evitar o potencial depressor desta queda relativa. $\mathrm{O}$ fato de que os níveis de endividamento externo se elevaram ao longo dos "prodigiosos anos (19)90", paralelamente à elevação da taxa de lucro nos setores industriais, mostrou que o endividamento externo tinha de compensar os efeitos irremediavelmente decrescentes para o produto de um setor industrial a sofrer este processo assinalado.

Assim, a elevação da taxa de lucro é essencial para a expansão do produto, mas sua própria elevação se torna cada vez menos intensa em seus efeitos, e o resultado é uma permanência da tendência para a estagnação no longo prazo, para além dos efeitos da política econômica ou de outras variáveis mais localizáveis e que atuam sobre o produto no curto prazo. Reconhece-se assim que necessitar-se-ia de grande reviravolta, tal como uma grande destruição do parque industrial ou coisa semelhante causada por conflitos de grandes decorrências físicas, para trazer de volta o crescimento dos "30 gloriosos".

Não é desarrazoado então concluir que se o endividamento externo nascera no bojo da crise da lucratividade dos setores industriais no fim dos (19)70, ao longo dos anos subseqüentes, depois mesmo da recuperação parcial da lucratividade industrial, ele passou a ser utilizado para remediar as próprias conseqüências das transformações intersetoriais pelas quais a economia passava, rumo aos serviços - inerentemente menos estimulantes. Daí se vê porque o comportamento das outras economias industriais avançadas (Japão, Alemanha, Inglaterra...) mostrou, nas condições da Terceira Revolução Industrial e da hegemonia do dólar - que lhes negava a possibilidade do endividamento externo - um estancamento mais nítido do que o norte-americano, cuja situação "artificial" da relação entre poupança e investimentos conduziu a um desempenho mais satisfatório. 
Gráfico 1. Estados Unidos. Composição setorial do PIB. Setores selecionados. 1975-2004. Em porcentagem $(\%)$.

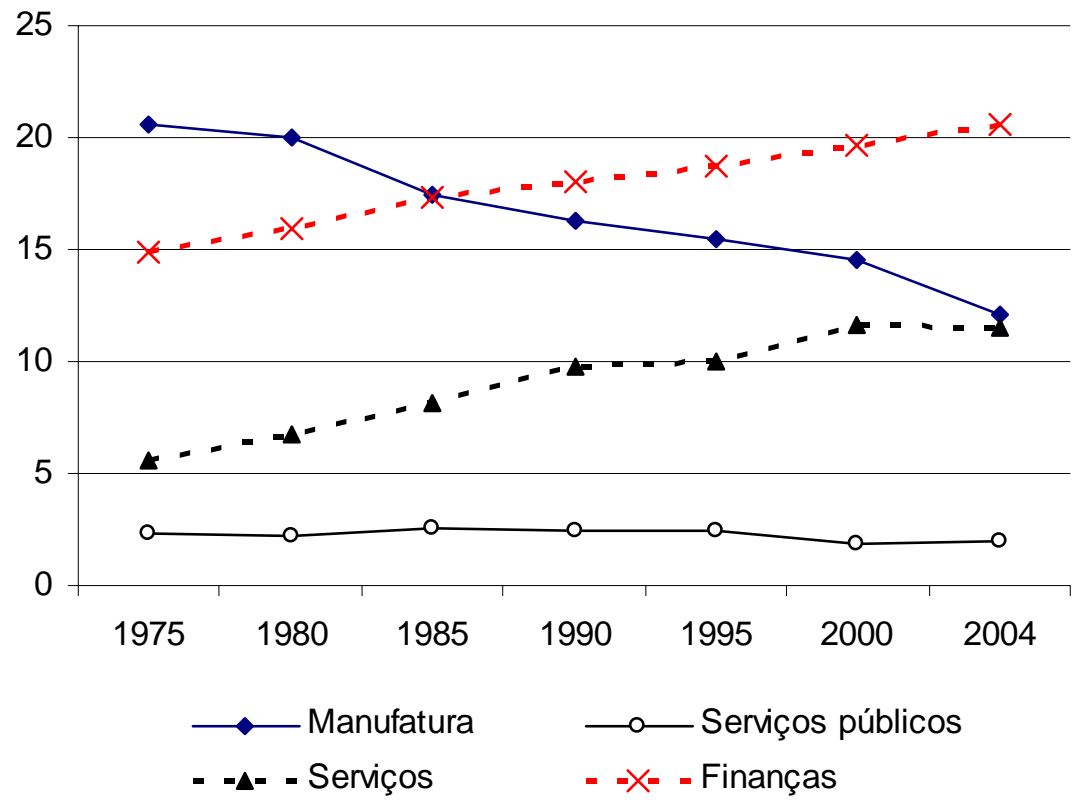

Fonte: Economic Report of the President, 2006. Tabela B-12: Gross domestic product (GDP) by industry, value added, in current dollars and as a percentage of GDP, 1974-2004.

Estas economias foram expostas aos mesmos impactos de altos juros e altos preços do petróleo, com conseqüente reformatação do processo produtivo, mas não puderam lançar mão do mecanismo de endividamento externo, pois suas moedas não tinham a centralidade mundial conferida ao dólar. Passaram, mormente Japão e Alemanha, à posição de exportadores de capital e mercadorias. Justamente a posição oposta à dos Estados Unidos, conhecendo todas as características decorrentes do processo. ${ }^{54}$

\subsection{Uma digressão: algumas opiniões divergentes}

A queda das taxas de lucro, como explicação para o movimento da economia norteamericana na década de (19)70, foi aceita pela maior parte dos autores marxistas norteamericanos, ainda que com ressalvas. Viu-se como Anwar Shaikh faz dela a pedra de toque explicativa para a crise. Mas se voltamos um pouco no tempo, para o estudo de períodos anteriores, não encontramos esta concordância quanto à eleição de um elemento explicativo determinante.

Joseph Steindl, exemplo, economista de inspiração kaleckiana, admite por exemplo que a lei tendencial "pode ser de grande importância prática para o capitalista individual, quando ele

\footnotetext{
54 Quais sejam: participação da indústria relativamente maior no produto, menor espaço para manipulações deficitárias do orçamento público, menor disponibilidade relativa de capital ofertado domesticamente, menor o consumo das famílias e maior taxa de poupança agregada, etc..
} 
leva em consideração [que] os métodos intensivos de capital para baratear a produção [podem causar um declínio na taxa de lucro] e assim impedi-lo de adotar tais métodos". ${ }^{55}$ Porém, afirma que "é difícil dizer até que ponto, durante a história do capitalismo, tem funcionado a lei da queda da taxa de lucro", de modo que julga que "outros fatores mais evidentes são de importância muito maior para os problemas da maturidade econômica". ${ }^{56}$ Ora, isto simplesmente desconsidera o fato simples de que as ações corporativas não são movidas apenas por determinações intra-firma, mas por circunstâncias alheias promovidas pela concorrência. Steindl simplesmente não entendeu a argumentação de Marx sobre como a concorrência aumenta a taxa de lucro nas empresas inovadoras mas rebaixa-a assim que as técnicas elevam a relação capital/salário. Para ele, era a teoria do "subconsumo" de Paul Sweezy que constituía a explicação mais satisfatória da "crise capitalista".

O trecho onde Paul Sweezy resume a citada abordagem, em Teoria do Desenvolvimento Capitalista, de 1942, é o seguinte:

"É importante perceber as diferenças entre as crises ligadas à tendência decrescente da taxa de lucro e as crises de realização. O capitalista prático não verá qualquer diferença: para ele, a questão é sempre um lucro insuficiente, qualquer que seja a sua causa. Mas do ponto de vista da análise causal, os dois tipos de crises apresentam problemas divergentes. Num exemplo, temos de tratar de movimentos na taxa de mais-valia e na composição do capital, permanecendo intacto o sistema de valor; no outro, temos forças ainda não especificadas que tendem a criar uma escassez geral na procura efetiva de mercadorias, não realmente no sentido de que a procura seja insuficiente para comprar todas as mercadorias oferecidas, mas de que é insuficiente para comprá-las todas a uma taxa de lucro satisfatória. O ponto de partida da crise é, em ambos os casos, o declínio da taxa de lucro. Porém, o que está por trás do declínio, num caso, exige uma análise muito diferente daquilo que está por trás do mesmo declínio no outro caso." 57

A explicação dada por Baran e Sweezy em O Capital Monopolista modificou-se um pouco. Nesta obra, os autores tentaram romper com a ortodoxia, alegando que as leis formuladas em $O$ Capital não mais se aplicavam à economia norte-americana, devido ao aparecimento do fenômeno do assim chamado capital monopolista. ${ }^{58}$ Para eles, o problema principal da economia norte-americana envolvia justamente o fenômeno oposto: incapacidade

\footnotetext{
${ }^{55}$ Maturidade e Estagnação no Capitalismo Americano, p. 2587-8.

${ }^{56} \mathrm{Ibid}$, p.258. Steindl atribui a Marx a não-resolução lógica da lei, para ele colocada em termos errôneos sob a forma de "composição orgânica". Mas Steindl não resolve a suposta contradição - mas sim apenas troca os termos - ao substituir o conceito pela relação entre capital e lucro líquido. Se tivesse procedido a um cálculo simples das taxas de mais-valia e de lucro, como feito abaixo, não teria afirmado o que afirmou.

${ }^{57}$ Teoria do Desenvolvimento Capitalista, p.122.

${ }^{58} \mathrm{Cf}$. o prefácio da obra.
} 
da economia em aplicar a formação crescente de lucros. Quer dizer, a contradição não envolvia exatamente o problema do encurtamento das margens de lucro, mas sim da própria incapacidade para aplicá-los porque cresciam rápido. “[...] Não só o excedente mas sim a parte deste em busca de inversão tende a subir em proporção à renda total. A tendência ascendente do excedente tem suas raízes nas políticas de preços e custos monopolistas." 59

De fato, não se trata exatamente de censurar os autores. Esta perspectiva parecia coerente nas décadas de (19)50 e (19)60, quando os Estados Unidos exportavam capital ao exterior e as taxas relativas de lucro na indústria eram as maiores na economia; parte importante dos capitais não podia ser aplicado internamente, porque, segundo eles, a aplicação de lucros era maior que a capacidade de sua reinversão lucrativa. Porém, a situação se apresentou de modo diferente entre (19)70 e (19)80, nas condições do endividamento externo e de queda das taxas de lucro.

Os acontecimentos da história econômica norte-americana da segunda metade do século XX modificaram o panorama analisado por Steindl, Baran e Sweezy. Deu-se queda sustentada das massas e das taxas de lucro ao longo na segunda metade dos anos (19)70, até a década de (19)80, e - mais importante - sua queda relativa aos outros setores. Realmente, os níveis de lucros auferidos pelo setor industrial ao longo dos anos (19)80 e (19)90 nunca mais voltariam, em dólares deflacionados, a atingir os patamares pré-crise do petróleo. Para ter-se ideia do tamanho do declínio absoluto e relativo, basta tomar a proporção dos lucros do setor manufatureiro em relação à renda nacional norte-americana ao longo do tempo: em 1955 era $0,05 \%$, e, em 2000 , estava em $0,01 \%$. ${ }^{60}$

Aqui opta-se por não se separarem as duas leis como se elas tivessem atuações distintas no espaço e tempo. De fato, adotando-se a hierarquia sistêmica adotada pelo próprio Marx, ${ }^{61}$ enfoca-se a queda da taxa de lucro como o nível mais abrangente de crise dos anos (19)70, que dá origem à queda dos investimentos e assim do consumo, portanto queda da demanda efetiva em termos globais. Ou, mais simplesmente, de tendência rumo à reprodução simples. De fato, "Sweezy se acha em grande parte sob a influência da noção tradicional do subconsumo, segundo a qual a demanda por bens de consumo regula a produção total". ${ }^{62}$ Isto porque a taxa de poupança mostrou-se decrescente no período estudado, tendo ela um papel determinante no desempenho da economia.

É verdade que o aumento da taxa de poupança das famílias constitui um impedimento ao aumento da realização das mercadorias, pelo lado da demanda. De nada vale que as corporações gastem mas que as famílias poupem. Torna-se necessário ampliar cada vez o crédito para consumir a oferta disponível. Mas, para a economia dos Estados Unidos, se a taxa

\footnotetext{
${ }^{59}$ O capital monopolista, p.68-69.

${ }^{60}$ Segundo o BEA, o produto em dólares correntes era 506 bilhões de dólares em 1959 e os lucros manufatureiros totais 26 bilhões; em 2000, o produto perfazia 9 trilhões e oitocentos bilhões e os lucros manufatureiros totais 166 bilhões de dólares, aproximadamente. (Conferir tabelas B-1 e B-29 do Economic Report of the President de 2006.)

${ }^{61}$ Cf. GRESPAN, Jorge. O Negativo do Capital.

${ }^{62}$ SHAIKH, Anwar. Valor, Acumulación y Crisis, p.334.
} 
de poupança vem caindo absolutamente, até chegar próxima de zero atualmente (2008), é evidente que é na taxa de lucro, e na participação da manufatura, que reside o segredo da diminuição da expansão, e, por outro lado, no endividamento externo o segredo do amortecimento dos impactos deste comportamento inconstante. Ora, "a taxa de acumulação depende das decisões de inversão das empresas, e não da poupança das famílias". ${ }^{63}$ Pelo lado do consumo, a economia tem se comportado sob a trajetória mais expansiva possível, excluída uma divisão mais eqüitativa da renda. A origem do "subconsumo" - se se puder falar em subconsumo, neste caso - é de outra natureza: é que na medida em que a mais-valia deixa de converter-se em aumento da produção, ela deixa de converter-se em salários e por conseqüencia em rendas para o Estado. A raiz de um suposto "subconsumo" para a economia norte-americana no período em voga só poderia ser entendida então como a não-criação de salários e rendas para o Estado que surgiriam se o desempenho econômico estivesse sob expansão progressiva. Mas isto foge da definição estrita de subconsumo, pois este significa rendimento insuficiente para comprar mercadorias (o outro lado da crise de realização).

Isto não significa que o "subconsumo" não atue, num período de curto ou médio prazo. Mas se há "subconsumo" no caso da economia norte-americana recente, ele é um subconsumo de tipo distinto do que Sweezy observava; tal "subconsumo" estará indicando que, se as corporações estão investindo menos, estão criando menos consumo pela diminuição da contratação de trabalhadores. Neste ínterim, o endividamento externo da economia, como se argumenta, é um processo estrutural que permite: (a) baratear os custos de financiamento para o capital que se vê diante de taxas menores de lucro; (b) trocar investimento por consumo para manter a demanda agregada.

Como Greenspan mesmo observou...

"Um país não pode depender para sempre da poupança externa; em algum ponto, teremos que depender mais de nossos próprios recursos. A insuficiência de poupança agregada doméstica nos anos recentes tem sido exacerbada por uma sustentada queda na poupança privada, e nós não podemos contar com uma grande reversão desta tendência. Nós tendemos nas últimas décadas a implementar polícias tributárias para elevar a poupança das famílias e das empresas; de qualquer modo, elas encontraram apenas um resultado limitado." 64

\footnotetext{
${ }^{63}$ ROBINSON, Joan e EATWELL, John. Introducción a la economia moderna, p.141.

${ }^{64}$ "A country cannot depend forever upon foreign saving; at some point we will have to rely more fully on our own resources. The paucity of aggregate domestic saving in recent years has been exacerbated by a sharp fall in private saving, and we cannot count on a major reversal of that trend. We have endeavoured in the past few decades to implement tax policies to augment household and business saving; by all accounts, they have met only with limited success." GREENSPAN, Alan. "Statement by Alan Greesnpan, Chairman, Board of Governors of the Federal Reserve System, before the Committee on Banking, Finance and Urban Affairs. U.S. House of Representatives.” 24 de Janeiro de 1989.
} 


\title{
Reprodução do capital social e endividamento externo
}

\begin{abstract}
"Haverá uma expansão da reprodução se existirem fatores que simplesmente não permitam que o sistema permaneça em estado de reprodução simples ou estacionário."
\end{abstract}

Michal Kalecki, Ensaios escolhidos sobre a dinâmica da economia capitalista

\subsection{Introdução}

Michal Kalecki é o economista que primeiro conectou a teoria marxista ao enfoque macroeconômico, do qual é um dos fundadores. Neste capítulo, retomam-se então aspectos de sua obra para caracterizar a tendência para a estagnação numa linguagem mais próxima à da economia moderna - economia esta de tradição keynesiana e robinsoniana cujos instrumentos de análise, em comunhão com a obra de Kalecki, permitiram os avanços analíticos hoje conhecidos por todos. Segue-se uma discussão referente à conexão entre taxa de lucro e demanda efetiva para a economia, sob a perspectiva da reprodução do capital social. Por fim, relaciona-se reprodução do capital social e endividamento externo.

\subsection{A reprodução simples}

Steindl estava certo, de todo modo, ao referir-se à "maturidade econômica" como sendo a tendência para estagnação da economia, com base seja na dificuldade para obter sempre taxas de lucro continuamente crescentes, seja no "subconsumo" como derivado daquele, seja com resultado do próprio processo de desenvolvimento geral da economia industrial. Ora, ver o oposto seria regressar a uma visão mítica de um sistema econômico livre de contradições. Como se vê pelas taxas de variação do PIB da economia norte-americana, esta é a tendência predominante nas últimas três décadas. Tem-se um produto que pode ser analisado a partir das contradições destacadas porque demanda mais acumulação do que efetivamente pode gerar. Nesta seção, vamos revisitar a obra de Kalecki em busca de uma apreciação, numa linguagem macroeconômica de inspiração marxista, desta (i) tendência à reprodução simples do sistema e (ii) do modo como ele pode ser impelido à reprodução ampliada - no caso dos Estados Unidos, pelo endividamento externo.

De fato, como observado acima, o próprio Kalecki não voltou sua atenção para a chamada lei de tendência, em primeiro lugar por uma preocupação voltada ao curto prazo. Por outro lado, sua visão e impressões do capitalismo são derivadas do marxismo, mas ele tentou 
construir uma visão própria dos fenômenos econômicos. Sua teoria está exposta fundamentalmente sob forma matemática; neste sentido, sua "função investimento" leva em consideração, além da taxa de lucro, o excesso de capacidade instalada nas firmas, uma categoria não desenvolvida por Marx. Tomar apenas sua função-investimento como elemento central da explicação do movimento de longo prazo conduzirá à perspectiva de Sweezy, já que ela aceita tanto o "excesso de capacidade" (sinal de subconsumo) como a taxa de lucro como elementos igualmente explicativos das inversões. É necessário, logo, abordar a perspectiva de Kalecki sobre a tendência geral de comportamento macroeconômico das economias capitalistas para conectar, ou pelo menos aproximar, sua visão sobre o processo de reprodução global do capital com a lei tendencial estabelecida por Marx.

Quando Kalecki aprofundou a análise abstrata de Marx sobre a reprodução de todo o capital social, desenvolvendo a inter-relação entre todos os vários setores da economia que nos "Esquemas de Reprodução" apareciam sob forma embrionária, argumentou que é possível que as contradições da produção capitalista possam conduzir a economia a um estado de estagnação: "a economia pode ajustar-se a um estado de reprodução simples com flutuações cíclicas ao redor dela". ${ }^{65}$ Todavia, o caso é que Kalecki não se refere diretamente à lei tendencial, no sentido de adotar a crescente relação entre capital constante e variável como o determinante para a queda de longo prazo da taxa de lucros. Talvez Kalecki a julgasse "demasiado abstrata" ou não preferisse adotar um "elemento explicativo último", aceitando argumentos mais pontuais para explicar porque a economia pode tender à reprodução simples, ou às flutuações em torno de uma posição estática. Dentro disto, tanto a queda da taxa de lucro como o excesso de "capacidade instalada" poderiam ser elementos igualmente determinantes.

Porém, não obstante esta variação para com a argumentação de Marx, não há nenhum impedimento para que a tendência à reprodução simples, nos termos de Kalecki, possa ser causada por uma tendência para a queda nas taxas de lucro, nos termos de Marx. O importante é o modo pelo qual a perspectiva macroeconômica vê o fenômeno. Neste caso, o que vale é o fato de que Kalecki aceitou a possibilidade da tendência para a reprodução simples, nos termos em que Marx a pontuou, e a pensou numa linguagem macroeconômica - mesmo não explicitando uma determinada causa "última" como explicativa para o movimento num prazo mais ou menos longo.

Não se precisar enfatizar que as várias modalidades de crise (como uma crise no sistema de crédito) evidentemente impactam na economia de várias maneiras, no curto e médio prazo, mas que se está neste momento discutindo o movimento tendencial, que se explica em última instância pelas condições nas quais as corporações investem, e que se reflete num prazo maior. Quer-se dizer que, no longo prazo, o elemento explicativo último para a desaceleração não pode ser "tanto o subconsumo como a tendência para a queda dos lucros". Necessariamente, deve ser o último. Ou, mais exatamente: o "subconsumo", entendido como o excesso de

\footnotetext{
${ }^{65}$ KALECKI, Michal. El problema de la demanda efectiva en Tugan-Baranovsky y Rosa Luxemburgo. In: Ensayos escogidos sobre la dinámica de la economía capitalista, p.171.
} 
capacidade, explica-se porque há menos investimentos. É determinante ressaltar o seguinte: se o controle dos meios de produção é feito pelas firmas, e "se os trabalhadores gastam o que ganham", o subconsumo não pode explicar o movimento tendencial de uma economia na qual as taxas de poupança vêm caindo sucessivamente ao longo das três décadas (ver próximo capítulo).

A desaceleração é a expressão de um processo subjacente ainda mais estrutural. Se a taxa de poupança tem caído de modo rápido, a propensão marginal a poupar no sistema norteamericano não tem sido particularmente um elemento impeditivo. Isto, é claro, não implica, absolutamente, desconsiderar as causas das flutuações conjunturais com base na diminuição do consumo, ocasionada, por exemplo, por uma política econômica contracionista. Mas, como neste momento se está discutindo o movimento de longo prazo, esta hierarquia sistêmica parece mais coerente. Deve-se frisar a diferença entre as causas do movimento de longo e curto prazo.

De todo modo, mesmo que o próprio Kalecki não tenha tido uma posição clara sobre a lei tendencial, ele aceita como possível a tendência para a desaceleração, e, a partir daí, desenvolve uma perspectiva macroeconômica de linguagem marxista muito bem estruturada, conceitualmente simples e de grande poder heurístico, que pensa as condições da reprodução simples e da reprodução ampliada em termos dos agregados aceitos pela contabilidade nacional. De certo modo, sua interpretação é feita como se a leitura dos esquemas de reprodução do Livro II de $O$ Capital fosse pensada levando-se em consideração as diversas modalidades da crise expostas por Marx (dentre as quais poderíamos inserir a lei tendencial), mas numa linguagem mais próxima à da macroeconomia.

Assim, em termos estritos, para que se dê a reprodução do capital social de modo a não haver acumulação em escala ampliada - a "reprodução simples" - basta que haja a resistência para as corporações quanto a continuarem investindo sob taxas - elou massas - de lucros cadentes. Sua assertiva de que "os capitalistas ganham o que gastam, e os trabalhadores gastam o que ganham" é um bom resumo da perspectiva. A taxa de lucro pode cair por um aumento da composição orgânica do capital; as massas de lucro podem cair por queda na demanda agregada, via política econômica, perda de mercados, ou outros efeitos macroeconômicos. Com isto se mantém a tendência para a reprodução simples do capital social, baseada nos gastos das firmas com depreciação do capital (necessária para que a produção corrente seja realizada). Os gastos com depreciação em nível agregado geram necessariamente um fluxo de salários e lucros correntes, e a arrecadação do Estado, mas sem que haja necessariamente crescimento. Aí, a centralidade para a interpretação do comportamento da economia reside no comportamento das corporações, e dentre elas as corporações industriais, que são os agentes detentores da maior parte da riqueza que pode ser convertida em investimentos.

O resultado final do estado de reprodução simples indica estritamente que houve um resultado conjunto para a economia de estagnação ou mesmo queda da taxa ou massa de lucros na maior parte dos setores industriais. Em termos dinâmicos, isto representará um menor crescimento: esta economia apresentará uma menor variação da demanda agregada em todos os 
setores da economia. Evidentemente, pode ocorrer que alguns setores continuem apresentando lucros ascendentes (que, como se vê na próxima seção, é o caso dos Estados Unidos, de fato), mas que, pela sua restrição a alguns setores, não culminaram em um aumento das inversões na maior parte dos setores. Isto é, seus impactos multiplicadores são mais restritos pela presença de menores lucros nos outros setores manufatureiros. ${ }^{66}$ Em termos simples: nesta situação há menores investimentos, o efeito multiplicador é menor, e assim o efeito acelerador. ${ }^{67}$

$\mathrm{O}$ artigo de Kalecki intitulado "As equações marxistas de reprodução e a economia moderna", publicado em 1968 no volume 7 do periódico Social Science Information, foi um dos últimos textos de Kalecki a respeito do tema. ${ }^{68}$ Neste artigo, o autor busca validar a possibilidade da reprodução simples. Aí, põe o problema da reprodução sob o ponto de vista dos esquemas de reprodução, com algumas modificações nos próprios esquemas. Busca-se dar um tratamento algébrico ao problema da reprodução simples e ampliada, mostrando como não há nenhum impedimento para que aquela se estabeleça em detrimento desta, ao longo do tempo, como fruto da queda das inversões e da demanda efetiva ocasionada por um comportamento estagnativo dos investimentos. Aí, as "crises" capitalistas de queda dos lucros e de demanda efetiva podem ser enfocadas de modo conjunto, e numa escala ordenada de determinações.

No texto de Kalecki, o departamento I fabrica não apenas as máquinas, mas todos os meios de produção utilizados neste mesmo setor e nos outros - incluídas assim as matériasprimas. O departamento II produz os bens de consumo para os capitalistas, e, similarmente, produz também todas as matérias-primas (relacionadas aos bens de consumo) utilizadas neste próprio setor. O departamento III produz todos os bens de consumo utilizados pelos trabalhadores, segundo a mesma lógica. Um modelo de economia nacional pode então ser traçado do seguinte modo:

No esquema abaixo organizado por Kalecki, P são os lucros totais nos três departamentos (Kalecki considera os lucros brutos, antes da depreciação); W são os salários totais de todos os trabalhadores. Y é a renda nacional bruta, a soma de W e P. Por sua vez, $\mathrm{W}_{1}$, $\mathrm{W}_{2}$ e $\mathrm{W}_{3}$ são os salários dos trabalhadores em cada departamento, assim como $\mathrm{P}_{1}, \mathrm{P}_{2}$ e $\mathrm{P}_{3}$ são os

\footnotetext{
${ }^{66}$ É claro que as inversões podem cair por outros motivos. Kalecki aponta por exemplo que, para além da queda das taxas de lucro, os investimentos podem cair também no caso de as decisões de investimento corporativo se tornarem progressivamente sujeitas - como ele mesmo diz - a um "aumento de cautela" por parte dos empresários e corporações - devido a alguma situação política potencialmente desestabilizadora para a classe capitalista, por exemplo. Isso levaria a uma taxa de investimento corrente menor do que a passada, ou igual, no caso de ela se limitar à depreciação do capital.

${ }^{67}$ De fato, como Joan Robinson e John Eatwell observaram, "de certo modo, para o caso de qualquer sociedade tomada como conjunto, a poupança e o investimento realizados ao longo do tempo devem ser iguais, se as definições contábeis são corretas, porque a poupança e a inversão ex post são duas formas de ver a mesma coisa - o aumento total da riqueza efetuado neste período." (Introdução à Economia Moderna, p.128.) Logo, a formação de poupança no longo prazo é benéfica, contrariamente à preservação da poupança no curto prazo, que representa um problema de demanda efetiva.

68 Originalmente escrito para o Seminário intitulado "A influência de Karl Marx no Pensamento Científico Contemporâneo" realizado em Paris em Maio de 1968. O texto aqui utilizado está publicado no Brasil em Crescimento e Ciclo das Economias Capitalistas, organizado por Jorge Miglioli (1983).
} 
lucros "setoriais" de cada departamento. Ainda, Cc forma o consumo da classe capitalista como um todo e $\mathrm{Cw}$ o consumo da classe trabalhadora. Eliminando-se da renda nacional (Y) o consumo de ambas as classes $(\mathrm{Cc}$ e $\mathrm{Cw}$ ) têm-se os investimentos desta economia, aí representados por I.

$\begin{array}{cccc}\mathrm{I} & \text { II } & \text { III } & \text { Total } \\ \mathrm{P}_{1} & \mathrm{P}_{2} & \mathrm{P}_{3} & \mathrm{P} \\ \mathrm{W}_{1} & \mathrm{~W}_{2} & \mathrm{~W}_{3} & \mathrm{~W} \\ \mathrm{I} & \mathrm{Cc} & \mathrm{CW} & \mathrm{Y}\end{array}$

O departamento III produz bens para todos os trabalhadores, dos setores I, II e III. Os trabalhadores deste setor consomem sua própria parte de bens de consumo, de modo que a interrelação do departamento III com os trabalhadores dos outros dois departamentos se dá com os lucros dos capitalistas deste setor III sendo trocados com os salários dos trabalhadores de I e II. Pode-se representar a relação pelo próprio esquema de Kalecki ou algebricamente.

$\begin{array}{cccc}\mathrm{I} & \text { II } & \text { III } & \text { Total } \\ \mathrm{P}_{1} & \mathrm{P}_{2} & \underline{P}_{3} & \mathrm{P} \\ \underline{W}+7 & \frac{W}{\mathrm{~W}} z & \mathrm{~W}_{3} & \mathrm{~W} \\ \mathrm{I} & \mathrm{Cc} & \mathrm{CW} & \mathrm{Y}\end{array}$

$\mathrm{Ou}:$

$$
P_{3}=W_{1}+W_{2}
$$

A relação do setor III com a economia nacional é assim a mais simples; os trabalhadores deste setor consomem sua parte relativa da produção. O restante da produção é vendida aos trabalhadores dos outros dois setores, o que confere os lucros dos capitalistas do setor III.

Ao adicionar aos dois lados desta equação os lucros dos outros dois departamentos I e II, têm-se a seguinte expressão:

$$
P_{1}+P_{2}+P_{3}=P_{1}+W_{1}+P_{2}+W_{2}
$$

Kalecki deriva desta equação uma outra mais geral:

$$
P=I+C c
$$

Esta última expressão indica que, segundo as trocas entre os lucros do departamento III e o consumo dos trabalhadores dos departamentos I e II, assim como entre os lucros do departamento I e os lucros do departamento II, o lucro total da classe capitalista pode ser dividido entre a parte que cabe a seu consumo como classe e a parte que cabe aos investimentos. 
Ademais, esta é uma das equações macroeconômicas mais fundamentais. (Enfatize-se que pelo fato de que $\mathrm{W}_{1}$ e $\mathrm{W}_{2}$ compram $\mathrm{P}_{3}$, só restam entre I e II as trocas entre os lucros $\mathrm{P}_{1}$ e $\mathrm{P}_{2}$ ). Kalecki assinala ainda que a capacidade de produção em III deve ser compatível com o aumento dos investimentos em I e II, já que o aumento dos investimentos em I e II fará crescer os salários nestes setores e assim exigirá um crescimento em $\mathrm{P}_{3}$, proporcional a este aumento dos salários. Se este aumento da ampliação da capacidade em III não se der, os salários em I e II podem cair pelo virtual aumento dos preços dos bens de consumo fabricados em III. Uma das conseqüências disto seria que - apesar de Kalecki não enfatizar este ponto - os salários em I e II teriam de crescer a ponto de minar as taxas de lucro de I e II, atrapalhando a acumulação.

O próximo passo é denotar W1/I, W2/Cc e W3/Cw (os salários de I sobre os investimentos, os salários de II sobre o consumo dos capitalistas e o salário de III sobre o consumo dos trabalhadores) como $\mathrm{w}_{1}, \mathrm{w}_{2}$ e $\mathrm{w}_{3}$. A equação $P_{3}=W_{1}+W_{2}$ pode então ser reescrita como:

$$
\left(1-w_{3}\right) C w=w_{1} I+w_{2} C c^{69}
$$

O que permite reescrever que o consumo dos trabalhadores é:

$$
C w=w_{1} I+w_{2} C c / 1-w_{3}
$$

Sendo a renda nacional a soma do consumo dos trabalhadores, dos capitalistas, e parte da renda dos capitalistas que não é consumida mas investida, tem-se:

$$
Y=I+C c+C w=I+C c+w_{1} I+w_{2} C c / 1-w_{3}
$$

Para enfocar o sistema sob o ponto de vista da acumulação, Kalecki esboça a expressão:

$$
I=(r+\delta) K
$$

"K" representa o "estoque de capital real", "r" a taxa de acumulação líquida - quer dizer, os investimentos que excedem as necessidades de depreciação - e " $\delta$ " a própria depreciação. Deste modo, os investimentos totais são os investimentos necessários à

\section{${ }^{69}$ Pois:}

a) $\mathrm{W}_{1}=\mathrm{W}_{1} / \mathrm{I}$

$\mathrm{W}_{1}=\mathrm{w}_{1} \mathrm{I}$

b) $\mathrm{W}_{2} / \mathrm{Cc}=\mathrm{W}_{2}$

$\mathrm{W}_{2}=\mathrm{Cc}_{2}$

c) $\mathrm{Cw}\left(1-\mathrm{w}_{3}\right)=$

$\mathrm{Cw}-\mathrm{Cw} \mathrm{w}_{3}$

$\mathrm{Cw}-\mathrm{Cw} \times \mathrm{W}_{3} / \mathrm{CW}$

$=\mathrm{CW}-\mathrm{W}_{3}=\mathrm{P}_{3}$, porque o consumo de todos os trabalhadores, menos o consumo dos trabalhadores do setor III, dá, como visto, o lucro dos capitalistas de III. 
manutenção do capital existente e os investimentos para ampliação da capacidade instalada. As teorias contemporâneas do crescimento (no fim dos anos (19)60) são derivadas, diz Kalecki, das equações (3) e (7), originadas das equações de reprodução marxistas.

Do mesmo modo, o consumo dos capitalistas é proporcional aos lucros P (dados por I $+\mathrm{Cc}$ ). Dá no mesmo dizer que Cc, consumo dos capitalistas, mantém uma relação proporcional com I, dada por "m".

$$
C c=m I
$$

Ele reescreve a partir disto a equação (6). Substituindo em partes os dois "Cc" da expressão, temos:

$$
\begin{gathered}
Y=I+C c+w_{1} I+w_{2} C c / 1-w_{3}= \\
Y=I+m I+w_{1} I+w_{2} C c / 1-w_{3}= \\
Y=I=m I+w_{1} I+w_{2} m I / 1-w_{3}= \\
Y=(1+m) I+I\left(w_{1}+m w_{2}\right) / 1-w_{3} \\
\cdot \\
\cdots \\
=I\left(1+m+\underline{w}_{\underline{1}}+m w_{2}\right) \\
1-w_{3}
\end{gathered}
$$

Por fim: substitui-se I por seu correspondente dado na equação (7), que o desmembra entre depreciação e investimento líquido:

$$
Y=K(r+\delta)\left(1+m+\underline{w}_{\underline{l}} \frac{+m w_{2}}{1-w_{3}}\right)
$$

Que diz Kalecki sobre este esboço teórico? Em primeiro lugar, que "a renda nacional [Y] mantém uma relação constante com o estoque de capital". Se o estoque de capital cai, a renda nacional (lucros e salários), deverá cair, porque ambos são determinados pelos investimentos dos "detentores de riqueza". Se a capacidade produtiva nos três departamentos aumenta, "não há escassez de bens de consumo"; e, também: "com uma dada relação entre a capacidade produtiva e o estoque de capital, o grau de utilização do estoque de equipamento é constante" (p. 6). Assim, "se o equipamento de capital é utilizado satisfatoriamente na posição inicial, essa situação se mantém no decorrer da reprodução ampliada e não surge o problema da demanda efetiva." 
Porém, o equilíbrio depende do que Kalecki chama de "extrema suposição de que os capitalistas estão dispostos a efetuar investimentos que aumentem seu capital a uma taxa constante $r$ ao ano". Mas se eles se tornam "mais cautelosos", por outro lado, decidindo reduzir os investimentos de $(r+\delta) K$ para $\left(r^{\prime}+\delta\right) K-$ sendo r' $<\mathrm{r}-$ a proporção da renda $\mathrm{Y}$ sobre o estoque $\mathrm{K}$ de capital vistas na equação (10) cai na proporção em que cai $\left(r^{\prime}+\delta\right) K /(r+\delta) K$. Há uma pressão negativa na demanda agregada.

Kalecki vai mais longe do que aceitar que esta pode ser apenas uma fase declinante de um comportamento cíclico. Para ele, não há razão para que, "tendo deixado a instável trajetória inicial, o investimento deva flutuar em torno dela [i.é, da trajetória inicial] em vez de em torno do nível de depreciação de $\delta K^{\prime \prime}$, no qual a taxa de investimento líquido é nula. Flutuar em torno do nível $\delta K$ implica manter a reprodução simples no longo prazo. Assim, para o autor, dão-se flutuações explicadas pelo desgaste do capital, mas não em pendente ascendente. Neste caso, não exatamente, ou necessariamente, porque os empresários se tornaram mais "cautelosos", mas simplesmente porque a lucratividade média corrente das firmas pode estar sendo suficiente apenas para cobrir os gastos com depreciação e com o consumo da classe capitalista, ou porque a lucratividade obtida está abaixo da esperada - situação na qual " $r$ " seria sempre o mesmo.

Tabela 1. Estados Unidos. Relação da poupança líquida com a poupança total. Calculado a partir dos dados de poupança, em bilhões de dólares correntes. 1970-2005.

\begin{tabular}{cc}
\hline$(1)$ & $(2)$ \\
Anos & $\begin{array}{c}\text { Poupança líquida/ } \\
\text { poupança total }\end{array}$ \\
& 0,44 \\
1970 & 0,36 \\
1975 & 0,37 \\
1980 & 0,33 \\
1985 & 0,27 \\
1990 & 0,25 \\
1995 & 0,32 \\
2000 & 0,22 \\
2001 & 0,13 \\
2002 & 0,09 \\
2004 & \\
\hline
\end{tabular}

Fonte: Economic Report of the President, 2007. Tabela B-32: Gross saving and investment, 1959-2005.

Aí está portanto a possível concordância entre os esquemas e lei tendencial: a queda da acumulação produtiva leva a uma menor expansão. ${ }^{70} \mathrm{~A}$ abordagem dos ciclos em tendência decrescente é, portanto, uma decorrência da junção entre a lei tendencial e o problema da reprodução num caso concreto - onde os fatores "contrabalanceadores" não estão atuando a contento - assim como uma dedução da assertiva de Kalecki de que não há motivo algum para esperar que o setor inversor continue investindo sem interrupção.

\footnotetext{
${ }^{70}$ Como se sabe, Kalecki elogia o trabalho de Tugan-Baranovski porque ele mostra que o capitalismo pode reproduzir-se (e não necessariamente expandir-se) indefinidamente, desde que as proporções entre o consumo e a produção dos vários setores da economia sejam atendidas. Cf. "O problema da demanda efetiva em Tugan-Baranovski e Rosa Luxemburgo", em Crescimento e Ciclo..., p.10.
} 


\subsection{A reprodução ampliada do capital social}

Assim, sob uma taxa de lucro estagnada, o sistema poderia manter-se sob reprodução simples, o que se refletiria na estável ou mesmo cadente taxa de formação de capital fixo ao longo do tempo. Daí, a manutenção da taxa de investimento em patamares estabilizados implicaria uma estabilização do crescimento da renda e da arrecadação do Estado, bloqueando ao mesmo tempo a ampliação da massa de lucros obtida pelas empresas. De fato, como na já citada assertiva de Kalecki, "os capitalistas ganham [apenas] o que gastam". ${ }^{71}$

Porém, é um erro julgar que a tendência para a reprodução simples se estabeleça de modo natural, e que os agentes capitalistas a aceitem como um fato imutável. "A reprodução simples, reprodução na mesma escala, aparece-nos como uma abstração, dado que, por um lado, a ausência de toda a acumulação ou reprodução numa escala estendida é uma estranha suposição sob condições capitalistas de produção, e que por outro lado as condições de produção não permanecem exatamente as mesmas em diferentes anos". ${ }^{72}$ Daí, é claro que, para as corporações e para o Estado no capitalismo, as conseqüências sistêmicas da cadente taxa de investimentos líquidos devem ser compensadas seja por (1) tentativas constantes de restaurar e mesmo elevar as taxas de lucros, seja pela (2) manutenção ou mesmo elevação da demanda agregada, em forma de gastos das famílias, do Estado, e mesmo de investimentos correntes das firmas. Eis aí o segredo do problema do endividamento externo: ele não seria necessário se a tendência à desacumulação não tivesse de ser compensada por algum tipo de artifício que a contrapusesse.

A lógica da acumulação leva as firmas e o Estado capitalista, que lhes apoia incondicionalmente, às políticas que deem conta de (1) e (2), de modo que mesmo a tendência para a reprodução simples aparece, de fato, como tendência apenas potencial, contrabalançada por políticas que permitam seja reativar a taxa de lucros, seja manter a demanda efetiva suficiente para a utilização da capacidade instalada, aumentando a massa de lucros. Isto significa que, mesmo com uma queda relativa da taxa de investimentos líquidos, i.é, da formação líquida de capital fixo, o sistema pode continuar crescendo com base primordialmente dirigida pela manutenção do consumo e gastos do Estado, e seu impacto positivo na taxa de acumulação, obrigando as firmas a realizar constante depreciação do capital para atender o consumo corrente. Neste caso, os investimentos são estimulados pelo consumo, e não o oposto.

As corporações exigem do Estado políticas que permitam elevar a taxa de lucro e a demanda agregada. Isto se dá mediante práticas diversas, como cortes de direitos dos trabalhadores, rebaixamento da alíquota de impostos, abertura de mercados externos, manipulações da taxa de câmbio e da política monetária, altas taxas de endividamento dos

\footnotetext{
71 "Está claro que os capitalistas podem decidir investir e consumir mais em um período dado de tempo do que no anterior, mas não podem decidir ganhar mais.” Teoría de la Dinámica Económica, p.47.

${ }^{72}$ MARX, K., Capital, V.II, p.394-395.
} 
agentes econômicos. Num ambiente de investimentos estagnados, sob "condições capitalistas", deve-se favorecer um consumo das famílias e os gastos do Estado financiados com poupança "inativa" de modo compensatório, para estimular pelo menos a taxa corrente de investimentos em depreciação. Não se precisa enfatizar de novo que, em condições de já baixíssima formação de poupança das famílias, o financiamento externo das contas deficitárias do governo ganha relevância cabal.

Os investimentos nas empresas do complexo industrial-militar e a agressão militar a outros países aparecem, neste leque de políticas mencionadas, como o mais perverso meio de elevação da demanda efetiva e da taxa de lucros, pois as benesses da guerra para o capital não residem apenas nos gastos do Estado, mas no botim que a guerra permite abocanhar - na forma atual, controle de reservas de petróleo, manutenção de seus preços, contratos de reconstrução etc.. O aumento do consumo e dos investimentos do Estado contrapõe a queda dos investimentos e permite obter, no longo prazo, alguma acumulação de capital, o que se reflete num aumento, ainda que pequeno, do crescimento da economia. ${ }^{73}$

É importante assinalar que o consumo e os gastos do Estado têm se dado de modo a eliminar a poupança ociosa quase que em totalidade, no período em questão. Mesmo assim, apresentou-se um desempenho pior do que o do pós-guerra (1945-1973). Porém, o que torna o cenário ainda mais ruim é o fato de que a economia dos Estados Unidos, para adiante da aplicação destas medidas de resolução parcial contrárias à queda relativa da acumulação produtiva, tem crescido à base do endividamento externo. Todos estes mecanismos assinalados acima para elevar o crescimento podem ser facilitados pela estratégia do endividamento externo, escolha política dos grupos dominantes norte-americanos. A posição do dólar lhes confere meios adicionais, específicos ao país que detêm a moeda de livre curso internacional, de contribuir para debelar a tendência à reprodução simples, via elevação da demanda agregada pelo endividamento externo. Tal posição é referente ao papel de sua moeda no mundo.

O fato de o dólar ser a mais difundida moeda de reserva da economia internacional possibilita aos Estados Unidos um meio adicional de colher recursos para consumo e investimentos internos, na medida em que o exterior demanda títulos denominados em dólar. Este processo tem sido central como meio específico adicional de remediar a tendência à reprodução simples do capital social, para além dos limites da política econômica e do sistema de crédito tomados em si mesmos. Este artifício é marcadamente relevante numa situação em que um baixo crescimento é obtido mesmo quando as famílias estão poupando cada vez menos e quando o Estado já incorre em enormes déficits.

\footnotetext{
${ }^{73}$ Neste sentido, classificar a guerra como "negativa" em si mesma para a economia (como faz Stiglitz e Bilmes em The Three Trillion Dollar War (2008) é um erro; a guerra é "ruim" somente se classificada sob um juízo de valor.
} 


\subsection{Lógica do endividamento externo}

Segue-se agora a argumentação em termos kaleckianos de como a economia norteamericana vai valer-se do endividamento externo como meio de compensar a queda da acumulação produtiva. Aí se discutem os termos em que o endividamento externo da economia relaciona-se com a manutenção da demanda efetiva. Mostra-se como a economia cresce mais do que poderia na ausência do endividamento externo, mediante (a) financiamento externo dos investimentos domésticos; (b) financiamento externo dos gastos do governo; (c) financiamento indireto do consumo das famílias, mediante o sistema creditício. Segue-se depois uma análise empírica sobre os pontos discutidos.

\subsubsection{Método e hierarquia das variáveis}

A análise macroeconômica aplicada às contas nacionais e a uma visão históricoeconômica fornece uma visão global e objetiva dos elementos que permitem a uma determinada economia crescer. A dificuldade da interpretação histórico-econômica reside no entrelaçamento, na vida real, do comportamento das variáveis-macro, de modo que elas, por influenciarem-se mutuamente, impedem muitas vezes de determinar, na conjuntura, o quê explica o quê. Isso se reflete de modo óbvio nos resultados muitas vezes parecidos que duas regressões apresentam ao serem feitas com as mesmas séries, tomando-se uma série ora como variável explicada, ora como explicativa.

Contudo, a macroeconomia desenvolveu-se de modo razoável para que os analistas possam localizar com mais ou menos certeza quais fatores são determinantes para o crescimento, ainda que sob o calor da conjuntura não se saiba identificar às vezes com exatidão os impactos desta ou daquela variável nas outras variáveis. De qualquer modo, pode-se aceitar que a taxa de lucro vai orientar os donos dos meios de produção a investir ou não seus recursos excedentes em aumento da produção física. Pode-se aceitar também que um processo de endividamento externo representa investimentos e consumo adicionais a um determinado volume de investimentos e consumo propiciados por uma determinada taxa de lucro. Da mesma forma, o endividamento externo pode ser equacionado num momento depois, mediante um crescimento adequado do produto e dos saldos comerciais com o exterior. Ou pode elevar-se sem interrupção, caso no qual o nível de crescimento do produto estará acima de sua capacidade, dada uma determinada taxa de lucro e um volume de investimentos produtivos estimulado por ela. Numa linguagem marxista, estes são os problemas da tendência para a queda da taxa de lucro e o problema da reprodução do capital social.

Deve-se buscar na história a atuação das leis concernentes a estas variáveis. Deste modo, partindo-se destas duas variáveis para um nível de abordagem menos geral, há de se considerar o comportamento de outras variáveis dependentes delas: o comportamento do 
consumo das famílias e a arrecadação do Estado. Depois, partir para componentes não dependentes diretamente da taxa de lucro e da formação de poupança: a trajetória das exportações; os limites para que a política econômica do Estado possa converter poupança inativa em consumo e investimento; a disposição das famílias em consumir e poupar; a habilidade da força de trabalho etc.. Estas variáveis são influenciadas por razões sociais, políticas, sociológicas, e mesmo geográficas e naturais, e se dão no curto e médio prazos. Um terremoto causa interrupção da produção física em alguma localidade, o que afeta as áreas mais próximas etc.. Alguns países têm uma mão-de-obra mais educada, e assim são mais produtivos etc.. A regressão econométrica com muitas variáveis, com auxílio dos processadores modernos, ajuda os economistas e historiadores a desenvolver tais problemas com um grau de exatidão ainda maior, desde que os pressupostos do modelo sejam formulados de modo realista e probabilístico.

Sendo assim, para a economia dos Estados Unidos no período que se está considerando neste estudo, estão se abordando macroindicadores a partir deste nível decrescente de generalidade: da tendência para a queda da taxa de lucro nos setores responsáveis pela acumulação produtiva deriva-se o aumento do cômputo da poupança externa na poupança agregada, como opção de política econômica para minorar os efeitos da queda. Então não se trata nunca de negar o papel da política econômica sobre o desempenho de curto prazo da economia. Não obstante, vê-se que para além das flutuações de curto e médio prazos, atuam mecanismos que a política econômica não pode conter. No caso dos Estados Unidos tal tem sido a tendência para a reprodução simples do capital social pela diminuição do crescimento do setor industrial.

Inicialmente têm-se o comportamento da taxa de lucro nos setores da manufatura e o aumento dos recursos externos na demanda efetiva local: a demanda por recursos para acumular nas condições onde já não se acumula tanto explica a funcionalidade do endividamento. Seguese a queda da participação da indústria no produto e do estancamento de suas taxas de lucro face aos outros setores. Tem-se daí que o endividamento externo, como um meio estrutural de permitir mais consumo e investimento, contribui para que a reprodução do capital social seja mantida num nível maior de demanda efetiva, do que aquele que permitiria o desenvolvimento "normal" da economia.

Porém, a análise histórico-econômica não aborda apenas tais aspectos globais. Vai além deles, no sentido de mostrar porque as outras variáveis-macro se comportam desta ou daquela maneira, em dependência das primeiras. Os desempenhos concretos das variáveis secundárias ilustram o que ocorre nas variáveis determinantes. Por exemplo: o déficit federal financiado externamente explica-se pela necessidade da manutenção da demanda efetiva, no contexto da queda relativa da taxa de lucros dos setores produtivos. Porém, o endividamento externo do governo federal, uma vez feito, torna-se investimento doméstico na compra de mais armas, na construção de mais rodovias etc.. Tal, por sua vez, gera um montante de renda e investimentos que impactam nos setores que não produzem armas. Pode-se afirmar daí então que o saldo em 
conta de capitais, no conceito de títulos comprados ao Tesouro Federal, explica em parte a acumulação bruta de capital doméstica, e assim por diante.

Quando se enfocam, por fim, as variáveis que não são explicadas pela queda da taxa de lucro e pelo endividamento, e o modo pelo qual o comportamento destas variáveis determinadas deve ser explicado por elementos quase invariantes, como a estrutura de classes, os traços culturais das classes dominantes e dos outros agrupamentos sociais, tem-se então uma descrição histórico-econômica global, que considera as variáveis determinantes, as por ela determinadas, as aleatórias, e as permanentes (ou quase invariantes), no comportamento histórico-econômico de uma economia nacional.

Por fim, como pertencente ao campo da história em primeiro lugar, a história econômica existe com os deveres conjuntos de narrar e explicar, como já ensinou Fernand Braudel. Ao lado da interpretação dos agregados macroeconômicos, com auxílio também de métodos econométricos que possibilitam a verificação das hipóteses adotadas, segue-se este mote durante todo o trabalho: os historiadores devem não só narrar mas sim também explicar como os processos econômicos se dão ao longo do desenvolvimento histórico. Aí o terreno da disputa política ganha predominância. Neste sentido, a história econômica aparece como um procedimento heurístico superior à mera análise econômica, por sua possibilidade de incursões abordativas em outras esferas da vida social, o que enriquece a investigação não apenas do objeto, mas das próprias variáveis.

3.4.2. Endividamento externo e agregados macroeconômicos: seu papel na manutenção da demanda efetiva e na ampliação da capacidade de financiamento da economia

Observou Paul Volcker, em 1985:

“O rápido crescimento da dívida em relação ao $\mathrm{PIB}{ }^{74}$ pode refletir o fato de que os gastos domésticos cresceram muito mais rapidamente que a produção doméstica, que é o que o PIB mede. [...] Como eu indiquei anteriormente, este financiamento pode ser fornecido pelo exterior, aliviando as pressões sobre nosso mercado [de capitais]. Mas o encargo da dívida inevitavelmente pesa sobre o devedor." 75

\footnotetext{
${ }^{74}$ Como se sabe, o sistema de Contas Nacionais norte-americanas abandonou em 1991 a utilização do conceito de Produto Nacional Bruto - PNB (GNP - Gross National Product) em favor da noção de Produto Interno Bruto - PIB (GDP - Gross Domestic Product). Esta mesma notação é então utilizada aqui, com exceção dos capítulos 5 e 6, construídos com dados trimestrais do Economic Report of the President da década de 1980 que utilizavam a noção de PNB. Evidentemente, a mudança reflete o próprio endividamento externo da economia, situação na qual o conceito de PIB é mais interessante à perspectiva oficial do que outro.

75 "While the effect cannot be isolated, the rapid growth of debt relative to GNP may also reflect the fact that domestic spending increased appreciably faster than domestic production, which is what GNP measures. [...] As I indicated earlier, directly or indirectly, that financing may be supplied form abroad, alleviating the pressures on our market. But the debt burden inevitably rests on the borrower." Statement by Paul Volcker, Chairman, Board of Governors of the Federal Reserve System, before the Committee on
} 
“Os Estados Unidos são o campeão mundial de empréstimos nos mercados internacionais. Bancos centrais, que detêm mais da metade do estoque remanescente de títulos do Tesouro americano, tornaram-se a principal fonte de financiamento para os enormes déficits fiscais do governo - mais ou menos 4\% do PIB em 2004. Além da enorme despoupança do governo, a baixa poupança das famílias americanas força as empresas americanas também a financiarem-se fora do país para obter créditos adicionais para seu investimento doméstico. Portanto, os ganhos em dólares por estrangeiros exportando aos Estados Unidos que seriam normalmente usados para comprar bens e serviços americanos estão sendo ao invés disto desviados para comprar títulos do Tesouro. O resultado é saldo negativo em conta corrente atual de mais de 600 bilhões por ano, uma medida geral de empréstimos feitos do exterior somando quase 5,5\% do PIB. Altos empréstimos do exterior e os déficits comerciais associados começaram nos anos (19)80, e hoje a dívida externa total acumulada americana é de $30 \%$ do PIB, e está crescendo rapidamente." 76

De fato, no caso dos Estados Unidos, as políticas de ampliação das condições para que a demanda agregada seja sustentada podem ser amplificadas com auxílio de recursos não efetivamente gerados na economia doméstica, mas sim no exterior. Isso dada a disposição existente para que os agentes entreguem recursos líquidos ao país em troca de títulos denominados em dólar. Como se já não bastasse a notável obstinação pela qual os administradores da economia buscam o crescimento em suas políticas locais, adicionais aportes de recursos ao exterior vêm somar mais consumo; os impostos podem diminuir, relativamente, pois o governo federal pode financiá-los com títulos emitidos ao exterior; e as firmas mobilizam mais recursos do que os que foram criados pelo investimento agregado passado.

São os Estados Unidos o único país que desfruta de plenas condições para que a poupança externa venha financiar seus gastos e investimentos de modo perene, dado o papel de seu sistema financeiro e de sua moeda no mundo. Fundamentalmente, a lógica do crescimento

Banking, Housing and Urban Affairs - U.S.Senate. 20 de Fevereiro de 1985. Disponível em http://fraser.stlouisfed.org/historicaldocs /., p.13.

76 "The United States is the world's champion borrower in international markets. Foreign central banks, which hold more than half of the outstanding stock of U.S. Treasury bonds, have become the principal source of finance for the federal government's bourgeoning fiscal deficits - about 4 percent of gross domestic product (GDP) in 2004. Besides this massive government dissaving, meager saving by American households forces U.S. corporations also to borrow abroad to supplement finance for domestic investment. Thus dollar earnings by foreigners selling exports to the United States that would normally be used to buy American goods and services are being diverted and used to buy Treasury bonds instead. The upshot is today's current account deficit of more than $\$ 600$ billion per year, a measure of overall net borrowing from foreigners amounting to almost 5.5 percent of U.S. GDP. Heavy foreign borrowing and associated trade deficits began in earnest in the 1980s, and so today America's cumulative net foreign indebtedness is 30 percent of GDP and rising fast." MCKINNON, Ronald. Government Deficits and Desindustrialization of America. In: The Economist's Voice - Top economists take on today's problems, p.101. 
auxiliado pelo endividamento externo da economia é a captação externa de recursos que não foram gerados efetivamente na economia local, possibilitada pela posição particular que a moeda e o sistema financeiro do país ocupam no exterior. ${ }^{77}$ Dado o papel do dólar no mundo, tanto o Estado como as corporações encontram meios de financiar investimentos e gastos no exterior. Por sua vez, a posição central de seu sistema financeiro possibilita, pela captação de empréstimos e poupanças externas, dinamizar o crédito doméstico a todos os agentes da economia, catapultando o consumo e investimento com base na dívida.

"[Dito de forma mais simples]: um país, como um todo, toma emprestado no exterior quando esse país, como um todo, está gastando mais que sua receita. Por sua vez, isto significa que o país está importando mais do que exportando e está tomando emprestado para financiar a diferença." 78

Em tempo: o nível de investimento, consumo e gastos do Estado torna-se maior que aquele que haveria se a economia prescindisse do endividamento externo. $\mathrm{O}$ nível de demanda agregada seria menor se se prescindisse deste volume adicional de recursos não gerados pelos investimentos sob taxa de lucro cadente. O endividamento externo é elemento estrutural para a continuidade do crescimento, nas condições de diminuição relativa da formação de excedente provocada pela tendência à queda dos investimentos produtivos. A atração de recursos vem adicionar-se à demanda agregada, em todos os níveis. Ao mesmo tempo, a parte do consumo na economia nacional vai aumentar, e as dos investimentos cair, porque vão se manter as dificuldades para a taxa de lucro nos setores produtivos. A demanda efetiva vai ganhar cada vez mais a forma de consumo das famílias.

\footnotetext{
${ }^{77} \mathrm{Ou}$, como no modo de Stiglitz explicar: "a popularidade do dólar nas reservas internacionais deriva principalmente do domínio dos Estados Unidos na economia mundial e da história bastante razoável desta moeda." STIGLITZ, Joseph. Globalização, como dar certo, p.385.

${ }^{78} \mathrm{Ibid}, \mathrm{p} .389$.
} 
Gráfico 1. Estados Unidos. Ativos estrangeiros totais na economia dos Estados Unidos e PIB dos Estados Unidos. 1976-2000. Em bilhões de dólares correntes.

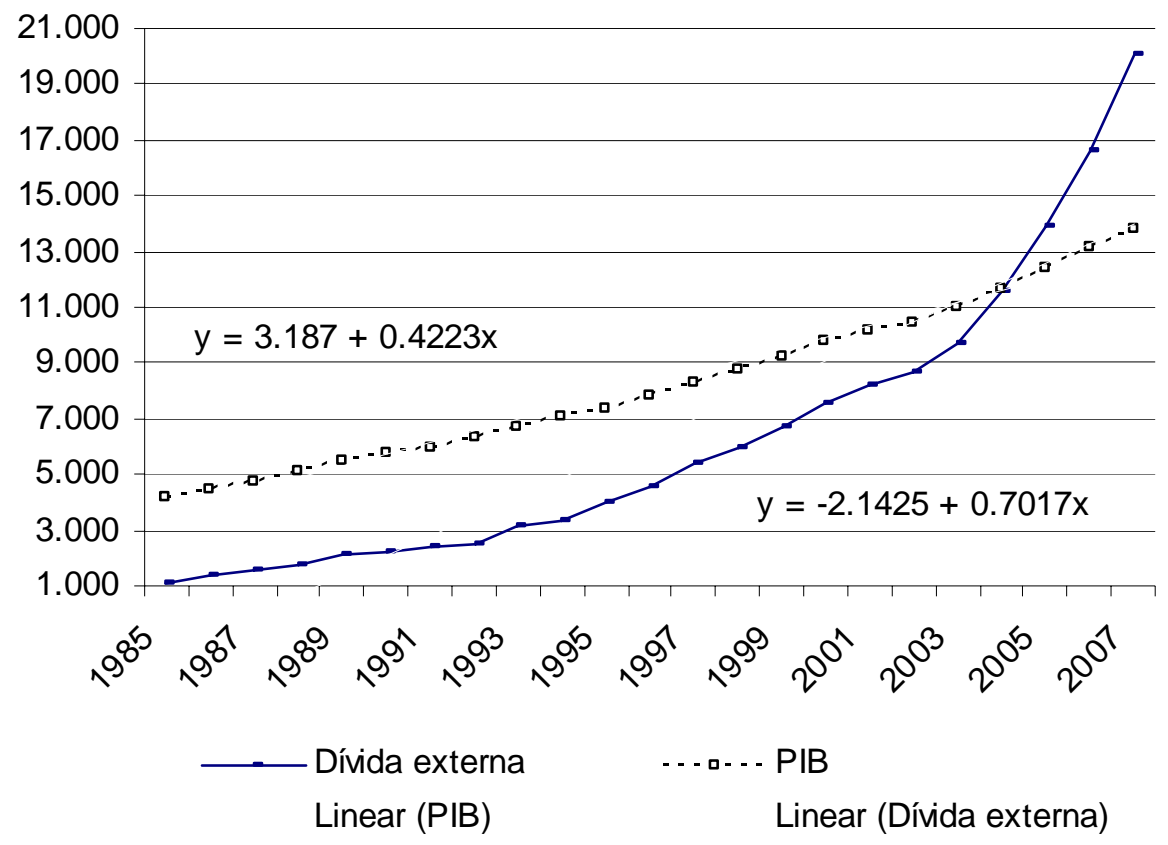

Fonte: Economic Report of the President, vários anos (1984-2008). Para PIB: Tabela B-1, Gross Domestic Product, 1959-2007; para Ativos Estrangeiros totais na economia dos Estados Unidos: International Investment Position of the United States at year-end, vários anos.

Mas como o comportamento de cada um dos setores da economia nacional é afetado pelo endividamento externo?

Na verdade, não é difícil conceber, em termos do enfoque macroeconômico, como a dinâmica da renda nacional pode ser afetada positivamente pelo endividamento externo da economia, com exclusão do comportamento das exportações. Dada a divisão da renda nacional proposta por Kalecki no capítulo Os determinantes dos lucros, em Teoria da Dinâmica Capitalista, pode-se dividir o Produto Nacional Bruto em:

\begin{tabular}{ll}
\hline Lucros Brutos & Investimento Bruto \\
descontados os impostos diretos & Saldo de exportação \\
Salários e ordenados & Gastos do governo em bens e serviços \\
Descontados os impostos diretos & Consumo dos capitalistas \\
Tributos (diretos e indiretos) & Consumo dos trabalhadores \\
Oferta Nacional Bruta & \\
\hline
\end{tabular}

Veja-se como o comportamento de cada setor pode se relacionar com o endividamento externo. Comece-se pelo investimento corporativo (1). Segundo Kalecki, quando uma parcela 
da taxa de investimentos é financiada externamente, pode-se ter uma taxa de investimentos maior do que a que a estimulada pela taxa de lucro corrente. Por outro lado, quanto maior é o financiamento da taxa doméstica de investimento pelo endividamento externo, maior é o volume de consumo agregado das famílias (tanto de trabalhadores como de capitalistas). Quer dizer, quanto maior fôr a participação da poupança internacional no financiamento dos investimentos domésticos, maior será o cômputo que o investimento poderá apresentar sem pressionar o consumo das famílias. Por conseguinte, poderá ser também maior a taxa de investimentos. Sob outro modo de ver, quanto maior o volume de consumo, maior a utilização da capacidade instalada das firmas.

Gráfico 2. Estados Unidos. Bonds e Ações de corporações norte-americanas detidos por estrangeiros e investimento bruto doméstico privado. Em dólares correntes. 1976-2004.

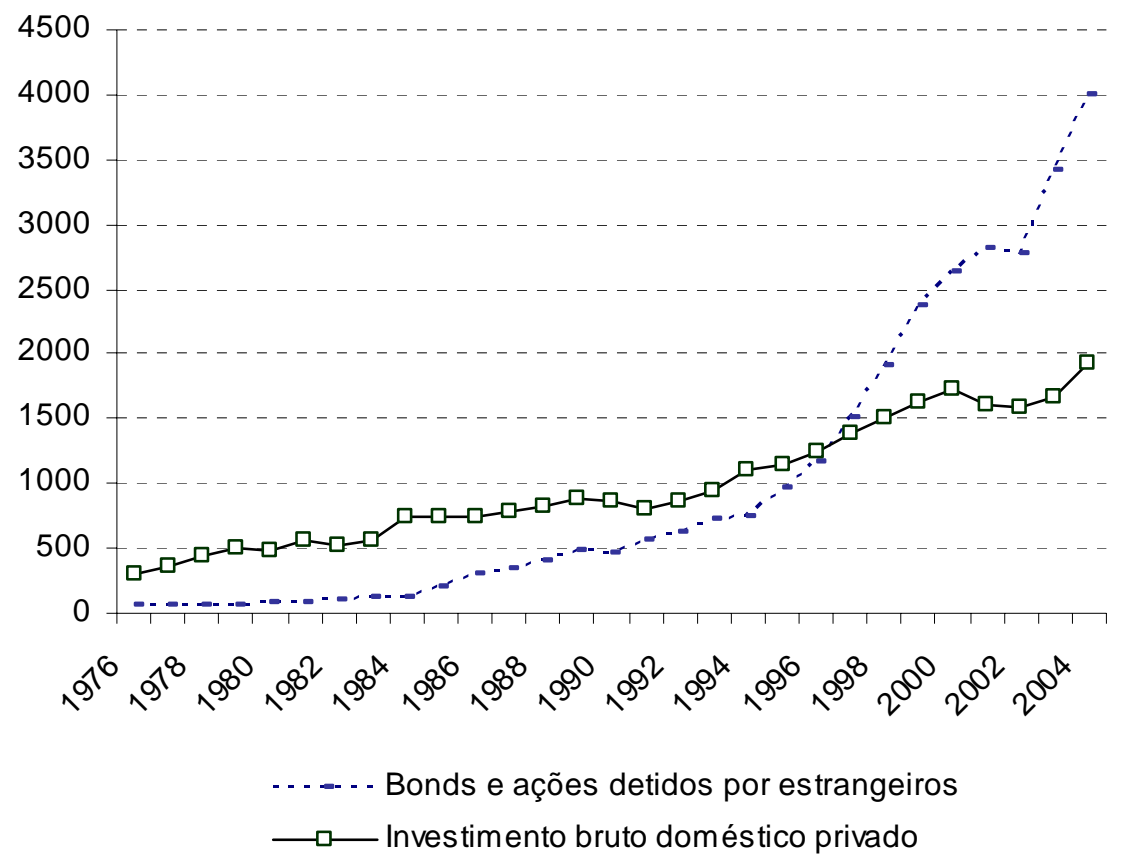

Fonte: Economic Report of the President, vários números. Para bonds e ações, foram utilizadas as Tabelas International Investment Position of the United States at year-end, na seção International Statistics (linhas Corporate Bonds and other bonds e Corporate Stocks). Para investimento bruto doméstico privado, foi utilizada a primeira tabela, B-1, do apêndice estatístico de 2006, Gross Domestic Product, 1959-2005.

Não seria possível a existência dos atuais níveis de endividamento das firmas em condições onde o capital não fosse tornado abundante pelo endividamento. A relação entre endividamento externo e investimento bruto torna possível um investimento maior do que aquele que poderia haver, no caso de o investimento ser financiado apenas pelos lucros passados das empresas. $\mathrm{O}$ endividamento torna possível uma taxa de endividamento relativamente maior das corporações, que seria menor nas condições de menor disponibilidade de capital e de juros maiores. A figura acima permite ver tal mais claramente: a soma das ações e dos bonds (títulos que pagam juros) em posse de agentes externos, isto é, de recursos líquidos em dólar fornecidos aos Estados Unidos por tais agentes, tornou-se já maior que o investimento bruto doméstico a 
desde 1996. Em suma: o endividamento externo permite com que as duas variáveis possam ser maiores do que seriam nas condições de equilíbrio do balanço de pagamentos.

Em segundo lugar (2), veja-se a relação entre os gastos do governo e o endividamento externo. Segundo Kalecki, "a tributação, ao contrário do gasto deficitário, tende a reduzir o consumo das pessoas tributadas, e assim estimula a demanda efetiva apenas na medida em que incide sobre a poupança". ${ }^{79}$ Atualmente (2009), quase 40\% do déficit público do governo federal dos Estados Unidos é financiado com dólares vindos da economia internacional (ver figura abaixo). Quanto mais o déficit público fôr pago com dólares de fora, maior a disponibilidade de capital doméstico para empréstimos, consumo e investimentos, e menor pressão relativa sobre os juros. Ora, "se o déficit do governo é financiado à custa de uma redução de créditos para as empresas privadas e, portanto, sem a criação de um adicional poder de compra, então ele não provoca um aumento da produção". ${ }^{80}$ No caso do endividamento externo caso, dá-se o contrário: o déficit do governo não concorre com a poupança doméstica.

Gráfico 3. Estados Unidos. Estados Unidos. Porcentagem (\%) da dívida federal detida por estrangeiros (oficiais e privados). 1970-2003.

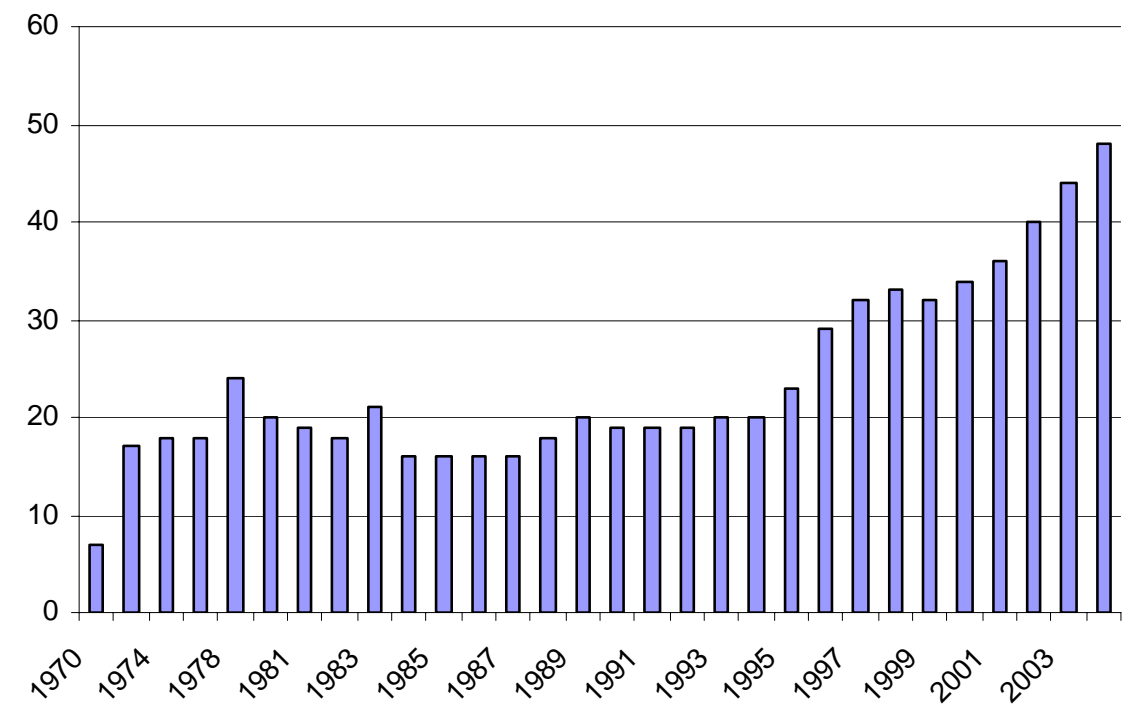

Fonte: Economic Report of the President, vários números. As tabelas utilizadas intitulam-se International Investment Position of the United States at year-end, na seção International Statistics. As linhas e sub-seções são: linha "Government Securities" e "Other U.S. government liabilities" na sub-seção "Foreign official assets in the United States" (Ativos oficiais estrangeiros nos Estados Unidos) e a linha "U.S. Treasury Securities" na sub-seção "Other Foreign Assets" (Ativos privados estrangeiros nos Estados Unidos).

Ao mesmo tempo, mediante o expediente, ocorre menor pressão para baixo na capacidade de consumir, com conseqüente impacto "acelerador" na propensão a investir, e menor necessidade de o governo tributar as rendas e os lucros. O financiamento de parte dos

\footnotetext{
${ }^{79}$ KALECKI, M., Três caminhos para o pleno emprego, Grandes Cientistas Sociais: Kalecki, p.94.

${ }^{80}$ KALECKI, M., Conjuntura e Balanço de Pagamentos. Ibid, p.70.
} 
déficits fiscais pela emissão de papéis ao mundo é literalmente um modo adicional pelo qual a demanda agregada local pode ser financiada pelo exterior, a título de um aumento da dívida. Ainda, na mesma medida em que parte dos déficits relaciona-se com as inversões no setor de "defesa", pode-se dizer que existe uma relação entre os recursos externos e a existência do complexo industrial-militar. Por detrás da simples posse de títulos nas mãos da economia mundial, está inclusive o financiamento da máquina de guerra norte-americana.

Em terceiro lugar (3), há o consumo das famílias (capitalistas e trabalhadores). De fato, quando o governo toma no exterior os dólares que deveria buscar em âmbito doméstico, se não houvesse a possibilidade da dívida externa, está possibilitando que o consumo tanto dos capitalistas como dos trabalhadores seja maior do que seria. Isto no caso de os déficits terem de ser obtidos, ainda que em fração, a partir do consumo das duas classes sociais. Também, não se poderia obter uma taxa crescente de endividamento das famílias e das empresas tão grande se os recursos líquidos existentes no sistema financeiro local não contassem com o mecanismo do endividamento externo. A taxa crescente de endividamento dos agentes domésticos pode ser definida como o financiamento de seu consumo e/ou investimento presentes com base na promessa de pagamentos futura. A posição do sistema financeiro do país, reflexo da condição de sua moeda, relaciona-se diretamente com a baixa formação de poupança e com os níveis de endividamento das famílias. ${ }^{81}$

É claro que o endividamento externo aparece então sempre como uma "fuga para frente", do ponto de vista de todos os macroindicadores.

\footnotetext{
${ }^{81}$ No caso da atual crise no sistema financeiro (2008), explica-se portanto porque a crise nos créditos hipotecários culmina sempre em perdas para os bancos estrangeiros que têm capital aplicados nos bancos norte-americanos. As famílias não pagam porque o emprego não cresce, dada a estagnação da economia como um todo; os bancos não recebem e ficam com seus compromissos comprometidos; a reação em cadeia culmina em perdas para a fonte última de parte dos créditos, as casas estrangeiras com capital aplicado nos Estados Unidos. No momento em que se redige este trabalho (Setembro de 2008), a quarta maior casa de crédito de investimentos norte-americana - Lehman Brothers - foi à falência. As perdas chegam a 500 bilhões de dólares e a queda da liquidez chegará a 2 trilhões, o que aprofundará a crise e jogará a economia na recessão em 2009. Sobre a reação em cadeia vinda da quebra do Lehman Brothers, comentou o The Economist de 15 de Setembro de 2008: "Even if markets can be stabilized this week, the pain is far from over-and could yet spread. Worldwide credit-related losses by financial institutions now top $\$ 500$ billion, of which only $\$ 350$ billion of equity has been replenished. This $\$ 150$ billion gap, leveraged 14.5 times (the average gearing for the industry), translates to a $\$ 2$ trillion reduction in liquidity. Hence the severe shortage of credit and predictions of worse to come. With these developments the crisis is entering a new and extremely dangerous phase. If Lehman's assets are dumped in a liquidation, prices of like assets on other firms' books will also have to be marked down, eroding their capital bases. The government's refusal to help with a bail-out of Lehman will strip many firms of the benefit of being thought too big to fail, raising their borrowing costs. Lehman's demise highlights the industry's inability, or unwillingness, to rescue the sick, even when the consequences of inaction are potentially dire." Ver www.economist.com $/$.
} 
Gráfico 4. Estados Unidos. Poupança líquida das famílias, como porcentagem da renda disponível. 1972-2005.

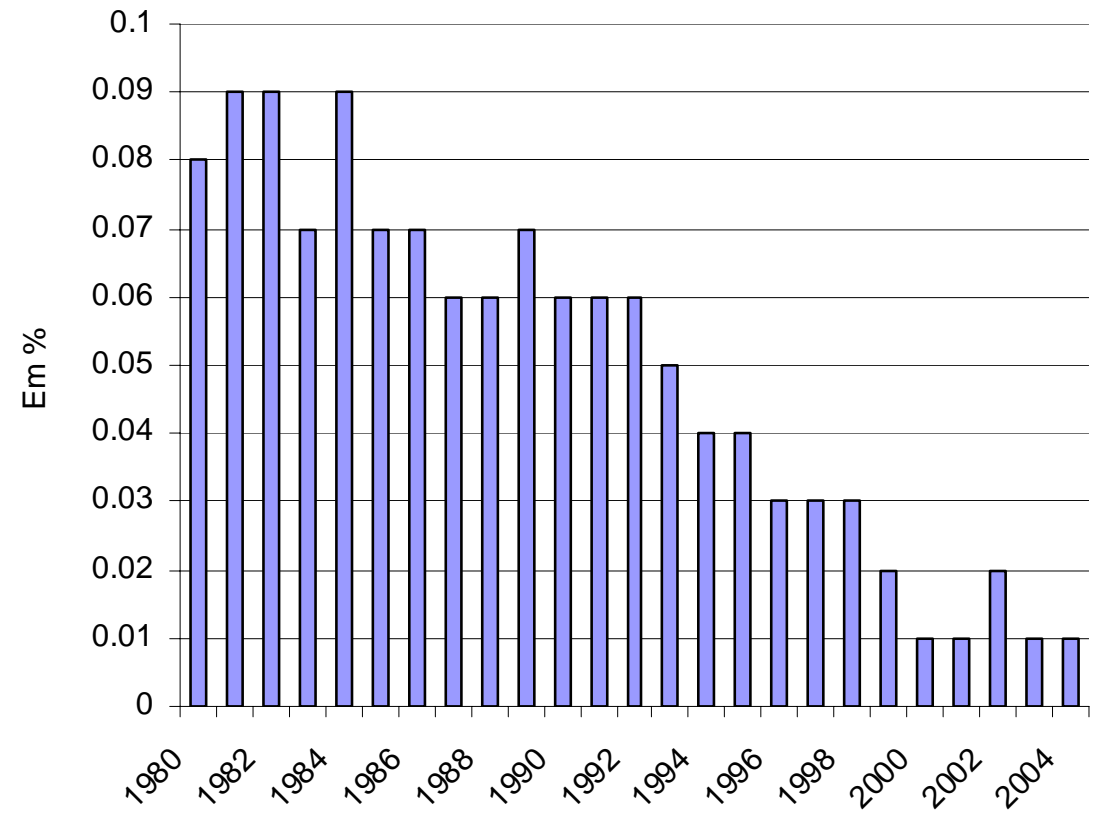

Fonte: calculada a partir de dados do Economic Report of the President de 2006. Para poupança líquida das famílias, Tabela B-32, Gross Saving and Investment, 1959-2005 - "Net personal saving”. Para renda disponível, Tabela B-30, Disposition of Personal Income.

Tal como se vê figura na seguir, o saldo de exportação (4) é a única variável cujo desempenho é negativamente afetado, entre outros fatores, pelo endividamento progressivo. Já que o endividamento externo só ocorre em âmbito global porque os Estados Unidos impuseram o uso do dólar, a posição do dólar é sustentada estruturalmente mesmo diante dos déficits comerciais acumulados. Eles são então o próprio sintoma da condição hegemônica de tal moeda. O papel dominante dos Estados Unidos no mundo assegura o próprio valor de sua moeda mesmo em condições de desequilíbrio no balanço de pagamentos. O endividamento externo tendencialmente contribui para trazer abaixo as exportações norte-americanas, independentemente das flutuações cíclicas, mas a taxa de câmbio nunca entra em colapso, pois é determinada por fatores extra-econômicos.

Assim, o dólar pode flutuar, mas não colapsa diante de outras moedas enquanto seu papel na economia mundial for assegurado pela posição dos Estados Unidos como centro militar e centro financeiro. Por outro lado, os superávits na conta de capitais permitem a elevação progressiva de déficits na balança comercial, que pressionam negativamente o emprego e a produção industrial internas. No caso, parece errôneo ver nos déficits fiscais a origem principal dos déficits comerciais. Ele existe por uma situação estrutural: a posição do dólar no mundo, vinda da posição financeira e militar do país, engendra os déficits comerciais sustentados. Os déficits fiscais do governo federal norte-americano podem aumentar os déficits comerciais ou diminuí-los, mas não ser sua causa determinante. Realmente, uma grande parte dos próprios 
déficits fiscais existe pela mesma causa que os déficits comerciais: o fato de haver o financiamento externo dos gastos correntes da economia.

Gráfico 5. Estados Unidos. Saldos de balança comercial (bens e serviços).

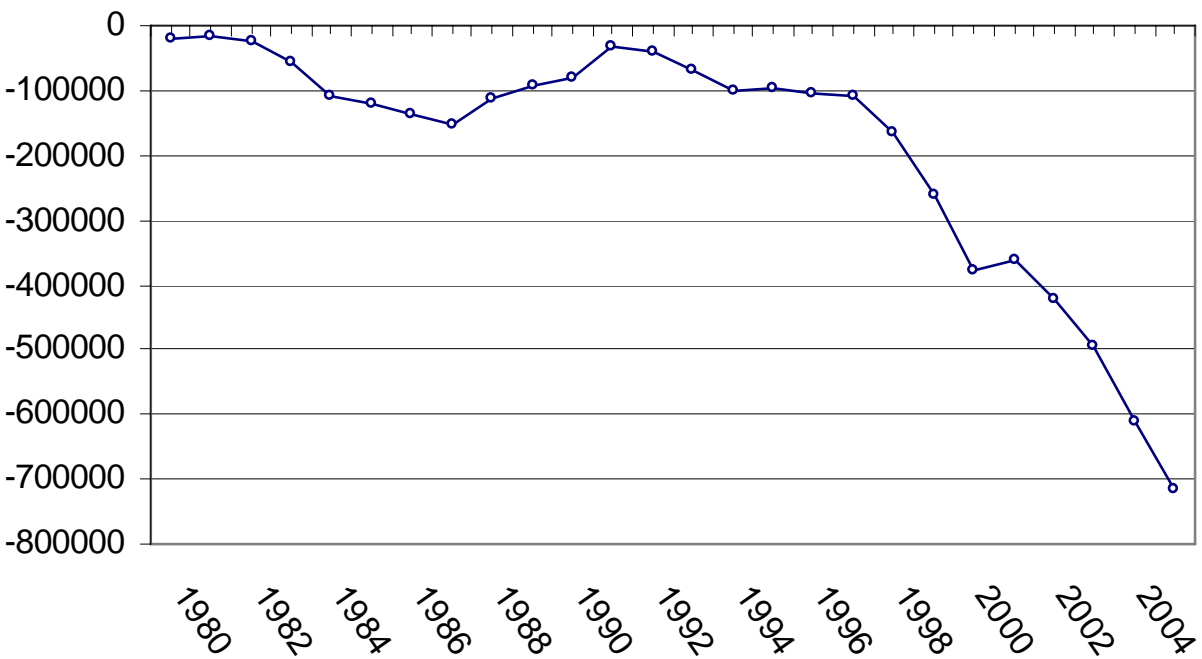

Em milhões de dólares correntes. 1980-2005. Fonte: NIPA-BEA. Seção 4: Foreign Transactions. Tabela 4.1. Foreign Transactions in the National Income and Product Accounts.

Resta o problema da relação dívida externa/PIB. Lembremos de uma observação de Kalecki, de que "a alíquota existente de imposto sobre a renda, necessária para financiar o montante crescente de juros sobre a Dívida Pública, não precisa elevar-se se a taxa de expansão da renda nacional é suficientemente alta, como resultado do aumento da população trabalhadora e do progresso técnico". ${ }^{82}$ Sob que condições então os níveis de endividamento sobre o PIB poderiam se estabilizar? Ou, feita de outro modo a questão: por que se elevaram ao longo das última três décadas (1980-2008) os níveis de endividamento externo?

Poder-se-ia supor que a atração de poupança externa engendrasse um volume de consumo e investimentos tais que a formação de poupança resultante pudesse equacionar o nível de endividamento, mantendo-o estável ao longo do tempo, ou mesmo - na melhor das hipóteses - diminuindo-o. Todavia, não há resposta para esta questão que esteja fora da perspectiva de que a tendência para a diminuição dos lucros industriais face aos outros setores econômicos, assim como à própria diminuição da participação da indústria no PIB, esteja atuando sob toda produção econômica. $\mathrm{Na}$ ausência disto, o aporte de recursos forâneos estaria se dando de forma a contribuir para a elevação da acumulação produtiva. Isto virtualmente geraria um volume de investimentos adequado para manter uma demanda efetiva suficiente para permitir taxas de crescimento que só são possíveis com o expediente do endividamento externo. A queda na taxa de lucro impede esta saída.

82 "Três caminhos para o pleno emprego", ibid, p.82. 
Os dois modos pelos quais observar-se-iam a ruptura da tendência à reprodução simples seriam, portanto, (1) a via de uma nova rodada de aumento sustentado dos investimentos de forma crescentemente lucrativa (uma nova pendente ascendente dos ciclos de Kondratiev?), de modo a "internalizar" novamente o comportamento determinante das variáveis macroeconômicas com base num crescimento centrado na economia doméstica, ou (2) o endividamento elevado progressivamente, na ausência de (1).

A economia dos Estados Unidos se comportou então, desde os anos 19(70) até o início dos anos (19)90, sob as condições de que houve (1) a tendência potencial para a "reprodução simples", conjugada com (2) o endividamento externo do governo e com o financiamento externo crescente dos investimentos, dos gastos do governo e do consumo das famílias, como resposta a (1). O endividamento externo pode ser considerado então uma resposta cada vez mais adequada da economia ao processo de desaceleração, que ganhou força ao longo dos anos (19)80 e, mesmo diante da ascensão cíclica da década de (19)90, não diminuiu - aumentando, pelo contrário. Cabe então investigar, mais uma vez no capítulo 7, como o novo ciclo expansivo coadunou-se com o crescimento do endividamento, tentando responder em que medida dependeu dele. 
Mudanças estruturais 
Uma análise de dados

"O crescimento e o emprego norte-americanos estão hoje sustentados pelo inexorável crescimento da dívida externa."

Lance Taylor e John Eatwell, Finanças globais em risco uma análise a favor da regulação internacional

\subsection{A queda das massas de lucro no setor manufatureiro}

$\mathrm{N}$

este capítulo realiza-se uma análise empírica referente aos pontos discutidos anteriormente. Calcula-se: (a) o comportamento da massa e de uma estimativa de taxa de lucros no setor industrial norte-americano no período considerado neste trabalho; (b) a eficiência decrescente dos investimentos domésticos norteamericanos, sob a relação investimento/poupança, numa perspectiva macroeconômica; (c) um cálculo alternativo da taxa de lucro na manufatura norte-americana e um cálculo das taxas de lucro setoriais para a economia norte-americana; (d) um cálculo da participação no endividamento externo norte-americano dos principais países emprestadores; (e) o comportamento dos preços relativos domésticos e o aumento da participação de bens tangíveis no cômputo das importações norte-americanas, assim como a queda da exportação de bens na pauta de exportação norte-americana. Vamos começar pela análise do comportamento das massas de lucro na indústria manufatureira norte-americana para o período abarcado entre 1970 e 2000, aproximadamente.

Quais causas atuaram para tal queda nas taxas e nas massas de lucro nos (19)70? Certamente, o impacto conjunto do aumento dos preços do petróleo e da alta elevação dos juros, e a conseqüente elevação da relação capital/trabalho, oriunda do aumento dos níveis de mecanização. Os impactos da Terceira Revolução Industrial fizeram crescer a relação capital/trabalho, elevando enormemente os índices de produtividade do trabalho no momento de sua adoção, mas tornando maior a relação entre capital constante e variável ao longo do tempo. Os setores industriais nas áreas capitalistas mais antigas tiveram uma grande diminuição em sua participação no PIB, com a contrapartida do crescimento do capital financeiro e menores taxas de crescimento. As políticas econômicas adotadas pelo governo Reagan, como o aumento dos juros e a enorme retração dos meios de pagamento no início dos anos (19)80, puseram uma carga adicional à taxa de lucros, no plano da política econômica. Os impactos do aumento do 
preço do petróleo expressavam então uma "contenção artificial dos preços das matérias-primas" vendidas pelos países subdesenvolvidos até então. ${ }^{83}$

Vejam-se então algumas observações empíricas. Primeiramente, a questão da diminuição do crescimento dos lucros das firmas desde os anos (19)70. Por definição, quando abordada num nível estrutural, a diminuição da massa de lucros nos setores manufatureiros indica que houve menos investimentos, devido à deterioração da taxa de lucro, culminando em menores vendas. É verdade que num nível mais específico, pode-se sugerir que a diminuição da massa de lucros para alguns ramos deu-se por perdas de mercado para as importações ou mudança na pauta de consumo das famílias. Mas, dada a centralidade dos investimentos privados na economia capitalista, não se pode considerar que, num nível sistêmico, a massa de lucros na maior parte dos setores econômicos caiu por "pressões na demanda" por tais bens. Se houvesse muitas oportunidades de inversões lucrativas, os investimentos privados criariam a própria renda e demanda para o consumo de sua própria produção, logrando aumento nas massas de lucro. Mas se esta renda e esta demanda não foram criadas, culminando em menos vendas, é porque os investimentos não estão sendo realizados a taxas de lucro crescentes.

Gráfico 1. Estados Unidos. Média móvel (três anos) dos lucros no setor manufatureiro feita a partir dos lucros deflacionados pelo dólar de 1980. 1956-2000. Em bilhões de dólares.

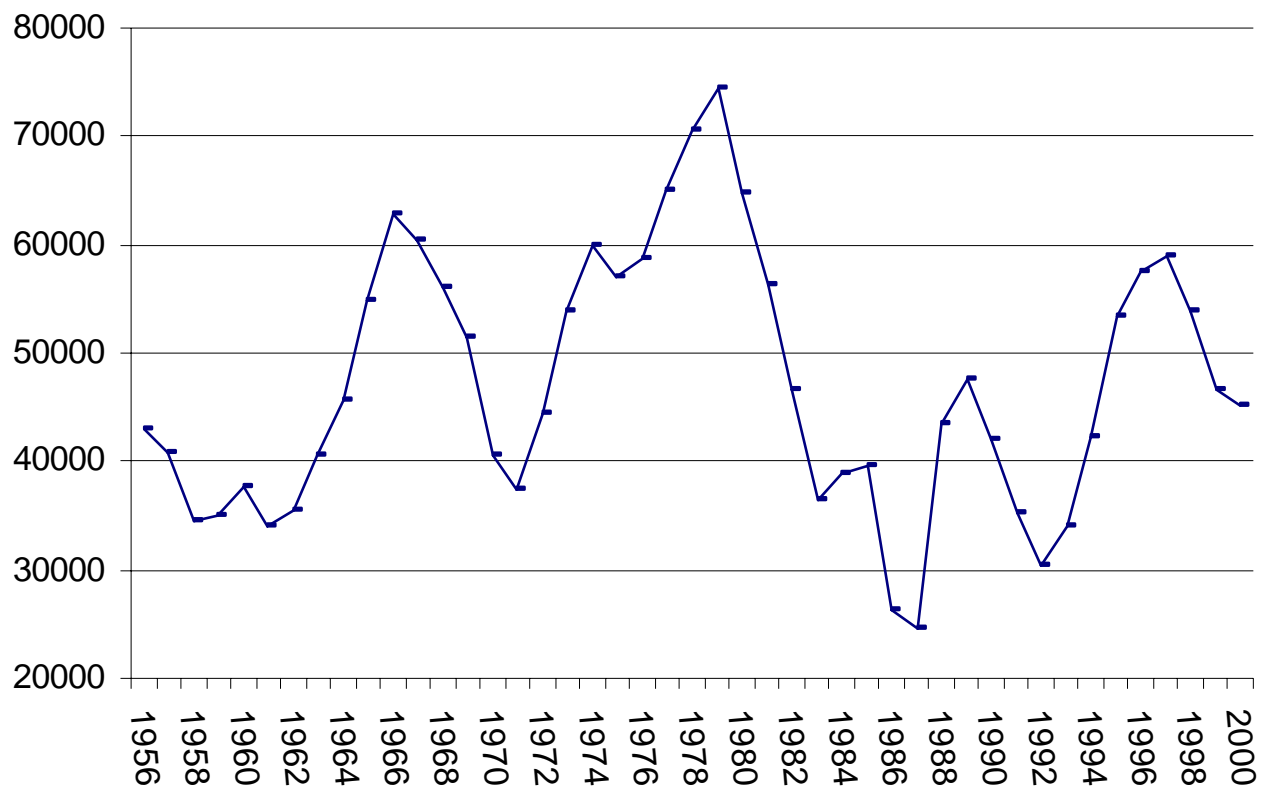

Fonte: NIPA-BEA. Seção 6: Income and Employment by Industry. Tabela 6.16: Corporate Profits by Industry. Deflator fornecido pelo BLS.

Não se pode perder de vista que (i), admitindo-se que a variável "investimento privado", nos setores industriais, é determinante para as flutuações e para o movimento de longo prazo, se

${ }^{83}$ BARBOSA, Wilson do Nascimento. "A crise econômica-financeira e o recurso a uma política anticíclica", p.6. 
a massa de lucros caiu, é porque justamente (b) se deixou de fazer mais investimentos no curto e médio prazos, o que culminou em menos vendas etc.. Quer dizer: para elucidar um movimento estrutural de crescimento das finanças e queda nas taxas de crescimento da produção material, é uma explicação estrutural que deve ser construída, e não apenas um enfoque parcial que centre foco na queda da "demanda" ou na perda de mercados. Em última instância, para uma economia que apresente crescimento da produção sem poupança externa, a demanda é criada pelos investimentos industriais. $\mathrm{O}$ fato de que as taxas de lucro caíram em paralelo com as massas de lucro, num longo período entre 1973 e 1987, e que se elevaram em paralelo com a taxa de lucro entre 1987 e 2000 , mostra isto.

Observando a figura acima, vê-se a partir do cálculo deflator que a massa agregada de lucros no setor manufatureiro caiu a partir dos anos (19)80, e, mesmo quando ela se recupera nos (19)90, não atinge o patamar dos anos (19)70 e (19)60. Quer dizer, a massa de lucros, quando deflacionada, não supera nunca, nem mesmo durante a década de (19)90, os lucros no período dos "Trinta Gloriosos" (1945-1973). Há três sub-períodos distintos (a) ascensão entre 1952 e 1978; (b) queda entre 1978 e 1988; e (c) nova viragem até 2000. Especificamente, (a) divide-se em um descenso entre 1956 e 1962; uma viragem ascendente entre 1962 e 1967; nova queda até 1971; ascensão até 1978. O período (b) é marcado por mergulho depressivo apenas diminuído pelo crescimento de 1984-1985; segue-se queda até 1988. A partir daí, tem-se nova recuperação, com flutuações entre 1990-1992 e depois de $2000 .{ }^{84}$

A tabela abaixo, cuja subdivisão atende ao Standard Industrial Classification (SIC) seguido pelo Bureau of Economic Analysis, deixa ver o comportamento dos lucros nos setores manufatureiros com mais detalhes. Quando desagregada a série, observam-se diferentes movimentos para cada setor específico, de acordo com (1), (2) e (3) pontuados acima. Os dados referem-se ao período 1948-2000, e foram divididos em dois períodos (1948-1974 e 19752000): um anterior ao primeiro impacto nos preços do petróleo e outro posterior. Indicam-se ali as equações de tendência estimadas para os lucros de cada setor específico, obtidas a partir dos lucros de tais setores (deflacionados pelo dólar de 1980).

De fato, houve setores com aumento dos lucros obtidos, como "produtos fabricados a partir de metais", "alimentos", "elétricos e eletrônicos" e "químicos e derivados". Não à toa, com exceção dos alimentos, são os setores identificados mais de perto com a Terceira Revolução Industrial, e que lograram melhor desempenho com a massa de inovações que a caracterizou. Pode-se aceitar que em muitos as taxas de lucros foram e estão sendo crescentes, o que leva a investimentos crescentes, maiores massas de lucro, e assim impactos positivos no produto. Mas, duas ressalvas devem ser feitas. Em primeiro lugar: mesmo com os impedimentos à mobilidade dos capitais vindos da tendência à monopolização, não se pode aceitar que alguns ramos apresentem ao longo do tempo uma lucratividade muito maior do que a média sem que atraiam mais concorrentes que tratem de jogar abaixo as taxas. E, em segundo: as séries não

\footnotetext{
${ }^{84}$ Note-se que não se inclui a crise de 2001 , o que faria a pendente ser ainda mais negativa.
} 
indicam necessariamente que as taxas de lucro foram e são ainda constantemente crescentes nestes setores: como visto, mesmo massas de lucros maiores podem ser obtidas a taxas de lucros menores.

Assim, a série massa de lucros pode indicar não exatamente maiores lucros sendo obtidos por maiores investimentos mais lucrativos sendo seguidos de mais vendas, mas sim apenas mais lucros sendo obtidos por mais vendas a partir de investimentos realizados a taxas de lucro estagnadas, tal como explica o assim chamado efeito acelerador. Tais investimentos continuam sendo feitos, mas de modo mais lento do que o seriam num ambiente mais próspero para o capital. Similarmente, uma pendente negativa dos lucros de alguns setores, mesmo com a presença de taxas de lucros favoráveis neste setor, pode indicar que a demanda para estes produtos pode estar caindo.

Tabela 1. Estados Unidos. Setores manufatureiros. Equações de tendência estimadas $(y=a+$ bx) para cada setor obtidas a partir de seus lucros deflacionados (pelo dólar de 1980). 19481974. Em bilhões de dólares.

\begin{tabular}{|c|c|c|}
\hline \multicolumn{3}{|c|}{ Tendências estimadas $(\mathrm{y}=\mathrm{a}+\mathrm{bx})$} \\
\hline \multicolumn{3}{|c|}{ Manufaturas: bens duráveis } \\
\hline Regressões (I) & $(1948-1974)$ & $(1975-2000)$ \\
\hline Metais & $y=7,7783-0,1234 x$ & $y=1,8202-0,008 x$ \\
\hline Maquinários (exceto elétricos) & $y=4,9253+0,1448 x$ & $y=7,9174-0,0778 x$ \\
\hline Veículos & $y=7,6213+0,0958 x$ & $y=6,0458-0,2253 x$ \\
\hline Produtos fabricados com metais & $y=2,8163+0,0601 x$ & $y=3,6707+0,1092 x$ \\
\hline Elétricos e eletrônicos & $y=3,485+0,0668 x$ & $y=4,2934+0,1162 x$ \\
\hline \multicolumn{3}{|c|}{ Manufaturas: não-duráveis } \\
\hline Regressões (II) & $(1948-1974)$ & $(1975-2000)$ \\
\hline Alimentos & $y=5,6864+0,0434 x$ & $y=6,6881+0,1952 x$ \\
\hline Químicos e derivados & $y=6,823+0,163 x$ & $y=7,2218+0,2012 x$ \\
\hline Petróleo e derivados do carvão & $y=7,1669+0,0753 x$ & $y=24,931-0,9495 x$ \\
\hline Outros & $y=10,031+0,1924 x$ & $y=14,912+0,0463 x$ \\
\hline
\end{tabular}

Fonte: NIPA-BEA. Seção 6: Income and Employment by Industry. Tabela 6.16: Corporate Profits by Industry.

O que se pode averiguar com certeza é que, dos nove setores, cinco apresentaram tendência decrescente da massa de lucros auferida no segundo período (metais, maquinários, veículos, derivados do petróleo e "outros"). Dentre eles quatro (maquinários, veículos e petróleo) apresentam pendentes negativas no segundo período, o que mostra que neles se deu decréscimo absoluto das massas de lucro auferidas, e não apenas crescimento menor. Sugerese então queda nas taxas de lucro, desestimulando relativamente as inversões. Não por acaso, isto se dá nos setores mais antigos do ponto de vista das etapas da Revolução Industrial, e de 
alta utilização de capital fixo, onde as inovações técnicas são em geral efetuadas a partir de realizações feitas nos outros setores mais dinâmicos.

Alguns setores apresentam lucros em trajetória crescente porque são explicados principalmente pelo crescimento da população, como é o caso do setor de alimentos. Nele, a massa de lucros ao longo do tempo é crescente. Para outros setores, como "produtos fabricados a partir de metais", onde os lucros também continuaram crescendo no segundo período - mas a uma menor velocidade - sugere-se que as taxas de lucro continuaram crescendo, mas a uma velocidade menor que a do primeiro período. No caso deste setor específico, trata-se da continuidade do aumento da taxa de lucro, mas a uma menor velocidade.

De qualquer modo, as diferentes trajetórias dos lucros expressam o fato de que durante o período referido, alguns setores mais dinâmicos apresentaram comportamento melhor do que os dos outros, por uma taxa de lucro maior que conduziu a mais investimentos e assim a mais vendas. Os setores com vendas menores ou taxa de lucros menores, investiram menos e impactaram menos na economia. Eles foram os responsáveis mais diretos pelo crescimento que a economia efetivamente apresentou. Não é nunca demais: houve sempre crescimento; a questão problemática é porque as variações diminuíram ao longo do tempo. Não se tratou nunca do caso de a economia ter tido seu crescimento bloqueado como um todo, sem que houvesse setores com taxas ascendentes de lucro.

Trata-se antes do fato de que os setores manufatureiros mais antigos não cresceram tanto - o que os levou a serem setores de menor importância para as taxas de acumulação. Se grande parte dos setores industriais ficou estagnada, é claro que a parte precípua do crescimento do produto não se referiu a investimentos realizados nestes setores. A queda das taxas de crescimento do PIB indica portanto que os impactos acumulativos dos setores "pioneiros" no resto da economia foram relativamente menores do que os dos setores "pioneiros" do passado. Isto é: houve crescimento, mas ele foi menor, mais restrito, e gerou menores impactos acumulativos. A teoria não nega que o sistema produza bens em enorme escala; ela apenas indica que esta produção se dá sob contradições específicas a este mesmo sistema.

\subsection{Taxas de lucro no setor manufatureiro}

Mas pode-se sugerir com alguma exatidão que (i) as taxas de lucro no setor manufatureiro, e não só as massas, caíram durante a crise dos anos (19)70, crise que desencadeia o processo de endividamento externo, e que (ii) as taxas de lucro industriais têm sido ultrapassadas pelas taxas de lucro dos setores que não são responsáveis primários pela taxa de expansão do produto. Abaixo se encontra uma primeira figura essencial quanto à verificação desta hipótese adotada, que é justamente a do maior cômputo de capital constante nos setores industriais em relação aos gastos com salários, face aos setores de serviços, que põe força para baixo nas taxas de lucro dos ditos setores industriais. Quanto à comparação histórica do desempenho do setor industrial como um todo face a todos os outros setores de serviços na 
economia, a relação entre o capital constante e os custos com mão-de-obra acusam uma elevação do valor do capital fixo e dos insumos face aos gastos com salários nos setores industriais em comparação com o setor de serviços.

Gráfico 7. Estados Unidos. Relação entre o capital fixo e circulante e os salários, no setor manufatureiro e o de serviços. 1970-20000. Eixo da direita: serviços; eixo da esquerda: manufatura.

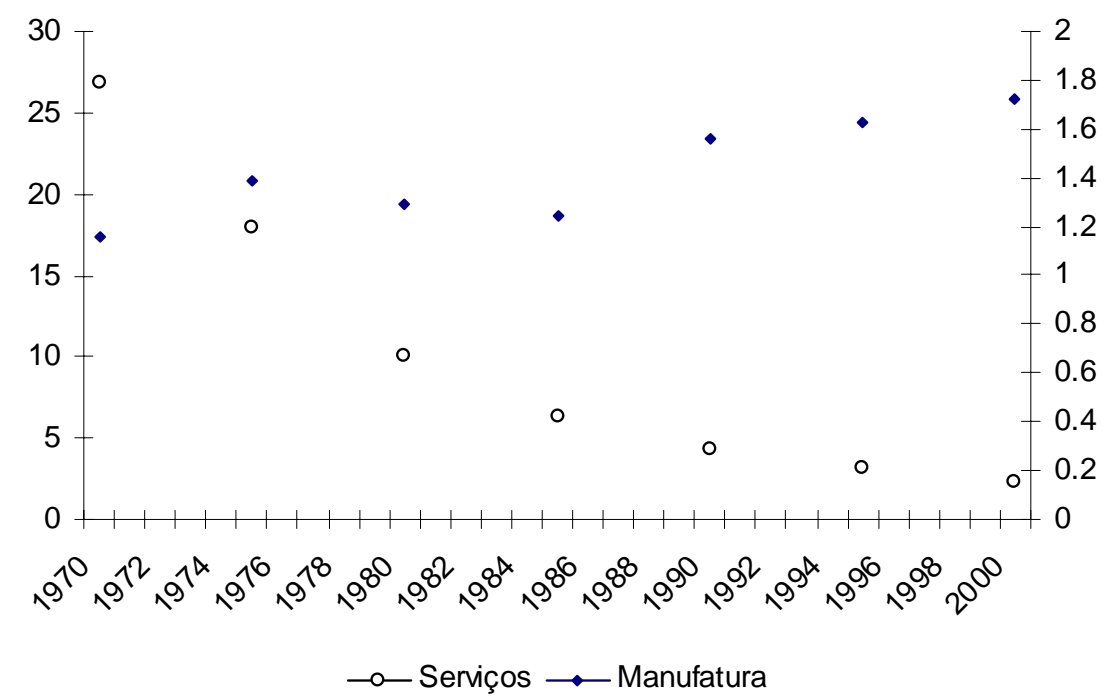

Fonte: NIPA-BEA. Seção 6: Income and Employment by Industry. Tabela 6.2. Compensation of Employees by Industry e Tabela 6.22: Corporate Capital Consumption Allowances by Industry. Ambos dados estão em milhões de dólares correntes.

A figura mostra a mera relação entre os dispêndios com capital fixo e circulante - aqui tomados como o capital depreciado (corporate capital consumption allowances) - e os dispêndios com salários na manufatura (compensation). Eles indicam que, no longo prazo, deuse o crescimento da composição orgânica do capital - ou o aumento da parte constante sobre o capital variável na produção, especialmente o capital fixo. Tal figura foi construída, a partir de dados fornecidos pelo BEA, com a divisão dos gastos dos setores manufatureiros e dos setores de serviços como um todo de (i) capital depreciado (como dito acima, corporate capital consumption allowances) por (ii) salários (compensation of employees by industry). ${ }^{85} \mathrm{~A}$ tendência ascendente para o setor industrial e decrescente para o setor de serviços é indicativa de como as taxas de lucro industriais tendem aos poucos a diminuir relativamente face aos outros setores da economia - justamente porque o cômputo dos gastos de capital constante (principalmente com capital fixo) assume um papel tendencialmente maior ao longo do tempo para a indústria. Por seu turno, a relação para o setor financeiro deve ser a relação existente nos

\footnotetext{
${ }^{85}$ Nas tabelas com as Contas Nacionais fornecidas pelo BEA, em seu endereço eletrônico, estes dois dados são classificados como "Compensation of Employees by Industry" e "Corporate Capital Consumption Allowances by Industry". Eles são respectivamente a seção 6.2 e 6.21 da Seção 6, "Income and Employment by Industry".
} 
serviços exponenciada, já que por definição a relação entre os valores que transaciona e o número de empregados que ocupa não tem conexão: muitos recursos para relativamente poucos empregados que não criam valores físicos - e assim, valor.

Mas calcule-se uma estimativa aproximativa (uma proxy) para a taxa de lucro do setor manufatureiro como um todo. Ela é muito aproximada porque leva em conta os dados do setor manufatureiro inteiro, mas serve como guia para uma orientação geral.

A partir das tabelas do BEA, podem ser estimados os gastos que, numa linguagem marxista, chamar-se-iam de capital variável, de capital constante, assim como a mais-valia obtida pelas firmas, e os outros gastos destas, principalmente com impostos e juros. Dada a estrutura do valor dos bens produzidos numa acepção de $O$ Capital, tem-se que o valor das mercadorias pode ser decomposto em (a) gastos com máquinas, equipamentos, matérias-primas e outros bens que entram no valor da mercadoria, (b) salários, (c) mais-valia - soma surgida da diferença entre o valor dos bens a serem vendidos vendidos e $(a+b)$. Podem-se adicionar como custos os juros e os impostos pagos aos bancos e ao governo, pelas firmas, como custos que entram no denominador da taxa de lucro. ${ }^{86}$

A noção de capital constante envolve uma dificuldade que é sua diferenciação entre fixo (1) e circulante (2), entendidos como (1) prédios e máquinas e (2) matérias-primas e outros componentes do valor que se adicionam num período curto de tempo ao que é produzido. Não há exatamente um período correto para tal definição. É difícil também deduzir a partir das contas nacionais os estoques totais de capital constante, porque os capitais fixos têm um período de rotação (quer dizer, um período total no qual seu valor é completamente depreciado) que é muito variado de corporação para corporação.

Os dados específicos das contas nacionais norte-americanas em relação a alternativas de cálculo da taxa de lucros são numerosos. Há de se fazer opções, assim. Aqui opta-se por algumas delas. Os métodos permitem as mesmas inferências, porém.

Para o primeiro método, para o denominador da expressão "taxa de lucro = maisvalia/salários + capital constante" no setor manufatureiro, usar-se-ão as seguintes séries: salários (compensation of employees); gastos com capital, ou depreciação (corporate capital consumption allowances), mais juros e impostos pagos pelas corporações. Não fica claro pelas Contas Nacionais norte-americanas se tais corporate capital cosumption allowances referem-se apenas a capital fixo ou se incluem todo o capital constante (fixo e circulante). (Os juros são deduções da mais-valia mas são gastos das corporações, de modo que podem ser encarados como parte dos gastos em relação à qual a mais-valia é calculada para dar a taxa de lucro.) ${ }^{87}$

Para a obtenção de uma proxy de "mais-valia", opta-se aqui pelo seguinte raciocínio: toma-se em primeiro lugar a série gross product by type of product, para o setor de bens, no

\footnotetext{
${ }^{86}$ Para um método similar, mas alternativo, de cálculo de taxa de lucro, cf. Apêndice II de BRENNER, Robert. O boom e a bolha.

${ }^{87}$ As séries estão na Seção 6 do NIPA-BEA, Income and Employment by Industry.
} 
(goods, no original). ${ }^{88} \mathrm{O}$ termo "bruto" é usado porque o valor das mercadorias contém também a depreciação do capital utilizado. Dela se subtraem os salários, a depreciação, os juros e os impostos. Tem-se assim o excedente aproximado produzido pelo trabalho; quer dizer, tem-se a massa de mais-valia. Esta mais-valia é então dividida pelos gastos com juros, capital, e salários. Este método tem a vantagem de obter de modo mais "puro" o excedente no setor a cada ano. Os valores de depreciação no tempo t1, t2 etc., representam os investimentos novos em equipamentos nos tempos t-1, t-2 etc., de modo que um aumento dos valores de depreciação indica tão-somente que anteriormente o volume de investimentos aumentou, ou uma baixa nos valores de depreciação indicam uma baixa anterior no nível de investimentos novos. Esquematicamente: mais-valia $=$ valor produzido $($ gross product by type of product $)-$ salários (compensation of employees by industry) - juros e impostos (net interest e taxes on corporate income) - capital depreciado (corporate capital consumption allowances)

taxa de mais-valia $=$ mais-valia $(1) \div$ salários

taxa de lucro $=$ mais-valia $(1) \div$ salários + juros + capital depreciado

É então simples proceder com o cálculo das taxas de mais-valia a partir disto. Basta calcular as relações entre a mais-valia (o resultado ao qual se chegou acima) e os salários. Ocorre contudo uma dificuldade com as taxas de lucro. A taxa de lucro é a relação entre a maisvalia e o capital total invertido pela firma. Mas não pode ser calculada com completa exatidão porque não é dado saber qual é o estoque de capital total num determinado período de tempo, para as firmas em conjunto. A informação de que se dispõe é a quantidade de capital depreciado num ano. Mas não é possível saber qual proporção (em \%) este capital tem sobre um capital total. Mesmo somando todos os gastos com depreciação, ter-se-ia um número inexato para alguma inferência relevante. Ora, a pergunta é simples: a partir de quando se deveria, neste caso, somar os gastos com capital depreciado num tempo $\mathrm{t}+1$ para achar-se o capital total do qual deduzir a depreciação, em forma de porcentagem, de um capital total num tempo anterior t? E mais. Se a série numérica corporate capital consumption allowances envolve o capital

\footnotetext{
${ }^{88}$ A série está na Seção 5 do NIPA-BEA, Domestic Product and Income.
} 
depreciado ao longo de um ano no valor das mercadorias, ela contém, junto à depreciação do capital constante, o valor do capital circulante na forma de matérias-primas. ${ }^{89}$

É necessário então que se tomem as massas de mais-valia sobre o capital total apenas em cada um dos anos; o expediente evidentemente eleva para cima a taxa encontrada. De modo que o que importa, sob este método, é ver o fluxo em forma histórica, para ter-se uma estimativa do desempenho histórico, para além da pressuposição de que o tempo médio de depreciação do capital fixo é de sete anos. O movimento diacrônico encontrado é útil, de qualquer modo.

Gráfico 2. Estados Unidos. Relação entre o capital constante e os salários, no setor manufatureiro. 1948-2000.

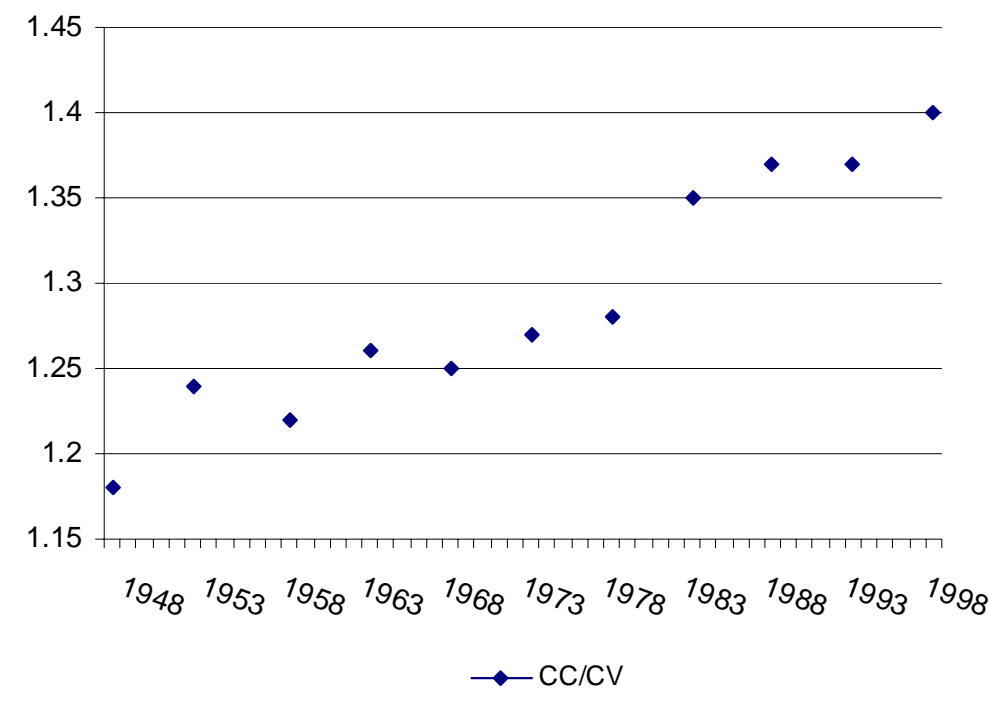

Fonte: NIPA-BEA. Para Juros, Salários, e Capital Fixo, Seção 6: Income and Employment by Industry. Para o valor produzido, Seção 5, Domestic Product and Income, Tabela 1.2.5. Gross Domestic Product by Major Type of Product. Ambos dados estão em bilhões de dólares correntes.

A primeira figura mostra a relação crescente entre o peso do capital constante face ao do capital variável, mostrando assim, com clareza, o peso para as taxas de lucro da crescente relação capital-produto nos setores industriais. A próxima figura é também interessante. Ela traz as proxies taxas de lucro e de mais-valia no setor manufatureiro. A taxa de lucro foi calculada como a relação entre (1) a mais-valia, tal como posto acima, e (2) o capital total, dado como a soma de salários (compensation), juros e impostos (net interest e taxes on corporate income), e o capital depreciado (corporate capital consumption allowances). A taxa de mais-valia é mais facilmente obtida: é a relação entre (2) e os salários (compensation).

\footnotetext{
${ }^{89}$ Por outro lado, se a série corporate capital consumption allowances envolve o capital depreciado ao longo de um ano no valor das mercadorias, é claro que ela contém, junto da depreciação do capital constante, o valor do capital circulante em forma de matérias-primas. Assim, é necessário que se tomem as massas de mais-valia sobre o capital total apenas em cada ano, o que evidentemente joga muito para cima a taxa. Porém, vendo o fluxo em forma histórica, pode-se ter uma estimativa sobre o desempenho histórico aproximado não só da taxa de lucro, mas sim sobre outras variáveis de perspectiva marxista, pressupondo-se que o tempo médio de depreciação do capital fixo é de sete anos. É o movimento diacrônico que interessa neste momento.
} 
Obviamente a taxa de mais-valia é maior porque é calculada sobre os salários, com exclusão dos gastos com capital fixo e insumos. Vê-se um desempenho próximo das duas taxas até fins dos anos 19(70). Justamente após 1980, as taxas de mais-valia começaram crescimento mais rápido, confirmando as hipóteses da literatura sobre o aumento das taxas de mais-valia com a intensificação do processo de automatização do trabalho. Tal ocorreu com um aumento da massa de lucros concomitante, mas sob uma velocidade mais lenta da taxa de lucro. Pode-se claramente observar como a pendente calculada para a taxa de mais-valia acusa maior velocidade de crescimento do que para a da taxa de lucro.

Gráfico 3. Estados Unidos. Proxy de taxa de lucro e mais-valia no setor manufatureiro. 19481996. Valor excedente (ou mais-valia, calculada a partir do valor adicionado total subtraído pelos outros gastos com salários, depreciação, impostos e juros) sobre capital (salários, depreciação, impostos e juros) no setor manufatureiro. 1948-2000.

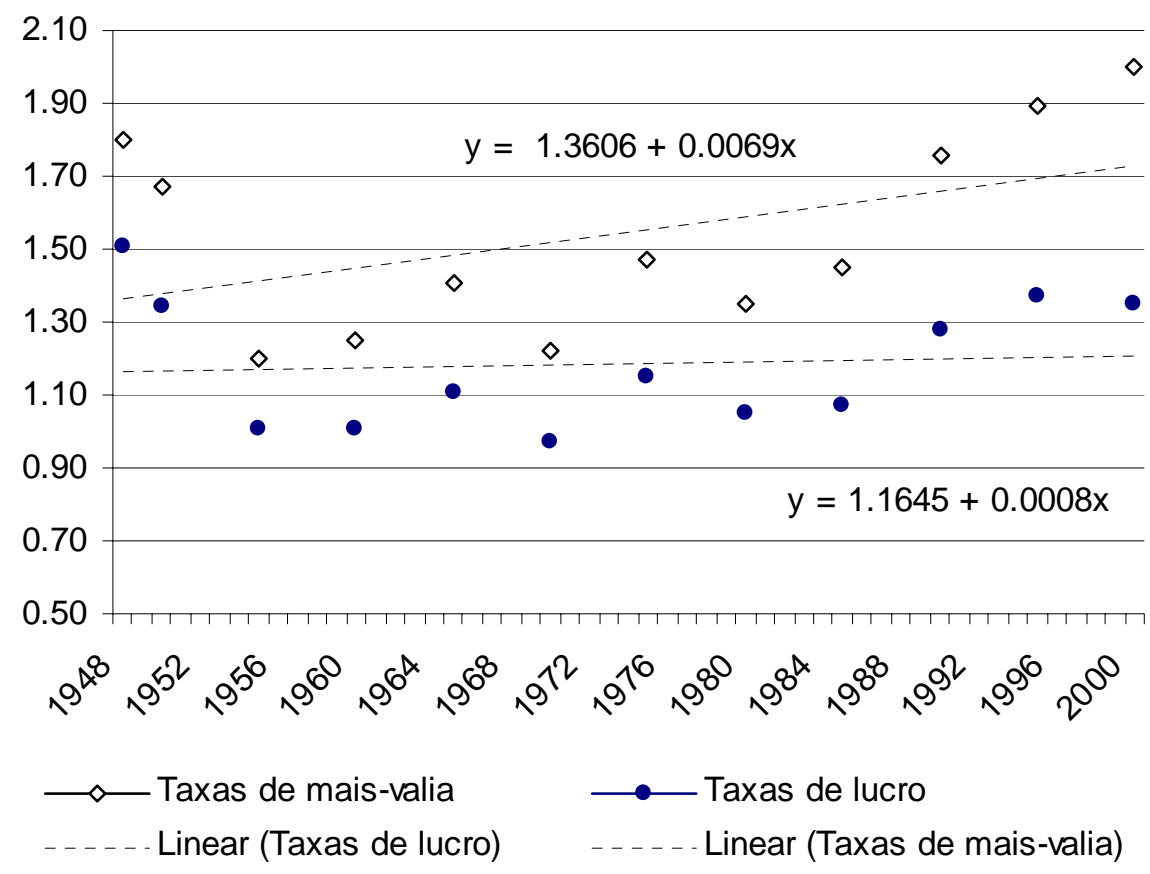

Fonte: NIPA-BEA. Para Juros, Salários, e Capital Fixo, Seção 6: Income and Employment by Industry. Para o valor produzido, Seção 5, Domestic Product and Income, Tabela 1.2.5. Gross Domestic Product by Major Type of Product. Ambos dados estão em bilhões de dólares correntes. Obs.: calculada sobre o capital total no período de um ano, excluído assim o capital a amortizar-se no futuro.

O período da Segunda Guerra Mundial (1939-1945) deve ser tomado como específico, dada a enorme contração dos salários. A trajetória da taxa de lucro depois de recompostos os salários num nível mais normalizado, mais ou menos a partir de 1950, é de ascensão até 1975. Este é o período dos "anos dourados" do grande crescimento do pós-guerra. Depois deste período, elas caem e ficam estagnadas durante dez anos, até aproximadamente 1988. Este é o período no qual a taxa de crescimento da economia caiu e o endividamento externo se iniciou. Depois de 1987, a taxa de lucro começa a recompor-se novamente, o que ajudará a economia a ingressar nos "prodigiosos anos (19)90". Aí a taxa de lucro será maior que antes da crise dos (19)70, mas o setor industrial será bem menor em termos da distribuição setorial do PIB, assim 
como as taxas de lucro são maiores nos outros setores (serviços e financeiros). Por isto a expansão da taxa de lucro para um patamar aparentemente maior do que o dos "trinta gloriosos" não conduz a economia a um crescimento similar. Não há dados nas estatísticas do BEA para estimar sob o mesmo procedimento a taxa de lucro no período posterior a $2000 .{ }^{90}$

Nos anos (19)90 as taxas chegaram a atingir o patamar do pós-guerra, indicando a afirmação acima posta de que a tendência tem caráter reversível. A tendência para a queda foi debelada entre 1987 e 2000, e cabe então investigar o porquê disto. Por outro lado, relativamente, ainda esteve atrás das finanças, o que gera o resultado de estagnação. Aproximando-se de 2000, ela cai novamente. O período dos anos (19)90 merece atenção particular porque permite ver que para a reativação do setor industrial bastou haver aumento nas taxas de lucro. Mas deve-se ter cuidado aqui: não basta que elas cresçam se as outras taxas de lucro crescerem ainda mais rapidamente (aqui encarando-se a coisa de um ponto de vista da diminuição dos níveis de endividamento externo).

Porém, é crucial enfatizar que o crescimento das taxas de lucro no setor manufatureiro impacta na economia cada vez menos quanto menor é a proporção do setor manufatureiro na composição do produto nacional. Tal participação no produto nacional cai ao longo de tempo, devido ao crescimento maior das taxas de lucro em outros setores e ao barateamento dos preços relativos, que expressa o maior cômputo em valor do capital fixo nos setores produtivos. Cai também, por último, pela exportação de capital produtivo. Esta pode ser considerada mesmo uma lei geral tendencial do desenvolvimento das economias industriais, e especialmente norteamericano, pela posição financeirizada que a economia ocupa no sistema econômico internacional hoje; mesmo um crescimento rápido das taxas de lucro no presente não impacta tão fortemente quanto um crescimento menor da taxa no passado. Ora, o valor representado pela produção manufatureira em 1974 representava $21 \%$ do produto nacional bruto; em 2000 14\% etc..

Por conseguinte, deve-se esclarecer a influência da lei sobre o movimento da economia, para evitar certa confusão interpretativa: não é tão simples a apreciação do comportamento dos lucros. Não se podem contrapor dois momentos distintos no tempo - anos (19)90 e anos (19)60, por exemplo - para fazer-se inferências sobre o movimento da economia durante todo um período (dos anos (19)60 aos (19)80). Quer dizer, não basta que o valor absoluto das taxas de lucro num determinado período (por exemplo, segunda metade dos anos (19)80) seja mais alto do que o das taxas num período anterior (exemplo: meados da década de sessenta) para que se considere que deveria haver muito mais investimentos industriais no período nos quais ela é maior. Se ela é muito mais alta mas o setor é relativamente pequeno na economia, o impulso será menor do que na situação oposta.

\footnotetext{
${ }^{90} \mathrm{O}$ BEA alterou a série de salários no setor manufatureiro, de modo que ela muda seu padrão a partir de 2000. Sem a continuação da série, é impossível usar a mesma metodologia para depois de 2000, portanto. Isto é curioso, pois foge ao ótimo padrão de formulação de dados que lhe é característico.
} 
Ainda, devido ao elemento de incerteza, os capitais deixam de investir se a taxa de lucro sofre uma interrupção de seu crescimento sustentado, durante um tempo contínuo; quer dizer, a expectativa em torno da taxa de lucro deve ser encarada como ocorrendo em forma de fluxo. Não há "uma" taxa de lucro específica esperada pelas corporações, do ponto de vista da comparação intertemporal (ou seja, diferentes momentos ao longo do tempo), mas sim apenas a comparação entre elas num tempo contínuo - e não fazendo referência ao passado distante. A verificação de que a taxa cresce leva a investir; se a taxa deixa de crescer, deixa-se de investir, não importando que no momento em que se deixa de investir a taxa se encontre mais alta do que era no passado. A queda dos investimentos num tempo $\mathrm{t}+1$ sempre se dá num momento em que a taxa é maior do que num tempo t. É o fato de que a taxa não cresce mais que leva à desaceleração. Como afirmou Joan Robinson...

"Tanto a taxa de lucro esperada como a taxa esperada são entidades vagas e complexas. A taxa obtida é vaga porque há várias convenções que podem ser usadas para estimá-la. A taxa esperada é vaga devido à incerteza. Ambas são complexas devido a cada uma delas constituir um amálgama da experiência variada de um grande número de firmas. [...] Na construção de um modelo histórico, é necessário distinguir entre a taxa de lucro corrente e a esperada, e especificar o que se supõe ser a ligação entre elas. [...] Onde a experiência tem sido muito variada, não é possível manter expectativas confiantes. Nessas condições, há uma propensão no sentido de a experiência presente ser privilegiada quando da formação de expectativas; uma modificação aleatória nos rendimentos correntes então afetará as decisões de investimento." 91

Ora, entre os anos (19)50 e (19)70 houve "apenas" a interrupção do crescimento, e a queda, das taxas. O que muda tudo. Tal interrupção, aliada ao novo papel do dólar na economia mundial, engendrou a pressão pelo endividamento externo. Veja-se o gráfico novamente. Ele mostra as taxas de lucro, calculadas com o método acima definido, entre 1950 e 2000. Dado este método de cálculo, vê-se que as taxas nos anos (19)80 são de fato mais altas que eram nos anos (19)60. Mas por que a crise da segunda metade dos (19)70? Porque não se conseguiu manter a taxa de lucro em processo ascendente, tal como ela se apresentava, não obstante as flutuações, desde os anos (19)60. Os eventos da segunda metade dos anos (19)70 jogaram-na abaixo, e para as corporações não importa que num passado mais ou menos distante ela tivesse sido maior. Simplesmente o processo de crescimento havia sido interrompido, destruindo-se as expectativas de que fosse crescer ainda mais, levando assim a uma diminuição relativa dos investimentos, que desencadearam por seu turno os processos concernentes ao período da administração Reagan.

${ }^{91}$ ROBINSON, Joan. Ensaios sobre a teoria do crescimento econômico, p.326. 
No curto prazo, pode dar-se um aumento da taxa de lucro que não se revele muito expansivo para o produto porque pode haver baixa demanda; o aumento da taxa pode estar se dando justamente pela queda do poder dos salários. Deve-se sempre lembrar que pode se apresentar um aumento da taxa de lucro em muitos setores em presença de uma queda na demanda ou à diminuição de sua participação no produto. Ora, ao afirmar-se que a taxa de lucro é o guia da expansão acumulativa não se exclui o fato de que no curto prazo pode-se ter estancamento do crescimento em presença de taxas de lucro altas, por meio de elementos depressivos, como a política econômica ou uma estrutura de gastos improdutiva etc.. ${ }^{92} \mathrm{O}$ aumento das taxas de endividamento das famílias e empresas é uma maneira de resolver esta debilidade, e melhor ainda se feita com base em recursos externos. Isto explica porque, superada a crise dos (19)70-80, a taxa de lucro se veja maior do que era no passado, mas não as taxas de crescimento da economia.

Então, à pergunta "por que as taxas de expansão da economia foram menores mesmo durante a grande elevação da taxa de lucro ao longo dos anos (19)90", poder-se-ia dizer, antecipando-se o capítulo 8, que o tamanho relativo do setor industrial norte-americano é muito menor do que era há quarenta anos atrás, justamente pela realocação dos investimentos pela ultrapassagem dos lucros industriais, assim como, num nível também estrutural, pela queda dos preços relativos dos bens industriais e da participação destes no produto. Este fruto do próprio barateamento dos custos na indústria diminui a lucratividade média ao longo do tempo porque menos mais-valia é realizada por mercadoria, com relação ao capital fixo. De fato, as empresas pioneiras aproveitam-se de um aumento da mais-valia obtida ao venderem pelo preço médio; porém, quando suas vantagens produtivas são copiadas pelos concorrentes, tais vantagens se anulam e a queda dos preços se estabelece.

Gráfico 4. Estados Unidos. Massa de lucros no setor manufatureiro. 1948-2000. Em bilhões de dólares.

Massa de lucros

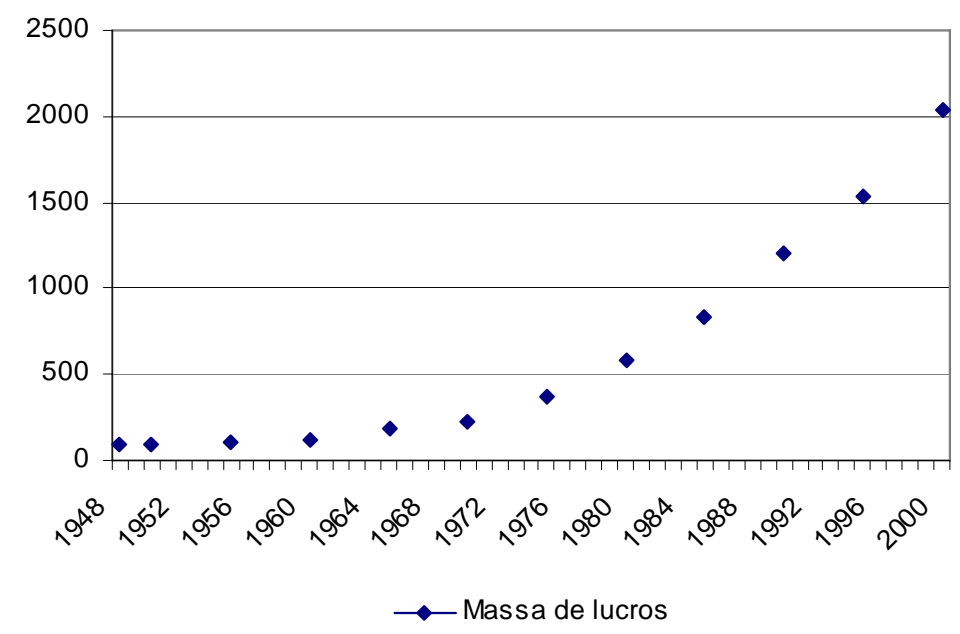

Fonte: NIPA-BEA. Seção 6: Income and Employment by Industry. Tabela 6.16: Corporate Profits by Industry.

${ }^{92}$ Esta condição chega ao paroxismo nas economias subdesenvolvidas. 
Deriva-se daí a noção de que a economia industrializada tende a crescer menos à medida que se desenvolve, porque a capacidade que o setor-chave da economia tem - o setor industrial - para afetar a expansão do PIB é menor ao longo do tempo. Não bastam, daí, sucessivos aumentos da taxa de lucro para que se tenha crescimento. Pelo contrário, dada tal modificação na estrutura de preços relativos, são necessários aumentos da taxa de lucro cada vez maiores ao longo do tempo para continuar induzindo-se às mesmas taxas de crescimento no restante da economia que havia no passado. Inevitavelmente, o ritmo de crescimento da economia deve ser relativamente menor à medida que passa o tempo. A esta queda relativa do investimento produtivo, a economia tem respondido, porém, com mais consumo, via endividamento externo.

Certo: o endividamento cria condições para que os próprios investimentos produtivos sejam mais lucrativos: eles permitem taxas de juros mais baixas e custos de reprodução dos trabalhadores igualmente mais baixos, pela ampliação das condições de crédito e financiamento. Mas a queda da acumulação em capital fixo mostra como o endividamento não permitiu anular de todo a tendência estagnativa, mas sim, como se está argumentando, apenas a remediar.

\subsection{Um cálculo alternativo de taxa de lucro na manufatura e taxas de lucro setoriais}

O sistema de Contas Nacionais norte-americano é um dos mais desenvolvidos entre as nações industriais. Assim, às vezes é possível calcular cada fenômeno econômico - taxa de lucro, propensão marginal ao consumo, termos de intercâmbio, entre outros - de duas ou mais formas, porque para cada aspecto econômico há muitas vezes mais de uma série histórica existente. Se os métodos de cálculo e/ou coleta variam, tem-se mais de uma variável disponível ao pesquisador. Neste item explora-se um cálculo alternativo de taxa de lucro no setor manufatureiro, para confirmar as hipóteses dos capítulos anteriores. Calcula-se também a taxa de lucro de modo mais desagregado do que se viu ao longo do trabalho, inclusive para o setor financeiro, e, dentro deste, o setor de bancos de depósito.

Acima, optou-se por subtrair do valor produzido pelo setor produtor de bens (goods) os gastos com salários, juros, e capital fixo. Assim, obteve-se um valor aproximado do excedente produzido pelas firmas produtoras de bens em conjunto. Neste momento, vai-se proceder de outro modo, mais simples, mas menos rigoroso, por limitações da base de dados. Vão-se tomar as séries de lucros setoriais, e dividi-las pelos gastos com salários e capital fixo. Por que menos rigoroso? Porque não há, para os setores de forma desagregada, séries para pagamentos de juros, de modo que os juros não entram neste cálculo de outra proxy de taxa de lucro.

A utilização da série de lucros (profits by industry) para obtenção do excedente em vários setores da economia, ao invés de deduzir do valor produzido por setor os gastos de cada setor, explica-se em primeiro lugar porque não há séries disponíveis de gross product para todos os setores, mas sim apenas para "goods" e "services". Esta última série é inclusive muito 
agregada, com inclusão das firmas do governo. ${ }^{93} \mathrm{~A}$ estimativa feita acima serve assim para dar a lucratividade aproximada na manufatura e serviços, mas não para os outros setores. Para estimar a lucratividade em outros setores, para além da manufatura, há as séries de lucros setoriais propriamente ditos.

A Seção 6 das Tabelas do BEA-NIPA contém quatro principais séries de lucros setoriais: "corporate profits by industry"; "corporate profits before tax by industry"; "corporate profits after tax by industry"; e "undistributed corporate profits by industry". Aqui se vai utilizar a mais realista, "undistributed corporate profits by industry", porque ela fornece os lucros retidos pelas empresas depois de pagos os acionistas e os impostos. A depreciação é tomada como o indicador do volume de investimento passado: quanto maior os gastos com depreciação, maior foi o volume de investimentos anteriores. Assim, maior o volume de gastos para manter a produção corrente. A taxa de lucro estimada será considerada como sendo simplesmente:

Taxa de lucro $=$ lucros (profits after tax by industry) $\div$ salários (compensation of employees by industry) + gastos com depreciação (capital consumption allowances by industry). ${ }^{94}$, ou...

Taxa de lucro $=$ lucros/salários + gastos com depreciação

Com este método, pode-se saltar a etapa da dedução do excedente a partir do valor produzido, tal como anteriormente feito. Toma-se o excedente como sendo os lucros não distribuídos propriamente ditos. Dividem-se então os lucros setoriais pelos gastos com a manutenção das atividades (salários e capital, aqui excetuando-se os juros). Este método tem a vantagem de servir como comparativo com o primeiro método utilizado no capítulo 3 , para o setor industrial.

Abaixo está disposta o resultado destas estimativas para vários setores da economia. A tabela contém os gastos em salário, consumo de capital fixo, lucros não distribuídos, e a taxa de lucro aproximada, para os seguintes setores: finance (financeiros); um sub-setor de finance, chamado banking and depositary institutions (bancos e outras instituições de depósito); ${ }^{95}$ manufacturing (manufatura), mining (mineração), construction (construção), transportation and public utilities (transportes e serviços de utilidade pública), comércio por atacado (whole sale trading). A taxa de lucro é entendida como sendo a divisão da linha 1 (lucros não distribuídos) pela linha 4 (soma de salários e consumo de capital fixo), para cada setor. Mostra-se também a relação entre os gastos com capital fixo e salários. Os dados estão calculados com intervalos de dois-três anos.

\footnotetext{
${ }^{93}$ Ver a Tabela 1.2.5, Gross Domestic Product by Major Type of Product, usada no capítulo 3.

${ }^{94}$ As três séries estão na Seção 6 do NIPA-BEA.

${ }^{95}$ Há uma quebra de seqüência na série de bancos e instituições de depósito a partir de 1987. "Banking" torna-se "Depository Institutions" a partir deste ano.
} 
Tabela 2. Estados Unidos. Lucros não distribuídos, gastos com salários e capital fixo, e taxa de lucro, por setor econômico (em \%).

\begin{tabular}{|c|c|c|c|c|c|c|c|c|c|c|c|c|}
\hline & Anos & 1975 & 1977 & 1980 & 1982 & 1985 & 1986 & 1990 & 1992 & 1995 & 1997 & 2000 \\
\hline & Financeiros & & & & & & & & & & & \\
\hline 1 & $\begin{array}{l}\text { Lucros não } \\
\text { distribuídos }\end{array}$ & 7921 & 15514 & 11487 & -2907 & -3103 & 315 & 11898 & 40466 & 35088 & 33651 & 2541 \\
\hline 2 & Salários & 50274 & 63019 & 94207 & 116,434 & 160897 & 183061 & 243476 & 274696 & 324593 & 382565 & 505821 \\
\hline 3 & $\begin{array}{l}\text { Consumo de } \\
\text { capital fixo }\end{array}$ & 8121 & 9740 & 13771 & 19814 & 32491 & 36408 & 48811 & 49716 & 69162 & 85993 & 123050 \\
\hline 4 & Soma de 2 e 3 & 58395 & 72759 & 107978 & 136,248 & 193388 & 219469 & 292287 & 324412 & 393755 & 468558 & 628871 \\
\hline 5 & Taxa de lucro & $13 \%$ & $21 \%$ & $10 \%$ & $-2 \%$ & $-1 \%$ & $01 \%$ & $4 \%$ & $12 \%$ & $8 \%$ & $7 \%$ & $4 \%$ \\
\hline \multirow[t]{3}{*}{6} & $\begin{array}{l}\text { Capital fixo } \\
\text { sobre salários }\end{array}$ & 0.16 & 0.15 & 0.15 & 0.17 & 0.20 & 0.20 & 0.20 & 0.18 & 0.21 & 0.22 & 0.24 \\
\hline & $\begin{array}{l}\text { Bancos e } \\
\text { instituições de } \\
\text { depósitos }\end{array}$ & & & & & & & & & & & \\
\hline & & 1975 & 1977 & 1980 & 1982 & 1985 & 1986 & 1990 & 1992 & 1995 & 1997 & 2000 \\
\hline 1 & $\begin{array}{l}\text { Lucros não } \\
\text { distribuídos }\end{array}$ & 5575 & 5377 & 4804 & 5647 & 13771 & 16807 & 27710 & 49090 & 33868 & 37166 & 65876 \\
\hline 2 & Salários & 14542 & 17747 & 25916 & 33457 & 40498 & 43564 & 67341 & 70593 & 73843 & 79273 & 99937 \\
\hline 3 & $\begin{array}{l}\text { Consumo de } \\
\text { capital fixo }\end{array}$ & 3402 & 4420 & 6749 & 9076 & 15511 & 20342 & 24800 & 24789 & 36059 & 48513 & 68877 \\
\hline 4 & Soma de 2 e 3 & 17944 & 22167 & 32665 & 42533 & 56009 & 63906 & 92141 & 95382 & 109902 & 127786 & 168814 \\
\hline 5 & Taxa de lucro & $31 \%$ & $24 \%$ & $15 \%$ & $13 \%$ & $25 \%$ & $26 \%$ & $30 \%$ & $51 \%$ & $31 \%$ & $29 \%$ & $39 \%$ \\
\hline \multirow[t]{3}{*}{6} & $\begin{array}{l}\text { Capital fixo } \\
\text { sobre salários }\end{array}$ & 0.23 & 0.25 & 0.26 & 0.27 & 0.38 & 0.47 & 0.37 & 0.35 & 0.49 & 0.61 & 0.69 \\
\hline & Manufatura & & & & & & & & & & & \\
\hline & & 1975 & 1977 & 1980 & 1982 & 1985 & 1986 & 1990 & 1992 & 1995 & 1997 & 2000 \\
\hline 1 & $\begin{array}{l}\text { Lucros não } \\
\text { distribuídos }\end{array}$ & 23039 & 38614 & 40548 & 24193 & 24139 & -5426 & 17209 & -447 & 47618 & 44322 & 11520 \\
\hline 2 & Salários & 251822 & 323863 & 435651 & 477371 & 572119 & 587734 & 686778 & 725732 & 813394 & 868241 & 1014791 \\
\hline 3 & $\begin{array}{l}\text { Consumo de } \\
\text { capital fixo }\end{array}$ & 37904 & 48337 & 70000 & 106008 & 143785 & 143031 & 155643 & 164467 & 196074 & 226898 & 251211 \\
\hline 4 & Soma de 2 e 3 & 289726 & 372200 & 505651 & 583379 & 715904 & 730765 & 842421 & 890199 & 1009468 & 1095139 & 1266002 \\
\hline 5 & Taxa de lucro & $8 \%$ & $10 \%$ & $8 \%$ & $4 \%$ & $3 \%$ & $-1 \%$ & $2 \%$ & $1 \%$ & $5 \%$ & $4 \%$ & $1 \%$ \\
\hline \multirow[t]{3}{*}{6} & $\begin{array}{l}\text { Capital fixo } \\
\text { sobre salários }\end{array}$ & 0.15 & 0.14 & 0.16 & 0.22 & 0.25 & 0.24 & 0.22 & 0.23 & 0.24 & 0.26 & 0.25 \\
\hline & \multicolumn{12}{|l|}{ Mineração } \\
\hline & & 1975 & 1977 & 1980 & 1982 & 1985 & 1986 & 1990 & 1992 & 1995 & 1997 & 2000 \\
\hline 1 & $\begin{array}{l}\text { Lucros não } \\
\text { distribuídos }\end{array}$ & 3799 & -175 & 959 & -5804 & -7352 & -7727 & -2988 & -1084 & -373 & 4566 & 3942 \\
\hline
\end{tabular}




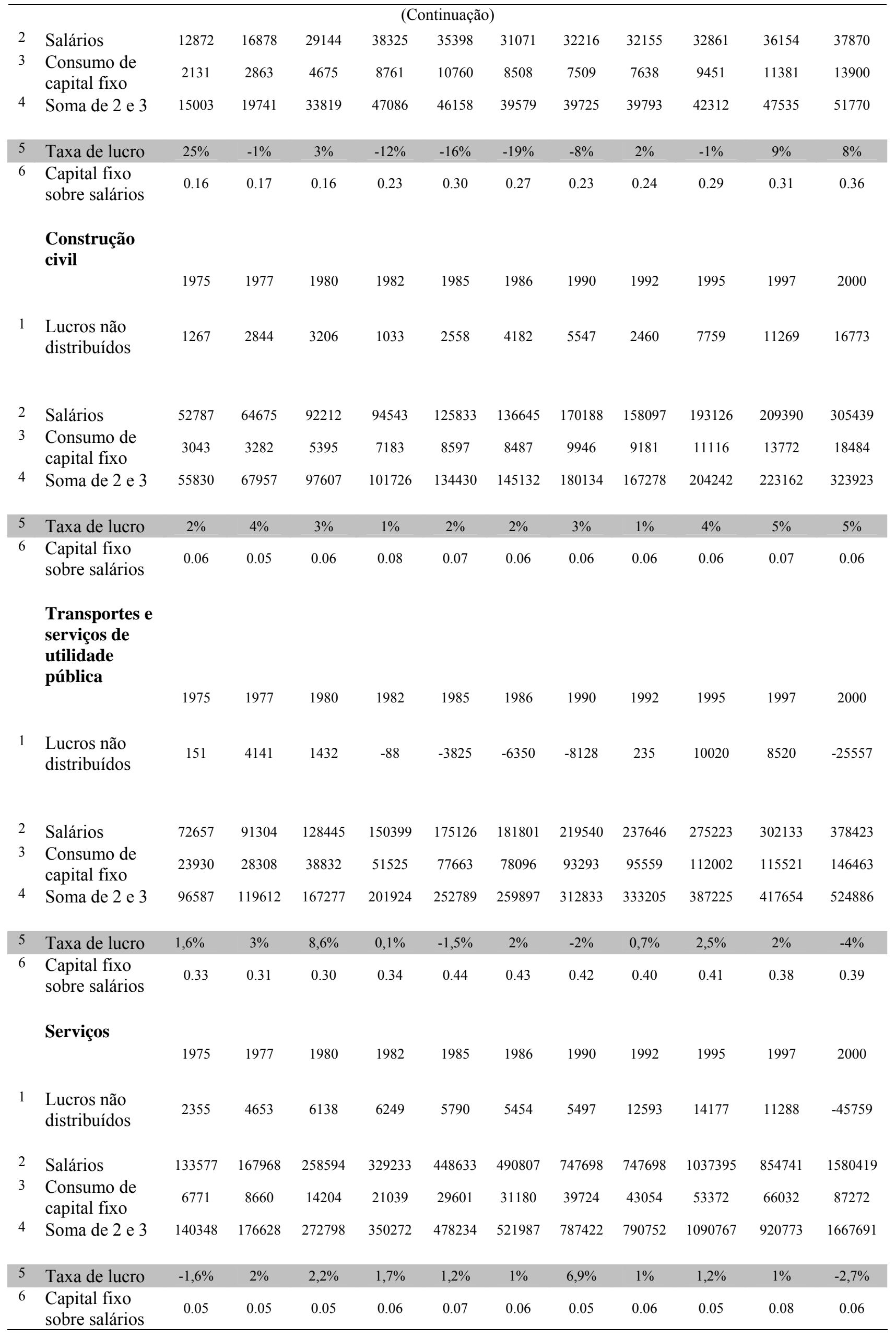




\begin{tabular}{|c|c|c|c|c|c|c|c|c|c|c|c|c|}
\hline \multicolumn{13}{|c|}{ (Continuação) } \\
\hline & & 1975 & 1977 & 1980 & 1982 & 1985 & 1986 & 1990 & 1992 & 1995 & 1997 & 2000 \\
\hline 1 & $\begin{array}{l}\text { Lucros não } \\
\text { distribuídos }\end{array}$ & 8628 & 9288 & 13304 & 8761 & 6265 & 7266 & 7751 & 11502 & 10719 & 17274 & 21853 \\
\hline 2 & Salários & 61274 & 75771 & 111211 & 129890 & 160400 & 168968 & 221950 & 237700 & 275082 & 310194 & 388787 \\
\hline 3 & $\begin{array}{l}\text { Consumo de } \\
\text { capital fixo }\end{array}$ & 3863 & 5120 & 9245 & 12675 & 16880 & 17165 & 22746 & 27547 & 39161 & 46018 & 53815 \\
\hline 4 & Soma de 2 e 3 & 65137 & 80891 & 120456 & 142565 & 177280 & 186133 & 244696 & 265247 & 314243 & 356212 & $\begin{array}{c}442602 \\
10.13\end{array}$ \\
\hline 5 & Taxa de lucro & $13 \%$ & $11 \%$ & $11 \%$ & $6 \%$ & $4 \%$ & $3 \%$ & $3 \%$ & $4 \%$ & $3 \%$ & $4 \%$ & $5 \%$ \\
\hline 6 & $\begin{array}{l}\text { Capital fixo } \\
\text { sobre salários }\end{array}$ & 0.06 & 0.07 & 0.08 & 0.10 & 0.11 & 0.10 & 0.10 & 0.12 & 0.14 & 0.15 & 0.14 \\
\hline
\end{tabular}

Fonte: NIPA-BEA. Tabelas: Seção 6, Income and Employment by industry; Tabelas 6.2., Compensation of employees by industry; 6.21, Undistributed corporate profits by industry; e 6.22, Corporate Capital Consuption Allowances by industry.

Os dados a partir desta tabela corroboram as hipóteses estabelecidas anteriormente. Em primeiro lugar, nota-se que a relação entre os gastos com capital fixo é maior nos setores produtivos - manufatura, mineração, construção civil e serviços de utilidade pública - que nos setores de comércio e serviços. Em segundo lugar, percebe-se a grande automatização dos processos de trabalho nos setores financeiros, e especificamente no sub-setor do sistema financeiro "bancos e instituições de depósitos". Isto está refletido em suas altas taxas de gastos com capital fixo, proporcionalmente às vezes maiores que as referentes à manufatura e à mineração, por exemplo. Ocorre, porém, que estas grandes taxas de gastos com capital fixo em tais setores financeiros (automação, principalmente) são mais que compensadas por suas muito maiores relações lucros/gastos, o que deixa ver uma taxa de lucro maior, sempre, para ambos setores financeiros aí considerados. O comparativo entre as taxas de lucros dos bancos e da manufatura, assim como outros setores produtivos, dá a dimensão da financeirização da economia e das dificuldades existentes para uma maior expansão consolidada.

Abaixo, uma tabela apenas com as taxas de lucro. Percebe-se uma hierarquia de taxas de lucro entre os bancos e instituições de depósito e a manufatura, em primeiro lugar. A taxa de lucro global para o setor financeiro é mais baixa que a média para os bancos e instituições de depósito pela presença nele de setores nem tão lucrativos como os bancos de depósitos, como por exemplo o próprio Banco Central (Fed). Observam-se baixas taxas de lucro consolidadas de transportes e serviços de utilidade pública e mineração, menores, em média, que a dos serviços e comércio por atacado, que são mais constantes. Percebem-se os efeitos da crise de 2001 especialmente nos serviços e comércio por atacado. 
Tabela 3. Estados Unidos. Taxas de lucro setoriais.

$\begin{array}{ll} & \text { Taxas de lucro } \\ 1 & \text { Financeiros } \\ 2 & \text { Bancos e outras instituições de depósito } \\ 3 & \text { Manufatura } \\ 4 & \text { Mineração } \\ 5 & \text { Construção Civil } \\ 6 & \text { Transportes e services de utilidade pública } \\ 7 & \text { Serviços } \\ 8 & \text { Comércio por Atacado }\end{array}$

(Continuação)

Taxas de lucro
Financeiros
Bancos e outras instituições de depósito
Manufatura
Mineração
Construção Civil
Transportes e services de utilidade pública
Serviços
Comércio por Atacado

$\begin{array}{cccccc}\mathbf{1 9 7 5} & \mathbf{1 9 7 7} & \mathbf{1 9 8 0} & \mathbf{1 9 8 2} & \mathbf{1 9 8 5} & \mathbf{1 9 8 6} \\ 13 \% & 21 \% & 10 \% & -2 \% & -1 \% & 1 \% \\ 31 \% & 24 \% & 15 \% & 13 \% & 25 \% & 26 \% \\ 8 \% & 10 \% & 8 \% & 4 \% & 3 \% & -1 \% \\ 25 \% & -1 \% & 3 \% & -12 \% & -16 \% & -19 \% \\ 2 \% & 4 \% & 3 \% & 1 \% & 2 \% & 2 \% \\ 1,6 \% & 3 \% & 8,6 \% & 0,1 \% & -1,5 \% & 2 \% \\ -1,6 \% & 2 \% & 2,2 \% & 1,7 \% & 1,2 \% & 1 \% \\ 13 \% & 11 \% & 11 \% & 6 \% & 4 \% & 3 \%\end{array}$

$\begin{array}{cccccc}\mathbf{1 9 9 0} & \mathbf{1 9 9 2} & \mathbf{1 9 9 5} & \mathbf{1 9 9 7} & \mathbf{2 0 0 0} & - \\ 4 \% & 12 \% & 8 \% & 7 \% & 4 \% & - \\ 30 \% & 51 \% & 31 \% & 29 \% & 39 \% & - \\ 2 \% & 1 \% & 5 \% & 4 \% & 1 \% & - \\ -8 \% & 2 \% & -1 \% & 9 \% & 8 \% & - \\ 3 \% & 1 \% & 4 \% & 5 \% & 5 \% & - \\ -2 \% & 0,7 \% & 2,5 \% & 2 \% & -4 \% & - \\ 6,9 \% & 1 \% & 1,2 \% & 1 \% & -2,7 \% & - \\ 3 \% & 4 \% & 3 \% & 4 \% & 5 \% & -\end{array}$

Fonte: dados da tabela anterior.

Visto no longo prazo, há uma tendência de estabilização da taxa de lucro para os setores de serviços e comércio; uma tendência e/ou estagnação para manufatura e outros setores produtivos (aqui contabilizados também os transportes e serviços de utilidade pública, porque fazem parte da reprodução material do processo produtivo); e uma clara tendência de elevação da taxa de lucro para os setores financeiros, especialmente bancos e instituições de depósito. Os déficits comerciais crescentes e o comportamento dos preços relativos impedem que mesmo as taxas de lucro na manufatura por vezes maiores que as dos setores de serviços e comércio por atacado impulsionem uma elevação do setor na economia.

A análise gráfica permite uma visão mais clara dos comportamentos da taxa de lucro. Na figura abaixo, percebe-se a ascensão da taxa de lucro no sistema bancário, em contraposição ao comportamento mais estável dos outros setores. O comportamento desta primeira série atende às seguintes conjunturas: (1) uma queda com a crise de 1980-82, sucedida por (2) uma elevação a partir da recuperação da crise, desde 1986; (3) uma queda absoluta a partir de 1992, depois de um de 50\% aproximadamente, queda esta que não deixava de denotar um aumento das oportunidades para as inversões produtivas no período, tal como já visto anteriormente.

O setor manufatureiro tem taxas de lucro globais muito menores do que as do setor bancário, ainda que seu comportamento tendencial tenha aparentemente mesmo perfil aproximado que o do setor dos bancos. O perfil da série lembra o da série obtida com o método anterior, mas traz resultados distintos significativos. A taxa cai depois da crise dos anos (19)70, eleva-se a partir de 1985, e começa a cair no fim dos anos (19)90, como sinal da crise de 2001, tal como na primeira proxy obtida. 
Gráfico 5. Proxies de taxa de lucro em diferentes setores da economia norte-americana. Em porcentagem $(\%)$.

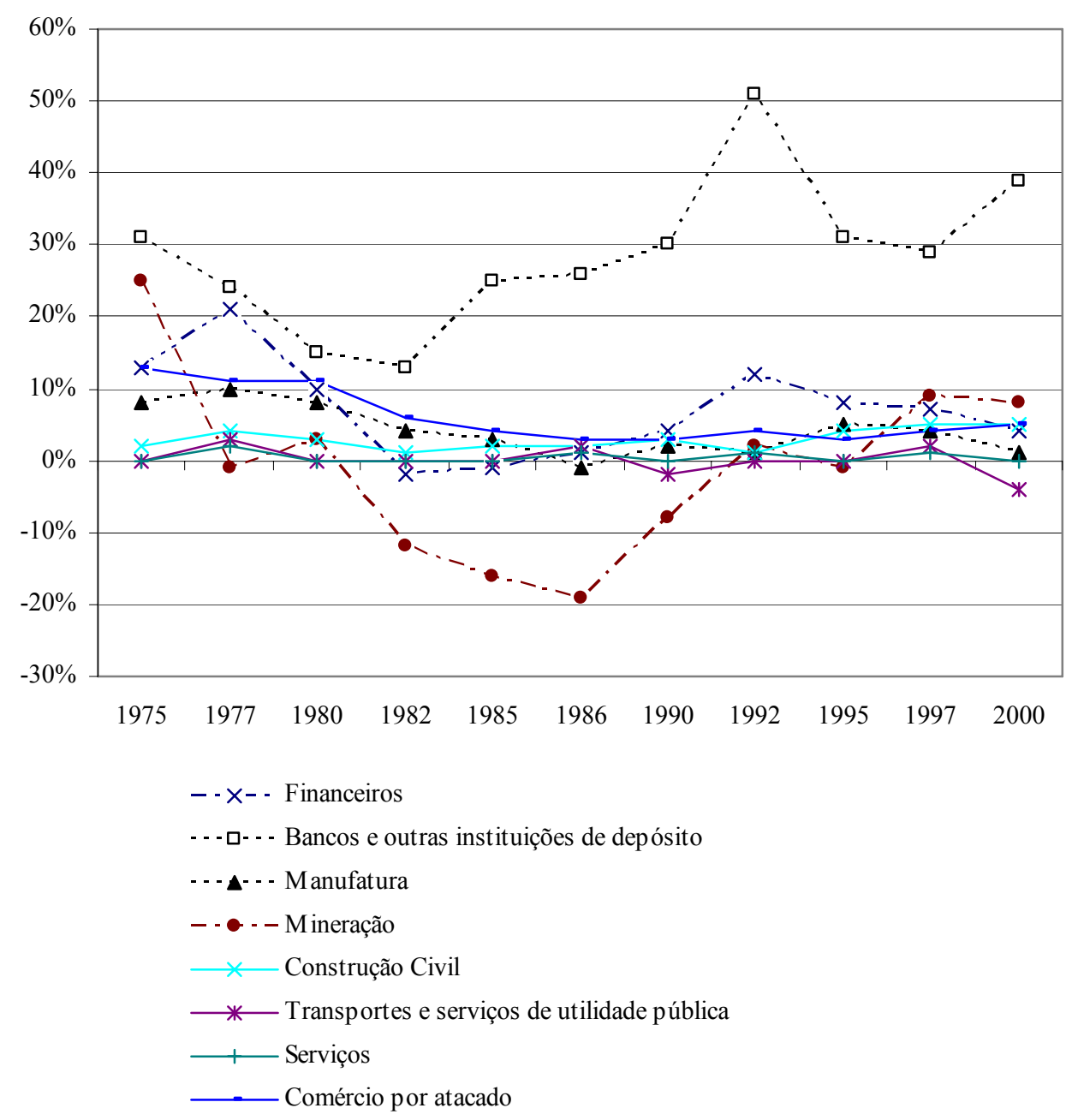

Fonte: dados a partir da tabela anterior.

A diferença crucial, todavia, é que a taxa de lucro na manufatura, segundo este método de avaliação, nunca retorna ao patamar pré-crise dos anos (19)70, diferentemente do que se obtém com o outro método de cálculo. A taxa de lucro no setor bancário, por sua vez, tem ascensão consolidada, com o resultado no fim da série sendo maior que o resultado do início da série. Isto demonstra o argumento de que mesmo se a taxa de lucro no setor produtivo se elevar paralelamente a um aumento ainda mais rápido dos ganhos financeiros, a economia estará numa trajetória de diminuição relativa de sua taxa de produção material.

Para concluir a seção, pode-se dizer que há ainda um outro método possível para verificar a queda consolidada da taxa de lucro do setor industrial. Ele é mais simplificado e inclui todo o capital das firmas. ${ }^{96}$ Ele não permite verificar a trajetória do capital fixo, crucial para o argumento traçado no trabalho, mas permite ver com mais clareza a queda da taxa de

\footnotetext{
${ }^{96}$ Agradeço a Leda Paulani pela sugestão deste método.
} 
lucro no setor industrial por si mesmo. Ele consiste simplesmente em tomar a produção bruta do setor industrial, que inclui salários, capital e mais-valia, e dele retirar o lucro do setor. Retirando-se assim a mais-valia, fica-se com o capital constante e capital variável (salários), o primeiro incluindo seguramente o fixo e o circulante. Pode-se optar por usar as séries de lucros antes do pagamento de impostos ou depois. A trajetória da série, porém, ficará inalterada, variando apenas a porcentagem da taxa. Para obter tal resultado, utilizaram-se as seguintes séries do BEA: Tabela 6.1.B, National Income Without Capital Consumption Adjustment by Industry - Manufacturing; Tabela 6.19B, Corporate Profits After Tax by Industry Manufacturing.

Com tais dados, subtraíram-se os valores de corporate profits da produção do setor manufacturing; obteve-se assim a "mais-valia". Este valor foi então dividido pelo número que sobrou da divisão, sendo este o capital "constante" e os salários. Isto é:

National Income Without Capital Consumption Adjustment by Industry (Manufacturing) Corporate Profits after Tax by Industry (Manufacturing)

= Mais-valia

Mais-valia / capital constante + salários $=$ taxa de lucro

Para o caso de incluirem-se os impostos, deve-se adicionar a série Taxes on Corporate Income by Industry, Tabela $6.18 \mathrm{~B}$, aos lucros, para ter-se a massa de lucros total gerada no setor. É este valor, lucros mais impostos, que deve então ser subtraído da produção bruta. No caso de optar-se por usar as séries de lucro do setor manufatureiro antes dos impostos, temse cálculo com os lucros brutos. Se se optar pelos lucros existentes depois de pagos os impostos, trata-se do lucro líquido do setor. O cálculo para os anos compreendendo 1948 e 1987 estão ilustrados no gráfico abaixo. 
Gráfico 6. Estados Unidos. Outras proxies de taxa de lucro no setor manufatureiro: produção bruta menos lucros, divididos pelo capital e por salários, e incluindo e excluindo impostos pagos.

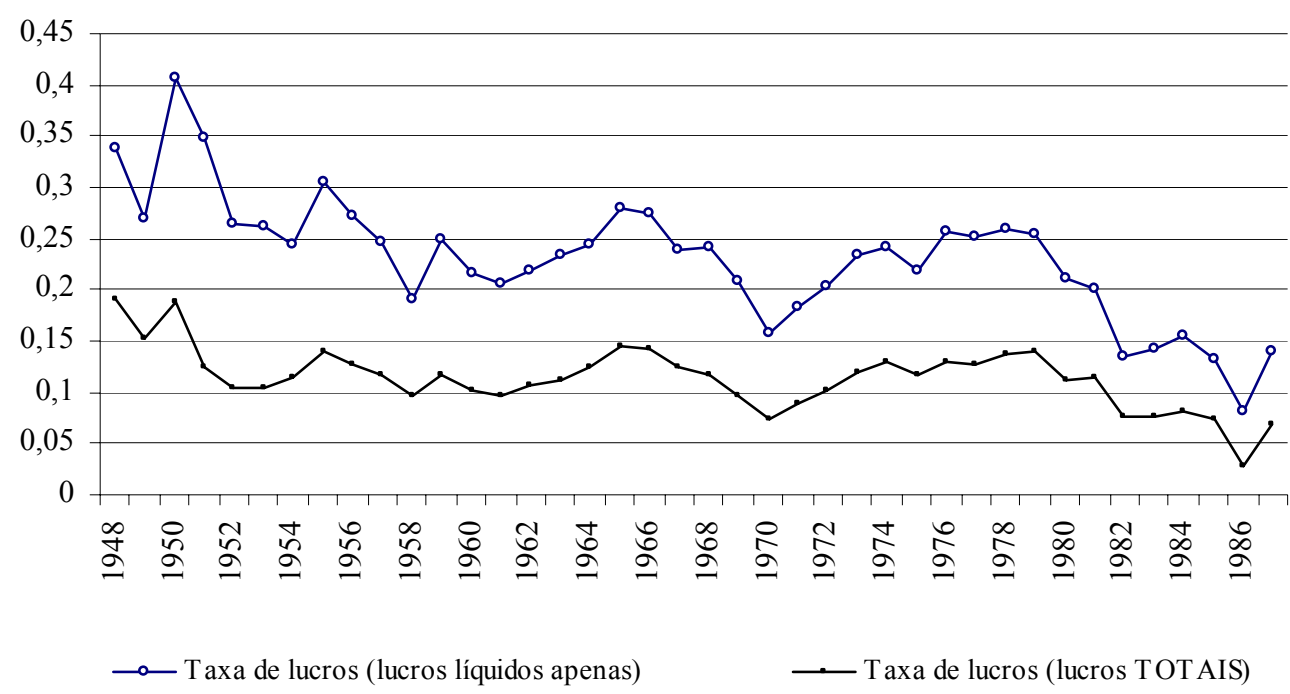

Fontes: Tabela 6.1B, National Income Without Capital Consumption Adjustment by Industry; Tabela 6.19B, Corporate Profits After Tax by Industry; Tabela 6.18B, Taxes on Corporate Income by Industry.

A partir deste método, vê-se que a tendência é de queda consolidada, não obstante as variações cíclicas. Porém, as mesmas ressalvas devem ser ditas: o pós-guerra é período de exceção, com baixos salários. Dos anos (19)50 aos (19)60, há ascensão; há uma forte queda depois de 1966, retomada até 1977, aproximadamente, e mergulho para as mais baixas taxas do pós-guerra, extendendo-se isto até 1987. Este método leva, inclusive, a uma situação ainda mais pessimista do que os anteriores.

O cálculo poderia ser extendido até 2000 etc., assim como poderia ser feito para todos os setores, chegando aos mesmos resultados acima ilustrados.

\subsection{Impactos do petróleo, produtividade e investimento estrangeiro direto}

Tome-se agora a questão referente ao comportamento dos salários e à pressão sobre a taxa de lucro oriunda do encarecimento do preço do petróleo, a partir dos anos (19)70. A revolução tecnológica dos anos (19)70 é uma reação aos aumentos do preço do petróleo. A figura na próxima página corrobora as indicações acima colocadas: nos setores produtivos "nãoagrícolas" (segundo a terminologia do próprio Economic Report of the President), os níveis de variação de produtividade, grandes mas em trajeto cadente, sugerem (i) os ganhos da Terceira Revolução Industrial, mas (ii) uma impossibilidade de obtenção de níveis sempre crescentes para tais ganhos. Quer dizer, aumenta-se de início a taxa de lucro e a taxa de produtividade com emprego de novas técnicas e capital constante mais barato. Uma maior produtividade, que indica capital constante com menores preços e valores, tem variações positivas anuais. 
Porém, como o emprego dos meios produtivos mais eficientes se alastra, a taxa de lucro encontra dificuldade para crescer sem interrupção. De modo que o crescimento da produtividade pela renovação da técnica, como apontou Marx, tem um aspecto contraditório: barateia os elementos do capital constante e aumenta a taxa de lucro inicialmente. Depois, a taxa de lucro tende a crescer menos, e às vezes mesmo cair, à medida que as técnicas se espalham por todos os produtores, eliminando trabalho vivo. Se a produtividade nos próprios setores de bens de produção não continua crescendo (como mostra as variações em trajeto cadente), não serão permitidas novas elevações da taxa de lucro mediante maior barateamento do capital constante, tirante novos rebaixamentos dos salários reais. Essa impossibilidade é sugerida pelo gráfico de variação de taxas de produtividade. ${ }^{97}$

Gráfico 7. Mudanças (\% face ao período anterior) na produtividade, produção e salários reais nos setores não-agrícolas. 1959-1979.

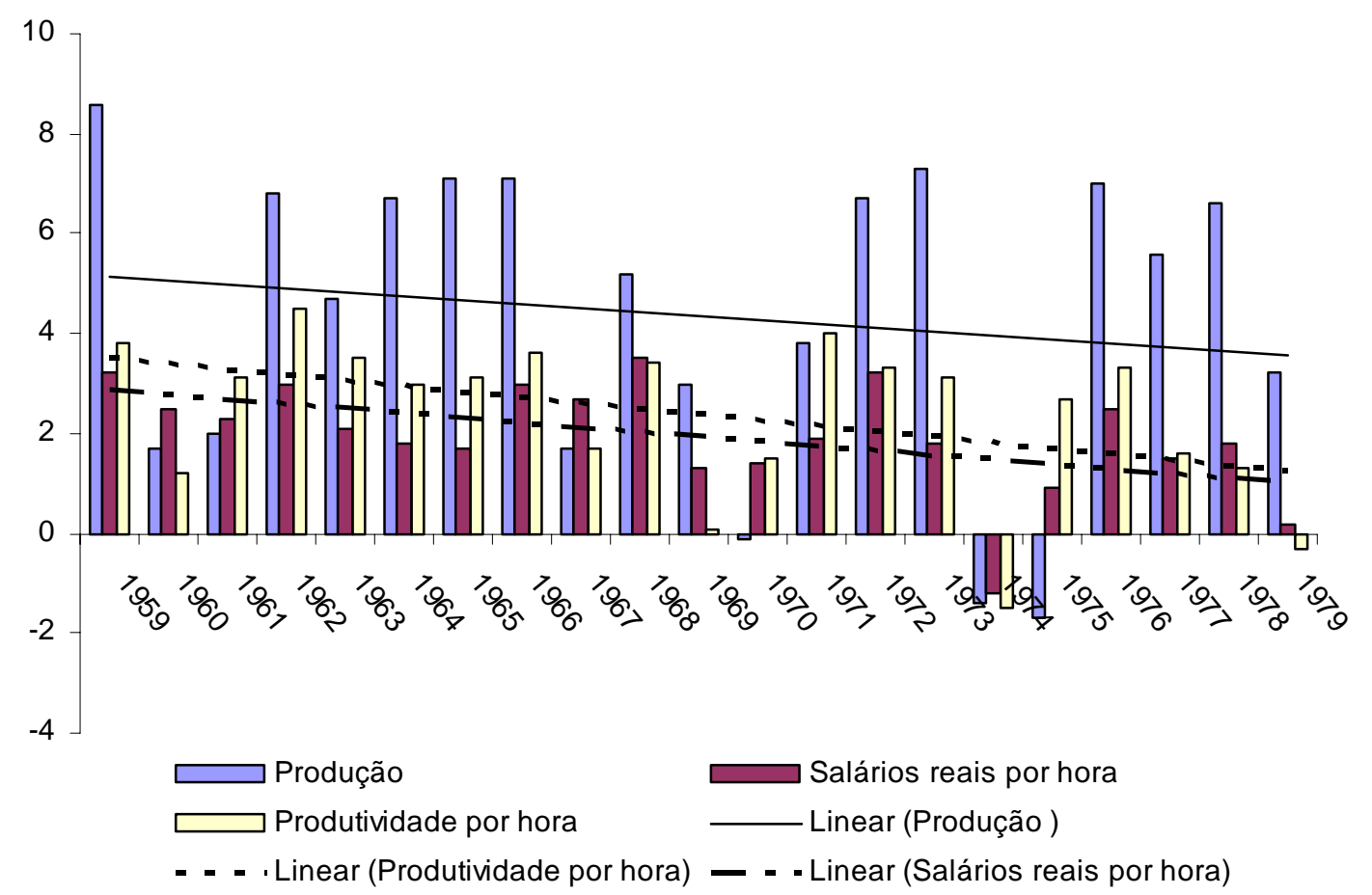

Fonte: Economic Report of the President, 2006, Tabela B-49, Productivity and related data, business sector.

A estagnação dos salários explica melhor porque as taxas de lucro começariam a subir depois de 1987. A variação do valor dos salários também é decrescente ao longo desta década, e continuaria assim até aproximadamente 1994. Para o período referente à década de (19)70, como Brenner ressalta, de fato a variação dos ganhos por hora dos trabalhadores esteve abaixo da variação dos índices de produção e dos níveis de produtividade em todo o período até o início da crise dos (19)70. Portanto, não se pode imputar o comportamento mais instável da economia ao crescimento "excessivo" dos salários.

\footnotetext{
${ }^{97}$ É interessante notar também que o aumento das taxas de lucro nos (19)90 coincide com a entrada da China como grande fabricador de bens de produção no mercado internacional.
} 
Gráfico 8. Estados Unidos. Variações da produção nos setores não-agrícolas e dos salários reais por hora. 1970-2004.

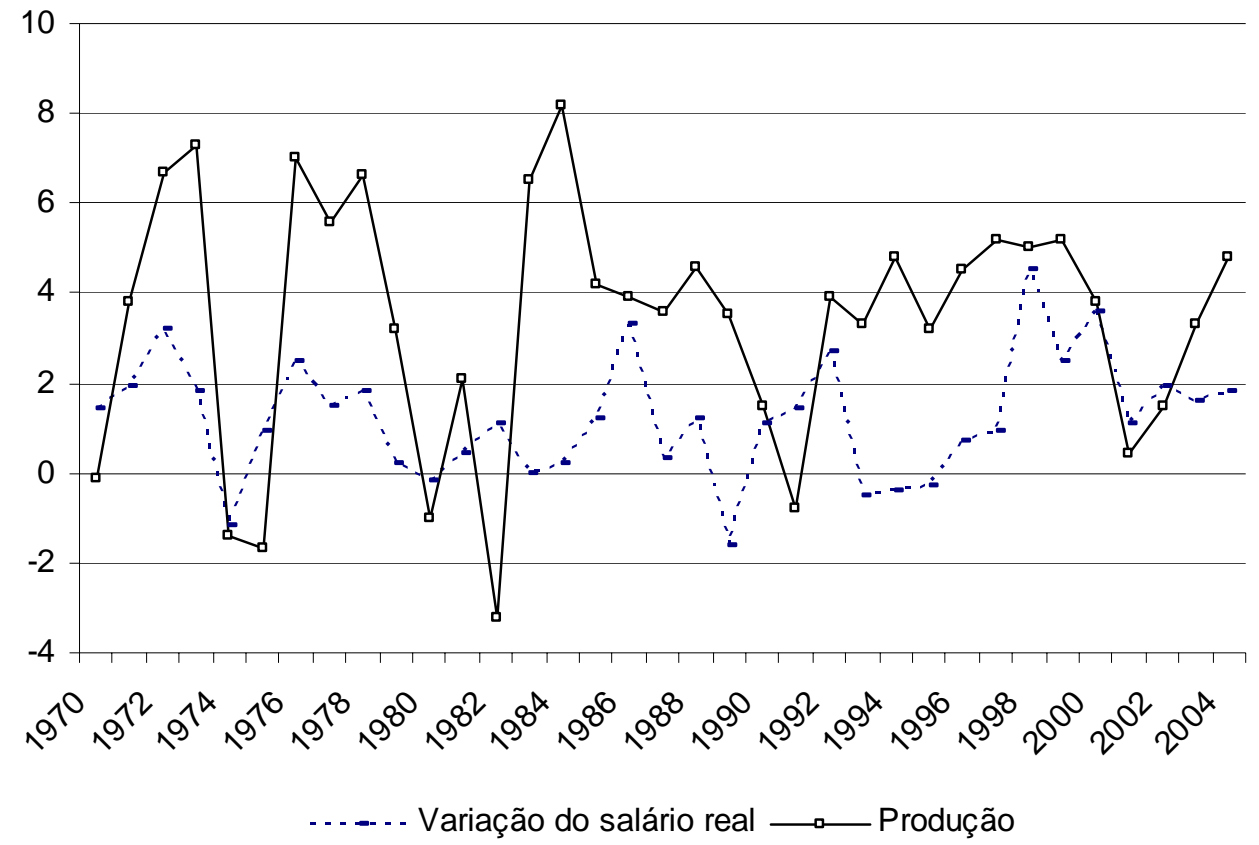

Fonte: Economic Report of the President, 2006, Tabela B-49, Productivity and related data, business sector.

No nível microeconômico, a elevação sustentada das taxas de lucro nos setores manufatureiros depende fundamentalmente da relação capital/trabalho, ainda que no macro a elevação dos salários venha acompanhada do aumento conjunto dos lucros. Como se vê na figura acima, em todas as flutuações da economia a partir dos anos (19)80, as variações da taxa de produção nos setores não-agrícolas, tal como informa o Economic Report of the President de 2008, tem sido bastante intensas, contrariamente às variações do salário real nos setores nãoagrícolas. De fato, mesmo que nas variações negativas do PIB as flutuações da produção sejam mais acentuadas, estas perdas são mais que compensadas pelas ascensões. O comportamento da variação dos salários é bem mais estável e, com exceção do período da ascensão induzido pela "bolha" que explodiu em 2001, tem suas variações bem mais achatadas que os níveis de produção. Em tempo: entre 1970 e 2004, a soma das variações dos níveis de produção chega a $42,5 \%$, enquanto que as dos níveis de produção a $119 \%$.

Dada a estabilidade duradoura vista na relação lucros/salários, é improvável que se possam esperar maiores induções negativas significativas ao poder dos salários reais, o que necessariamente mantém pressão baixista nas taxas de lucro dos setores "reais". O fato de a economia não ter apresentado um crescimento historicamente maior que o verificado antes da década de (19)70, não obstante esta relação ao longo dos últimos trinta anos ter sido bastante favorável às taxas de lucro em detrimento dos salários, mostra que os capitais terão cada vez mais que desenvolver a técnica como meio de elevar a taxa de lucro. Todavia, a taxa de lucro global baixará à medida que tais técnicas se difundirem por todo o sistema. Neste sentido, não 
deixa de ser curioso, apesar de fazer sentido, constatar que no mesmo período em que tenha ocorrido uma grande revolução técnica nos modos de produzir, e que a economia tenha se endividado cada vez no exterior, as taxas de crescimento do PIB no período tenham sido, vistas sob o longo prazo, menores. Tem-se uma economia maior, mais rica e produtiva, com níveis de vida médios maiores, mas que cresce menos.

Gráfico 9. Estados Unidos. Lucros deflacionados (1980) nos setores manufatureiros, de serviços e financeiros. 1971-2001. Em milhões de dólares.

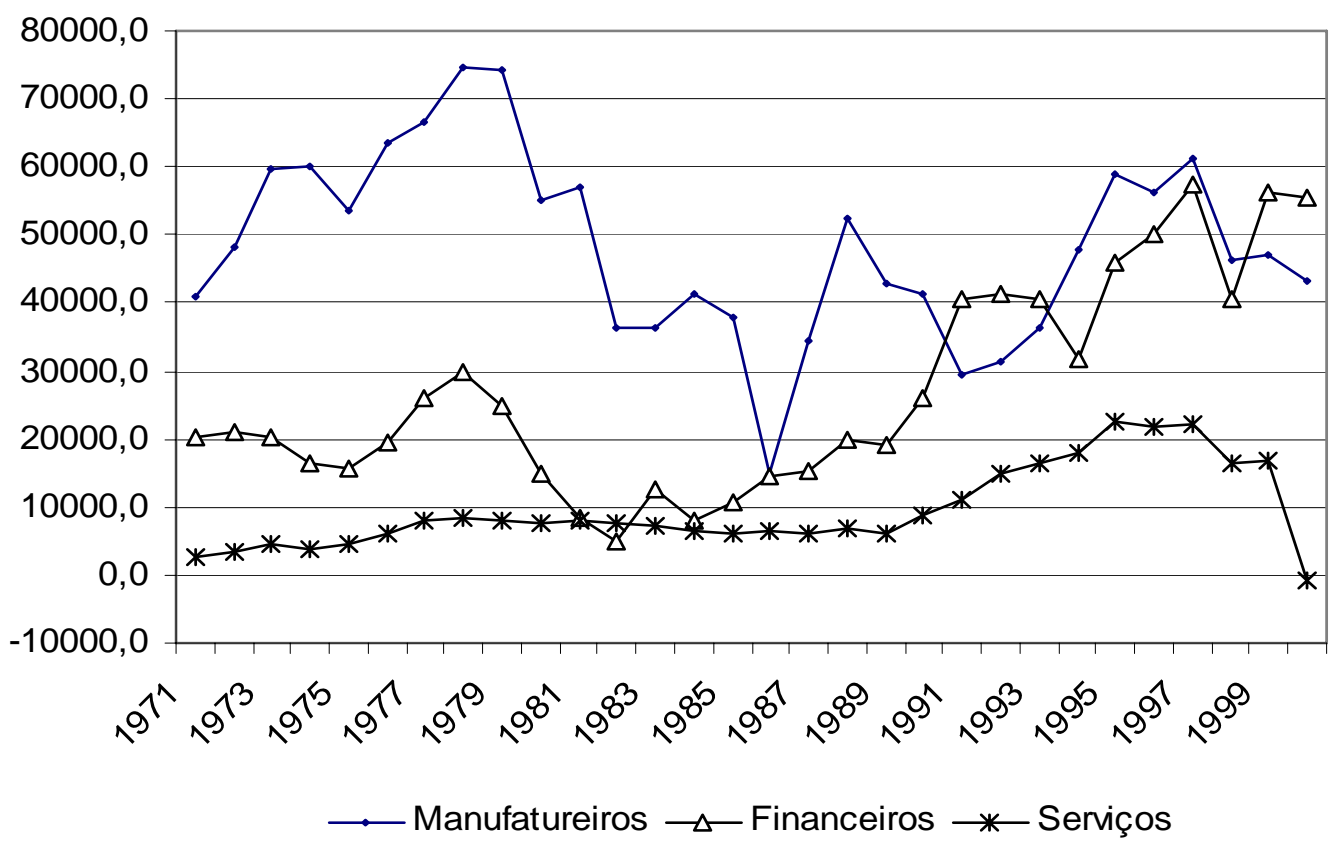

Fonte dos dados deflacionados: NIPA-BEA. Seção 6: Income and Employment by Industry. Tabelas: 6.19: Corporate profits after tax by industry. Fonte do deflator: dados fornecidos pelo calculador automático (inflation calculator) fornecido pelo BLS em seu endereço eletrônico, especificamente no link Consumer Price Index: ver http://www.bls.gov/cpi/ .

Pode-se afirmar que os ganhos corporativos às custas dos salários não permitiram aumentos contínuos da taxa de lucro nos setores industriais, a troco de a economia ter crescido muito mais na situação oposta. O gráfico abaixo, onde se notam as massas de lucro para os três grandes setores da economia, é outra maneira de ver isto. A própria massa dos lucros real caiu ao longo dos anos (19)80 nos manufaturados, e mesmo durante o boom dos anos (19)90 não tinha recuperado ainda o montante atingido antes da crise do petróleo (1974-79). O fato de que os setores financeiros têm tido ganhos continuamente maiores indica a dificuldade das inversões crescentemente lucrativas nos ramos industriais. A economia paira numa situação de "maturidade" onde a taxa de lucro nas indústrias não se eleva mais com facilidade, o que contribui para a diversificação dos investimentos em outros setores, exportação de capital, e crescimento menor.

A enorme quantidade de dados que as Contas Nacionais dos Estados Unidos fornecem permite mais inferências sobre o movimento de queda da taxa de lucro do capital com a crise do petróleo. A elevação dos preços dos elementos do capital constante como um fator a fazer 
cair a taxa de lucro pode ser vista nas tabelas na seqüência. Nela dão-se os aumentos de preços para os artigos consumidos em todos os setores produtivos (aqui incluídos os serviços e a agricultura), divididos por estágio de processamento de tais artigos. (Cada um dos itens pode ocupar o estágio de bem intermediário ou de bem final, dependendo-se do estágio que ocupa no processo produtivo.)

Tabela 4. Estados Unidos. Preços para a produção por níveis de processamento (1982=100); ganhos médios por hora e ganhos semanais médios, em dólares correntes divididos pelo índice de preços ao consumidor para salários urbanos (onde, para o deflator, $1982=1$ ). 1976-1984.

Preços para a produção por nível de processamento $(1982=100)$

\begin{tabular}{|c|c|c|c|c|c|c|}
\hline & \multicolumn{3}{|c|}{ Bens finais } & \multicolumn{3}{|c|}{ Bens intermediários, suprimentos, componentes } \\
\hline & Alimentos & Energia & $\begin{array}{c}\text { Bens de } \\
\text { capital }\end{array}$ & $\begin{array}{c}\text { Alimentos, } \\
\text { sementes }\end{array}$ & Energia & Outros \\
\hline 1976 & 69,6 & 34,3 & 62,1 & 77,4 & 41,5 & 63,8 \\
\hline 1977 & 73,3 & 39,7 & 66,1 & 79,6 & 46,8 & 67,6 \\
\hline 1978 & 79,9 & 42,3 & 71,3 & 84,8 & 49,1 & 72,5 \\
\hline 1979 & 87,3 & 57,1 & 77,5 & 94,5 & 61,1 & 80,7 \\
\hline 1981 & 97,8 & 101,5 & 94,6 & 104,6 & 100,5 & 97,7 \\
\hline 1982 & 100 & 100 & 100 & 100 & 100 & 100 \\
\hline 1983 & 101 & 95,2 & 102,8 & 103,6 & 95,3 & 101,6 \\
\hline 1984 & 105,4 & 91,2 & 105,2 & 105,7 & 95,5 & 104,7 \\
\hline
\end{tabular}

\begin{tabular}{|c|c|c|c|c|c|}
\hline \multicolumn{4}{|c|}{ Materiais brutos, para processamento posterior } & \multicolumn{2}{|c|}{ Salários } \\
\hline & $\begin{array}{l}\text { Derivados de } \\
\text { sementes e } \\
\text { alimentos }\end{array}$ & Energia & Outros & $\begin{array}{c}\text { Ganhos médios } \\
\text { por hora } *\end{array}$ & $\begin{array}{c}\text { Ganhos semanais } \\
\text { médios * }\end{array}$ \\
\hline 1976 & 76,8 & 35,3 & 80,2 & 8,58 & 309,61 \\
\hline 1977 & 77,5 & 40,4 & 79,8 & 8,56 & 310,99 \\
\hline 1978 & 87,3 & 45,2 & 87,8 & 8,67 & 310,41 \\
\hline 1979 & 100 & 54,9 & 106,2 & 8,4 & 298,87 \\
\hline 1980 & 104,6 & 73,1 & 113,1 & 7,99 & 281,27 \\
\hline 1981 & 103,9 & 97,7 & 111,7 & 7,88 & 277,35 \\
\hline 1982 & 100 & 100 & 100 & 7,86 & 272,74 \\
\hline 1983 & 101,8 & 98,7 & 105,3 & 7,95 & 277,51 \\
\hline 1984 & 104,7 & 98 & 111,7 & 7,95 & 279,22 \\
\hline
\end{tabular}

* Em dólares correntes divididos pelo índice de preços ao consumidor para salários urbanos, onde, para o deflator, $1982=100$.

Fonte: Economic Report of the President, 2006, Tabela B-66, Producer price indexes by stage of processing, special groups, 1974-2005 (1982=100).

A partir de 1979, houve um aumento brusco de preços, tantos dos bens finais como intermediários, que não se limitou aos produtos diretamente derivados do petróleo. Os preços dos bens intermediários e brutos de energia elevaram-se nada menos que 20\% entre 1976 e 1979; os bens de capital encareceram 15\% no mesmo período. Os preços se estabilizaram apenas depois de 1983. Por outro lado, os salários, ou os ganhos médios dos trabalhadores no setor privado não-agrícola, caíram fortemente desde 1979.

As variações mais bruscas dão-se nos produtos relacionados ao petróleo e dele derivados. Para o índice de 1982=100, os preços dos bens energéticos sobem a partir de um patamar bem inferior em 1976, na base de $35-40 \%$, ao passo que os preços dos outros bens 
partem de um patamar médio de $65-80 \%$ - o que indica a maior variação dos primeiros. Neste contexto, no momento em que em toda a cadeia produtiva os preços disparavam, os ganhos salariais (gastos com capital variável) estagnaram.

Deu-se assim um aumento das taxas de mais-valia conjugado com uma queda nas taxa de lucro. ${ }^{98}$ Não tivessem os trabalhadores ganhado menos, absolutamente, num período de alta geral dos preços, isto é, se os trabalhadores tivessem logrado manter os salários constantes, a taxa de lucro teria caído ainda mais em muitos ramos. Como as elevações de preço foram gerais, e geradas exogenamente à economia, todos capitais foram atingidos, o que impediu que uns ganhassem à custa dos outros mediante aumentos indiscriminados em seus preços de produção. Os custos foram repassados aos setores menos oligopolizados e aos trabalhadores, que não tinham a quem repassar o aumento de custos. Os setores cujos bens intermediários foram mais dependentes dos insumos derivados diretamente do petróleo também foram necessariamente mais afetados, estando em situação oposta aos fabricantes de petróleo e combustíveis.

Na tabela abaixo, que separa os preços dos artigos consumidos na produção por setores industriais, percebe-se do mesmo modo que foram os derivados do petróleo que irradiaram o choque para o resto da economia, pois apresentaram as maiores variações. Vê-se que estes setores são principalmente os de combustíveis, cuja alta foi mais rápida, mas cuja estabilização também o foi. Os impactos da elevação permaneceram, no entanto, por mais tempo nos outros setores.

\footnotetext{
98 "Uma queda na taxa de lucro não expressa uma queda da taxa de mais-valia, a não ser que a proporção do valor do capital constante face à quantidade de força de trabalho que o põe em funcionamento permaneça inalterada ou que a quantidade de força de trabalho cresça em relação ao valor do capital constante." MARX, Karl. Capital, V.III, p.236. Veja um exemplo hipotético: a mais-valia poderia cair de 100 para 90, enquanto o capital variável permaneceria sendo, por exemplo, 80, e o capital variável, também 80 . Neste caso, $100 \mathrm{mv} / 80 \mathrm{cc}+80 \mathrm{cv}>90 \mathrm{mv} / 80 \mathrm{cc}+80 \mathrm{cv}$, e $100 \mathrm{mv} / 80 \mathrm{cv}>90 \mathrm{mv} / 80 \mathrm{cv}$. Cairiam as taxas de lucro e mais-valia, permanecendo o capital constante o mesmo. E, na segunda condição: crescimento do trabalho empregado em capital variável de 80 para 90 , mantendo-se uma mais-valia de 100. Neste caso, cai a taxa de lucro $-100 \mathrm{mv} / 80 \mathrm{cc}+80 \mathrm{cv}>100 / 80 \mathrm{cc}+90 \mathrm{cv}$ - e cai a taxa de mais-valia: $100 \mathrm{mv} / 80 \mathrm{cv}>100 \mathrm{mv} / 90 \mathrm{cv}$.
} 
Tabela 5. Preços para a produção por setor industrial em setores selecionados. $1982=100$. 1976-1984.

Preços para a produção por setor industrial $(1982=100)$

\begin{tabular}{|c|c|c|c|c|c|c|}
\hline & Alimentos & Têxteis & Peles, couro & Combustíveis & Químicos & Farmacêuticos \\
\hline 1976 & 70,8 & 72,4 & 63,9 & 38,3 & 64 & 78,8 \\
\hline 1977 & 74 & 75,3 & 68,3 & 43,6 & 65,9 & 79,4 \\
\hline 1978 & 80,6 & 78,1 & 76,1 & 46,5 & 68 & 87,7 \\
\hline 1979 & 88,5 & 82,5 & 96,1 & 58,9 & 76 & 99,6 \\
\hline 1980 & 95,9 & 89,7 & 94,7 & 82,8 & 89 & 102,9 \\
\hline 1981 & 98,9 & 97,6 & 99,3 & 100,2 & 98,4 & 105,2 \\
\hline 1982 & 100 & 100 & 100 & 100 & 100 & 100 \\
\hline 1983 & 101,8 & 100,3 & 103,2 & 95,9 & 100,3 & 102,4 \\
\hline \multirow[t]{2}{*}{1984} & 105,4 & 102,7 & 109 & 94,8 & 102,9 & 105,5 \\
\hline & $\begin{array}{l}\text { Borracha, } \\
\text { plásticos }\end{array}$ & Madeiras & Papéis & Metais & $\begin{array}{l}\text { Maquinaria, } \\
\text { equipamentos }\end{array}$ & Mobília \\
\hline 1976 & 66 & 72,2 & 62,1 & 65 & 61,3 & 70,3 \\
\hline 1977 & 69,4 & 83 & 64,6 & 69,3 & 65,2 & 73,2 \\
\hline 1978 & 72,4 & 96,9 & 67,7 & 75,3 & 70,3 & 77,5 \\
\hline 1979 & 80,5 & 105,5 & 75,9 & 86 & 76,7 & 82,8 \\
\hline 1980 & 90,1 & 101,5 & 86,3 & 95 & 86 & 90,7 \\
\hline 1981 & 96,4 & 102,8 & 94,8 & 99,6 & 94,4 & 95,9 \\
\hline 1982 & 100 & 100 & 100 & 100 & 100 & 100 \\
\hline 1983 & 100,8 & 107,9 & 103,3 & 101,8 & 102,7 & 103,4 \\
\hline 1984 & 102,3 & 108 & 110,3 & 104,8 & 105,1 & 105,7 \\
\hline
\end{tabular}

Fonte: Economic Report of the President, 2006, Tabela B-66, Producer price indexes by stage of processing, special groups, 1974-2005 (1982=100).

Assim, como sugere Shaikh, o que provocou nos Estados Unidos a tendência para a queda da taxa de lucro em muitos setores industriais foi o crescimento da composição orgânica do capital, e não a "saturação" do excesso de capital, das "oportunidades de investimento", ou o “crescimento excessivo dos salários", na visão mística dos liberais. Na verdade, este debate remete às diferentes perspectivas de Smith e de Marx sobre a tendência de os lucros caírem. A migração do capital produtivo se dá para áreas onde a taxa de lucro seja maior. Daí que a tendência do movimento do capital, de superação constante das barreiras à continuidade da acumulação lucrativa, é amortecida pela "contra-tendência" do capital de migrar em escala geográfica.

Quer dizer: (a) quanto mais oportunidades de inversão lucrativa no exterior, (b) menores as tendências para que o capital em escala doméstica supere suas dificuldades, atingido um determinado estágio da acumulação. A superação da queda implica na própria queda da acumulação do capital produtivo nas áreas onde a taxa de lucro se apresenta menor. As áreas de acumulação mais antiga têm de prosseguir, assim, num ritmo mais lento; elas aparecem, como na visão de Smith, como áreas onde há “oferta excessiva de capital”. Deste modo, a exportação de capital deixa de ser um traço de um país de crescimento rápido que forma muito capital onde as taxas de lucro são muito altas - para tornar-se um indício de que o capital produtivo pode ser aplicado de modo mais rentável agora no exterior; um indício que a taxa de lucro baixou e não é mais tão compensadora. 
Gráfico 10. Estados Unidos. Investimento Direto Estrangeiro dos Estados Unidos no exterior e Investimento Estrangeiro Direto (IED) do exterior nos Estados Unidos. 1980-2000. Em bilhões de dólares correntes.

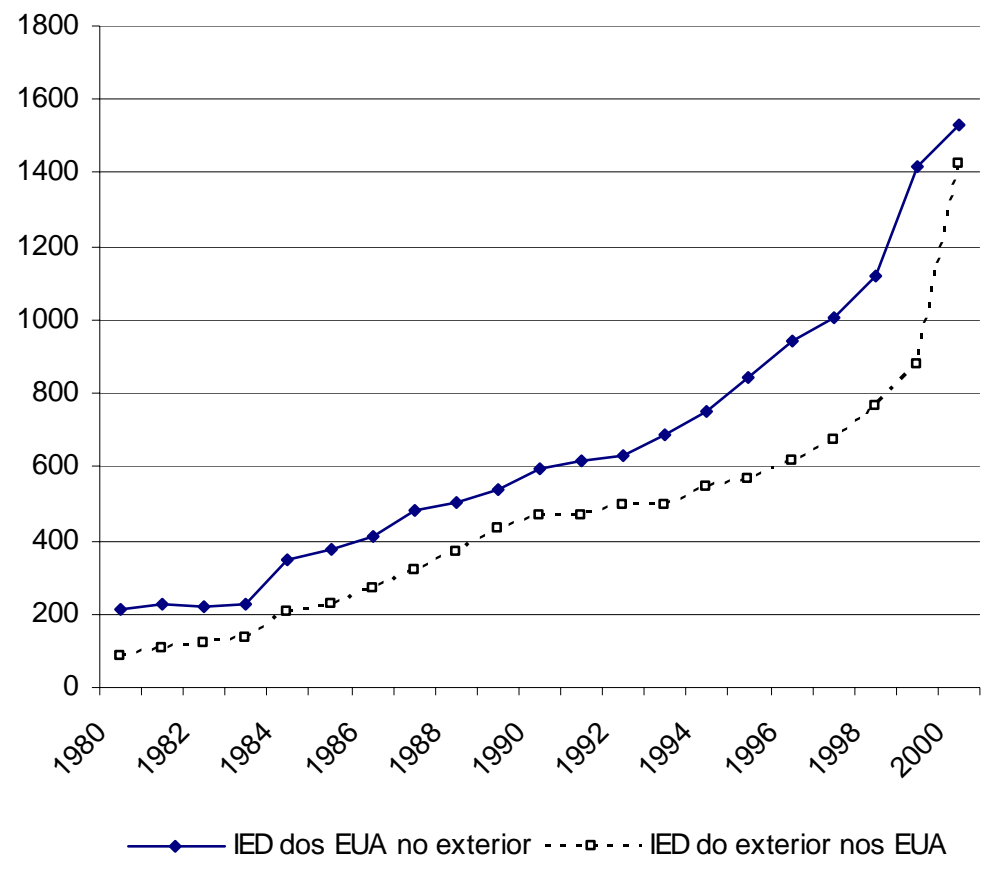

Fonte: Economic Report of the President, Tabela B-107, International investment position of the United States at year-end, 1997-2004, vários números.

Neste sentido, a comparação dos gráficos acima e abaixo (investimento direto e formação de capital fixo) é interessante: em primeiro lugar, porque se vê que a exportação de capital dos Estados Unidos para o exterior é sempre maior que sua importação de investimento estrangeiro direto. Em segundo lugar, porque o investimento em capital fixo tem tendência decrescente nos Estados Unidos, e em proporção do produto interno bruto esteve bem abaixo das taxas de Japão e Alemanha ao longo do período. Tal evidencia que a grande parte dos investimentos diretos do exterior na economia norte-americana não tem sido de caráter produtivo. Por sua vez, a similar queda da formação bruta de capital nestas duas outras nações industriais mostra que ambas também conheceram um declínio de suas taxas de acumulação produtiva, não estando assim livres da tendência presente nos Estados Unidos. ${ }^{99}$

Porém, suas diferentes inserções externas, mediante o papel de suas moedas face ao dólar, tenderam a fazer com que lidassem com tal declínio de modo diferente. Exportando seus saldos comerciais aos Estados Unidos e acumulando papéis denominados em dólar, permitiram a este um maior volume de consumo, diminuindo as suas próprias, mas mantiveram uma maior presença de seus parques manufatureiros na renda nacional, estruturados em torno da exportação. $\mathrm{O}$ acúmulo de papéis em dólar tinha então o papel de reforçar a posição

\footnotetext{
${ }^{99}$ Pois, como assinalaram Eatwell e Taylor, se "as tendências de crescimento e emprego no longo prazo mostram uma quebra clara em meados de $1970 \mathrm{em}$ todos os países industriais [isto] indica que as causas do baixo crescimento e alto desemprego dos últimos vinte e cinco anos devem ser buscadas em fatores que incidam em todos os países de maneira similar, e não em circunstâncias individuais a cada país". Finanzas globales en riesgo, p.123-124.
} 
desvalorizada de suas moedas para assegurar as posições vantajosas de suas exportações no mercado externo.

Gráfico 11. Países selecionados. Investimentos em formação de capital fixo, em porcentagem do PIB. 1970-2004.

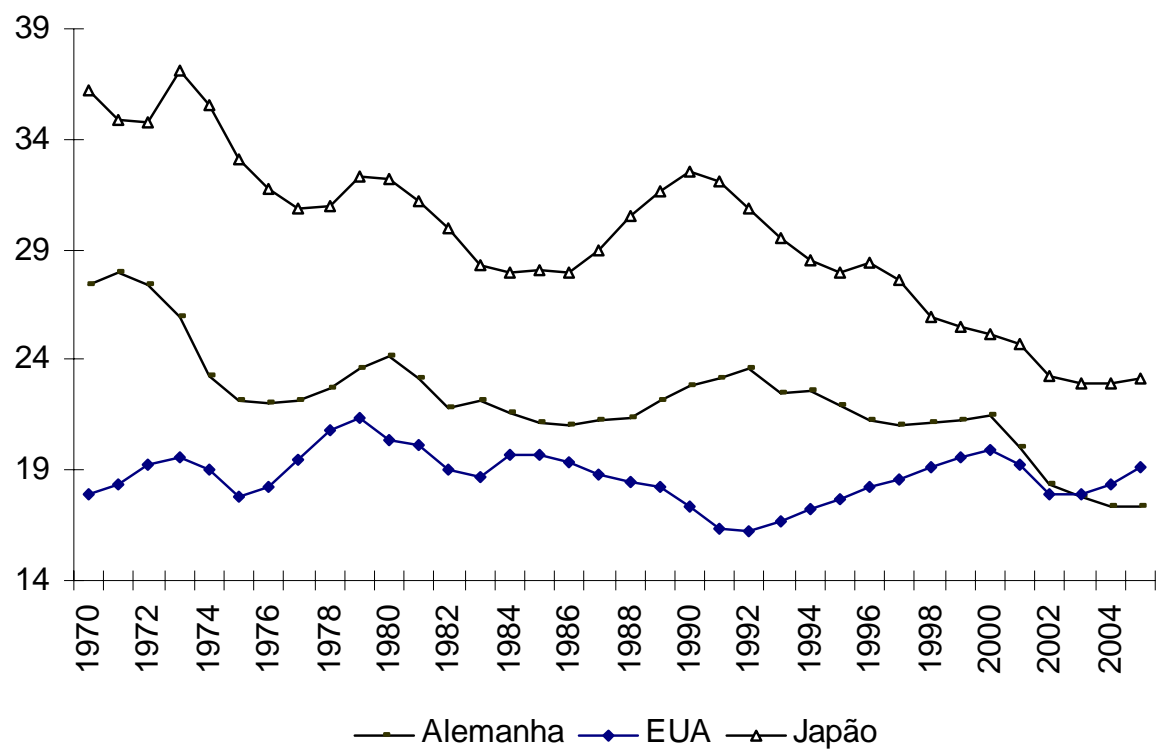

Fonte: OCDE. (Ver http://stats.oecd.org)

Todavia, mesmo mantendo seus parques industriais no eixo mais seguro das exportações, Japão e Alemanha não tiveram como evitar de todo a tendência para a queda da acumulação produtiva, que é geral dentro das economias de industrialização mais antiga. Ela só se expressa de modo diferente face aos Estados Unidos devido à própria posição da moeda e do sistema financeiro deste país na economia mundial. Para os Estados Unidos, o aumento do passivo externo indica que os países industriais deixaram de investir e consumir seus recursos, em troca do aumento de seus recursos contra os Estados Unidos. Poder-se-ia dizer que é o aumento líquido do passivo externo norte-americano que expressa o modo diferencial como o país enfrentou a crise dos anos (19)70 e (19)80, contrariamente a Japão e Alemanha.

Logo, o capital produtivo em escala doméstica fica estagnado não porque há um impedimento absoluto à sua auto-expansão, mas sim porque ele pode deslocar-se territorialmente, para áreas onde a tendência à queda dos lucros se mostre menos vigorosa. No âmbito doméstico, todavia, as flutuações econômicas devem ser explicadas com base seja nas oscilações da taxa de lucro, seja nas oscilações do poder de compra, seja nos impactos das políticas do governo. Para os Estados Unidos, é pela necessidade de impedir a estagnação provocada pela tendência para a queda dos lucros que ocorre o endividamento externo, ou a atração de recursos estrangeiros para a economia. O gráfico acima deixa perceber ainda um crescimento do capital fixo para os Estados Unidos durante o período de crescimento entre 1993-2000, ao passo que para o Japão a tendência é de permanente queda - explicada, em parte, pela transferência de investimentos para a China. 


\subsection{Destinos da poupança internacional}

Deve-se fazer uma menção aos países que mais têm fornecido poupança aos Estados Unidos. As tabelas abaixo mostram as poupanças domésticas, e os investimentos, de Estados Unidos, Alemanha, Japão, Rússia e países industrializados da Ásia (China, Coreia do Sul, Taiwan, Cingapura e outros) nos anos (19)80 e (19)90. Abordam também países do Oriente Médio (Irã, Bahrein, Iraque, Kwait, Líbia, Qatar, Arábia Saudita, Emirados Árabes e Iêmen). Os Estados Unidos mostram-se os grandes tomadores de empréstimos líquidos, enquanto estes outros países são emprestadores líquidos.

Em porcentagem do produto, a Rússia é a que maior formação de poupança apresenta, intensificada nos últimos anos pelos aumentos recentes do preço do petróleo, um item central de suas exportações. Os Novos Países Industrializados da Ásia também são emprestadores líquidos, com média de 5\% de seu PIB colocado no exterior. As médias de Japão e Alemanha são menores, refletindo seus enormes produtos internos brutos. Estas porcentagens menores são maiores absolutamente, no entanto, que o valor das porcentagens de outros países. Porém, em termos relativos, são os países do Oriente Médio os grandes colocadores de capital no exterior, em direção preponderante aos Estados Unidos. Nas tabelas, percebe-se a altíssima taxa de formação de poupança destas nações exportadoras de petróleo, e como estas poupanças tornamse empréstimos no sistema financeiro internacional.

Veja-se, a título de ilustração, os dados sobre poupança mundial para o ano de 2005, com base nos registros da OCDE, partir das tabelas a seguir.

Tabela 6. Poupança, investimento e empréstimos líquidos. Países selecionados. Em \% do Produto nacional Bruto (Gross Domestic Product). 1984-2007.

$\begin{array}{lrrrrrr}\text { EUA } & 1984-91 & 1992-99 & 2000 & 2001 & 2002 & 2003 \\ \text { Poupança } & 17,3 & 16,4 & 18 & 16,4 & 14,2 & 13,3 \\ \text { Investimento } & 19,9 & 19 & 20,8 & 19,1 & 18,4 & 18,4 \\ \text { Empréstimos } & -2,6 & -2,6 & -2,7 & -2,8 & -4,2 & -5,1 \\ \text { Líquidos } & & & & & & \\ & 2004 & 2005 & 2006 & 2007 & 2008-11 & \\ \text { Poupança } & 13,2 & 12,9 & 13,7 & 13,5 & 13,9 & \\ \text { Investimento } & 19,3 & 19,7 & 20,2 & 20,4 & 20,8 & \\ \text { Empréstimos } & -6,1 & -6,8 & -6,6 & -6,9 & -6,8 & \\ \text { Líquidos } & & & & & & \end{array}$


[Continuação]

\begin{tabular}{|c|c|c|c|c|c|c|}
\hline Alemanha & 1984-91 & 1992-99 & 2000 & 2001 & 2002 & 2003 \\
\hline Poupança & 24 & 21 & 20,1 & 19,5 & 19,3 & 19,3 \\
\hline Investimento & 21,2 & 21,9 & 21,8 & 19,5 & 17,3 & 17,4 \\
\hline Empréstimos & 2,8 & -1 & $-1,7$ & - & 2 & 1,9 \\
\hline \multicolumn{7}{|l|}{ Líquidos } \\
\hline & 2004 & 2005 & 2006 & 2007 & $2008-11$ & \\
\hline Poupança & 20,9 & 21,3 & 21,6 & 21,8 & 21,9 & \\
\hline Investimento & 17,1 & 17,1 & 17,4 & 17,8 & 18,6 & \\
\hline Empréstimos & 3,7 & 4,1 & 4,2 & 4 & 3,4 & \\
\hline \multicolumn{7}{|l|}{ Líquidos } \\
\hline Japão & 1984-91 & 1992-99 & 2000 & 2001 & 2002 & 2003 \\
\hline Poupança & 33,3 & 30,7 & 27,8 & 26,9 & 25,9 & 26,2 \\
\hline Investimento & 30,5 & 28,2 & 25,2 & 24,8 & 23 & 23 \\
\hline Empréstimos & 2,8 & 2,5 & 2,6 & 2,1 & 2,9 & 3,2 \\
\hline \multicolumn{7}{|l|}{ Líquidos } \\
\hline & 2004 & 2005 & 2006 & 2007 & 2008-11 & \\
\hline Poupança & 26,4 & 26,9 & 27,6 & 27,8 & 27,7 & \\
\hline \multicolumn{7}{|l|}{ Investiment } \\
\hline $\mathrm{O}$ & 22,7 & 23,2 & 23,9 & 24,3 & 24,6 & \\
\hline \multicolumn{7}{|l|}{ Empréstimo } \\
\hline S & 3,7 & 3,6 & 3,7 & 3,5 & 3,2 & \\
\hline
\end{tabular}

Fonte: World Economic Outlook. OCDE. Statistical Appendix, 2006, Tabela 43, Summary of sources and uses of world saving. Os dados referentes aos anos entre 1984-1991 são médias calculadas pela OCDE. 

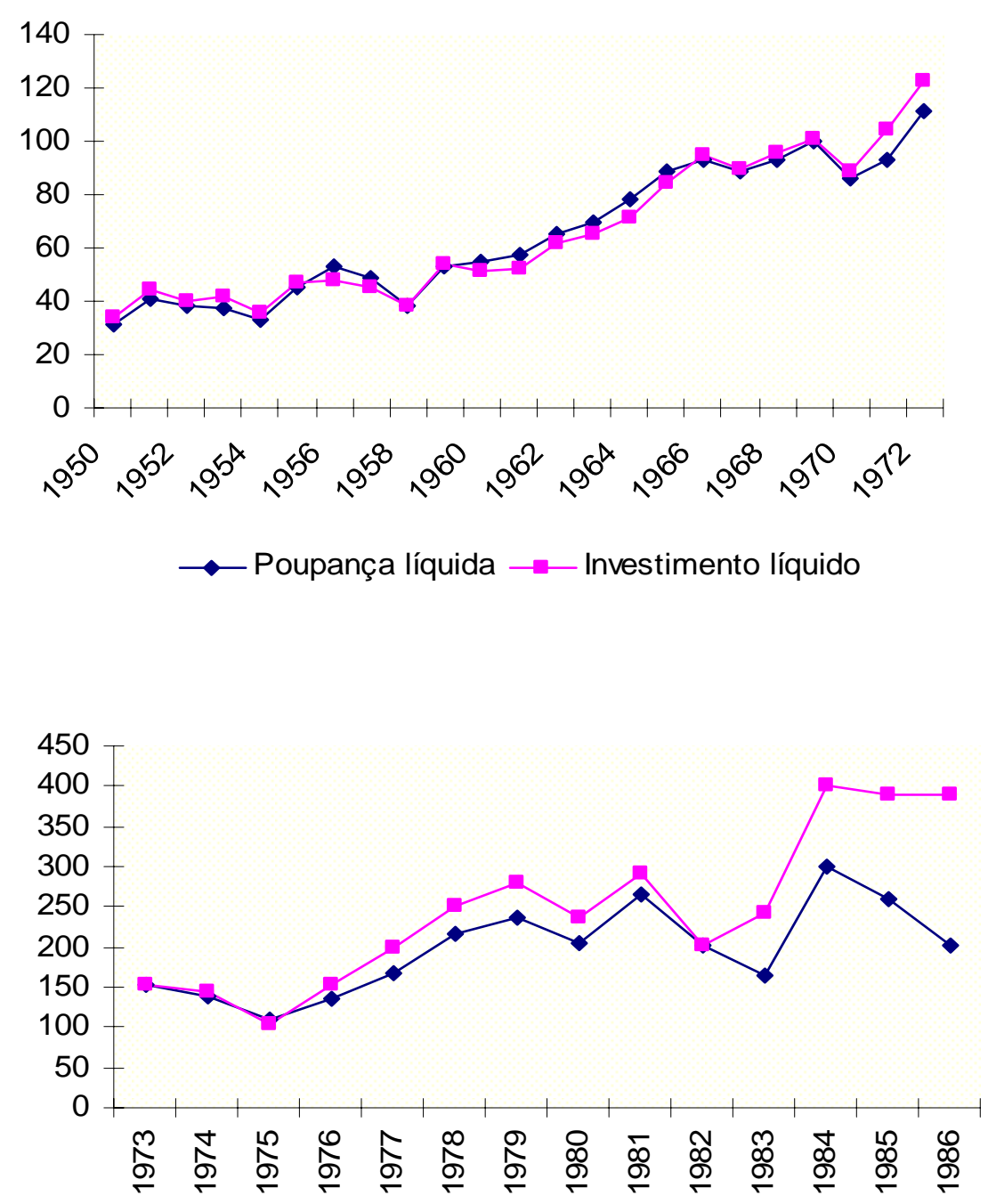

$\longrightarrow$ - Poupança líquida $\longrightarrow$ Investimento líquido

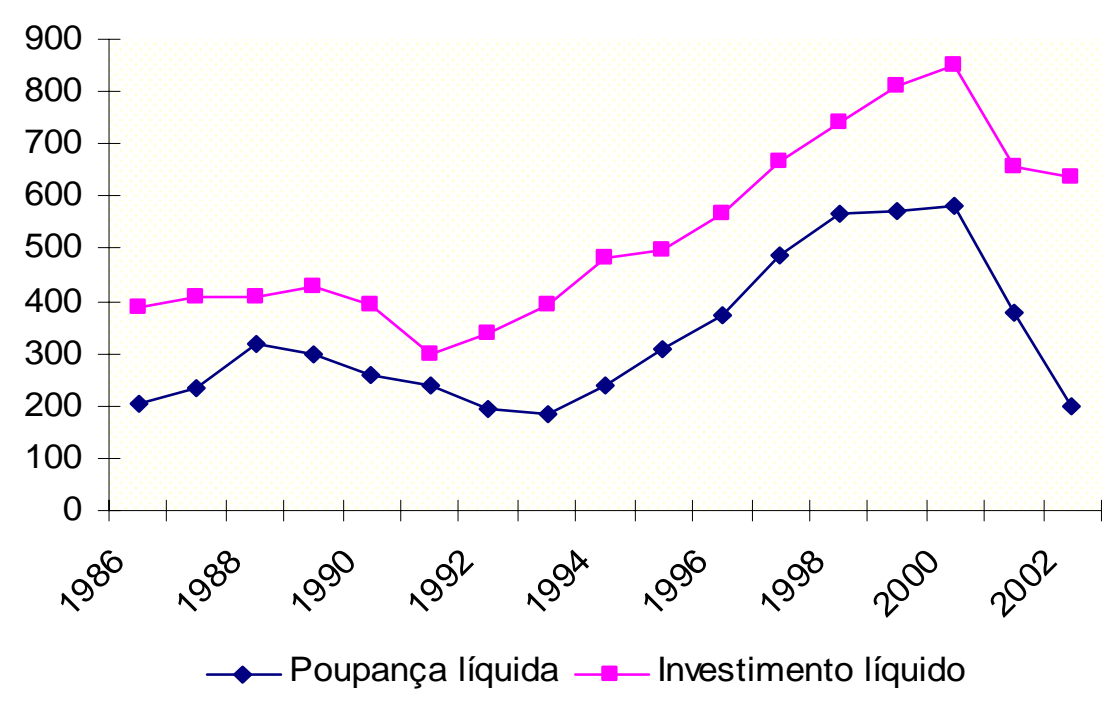


Tabela 7. Poupança e investimentos, e empréstimos líquidos. Grupos de países selecionados. Em \% do Produto nacional Bruto (Gross Domestic Product). 1984-2007.

\begin{tabular}{|c|c|c|c|c|c|c|}
\hline N.P.I. da Ásia & 1984-91 & 1992-99 & 2000 & 2001 & 2002 & 2003 \\
\hline Poupança & 35,1 & 33,8 & 31,9 & 29,9 & 29,6 & 31,4 \\
\hline Investimento & 28,7 & 31,1 & 28,4 & 25,3 & 24,6 & 24,5 \\
\hline Empréstimos & 6,4 & 2,7 & 3,5 & 4,6 & 5,1 & 6,9 \\
\hline \multicolumn{7}{|l|}{ Líquidos } \\
\hline & 2004 & 2005 & 2006 & 200720 & $8-11$ & \\
\hline Poupança & 33 & 31,8 & 30,6 & 30,6 & 30,6 & \\
\hline Investimento & 26,1 & 25,6 & 25,6 & 25,7 & 26,1 & \\
\hline Empréstimos & 7 & 6,2 & 5 & 4,9 & 4,5 & \\
\hline \multicolumn{7}{|l|}{ Líquidos } \\
\hline Rússia & 1984-91 & 1992-99 & 2000 & 2001 & 2002 & 2003 \\
\hline Poupança & - & 23,5 & 31,9 & 29,4 & 26,3 & 27,1 \\
\hline Investimento & - & 22,4 & 17,9 & 21,1 & 19,8 & 20,9 \\
\hline Empréstimos & - & 1,1 & 14 & 8,3 & 6,6 & 6,2 \\
\hline \multicolumn{7}{|l|}{ Líquidos } \\
\hline & 2004 & 2005 & 2006 & 2007 & 2008-11 & \\
\hline Poupança & 28,7 & 29,5 & 30,4 & 30 & 28,5 & \\
\hline Investimento & 21,1 & 20,9 & 20,5 & 20,8 & 22,5 & \\
\hline Empréstimos & 7,7 & 8,6 & 9,9 & 9,2 & 6 & \\
\hline \multicolumn{7}{|l|}{ Líquidos } \\
\hline Oriente Médio & 1984-91 & 1992-99 & 2000 & 2001 & 2002 & 2003 \\
\hline Poupança & 16,7 & 22,8 & 29,4 & 26,3 & 25,7 & 29,2 \\
\hline Investimento & 22,8 & 23,5 & 20 & 21,9 & 23,2 & 23,1 \\
\hline Empréstimos & $-6,1$ & 0,07 & 9,4 & 4,4 & 2,5 & 6,1 \\
\hline \multicolumn{7}{|l|}{ Líquidos } \\
\hline & 2004 & 2005 & 2006 & 2007 & $008-11$ & \\
\hline Poupança & 33,2 & 40,6 & 45,1 & 44,6 & 41,1 & \\
\hline Investimento & 22,5 & 22,5 & 23,1 & 23,6 & 25,6 & \\
\hline Empréstimos & 10,7 & 18,1 & 22 & 21 & 15,5 & \\
\hline
\end{tabular}

Fonte: World Economic Outlook. OCDE. Statistical Appendix. 2006, Tabela 43, Summary of sources and uses of world saving. Os dados referentes aos anos entre 1984-1991 são médias calculadas pela OCDE.

Em 2005, os Estados Unidos tinham um produto nacional bruto de aproximadamente $20 \%$ do produto total mundial (de acordo com Apêndice Estatístico da OCDE que se utiliza aqui). Este PIB era, em dólares, 12 trilhões e 455 bilhões de dólares, em valores aproximados. $\mathrm{O}$ "produto bruto mundial", a partir disto, pode ser estimado em 62 trilhões e 275 bilhões; a Alemanha detinha 4,1\% dele, ou, de acordo com este cálculo, 2 trilhões e 553 bilhões de dólares, e o Japão, 3 trilhões e 985 bilhões $(6,4 \%$ do produto mundial vezes o produto mundial total, ou 0,064 x 62.275 trilhões). Por sua vez, o Oriente Médio, com 2,8\% do produto mundial, apresentou em 2005 um produto estimado em 1 trilhão e 743 bilhões, e a Rússia, 3,8\% do PIB mundial. Logo, seu produto pode ser estimado em 2 trilhões e 366 bilhões. Por fim, os Novos 
Países Industrializados da Ásia tinham 3,2\% do produto mundial; logo, formando 1 trilhão e 992 bilhões de dólares. Os empréstimos líquidos, sobre o PIB do grupo de países selecionados, em 2005, e os empréstimos tomados pelos Estados Unidos, podem ser assim calculados: (a) Novos Países Industrializados da Ásia: 3,2\% de 1.992 bilhões: 63,7 bilhões de dólares, em média; (b) Oriente Médio: 18,1\% de 1.743 bilhões: 313 bilhões de dólares de empréstimos líquidos; (c) Rússia: 8,6\% de 2.366 bilhões: 203 bilhões de dólares de empréstimos líquidos; (d) Japão: 3,6\% de 3.985 bilhões: 144 bilhões de dólares de empréstimos líquidos; (e) Alemanha: 4,1\% de 2 trilhões e 553 bilhões: 105 bilhões de empréstimos líquidos; (f) Estados Unidos: 6,8\% de 12.455 bilhões de dólares: 846 bilhões de dólares emprestados do exterior, aproximadamente. As tabelas com os respectivos recursos emprestados e tomados estão na seqüência, divididos por países desenvolvidos e subdesenvolvidos:

Quando somadas as quantidades emprestadas de todos os países acima, com exceção dos EUA, que são tomadores líquidos, obtêm-se os seguintes valores, para o citado ano de 2005: 64 bilhões (Novos Países Industrializados da Ásia) + 313 bilhões (Oriente Médio) + 203 bilhões (Rússia) +144 bilhões (Japão) +105 bilhões (Alemanha). Soma esta que vai a 829 bilhões de dólares, aproximadamente a quantia emprestada pelos Estados Unidos. (O número emprestado pelos Estados Unidos é um pouco maior porque não se contaram alguns empréstimos menores, tomados de outros países periféricos e outros países industrializados.)

Portanto, na medida em que a importação líquida de capital nos Estados Unidos é usada para financiar seja parte do consumo das famílias, seja parte dos gastos do Estado, seja parte dos investimentos das firmas, a análise histórica de longo prazo de Arrighi pode ser interpretada como não contraditória face à importação líquida de capital pelos Estados Unidos. Ainda que a fundamentação teórica de Arrighi seja discrepante com aquela que se mostra aqui, as conclusões convergem para um mesmo diagnóstico: a queda da acumulação produtiva nos Estados Unidos.

\subsection{Preços relativos e importações}

Como se argumenta neste estudo, os desfavorecimentos ao crescimento do setor produtivo norte-americano, e em especial o manufatureiro, não se atribuem somente à tendência para a queda relativa de suas taxa de lucros, que desfavorecem aos poucos o aumento de inversões neste setor, mas sim também ao (i) comportamento dos preços relativos e (2) ao aumento dos déficits comerciais norte-americanos em forma de bens transáveis. Começando por (i), o barateamento dos preços das mercadorias industrializadas reflete os custos crescentemente menores de fabricação na manufatura e um aumento dos gastos das famílias com serviços. Este processo é estrutural e se dá quase independentemente da política econômica. Ele pode ser freado mas não barrado de todo pelo aumento do grau de monopólio. Mas mesmo a 
monopolização da economia não pode impedi-lo de todo. ${ }^{100}$ Em segundo lugar, o aumento relativo dos déficits comerciais em forma de bens tangíveis pressiona ainda mais a produção doméstica. Ambos fatores culminam numa pressão sobre os setores produtores de bens manufaturados e desestimulam grandes expansões do produto interno bruto, pondo peso adicional sobre as desvantagens para a taxa de lucros do setor industrial norte-americano.

A contrapartida de uma maior utilização do capital fixo nos setores produtivos é uma menor taxa de lucro tendencial ao longo do tempo para estes setores. Isto é, a queda tendencial da taxa de lucro denota um aumento do capital constante face ao variável nos setores produtivos, face aos setores não produtivos. E a expressão nos preços das mercadorias do aumento relativo do componente capital fixo na produção é um maior barateamento ao longo do tempo, contrariamente aos setores onde o trabalho vivo não pode ser substituído tão facilmente. Quanto menor o componente de trabalho vivo ao longo do tempo, mais produtiva é a produção, e por conseqüência mais barato será produzir. Para os setores onde a composição orgânica não cresce tão rapidamente, a queda dos preços não se dá de modo tão rápido.

Qual a importância disto no que toca à relação entre preços e pauta de demanda das famílias? A importância refere-se ao fato de que o comportamento da estrutura de preços relativos conduz a uma menor demanda relativa das famílias face aos bens produzidos pelo setor produtivo sobre a economia. A maior produtividade reflete-se num primeiro momento num aumento do volume de vendas e mercadorias realizadas; mas num segundo, leva a uma modificação da pauta de consumo, em favor dos serviços e em detrimento dos bens industriais.

Tais expressões dos custos sobre os preços podem ser verificadas a partir das variações setoriais de preços fornecidas pelas Contas Nacionais norte-americanas. Através delas, pode-se ver como os preços das mercadorias tangíveis (manufaturadas) produzidas pelos setores industriais variam menos do que os preços de outros serviços à disposição das compras das famílias ao longo do tempo. Abaixo há figura com o comportamento dos preços dos bens manufaturados e dos preços dos bens de serviço ao longo do tempo.

Do ponto de vista das conjunturas, notam-se primeiramente as flutuações de 1974 e 1979 como resultados da crise do petróleo. No início da década de (19)80, dá-se a estabilização da variação dos preços, partir das políticas de Paul Volcker (presidente da Reserva Federal), sob a administração do presidente Reagan. Nota-se que os preços dos bens manufaturados caem mais no período subseqüente ao plano de estabilização, encontrando seu ponto mais baixo em 1987. No fim da década os preços de ambas as séries iniciam nova ascensão, reforçada pelo novo ciclo expansivo a partir de 1987; o aumento dos preços do petróleo em 1990 contribui também para a elevação. Nos anos (19)90 há queda acentuada nas variações de preços, e principalmente dos bens manufaturados, como resultado do aumento dos níveis de produtividade e dos déficits comerciais neste período. A variação dos preços dos bens

\footnotetext{
100 "Os preços relativos tendem a mover-se em um prazo grande mais ou menos no sentido inverso da produtividade relativa, e as mercadorias cuja produção per capita aumenta menos se tornam progressivamente mais e mais caras à medida que passa o tempo.” ROBINSON, Joan. A Acumulação de Capital, p.373.
} 
manufaturados continua sempre abaixo da variação dos preços dos serviços. Por sua vez, as flutuações dos preços das mercadorias são sempre mais elásticas do que as flutuações dos bens de serviços $\left(\mathrm{R}^{2}\right.$ menor que $\mathrm{R}^{2}$ da linha de tendência dos preços de serviços), indicando menor poder relativo dos produtores em controlar a oferta.

Gráfico 15. Estados Unidos. Mudanças nos preços ao consumidor (de Dezembro a Dezembro) para mercadorias e serviços. Para todos os consumidores urbanos. Em porcentagem (\%).

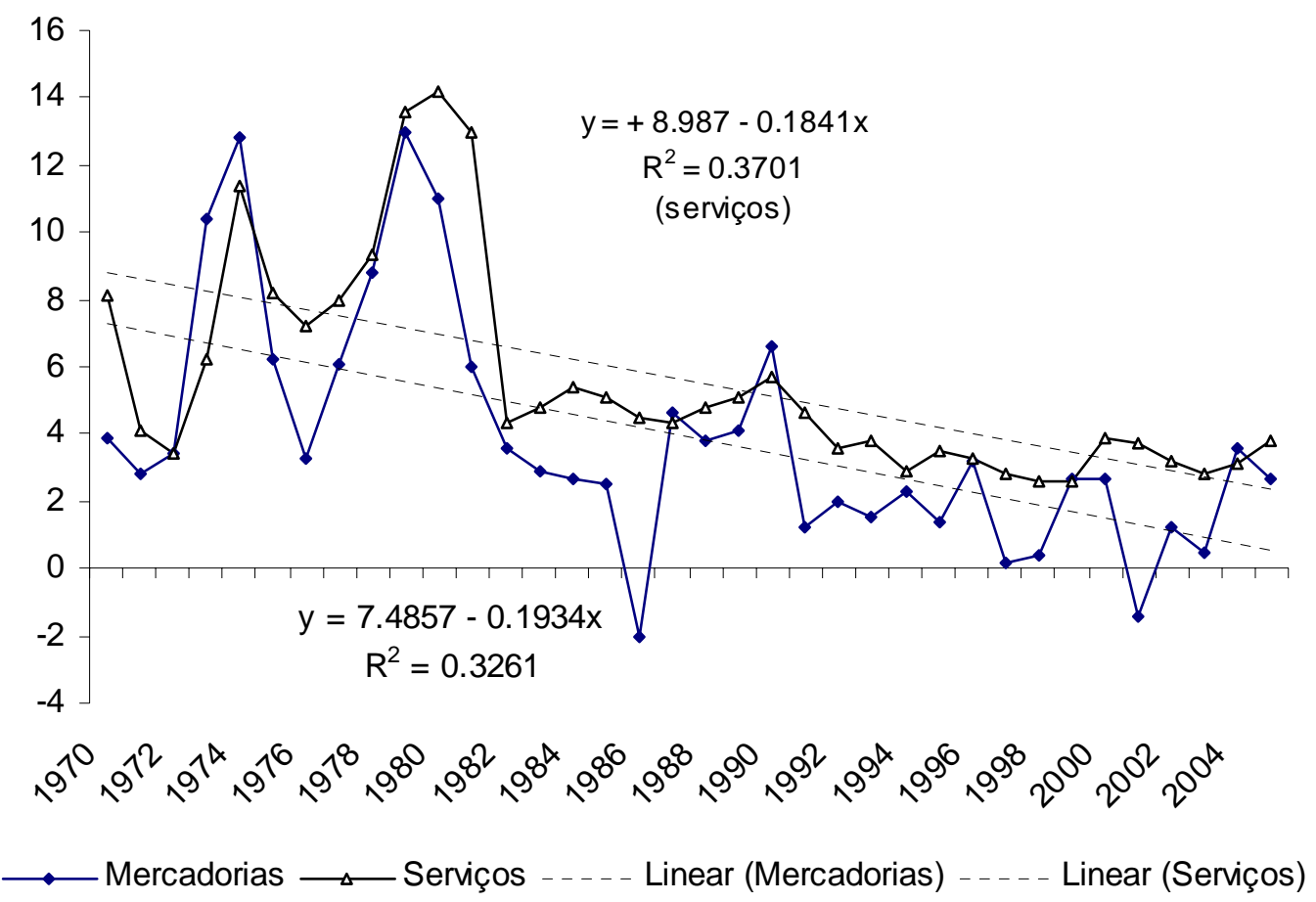

Fonte: Economic Report of the President, 2006. Tabela B-64, Changes in Consumer Prices Indexes for commodities and services, 1929-2005.

Abaixo segue a tabela, com dados fornecidos pelo Economic Report de 2006, com os valores da variação percentual dos preços de (a) mercadorias ("goods") e (b) serviços ("services"), exposta na figura anterior. Pela observação da tabela, pode-se notar as diferentes evoluções dos preços, face à tendência geral, o que dá a própria definição de preços relativos. A evolução geral dos preços ao consumidor, medido pelo CPI-U (United States Consumer Prices Index), soma $170.6 \%$ de variação de 1970 a 2000. A evolução dos preços das mercadorias (commodities) soma $140.7 \%$ de variação no mesmo período; já os serviços somam $200.9 \%$. A variação dos preços nos setores de serviços é então 1.42 vezes maior do que a variação dos preços das mercadorias.

Verificando alguns dados mais desagregados, podem-se identificar a mesma tendência. Na segunda tabela da seqüência abaixo, pode-se notar a evolução dos preços de alguns serviços e de bens industriais. Desta vez, a evolução da tendência é marcada por números-índice de base 100, sendo, de acordo com o Economic Report, o valor 100 dado ao período 1982-1984. ${ }^{101} \mathrm{O}$

${ }^{101}$ Não fica claro como o Economic Report estabeleceu este intervalo de dois anos como assumindo o valor de 100 . 
valor da evolução dos preços dos bens industriais aparece nas seguintes colunas: 2, geral, coluna 3, veículos novos, e coluna 4, materiais e componentes para manufatura. Nas colunas subseqüentes, há os valores para serviços: na coluna 5, os valores da evolução dos preços dos serviços de alimentação fornecidos por serviços às famílias; na coluna 6 , a variação dos preços de gastos com moradia; na coluna 7 , serviços médicos; e na coluna 8 , os valores da evolução dos preços de transporte público.

Tabela 8. Estados Unidos. Mudanças nos preços ao consumidor (de Dezembro a Dezembro) para mercadorias e serviços. Para todos os consumidores urbanos. Em porcentagem (\%).

\begin{tabular}{|c|c|c|c|}
\hline (1) & $(2)$ & (3) & (4) \\
\hline Anos & $\begin{array}{l}\text { Preços ao consumidor: } \\
\text { todos itens (CPI-U) }\end{array}$ & Mercadorias & Serviços \\
\hline 1970 & 5.6 & 3.9 & 8.1 \\
\hline 1971 & 3.3 & 2.8 & 4.1 \\
\hline 1972 & 3.4 & 3.4 & 3.4 \\
\hline 1973 & 8.7 & 10.4 & 6.2 \\
\hline 1974 & 12.3 & 12.8 & 11.4 \\
\hline 1975 & 6.9 & 6.2 & 8.2 \\
\hline 1976 & 4.9 & 3.3 & 7.2 \\
\hline 1977 & 6.7 & 6.1 & 8 \\
\hline 1978 & 9.0 & 8.8 & 9.3 \\
\hline 1979 & 13.3 & 13 & 13.6 \\
\hline 1980 & 12.5 & 11 & 14.2 \\
\hline 1981 & 8.9 & 6 & 13 \\
\hline 1982 & 3.8 & 3.6 & 4.3 \\
\hline 1983 & 3.8 & 2.9 & 4.8 \\
\hline 1984 & 3.9 & 2.7 & 5.4 \\
\hline 1985 & 3.8 & 2.5 & 5.1 \\
\hline 1986 & 1.1 & -2 & 4.5 \\
\hline 1987 & 4.4 & 4.6 & 4.3 \\
\hline 1988 & 4.4 & 3.8 & 4.8 \\
\hline 1989 & 4.6 & 4.1 & 5.1 \\
\hline 1990 & 6.1 & 6.6 & 5.7 \\
\hline 1991 & 3.1 & 1.2 & 4.6 \\
\hline 1992 & 2.9 & 2 & 3.6 \\
\hline 1993 & 2.7 & 1.5 & 3.8 \\
\hline 1994 & 2.7 & 2.3 & 2.9 \\
\hline 1995 & 2.5 & 1.4 & 3.5 \\
\hline 1996 & 3.3 & 3.2 & 3.3 \\
\hline 1997 & 1.7 & 0.2 & 2.8 \\
\hline 1998 & 1.6 & 0.4 & 2.6 \\
\hline 1999 & 2.7 & 2.7 & 2.6 \\
\hline 2000 & 3.4 & 2.7 & 3.9 \\
\hline 2001 & 1.6 & -1.4 & 3.7 \\
\hline 2002 & 2.4 & 1.2 & 3.2 \\
\hline 2003 & 1.9 & 0.5 & 2.8 \\
\hline 2004 & 3.3 & 3.6 & 3.1 \\
\hline 2005 & 3.4 & 2.7 & 3.8 \\
\hline Soma & 170.6 & 140.7 & 200.9 \\
\hline
\end{tabular}

Fonte: Economic Report of the President, 2006. Tabela B-64, Changes in Consumer Prices Indexes for commodities and services, 1929-2005. 
Tabela 9. Estados Unidos. Índices de preços selecionados. 1982-1984 = 100.

\begin{tabular}{|c|c|c|c|c|c|c|c|}
\hline \multirow[t]{2}{*}{ (1) } & (2) & (3) & (4) & (5) & (6) & (7) & (8) \\
\hline & Geral & $\begin{array}{l}\text { Veículos } \\
\text { Novos }\end{array}$ & $\begin{array}{c}\text { Materiais e } \\
\text { componentes } \\
\text { para a } \\
\text { manufatura }\end{array}$ & $\begin{array}{l}\text { Serviços de } \\
\text { Alimentação }\end{array}$ & Moradia & Serviços Médicos & Transporte Público \\
\hline 1970 & 35.2 & 53 & 38 & 37.5 & 36.4 & 34 & 35.2 \\
\hline 1971 & 36.5 & 55.2 & 38.9 & 39.4 & 38 & 36.1 & 37.8 \\
\hline 1972 & 37.8 & 54.7 & 40.4 & 41 & 39.4 & 37.3 & 39.3 \\
\hline 1973 & 40.3 & 54.8 & 44.1 & 44.2 & 41.2 & 38.8 & 39.7 \\
\hline 1974 & 49.2 & 57.9 & 56 & 49.8 & 45.8 & 42.4 & 40.6 \\
\hline 1975 & 54.9 & 62.9 & 61.7 & 54.5 & 50.7 & 47.5 & 43.5 \\
\hline 1976 & 58.4 & 66.9 & 64 & 58.2 & 53.8 & 52 & 47.8 \\
\hline 1977 & 62.5 & 70.4 & 67.4 & 62.6 & 57.4 & 57 & 50 \\
\hline 1978 & 67 & 75.8 & 72 & 68.3 & 62.4 & 61.8 & 51.5 \\
\hline 1979 & 75.7 & 81.8 & 80.9 & 75.9 & 70.1 & 67.5 & 54.9 \\
\hline 1980 & 88 & 88.4 & 91.7 & 83.4 & 81.1 & 74.9 & 69 \\
\hline 1981 & 97.4 & 93.7 & 98.7 & 90.9 & 90.4 & 82.9 & 85.6 \\
\hline 1982 & 100 & 97.4 & 100 & 95.8 & 96.9 & 92.5 & 94.9 \\
\hline 1983 & 101.1 & 99.9 & 101.2 & 100 & 99.5 & 100.6 & 99.5 \\
\hline 1984 & 103.3 & 102.8 & 104.1 & 104.2 & 103.6 & 106.8 & 105.7 \\
\hline 1985 & 103.7 & 106.1 & 103.3 & 108.3 & 107.7 & 113.5 & 110.5 \\
\hline 1986 & 100 & 110.6 & 102.2 & 112.5 & 110.9 & 122 & 117 \\
\hline 1987 & 102.6 & 114.6 & 105.3 & 117 & 114.2 & 130.1 & 121.1 \\
\hline 1988 & 106.3 & 116.9 & 113.2 & 121.8 & 118.5 & 138.6 & 123.3 \\
\hline 1989 & 111.6 & 119.2 & 118.1 & 127.4 & 123 & 149.3 & 129.5 \\
\hline 1990 & 115.8 & 121.1 & 118.7 & 133.4 & 128.5 & 162.8 & 142.6 \\
\hline 1991 & 116.5 & 125.3 & 118.1 & 137.9 & 133.6 & 177 & 148.9 \\
\hline 1992 & 117.4 & 128.4 & 117.9 & 140.7 & 137.5 & 190.1 & 151.4 \\
\hline 1993 & 119.1 & 131.5 & 118.9 & 143.2 & 141.1 & 201.4 & 167 \\
\hline 1994 & 120.7 & 136 & 122.1 & 145.7 & 144.8 & 211 & 172 \\
\hline 1995 & 125.5 & 139 & 130.4 & 149 & 148.5 & 220.5 & 175.9 \\
\hline 1996 & 127.3 & 141.4 & 128.6 & 152.7 & 152.8 & 228.2 & 181.9 \\
\hline 1997 & 127.7 & 141.7 & 128.3 & 157 & 156.8 & 234.6 & 186.7 \\
\hline 1998 & 124.8 & 140.7 & 126.1 & 161.1 & 160.4 & 242.1 & 190.3 \\
\hline 1999 & 126.5 & 139.6 & 124.6 & 165.1 & 163.9 & 250.6 & 197.7 \\
\hline 2000 & 134.8 & 139.6 & 128.1 & 169 & 169.9 & 260.8 & 209.6 \\
\hline 2001 & 135.7 & 138.9 & 127.4 & 173.9 & 176.4 & 272.8 & 201.6 \\
\hline 2002 & 132.4 & 137.3 & 126.1 & 178.3 & 180.3 & 285.6 & 207.4 \\
\hline 2003 & 139.1 & 134.7 & 129.7 & 182.1 & 184.8 & 297.1 & 209.3 \\
\hline 2004 & 147.6 & 133.9 & 137.9 & 187.5 & 189.5 & 310.1 & 209.1 \\
\hline 2005 & 160.2 & 135.9 & 145.8 & 193.4 & 195.7 & 323.2 & 217.3 \\
\hline Soma & 3602.6 & 3848 & 3629.9 & 4162.7 & 4105.5 & 5453.5 & 4465.1 \\
\hline
\end{tabular}

Fonte: Economic Report of the President, 2006. Várias tabelas. Para Alimentos, Serviços Médicos, Moradia, Tabela B-61, Consumer price indexes for selected expenditure classes, 1959-2005; para Transportes Públicos e Veículos novos, Tabela B-61, Consumer price indexes for selected expenditure classes, 1959-2005; para bens industriais, B-67, Producer price indexes for major commodity groups, 1959-2005. E para Materiais e Componentes para a Manufatura, Tabela B-65, Producer Price Indexes by stage of processing, 1959-2005.

É constante a evolução menor das variações dos preços para os bens industriais face aos preços referentes aos serviços. Particularmente, nos serviços médicos, onde o trabalho vivo não pode ser substituído totalmente por mecanismos automativos, sendo o componente principal na realização dos serviços médicos, a evolução dos custos é mais alta que a média inclusive para os 
serviços de modo geral. O transporte público aqui aparece como serviço, e não como atividade produtiva, porque ele não se liga ao transporte de mercadorias. Seus preços evoluíram de modo mais rápido, na média, que os preços dos bens industriais.

Nota-se também um grande emparelhamento da evolução do conjunto de preços até aproximadamente o início da década de 1980. Depois de 1980, os preços dos bens industriais passam a evoluir de modo mais lento. As empresas produtivas aplicaram cada vez mais rapidamente os processos tecnológicos desenvolvidos à base da microeletrônica no processo de produção, com resultantes (1) aumentos no cômputo do trabalho morto no processo produtivo, aliado a (2) uma queda relativa posterior das taxas de lucro face aos setores menos mecanizados com (3) uma posterior queda dos preços das mercadorias. A queda dos preços das mercadorias para o setor industrial aguça a tendência desfavorável para suas taxas de lucro, e só pode ser efetivamente impedida por um aumento no grau de monopolização. A queda dos preços dos bens manufaturados reflete-se então numa diminuição das compras de bens manufaturados pelas famílias, favorecendo os gastos com serviços, tal como se vê na tabela na seqüência. A relação entre os gastos com serviços e com bens duráveis elevou-se de 3.42 vezes em 1970 para 4.55 vezes em 2000; e a relação entre o valor total de gastos com serviços face aos bens duráveis na economia norte-americana subiu de $1.07 \mathrm{em} 1975$ para $2.01 \mathrm{em} 2000$.

Tabela 10. Estados Unidos. Gastos de consumo pessoais. 1970-2000. Em bilhões de dólares.

\begin{tabular}{cccccc}
\hline$(1)$ & $\begin{array}{c}(2) \\
\text { Gastos em bens } \\
\text { duráveis }\end{array}$ & $\begin{array}{c}(3) \\
\text { Gastos em bens } \\
\text { não-duráveis }\end{array}$ & $\begin{array}{c}(4) \\
\text { Gastos em } \\
\text { serviços }\end{array}$ & $\begin{array}{c}(5) \\
\text { Serviços/ } \\
\text { Duráveis }\end{array}$ & $\begin{array}{c}(6) \\
\text { Serviços/ } \\
\text { Não-duráveis }\end{array}$ \\
1970 & 85.0 & 272.0 & 291.5 & 3.42 & 1.07 \\
1975 & 133.5 & 420.7 & 480.2 & 3.59 & 1.14 \\
1980 & 214.2 & 696.1 & 846.9 & 3.95 & 1.21 \\
1985 & 363.5 & 928.7 & 1428.1 & 3.92 & 1.53 \\
1990 & 474.2 & 1166.7 & 2115.9 & 4.46 & 1.81 \\
1995 & 611.6 & 1485.1 & 2879.1 & 4.70 & 1.93 \\
2000 & 863.3 & 1947.2 & 3928.8 & 4.55 & 2.01 \\
\hline
\end{tabular}

Fonte: Economic Report of the President, 2006. Tabela B-16, Personal Consumption Expenditures, 1959-2005.

Por fim, o aumento da importação de bens tangíveis dentro dos déficits comerciais consolidados norte-americanos consolida as pressões sobre a produção doméstica norteamericana. A tendência de comércio exterior desfavorável, mormente a relação com o Leste Asiático, põe o setor produtivo em xeque de modo ainda mais intenso, dada maior facilidade de importação dos bens industriais face aos serviços. Abaixo há um gráfico com a proporção de importação de bens tangíveis sobre a importação de serviços, e com a proporção da exportação de bens tangíveis sobre a exportação de serviços. A primeira tem trajetória crescente a partir dos anos (19)90. Mesmo considerando-se a interrupção de uma tendência de ascensão rápida até 1997, com um intervalo de queda desde aí até 2003, a tendência é de franca ascendência nos últimos dezesseis anos (1990-2006). Já a exportação de tangíveis sobre a exportação de serviços 
tem trajetória oposta, desde 1980. Há uma pequena recuperação no fim dos anos (19)80, com o Acordo do Plaza (1985, comentado à frente), e uma nova queda na primeira metade dos anos (19)90. Deu-se depois certa recuperação, mas que não evitou o trajeto consolidado de perdas em bens tangíveis para o setor produtor norte-americano.

Gráfico 16. Estados Unidos. Relação de bens tangíveis importados sobre a importação de serviços e relação da exportação de bens tangíveis exportados sobre a exportação de serviços.

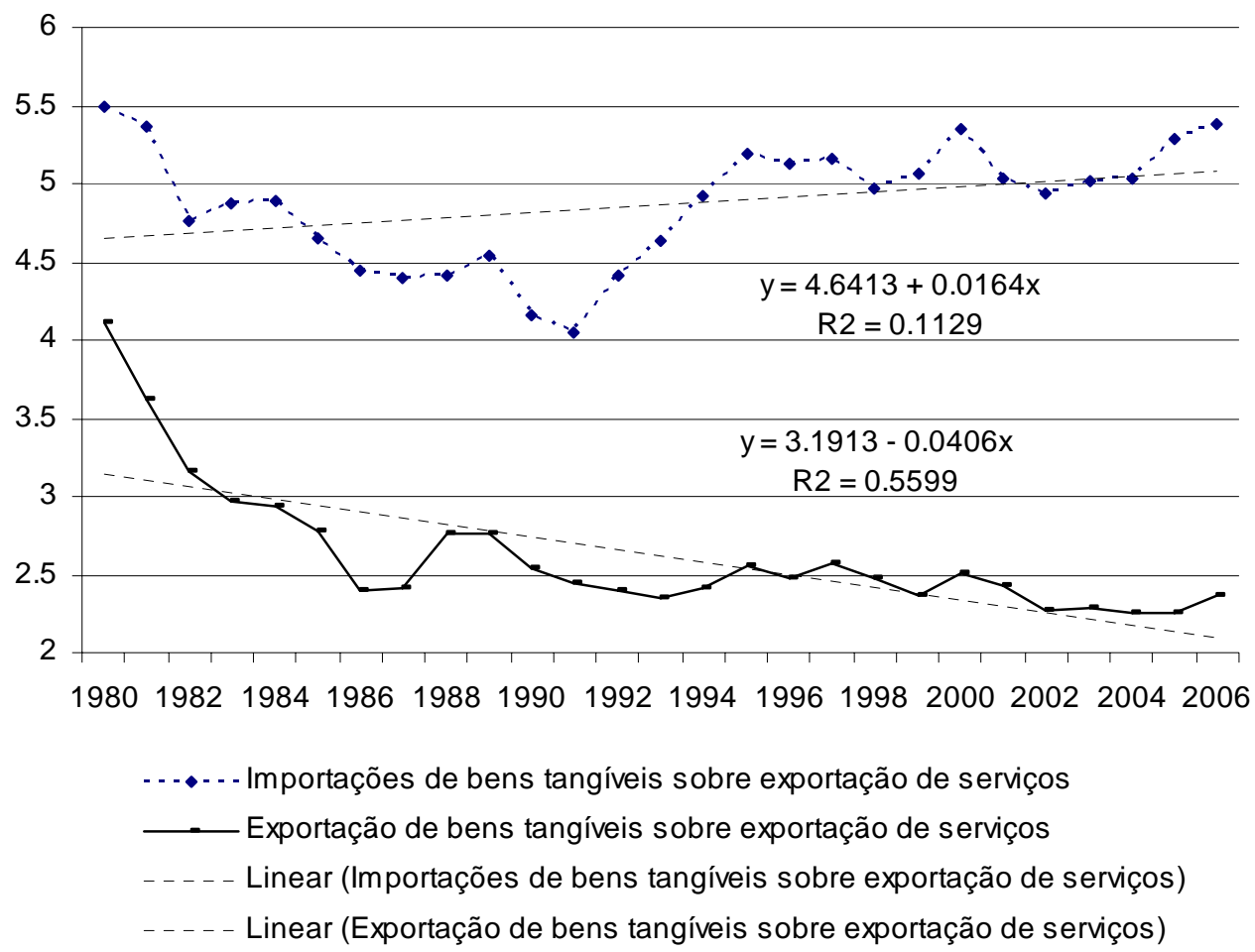

Fonte: calculado a partir dos dados em bilhões de dólares do NIPA-BEA. Seção 4, Foreign Transactions, Tabela 4.2.5., Exports and Imports of Goods and Services by Type of Product.

Por outro lado, o Acordo do Plaza, desvalorizando o dólar, foi o último momento na história econômica recente dos Estados Unidos em que a proporção de importações de manufaturados norte-americana caiu face à importação de serviços. A partir deste momento, a progressiva valorização do dólar, principalmente a partir de 1994, levaria a uma importação de bens crescente.

Assim, a proporção de bens tangíveis exportados sobre a exportação de serviços exportados tem um comportamento declinante, mostrando a perda crescente de posições da manufatura norte-americana no mundo. A própria perda de posições da indústria no ambiente doméstico, aliada a um saldo comercial estruturalmente deficitário, a uma exportação líquida de capitais produtivos, e a um crescimento da base manufatureira na economia mundial principalmente no leste da Ásia - são responsáveis por uma diminuição cada vez maior da venda de bens norte-americanos no mundo, e, por decorrência, de um crescimento industrial menor para o país. Isto tende a se agravar à medida em que países como a China percorrem rapidamente as várias etapas da Revolução Industrial, desenvolvendo cada vez mais a produção 
de máquinas, ferramentas, aparelhos de controle eletrônico e todo o aparato das modernas técnicas de produção. O processo torna mais ou menos inevitável que não somente a produção de bens finais norte-americana seja diminuída em termos relativos. A instalação de firmas norteamericanas, com reforço das remessas de lucro a partir do exterior, continua assim como uma estratégia de vital importância para amortecer o aumento contínuo das remessas de renda norteamericanas para o exterior, como resultado do aumento do endividamento externo.

Portanto, pode-se afirmar que, para a economia norte-americana: (1) o setor produtivo tem sua participação reduzida em valor no produto interno bruto ao longo do tempo, devido à (i) queda relativa de sua taxa de lucro, ao (b) comportamento dos preços relativos e (c) aumento dos déficits comerciais em forma de bens tangíveis. Tal culmina em (2) diminuição do crescimento relativo da produção material doméstica, e assim da taxa de crescimento do produto interno bruto. A maior composição do capital fixo na produção industrial leva à queda da taxa de lucro tendencial; e leva a uma maior queda dos preços das mercadorias industriais, também ao longo do tempo. As menores taxas de lucro desestimulam os investimentos produtivos, de forma relativa; os menores preços dos bens manufaturados permitem com que os dispêndios (pauta de consumo) dirijam-se crescentemente aos gastos com serviços, desestimulando maiores inversões. Somado este processo com (a) a exportação líquida de capitais produtivos e (b) com os crescentes déficits comerciais, é inevitável que o crescimento norte-americano seja menor ao longo do tempo, dados os menores investimentos produtivos. A população empregada na indústria cai, crescem as atividades não-produtivas e reina a finança.

\subsection{Relação investimento-poupança}

Outras induções a partir de relações entre os agregados sob perspectiva macroeconômica pode sugerir inferências adicionais sobre o comportamento da renda nacional norte-americana. A mais fundamental delas refere-se à divisão da poupança bruta agregada num tempo t pelos investimentos em capital fixo feitos num período anterior (t-1). A observação da relação, em perspectiva dinâmica, pode lançar mais luz ao comportamento da economia no longo prazo. A pergunta fundamental é: os investimentos passados em capital fixo estão gerando mais poupança doméstica ao longo do tempo? A relação é estável, crescente ou decrescente? Se é crescente, os impactos dos investimentos da economia vão estar sendo cada vez mais produtivos. Se a relação é estável, os investimentos estão gerando uma poupança futura proporcional a eles mesmos. Mas se cai a relação, tem havido a necessidade de investir cada vez mais para obter-se uma mesma poupança doméstica bruta. Quer dizer, mesmo um mesmo investimento num tempo $t$ não gera a mesma poupança, mas sim menos, que um mesmo investimento num tempo $t+1$. Os resultados desta análise prévia servem como guia ao estudo da transformação dos componentes da poupança nacional ao longo do tempo.

Para os Estados Unidos, a trajetória decrescente da relação da poupança num tempo $t$ com os investimentos em t-1 é claramente decrescente. Aqui se tomam os dados de poupança - 
em 1946 por exemplo - para dividi-las pelo investimento em 1945. O resultado de longo prazo é que, a partir desta relação, os investimentos têm gerado uma poupança proporcionalmente menor em relação a eles ao longo do tempo assinalado. Isto explica porque as taxas de variação de crescimento do produto têm tido a trajetória assinalada, e mostra também como se apresenta difícil para a economia superar a atual crise (2008) mediante uma nova rodada de crescimento.

Olhando esta relação a partir do comportamento específico das corporações e seus lucros, o mesmo pode ser observado, ainda que numa escala menor. A relação média entre os lucros corporativos e os investimentos em capital fixo caem da casa de 0,7 em 1955 para 0,47 nos anos (19)70, e para a média de 0,39 na década de (19)80 e (19)90. No caso de explicação pela perspectiva estritamente keynesiana, poder-se-ia afirmar que, ao longo do tempo, a acumulação de capital vai tornando-o "abundante" demais, não obstante as flutuações cíclicas que o fazem novamente "escasso" nos períodos de queda dos investimentos. Se é certo que cada crise permitiria "eliminar" capital ocioso e recompor parte do investimento, isto se daria, por outro lado, sob perspectiva decrescente.

Gráfico 17. Estados Unidos. Relação da poupança bruta em t com o consumo de capital fixo em t-1. 1948-2006.

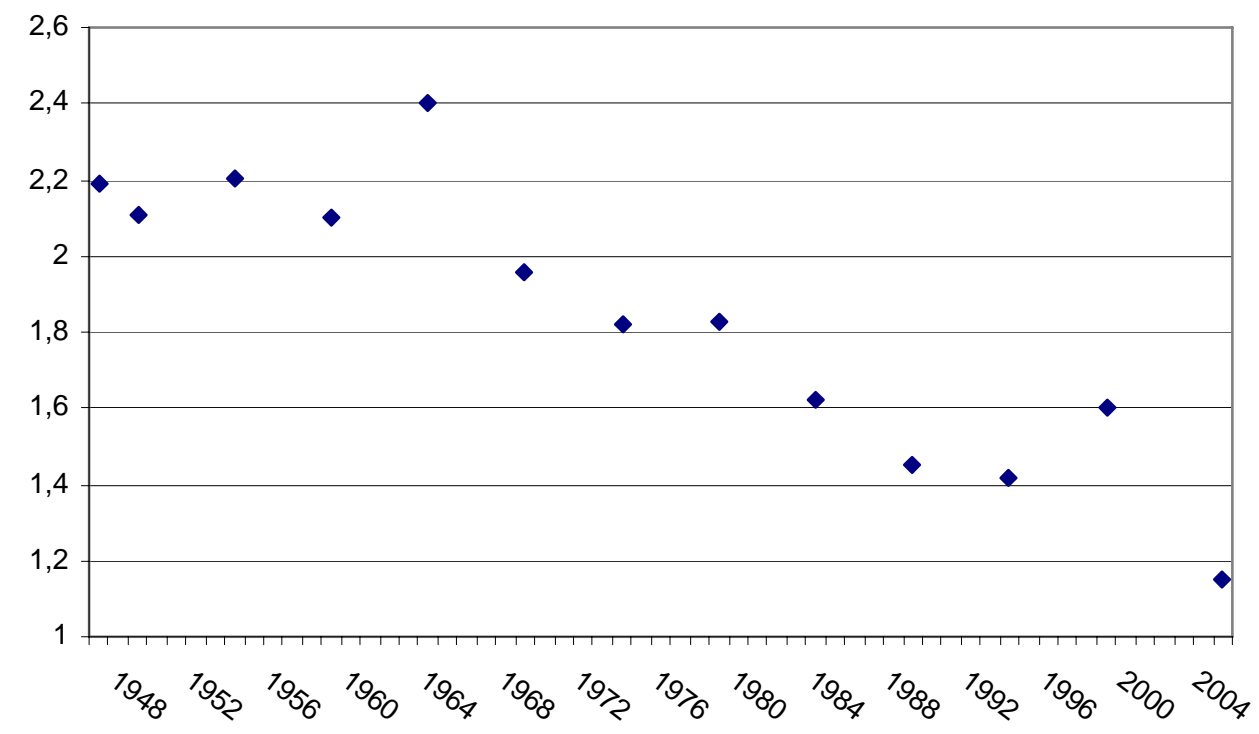

Fonte: NIPA-BEA. Seção 5. Saving and Investment. Tabela 5.1. Saving and Investment: Net saving e consumption of fixed capital. 
Gráfico 18. Estados Unidos. Relação dos lucros no tempo t com os gastos com capital fixo das empresas domésticas em t-1. 1945-2006.

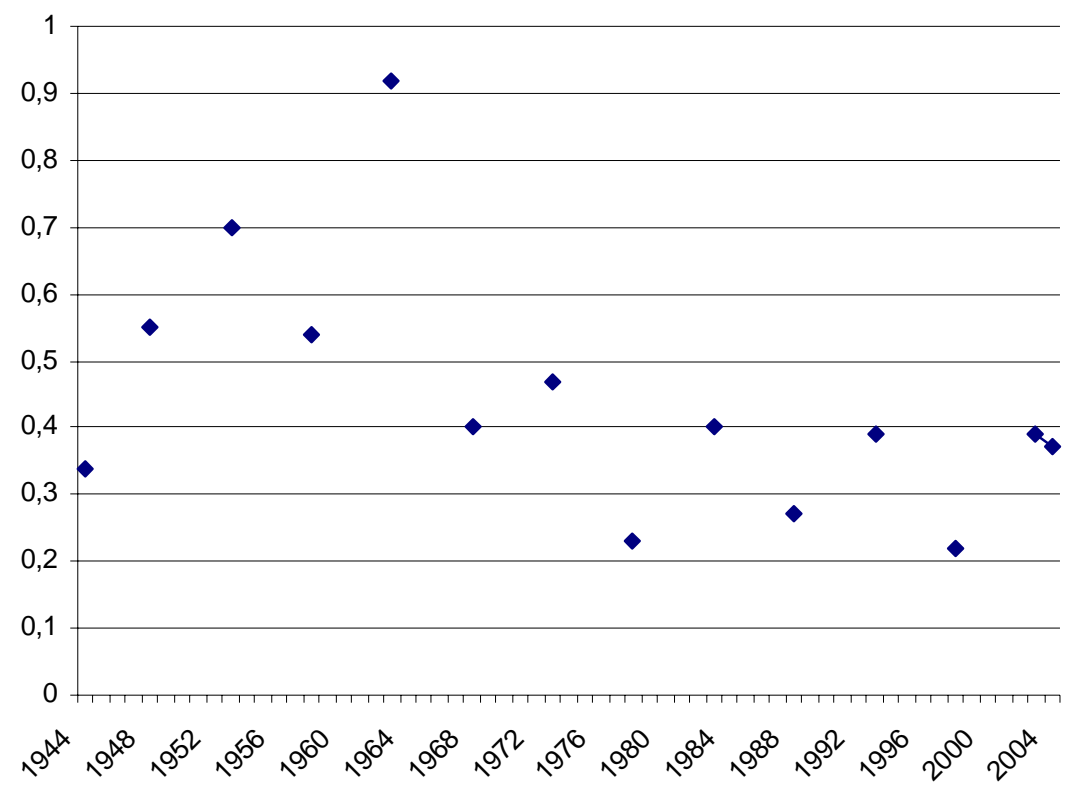

Fonte dos dados: para ambas séries, NIPA-BEA. Seção 5, Net saving and investment; Tabela 5.1, Saving and Investment.

De fato, caiu a relação investimento-poupança para os Estados Unidos ao longo do tempo? A queda expressa (a) o surgimento e o crescimento dos déficits comerciais da economia, a partir da década de (19)70; (b) a queda dos investimentos produtivos, únicos capazes de formação de poupança; e (c) a queda da taxa de poupança das famílias. Todos estes processos contribuem para que a poupança formada pelos investimentos produtivos tenha trajetória de queda ao longo do tempo.

De fato, os investimentos ( $\mathrm{X} 1$ ou $\left.\mathrm{I}_{\mathrm{cf}}\right)$ explicam melhor a poupança doméstica ( $\mathrm{Y} 1$ ou $\left.\mathrm{P}_{\mathrm{d}}\right)$ dos Estados Unidos no período 1945-1976 do que no período 1976-2004. Veja-se a partir da análise regressional. Tomem-se as duas regressões abaixo, feitas com os dados da Tabela 3 na seqüência. Elas expressam os regressores da regressão entre a poupança doméstica em função dos investimentos para dois sub-períodos: 1948-1976 e 1976-2004.

Regressão (III)

29 observações (1948-1976, dados anuais)

$\mathrm{P}_{\mathrm{d}}=15,4+1,88 \mathrm{I}_{\mathrm{cf}}$, em que...

$\mathrm{P}_{\mathrm{d}}=$ poupança doméstica

$\mathrm{I}_{\mathrm{cf}}=$ investimentos em capital fixo

$\mathrm{R}^{2}: 0,97$

Durbin-Watson: 0,95

Valor P para $\beta: 1,11396 \mathrm{E}-07$ 
Regressão (IV)

29 observações (1976-2004, dados anuais)

$\mathrm{P}_{\mathrm{d}}=227+1,13 \mathrm{I}_{\mathrm{cf}}$, em que...

$\mathrm{P}_{\mathrm{d}}=$ poupança doméstica

$\mathrm{I}_{\mathrm{cf}}=$ investimentos em capital fixo

$\mathrm{R}^{2}: 0,90$

Durbin-Watson: 0,49

Valor P para $\beta: 1,29 \mathrm{E}-15$

A relação entre poupança e investimento é mais eficiente no primeiro período porque os investimentos e o consumo - e assim a poupança doméstica propriamente dita - passam a depender dos recursos externos a partir dos anos (19)80. Isto é, uma terceira variável não presente no primeiro momento passou a ser componente explicativo crucial. O coeficiente de explicação cai de 0,97 para 0,90 no segundo período.

Tabela 11. Estados Unidos. Investimento em capital fixo e poupança doméstica bruta. Em bilhões de dólares. 1945-2004.

(1)

Anos

1948

1949

1950

1951

1952

1953

1954

1955

1956

1957

1958

1959

1960

1961

1962

1963

1964

1965

1966

1967

1968

1969

1970

1971

1972

1973

1974

1975
(2) Inv. Cap. Fixo

(Y1)

28,1

28,7

29,4

33,2

35,7

37,8

39,9

42,1

46,4

49,9

52

53

55,6

57,2

59,3

62,4

65

69,4

75,6

81,5

88,4

97,9

106,7

115

126,5

139,3

162,5

187,7
(3)

Poup. Bruta

(X1)

45,6

60,6

75

74,2

75,1

73,4

88

99,4

99,6

90,8

106,2

111,3

114,3

124,9

133,2

143,4

158,5

168,7

170,5

182

198,3

192,7

208,9

237,5

292

301,5

297

342,1
(4)

Anos

1976

1977

1978

1979

1980

1981

1982

1983

1984

1985

1986

1987

1988

1989

1990

1991

1992

1993

1994

1995

1996

1997

1998

1999

2000

2001

2002

2003

2004
(5)

(6)

Inv. cap. fixo

(Y1)

205,2

230

262,3

300,1

343

388,1

426,9

443,8

472,6

506,7

531,3

561,9

597,6

644,3

682,5

725,9

751,9

776,4

833,7

878,4

918,1

974,4

1030,2

1101,3

1187,8

1281,5

1292,1

1336,5

1436,1
Poup. Bruta

(x1)

397,5

478

536,7

549,4

654,7

629,1

609,4

773,4

767,5

733,5

796,8

915

944,7

940,4

964,1

948,2

962,4

1070,7

1184,5

1291,1

1461,1

1598,7

1674,3

1779,5

1657,6

1489,1

1459

1618,1

1734,6

Fonte: BEA, Seção 5, Net saving and investment; Tabela 5.1, Saving and Investment. 
O endividamento externo da economia, não obstante facilitar o desempenho dos agregados no médio prazo, não pôde, por si, levar a uma elevação das taxas de acumulação produtiva sobre o produto. Tal pode ser observado na leitura da tabela e das operações de regressão dispostas abaixo. A tabela indica uma fração cada vez maior do consumo sobre o produto, em contraposição à parcela do investimento.

Tabela 12. Estados Unidos. Consumo das famílias e investimentos privados. Em bilhões de dólares correntes. 1980-2004.

\begin{tabular}{cccccc}
\hline 1 & 2 & 3 & 4 & 5 & 6 \\
Anos & $\begin{array}{c}\text { Consumo das } \\
\text { famílias (X1) }\end{array}$ & $\begin{array}{c}\text { Investimentos } \\
\text { Privados (X2) }\end{array}$ & PIB (Y) & $\begin{array}{c}\text { Consumo/PIB } \\
\text { Investimento } \\
\text { privado/PIB }\end{array}$ \\
1980 & 1751 & 4856 & 2789 & 0,62 & 0,17 \\
1981 & 1941 & 542,6 & 3128 & 0,62 & 0,17 \\
1982 & 2077 & 532,1 & 3255 & 0,64 & 0,16 \\
1983 & 2290 & 570,1 & 3536 & 0,65 & 0,16 \\
1984 & 2503 & 670,2 & 3933 & 0,64 & 0,17 \\
1985 & 2702 & 714,4 & 4220 & 0,64 & 0,16 \\
1986 & 2899 & 739,9 & 4462 & 0,65 & 0,17 \\
1987 & 3100 & 757,8 & 4739 & 0,65 & 0,16 \\
1988 & 3353 & 803,1 & 5103 & 0,66 & 0,15 \\
1989 & 3598 & 847,3 & 5484 & 0,66 & 0,14 \\
1990 & 3839 & 846,4 & 5803 & 0,66 & 0,13 \\
1991 & 3986 & 803,3 & 5995 & 0,66 & 0,13 \\
1992 & 4235 & 848,5 & 6337 & 0,67 & 0,14 \\
1993 & 4477 & 932,5 & 6657 & 0,67 & 0,15 \\
1994 & 4743 & 1033,3 & 7072 & 0,67 & 0,15 \\
1995 & 4975 & 1112,9 & 7397 & 0,67 & 0,15 \\
1996 & 5256 & 1209,5 & 7816 & 0,67 & 0,16 \\
1997 & 5547 & 1317,8 & 8304 & 0,67 & 0,16 \\
1998 & 5879 & 1438,4 & 8747 & 0,67 & 0,17 \\
1999 & 6285 & 1558,8 & 9268 & 0,68 & 0,17 \\
2000 & 6739 & 1679,1 & 9817 & 0,68 & 0,16 \\
2001 & 7055 & 1641,1 & 10128 & 0,70 & 0,15 \\
2002 & 7350 & 1570,2 & 10469 & 0,70 & 0,15 \\
2003 & 7709 & 1654,9 & 10971 & 0 & \\
\hline
\end{tabular}

Fonte: Economic Report of the President, 2006, Tabela B-1, Gross Domestic Product, 19592005.

Ora, isto revela que a economia investe cada vez menos na acumulação, o que, se indica por um lado justamente a tendência para a queda da acumulação devido às dificuldades da taxa de lucros no setor industrial, não deixa por outro lado de indicar o grau de riqueza a que justamente esta sociedade chegou: uma taxa maior de consumo sobre o investimento indica justamente maiores níveis de bem-estar, ou uma menor renúncia presente à riqueza em função de obtenção de mais riqueza no futuro.

A análise de regressão simples $(y=a+b x)$ deixa ver o mesmo fato sob outra perspectiva. A análise de regressão simples do produto interno bruto norte-americano (Y) explicado primeiro pelo consumo das famílias (X1) e depois pelos investimentos privados (X2), em dois sub-períodos distintos (1980-1992 e 1992-2004, com treze observações cada), gera as seguintes equações: 
a.1) PIB explicado pelo consumo das famílias (c): 1980-1992

$\mathrm{PIB}=254,13+0,15 \mathrm{C}$

$\mathrm{R}^{2}: 0,99$

a.2) PIB explicado pelo consumo das famílias (c): 1992-2003

$\mathrm{PIB}=-92,5+0,24 \mathrm{C}$

$\mathrm{R}^{2}: 0,99$

b.1)PIB explicado por investimentos privados (Ip): 1980-1992

$\mathrm{PIB}=-1460+8,48 \mathrm{Ip}$

$\mathrm{R}^{2}: 0,99$

b.2) PIB explicado por investimentos privados 1992-2004 (Ip): 1992-2003

$\mathrm{PIB}=1868,3+5,03 \mathrm{Ip}$

$\mathrm{R}^{2}: 0,93$

Nota-se a queda do coeficiente de explicação $R^{2}$ para as duas equações referentes aos investimentos, e também a queda de 8,48 para 5,03 no regressor que dá o índice de variações do produto em função dos investimentos privados. Ao passo que o regressor que dá a variação do produto em função do consumo eleva-se entre os dois períodos de 0,15 para 0,24 . Isto é, além de em termos absolutos o consumo explicar muito mais o produto nos dois períodos - o que, num modo mais claro de expressar o ponto, indica justamente que a maior parte dos gastos que compõem o produto não são produtivos - sua participação se elevou ao longo do tempo, indicando uma constância da diminuição da acumulação produtiva que o endividamento externo não debelou. Isto supõe o fato de que o endividamento externo permite lograr maiores ganhos aos capitais em função do efeito acelerador e de rebaixamento de custos ao capital (via juros menores, e menores custos de reprodução dos trabalhadores), mas não puderam, porém, influenciar a taxa de lucro a ponto de impedir que os setores responsáveis pela acumulação produtiva diminuíssem relativamente suas inversões.

\subsection{Propensão a investir e propensão a consumir}

O crescimento do PIB norte-americano ao longo de sua linha de tendência está ilustrado na figura abaixo. Nesta figura, existe outra maneira de ver a desaceleração da economia norteamericana. Percebe-se que o produto norte-americano cresceu toda a década de (19)80 e (19)90 abaixo de sua tendência histórica. De fato, certamente as decorrências da queda da lucratividade do capital, e assim da propensão ao investimento, teriam sido muito mais pesadas para os Estados Unidos na ausência do endividamento externo. Tal como se vê na figura, mesmo com a utilização cada vez maior do expediente da poupança externa, o produto interno bruto norteamericano só excede sua linha de tendência depois de 2000 (mediante um aumento colossal da dívida externa). 
Gráfico 19. Estados Unidos. Produto interno bruto e tendência estimada. Em bilhões de dólares.

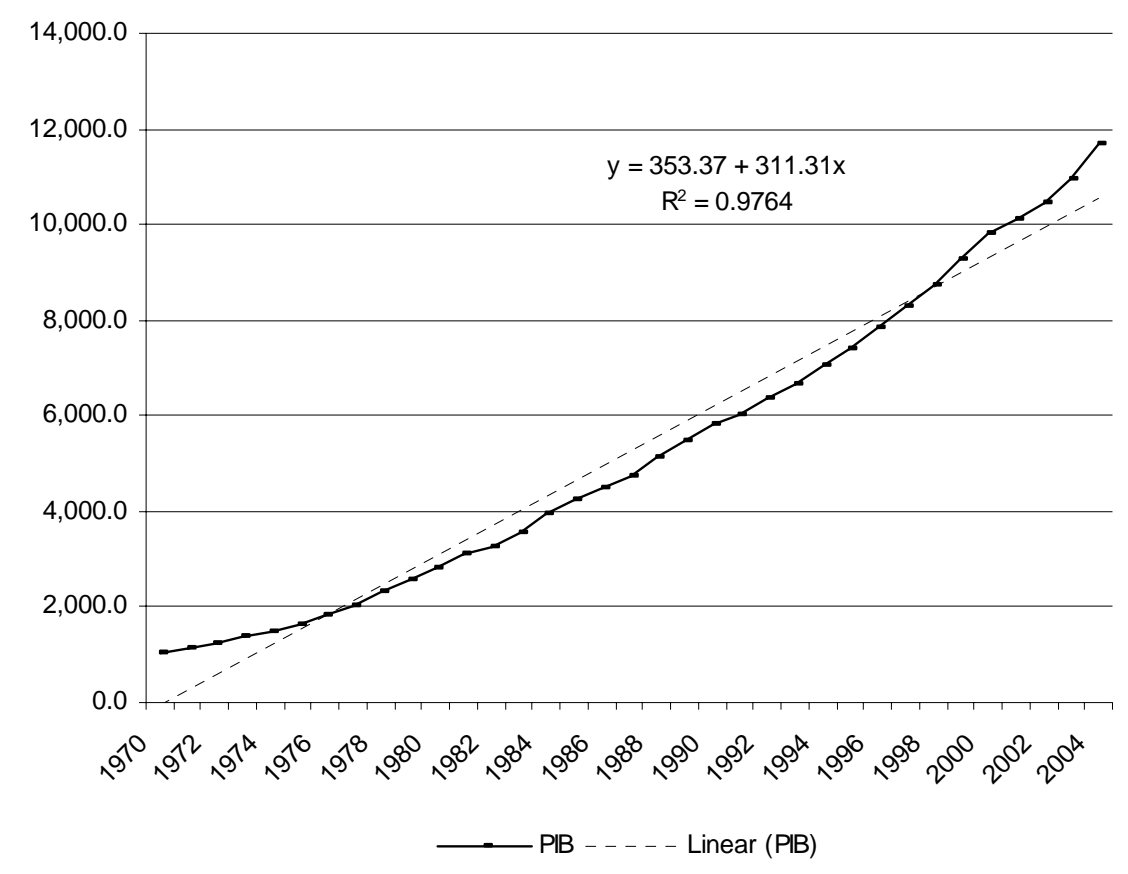

Fonte: NIPA-BEA. Seção 1, Domestic Product and Income, Tabela 1.1.5., Gross Domestic Product.

Neste ínterim, é interessante comentar as transformações estruturais de longo prazo dos componentes do produto interno bruto, principalmente no que se refere à poupança, investimento e consumo. As transformações nas estruturas dos agregados macroeconômicos devem permitir demonstrar as hipóteses assumidas anteriormente, a partir de inferências macroeconômicas. Numa perspectiva estritamente keynesiana, elas poderiam ser assim pensadas:

(1) Dada a baixa relativa da eficiência marginal do capital, a economia norte-americana tem apresentado quedas em sua propensão marginal ao investimento ao longo do período aqui considerado. Tal propensão a investir é aqui entendida como sendo a variação dos investimentos dada uma variação anterior do PIB (relação marginal capital-produto). Este desempenho, conjugado com o endividamento externo da economia, tem como resultado o aumento do volume de consumo das famílias (2) em relação à renda nacional. $\mathrm{O}$ aumento do cômputo do consumo na renda nacional, em detrimento do investimento, é resultado da queda da lucratividade.

Por definição, um aumento do componente de consumo sobre o PIB significa desestimular maiores expansões futuras do produto, porque cairá relativamente a capacidade produtiva. Para que estas expansões futuras não caiam drasticamente, no caso de uma queda sustentada dos investimentos, o nível de consumo das famílias deve ser cada vez mais alto, para substituir os efeitos de uma taxa de investimento declinante (a troca de investimento por consumo na demanda agregada, de que fala Keynes). Por isso se fala numa compensação parcial 
da queda relativa dos investimentos mediante um aumento do (1) volume total de consumo e também (2) do aumento da propensão marginal ao consumo das famílias ao longo do tempo. Isto não significa dizer que o nível efetivo de investimento não seja facilitado pelo aumento do endividamento externo, e que o endividamento externo não seja visto pelas autoridades como um modo de diminuir o declínio da taxa de acumulação. O que ocorre é os recursos exteriores são canalizados cada vez mais em função do consumo das famílias porque a taxa de investimento não pode ser elevada de modo muito sustentado ao longo do tempo, dado que a taxa de lucro nos setores produtivos continuou permanentemente desfavorável. A política econômica não pode determinar o nível relativo da taxa de lucro no longo prazo, pois tal nível depende também, por exemplo, do que ocorre em outros espaços nacionais.

Do ponto de vista específico do consumo das famílias, o aumento do endividamento externo contribuiu para maiores propensões marginais ao consumo, já que, aumentando a liquidez doméstica, favoreceu o volume de empréstimos bancários. No volume de poupança agregada, o componente dos empréstimos externos cresceu ao longo do tempo. Por conseqüência, observou-se uma propensão marginal a poupar das famílias e uma relação marginal capital-produto cadentes ao longo do tempo. Na medida em que a propensão a investir caiu e a propensão marginal a poupar das famílias também, um contínuo aumento do consumo das famílias na renda nacional só pôde se dar com um aumento do componente externo da poupança na poupança doméstica. Assim, o papel do endividamento externo pode ser resumido às seguintes funções: (a) mediante favorecimento à propensão marginal ao consumo das famílias, diminuir parcialmente a queda da propensão marginal ao investimento, mediante manutenção da utilização da capacidade instalada via efeito acelerador; (b) como a queda da propensão a investir não foi evitada de todo, dada a baixa da eficiência marginal do capital não modificada de todo pelos mecanismos barateadores da poupança externa, o endividamento externo contribuiu para sustentar a demanda agregada em forma de aumento do consumo das famílias no PIB; (c) liberar recursos às famílias pelo financiamento externo de parte das contas do governo, o que permite diminuir a arrecadação de base doméstica; (d) o favorecimento ao consumo doméstico libera também relativamente mais recursos para o investimento doméstico.

Estas relações podem ser demonstradas a partir da comparação intertemporal do desempenho dos agregados consumo e investimentos, mediante análise regressional.

No gráfico abaixo, pode-se ver as transformações dos componentes do produto interno bruto norte-americano ao longo do tempo.

Pode-se observar com facilidade um crescimento mais rápido do consumo face aos investimentos na economia norte-americana no período ora considerado neste estudo. Ao mesmo tempo, vê-se como os gastos e investimentos do governo têm atuado de modo contracíclico às flutuações dos investimentos privados. Isto se deu principalmente (1) durante as crises de 1981-82 e durante o decorrer desta década; e (2) depois da crise de 2001. Vale notar que o volume de gastos do governo e os investimentos privados têm aproximadamente o mesmo valor 
ao longo do tempo, e que, assim, um suposto primado da empresa privada quanto ao carro-chefe do movimento acumulativo local é uma noção algo mistificadora. A participação dos gastos do Estado na economia tem sido mais ou menos constante, flutuando entre 20\% (1980), 19\% (1990) e 17\% (2000). Dado o crescimento da emissão de títulos ao exterior, o endividamento externo tem tido para o Estado a função, portanto, de permitir a manutenção dos investimentos do governo norte-americano, principalmente os ligados à economia de guerra. Por fim, o aumento dos déficits comerciais contribuem para saldos crescentemente negativos sob o conceito de exportações líquidas.

Gráfico 20. Estados Unidos. Produto Interno Bruto desagregado. Em bilhões de dólares correntes.

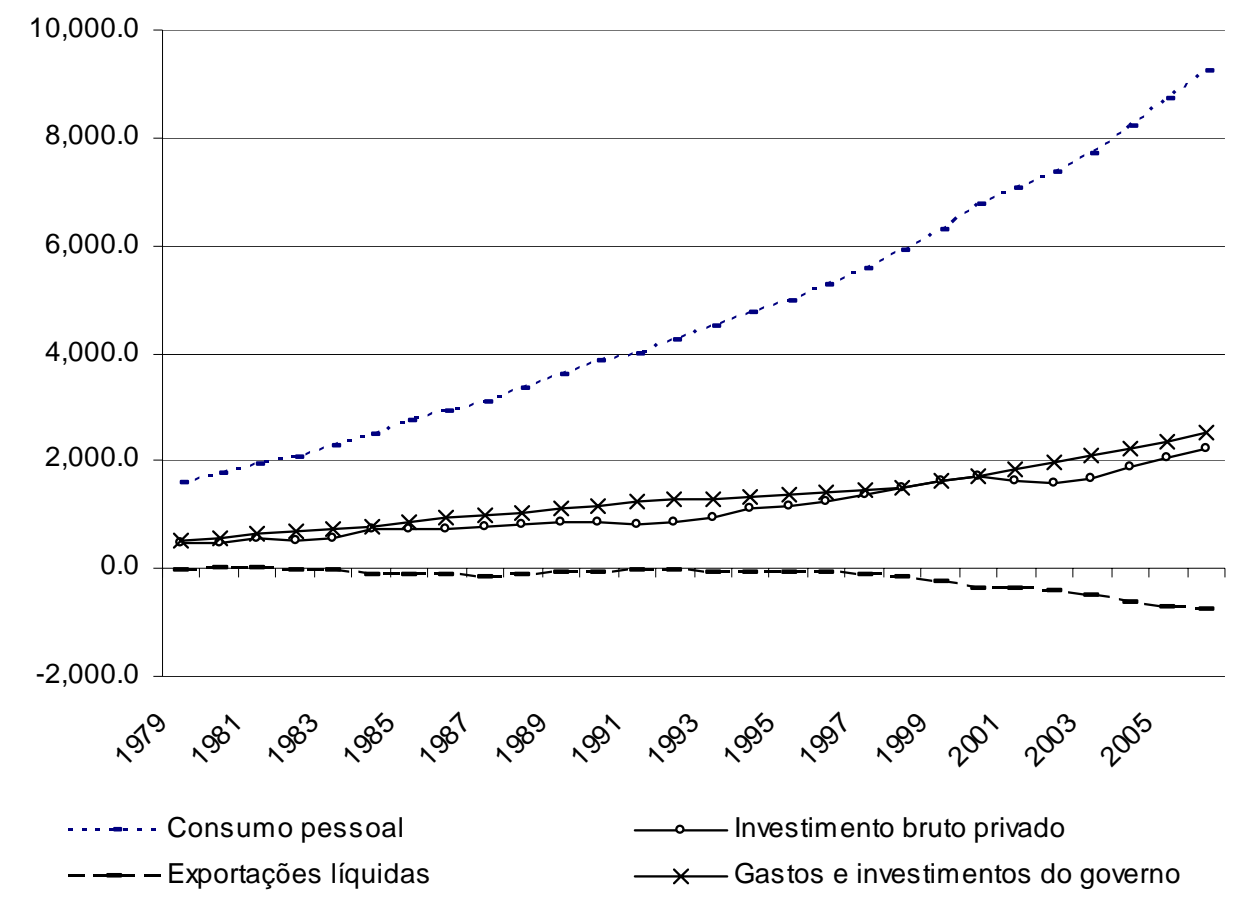

Fonte: NIPA-BEA. Seção I, Domestic Product and Income, Tabela 1.1.5., Gross Domestic Product.

Todavia, o comportamento dos investimentos e do consumo pode ser submetido a uma investigação mais específica, dentro da proposta das hipóteses assumidas. Primeiramente, observe-se a queda da propensão marginal ao investimento ao longo do tempo com a comparação de dois períodos: 1971-1985 e 1985-1999. A propensão marginal ao investimento pode ser entendida como sendo a relação que dá o nível de investimentos em uma economia ocorrido num tempo $\mathrm{t}$ dado um determinado valor da renda nacional (produto) num tempo anterior (t-1). Quanto menor fôr a propensão marginal ao investimento, menor estará sendo a influência do crescimento da renda nacional sobre o nível de investimentos. Uma possível formalização desta relação encontra-se na expressão: 


$$
\operatorname{Inv}_{\mathrm{t}}=\mathrm{a}+\text { PIB }_{\mathrm{t}-1} \mathrm{~b}
$$

Aí "b" é a relação marginal capital-produto ou propensão marginal ao investimento. Quanto menor "b", menor estará sendo a influência do crescimento do produto no nível de investimentos em uma determinada economia nacional. Vamos considerar aqui o hiato entre PIB e investimentos como sendo de um ano. Assim, a partir dos dados da tabela na seqüência, estimou-se a relação capital-produto para os dois períodos (1971-85 e 1985-99), a fim de traçar um comparativo.

Regressão (I)

15 observações (1971-1985, dados anuais; atraso de um ano de PIB face a investimentos)

$\operatorname{Inv}_{\mathrm{t}}=-30.090+0.14 \mathrm{PIB}_{\mathrm{t}-1}$ em que...

Inv $=$ investimentos em capital fixo

$\mathrm{PIB}=$ produto interno bruto

$\mathrm{R}^{2}: 0,99$

Durbin-Watson: 0,74

Regressão (II)

15 observações (1985-1999, dados anuais; atraso de um ano de PIB face a investimentos)

$\operatorname{Inv}_{\mathrm{t}}=14.966+0.12$ PIB $_{\mathrm{t}-1}$ em que...

Inv $=$ investimentos em capital fixo

$\mathrm{PIB}=$ produto interno bruto

$\mathrm{R}^{2}: 0,99$

Durbin-Watson: 1,96

Tabela 13. Estados Unidos. Investimentos em capital fixo e produto interno bruto. Em bilhões de dólares.

\begin{tabular}{|c|c|c|c|c|c|}
\hline (1) & $(2)$ & (3) & (4) & $(5)$ & (6) \\
\hline Anos & $\begin{array}{l}\text { Investimento em } \\
\text { Capital Fixo (Y1) }\end{array}$ & PIB (X1) & Anos & $\begin{array}{l}\text { Investimento em } \\
\text { Capital Fixo (Y1) }\end{array}$ & PIB (X1) \\
\hline 1970 & 106.7 & 1038.5 & 1985 & 506.7 & 4220.3 \\
\hline 1971 & 115.1 & 1127.1 & 1986 & 531.3 & 4462.8 \\
\hline 1972 & 126.5 & 1238.3 & 1987 & 561.9 & 4739.5 \\
\hline 1973 & 139.3 & 1382.7 & 1988 & 597.6 & 5103.8 \\
\hline 1974 & 162.5 & 1500.1 & 1989 & 644.3 & 5484.4 \\
\hline 1975 & 187.7 & 1638.3 & 1990 & 682.5 & 5803.1 \\
\hline 1976 & 205.2 & 1825.3 & 1991 & 725.9 & 5995.9 \\
\hline 1977 & 230 & 2030.9 & 1992 & 751.9 & 6337.7 \\
\hline 1978 & 262.3 & 2294.7 & 1993 & 776.4 & 6657.4 \\
\hline 1979 & 300.1 & 2563.3 & 1994 & 833.7 & 7072.2 \\
\hline 1980 & 343.1 & 2789.5 & 1995 & 878.4 & 7397.7 \\
\hline 1981 & 388.1 & 3128.4 & 1996 & 918.1 & 7816.9 \\
\hline 1982 & 426.9 & 3255.1 & 1997 & 974.4 & 8304.3 \\
\hline 1983 & 443.8 & 3536.7 & 1998 & 1030.2 & 8747.1 \\
\hline 1984 & 472.6 & 3933.2 & 1999 & 1101.3 & 9268.4 \\
\hline
\end{tabular}

Fonte: NIPA-BEA. Para investimentos em capital fixo, Seção 5, Saving and Investment, Tabela 5.1., Saving and Investment; para PIB, Seção 1, Domestic Product and Income, 1.1.5. Gross Domestic Product.

Os regressores "b" das equações acima podem ser lidos da seguinte maneira: para período 1 (1971-1985), uma elevação de um dólar do PIB em, por exemplo, 1971, acarretaria uma elevação de quatorze centavos em investimentos em 1972 na economia norte-americana. 
Para o segundo período (1985-1999), uma elevação de um dólar no PIB em, por exemplo, 1988, acarretaria uma elevação dos investimentos aproximada de doze centavos em 1989, e assim por diante. Isto pode ser interpretado, também, como uma queda do efeito acelerador ao longo dos anos. Quer dizer: os investimentos na economia norte-americana têm respondido cada vez menos a um aumento do produto nacional. Ou, sob outra maneira de ver, os investimentos em capital fixo têm sido cada vez menos responsáveis pelo crescimento da economia norteamericana.

O lugar das inversões foi ocupado por um aumento do consumo das famílias como modo de manter a demanda agregada ao longo do tempo. Tal queda na propensão marginal a investir foi compensada por (i) um aumento do volume de gastos das famílias e por (ii) um aumento da propensão ao consumo das famílias. ${ }^{102}$ A propensão marginal ao consumo pode ser entendida como a relação entre o comportamento dos gastos das famílias dado um determinado nível de renda ao longo do tempo, sob a forma de $\mathrm{C}=\mathrm{a}+\mathrm{bY}$. Aí " $\mathrm{b}$ " é a propensão marginal a consumir. Tomando os dois mesmos períodos (um anterior ao processo de endividamento externo e o outro referente a ele), têm-se, para a economia norte-americana, os seguintes valores de propensão marginal ao consumo para os seguintes valores de consumo e renda disponível:

\section{Regressão (I)}

15 observações (1970-1984)

$\mathrm{C}=26.086+0.75 \mathrm{Y}$

$\mathrm{C}=$ consumo

$\mathrm{Y}=$ renda disponível

$\mathrm{R}^{2}: 0,99$

Durbin-Watson: 1,48

Regressão (II)

15 observações (1985-1999)

$\mathrm{C}=-200.554+0.83 \mathrm{Y}$

$\mathrm{C}=$ consumo

$\mathrm{Y}=$ renda disponível

$\mathrm{R}^{2}: 0,99$

Durbin-Watson: 0,75

\footnotetext{
${ }^{102}$ Não são a mesma coisa. Um aumento do volume de gastos pode-se dar com uma queda da propensão marginal ao consumo, desde que o aumento do número de famílias consumindo seja suficiente para compensar a queda da propensão marginal a consumir.
} 
Tabela 14. Estados Unidos. Renda disponível e consumo pessoal. Em bilhões de dólares.

(1)

Anos

1970

1971

1972

1973

1974

1975

1976

1977

1978

1979

1980

1981

1982

1983

1984
(2)

Renda Pessoal

Disponível

838.8

903.5

992.7

1110.7

1222.6

1335.1

1474.8

1633.2

1837.7

2062.2

2307.9

2591.3

2775.3

2960.7

3289.5
(3)

Consumo Anos

$648.5 \quad 1985$

$701.9 \quad 1986$

$\begin{array}{ll}770.6 & 1987\end{array}$

$852.4 \quad 1988$

$933.4 \quad 1989$

$1034.4 \quad 1990$

$1151.9 \quad 1991$

$1278.6 \quad 1992$

$1428.5 \quad 1993$

$1592.2 \quad 1994$

$1757.1 \quad 1995$

$1941.1 \quad 1996$

$2077.3 \quad 1997$

$2290.6 \quad 1998$

$2503.3 \quad 1999$
(5)

Renda Pessoal

Disponível

3526.7

3722.4

3947.4

4253.7

4587.8

4878.6

5051.1

5362.1

5558.5

5842.5

6152.3

6520.6

6915.1

7423.1

7802.4
(6)

Consumo

2720.3

2899.7

3100.2

3353.6

3598.5

3839.9

3986.1

4235.3

4477.9

4743.1

4975.8

5256.8

5547.4

5879.5

6282.5

Fonte: NIPA-BEA. Seção 2, Personal Income and Outlays. Para renda disponível, Tabela 2.1, Personal Income and Its Disposition; para consumo, Tabela, 2.4.5. Personal Consumption Expenditures by Type of Product.

Houve, deste modo, uma elevação aproximada de $8 \%$ na propensão marginal ao consumo das famílias norte-americanas ao longo do período de endividamento externo. Porém, os valores atuais (2008) de propensão marginal ao consumo aproximam-se de 1, dada a quase ausência de poupança das famílias. ${ }^{103}$ Quer dizer, o aumento foi muito maior do que o sugerido pela diferença entre os dois valores estimados acima.

Assinalou Keynes: "Se é materialmente impraticável aumentar o investimento, torna-se evidente não haver outros meios de alcançar um nível maior de emprego além do de aumentar o consumo". ${ }^{104}$ A diminuição da propensão ao investimento conjugada com o endividamento externo conduziu então a um aumento do cômputo do consumo sobre o PIB. A divisão do consumo pessoal na economia norte-americana (colunas 3/6 da tabela referente ao consumo pessoal acima) pelos valores de investimento em capital fixo (colunas $2 / 5$ da tabela anterior referente ao investimento) fornece os dados plotados na figura a seguir. Nos capítulos seguintes vai-se analisar cada conjuntura desde o início da década de 1980, mas pode-se antecipar aqui claramente a inversão da tendência herdada desde a década de (19)70, e as conjunturas subseqüentes.

\footnotetext{
${ }^{103}$ Ver capítulo 10.

${ }^{104}$ A Teoria Geral do Emprego, do Juro e da Moeda, p.223-224.
} 
Gráfico 21. Estados Unidos. Relação entre consumo pessoal e investimentos em capital fixo. Calculado a partir de bilhões de dólares correntes.

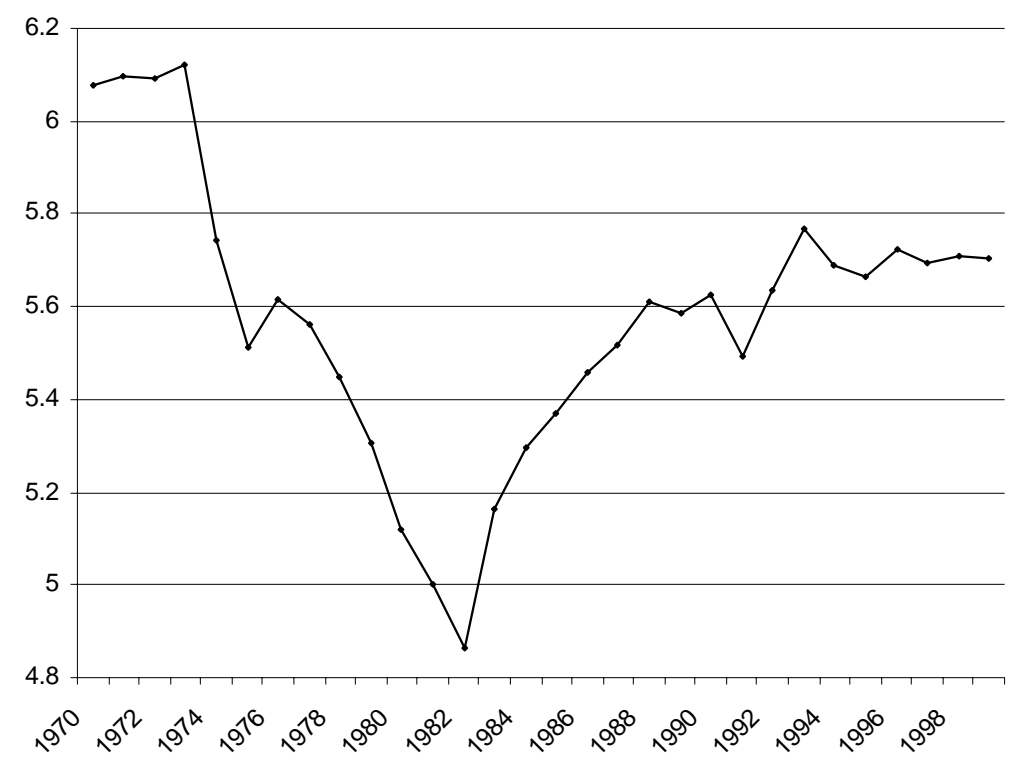

Fonte: NIPA-BEA. Para consumo, Seção 2, Personal Income and Outlays, Tabela, 2.4.5. Personal Consumption Expenditures by Type of Product. Para investimentos em capital fixo, Seção 5, Saving and Investment, Tabela 5.1., Saving and Investment;

O gráfico acima é uma boa maneira de ilustrar os períodos em que cai a taxa de investimento. Entre 1970 e 1980 a economia investia continuamente mais do que consumia, o que se refletia numa queda da relação consumo/investimento. Dadas as taxas de lucro maiores, investia-se uma parcela maior do produto. A relação consumo/investimento era de 6,07 em 1970, e estava em 5,12 em 1980. Todavia, as decorrências conjugadas dos (1) efeitos da crise dos (19)70 sobre o volume de investimentos com (2) o início do aumento do endividamento externo, levaram a relação consumo/investimento a crescer a partir de então, numa modificação da tendência histórica. O novo comportamento seguiu crescente até o fim da década de 1980. O aumento das exportações depois do Acordo do Plaza (1985), aliado ao aumento da lucratividade do capital na primeira metade da década de 1990, conduziu a um aumento da utilização da poupança nacional para fim de inversões, de modo a fazer a relação consumo/investimento diminuir sua trajetória de crescimento rápido.

A trajetória, porém, não caiu. Seu crescimento tornou-se mais vagaroso, mas continuou a crescer a relação consumo/investimento, mesmo durante o aumento da lucratividade nos anos (19)90. Sua queda face à tendência anterior reflete um maior investimento dos recursos domésticos. Ora, pode-se dar muito mais facilmente um crescimento do cômputo do consumo na renda nacional ao mesmo tempo em que as firmas aumentam o investimento, mediante o aumento da taxa de endividamento externo da economia. Principalmente porque o expediente permite manter mais baixas as taxas de juros, visto que aumenta a abundância dos recursos à disposição dos que consomem e investem. 


\subsection{A posição única dos Estados Unidos e do dólar na economia mundial}

A posição que os Estados Unidos detêm no circuito internacional do capital financeiro, e o papel de predomínio nas reservas mundiais que o dólar e os ativos financeiros nele denominados ocupam neste sistema - papel este inaugurado na Conferência de Bretton Woods (1945) e intensificado depois da crise deste padrão, no interlúdio (19)71-73 - explicam como é possível que a economia norte-americana responda com endividamento à queda da demanda agregada puxada pelos investimentos relativamente menores, opção que não é dada às outras economias industriais. O predomínio do dólar como moeda de reserva no mundo, catapultado depois que sua conversão face ao ouro foi cancelada em 1971, torna auto-evidente a facilidade que os agentes da economia norte-americana encontram para atrair recursos em dólar da economia mundial. Dá-se isto mediante a emissão de papéis denominados em sua própria moeda. Ao mesmo tempo, dada a dimensão do sistema financeiro do país, que ainda reflete o tamanho da economia, é evidente também que haverá uma correlação positiva entre o aumento dos depósitos estrangeiros feitos em seu sistema financeiro e a taxa interna de financiamento ao consumo, aos investimentos e aos gastos do Estado.

Em suma: a posição de destaque da moeda e a dimensão de seu sistema financeiro explicam porque a economia dos Estados Unidos pode responder à queda da demanda agregada com elevação da captação de recursos de fora de sua economia. É que todos os agentes da economia mundial acumulam reservas em dólar; e seu sistema financeiro, sendo o mais desenvolvido, mais complexo e maior, em termos absolutos, atrai não somente depósitos, mas sim todo tipo de demanda por serviços financeiros requerida pelo capital financeiro mundial. A condição de única potência militar é o pano de fundo, de cunho político-ideológico, que coroa a confiança dos agentes no dólar e nos títulos denominados em dólar. 
Conjunturas 
Antecedentes: balanço de pagamentos e Acordo de Bretton Woods

\begin{abstract}
"Senhor Presidente, nós, os Delegados desta Conferência, temos tentado obter algo muito difícil de obter. A nossa tarefa tem sido achar uma medida comum, um padrão comum, uma regra comum aceitável [a cada aspecto do arranjo financeiro e monetário internacional], e não dificultar a formulação de cada um deles."
\end{abstract}

John Maynard Keynes, em discurso na sessão plenária final da Conferência de Bretton Woods, em Junho de 1944.

\subsection{Introdução}

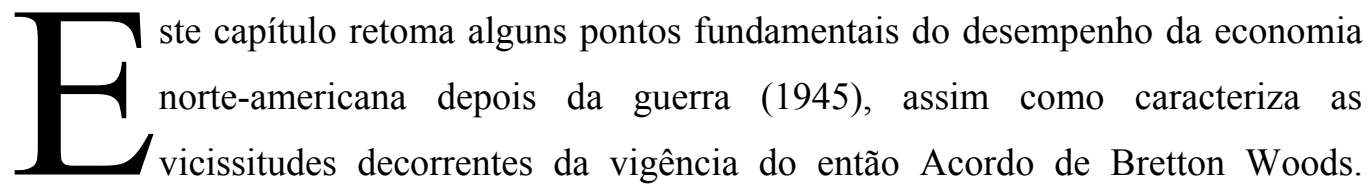

Depois, retomam-se as fontes que levaram este arranjo à crise, para discutir as novas condições em que o sistema monetário se encontra, de modo a favorecer a condução autônoma das políticas norte-americanas. Tenta-se argumentar que, assim como no período 1945-1973, a continuidade dos desequilíbrios do balanço de pagamentos norte-americano - agora sob a perspectiva de crescentes déficits em conta corrente - tem refletido as transformações gerais de sua estrutura econômica. E que, assim, mantidas tais transformações e tais desbalanços, não pode haver a construção de um novo regime de regulação monetária internacional mais seguro e organizado. Tal implicaria o abandono do próprio poder do dólar, e o abandono do modo pelo qual as políticas externas da economia se ajustam ao tipo de crescimento que a queda da lucratividade nos anos (19)70 the tem imposto. A crise de Bretton Woods e a inexistência de um novo arranjo simplesmente indicam, assim, que o (des)arranjo monetário internacional centrado no dólar são a melhor maneira, no que se refere à organização das finanças mundiais, que a economia norte-americana encontra para ajustar os fluxos financeiros internacionais ao seu tipo de crescimento, com base no endividamento externo, que a própria crise da lucratividade provocou.

\subsection{O panorama no pós-1945 e a conferência de Bretton Woods}

A partir da Primeira Guerra Mundial (1914-1918) os Estados Unidos tornaram-se de fato a economia mais industrializada do planeta. Com o conflito na Europa, puderam abandonar sua posição de antiga nação devedora da Europa para a posição de emprestadores líquidos. Como a Europa estava em conflito, as nações beligerantes tiveram de financiar seus gastos com 
dívidas externas e adquirir armamentos adicionais que apenas os Estados Unidos tinham condições de fornecer e produzir à época.

Ao longo dos anos (19)20 e (19)30, o país consolidou tal posição de credor mundial e de nação com o maior parque manufatureiro mundial, condição esta que atravessaria as duas próximas décadas (1940-60). Novamente, um segundo conflito mundial entre 1939 e 1945 favoreceu os norte-americanos. Livre seu território dos principais teatros de guerra, assistiram eles a (a) uma nova rodada de destruição física nos países que eram seus rivais econômicos potenciais (Alemanha, França, Inglaterra e União Soviética), (b) mais o endividamento destes (com exclusão do último) e (c) mais dependência das exportações dos europeus para com os próprios Estados Unidos.

Foi a vitória norte-americana em 1945, ao lado da União Soviética, que permitiu a conformação completa de um sistema de hierarquia entre as nações definitivamente sob controle dos Estados Unidos. O elemento "ideológico" - isto é, a reafirmação pelas burguesias locais na Europa, e mesmo pelos trabalhadores, do sistema capitalista - foi o cimento que estruturou as relações entre as grandes economias desde então. A presença dos Estados Unidos na Europa ocidental e Japão garantiu a manutenção do capitalismo em todos os grandes centros industriais. Por sua vez, o socialismo difundiu-se pela periferia da economia mundial.

As necessidades de reconstrução do Japão e da Europa ocidental explicam o rápido crescimento depois do conflito, impulsionado por uma grande participação seja de capitais dos Estados Unidos, seja de mercadorias norte-americanas exportadas. O rearmamento e a posterior regionalização das economias da Europa ocidental conduziram a Europa a uma grande prosperidade a partir dos anos (19)60. ${ }^{105}$ No então formado campo socialista, na região oriental da Europa, a reconstrução, sob a égide da então União Soviética, levou também à regionalização, mas com maiores dificuldades de integração. As necessidades da União Soviética levaram a uma muito menor disponibilidade de capital para outros países vizinhos, quando não, de início, a uma transferência líquida de capital de outros países à União Soviética. ${ }^{106}$

Desde então, os mecanismos políticos e econômicos de coordenação da economia mundial foram manipulados pelos Estados Unidos e aceitos, em maior ou menor grau, pelos países capitalista de "segunda ordem", fugindo-se de um tipo de atuação de molde imperialista entre eles. Restou inconteste a hegemonia dos Estados Unidos. Evidentemente, continuou havendo disputas no interior desse núcleo, porque as burguesias nacionais não foram extintas pelos Estados Unidos. A larga aplicação de medidas de planejamento e protecionismo econômico pelo Japão e Europa ocidental indicava que usariam o espaço de manobra concedido pelos Estados Unidos para diminuir, como pudessem, o hiato entre os respectivos poderes econômicos.

${ }^{105}$ Cf. BLOCK, Fred. Los Orígenes del desorden económico internacional.

${ }^{106}$ Ver ELLMAN, Michael. Planejamento Socialista. 
Todavia, as burguesias nacionais aceitaram a tutela norte-americana, porque simplesmente foram derrotadas ou destroçadas pelas conseqüências da Segunda Guerra Mundial. E a aceitação da "liderança" dos Estados Unidos foi catapultada pela existência do campo antagônico representado pela União Soviética. Esta era a ameaça a todo o sistema capitalista mundial, e que nenhuma potência capitalista de segunda ordem podia enfrentar sozinha. O campo socialista era infenso e inacessível ao mundo capitalista, representando perdas de áreas econômicas potenciais e ameaça a toda a ordem assentada sobre a propriedade privada. A proximidade geográfica com a Europa e o Japão tornaram praticamente inevitáveis os apelos das classes dirigentes dos países capitalistas aos Estados Unidos. ${ }^{107}$

Em suma: os Estados Unidos detinham o monopólio militar, o poder político para construir os arranjos financeiros internacionais, e o capital necessário para - por meio de empréstimos praticamente a fundo perdido - auxiliar a reativar as economias japonesa e Europeia. A América Latina, distante dos centros de "subversão", não logrou obter a mesma disponibilidade de capitais norte-americano, tendo sido a "Aliança para o Progresso", de John Kennedy uma versão muito reduzida do auxílio dado à Europa. No campo das armas, basta assinalar que os Estados Unidos ocuparam militarmente, de modo permanente, a então República Federal da Alemanha. O Japão também foi anulado militarmente. É correto afirmar, portanto, que quando do fim do conflito, os Estados Unidos estavam no auge de seu poderio político-econômico. A União Soviética, destruída em parte pela guerra, desfrutava de grande influência política - já que eram os primeiros responsáveis pela derrota da Alemanha no campo de batalha - mas economicamente estava muito debilitada, somando às perdas de vinte milhões de pessoas a avaria de seu parque fAbril e de terras cultiváveis.

O fim da guerra apresentou a necessidade da reconstrução dos países afetados e da organização do sistema financeiro internacional que propiciasse condições internacionais para tanto. Esta organização envolvia decidir: qual seria a moeda padrão utilizada nas transações internacionais a partir daquele momento? Manter-se-ia a libra esterlina no papel de moeda internacionalmente aceita, tal como tinha vigorado até ali? E quanto aos investimentos estrangeiros? Facilitá-los ou dificultá-los? Por sua vez: em relação às taxas de câmbio, seriam decididas pela livre flutuação, ou seriam fixas?

Estes arranjos do sistema financeiro internacional deram-se nas condições em que os Estados Unidos impuseram à maioria. Na chamada Conferência de Bretton Woods, realizada em 1944 no Hotel Mount Washington, em New Hampshire, Estados Unidos, decidiram-se quais seriam as regras de funcionamento das finanças internacionais a partir de então. Neste contexto, as autoridades norte-americanas valeram-se da desproporção de seu poderio face às outras nações para decidir as questões-chave. Assim, impuseram o uso do dólar como principal moeda referencial, moldando o funcionamento do recém-criado Fundo Monetário Internacional à lógica que lhes interessava: liberação de recursos mediante a obrigação de condicionalidades

${ }^{107}$ Cf. HOBSBAWM, Eric. A Era dos Extremos. Ver também MAZOWER, Mark. Continente Sombrio. 
restritivas. De fato, as propostas de John Maynard Keynes para o Fundo Monetário Internacional (FMI), e para a organização do sistema monetário internacional, haviam sido postas de lado pelos interesses norte-americanos. Basicamente, Keynes propunha uma maior autonomia nacional, com (1) sustentação dos déficits dos países com resultados negativos na balança comercial pelos países superavitários, (2) mais liberdade para a flutuação do câmbio e (3) a substituição do dólar pelo "Bancor", que seria emitida pelo FMI, como moeda internacional. Keynes queria com isso minorar o poder norte-americano sobre as políticas da Inglaterra; mas essa contenção do poder americano acabaria também servindo aos outros países filiados ao Fundo.

De qualquer modo, estabeleceram-se na Conferência dois pilares do que veio a ser chamado de o "Padrão Dólar-Ouro" do sistema monetário internacional: a) necessidade de que cada Banco Central estabelecesse uma taxa de câmbio fixa da moeda de seu país para com as outras, para diminuir as instabilidades entre elas e facilitar os cálculos de câmbio envolvidos com as trocas comerciais internacionais; b) "repressão às finanças internacionais", isto é, dificultar-se-iam os fluxos financeiros de curto prazo que buscassem investimentos de corte especulativo. Por regras legais estabelecidas na Conferência, foram desestimuladas a maior parte das finanças do pós-guerra que não buscassem investimentos duradouros, e que portanto servissem apenas para desestabilizar as taxas de câmbio e o ambiente macroeconômico, para fins de ganhos rápidos.

Era o crescimento econômico, sob égide dos interesses privados corporativos, que estava na meta daqueles formuladores de política econômica. Naquele momento, os Estados Unidos viam como urgente a reconstrução da Europa ocidental e do Japão, para frear a expansão do socialismo, que agora abarcava todos os países do Leste Europeu e que depois iria ser vitorioso na China, em 1949. Um grande protecionismo comercial na Europa e Japão, ainda que indesejado pelas autoridades dos Estados Unidos, foi também aceito. Os planos econômicos estadunidenses de ajuda à Europa e Japão - os Planos Marshall e Colombo - devem ser entendidos nesta perspectiva. As outras regiões do planeta, também dependentes de auxílio internacional, foram muito menos privilegiadas, devido à distância que mantinham da influência soviética.

Assim, a moeda imposta nas regras que constam da criação do FMI foi o dólar. Deste modo, a criação da necessária liquidez internacional foi feita menos à base de empréstimos deste órgão do que por maciças inversões norte-americanas em outros países. Ao mesmo tempo, no período pós-guerra, tornou-se difícil reduzir os gastos militares norte-americanos no exterior, dadas as pressões da guerra-fria e os conflitos que os Estados Unidos criaram. Por exemplo, em 1959, para uma renda nacional de 506 bilhões de dólares, os gastos com "defesa", um eufemismo para as agressões externas, atingiram 53 bilhões. O comércio e a guerra criariam a 
"liquidez" internacional que posteriormente pressionaria por liberalizações das "contas de capital" em âmbito mundial. 108

Assegurando o poder liberatório do dólar em âmbito mundial, o controle do Fundo Monetário Internacional e o monopólio militar entre as potências aliadas, as autoridades norteamericanas asseguravam a imposição da hegemonia sobre as potências de segunda ordem e sobre a maior parte da periferia capitalista, depois da vitória em 1945. Assim, o dólar foi elevado, contrariamente ao que propôs Keynes, à condição de única reserva de valor de que os Bancos Centrais poderiam se valer, além do ouro. As autoridades norte-americanas não podiam deixar de impor ao mundo a condição de este realizar investimentos e comércio ou em ouro ou em dólares. Os dólares eram de impressão do próprio governo federal; o ouro, os Estados Unidos dispunham quase que exclusivamente, dado que tinham se tornado credores da Europa desde o fim da Primeira Guerra Mundial, condição que se aprofundou ao longo do segundo conflito mundial.

\subsection{O crescimento do pós-guerra}

Observaram os autores da obra Breve História dos Estados Unidos:

"Qual a explicação para a prosperidade do pós-guerra? Em parte, a acelerada produção de bens depois de cinco anos de guerra; em parte, o mercado para [bens] excedentes norte-americanos, assegurado pelo programa de ajuda e reconstrução no estrangeiro; em parte, o explosivo aumento das inversões privadas; em parte, a continuação de grandes gastos do governo [no setor militar, poder-se-ia completar V.E.S.]." 109

Como resultado destas articulações, deu-se grande crescimento econômico no mundo capitalista do pós-guerra, puxado por um enorme deslocamento de capitais estadunidenses em direção às regiões da Europa ocidental e Japão, pela reconversão de parte do parque produtivo para a produção civil e pela descompressão dos salários, situados num nível baixo em todos os países beligerantes. Lembre-se que, como mostraram as proxies de taxa de lucro construídas no capítulo anterior, as taxas se mostravam excessivamente altas no período da guerra, e no imediatamente pós-guerra, justamente pela manutenção dos salários num índice baixo.

O consumo das famílias conseqüentemente se elevou enormemente depois da permissão à elevação dos salários. De fato, nos Estados Unidos, o início da reativação econômica pela produção de guerra puxou para cima os salários, deprimidos pela estagnação da década de (19)30. Quando a guerra terminou, os salários caíram em 1946, mas logo em seguida passaram

\footnotetext{
${ }^{108}$ Para uma descrição pormenorizada destes eventos, conferir BLOCK, Fred. op. cit.

${ }^{109}$ MORISON, Samuel; COMMAGER, Henry S.; LEUCHTENBURG, William E.. Breve historia de los Estados Unidos, p.744.
} 
a crescer rapidamente (ver figura abaixo). As exportações de mercadorias dos Estados Unidos em direção a estas regiões em grande crescimento também cresceu. Em fins da década de (19)50, assim que as economias da Europa ocidental e do Japão se reativaram, as medidas de contenção das taxas fixas de câmbio e de protecionismo no comércio exterior passaram a ser relaxadas.

Gráfico 1. Salários nos Estados Unidos. Em milhões de dólares correntes. 1929-1945.

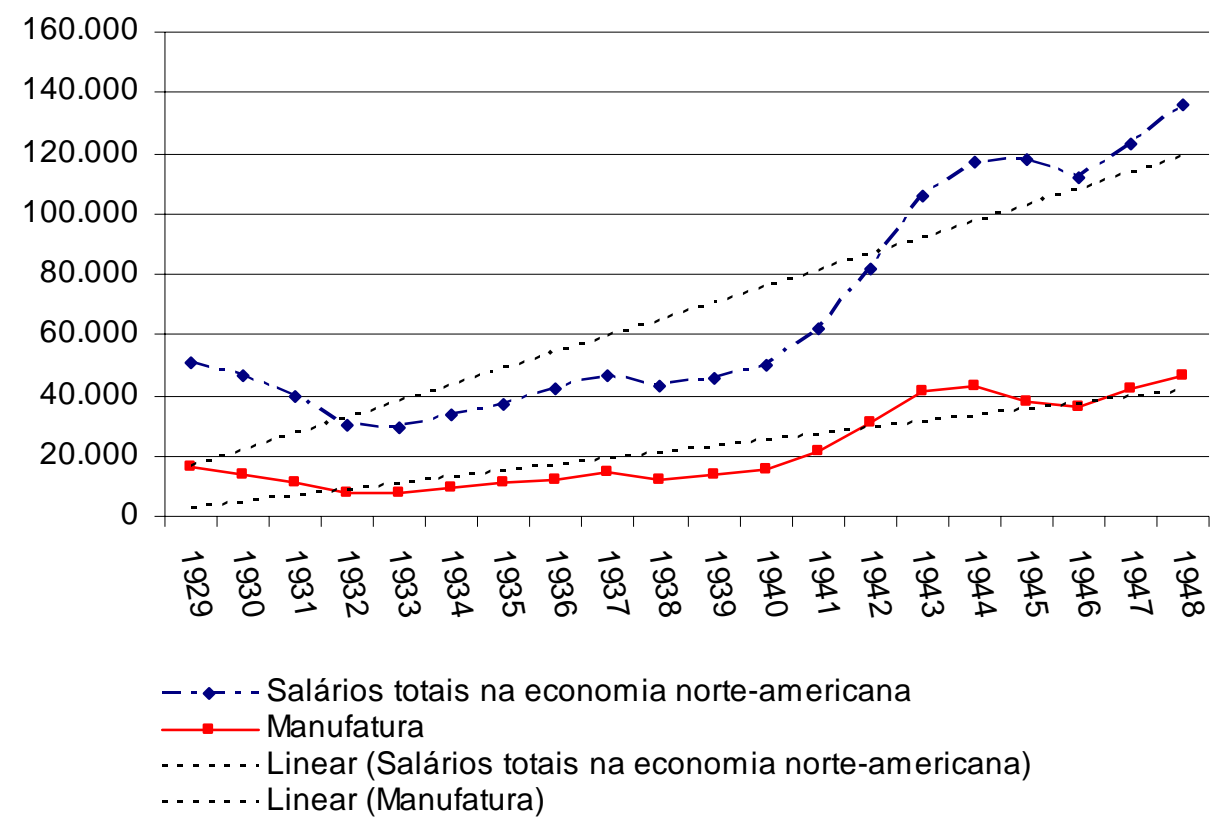

Fonte: NIPA-BEA. Seção 6, Income and employment by industry, Tabela 6.2A e 6.2.B,. Compensation of Employees by Industry.

Estas medidas de reativação da economia internacional, em âmbitos multilaterais, eram também necessárias à economia dos Estados Unidos devido à forte queda das inversões na indústria militar, com o fim da guerra. A percepção de que as inversões bélicas eram necessárias, junto da reativação do comércio internacional, para conter as tendências à estagnação, reforçou-se no pós-1945. Ela foi percebida nitidamente no fim dos anos (19)30, naquele contexto de crise. Realmente, os níveis de inversão no complexo industrial militar, depois da queda nos anos (19)30, elevaram-se rapidamente nos anos (19)50. Por isso a Guerra na Coreia, em 1950, representou um desafogo adicional à economia norte-americana, altamente dependente da produção militar naquele momento. Ao mesmo tempo, abriu possibilidades adicionais para as exportações do Japão. Com o desenrolar da Guerra Fria “...cada vez mais as instituições norte-americanas - o governo, as empresas, a universidade, as fundações - foram postas ao serviço da Guerra Fria; a economia chegou a ser uma arma em guerra." 110

${ }^{110}$ MORISON, Samuel; COMMAGER, Henry S.; LEUCHTENBURG, William E.. Breve historia de los Estados Unidos, p.742. 
Gráfico 2. Estados Unidos. Gastos do governo federal discriminados: defesa e não-defesa. 19441960. Em bilhões de dólares.

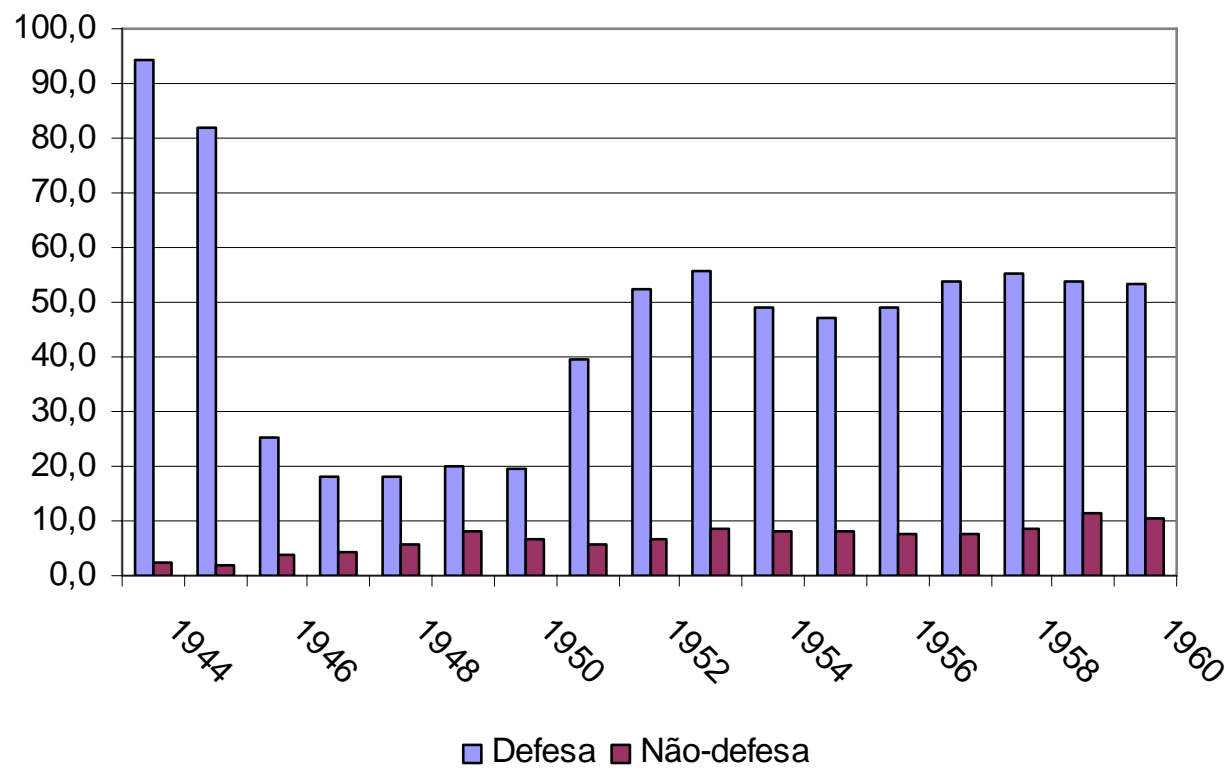

Fonte: NIPA-BEA. Seção 3, Government Current Receipts and Expenditures, Tabela 3.9.5, Government Consumption Expenditures and Gross Investment.

Assim, durante todo o hiato 1945-1970, os saldos na balança comercial norte-americana foram positivos (ver figura seguinte), refletindo a forte demanda por bens finais e por meios de produção de seus principais parceiros comerciais. Ao mesmo tempo, foi característica do balanço de pagamentos dos Estados Unidos até fins dos anos (19)60 uma grande saída de capitais em direção aos países convertidos em seus aliados, em forma de investimentos diretos. "Como o superávit na balança comercial dos Estados Unidos aumentasse depois de 1960, o desequilíbrio norte-americano-europeu veio a ser considerado sobretudo como um problema de fluxo de capital. Havia uma tendência - por numerosas razões, cíclicas ou estruturais - a considerar excessiva a saída da capitais privados dos Estados Unidos". ${ }^{111}$ Houve então um enorme movimento de ocupação de espaços econômicos das firmas norte-americanas no exterior, principalmente na Europa. Isto suscitou, principalmente de parte de autoridades francesas, uma grande discussão sobre a desnacionalização na Europa.

A saída de capitais produtivos naquele momento foi de natureza diferente da saída de capitais atual; naquele momento, os Estados Unidos exportavam capital produtivo porque lembrando de novo $O$ capital monopolista de Sweezy e Baran - o crescimento doméstico era tão rápido que ele proporcionava uma quantidade de excedentes suficientes para ser aplicada no exterior, sem prejuízo para a acumulação doméstica. Hoje, como tais capitais são relativamente menos lucrativos, deixa-se aos poucos de reinvesti-los domesticamente para investir no exterior. De modo esquemático, antes os lucros eram muito grandes para o capital - alta taxa de lucro -; hoje, o capital é muito grande para os lucros - baixa da taxa de lucro.

${ }^{111}$ SOLOMON, Robert. O Sistema Monetário Internacional, p.78. 
Até o momento em que as taxas de crescimento relativo da economia norte-americana verificavam-se mais ou menos altas - até o fim da década de (19)70, como se viu na introdução - os Estados Unidos permaneceram sendo uma economia que exportava poupança, em termos líquidos. As taxas de lucro eram mais altas, e por conseqüência a formação relativa de poupança doméstica originada por tais investimentos; o setor manufatureiro era relativamente muito maior relativamente ao produto, e parte da poupança não era reinvestida, sendo assim reexportada, na forma de investimentos diretos, empréstimos, gastos militares, dentre outros. E, como decorrência direta neste momento, "a característica mais destacada sobre este balanço é provavelmente a grande diferença entre nossas importações e as exportações de bens e serviços. Os estrangeiros compraram muito mais [dos EUA] do que compramos deles. A diferença foi compensada em maior parte pela ajuda externa e pelos gastos militares [no exterior]." 112

Como tal, anteriormente ao desencadeamento do processo de endividamento externo líquido, as contas externas mostravam, fundamentalmente, uma balança comercial positiva, e uma conta de capitais negativa, que expressavam, em primeiro lugar, a posição de exportador líquido de capitais, e, em segundo, a grande participação das exportações norte-americanas na economia mundial. A posterior exportação de capitais produtivos a partir dos Estados Unidos e a transformação da balança comercial de superavitária em deficitária, o outro lado de uma conta de capitais crescentemente superavitária, refletiriam assim a crescente dificuldade de produção de poupança doméstica, instaurada a partir da crise da lucratividade nos anos (19)70. Uma forte expansão do comércio exterior e uma grande colocação de capital em seus países aliados foram assim duas características do comportamento externo dos Estados Unidos no período anterior à crise da lucratividade em meados dos anos (19)70. Isto se refletiu nos resultados de conta corrente do balanço de pagamentos, que registrou saldos líquidos até fins dos anos (19)60, principalmente mediante saldos positivos na balança comercial. Nesse ínterim, os ativos norteamericanos no exterior cresceram a uma velocidade maior do que os ativos estrangeiros em seu próprio país.

\footnotetext{
112 "The most striking thing about this balance is probably the large gap between exports and imports of goods and services. Foreigners bought far more from us than we bought from them. The difference was made up largely by our gifts and military aid." HARRIS, C. Lowell. The American Economy, p.579.
} 
Gráfico 3. Estados Unidos. Balanço de Pagamentos entre 1960-1969. Em milhões de dólares.

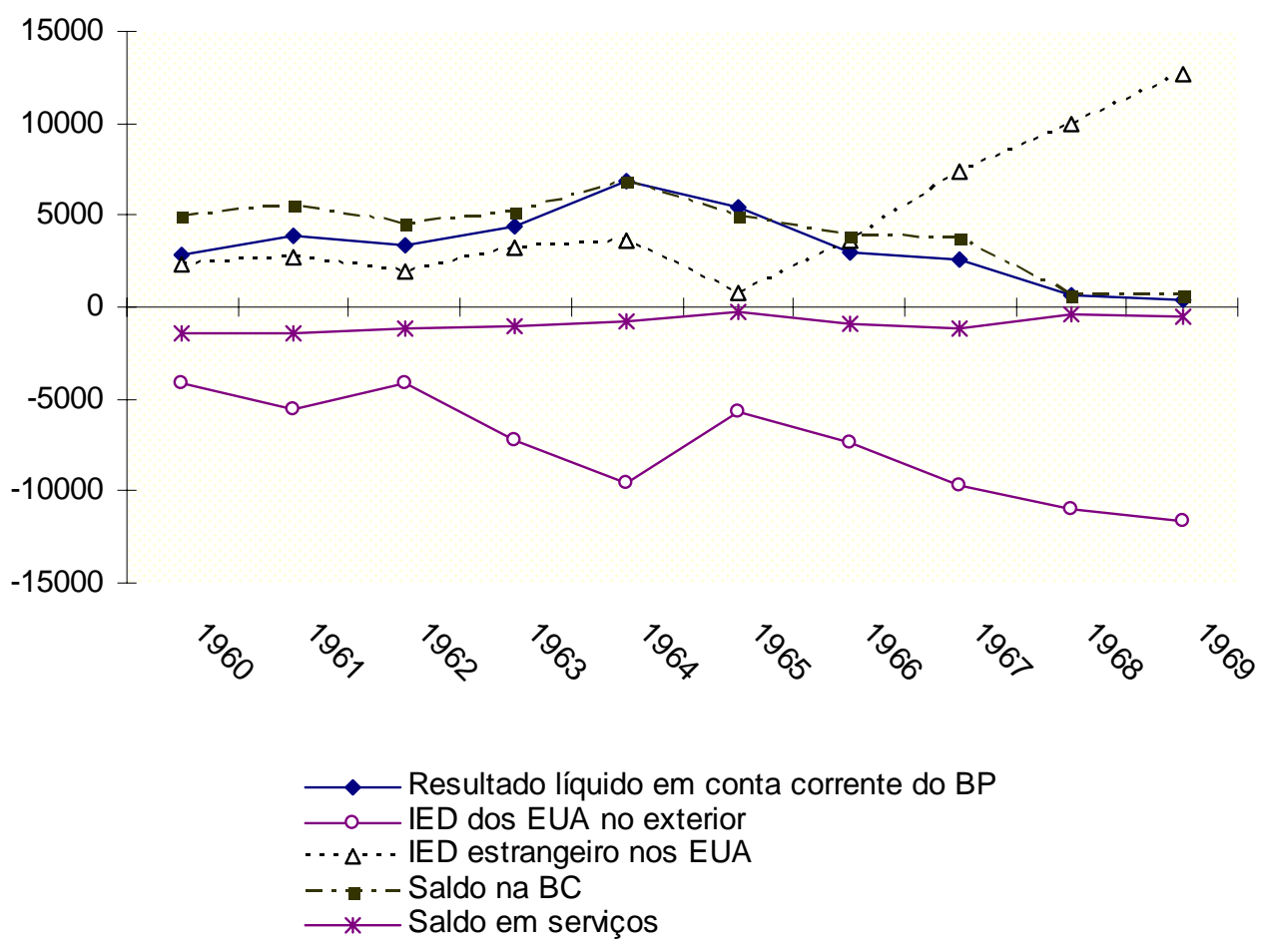

Fonte: BEA. Tabela 1, U.S. International Transactions.

O próprio resultado global do balanço de pagamentos - a soma de todas as transações econômicas dos Estados Unidos com o exterior - registrou sucessivos saldos negativos. Havia mais compromissos a pagar no exterior do que a receber, apesar de quase sempre a renda dos investimentos no exterior ser superior aos próprios recursos que deixavam o país. Os Estados Unidos estavam gastando demais com a militarização e combate ao socialismo fora de seu território, na forma de bases militares, tropas estacionadas em fronteiras estratégicas, e "ajuda externa", isto é, programas de auxílio a países do Terceiro Mundo vinculados ao combate aos movimentos socialistas.

Estes saldos negativos foram cobertos com as vantagens que as regras do padrão dólarouro conferiam aos Estados Unidos: pagamentos mediante reservas de ouro ou endividamento de curto prazo, em papéis denominados em dólar. Isto é: os Estados Unidos podiam mais pagar do que receber ao exterior, porque dispunham de muitas reservas de ouro e porque podiam imprimir a moeda de aceitação internacional. Esta era a vantagem que Keynes queria evitar, tornando as relações econômicas mais favoráveis às nações menos ricas. Como resultado, os países estrangeiros começaram a acumular rapidamente dólares e títulos em dólar, de modo que "a conversão de dólares por ouro [era] uma constante fonte de preocupação para as autoridades norte-americanas". 113

113 "The conversion of dollars into gold is a constant source of concern to the American Authorities". HARRIS, Seymour. The Dollar in Crisis, p.4. 
Gráfico 4. Estados Unidos. Médias de crescimento do produto interno bruto por década (\%).

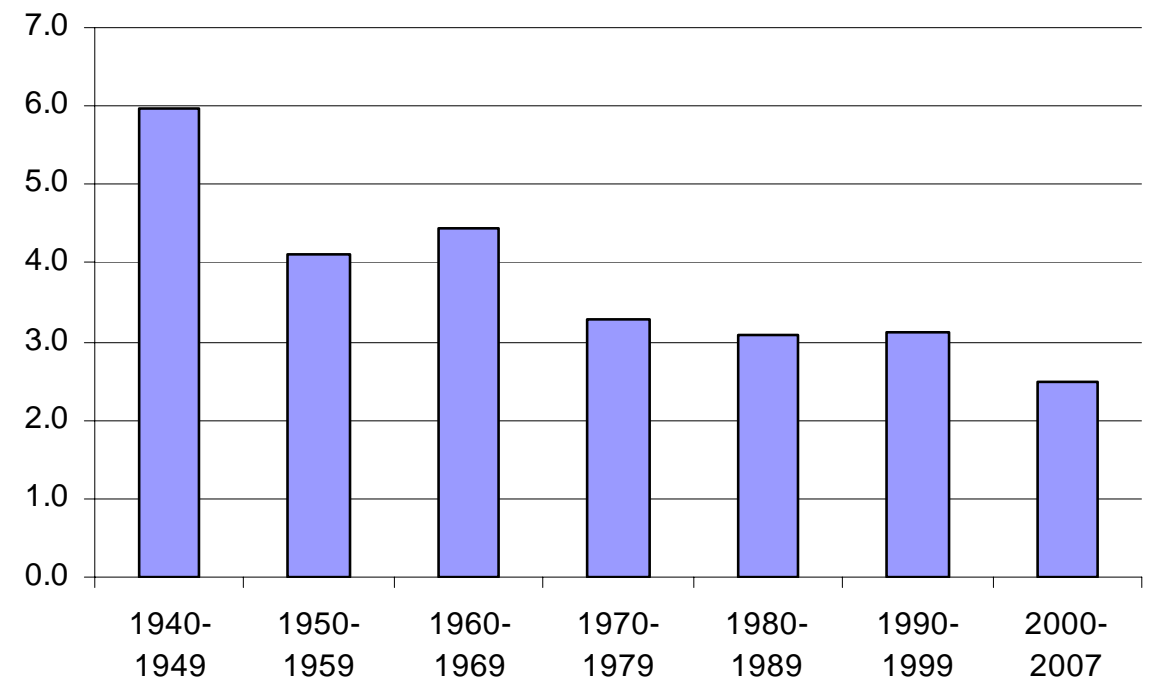

Fonte: NIPA-BEA. Seção 1, Domestic Product and Income, Tabela 1.1.1. Percent Change From Preceding Period in Real Gross Domestic Product. .

Como afirmou o presidente Kennedy à época, a conseqüente e crescente pressão sobre o dólar, causada pelo próprio arranjo de Bretton Woods, forçaria necessariamente um ajuste do balanço de pagamentos dos Estados Unidos, no sentido de ajustar as fugas de capitais para tentar-se diminuir os déficits globais. O que por sua vez manteria o valor internacional do dólar. Nas palavras do presidente Kennedy, "isto significa que os Estados Unidos precisam, nas décadas à frente, muito mais do que em qualquer época passada, levar em conta o ajuste de seu balanço de pagamentos ao formular suas políticas econômicas e conduzir suas relações exteriores." ${ }^{114}$ Não é difícil perceber que as autoridades não aceitariam então tal restrição externa à condução das políticas domésticas.

Dada a continuidade das pressões sobre o dólar, devido à manutenção das saídas de capital dos Estados Unidos, mas dada também a importância para os Estados Unidos de manter o papel do dólar, "o elenco de artifícios aos quais recorreram as administrações Kennedy e Johnson tornou-se, inquestionavelmente, motivo de grande embaraço. Elas admitiam a gravidade do problema do dólar, embora demonstrassem uma disposição para atacar apenas os sintomas, e não as causas." ${ }^{115}$ As pressões sobre o dólar iriam acumular-se cada vez à medida que os anos (19)60 terminavam.

\footnotetext{
${ }^{114}$ Citado por HARRIS, Seymour, op. cit. , p.5.

${ }^{115}$ EICHENGREEEN, Barry. A globalização do capital, p.75.
} 
Tabela 1. Estados Unidos. Balanço de Pagamentos. 1951-1961. Em bilhões de dólares.

\begin{tabular}{lcccccc}
\hline \multicolumn{7}{c}{ Balanço de Pagamentos dos EUA entre 1951 e 1961 } \\
& Média & Média & 1958 & 1959 & 1960 & 1961 \\
& $1951-55$ & $1956-60$ & & & & \\
Conta corrente e transferências & 0,6 & 0,8 & $-0,1$ & $-2,3$ & 1,5 & 2,4 \\
unilaterais & 2,4 & 3,9 & 3,8 & 1 & 4,7 & 5,5 \\
Balanço em bens tangíveis & $-2,1$ & $-2,8$ & $-3,1$ & $-2,8$ & $-2,7$ & $-2,5$ \\
Gastos militares & 1,6 & 2,2 & 2,2 & 2,2 & 2,3 & 2,7 \\
Juros e Dividendos & $-2,1$ & $-1,6$ & $-1,6$ & $-1,6$ & $-1,6$ & $-1,9$ \\
Auxílios não-militares & $-0,9$ & -3 & $-3,5$ & $-2,1$ & $-3,4$ & $-2,5$ \\
& $-0,7$ & $-1,6$ & $-1,1$ & $-1,4$ & $-1,7$ & $-1,7$ \\
Conta de capital (longo prazo) & $-0,2$ & $-0,1$ & $-1,4$ & $-0,9$ & $-0,9$ & $-0,6$ \\
Investimento Direto & $-0,02$ & $-0,8$ & -1 & $-0,4$ & $-1,1$ & $-0,7$ \\
Outros investimentos privados & 0,2 & 0,4 & $\ldots$ & 0,6 & 0,3 & 0,4 \\
Empréstimos oficiais & & & & & & \\
Investimento direto nos Estados & $-1,4$ & $-2,2$ & $-3,6$ & $-4,3$ & $-1,9$ & $-0,1$ \\
Unidos & $-1,2$ & $-2,3$ & $-3,5$ & $-3,7$ & $-3,9$ & $-1,5$ \\
Balanço das Contas Básicas & & & & & & \\
Balanço Global com erros e & & & & & & \\
omissões & & & & & & \\
& & &
\end{tabular}

Fonte: Economic Report of the President de 1962. Nota: Sinais negativos indicam pagamentos ao exterior.

Tabela 2. Estados Unidos. Balanço de Pagamentos. 1961-1967. Em bilhões de dólares. Fonte: Economic Report of the President de 1968.

\begin{tabular}{|c|c|c|c|c|c|c|c|}
\hline & 1961 & 1962 & 1963 & 1964 & 1965 & 1966 & 1967 \\
\hline Bens e Serviços & 5,5 & 5 & 5,9 & 8,5 & 6,9 & 5,1 & 5,4 \\
\hline Comércio de Bens & 5,4 & 4,4 & 5,1 & 6,7 & 4,8 & 3,7 & 4,3 \\
\hline Gastos militares líquidos & $-2,6$ & $-2,4$ & $-2,3$ & $-2,1$ & $-2,1$ & $-2,8$ & $-3,1$ \\
\hline Outros Serviços & 2,6 & 3,1 & 3,1 & 3,9 & 4,2 & 4,3 & 4,1 \\
\hline Conta de Capitais & $-2,8$ & -3 & $-3,6$ & $-3,6$ & $-3,4$ & $-3,4$ & $-4,2$ \\
\hline Auxílios do governo & $-4,2$ &,- 034 & $-4,5$ & $-6,5$ & $-3,7$ & $-4,2$ & $-5,1$ \\
\hline $\begin{array}{l}\text { Capital Privado dos EUA } \\
\text { (IED) } \\
\text { Capitais Estrangeiros (IED } \\
\text { nos EUA) }\end{array}$ & $-0,7$ & 1 & 0,7 & 0,7 & 0,3 & 2,5 & 3,9 \\
\hline Balanço em base líquida & $-2,4$ & $-2,2$ & $-2,7$ & $-2,8$ & $-1,3$ & $-1,4$ & $-2,3$ \\
\hline $\begin{array}{l}\text { Balanço na base de } \\
\text { transações de reservas } \\
\text { oficiais }\end{array}$ & $-1,3$ & $-2,7$ & -2 & $-1,5$ & $-1,3$ & 0,2 & $-2,9$ \\
\hline $\begin{array}{l}\text { Variação de ouro } \\
(\text { decréscimo têm sinal +) }\end{array}$ & 0,9 & 0,9 & 0,5 & 0,1 & 1,7 & 0,6 & 0,2 \\
\hline Moedas conversíveis (idem) & $-0,1$ & $\ldots$ & $-0,1$ & $-0,2$ & $-0,3$ & $-0,5$ & 0,2 \\
\hline $\begin{array}{l}\text { Posições no FMI (idem) } \\
\text { Endividamento externo com }\end{array}$ & $-0,1$ & 0,6 & $\ldots$ & 0,3 & $-0,1$ & $\begin{array}{l}-0,5 \\
-0,8\end{array}$ & $\ldots$ \\
\hline $\begin{array}{l}\text { instituições monetárias } \\
\text { estrangeiras oficiais } \\
\text { (aumento = sinal positivo) }\end{array}$ & 0,7 & 1,2 & 1,7 & 1,4 & 0,1 & & 2,6 \\
\hline
\end{tabular}

Nota: Sinais negativos indicam pagamentos ao exterior. Obs.: Para 1967, os dados referem-se aos três primeiros bimestres. 
Gráfico 5. Estados Unidos. Investimento estrangeiro direto norte-americano no exterior e investimento estrangeiro direto nos Estados Unidos. 1960-1980. Em milhões de dólares.

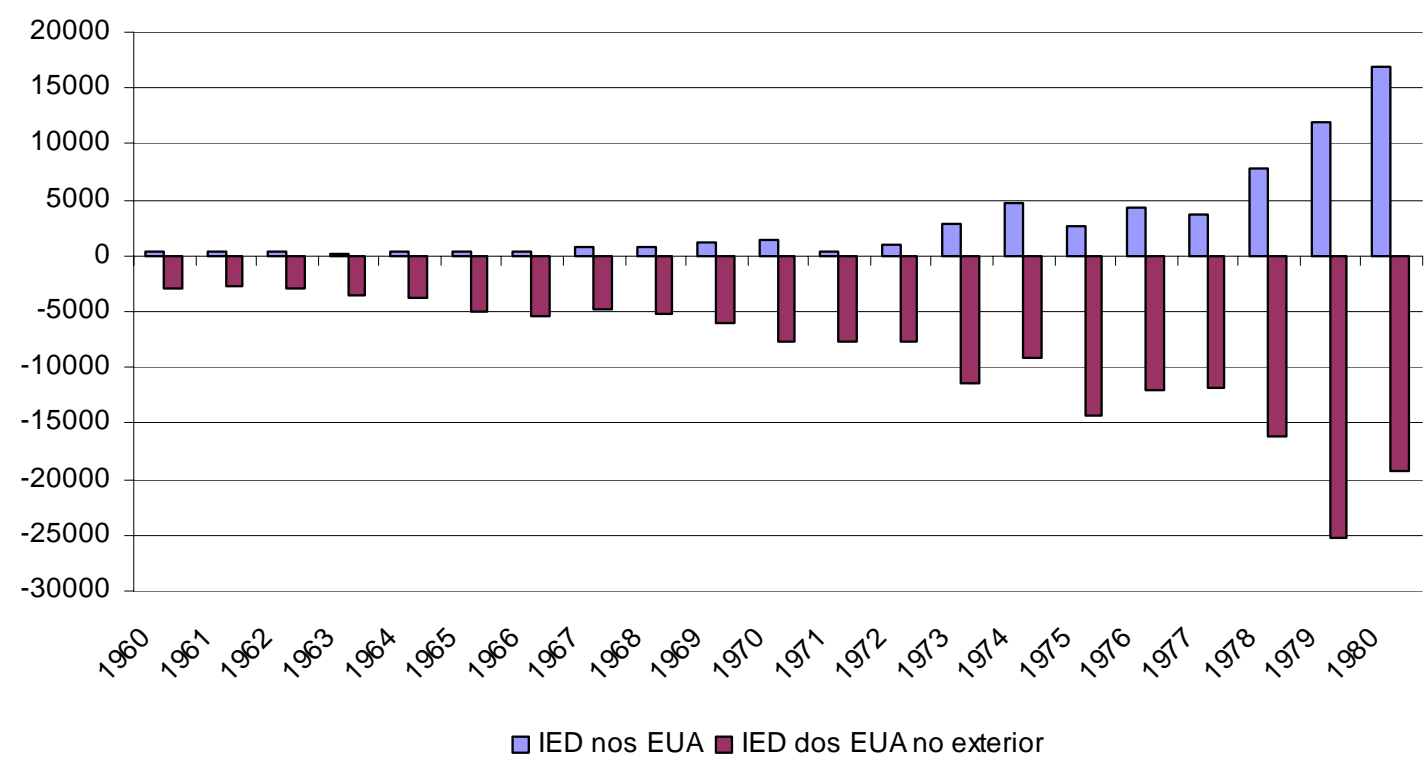

Fonte: NIPA-BEA, Seção 4 - Foreign Transactions, Tabela 4.1., Foreign Transactions in the National Income and Product Accounts.

\subsection{Transformações nos anos (19)70}

Entre 1945 e o início dos anos (19)70, os Estados Unidos foram então os grandes fornecedores de capital e exportações à economia mundial. Tal como indicado, neste período, seu balanço de pagamentos indicava superávits em conta corrente e déficits na conta de capitais. Quer dizer: a colocação de capital norte-americano no exterior era financiada com exportação de bens e serviços, sendo o hiato entre eles coberto em maior parte com ouro ou emissão de títulos. Neste momento, durante o qual vigorava o padrão dólar-ouro, os Estados Unidos cumpriram o papel de fornecer capital e mercadorias à Europa ocidental e ao Japão, em sua política de isolamento do campo socialista. Tal por sua vez catapultou o forte crescimento destas duas nações. De modo geral, o resultado global do balanço de pagamentos foi negativo, sendo coberto o hiato com variação de reservas em ouro e endividamento de curto prazo, já em papéis denominados em dólar. ${ }^{116}$

O governo dos Estados Unidos já dispunha, portanto, do expediente de financiar seus gastos com emissão de títulos em dólar. A diferença crucial, porém, é (1) a profundidade com que seria capaz de exercê-lo após 1973; e (2) a necessidade para tanto, após a crise da lucratividade no mesmo período. Quer dizer: este mecanismo de endividamento, via emissão de títulos denominados em dólar, estava limitado pela preferência dos Bancos Centrais em acumular ouro ao invés de dólares (ou papéis que tinham dólar como referência), e pelo bom desempenho da economia em si mesmo, que não gerava um problema de escassez relativa de

${ }^{116}$ Os Economic Report of the President ilustram fartamente esta situação; ver por exemplo a edição de 1962. 
formação de poupança doméstica. Foi apenas depois do rompimento das regras de Bretton Woods que os Estados Unidos, eliminando o papel do ouro, iriam aprofundar seu uso desta vantagem. $\mathrm{Na}$ verdade, as rápidas transformações da economia mundial neste período agitado iriam levar a uma enorme mudança neste papel da economia norte-americana face ao mundo, de supridores de mercadorias e capital.

Naquele momento, a grande concentração de dólares na Europa e Japão fazia crescer a dificuldade para a manutenção da paridade fixa entre o ouro e o dólar, já que as pressões sobre o dólar, para trocas em ouro, se acumulavam cada vez mais diante do Forte Knox. Havia expectativas de uma grande desvalorização do dólar. O governo norte-americano, à época presidido por Richard Nixon, respondeu desvalorizando-o, cancelando a conversão de dólares por ouro para instituições e agentes privados, e posteriormente rompendo sua paridade com o ouro, em 1973, para instituições oficiais. ${ }^{117}$ As elevações do preço do petróleo em 1974 culminaram em grande concentração de capitais depositados em bancos norte-americanos e ingleses, tornando irresistível, à administração dos Estados Unidos, utilizá-la em favor de uma abertura e liberalização das contas de capital das outras economias. Isto com o fito de reforçar o papel das próprias finanças norte-americanas e assim o papel de sua moeda.

Os acontecimentos dos anos (19)70 não se resumiram, portanto, na simples quebra de convenções estabelecidas em 1945, como as taxas fixas de câmbio ou a regulação dos sistemas financeiros nacionais. Eles foram vistos pelas autoridades norte-americanas como possibilidades de, eliminando a "repressão financeira" típica das políticas inspiradas em Keynes, fazer penetrar as finanças norte-americanas nos até então protegidos e regulados sistemas financeiros nacionais. Liberalizadas as contas de capital, as finanças norte-americanas atrairiam irresistivelmente os excedentes econômicos das economias periféricas, que passariam a orbitar em torno delas.

${ }^{117}$ Uma boa narração destes eventos encontra-se em EATWELL, John, e TAYLOR, John, Finanças Globais em Risco - um análise a favor da regulação internacional (2005), principalmente p.51 e subseqüentes. 
Gráfico 6. Estados Unidos. Poupança bruta doméstica e investimento bruto doméstico. Em bilhões de dólares correntes. 1940-1970.

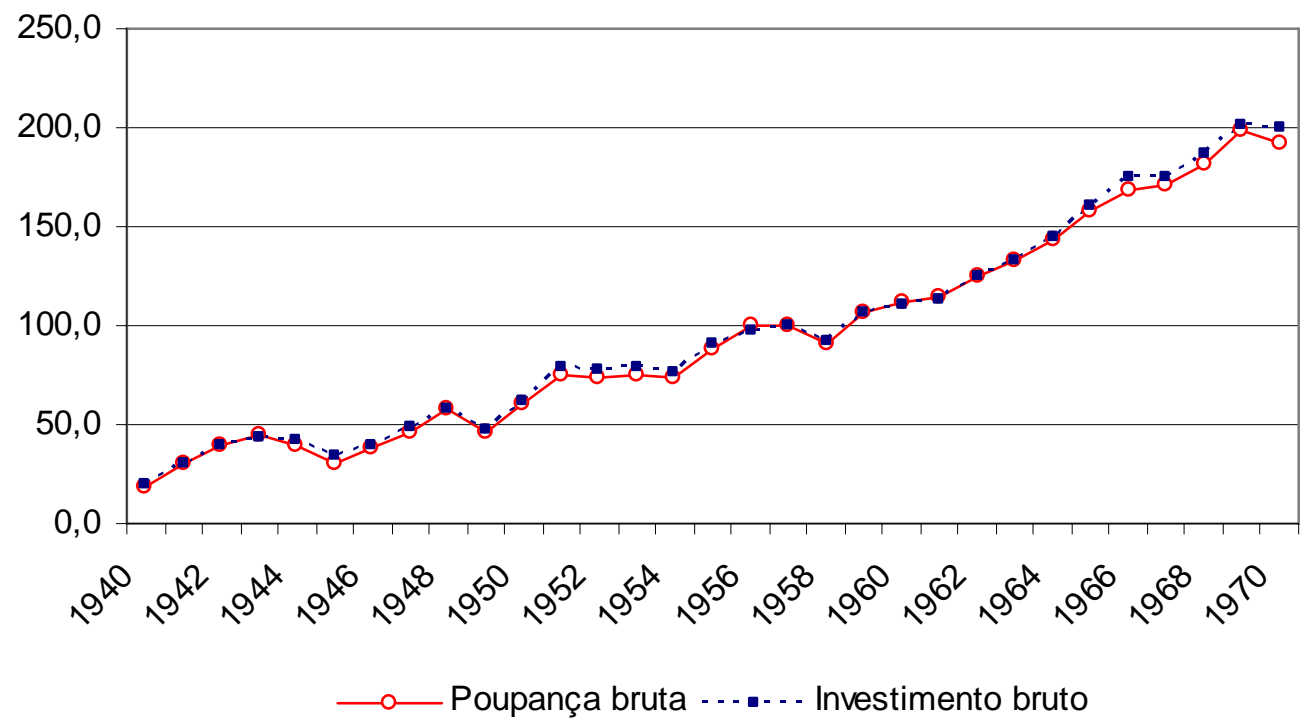

Fonte: NIPA-BEA, Seção 5, Saving and Investment, Tabela 5.1. Saving and Investment.

A pressão pela liberalização financeira em favor de Wall Street reforçou o papel do dólar contra moedas que, até então, tinham bastante importância regional, como o marco. Ela permitiu uma maior colocação do capital de empréstimo no eixo Londres-Nova York. Isto iria facilitar muito a utilização de crises cambiais em favor do reforço das finanças centrais. As típicas flutuações cambiais, expressões das liberalizações ao capital estrangeiro, passariam a culminar em fugas de capitais para moedas fortes - para o dólar, principalmente - o que reforçava o papel do centro estadunidense, minando o poder das exportações e da própria política econômica dos países em crise.

Como resumiu Peter Gowan:

"Senhoriagem é o nome dado aos privilégios conferidos por essa posição [de imprimir o dólar]: pode ser resumida dizendo-se que os Estados Unidos não enfrentam as mesmas restrições de balanço de pagamentos que outros países enfrentam. Podem gastar muito mais fora do país do que ganham lá. Assim, podem estabelecer bases militares dispendiosas sem nenhuma restrição cambial; suas corporações transnacionais podem comprar outras empresas estrangeiras ou se envolver em outras formas de investimento estrangeiro direto externo sem uma restrição relativa aos pagamentos; seus capitalistas financeiros podem enviar grandes fluxos de recursos para aplicações financeiras da mesma forma. [...] Quando muitos dos principais produtos comprados e vendidos em mercados internacionais têm seu comércio denominado em dólar, as empresas americanas 
importadoras ou exportadoras são muito menos afetadas na taxa de câmbio do dólar do que no caso de outros países." 118

À medida que se procedia com as liberalizações das contas de capital do balanço de pagamentos, obtinham-se impactos decisivos sobre a organização do sistema financeiro mundial, que se tornaria cada vez mais desregulado, levando a intensas variações cambiais e dificuldades de administração macroeconômica. Os impactos destas transformações desestabilizadoras nas economias periféricas são bastante conhecidos, tal como as sucessões de crises, desnacionalizações, destruição e desvalorizações do capital local instalado, e transferências líquidas de capital aos próprios centros financeiros norte-americanos.

O fim das taxas de câmbio fixas levou portanto à necessidade de as corporações e o sistema financeiro formularem instrumentos financeiros que minorassem os impactos de futuras variações cambiais, na forma de instrumentos derivativos e similares. $\mathrm{O}$ sistema financeiro norte-americano, o maior e mais desenvolvido já à época, foi pioneiro nestes desenvolvimentos, e canalizou, na forma destes serviços, enormes capitais em busca destes novos serviços financeiros. Seu desenvolvimento rápido era, ademais, um indício da desaceleração nos setores produtivos.

Portanto, com o fim do arranjo de Bretton Woods, a administração norte-americana, abandonando a conversibilidade do dólar pelo ouro, começou a cobrir seus passivos externos apenas em papéis denominados em dólar, que passaram a ser aceitos pelo público externo com o único substituto do ouro. Este é o ponto fundamental. Anteriormente, a variação de reservas em ouro continuava sendo um instrumento fundamental de pagamentos ao exterior. Mas, eliminado o papel do ouro, restou a dominância do dólar. Assim, os agentes nos Estados Unidos, principalmente o governo federal norte-americano, aprofundaram o financiamento de seus gastos com emissão de papéis, que, adquiridos internacionalmente, substituíram o ouro como ativo de reserva. A entrega de dólares em troca de papéis pelos investidores estrangeiros passou, destarte, a ser uma das formas mais dominantes de atração de recursos externos pelos Estados Unidos. Isto estava determinado, como se afirma, pela queda das taxas de lucro e pela crescente ampliação das instabilidades macroeconômicas.

\subsection{Desaceleração e a opção pelo endividamento externo}

A partir do exposto acima, pode-se afirmar que não se trata do caso de que o governo norte-americano, assim como as empresas norte-americanas, não se endividassem no exterior anteriormente à crise de Bretton Woods. Tendo o dólar um papel fundamental já no pós-guerra (1945), e o tendo o sistema financeiro nos Estados Unidos já adquirido a dimensão grandiosa que ainda hoje mantém, é natural que o país recebesse uma grande quantia de depósitos

${ }^{118}$ GOWAN, Peter. A roleta global, p.53. 
internacionais, assim como o governo federal financiasse suas dívidas não em ouro, mas sim em títulos denominados em dólar.

O que ocorre é que, em primeiro lugar, até meados dos anos (19)60 não havia poupança razoável disponível nos maiores países industrializados que pudesse ser canalizada rumo aos Estados Unidos. Os Estados Unidos apresentavam taxas de crescimento bem mais altas, e a formação de poupança era uma conseqüência direta deste crescimento mais rápido (baseado em taxas de lucro crescentes). $\mathrm{O}$ seu próprio produto nacional era, em termos relativos, muito maior na economia mundial. Isto é: o país mais exportava recursos do que importava, porque seu crescimento e sua formação de poupança assim o permitiam. Portanto: o consumo das famílias e do governo, assim como os investimentos, dispunham de formação suficiente de poupança doméstica tanto para manter as taxas de crescimento então vigentes, como para exportar poupança.

A transição dos anos (19)60 para os (19)70 assistiu à crise na lucratividade corporativa norte-americana, trazendo abaixo as taxas de crescimento relativo de seu PIB, a formação de poupança, e conseqüentemente a exportação de poupança. Tal acelerou a exportação de capital produtivo para fora do país, mas diminuiu radicalmente a variação negativa das outras contas da conta de capitais do balanço de pagamentos (gastos militares no exterior, empréstimos etc.). Os eventos que se seguiram apenas aceleraram esta viragem. Ao mesmo tempo, economia mundial cresceu mais e diversificou-se, tornando-se menos dependente dos fluxos econômicos a partir dos Estados Unidos.

“As economias Europeias fizeram sua própria recuperação rápida nos anos (19)60. Por volta de 1972 o produto nacional da Europa ocidental e do Japão era maior do que o dos Estados Unidos. Conseqüentemente, as fatias do mercado internacional dominadas pelos Estados Unidos declinaram drasticamente. [...] Ao mesmo tempo, as outras nações industriais começaram a reclamar por maiores fatias do mercado norte-americano." 119

Vê-se que o fim do regime de Bretton Woods coincidiu aos poucos com a transformação estrutural da economia norte-americana de credora mundial a devedora. E vê-se também que, criado uma nova forma de desajuste do balanço de pagamentos dos Estados Unidos a partir de sua transformação em nação devedora (expresso em déficits crescentes na conta corrente), nenhum regime monetário como o de Bretton Woods, que envolvia paridades fixas entre as moedas, podia subsistir. Como quase com tudo no capitalismo, a regulação neste caso atrapalhava. Por isso não houve e não há interesse das autoridades norte-americanas na

\footnotetext{
119 "The European economies made their own rapid recoveries in the 1960's. By 1972 Western Europe's and Japan's combined gross domestic output exceeded that of the United States. Accordingly, the U.S. share of world markets declined drastically. [...] At the same time, the other industrial nations began to claim larger shares of the American market." CARSON, Robert B.. Economy Issues Today, alternative approaches, p.318.
} 
criação de um novo padrão internacional mais racional e horizontal, porque necessariamente ele teria de levar (a) ao fim do dólar como moeda dominante e (b) ao ajuste das contas externas dos Estados Unidos, o que inevitavelmente colocaria em xeque todo o modelo de crescimento com base no endividamento externo.

Tabela 3. Estados Unidos, Japão e Alemanha (ocidental). Produção industrial. 1960-1980. 1967 $=100$.

\begin{tabular}{cccc}
\hline$(1)$ & $(2)$ & $(3)$ & $(4)$ \\
\hline & EUA & $\begin{array}{c}\text { Alemanha } \\
\text { (Ocidental) }\end{array}$ & Japão \\
1960 & 66,2 & 78,4 & 43 \\
1965 & 89,8 & 102,1 & 74,2 \\
1970 & 107,8 & 131,1 & 151,8 \\
1975 & 117,8 & 137,1 & 163,9 \\
1980 & 147 & 162,3 & 232,5 \\
\hline
\end{tabular}

Fonte: Economic Report of the President, 1982. Tabela B-110, Industrial Production and Consumer Prices, major industrial countries, 1960-81.

Tabela 4. Estados Unidos, Japão e Alemanha (ocidental). Exportações. 1965-1977. Bilhões de dólares correntes.

\begin{tabular}{cccccc}
\hline (1) & $(2)$ & $(3)$ & $(4)$ & $(5)$ & $(6)$ \\
& 1965 & 1970 & 1975 & 1977 & Variação \\
EUA & 27,5 & 43,2 & 107,6 & 122,4 & 4,45 \\
Japão & 8,5 & 19,3 & 55,8 & 80,6 & 9,48 \\
Alemanha (Oc.) & 17,9 & 34,2 & 90,2 & 116,4 & 6,5 \\
\hline
\end{tabular}

Fonte: Economic Report of the President, 1982. Tabela B-106, World Trade: Exports and Imports, 1965-1981.

No fim dos (19)70, as autoridades esforçavam-se por deter a queda do dólar, vinda das incertezas oriundas da própria crise de 1971-73. Aumentar os juros e valorizar a divisa implicavam automaticamente em estimular o endividamento externo. Ora, justamente, as opções das autoridades, quando exposta de modo inadiável a crise da lucratividade já no governo Reagan, estavam em (i) aceitar taxas de crescimento menores - expressas na queda da taxa de formação de poupança doméstica, que obrigaria num tempo posterior a diminuição das taxas de investimento - ou (ii) aceitar a crescente demanda por papéis norte-americanos como uma maneira de suavizar o comportamento difícil destes dois agregados fundamentais, os investimentos e a poupança agregados. Isto mediante, obviamente, a atração de poupança externa farta vinda duma economia mundial agora bem maior do que no fim dos anos (19)40. É claro que a segunda opção teria de ser permitida. As ações liberais de política econômica davam-se no curto prazo, e no curto prazo era melhor contar com dinheiro de fora e valorizar o dólar, contendo a crise, do que deixar o valor da moeda despencar e o dinheiro fugir do país. $\mathrm{O}$ endividamento externo do país não era uma preocupação para as autoridades, dada a 
possibilidade de um calote unilateral ou ação unilateral a qualquer momento (como as ações do governo Nixon mostravam).

Evidentemente, o modo pelo qual se deu a crise do padrão de Bretton Woods refletia o jogo de forças entre os países capitalistas dominantes, e esta balança culminava - como até hoje ocorre - numa corrida pela posse de ativos em dólar. Esta política interessa, logo, aos Estados Unidos, pois do contrário um ajuste muito maior de suas políticas teriam de ser feitas, e o resultado seria inevitavelmente um crescimento menor. A questão-chave para a fase posterior à queda na lucratividade foi o modo como endividar-se no exterior para suavizar o comportamento de uma economia que tendia a crescer abaixo das expectativas prévias.

Por isso, não é dado à Alemanha, Japão, e outros países industriais, valer-se deste expediente. E não poderia ser diferente. É evidente que se os Estados Unidos se endividam, estes recursos são oriundos destas outras economias. Poder-se-ia então perguntar: como estas economias poderiam valer-se do mesmo recurso, se eram elas mesmas que estavam na base do endividamento externo dos Estados Unidos, fornecendo-lhes tais recursos? Ora, esquece-se freqüentemente que o "balanço de pagamentos mundial" deve fechar sempre nulo. Daí que a crise da lucratividade ocorrida nos anos (19)70, atingindo a todos os países industriais, devia se refletir, do ponto de vista sistêmico, em: (i) endividamento externo norte-americano e crescimento relativo maior; e (ii) exportação de capitais das outras nações industrializadas e crescimento menor. Daí a centralidade do mercado norte-americano em determinar a função na Divisão Internacional do Trabalho das nações exportadoras de capital, já que parte deste capital exportado voltaria a elas na forma de bens importados pelo mercado norte-americano.

Neste ínterim, diferentemente de locais como a China, as taxas de lucro permaneceram mais ou menos as mesmas para as economias industrializadas do centro capitalista, devido à mobilidade do capital entre eles e os impactos mais ou menos homogêneos do aumento do preço do petróleo e suas conseqüências diretas. Veja-se que os três grandes pólos do sistema industrial atual mantêm baixo crescimento. São suas taxas de poupança e investimento que discrepam e permitem a atuação dos mecanismos acima descritos em favor dos Estados Unidos em primeiro lugar. Para sua poupança doméstica formada efetivamente, Japão e Alemanha mantêm níveis mais baixos de consumo relativo, exportando capital aos Estados Unidos, que por sua vez reimportam mercadorias ali fabricadas. E elas se comportam assim porque são os Estados Unidos os detentores da moeda mais demandada na economia internacional. $O$ aumento do endividamento externo norte-americano indica que nem todos os empréstimos estavam e estão voltando a estes países sob forma de importações, o que dá a vantagem norte-americana de consumir e investir o que Japão, Alemanha, e outras nações, não consomem e investem, a título de um aumento de seus haveres contra os Estados Unidos. O fim do padrão de Bretton Woods é assim o mecanismo pelo qual esta relação estrutural se dá, e ele reflete, em última instância, o poderio dos Estados Unidos expresso na imposição do dólar ao mundo.

O que suavizou as discrepâncias entre as taxas de crescimento verificadas entre Estados Unidos e outros países industriais, depois de iniciado o processo de endividamento externo do 
primeiro, foi que, justamente, o saldo na conta de capitais norte-americana refletiu-se no déficit em suas transações correntes. Os Estados Unidos aumentaram suas importações e isto manteve parte do parque manufatureiro japonês, alemão, e posteriormente sul-coreano, chinês etc. em funcionamento. Numa visão estilizada, os Estados Unidos trocam produção por consumo, e eles consumo por produção. Ou mais exatamente: nos Estados Unidos, a produção é subsidiária do consumo; fora dele, o consumo é subsidiário da produção. Mas como as conseqüências do choque do petróleo e da reformatação produtiva são similares a todos, em todas as economias industrializadas a taxa de acumulação de capital fixo tem caído, com exceção daquelas nações de industrialização mais recente onde a taxa de lucro tenha se mostrado muito favorável. Inclusive, uma coisa não pode ser tratada sem levar em consideração a outra: é também porque a China ingressou em sua Revolução Industrial que a taxa de formação de capital fixo em outros lugares, mormente o Japão, caiu (ver gráfico 12 do capítulo 4). Pode-se imaginar então que se tais nações, diante da similar crise de lucratividade, têm exportado poupança aos Estados Unidos, seus níveis de investimento só podem ter também caído relativamente, como mostram as tabelas da seção 3.4.5 do capítulo 3. Ora, a exportação de poupança nada mais indica que se está investindo menos do que se poderia: mesmo que esta poupança retorne em forma de exportações aos Estados Unidos, tal implica mais em utilização de capacidade instalada do que em novas inversões.

Mas isto não dá um resultado de soma zero, e aí radica a vantagem relativa da posição de hegemonia dos Estados Unidos: a dívida cresceu mais do que o produto. Nos termos do balanço de pagamentos, é o aumento do superávit na conta de capitais norte-americana, e não o déficit em suas transações correntes (especialmente a balança comercial), que é rigorosamente igual ao aumento das remessas de renda em dólares dos países emprestadores. Ora, a diferença entre os déficits em conta corrente e o superávit em conta de capital (este maior que o déficit em conta corrente) dos Estados Unidos expressa então o aumento de seu endividamento externo. A diferença é o que o mundo deixa de consumir e investir, para que os Estados Unidos consumam localmente. Parte dos saldos comerciais positivos do mundo com os Estados Unidos não volta ao mundo em forma de importações norte-americanas, mas sim é consumido internamente nos Estados Unidos. Se os níveis de endividamento externo ultrapassaram o crescimento do PIB, isto significa que os Estados Unidos consumiram menos importações de bens e serviços do que o exterior lhe entregou em forma de recursos em sua própria moeda.

É fato: o crescimento norte-americano deu-se em boa parte pelo aumento da troca de investimentos por consumo, permitindo manter o próprio comércio internacional num fluxo crescente - ainda que à base do aumento do endividamento e da crescente fragilidade da estabilidade das convenções aceitas em torno do valor do dólar. Não obstante, não se tratou do caso de que os superávits na conta de capitais foram simplesmente cancelados pelos déficits na conta corrente: o nível de endividamento externo da economia cresceu mais rapidamente que o do produto. Ora, se o nivel de endividamento líquido aumentou, nem tudo os que os Estados Unidos tomaram da economia internacional voltou a ela em forma de importações, mas 
simplesmente serviu para que se mantivesse um volume de consumo mais alto na própria economia norte-americana. Neste caso, o exterior retém mais papéis, e a economia norteamericana investe e consome internamente com tais recursos emprestados, sem que eles sejam inteiramente retornados no exterior. Supor o contrário seria não compreender porque se dá um crescimento mais rápido da taxa de endividamento face ao do PIB.

Veja-se novamente a figura que contrapõe dívida e PIB, já exposta anteriormente:

Gráfico 7. Estados Unidos. Ativos estrangeiros totais na economia dos Estados Unidos e PIB dos Estados Unidos. 1976-2000. Em bilhões de dólares correntes.

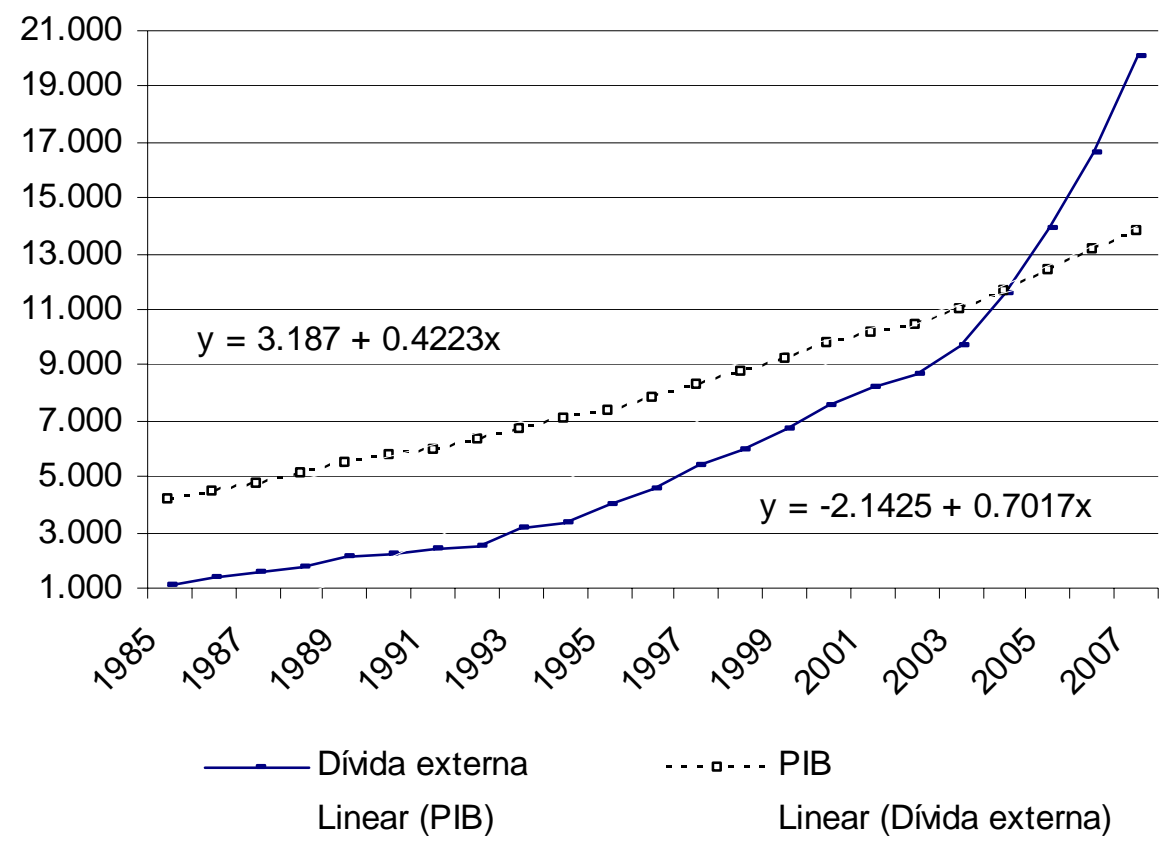

Fonte: Economic Report of the President, vários anos (1984-2008). Para PIB: Tabela B-1, Gross Domestic Product, 1959-2007; para Ativos Estrangeiros totais na economia dos Estados Unidos: International Investment Position of the United States at year-end, vários anos.

Afirmar o oposto significaria argüir-se que a dívida externa poderia aumentar sobre o produto interno bruto paralelamente ao aumento das importações sobre o produto, de modo que o aumento da captação de recursos se traduziria numa contrapartida exata de aumento das importações. Basicamente, há dois modos de refutação deste postulado: empírico e teórico. Comece-se pelo teórico.

Aparentemente o argumento faz sentido; mas não o tem, de fato. A noção de que o nível crescente de endividamento externo não se traduz numa contrapartida exata de importações de mercadorias pelos Estados Unidos é verdadeira porque o crescimento da divida sobre o produto implica necessariamente uma elevação dos haveres detidos pelo exterior contra a economia norte-americana que expressa a recusa em investir dos países credores.

Em termos estritos, o argumento é de que (1) um país exporta aos Estados Unidos; (2) os Estados Unidos captam os dólares e emitem papéis; (3) estes dólares retornam todos à 
economia exportadora de mercadorias e emprestadora. O fluxo recomeça num momento seguinte, com a relação estável. Mas porque isto não é verdadeiro? Ora, o aumento do endividamento externo indica que o fluxo de mercadorias importadas pelos Estados Unidos é, por definição, menor do que o fluxo de capitais que entra no país; veja-se isto em termos dinâmicos e sob outra perspectiva - a do país que exporta capital e mercadorias. Se todas as importações de mercadorias e serviços feitas pelos Estados Unidos estivessem sendo reaplicadas em cada uma destas economias exportadoras líquidas de capital, sem que parte alguma fosse poupada para efeitos de empréstimo e entesouramento de papéis, é fácil ver que não haveria os recursos que foram utilizados para o crescimento da própria dívida norte-americana. Alguém tem de renunciar ao consumo se os Estados Unidos aumentam ano a ano a taxa de endividamento externo em proporção do PIB.

A série de endividamento líquido total com o exterior, fornecido pelo BEA, ajuda a entender o fenômeno por completo. Ela é o resultado, simplesmente, dos saldos de conta corrente do balanço de pagamentos substraídos aos saldos de conta de capitais do B.P.. Isto é: da quantidade (1) de recursos que o país paga ao exterior em forma de importações de mercadorias e remessas de renda, contraposta à (2) quantidade similar que o país recebe do mundo. $\mathrm{O}$ aumento mais rápido de (2) face a (1) dá o endividamento externo líquido.

Gráfico 8. Estados Unidos. Endividamento líquido com o exterior. 1970-2006. Em bilhões de dólares. Resultados positivos haveres líquidos contra o exterior.

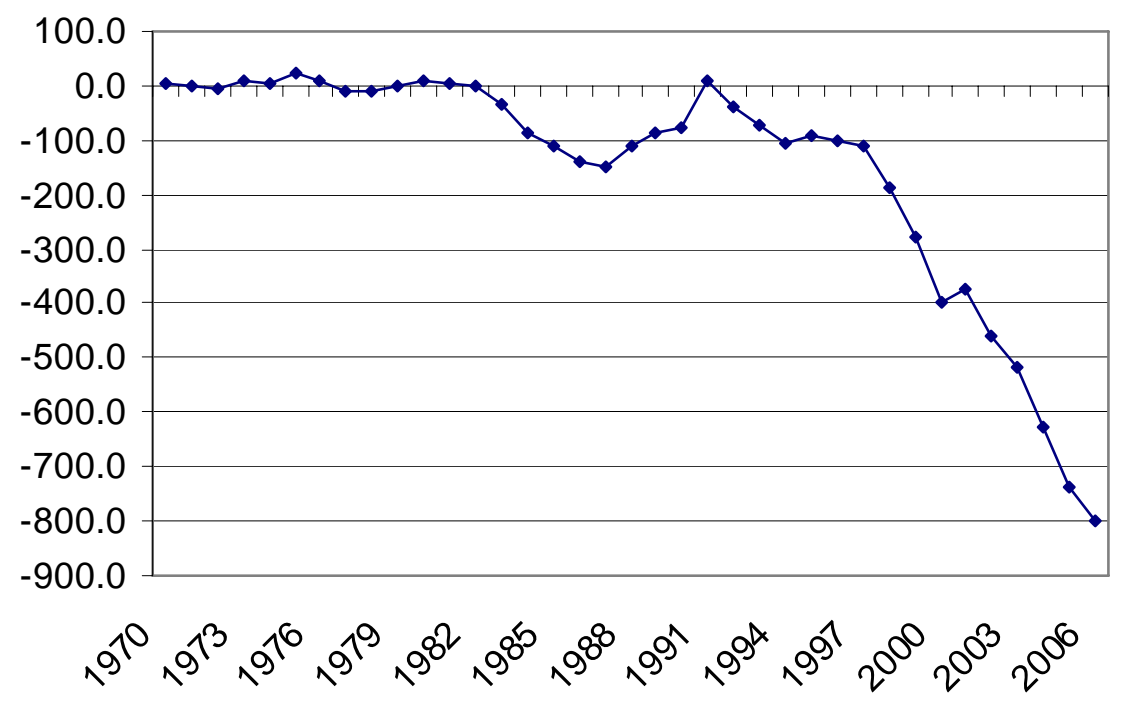

Fonte: NIPA-BEA. Seção 4, Foreign Transactions, Tabela 4.1, Foreign Transactions in the National Income and Product Accounts.

Para que o país não fosse um devedor líquido, o saldo negativo na conta corrente deveria ser menor que o saldo na conta de capitais, e não é o que se encontra tanto nesta figura como em todas as outras. Vê-se acima que, como se notou já, a economia se torna devedora do mundo a partir do início dos (19)80; o endividamento externo aumenta até 1987, aproximadamente. A recuperação das exportações pós 1987 faz diminuir tal endividamento. Ele 
volta a crescer entre 1991 e 1994 . Diminuiu durante o início do crescimento verificado entre 1993 e 1997; a economia continuou, porém, devedora líquida. Após 1997, o endividamento cresce sem parada.

Qual é a atenção que o analista deve tomar ao analisar esta serie, em particular, não obstante sua validade? A atenção reside no fato de que estes são os resultados líquidos, totais, das relações do país com o exterior. Isto é, levam em conta toda a exportação de capital e mercadorias dos Estados Unidos ao mundo, subtraindo dela as importações de recursos e bens. Ela não serve, assim, como uma orientação principal da análise da economia norte-americana, pois, por definição, abarca fenômenos econômicos que acontecem em todas as economias para as quais os Estados Unidos exportam capita e mercadorias. É muito agregada. Ela abarca, por exemplo, todas as novas oportunidades de colocação de investimentos e mercadorias norteamericanas em mercados recém abertos ao capitalismo, como no Leste Europeu - fenômenos que não atendiam exatamente às flutuações da economia local norte-americana, mas sim a transformações políticas nestas outras áreas do mundo. Para uma análise específica e centrada das flutuações da economia doméstica norte-americana, utilizar-se-ão então as séries de recursos externos na economia dos Estados Unidos, pois o interesse deste estudo é analisar como as flutuações da economia norte-americana relacionam-se com tais recursos, que compõem o endividamento externo.

A crise do padrão de Bretton Woods, dando-se como ante-sala da crise da lucratividade nos anos (19)70 - mas refletindo um processo de natureza diferente e anterior à desta crise (qual seja, o zênite das pressões sobre o dólar, vindos da desproporção entre sua emissão e a quantidade de ouro nos Estados Unidos) ${ }^{120}$ permitiria o processo de endividamento externo como meio parcial de contenção da crise aberta nos anos (19)70. O fim do padrão de Bretton Woods (1971-73), tornando o dólar o mais importante ativo monetário internacional, iria facilitar o processo de endividamento externo dos Estados Unidos, na medida em que o aumento da demanda por dólares estimulou os bancos, as corporações, e o governo federal norte-americano a aumentarem seus financiamentos a partir de empréstimos de agentes estrangeiros. Mas os acontecimentos de 1971-73 não são a causa determinante desta transformação no balanço de pagamentos dos Estados Unidos. Elas residem antes no próprio comportamento das variáveis econômicas fundamentais: a taxa de lucro, a formação de poupança, cada vez menos eficientes em termos agregados, e a opção das autoridades por permitir o endividamento externo.

\footnotetext{
${ }^{120}$ Que expressava, por sua vez, a utilização de um mecanismo benéfico permitido pelo monopólio sobre o ouro, ou simplesmente a vantagem da vitória na Segunda Grande Guerra (1945).
} 
Gráfico 9. Países selecionados. Médias decenais de crescimento do produto (\%). 1970-2000.

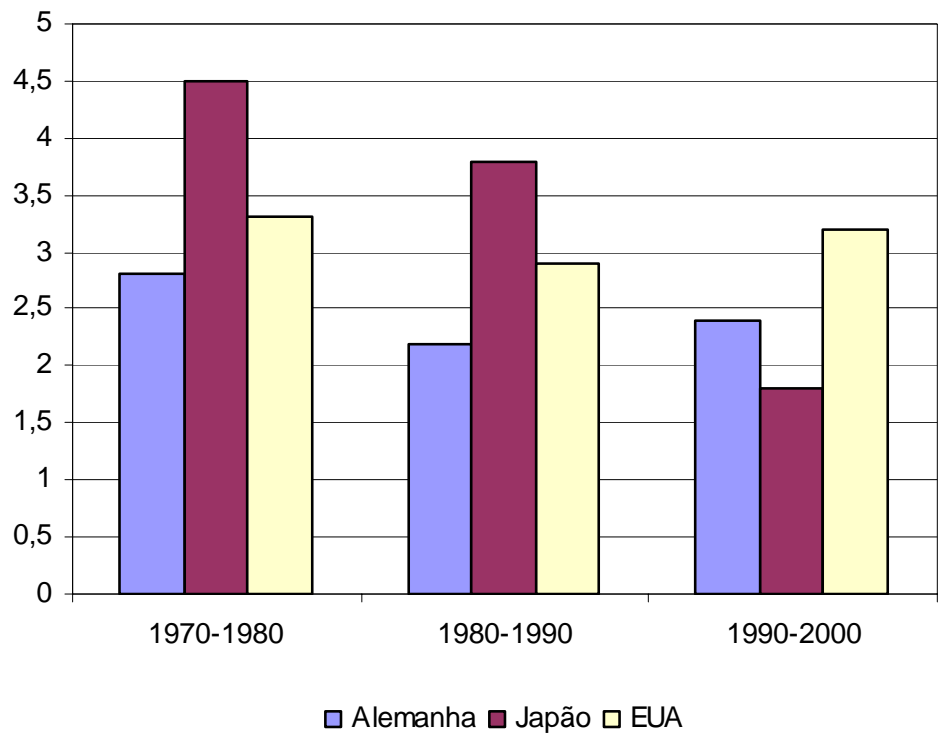

Fonte: OCDE (http://oecd.org/stats).

Dada esta relação de longo prazo na economia norte-americana, pode-se afirmar então que o balanço de pagamentos do país refletiu a viragem estrutural em direção ao endividamento externo, e que os arranjos de Bretton Woods, que impunham paridade fixa entre as moedas, eram muito "rígidos" para o comportamento real das variáveis macroeconômicas. Na medida em que a economia exportava demais capital em forma de dólares, houve pressão sobre a moeda, o que levaria ao fim do arranjo. E na medida em que a economia passou a importar capital, já entrando-se na década de (19)80, o desequilíbrio do balanço de pagamentos assumiu a forma de déficits crescentes na conta corrente, o que continuou desestimulando as autoridades no sentido de promover um novo arranjo monetário. Um novo arranjo monetário à la Bretton Woods inevitavelmente teria de contar com o ajuste das contas externas dos Estados Unidos, o que significaria pôr em xeque o próprio modelo de crescimento com base na dívida externa. Quanto a isso, existe muita concessão aos Estados Unidos, com elogios ao déficit na balança comercial como o "motor da economia mundial". Há aqui a típica posição de quem não vê nem um pouco por detrás da aparência. É como se tais déficits não fossem permitidos pelos recursos mundiais não investidos e entregues aos Estados Unidos; e como se sua posição de comprador na Divisão Internacional do Trabalho, e o monopólio do dólar - com conseqüente escassez forçada da divisa para os países que não podem transacionar em outras moedas - não exercessem pressões nos balanços de pagamentos periféricos, com desvalorizações periódicas dos bens primários exportados, das moedas locais etc..

O fato de que a economia norte-americana, contrariamente à japonesa e alemã, não pôde até aqui ajustar o seu próprio balanço de pagamentos no sentido de "zerá-lo" - o que refletiu, tanto antes como depois, as viragens estruturais do próprio desempenho doméstico - é que explica a contínua inexistência de um arranjo monetário internacional. No caso, a crise de 197173 expressou o desbalanço face à saída de capitais do país, que pressionava o dólar em relação a 
outras divisas, já que a emissão de dólar aumentava mais do que a própria existência física de ouro. E a permanente ameaça de crise do dólar até os dias de hoje, sem que nenhum outro sistema monetário substituísse o "desarranjo" feito após 1971-73, refletiu justamente a continuidade dos desajustes no balanço de pagamentos estadunidense, agora sob outra perspectiva - o que reflete o processo estrutural de transformação do país de exportador em importador de capitais, espelho da crescente dificuldade da formação relativa de poupança doméstica, tal como visto no capítulo anterior.

Porém, antes de interpretar mais de perto estes resultados para os Estados Unidos, é necessário descrevê-los. 
A primeira administração Reagan (1981-1984)

\begin{abstract}
"A prosperidade é um objetivo meritório, mas se o fato de se atingir um nível de vida mais alto interferir com a produção de armas em número suficiente para se poder resistir a uma possível agressão comunista, então teremos de impor sacrifícios materiais."
\end{abstract}

Ronald Reagan

\title{
6.1. Introdução
}

primeira administração de Ronald Reagan herdou um cenário econômico de
grande aumento de preços vindos do segundo choque do petróleo de 1979. A
inflação veio acompanhada de queda nas taxas de lucro, por uma baixa da produtividade do capital - devido ao encarecimento dos custos de produção em todos os setores - e por uma subseqüente diminuição dos investimentos. O montante de lucros caiu, como conseqüência. A administração Reagan teve então de estabilizar os preços, mediante repressão da demanda e altos juros, o que trouxe a economia para patamares ainda mais baixos de funcionamento. Porém, ao mesmo tempo em que o Fed aplicava esta política de estabilização, o governo federal colocou em ação uma política contra-cíclica, baseada na diminuição dos impostos ao capital e no aumento dos gastos com armas, para compensar a taxa de lucro e o montante de lucros em queda. Os níveis de endividamento do governo se elevaram como conseqüência.

Neste ínterim, o endividamento externo da economia, diversificado por diferentes tipos de empréstimos ao exterior, começou a desempenhar um papel importante na manutenção dos diferentes componentes da demanda agregada e da oferta de crédito, a partir do terceiro ano da administração Reagan - justamente o período no qual os Estados Unidos vão abandonar a posição de credores líquidos do exterior para entrarem na condição de devedores.

Aproximadamente $20 \%$ dos déficits do governo federal já estavam sendo financiados com recursos oriundos de fora da economia dos Estados Unidos. Ao mesmo tempo, aportou no sistema financeiro do país uma enorme quantidade de recursos de estrangeiros, sob uma ampla rubrica de empréstimos e depósitos, dada a atratividade dos papéis denominados a juros altos. Por sua vez, muitas corporações também buscaram muitos recursos externos em forma de emissão de ações e bônus, colhendo o embalo da valorização de todos os papéis em dólar no mundo. Com isto, parte da demanda agregada e do financiamento local do consumo, investimentos e gastos do governo, passou a ser estimulada com recursos não efetivamente gerados na economia local. Assim, algo que amiúde causa confusão nos analistas - o momento 
exato em que a economia deixa de ser credora líquida do mundo, situa-se no primeiro governo de Ronald Reagan.

Este capítulo busca então investigar: (1) a política implementada pela administração Reagan, durante a crise; (2) os impactos que tais políticas tiveram na economia. A partir daí, tenta-se ilustrar como (i) a inviabilidade do plano de rebaixar impostos e diminuir o déficit culminou num aumento do endividamento do governo, interno e externo; (ii) como a saída da economia de guerra era contraditória com a política de rebaixamento de impostos e diminuição dos déficits; (iii) como a inflação foi contida com uma retração no consumo das famílias e favorecimentos ao capital; e (iv) como o endividamento externo da economia favoreceu uma aplicação mais efetiva desta política, logrando diminuir os impactos da flutuação dos agregados.

\subsection{O conturbado panorama econômico}

O primeiro governo Reagan iniciou-se na esteira do duplo impacto da elevação dos preços do petróleo e na elevação dos juros, paralelamente a um aumento dos preços em geral. Entre 1978 e 1979, o índice de preços ao consumidor global, o CPI-U (United States Consumer Price Index) variou 7\%. De 1979 a 1980, houve 10\% de variação anual; de 1980 a 1981, 8\%. Por ser turno, o ano de 1980 tinha registrado crescimento nulo e retração do PNB ${ }^{121}$ per capita. A segunda elevação dos preços do petróleo, em 1979, resultou numa alta dos preços do barril para 14,57 dólares em 1978, preço que pulou para 21,67 dólares em 1979, e para 33,39 dólares em 1980. O barril do petróleo chegou a 36,69 dólares em 1981. ${ }^{122}$ Por outro lado, todos lembram como a administração Carter reagiu não só a estes acontecimentos, mas também à progressiva desvalorização do dólar durante os (19)70, com uma grande elevação dos juros. A média dos juros dos títulos do Tesouro (3 e 6 meses, e 3, 10 e 20 anos) passou de 7,2\% em 1978 para $10 \%$ em 1979. Este panorama recessivo atravessou todo o ano de 1980, levando à derrota de Carter e à ascensão de Reagan. A vitória de Reagan se daria, assim, num contexto bastante instável para a economia.

Alan Greenspan assim descreve o momento anterior à eleição de Reagan:

"A economia não trabalhou a favor de Carter. Por mais ou menos um ano, sua administração beneficiou da recuperação que tinha começado sob Ford. Daí o crescimento diminuiu e a inflação reassumiu uma ascensão firme e agourenta. Ela jogou

\footnotetext{
${ }^{121}$ Como se viu acima, o sistema de Contas Nacionais norte-americano abandonou a classificação de Produto Nacional Bruto (Gross National Product) pela de Produto Interno Bruto (Gross Domestic Product) em 1991. O Economic Report of the President trazia o produto norte-americano como Produto Nacional Bruto até 1991, ano depois do qual houve a mudança para Produto Interno Bruto. Os valores absolutos de produto que por ventura apareçam neste e no próximo capítulo foram construídos com edições do Economic Report of the President que vão até 1991, caso em que se mantém para eles a notação de PNB - Produto Nacional Bruto (GNP). Portanto, a partir do capítulo que estuda a administração de George Bush, a notação de PIB é de novo adotada, em consonância com os valores de produto fornecidos pelo Economic Report of the President.

${ }_{122}$ OCDE Factbook 2007.
} 
uma cortina de incerteza nas negociações salariais e decisões de investimento. Também afetou o resto do mundo, porque os outros países dependiam da estabilidade do dólar, e o dólar estava se enfraquecendo. Durante 1978 a inflação se elevou bastante - de 6,8 porcento no início do ano a 7,4 em Junho, e para 9 porcento no Natal. Daí, em Janeiro de 1979 os fundamentalistas islâmicos derrubaram o Xá do Irã, e a segunda crise do petróleo começou. À medida que as filas por gasolina se formavam devido aos controles de preço, a economia entrava numa espiral de inflação e recessão agora de novo sob dois dígitos, chegando a $12 \%$ no fim." 123

Neste contexto, a propensão a investir estava sendo golpeada de vários modos: pela queda da produtividade do capital, devido ao encarecimento de insumos derivados do petróleo; pelo encarecimento dos empréstimos, mediante os juros altos; e pelo maior valor do dólar face ao iene e marco - o que colocava um peso adicional sobre os setores exportadores norteamericanos. Por sua vez, consoante o aumento dos juros, o dólar passou a recuperar seu valor face ao iene e ao marco existente no início da década de (19)70, dado que tais juros altos haviam elevado a demanda por dólares em toda a economia mundial. Esta era justamente parte da estratégia norte-americana para recuperar o valor de sua moeda, e, num âmbito maior, parte da hegemonia perdida pela sucessão de fracassos ao longo dos anos (19)70, principalmente a perda do Vietnã e do Irã.

Como a administração de Reagan iria reagir a este acúmulo de situações conjuntamente recessivas? Como se vê na figura abaixo, desde 1979 as variações do produto eram bastante baixas, e, após o desempenho mais ou menos razoável do terceiro trimestre de 1979, ingressouse numa queda forte e cumulativa. No segundo trimestre de 1980 a variação negativa do produto chegou a $8 \%$ face ao trimestre anterior, sucedida por uma nova descida negativa de quase $1 \%$. Ora, sendo a ascensão do governo Reagan um resultado das articulações das corporações para, mediante as políticas do governo, administrar a crise em curso em favor delas mesmas, o plano econômico a ser aplicado teria marcas indeléveis de conservadorismo. Ele chamar-se-ia de Program for Economic Recovery.

\footnotetext{
123 “The Economy didn't work in Carter's favor. For a year or so, his administration enjoyed the benefits of the recovery that had started under Ford. Then growth slowed and inflation resumed a steady and ominous rise. It cast a continuing pall of uncertainty on wage negotiations and investment decisions. It affected the rest of the world too, because the other countries depended on the stability of dollar, and the dollar was weakening. Through 1978 inflation ratcheted up - from 6,8 percent at the beginning of the year to 7,4 in June to 9 percent in Christmas. Then in January 1979 the Islamic Fundamentalists overthrew the Shah of Iran, and the second oil crisis began. As gas lines formed that summer owing to gasoline price controls, the economy started to spiral toward another recession and inflation crossed again into double-digit range, hitting 12 percent by fall." The Age of Turbulence, p. 82 .
} 
Gráfico 1. Estados Unidos. Variações trimestrais do PNB. 1978-1980.

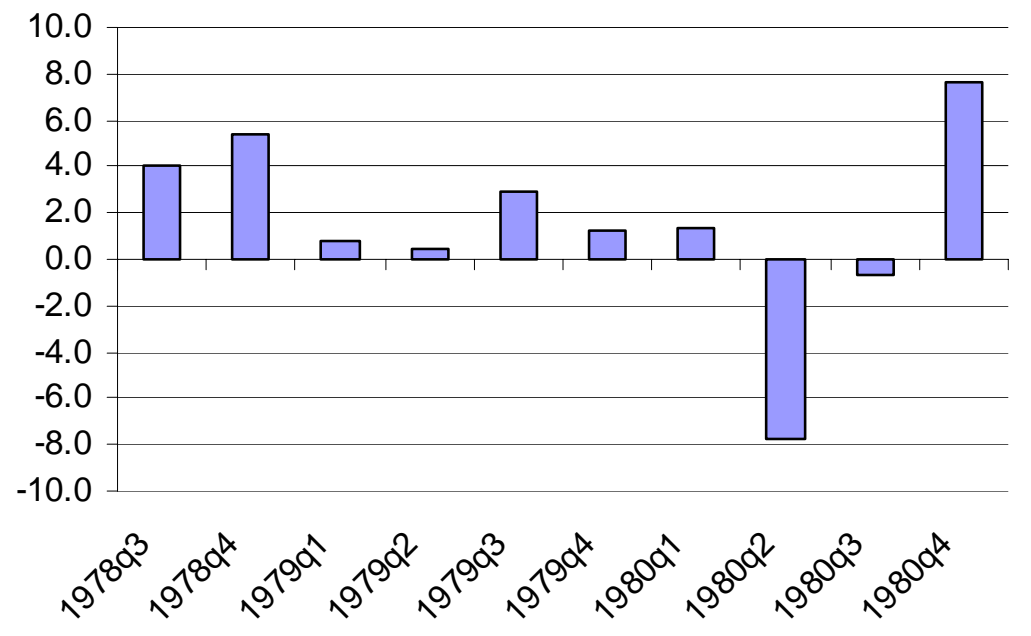

Fonte: NIPA-BEA. Seção 1, Domestic Product and Income, Tabela 1.1.1, Percent Change From Preceding Period in Real Gross Domestic Product.

\subsection{O Reaganomics e o Program for Economic Recovery}

Reagan, um ex-ator de filmes de segunda categoria que começou sua carreira política nos anos (19)60, havia sido governador do Estado da Califórnia entre 1967 e 1975. Outrora membro do Partido Democrata, filiou-se ao Partido Republicano em 1962. Desde os tempos de cinema, sua carreira fora marcada pelas ações da direita norte-americana: arrivismo, reacionarismo, anti-comunismo exacerbado, racismo e religiosidade fanática. Posteriormente, trabalhou para empresas de energia e do complexo industrial-militar, principalmente a General Electric. O vice-presidente de Reagan, George Bush, era um ex-diretor da CIA que também estava envolvido com o mesmo tipo de empresas e ligações políticas, inclusive na condição de proprietário. ${ }^{124}$

A eleição de Reagan fora uma grande conquista para a extrema-direita norte-americana. Ele canalizava opiniões fortemente conservadoras dentro dos diferentes grupos na sociedade e na economia, como os da "Nova Direita Religiosa". Basicamente, o miolo de tais demandas conservadoras consistia nas críticas ao Programa Great Society, do presidente Lyndon Johnson (1963-1969), aos impostos sobre o capital, aos déficits fiscais, e ao que chamavam de "minorias" que contavam com recursos públicos para sobreviver - desempregados, inválidos etc.. Por outro lado, seus grupos de apoio insistiam na necessidade de reforçar ainda mais as forças armadas e o aparato militar, inflando a opinião pública com ataques à União Soviética.

A administração de Reagan via a resolução da crise dentro de um espectro de políticas que reunia, oficialmente: (i) diminuição de impostos às corporações; (ii) diminuição dos déficits

\footnotetext{
${ }^{124}$ Suspeitou-se que Bush posteriormente tentou armar o assassinato de Reagan, sem sucesso, para chegar à condição de presidente, que almejava e perdera na disputa com Reagan. "Só Bush poderia tirar proveito deste crime. Tornar-se-ia ele o presidente, com a morte de Reagan, com quem competira ferozmente pela indicação do Partido Republicano, no início dos anos 1980.” BANDEIRA, Moniz. Formação do Império Americano, p.419.
} 
fiscais; (iii) desregulamentação da economia; (iv) reforço das inversões na indústria de guerra. Hoje todos sabemos em que consistiam tais políticas, mas é necessário voltar a elas mais uma vez.

Basicamente, quanto a (i), a perspectiva daquela equipe econômica era a do "supply side economics", ou da "economia do lado da oferta" - a perspectiva anti-keynesiana que vinha sendo desenvolvida em distintas instituições norte-americanas. Sua lógica: a recuperação da lucratividade do capital, como o principal elemento da demanda agregada que poderia trazer a recuperação da crise. Se a crise resultara numa menor lucratividade do capital, deveria então ser enfrentada por uma diminuição dos impostos cobrados às corporações, para que, mediante a diminuição de seus custos, voltasse a ser lucrativo investir. Segundo os princípios do supply side, todos os outros agregados macroeconômicos tinham uma importância decisiva menor: era o favorecimento à "oferta" corporativa a única maneira de efetivamente estabilizar a economia, mais do que a manipulação da demanda vias gastos governo e famílias.

Consoante esta visão, o Estado era visto como um impeditivo à aplicação desta receita. Dever-se-ia diminuir os déficits fiscais para que se diminuíssem os juros, e proceder com a desregulamentação da economia - retirando os monopólios detidos pelo Estado e aumentando a concorrência em áreas onde ela era restrita a poucas empresas - a fim de diminuir a participação do governo. Quer dizer, a presença deste era vista, pelo menos publicamente, como responsável pela diminuição da lucratividade corrente, por (a) ocupar ramos que a iniciativa privada podia ocupar; (b) por fazer elevar a taxa de juros devido à "diminuição da poupança doméstica" pelos altos déficits fiscais; (c) por sua supostamente alta carga de tributos. A política do governo de favorecer os gastos das corporações e dos detentores de riqueza perfazia então uma perspectiva oposta à da keynesiana basicamente porque não dava atenção à capacidade de manipular a renda no sentido de favorecer faixas de renda com maiores propensões ao consumo, e por interpretar a participação do Estado como empecilho às demandas do capital, e não como um indutor adicional de poupança, via gastos e o efeito multiplicador.

Por fim, via-se como necessário que as inversões na indústria de guerra crescessem novamente, após as diminuições do pós-Vietnã. Isto porque - mais uma vez supostamente - os Estados Unidos estariam sendo ultrapassados, em poder militar, pela então União Soviética. Todavia, o argumento aqui não ligava a nenhuma defesa de uma suposta racionalidade econômica, mas sim aos interesses puros e irrestritos da defesa nacional. A defesa dos investimentos em defesa formava, com efeito, um argumento ad hoc no discurso do governo, como se se desconsiderasse que os argumentos oficiais em apoio ao "lado da oferta" estivessem baseados numa tentativa de demonstrar uma superioridade econômica de um governo liberal face a uma outra política de administração do Estado.

Há um bom resumo do que se iria aplicar em 1981 e nos anos subseqüentes nas próprias palavras de Reagan, um ano após tomar posse em 1981. Em 1982, no discurso de 26 de Janeiro de 1982 para o "First State of Union Adress" - no qual o presidente fala ao Congresso no início 
do ano - ele assim se referiu às políticas que sua administração havia começado a implantar em 1981:

"A economia vai enfrentar momentos difíceis nos meses à frente. Mas o Programa para Recuperação Econômica que está por vir vai colocar a economia fora da crise e nos pôr na rota da prosperidade e crescimento estável na segunda metade deste ano. E é por isso que eu posso comunicar a vocês nesta noite que a situação da União e da economia será muito melhor se somarmos forças para continuar o curso que traçamos. Então, a questão: e agora, se os fundamentos estão no lugar? Duas coisas. Primeiro, precisamos entender o que está acontecendo neste momento na economia. Nossos problemas atuais não são produto do programa de recuperação que está apenas começando, como alguns querem que acreditem; eles são o resultado de décadas de impostos e impostos, e gastos e gastos. Em segundo lugar, devido ao fato de que nossos problemas econômicos estão profundamente enraizados e não vão responder rapidamente a rápidos consertos políticos, precisamos atentar [stick] para nosso cuidadoso plano integrado de recuperação. E tal plano está baseado em quatro sensoscomuns fundamentais: continuidade da redução dos gastos do governo federal, preservando as deduções de tributos individuais e corporativos que vão estimular a poupança e investimento, remover regulações federais desnecessárias para aumentar a produtividade e manter um dólar forte e uma política monetária estável, a última uma responsabilidade do Fed. A única alternativa a este nosso programa de recuperação é um retorno às políticas que nos deram uma dívida de um trilhão, inflação crescente, juros crescentes e desemprego." 125

\footnotetext{
125 "The economy will face difficult moments in the months ahead. But, the program for economic recovery that is in place will pull the economy out of its slump and put us on the road to prosperity and sTabela growth by the latter half of this year. That is why I can report to you tonight that in the near future the State of the Union and the economy will be better much better if we summon the strength to continue on the course that we've charted. And so the question: If the fundamentals are in place, what now? Two things. First, we must understand what's happening at the moment to the economy. Our current problems are not the product of the recovery program that's only just now getting under way, as some would have you believe; they are the inheritance of decades of tax and tax, and spend and spend. Second, because our economic problems are deeply rooted and will not respond to quick political fixes, we must stick to our carefully integrated plan for recovery. And that plan is based on four common-sense fundamentals: continued reduction of the growth in Federal spending, preserving the individual and business tax deductions that will stimulate saving and investment, removing unnecessary Federal regulations to spark productivity and maintaining a healthy dollar and a sTabela monetary policy, the latter a responsibility of the Federal Reserve System. The only alternative being offered to this economic program is a return to the policies that gave us a trillion-dollar debt, runaway inflation, runaway interest rates and unemployment." Este e outros discursos de Reagan podem ser encontrados no endereço www.reagan2020.us /.
} 
Este emaranhado de proposições foi condensado no que se chamou de "Program for Economic Recovery", o "Programa para Recuperação Econômica", de 1981. Num nível discursivo um pouco mais rigoroso, a equipe econômica do presidente assim descrevia o fundamento das políticas do novo governo:

"Todas nações que têm uma base de governos representativos e liberdades civis têm a maior parte de suas atividades organizadas pelo mercado. Nenhuma nação em que o governo tenha o papel econômico predominante tem mantido ampla liberdade política; as condições econômicas em tais países são geralmente inferiores àquelas comparadas em nações onde a economia é predominantemente de mercado." 126

Condizente com tal perspectiva, as políticas do Programa para Recuperação Econômica envolveriam, segundo o mesmo Economic Report de 1982:

“- cortar a taxa de crescimento dos gastos federais;

- reduzir os impostos de renda pessoais e criar empregos acelerando a depreciação para os investimentos corporativos em prédios e equipamentos;

- instituir um amplo programa de liberalização regulatória;

- em cooperação com o Fed, chegar a um novo acordo para a obtenção de uma política monetária que restaure uma moeda estável assim como mercados financeiros saudáveis." 127

De fato, era mais difícil argumentar a retomada dos gastos militares em termos tão aparentemente "neutros" do discurso econômico, de modo que não havia, em nenhuma parte dos documentos oficiais, nenhuma justificativa disto em termos de liberdade civil ou racionalidade econômica. Ou ainda em termos de algo que se assemelhasse à defesa das supostas sociedades liberais que embasavam o discurso anti-governo. Antes, eram os interesses de "defesa nacional" que justificavam o rearmamento, traduzidos no papel por um grande pragmatismo em evitar maiores questões quanto ao tema: de que o militarismo era apenas uma

\footnotetext{
126 "All nations which have broad-based representative government and civil liberties have most of their economic activity organized by the market. [...] No nation in which the government has the dominant economic role (as measured by the proportion of gross national product originating in the government sector) has maintained broad political freedom; economic conditions in such countries are generally inferior to those in comparable nations with a predominantly market economy." Economic Report of the President de 1982, p.27.

127 "Cutting the rate of growth in Federal spending; reducing personal income tax rates and creating jobs by accelerating depreciation for business investment in plant and equipment; instituting a far-reaching program of regulatory relief; in cooperation with the Federal Reserve, making a new commitment to a monetary policy that will restore a sTabela currency and healthy financial markets." Ibid., p.23.
} 
opção de política econômica, e que seu casamento com um programa de princípios liberais era realmente muito difícil.

Isto, como não poderia deixar de ser, escancarava as contradições no interior do discurso do reaganomics: como poderiam conciliar-se uma política militarista com a defesa dos interesses das liberdades do individuo, que o novo governo desejava perseguir? Assim, é forçoso admitir que para além da questão eminentemente teórica, havia o pragmatismo e os interesses do complexo industrial-militar, por detrás das figuras mais importantes do governo. Deste modo, os economistas do governo jactavam-se que em 1981 tinha havido redução dos gastos do governo, com "a composição dos gastos federais bastante modificada. Aceleraram-se os gastos em defesa, as despesas reais para a maior parte dos programas de transferência aos pobres e idosos foi mantida, e a maior parte das reduções foi feita em outros programas domésticos." 128

\subsection{As contradições do Programa}

Em 18 de Fevereiro de 1981, logo após tomar posse, Reagan propôs ao Congresso norte-americano cortes de 41 bilhões no orçamento herdado de Jimmy Carter, principalmente nas áreas contempladas pelo então chamado programa "Great Society”. Os benefícios cortados envolviam pensões para veteranos de guerra, refeições escolares, auxílios a famílias e no Medicare, o programa federal de auxílio à saúde. Ora, tais cortes, paralelamente aos futuros aumentos dos déficits com defesa, indicavam a natureza das políticas do governo: menos aos pobres, mais às corporações.

Como naquele momento os Republicanos não tinham a maioria no Congresso, Reagan tentou angariar o máximo apoio dos democratas no primeiro semestre de 1981, com intensa mobilização política. Ocorre, porém, que em 30 de Março Reagan sofreu uma tentativa de assassinato em frente a um hotel em Washington, pelas mãos de um John Hinckley. Este expediente, como se sugeriu acima, favoreceria George Bush, atrasou a implementação do programa. Só um mês depois, em 28 de Abril, Reagan retornava ao Congresso, ocasião em que foi bem recebido.

Neste momento, o presidente conseguiu aprovar seu orçamento ("Budget Bill") para 1982, o chamado "orçamento de base bi-partidária", ou "Graham-Latta II", devido aos congressistas Phil Gramm do Texas e Del Latta de Ohio. Estes assinaram sua formulação. A proposta destes vencera a do House Budget Committee, que previa menos cortes no orçamento e mais gastos militares. Em seguida, em 29 de Julho, o Congresso aprovou cortes nos tributos

\footnotetext{
128 "The composition of Federal spending was also substantially changed. Real defense spending was accelerated, real spending for the major transfer programs for the poor and aged was maintained, and most of the spending reductions were made in other domestic programs". Economic Report of the President de 1982, p. 23.
} 
(“Tax Bill”) em 25\%, ao contrário dos $30 \%$ propostos por Reagan. De qualquer forma, o Program for Economic Recovery seria implantado.

Naquele dia 28 de Abril, Reagan discursava ao Congresso, depois de recobrar sua saúde. Aí se viam sua brutalidade e cinismo característicos:

"No interesse desta administração, deixe-me dizer que aceito e apóio completamente a proposta substituta bi-partidária [opostamente à do House Budget Committee]. Ela vai conseguir atingir as metas essenciais de controle dos gastos do governo, reduzindo o peso tributário, colocando a defesa da nação em primeiro lugar, e estimular o crescimento econômico com criação de milhões de empregos. Ao mesmo tempo, entretanto, eu preciso colocar minha oposição à proposta do House Budget Committee. De fato, pode parecer que temos duas alternativas. $\mathrm{Na}$ verdade, porém, não há mais nenhuma alternativa. As propostas do House Budget Committee ficam aquém das ações que precisamos tomar. Por exemplo, nos próximos três anos, eles planejam gastar 141 bilhões a mais do que a proposta bi-partidária. Eles lamentavelmente cortam mais de 14 bilhões em gastos essenciais de defesa, necessários para restabelecer a segurança nacional dos Estados Unidos. Ela relacionase à proposta de tentar equilibrar o orçamento à custa dos contribuintes. [...] Tal medida reflete mais uma marca do passado, do que uma referência do futuro. Altas taxas e muitos gastos criaram nossa atual desordem econômica; mais do mesmo não vai eliminar as dificuldades, as durezas, e o desânimo que se abateu sobre o povo." 129

Mas o que iria significar na prática a implantação do leque de medidas do Reaganomics? O relato de Bill Clinton é útil neste sentido. Ele assim retrata as mudanças no sistema de auxílio a trabalhadores inválidos depois da ascensão de Reagan:

\footnotetext{
129 "On behalf of the administration, let me say that we embrace and fully support that bipartisan substitute. It will achieve all the essential aims of controlling government spending, reducing the tax burden, building a national defense second to none, and stimulating economic growth and creating millions of new jobs. At the same time, however, I must state our opposition to the measure offered by the House Budget Committee. It may appear that we have two alternatives. In reality, however, there are no more alternatives left. The committee measure quite simply falls far too short of the essential actions that we must take. For example, in the next three years, the committee measure projects spending $\$ 141$ billion more than does the bipartisan substitute. It regrettably cuts over $\$ 14$ billion in essential defense spending, funding required to restore America's national security. It adheres to the failed policy of trying to balance the budget on the taxpayer's back. It would increase tax payments over a third, adding up to a staggering quarter of a trillion dollars. Federal taxes would increase 12 percent each year. Taxpayers would be paying a larger share of their income to the government in 1984 than they do at present. In short, that measure reflects an echo of the past rather than a benchmark for the future. High taxes and excess spending growth created our present economic mess; more of the same will not cure the hardship, anxiety, and discouragement it has imposed on the American people." Este discurso foi colhido no endereço eletrônico Universidade de Seattle. Cf. http://www.seattleu.edu/artsci/history/.
} 
"As regras do recebimento de benefícios por invalidez haviam sido drasticamente apertadas. Tal como ocorrera com o programa das doenças pulmonares dos mineiros, dez anos antes, houve abusos no uso do programa de ajuda aos incapacitados, mas a cura imposta por Reagan foi muito pior que o problema. Os regulamentos eram tão restritos a ponto de se tornarem ridículos. No Arkansas, um motorista de caminhão que perdera um braço num acidente de trabalho teve negados seus benefícios por invalidez com base na hipótese de que ele poderia arrumar emprego em um escritório." 130

Assim, enquanto o desemprego aumentava, o governo diminuía direitos e gastos sociais, e combatia reivindicações trabalhistas. Veja-se por exemplo o tratamento dado aos controladores de tráfego aéreo que entraram em greve em 1981. Organizados em torno do PATCO - Professional Air Traffic Controllers Organization - eles paralizaram suas atividades na primeira semana de Agosto, contra o iminente corte de vagas e o ataque aos direitos trabalhistas. O presidente respondeu intimando os grevistas a interromperem a paralisação; os que não seguissem as diretrizes seriam despedidos em 48 horas. Ante à não interrupção, isto de fato acabou ocorrendo.

Gráfico 2. Estados Unidos. Gastos do governo federal: defesa e não-defesa. 1981-1984. Em bilhões de dólares.

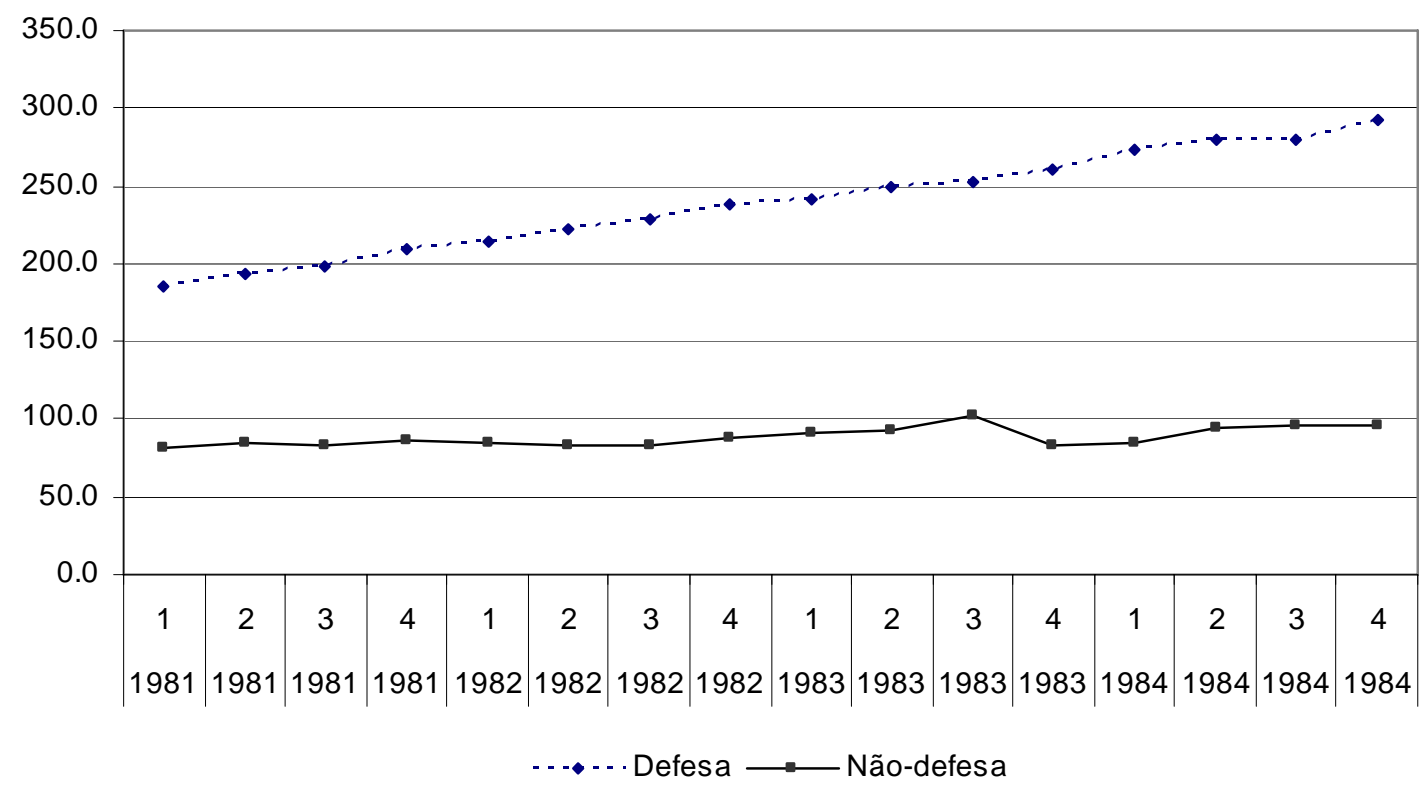

Fonte: NIPA-BEA. Seção 3, Government Current Receipts and Expenditures, Tabela 3.9.5. Government Consumption Expenditures and Gross Investment.

Logo, em meados de 1981, já estavam claros os delineamentos e a postura do governo face à crise. Tal se vê na enorme elevação dos gastos com defesa face aos outros gastos do

${ }^{130}$ Bill CLINTON, Minha vida, p.298. 
governo federal plotados na figura acima. Mas ficavam claras também as contradições das quais ia padecer a justificativa oficial do Program for Economic Recovery. Haveria um amplo espaço entre o que (i) teoricamente se buscava sustentar nos documentos oficiais, e (ii) a aplicação de tais postulados, com seus resultados bem diferentes dos previstos na prática. Em tempo: basicamente, a administração visava levar à frente uma diminuição dos impostos, tanto às famílias como às empresas, ao mesmo tempo em que declarava ser necessário pôr fim aos déficits. A redução dos impostos ocorreu como ilustra a figura abaixo: houve queda absoluta dos impostos corporativos, e uma interrupção da elevação dos impostos de renda das famílias. Adicionando-se isto o citado aumento nos gastos com defesa e levando-se em consideração que havia um forte contexto de desaceleração, balancear o orçamento parecia somente possível com alguma prática que apelasse ao sobrenatural, tal como caracterizava o próprio vice-presidente Bush (falava em "economia vodu").

Gráfico 3. Estados Unidos. Orçamento do governo federal: impostos sobre lucros corporativos e impostos de renda. 1981-1984. Em bilhões de dólares.

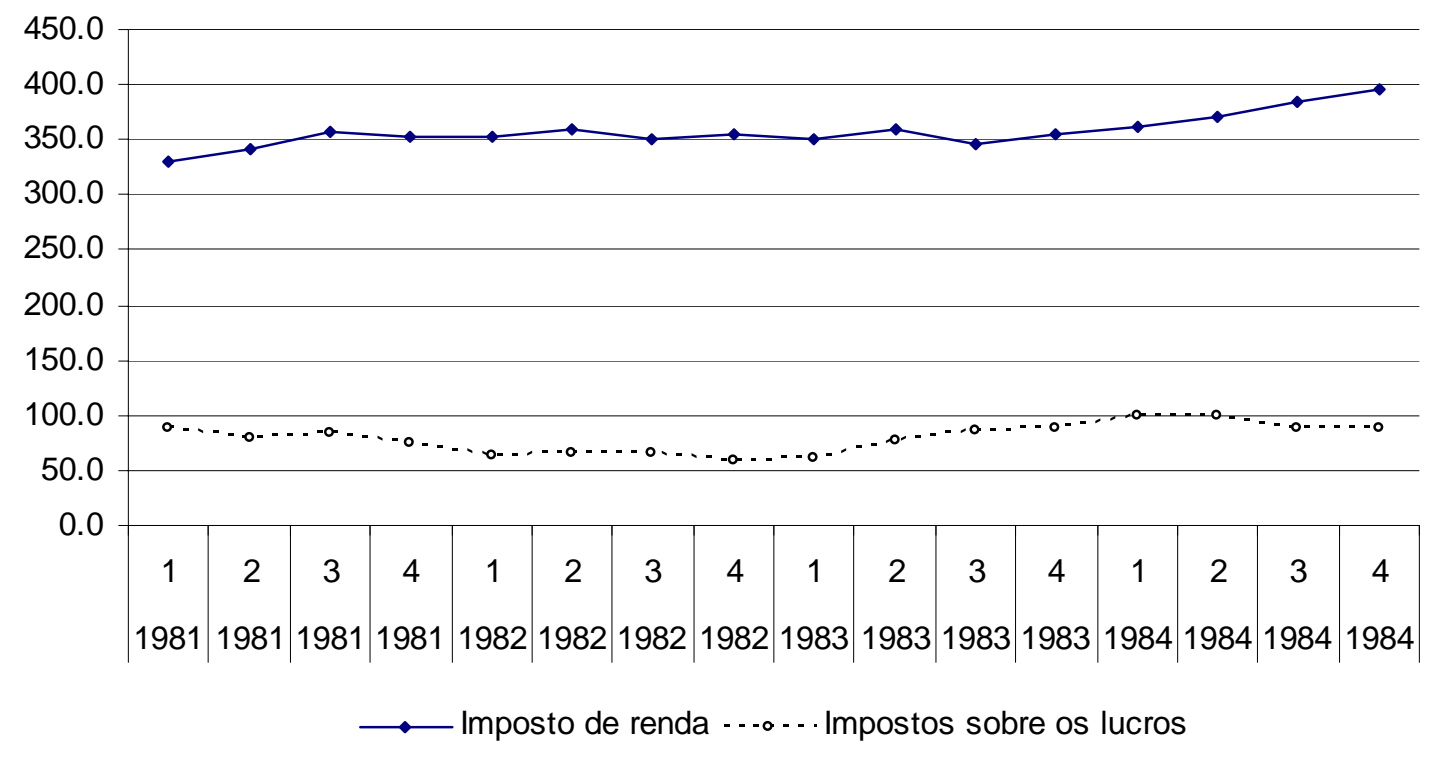

Fonte: NIPA-BEA. Seção 3, Government Current Receipts and Expenditures, Table 3.1. Government Current Receipts and Expenditures.

Não é necessária muita teoria para perceber-se que, caso fossem diminuídos os impostos e levados à frente os gastos nas indústrias de guerra, dever-se-ia aplicar uma redução nas outras esferas de gastos federais a ponto de fazer com que os déficits diminuíssem. Como se vê acima, tal pressão foi feita, mas à luz do aumento dos déficits ao longo do ano, podia-se dizer que havia um problema duplo no intento original, qual seja: (i) a impossibilidade de exercer uma pressão suficiente sobre os outros gastos a fim de manter um orçamento equilibrado; e (ii) a dificuldade de diminuir os gastos do governo durante a flutuação negativa do produto. Isto é, era impossível praticar todos os objetivos do Programa ao mesmo tempo. Diminuir impostos e aumentar gastos 
com defesa, num contexto de crise, reforçava a impossibilidade de reduzir drasticamente todos os quesitos do orçamento. Isto necessariamente significava aumentar os déficits. Justamente, a política do governo reforçava aquilo que julgava ser um dos grandes males da administração pública.

Realmente, a economia em 1981 apresentava uma situação ruim. Os lucros em todos os setores mostravam queda, enquanto a inflação apertava o passo e o desemprego se elevava. De acordo com o BEA (Bureau of Economic Analysis), os lucros reais das empresas financeiras (bancos, setor imobiliário, seguradoras) caíram de 25 bilhões em 1979 para 14,8 bilhões em 1980 e 8,3 bilhões em 1981; o setor manufatureiro, que em conjunto lucrara 74,3 bilhões em 1979, colhia lucros reduzidos de 55 bilhões em 1980. O amplo setor não-manufatureiro, de serviços, que havia amealhado 8 bilhões e 120 milhões de dólares em 1979, viu seus lucros diminuírem para 7,5 bilhões e 7,9 bilhões em 1980 e 1981. Segundo o BLS (Bureau of Labor Statistics), o desemprego para trabalhadores com mais de 16 anos aumentou de 6\% em 1979 para 7,2\% em 1980 e $8,5 \%$ em 1981.

Tabela 2. Estados Unidos. Déficits do governo federal. Em bilhões de dólares correntes. 19811983.

\begin{tabular}{cc}
\hline (1) & $(2)$ \\
Anos & Déficits \\
1981/I & 39,7 \\
II & 40,5 \\
III & 58,2 \\
IV & 101,7 \\
1982/I & 118,4 \\
II & 119,6 \\
III & 156,0 \\
IV & 208,1 \\
1983/I & 183,3 \\
II & 166,1 \\
III & 187,3 \\
\hline
\end{tabular}

Fonte: Economic Report of the President, 1984, Tabela B-75, Government receipts and expenditures, national income and product accounts.

Assim, no mesmo momento em que demonstrações anti-desarmamento ocorriam na Inglaterra e na Alemanha, Reagan discutia no segundo semestre de $1981 \mathrm{com}$ seus economistas quantos bilhões de dólares a mais o orçamento militar podia suportar, privilegiando a saída bélica à manutenção das promessas de campanha quanto a reduzir o déficit. Naturalmente, dadas as condições descritas, os déficits, ao invés de reduzirem-se em 1981, passaram de 39 a 101 bilhões, entre o primeiro e o quarto trimestre. Tornava-se claro, portanto, que com a reorganização dos gastos do governo rumo às inversões no setor militar, empresas como GE, Hewlett Packard, AT\&T, Raytheon, e outras, estavam sendo eleitas como o carro-chefe de uma tentativa de recuperação calcada sobre a intensificação, em última instância, da guerra fria. Abandonava-se parte das metas que o governo declarou ter no início do ano - basicamente, o controle do orçamento -, deixando claro que na impossibilidade de conciliar a teoria supply side 
e o orçamento balanceado com os interesses do complexo industrial-militar, não havia dúvidas do quê sacrificar. Dos objetivos expressos no Program for Economic Recovery, portanto, davase com sucesso a aplicação dos cortes de direitos sociais e impostos, assim como o rearmamento, às custas da situação do orçamento. Era evidente que toda malversação da participação do Estado na economia fora feita apenas para rebaixar os gastos do Estado que não interessavam às corporações - ao melhor estilo da micropolítica.

\subsection{A posição de Paul Volcker sobre a condução da política econômica}

Paul Volcker era presidente do Fed desde 1979, quando fora indicado pelo então presidente Carter. Professava o monetarismo, e sob esta perspectiva conduzia suas ações no Fed. Vejam-se algumas características da descrição da crise por Volcker.

De acordo com sua perspectiva teórica, a preocupação básica da política econômica do Fed deveria ser vigiar o crescimento da inflação. A inflação explicava-se basicamente pelo crescimento excessivo do dinheiro e do crédito. Não obstante o choque inflacionário à economia ter sido "real" - isto é, aumento dos preços do petróleo conjugados com crescente investimento na indústria de guerra - em sua perspectiva ele poderia ser combatido com sucesso por medidas monetárias. Em discurso ante o National Press Club, em 2 de Janeiro de 1980 - um ano antes do início do governo Reagan -, declarou:

"Nossa política, tomada numa perspectiva mais ampla, baseia-se numa premissa simples - documentada aliás por séculos de experiência - de que o processo inflacionário está relacionado em última instância com o crescimento excessivo do dinheiro e do crédito." 131

O objetivo expresso de Paul Volcker era reduzir a oferta de dinheiro, em conjunção com altos juros, para manter a estabilidade dos preços. Tal ajudaria a manter o valor interno e externo do dólar. Segundo tal, a aceleração da inflação havia alterado o modo pelo qual os bancos concediam créditos, no sentido de tornar tais políticas mais "agressivas". Para ele, neste ambiente, o significado particular de um nível determinado da taxa de juros era mais difícil de compreender sob uma inflação mais acelerada. Isso obrigava o Fed a focar sua atenção não somente nos juros, mas nos próprios agregados, "de modo a enfatizar o controle de oferta de dinheiro por meio da restrição do volume de reservas disponíveis para servir de base para

\footnotetext{
131 "Our policy, taken in a longer perspective, rests on a simple premise - one documented by centuries of experience - that the inflationary process is ultimately related to excessive growth in money and credit." "Remarks by Paul Volcker, Chairman of Board of Federal Reserve System, before National Press Club in Washington D.C", p. 2. Janeiro de 1980. Todos os documentos relacionados a Paul Volcker, a partir de agora (salvo menção em contrário), têm como fonte o endereço eletrônico do Fed de Saint Louis, a saber: http://fraser.stlouisfed.org/.
} 
depósitos no sistema bancário". ${ }^{132} \mathrm{O}$ Fed deveria portanto manejar os agregados monetários no sentido de uma forte contração, o que de fato foi feito.

Consoante tais perspectivas, Volcker opinava que a restrição sobre o dinheiro iria "alterar as expectativas" e contribuir para a manutenção dos preços baixos, algo que na rodada seguinte permitiria levar o capital a investir novamente. No fim deste citado discurso para o National Press Club em Janeiro de 1980, Volcker enfatizou, todavia, a necessidade de substituir o petróleo por outras fontes de energia, e também a importância de coordenação entre os países da IEA (Agência Internacional de Energia) para conter as pressões sobre o preço do insumo, em detrimento da OPEP.

A tese explícita nas propostas de Volcker para o aumento dos juros era, logo, a de que "a estabilidade do dinheiro ao longo de tempo é crítica para um crescimento sustentado e balanceado da própria atividade econômica", mas ao mesmo tempo reconhecia subrepticiamente a necessidade de conter os "choques" da economia real com medidas na economia real. Neste sentido, observava que a principal ameaça não só aos preços como à própria economia como um todo era o preço do petróleo e o lento crescimento da produtividade do trabalho. Os salários eram a variável da economia real que se deveria sacrificar em nome da "estabilização".

Porém, ao admitir isto abertamente, Volcker confessava que o aumento dos preços pela elevação do estoque monetário era a mera expressão da elevação dos preços na economia real, ou que, "mantendo todas as outras variáveis estáveis" (gastos com armas etc.), os salários deviam ser penalizados. Daí deveria argumentar que a inflação surgida de impactos da economia real resultava, de qualquer modo, num aumento da "oferta de dinheiro", e que a política monetária deveria focar, neste sentido, os próprios agregados. Mas, como se vê à frente, apontar para o alvo monetário traria apenas a aparência de resolução dos problemas - os preços estabilizados - em detrimento do crescimento, ainda que moderado, da economia (que era o fim ao qual supostamente dever-se-ia chegar).

Por outro lado, um fato crucial sobre a postura de Volcker no início do período Reagan foi sua oposição à (1) diminuição dos impostos e (2) ao aumento efetivo dos déficits federais, tal como ocorreria com a aplicação das políticas do governo. Neste sentido, sua perspectiva não era exatamente a mesma dos "Falcões" do governo. Volcker, ao contrário dos economistas da equipe republicana, passaria todo seu mandato no Fed criticando os resultados para o orçamento da política do governo. Esta e outras discordâncias face ao presidente certamente contribuiriam para a saída de Volcker em 1987, e para a ascensão de Alan Greenspan.

Basicamente, a posição de Volcker era de crer que os déficits federais já estavam em patamares altos. Numa reportagem no periódico Economic Outlook for the 80's, ainda em 1980, Volcker escreveu:

\footnotetext{
132 "In a manner to emphasize control of supply of money by means of restraining the volume of reserves avaible to support deposits in bank system" (p.7). "Economic Outlook for the 80's". Verão de 1980. In: The Texas Business Executive, p.42.
} 
"A redução dos tributos, com tudo o mais igual no curto prazo, iria incrementar os déficits orçamentários, mas os déficits têm sido muito altos por muito tempo. Realmente, a redução de impostos tem de ser conquista por redução persistente de gastos ao longo do tempo. As reduções de tributos deveriam ocorrer quando os negócios requeressem estímulo. Estas precondições não estão presentes, em minha opinião, hoje, e por isso o senso de austeridade e, creio, de responsabilidade, do Congresso e da Administração em resistir a prematuras reduções é admirável”. ${ }^{133}$

Isto estava em flagrante contradição com o que a política Reagan estava realizando e ia realizar. Ademais, o fato de que a redução dos gastos não fosse reduzida nunca demonstrava como as políticas anti-cíclicas eram um elemento fundamental na administração da economia norte-americana. O fato também de que o governo tinha já de coletar aproximadamente $20 \%$ de recursos para os déficits orçamentários no exterior em 1981 demonstrava como as contas do governo dependiam cada vez mais do endividamento externo.

"Uma vez que o senso de estabilidade é perdido, ele pode ser restaurado apenas com dor e sofrimento": ${ }^{134}$ para Volcker, monetarista rígido, só os juros e os preços baixos poderiam criar um ambiente que propiciasse condições para que as corporações investissem de novo, muito mais do que a diminuição de impostos ao capital. ${ }^{135}$ Os déficits federais apenas elevariam as taxas de juros e criariam "desconfiança" no mercado de capitais. O descontrole da criação da moeda geraria inflação e mais "desconfiança" para com o ambiente político. Se algo tinha de pagar pela estabilização, seriam os salários. Em sua declaração perante o Joint Economic Committee de 27 de Janeiro de 1983, ele continuava a enfatizar, ainda que de modo menos rigoroso, face ao déficit federal, que chegava a 207 bilhões: "Quanto mais perto cheguemos do equilíbrio orçamentário - tudo permanecendo igual - menor será a pressão nos mercados financeiros, e menor será a taxa de juros em conseqüência". ${ }^{136}$

Mas apesar do tratamento via juros altos à economia, do aperto do crédito e da posterior estabilização dos preços, a administração de Reagan não iria abrir mão dos déficits federais e da diminuição dos impostos. Contrariamente ao que prescrevia Volcker e sua perspectiva teórica. Não era a "confiança" dos mercados nos preços, mas sim os lucros e a demanda efetiva, que conduziam os gastos das empresas privadas. E a equipe de Reagan sabia que, mais do que

\footnotetext{
133 "Tax reduction, with other things equal in the short run, would increase budgetary deficits, but the deficits have been too high for too long. In a very real sense, tax reduction has to be earned by persistent spending restraint over a period of time. Tax reductions should be timed when business requires stimulus. These preconditions are not, in my judgement, present today and for that reason the sense of restraint and I think that the sense of responsibility by the Congress and the Administration in resisting premature tax reduction is admirable". Verão de 1980. In: The Texas Business Executive, p.44.

134 "Once a sense of price stability is lost, it can be restored only with pain and suffering". Ibid, p.44.

135 "Volcker estava disposto a deixar as taxas de juro subirem e o crescimento da base monetária cair até qualquer que fosse o nível necessário para puxar a inflação para menos de dois dígitos." EICHENGREEN, Barry. A globalização do capital, p.195.

136 "The closer the budget is to balance, all else equal, the less pressure will be felt in financial markets, the lower interest rates will be lessened" (p.8).
} 
preços estáveis às custas da retração da demanda e punição dos salários, o governo deveria endividar-se para contornar, ainda que em parte, os efeitos da crise surgida em 1979.

\subsection{A recuperação em 1983 e 1984}

O ano de 1982 não trouxe resultados rápidos das políticas da administração Reagan, com a economia atingindo o fundo da crise que se iniciara já na década passada. No início do ano, Reagan enviou a proposta de orçamento ao Congresso. Esta cortava mais verbas públicas com gastos sociais, mas mantinha elevados os gastos militares. Deflacionados, os déficits fiscais do governo federal no fim de 1982 chegariam a 208 bilhões de dólares, tendo estado a 108 bilhões no primeiro trimestre.

Enquanto isso, a postura de Reagan face à União Soviética se tornava mais belicosa e confiante. Em oito de Junho, ele discursou no Parlamento Britânico, antevendo a vitória da "liberdade sobre o comunismo". Brezhnev respondeu que os Estados Unidos estavam empurrando o mundo para as "chamas da guerra nuclear". Quatro dias depois, aproximadamente um milhão de nova-iorquinos realizaram um protesto pacífico pelo desarmamento no Central Park. Não obstante, o governo, depois de sancionar e apoiar a invasão do Líbano por Israel, decidiu enviar marines para a região. As tropas israelenses já estavam presentes no Líbano desde a invasão em 6 de Junho, para agressão militar a membros da Organização para a Libertação da Palestina alojados naquele país. ${ }^{137}$

Neste ínterim, a situação econômica se agravou em 1982. O desemprego chegou a 11\%, o que significava que dez milhões de trabalhadores estavam sem trabalho. Nas eleições para a "Câmara dos Deputados" (House of Representatives) no Congresso daquele ano, os Democratas conquistaram 26 novas cadeiras, enquanto o Partido Republicano administrava maioria no Senado. No começo de 1983, deu-se o pico dos efeitos da crise. No primeiro dia de 1983, em Milwaukee, no "Cinturão Manufatureiro" do nordeste dos Estados Unidos, vinte mil trabalhadores se apresentaram, sob temperatura de 20 graus negativos, para a disputa de 200 vagas numa firma de automação industrial.

Bill Clinton assim descreve o panorama econômico no Estado em que governava, o Arkansas:

“[Em 1983] o desafio à minha frente era cumprir a promessa de responder melhor às expectativas do povo, mantendo meu compromisso de trazer o progresso para nosso Estado [Arkansas]. Era uma tarefa complicada, e que se tornava mais importante pelo estado de penúria da economia. A taxa de desemprego no Estado era de 10,6\%. Em Dezembro, como governador eleito, fui a Truman, no nordeste do Arkansas, para cumprimentar um por um os seiscentos operários da fábrica

137 A carnificina promovida pelas forças israelenses contra os muçulmanos tornou-se conhecida mundialmente. Cf. BANDEIRA, Moniz. Formação do Império Americano, p.421. 
Singer, que durante décadas haviam construídos gabinetes de madeira para máquinas de costurar e que agora saíam da fábrica pela última vez. O fechamento da fábrica, um dos muitos que tivemos de suportar ao longo dos anos anteriores, foi um golpe duro na economia do condado de Poinsett e teve um impacto desanimador em todo o Estado. Ainda vejo o olhar de desespero no rosto de muitos daqueles operários da Singer. Sabiam que haviam sempre trabalhado duro, e que seu sustento lhe estava sendo tomado por forças além de seu controle." 138

Enquanto a aprovação de Reagan caía a 35\%, o governo mandava em 31 de Janeiro de 1983 a proposta orçamentária, que previa déficits ainda maiores, num reconhecimento tácito do fracasso do intento original do Program for Economic Recovery. A recessão, os gastos com armas, os altos juros pagos pelo governo, e os favorecimentos ao capital e aos mais ricos, pela diminuição desproporcional dos impostos às faixas mais opulentas dos contribuintes, explicavam a deterioração das contas do governo. Não obstante, em fins de Março, Reagan anunciou o Space Defense Initiative, algo como "Programa para a Defesa do Espaço", no qual apelava aos cientistas norte-americanos para que, depois das armas nucleares, construíssem um sistema de defesa do espaço aéreo norte-americano contra mísseis nucleares estrangeiros.

Apenas em meados de 1983 a economia iniciaria uma nova expansão, que vinha de: (i) uma elevação enorme da taxa de desemprego e do "enxugamento" dos capitais menos resistentes à crise, a deprimir os salários e elevar a taxa de lucro; (ii) dos déficits fiscais e seus efeitos multiplicadores. Começou então a haver variações trimestrais do PNB sem interrupções ao longo do ano, tal como se vê na figura abaixo. De fato, com o esboço de recuperação, as taxas de juros começaram a cair. A expansão dava-se pelo aumento das taxas de lucro à custa de menores custos do trabalho e de induções fiscais mediante déficits com as indústrias de guerra. Ao mesmo tempo, o governo e as corporações aumentavam seu endividamento no exterior, o que foi facilitado pela revalorização do dólar. Paralelamente, o que pode ser entendido como um terceiro elemento (iii) a debelar a crise, o preço do petróleo começou a cair.

Ocorre, porém, que esta recuperação sofria as vicissitudes de dois mecanismos contraatuantes: (i) a renda deprimida das famílias mais pobres impedia uma recuperação maior, pelo aumento relativo do consumo; e (ii) o dólar em alta trazia abaixo as exportações, causando por seu turno aumento das importações. Estas, entre 1982 e 1984, somaram variação de 25\%. Por sua vez, os pagamentos de rendas ao exterior aumentaram 2,2 vezes entre 1979 e 1984, enquanto que os recebimentos apenas 1,7. A posição externa do país piorava claramente, com aumento de captações de empréstimos bancários, de empresas e do governo no exterior, em detrimento do recebimento de rendas de capitais norte-americanos no exterior. ${ }^{139}$ De modo sintomático, neste ano de 1983, o resultado positivo na conta de capitais, dado pela diferença

\footnotetext{
${ }^{138}$ CLINTON, Bill. Minha vida, p.290.

${ }^{139}$ Mesmo que a esta altura a remessa de juros dos países endividados do terceiro mundo já tivesse se avolumando.
} 
entre os ativos nos Estados Unidos em poder dos estrangeiros e os ativos norte-americanos no exterior, ultrapassou os resultados em conta corrente do balanço de pagamentos. A importação de capital externo passava a ter um papel cada vez mais presente.

Gráfico 4. Estados Unidos. Variações trimestrais do PNB (em \%). 1980-1984.

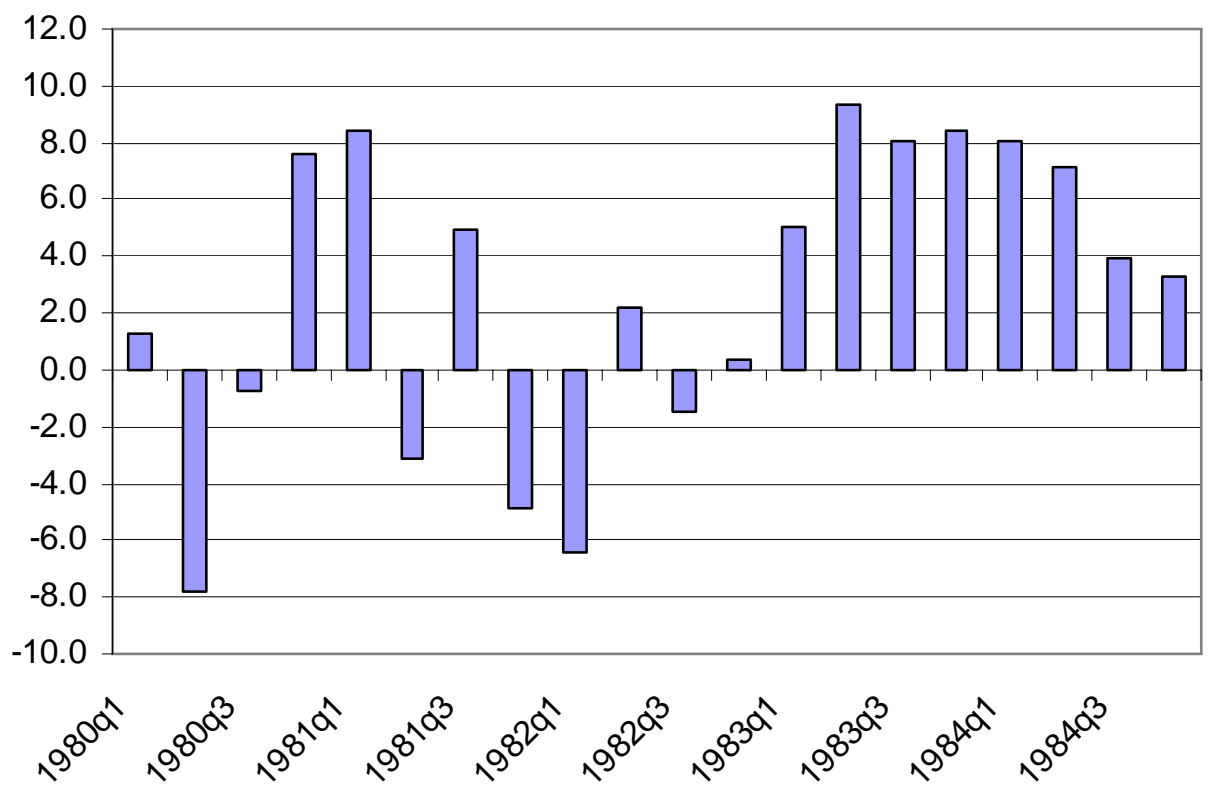

Fonte: NIPA-BEA. Seção 1, Domestic Product and Income, Tabela 1.1.1, Percent Change From Preceding Period in Real Gross Domestic Product.

Tabela 3. Estados Unidos. Balanço de Pagamentos. Contas Selecionadas: conta de capitais (1), balanço em rendas (2) e balança comercial (3). 1979-1984. Em milhões de dólares correntes.

\begin{tabular}{ccccccc}
\hline & \multicolumn{2}{c}{$(1)$} & \multicolumn{2}{c}{$(2)$} & \multicolumn{2}{c}{$(3)$} \\
& \multicolumn{2}{c}{ Conta de Capitais } & \multicolumn{2}{c}{ Balanço em Rendas } & \multicolumn{2}{c}{ Balança Comercial } \\
1979 & Recebimentos & Envios & Recebimentos & Envios & Importações & Exportações \\
1980 & -64915 & 40852 & -32961 & 63834 & -248696 & 224131 \\
1981 & -85815 & 62612 & -42532 & 72606 & -291241 & 271834 \\
1982 & -113054 & 86232 & -53626 & 86529 & -310570 & 294398 \\
1983 & -127882 & 96589 & -56583 & 91747 & -299391 & 275236 \\
1984 & -66373 & 88694 & -53614 & 90000 & -323874 & 266106 \\
\hline
\end{tabular}

Fonte: NIPA-BEA. Seção 4, Foreign Transactions, Tabela 4.1., Foreign Transactions in the National Income and Product Accounts.

Entrementes, a leitura oficial passou a falar da "maior recuperação já vista em tempos de paz". O termo "paz" era evidentemente um atentado ao bom senso. Coerentemente, o novo secretário-geral do Partido Comunista da União Soviética, Yuri Andropov, criticou os Estados Unidos, alegando que a passagem da disputa ideológica para a disputa nuclear, como os Estados Unidos pareciam querer, seria demasiado custosa a todos. Reagan respondia com uma política exterior que buscava justificar a existência da indústria de guerra: enviou marines ao Líbano, e 
fez desembarcar, em 25 de Outubro de 1983, 5.000 soldados na Ilha de Granada (Caribe), com o fito de combater ali o movimento comunista.

Gráfico 5. Japão (iene - eixo esquerdo) e Alemanha (marco - eixo direito). 1979-1984. Taxas de câmbio referentes ao dólar.

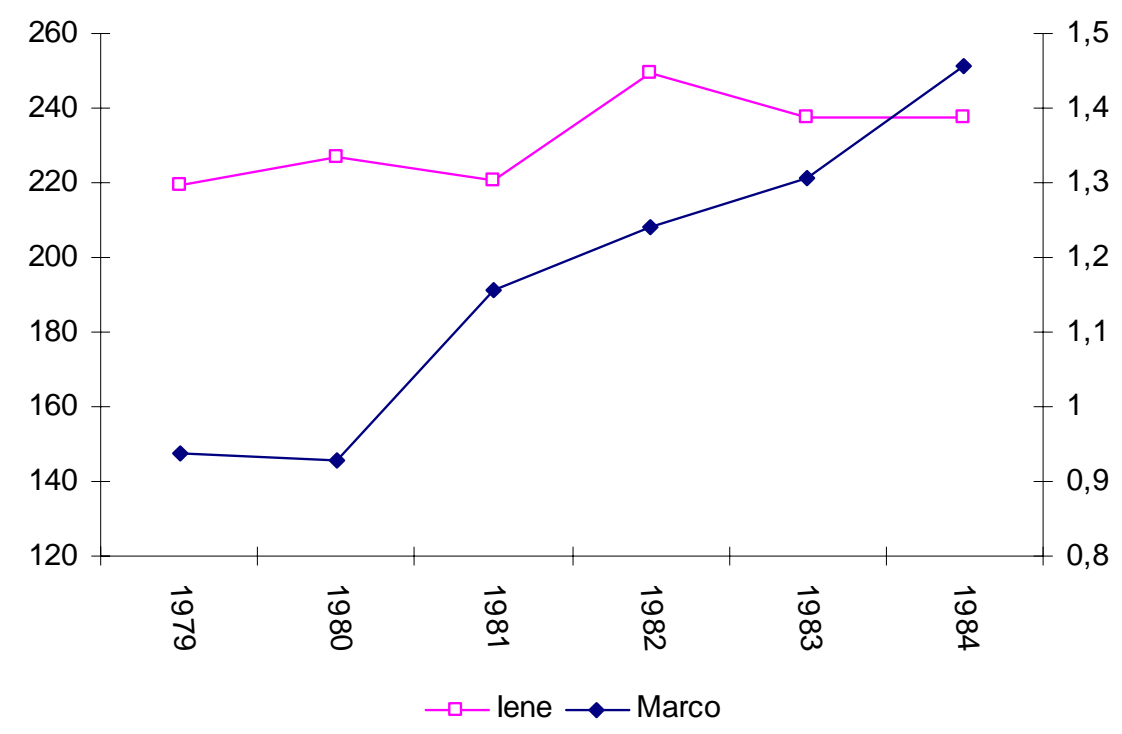

Fonte: OCDE. Ver http://stats.oecd.org /

Gráfico 6. Estados Unidos. Resultados líquidos de Conta de Capitais (ativos norte-americanos em mãos de estrangeiros menos ativos norte-americanos no exterior) e Conta Corrente de Balanço de Pagamentos. 1979-1984. Em milhões de dólares.

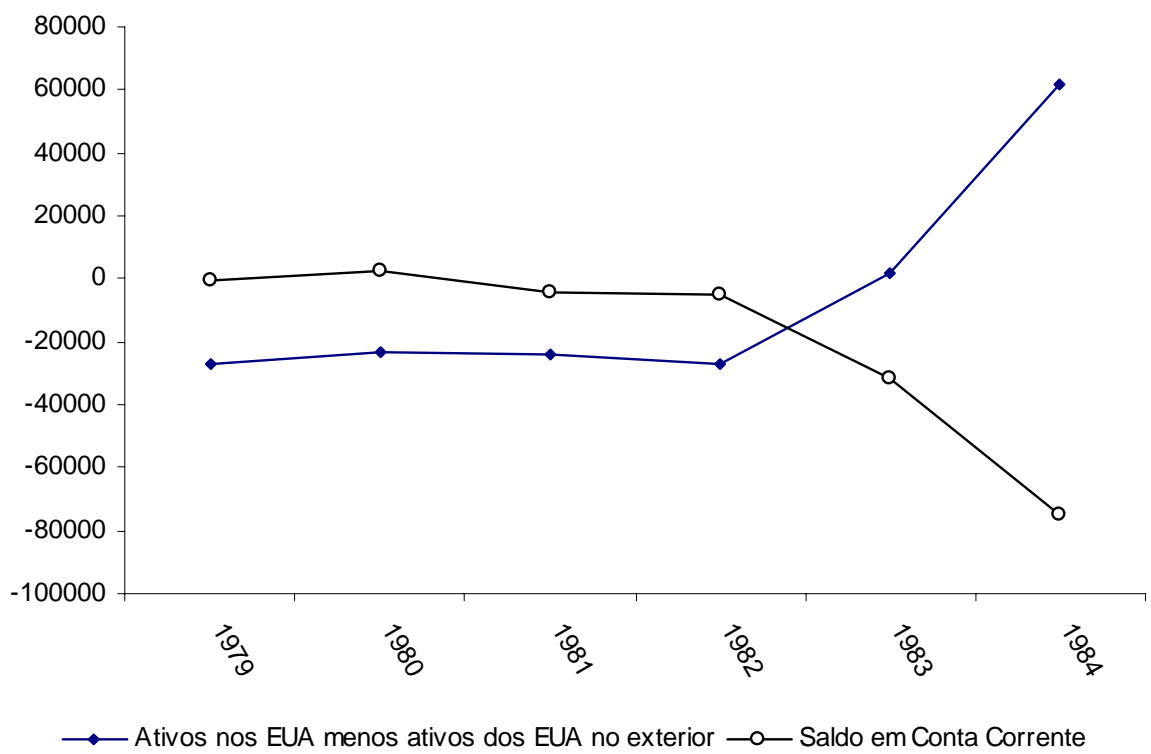

Fonte: Economic Report of the President, 1984, Tabela B-98 e B-99, U.S. International Transactions, 1946-1983. "Ativos nos EUA menos ativos dos EUA no exterior" forma obtidos a partir da soma de "U.S. Assets abroad, net" com "Foreign Assets in the U.S., net", na Tabela B-99. 
Em 23 de Novembro, os Estados Unidos instalaram novos mísseis interbalísticos Pershing II na Alemanha Ocidental. Promovendo ao mesmo tempo um esforço de isolamento internacional do Irã, as políticas de Reagan obrigavam as lideranças soviéticas a alguma postura mais decisiva, fosse de abertura, fosse de aceitação da nova corrida militar. No ano seguinte, 1984, a política externa aprofundou ainda mais o belicismo; em Maio de 1984, o governo norteamericano financiou os "Contra" na Nicarágua, com mais uma violação de soberania nacional e milhões em armas aos movimentos contra-revolucionários. ${ }^{140}$

Por sua vez, ante uma situação que sinalizava uma perda de controle dos gastos federais - para a qual era indiferente a estabilização dos preços - a política econômica em 1984 buscou limitar novos aumentos dos déficits. Ao mesmo tempo, elevou em parte a tributação às corporações e às famílias. Os juros também seriam elevados, dado o crescimento a partir do segundo trimestre de 1983. Os juros pagos pelo governo aos bancos norte-americanos, pelos financiamentos de grande parte da dívida fiscal, elevavam-se, chamando a atenção do presidente do Fed, Paul Volcker. Os déficits fiscais anunciados para 1985 estavam em estratosféricos 180 bilhões de dólares, ou quase 5\% do PNB. De 1980 a 1984, a dívida pública federal ascendera de $33 \%$ a $40 \%$ do PNB.

Em um importante documento - Statement by Paul Volcker, Chairman Board of Governors of Federal Reserve System, Before the Committee on the Budget - United States Senate - Volcker traçava o panorama da economia no ano. Iniciava elogiando a estabilização da inflação e a expansão desde 1983, assim como a desregulação que o governo de Reagan praticava em muitos setores da economia, dando continuidade à política de Ford. ${ }^{141}$ Mas ele observava o endividamento da economia, tanto do governo (que ficava sozinho com $35-40 \%$ de todos os fluxos de capital externo) como dos setores privados, como um problema determinante para aquele período. Volcker fazia uma análise honesta do papel crucial que o endividamento externo assumiu para a economia naquele momento, e dos perigos a que esta política conduzia. Alertava para o pagamento escorchante de juros pelo governo federal, e da impossibilidade para o Fed de "monetizar" a dívida. ${ }^{142}$

Vejam-se alguns trechos deste documento, onde se apontam as fragilidades da expansão baseada no endividamento da economia com o exterior. A "sinceridade" de Volcker quanto à crescente fragilidade da economia é um dos motivos pelos quais seria substituído por Alan Greenspan, aliado incondicional de Reagan.

\footnotetext{
${ }^{140}$ Neste momento, tornou-se célebre o descuido de Reagan ao divertir-se falando ao rádio, em tom de bazófia, que os Estados Unidos iriam atacar e eliminar a União Soviética em cinco minutos - piada que, por descuido, fora ao ar.

${ }^{141}$ Os primeiros setores visados eram os de companhias aéreas, de transporte rodoviário, oleodutos, telefonia, mercado financeiro, e serviços públicos. Para uma descrição pormenorizada (e laudatória), ver o relato de Alan Greenspan, em The Age of Turbulence, à página 71.

${ }^{142}$ Como Volcker observaria em 1985: "The Federal Reserve can theoretically run the modern equivalent of the printing press - we can create more money. But more money is not the same as correcting the gross imbalance between our ability to generate real savings and the demands for those savings posed by housing, by investment and by the federal deficit." Statement by Paul Volcker, Chairman, Board of Governors of the Federal Reserve System, before the Committee on Banking, Housing and Urban Affairs - U.S.Senate. 20 de Fevereiro de 1985.
} 
“1983 foi um ano de recuperação mais forte do que se supunha ocorrer. Mas a questão que permanece é se nós podemos, como nação, gerar a oferta de poupança necessária para suportar tanto os investimentos crescentes $e$ um grande déficit federal. [...] Os efeitos adversos do desequilíbrio da poupança e investimentos domésticos nos mercados de crédito e em nossas contas externas tornaram-se mais visíveis. [...] Por algum tempo, fomos capazes de obter poupança externa tranqüilamente. Tais recursos foram atraídos não somente pelos juros e pelo nosso mercado financeiro robusto, mas por uma relativa confiança em nossa estabilidade política e econômica. O efeito tem sido enfraquecer um pouco o impacto dos déficits sobre os juros, e ajudar a financiar tanto o déficit com o investimento. Mas, contar futuramente com mais influxos de capital estrangeiro é um modo tortuoso e arriscado de financiar o crescimento doméstico e a formação de capital. Ele cobra um custo alto em termos de aumentos dos déficits comerciais e de déficits em conta corrente - déficits que não podem ser sustentados eternamente [grifo meu - VES]. [...] Nós não podemos escapar de modo simples destes problemas 'monetizando' a dívida do Tesouro, mediante expansão excessiva do crédito bancário e da oferta de dinheiro." ${ }^{143}$

O ano de 1984 transcorreria já sob o calor da campanha para as próximas eleições. Em Junho, o exército testava um sistema de interceptação de mísseis interbalísticos. Os eleitores, volúveis, que antes rechaçavam Reagan pela crise, agora o ovacionavam, com sua popularidade crescendo junto das variações positivas do PNB. A relação com a União Soviética seguia em seus rumos hipócritas, com reuniões entre líderes, declarações favoráveis ao desarmamento, mas manutenção dos gastos com tecnologias bélicas e invasões de países da periferia. Neste ínterim, os democratas criticavam a capacidade de Reagan de levar à frente seu segundo governo, com base em sua idade avançada e capacidade intelectual contestada.

Mas não era um bom momento para os democratas. Ainda que assentado sobre uma base frágil, o crescimento da economia chegava a $7 \%$ no primeiro trimestre de 1984 . O candidato democrata, Walter Mondale, não foi um candidato forte. Sua declaração de que iria cortar o déficit federal pela metade, mas que para isto teria que aumentar impostos - e que sua diferença para com Reagan era que a de que ele simplesmente estava confessando o inevitável -

\footnotetext{
143 " 1983 was a year of recovery stronger than most had believed was likely to occur. But the question remains whether we can, as a nation, generate the supply of savings necessary to support both rising investment and a huge government deficit. [...] The adverse effects of the imbalance of domestic savings and investment on credit markets and on our external accounts have become more apparent. [...]. For some time, we have been able to draw upon foreign savings relatively easily. Funds have been attracted not just by our interests rate and by our strong stock market, but by relative confidence in our economic and political stability. The effect has been to blunt some of the impact of the budget deficit on our interest rates, and to help finance both the deficit and investment. But, over time reliance on increasing amounts of foreign capital is a tenuous and risky way to finance domestic growth and capital formation. It exacts a large cost in terms of rising trade and current account deficits - deficits that cannot be sustained indefinitely. [...] We cannot reasonably escape from these problems by 'monetizing' the Treasury debt through excessive expansion of bank credit and the money supply." O documento está disponível no mesmo endereço que os outros citados, referentes a Paul Volcker.
} 
impactou negativamente no eleitorado, sempre disposto a optar pelo discurso mais fácil. Reagan lhe imputava publicamente inexperiência, juventude demais, em comparação com ele próprio, o mais idoso presidente a governar o país. O resultado foi uma maciça vitória de Reagan. Venceu em 49 Estados, com $60 \%$ dos votos totais. Um quarto dos eleitores democratas registrados votou em Reagan.

\subsection{Análise empírica}

\subsubsection{O desempenho da economia durante o Programa para Recuperação Econômica}

A política econômica desempenhada pelo Fed conseguiu o que Volcker declarava ser necessário: manter os preços baixos até 1983. Mas trouxe junto a amarga retração que nos textos da "teoria das expectativas racionais" não poderia coadunar-se com preços estáveis. Os preços foram estabilizados, mas à custa de forte retração da economia em 1981 e 1982, principalmente pelo lado dos salários e dos programas de assistência social. Desde 1979, os juros elevados uniram-se aos lucros em queda - dada a pressão representada pelos aumentos passados nos preços do petróleo - para provocar enorme diminuição dos gastos privados. A queda dos lucros e assim dos investimentos provocou grande aumento do desemprego e perdas salariais. Estas perdas para o trabalho, enfraquecendo a já débil organização dos trabalhadores àquela altura, ajudariam as empresas a recompor a queda da taxa de lucro, o que foi auxiliado pela redução dos tributos ao capital feita pelo governo.

Todos os indicadores de emprego e renda mostram as perdas para os trabalhadores. $\mathrm{O}$ desemprego elevou-se de 7 para 10\% entre 1980 e 1983. Os ganhos salariais médios por hora diminuiriam de 8,4 dólares em 1980 para 7,86 em 1983 e para 7,94 dólares em 1984. Por sua vez, vistos de 1978 a 1984, a queda na utilização da capacidade instalada na indústria somou $10 \%$ no setor como um todo. Para ter-se ideia do tamanho da recessão, o setor de bens de consumo duráveis chegou a ter apenas 65\% de sua capacidade instalada utilizada em 1982. 
Tabela 7. Estados Unidos. (1) Novas empresas abertas por ano, (2) falências, em números absolutos, de empresas com capital menor que 100 mil dólares e (3) com capital superior a 100 mil dólares, e taxa de falências. 1979-1986.

\begin{tabular}{ccccc}
\hline$(1)$ & $\begin{array}{c}(2) \\
\text { Novas } \\
\text { empresas } \\
\text { abertas }\end{array}$ & $\begin{array}{c}\text { Falências de empresas com } \\
\text { capital menor que 100 mil }\end{array}$ & $\begin{array}{c}\text { Falências de empresas com } \\
\text { capital maior que 100 mil }\end{array}$ & $\begin{array}{c}\text { Taxa de } \\
\text { falências (\%) }\end{array}$ \\
1979 & 524565 & US\$ & US\$ & 27,8 \\
1980 & 533520 & 3930 & 3634 & 42,1 \\
1981 & 581242 & 5682 & 6060 & 61,3 \\
1982 & 566942 & 8233 & 8561 & 89 \\
1983 & 600400 & 11509 & 13399 & 110 \\
1984 & 634991 & 15509 & 15825 & 107 \\
1985 & 662047 & 19618 & 32460 & 115 \\
1986 & 702738 & 36531 & 20714 & 120 \\
\hline
\end{tabular}

Fonte: Economic Report of the President, 1991, Tabela B-4, Business formation and business failures, 1946-1990.

Gráfico 8. Estados Unidos. Lucros no setor manufatureiro, financeiro e de serviços, depois de cobrados os impostos, deflacionados pelo dólar de 1980. 1979-1984. Em milhões de dólares.

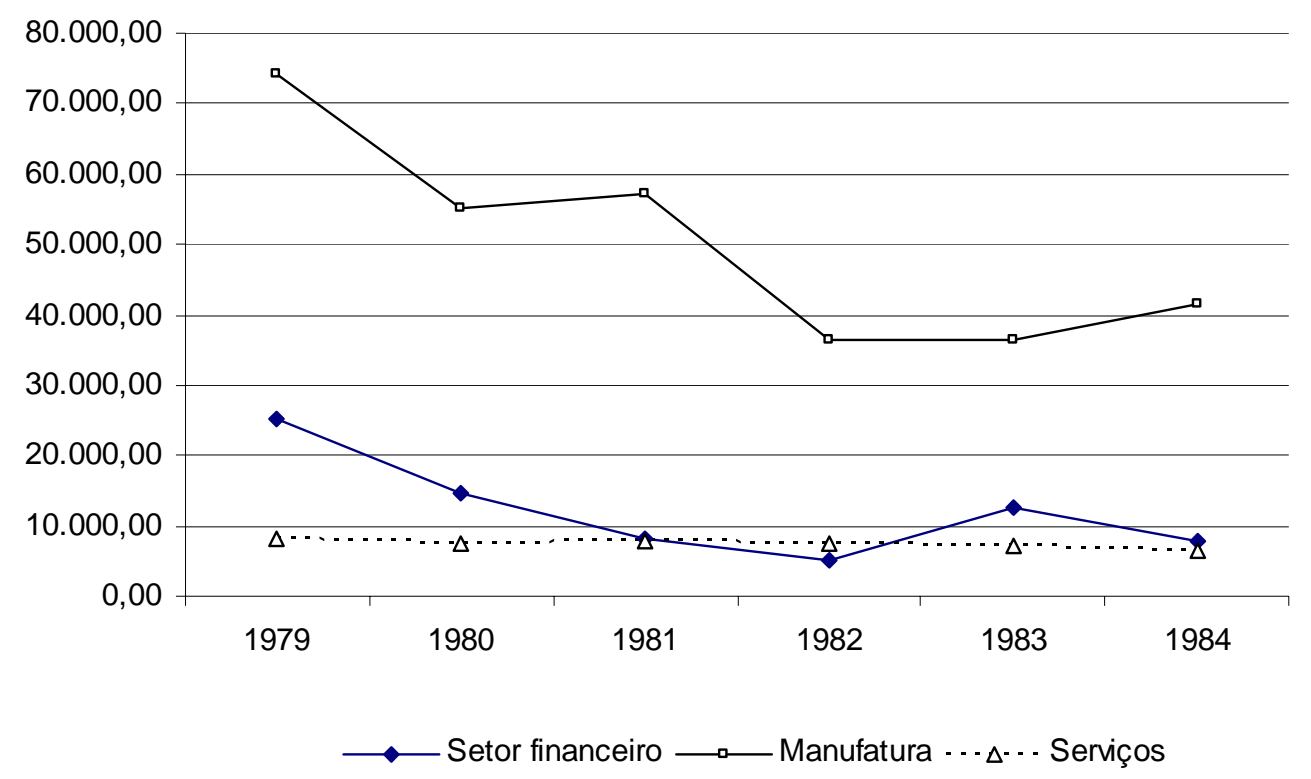

Fonte: NIPA-BEA. Seção 6, Income Employment by industry, Tabela 6.19B. Corporate Profits After Tax by Industry.

Entre 1981 e 1982, como resultado dos juros elevados, o crédito diminuiu e os meios de pagamento encolheram, assim como a base monetária. Exerceu-se sobre a atividade econômica forte impacto recessivo, para que a queda da demanda agregada, principalmente do consumo, ajudasse a estabilizar os preços. Isto eliminava também os capitais menores e menos lucrativos, diante de tais condições do crédito e da demanda (Brenner) ${ }^{144}$. O Economic Report de 1992, por exemplo, traz, em seu apêndice estatístico, a tabela Business Formation and Business Failures 
(B-29). A taxa de falências, medida em porcentagem sobre cada dez mil empresas registradas pelo governo, foi de $27 \%$ em 1979 , e subiu a nada menos que $61 \%$ em 1981 e $89 \%$ em 1982 , para atingir as incríveis marcas de $110 \%$ em 1983, 115\% em 1985 e 120\% em 1987. Em números específicos, em 1983 trinta e uma mil empresas faliram, e em 1984 e cinqüenta e duas mil (em 1979, apenas sete mil haviam falido). O topo do número de falências deu-se em 1986, com quarenta mil empreendimentos falidos, o que deixa ver que os efeitos da crise e do ajuste recessivo estenderam-se década adentro.

Assim, este ambiente facilitava, com eliminação do capital "excedente" e pulsão negativa sobre o salário, as futuras recomposições da taxa de lucro, dada a enorme desvalorização do capital instalado falido, e assim a consecutiva valorização do capital que restava de pé. Para muitas empresas, recompor os lucros face ao valor deprimido dos salários foi uma saída à queda das exportações, devido a um dólar mais valorizado. Os preços estabilizados asseguravam, porém, o próprio valor do dólar, restaurado a partir da elevação dos juros em 1979. Além disso, representavam (preços) menores perdas para os detentores de títulos préfixados.

Tabela 3. Estados Unidos. 1978-1984. Utilização de capacidade instalada na indústria, em \%.

\begin{tabular}{cccc}
\hline$(1)$ & $(2)$ & $(3)$ & $(4)$ \\
Anos & Total Indústria & Bens duráveis & Mineração \\
1978 & 84,8 & 83,9 & 89,8 \\
1979 & 85 & 84,5 & 91,1 \\
1980 & 80,7 & 77,6 & 91,5 \\
1981 & 79,7 & 75,3 & 91,4 \\
1982 & 73,7 & 66,6 & 83,7 \\
1983 & 74,7 & 68,4 & 78,5 \\
1984 & 80,4 & 76,7 & 84,7 \\
\hline
\end{tabular}

Fonte: Economic Report of the President, 2006, Tabela B-54, Capacity Utilization Rates, 19592005.

Tabela 3. Estados Unidos. Ganhos salariais nas empresas privadas não-agrícolas, em dólares de 1982, e taxa de desemprego (\%).1978-1984.

\begin{tabular}{cccc}
$(1)$ & $(2)$ & $(3)$ & $(4)$ \\
Anos & Ganhos médios por & $\begin{array}{c}\text { Ganhos médios } \\
\text { semanais totais }\end{array}$ & Taxa de desemprego \\
1978 & hora & 310,99 & 6,2 \\
1979 & 8,66 & 310,41 & 6,1 \\
1980 & 8,67 & 298,87 & 7,6 \\
1981 & 8,4 & 281,27 & 8,2 \\
1982 & 7,99 & 277,35 & 10,6 \\
1983 & 7,88 & 272,74 & 10,7 \\
1984 & 7,86 & 277,5 & 8,5 \\
\hline
\end{tabular}

Fonte: Economic Report of the President, 2006, Tabela B-49, Productivity and Related Data, Business Sector, 1959-2005. 
Os aumentos do preço do petróleo impactaram fortemente na taxa de lucro; de modo geral, quanto maior é o valor do capital fixo, menor é o valor das mercadorias que ele produz, se o tempo de rotação é muito grande e a mercadoria possui pequeno valor agregado. Mas o petróleo é capital circulante, e quanto maior seu preço maior será o impacto no valor da mercadoria produzida no curto prazo. Por isso, o aumento da composição orgânica do capital é imediato e muito mais deletério na ocasião em que ele aumenta do que quando cresce o grau de mecanização. Como capital circulante, o custo do petróleo entra diretamente na mercadoria.

Tabela 4. Estados Unidos, dados selecionados, 1978-1984.

Índices de preços ao consumidor para as principais categorias de gastos

$\begin{array}{ccccc} & \text { Todos itens } & \text { Energia } & \text { Alimentação } & \text { Transportes } \\ 1978 & & & & \\ 1979 & 65,2 & 52,5 & 72,2 & 61,7 \\ 1980 & 72,6 & 65,7 & 79,9 & 70,5 \\ 1981 & 82,4 & 86 & 86,7 & 83,1 \\ 1982 & 90,9 & 97,7 & 93,5 & 93,2 \\ 1983 & 96,5 & 99,2 & 97,3 & 97,1 \\ 1984 & 99,6 & 99,9 & 99,5 & 99,3 \\ & 103,9 & 100,9 & 103,2 & 103,7\end{array}$

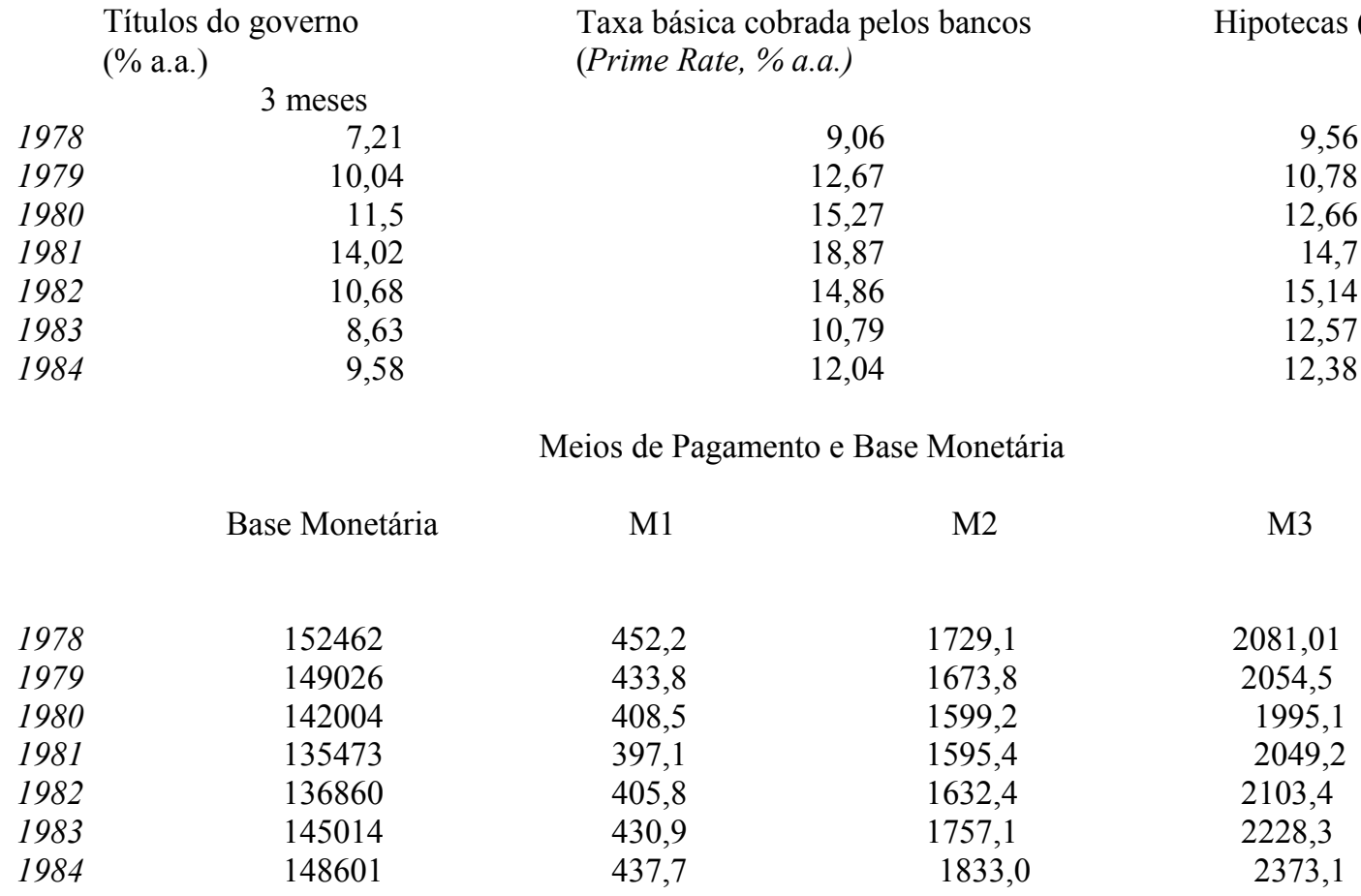

Fonte: Economic Report of the President, 2006. (1) Índices de Preço ao Consumidor de acordo com as principais categorias de gastos, 1978-1979. 1982-1984 = 100. (2) Taxas de juros selecionadas e taxa de juros básica cobrada pelos bancos está em porcentagem anual (\% a.a). (3) Base monetária, em milhões de dólares, e meios de pagamento, em bilhões de dólares. Onde: $\mathrm{M} 1$ = soma de moeda, depósitos à vista, travelers checks e outros depósitos. M2 = M1 mais Money Market Mutual Funds (MMMFs), e depósitos de curto prazo (small time deposits). M3 = depósitos de longo prazo, Euro-dólares, e Money Market Mutual Funds (MMMFs) institucionais. 
Gráfico 9. Estados Unidos, dados selecionados. 1978-1984. Variações anuais (\%). Setor privado não-agrícola. Produção por hora de todos os trabalhadores (1); Horas trabalhadas por todos trabalhadores (2); Ganhos reais por hora (3); (4) Produção total.

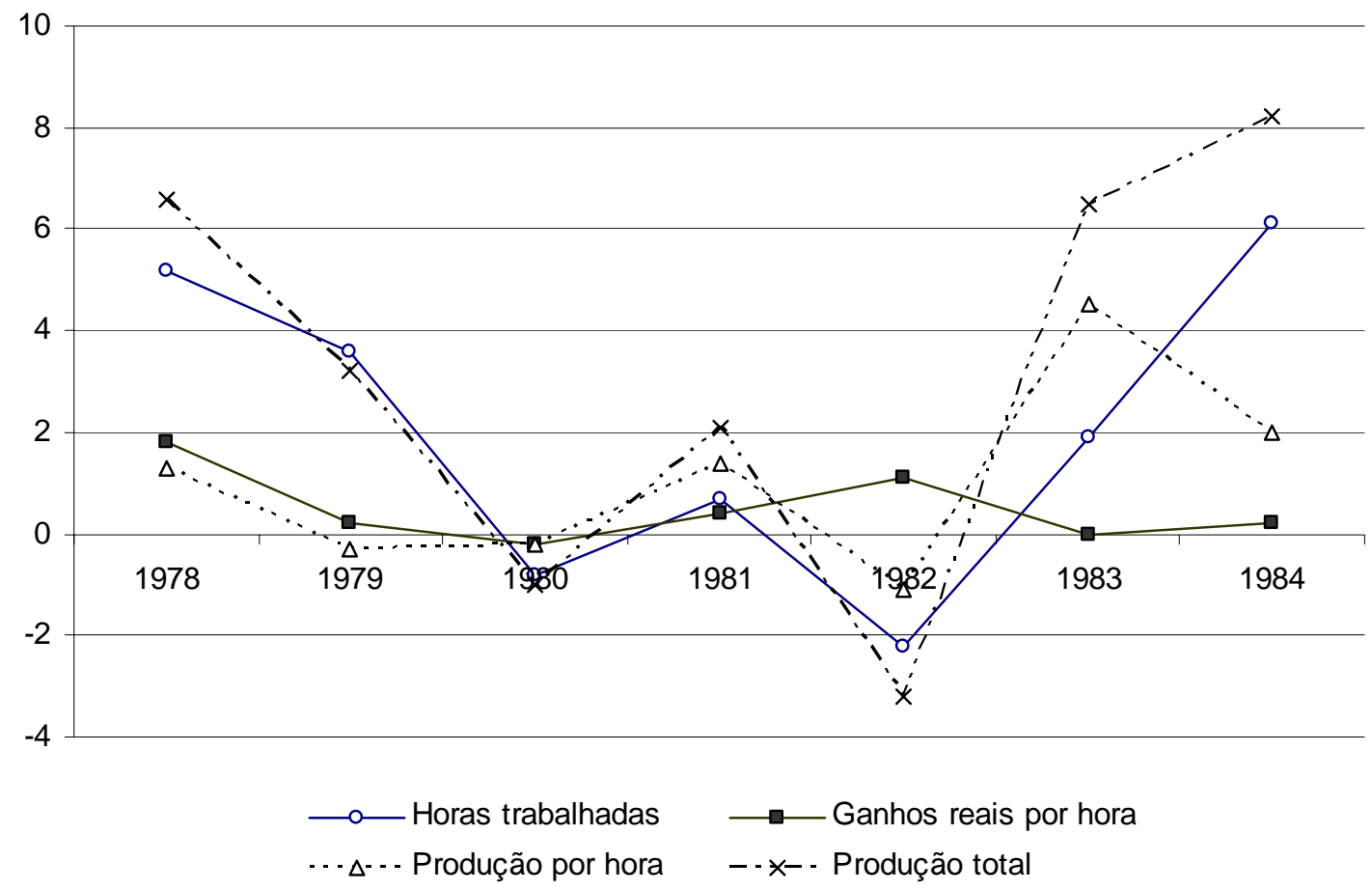

Fonte: Economic Report of the President, 2006, Tabela B-49, Productivity and Related Data, Business Sector, 1959-2005.

O gráfico acima é elucidativo sobre os motivos da desaceleração e sobre como foi possível recompor as taxas de lucros a partir de 1983. À estagnação da produtividade (produção por hora), os ganhos reais por hora também permanecem baixos desde 1978. A queda dos índices de produtividade do capital é a expressão do encarecimento de todos os custos de produção, que, sendo provocado por um choque externo - alta do preço do petróleo - atingiu todas as empresas. Produzem-se agora o mesmo número de valores de uso com um custo maior em insumo em forma de petróleo e seus derivados.

Com isto, os investimentos caíram, com isto caindo também as horas trabalhadas totais e a produção total. De fato, em 1981, houve um aumento das horas trabalhadas, da produção total e da produtividade, mas que não se refletiram num aumento dos ganhos por hora. Em 1982, a produção está no fundo do poço, assim como as horas trabalhadas, com uma taxa de desemprego em 11\%. No início de 1983, a produção, a produtividade e as horas trabalhadas começaram a crescer. Mas os ganhos por hora permaneceram estagnados. É fácil ver então que neste intervalo entre 1981-1983, o desemprego se refletiu na rigidez dos ganhos por hora e assim na recomposição de uma taxa de lucro mais favorável ao investimento, dada paralelamente à queda do preço do petróleo.

Deve-se notar ainda que quanto maior tenha sido a capacidade de as empresas repassarem seus aumentos de custos umas às outras, menor terá sido a pressão sobre a taxa de lucro do aumento do preço do petróleo. O prejuízo seria pelo lado da queda da demanda, já que 
os trabalhadores pagariam mais pelos bens finais, o que resultaria numa queda dos salários reais. Daí a queda na massa de lucros realizada durante a crise, já que "sob condições de depressão, uma queda nas taxas de salário pode levar a uma queda na atividade total". ${ }^{145}$ Aparecia aí a vantagem de se estar organizado sob um grau de monopólio mais ou menos alto. A crise do petróleo resulta então numa queda da taxa de lucro, conjugada com uma queda da demanda, e com uma concentração de recursos excedentes nos setores mais monopolizados e nos que produzem diretamente o insumo. "Se aumenta o grau de monopólio ou se se elevam os preços das matérias-primas em relação com os salários por unidade produzida, a proporção representada pelos salários no valor agregado diminui". ${ }^{146}$

No desempenho do comércio internacional, acumularam-se perdas líquidas; a alta do dólar e a atração de capitais tendeu a favorecer as importações em detrimento das exportações. Durante todo o período 1981-1984, estas estiveram abaixo de sua tendência já decrescente, enquanto as primeiras estiveram acima. O preço a pagar pelos juros altos e pela retomada do valor do dólar face ao iene e marco significou uma enorme pressão sobre os setores exportadores, e indiretamente sobre o emprego. Com a produtividade em queda desde a década passada, e uma importação líquida de capitais, o período do primeiro governo Reagan assistiu então a enorme deterioração dos "setores reais" na economia, com eliminação de capital excedente não lucrativo. Tal forçaria Reagan, no primeiro ano de seu novo mandato, a entabular o chamado "Acordo do Plaza" com Alemanha e Japão, para forçar uma nova queda do dólar.

Tabela 5. Estados Unidos. Exportações e importações por área, em milhões de dólares correntes. 1981-1984.

\begin{tabular}{ccccc}
\hline \multicolumn{5}{c}{ Exportações dos Estados Unidos } \\
$(1)$ & $(2)$ & $(3)$ & $(4)$ & \\
& 1981 & 1982 & 1983 & 1984 \\
Canadá & & & \\
Japão & 46016 & 39203 & 44374 & 53067 \\
Europa ocidental & 21796 & 20694 & 21789 & 23240 \\
& 65108 & 59701 & 55434 & 56866 \\
& & & \\
Canadá & Importações pelos Estados Unidos & & \\
Japão & 1981 & 1982 & 1983 & 1984 \\
Europa ocidental & -48253 & -48523 & -56010 & -69229 \\
& -37597 & -37683 & -42845 & -60211 \\
& -52864 & -52900 & -55624 & -72054 \\
\hline
\end{tabular}

Fonte: Economic Report of the President, 1986. Tabela B-101, U.S. Merchandise Exports and Imports by Area, 1976-85.

\footnotetext{
${ }^{145}$ TINBERGEN, Jan, Política Econômica: Princípios e Planejamento, p.177.

${ }^{146}$ KALECKI, Michal. Teoría de la dinámica econômica, p.30.
} 
Gráfico 10. Estados Unidos. Exportações e importações de mercadorias. Em milhões de dólares correntes. 1979-1984.

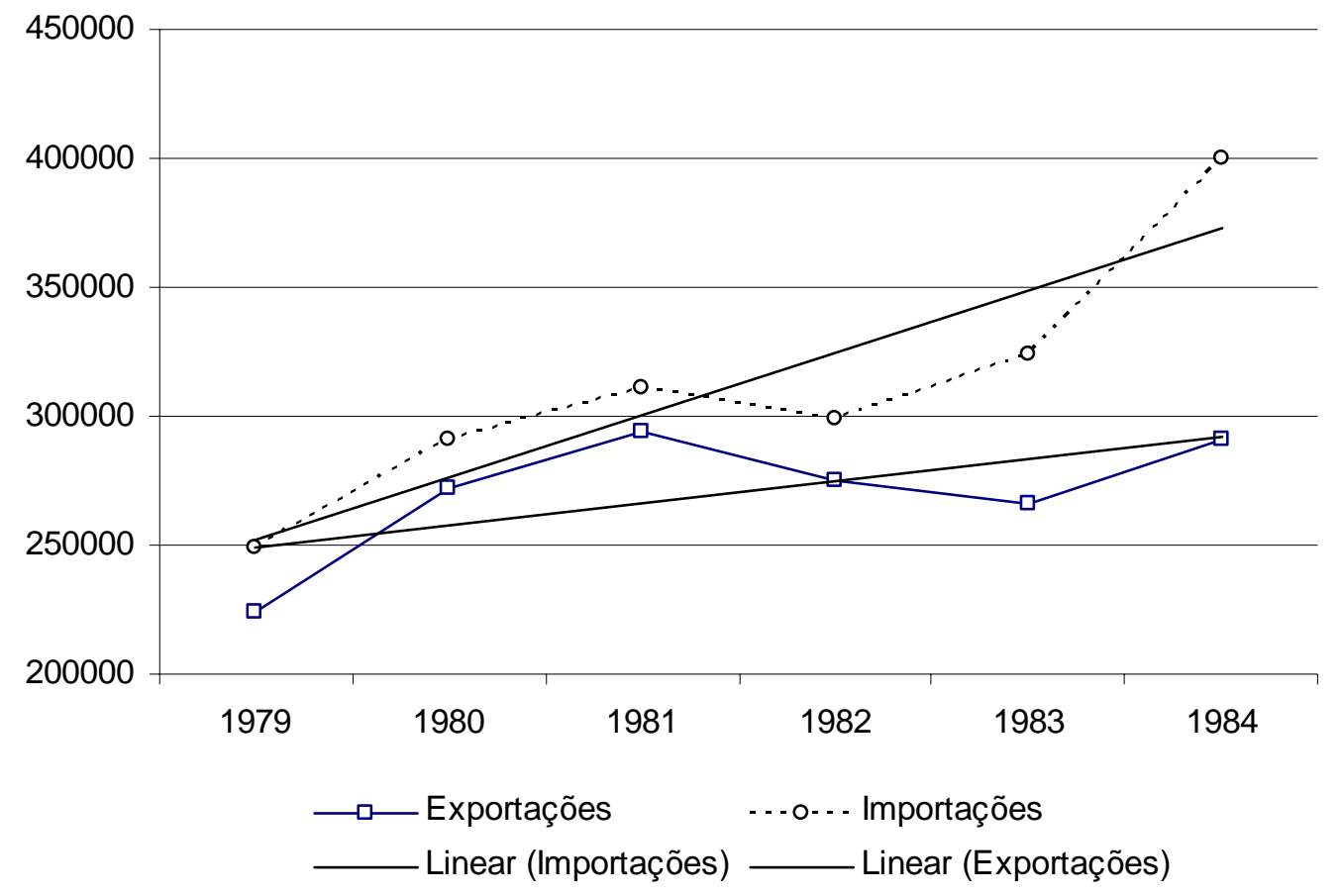

Fonte: NIPA-BEA, Seção 4, Foreign Transactions, Tabela 4.1. Foreign Transactions in the National Income and Product Accounts.

6.7.2. As contas do governo federal e a indústria de guerra

a) A questão dos "altos impostos"

Pela tabela abaixo, percebe-se inicialmente que é o governo federal dos Estados Unidos quem arcou com a política anti-cíclica, deixando às esferas locais e estaduais a manutenção de superávits fiscais. Esta será uma característica marcante da ingerência pública ao longo de todo o período estudado neste trabalho.

Tabela 6. Estados Unidos. Poupança do governo (déficits com sinal negativo). 1979-1984. Coluna 2: poupança total. Coluna Terceira: poupança do governo federal. Quarta: poupança dos governos locais e estaduais. Em bilhões de dólares correntes. 1979-1984.

\begin{tabular}{cccc}
\hline$(1)$ & $(2)$ & $(3)$ & $(4)$ \\
Anos & Poupança total & Poupança do governo & $\begin{array}{c}\text { Poupança dos governos } \\
\text { locais e estaduais }\end{array}$ \\
1979 & 1,7 & federal & 13 \\
1980 & $-44,8$ & $-11,3$ & 8,8 \\
1981 & $-45,7$ & $-53,6$ & 7,6 \\
1982 & $-134,1$ & $-53,3$ & $-2,2$ \\
1983 & $-168,1$ & $-131,9$ & 4,9 \\
1984 & $-144,1$ & -173 & 23,9 \\
\hline
\end{tabular}

Fonte: NIPA-BEA, Seção 5, Saving and Investment, Tabela 5.1, Saving and Investment. 
Veja-se primeiro a questão dos impostos tão alegada pelo presidente, evidentemente de modo falso. De fato, como a maior parte dos presidentes dos Estados Unidos, mas com um acento particularmente marcante, Reagan podia dizer o que quisesse, mesmo se isto estivesse em flagrante oposição à realidade. Os "WASP", o "deep United States", (os "americanos brancos de origem anglo-saxã" e os "Estados Unidos profundo", i.é, a população dos "rincões" dos Estados Unidos) haviam lhe dado condições para "testar os limites do impossível”. O que dizia não se baseava em nenhuma teoria econômica pretensamente "objetiva", mas em interesses políticos bem mais mesquinhos, que ele mesmo mal disfarçava.

Em verdade, nunca houvera algo como um aumento abrupto de impostos, em algum determinado momento da história econômica recente do país. Como visto, a queda do crescimento da economia explicava-se pelos efeitos que a elevação dos preços do petróleo causou nos índices de produtividade do capital, junto da elevação dos juros para conter a inflação e valorizar o dólar. A diminuição das exportações e a queda da demanda agregada subseqüente uniram-se, para determinar a crise. Uma consulta ao Economic Report of the President mostra um cenário muito diferente do apontado pelo discurso contra as "taxas, taxas e mais taxas".

O Economic Report consiste no "balanço oficial" do governo federal sobre o desempenho anual da economia. Supostamente, ele deveria ser lido pelo presidente. No apêndice estatístico daquele documento, mais especificamente na Tabela B-80 - "Federal Receipts and Outlays, by major category" - vê-se que a arrecadação do governo federal norteamericano mantinha-se em 1980, em proporção do PNB, muito similar à dos anos (19)60.

Em 1960, a receita total do governo federal foi 92,5 bilhões, e o PNB 526,4 bilhões, ao passo que a receita do governo federal em 1980 foi 517 bilhões, e o PNB 2.789,5 bilhões. Logo, houve aumento de aproximadamente $1 \%$ da arrecadação sobre o PNB (17\% para 18\%). Por sua vez, a relação entre os tributos sobre as corporações e a arrecadação dos impostos sobre as famílias, havia diminuído de 26\% em 1950 para 12\% apenas em 1980.

Não é necessário enfatizar que as taxas de expansão da economia tinham sido muito maiores naquele momento, onde os impostos e a arrecadação eram levemente maiores do que nos anos (19)70 e (19)80. Isso traz duas principais inferências. Em primeiro lugar, que a expansão da economia não é necessariamente limitada pela carga de impostos aos lucros corporativos, tendo de ser explicada por outras variáveis. ${ }^{147}$ Em segundo lugar, a elevação dos gastos sociais a partir da administração de L. Johnson havia sido financiada preponderantemente à custa das rendas das classes mais ricas, e não sobre a poupança das empresas.

\footnotetext{
147 “[Sobre esta questão dos impostos], tudo o que se tem a fazer é olhar o crescimento médio do PIB nos anos 50 e 60, quando os impostos de renda e corporativo estavam nas alturas e compará-los com as taxas de crescimento das décadas de 1980 e 1990, e até o momento na de 2000 (até 2004), quando os impostos eram baixos." BATRA, Ravi. Greenspan, a fraude, p. 255. O autor faz uma interessante discussão sobre este ponto nas páginas subseqüentes.
} 
Tabela 7. Estados Unidos. Receitas do governo federal - impostos de renda sobre indivíduos e empresas, em bilhões de dólares correntes. 1950-1980. Relação dos impostos recebidos com o PNB.

\begin{tabular}{ccccc}
\hline$(1)$ & $(2)$ & $(3)$ & $(4)$ & $(5)$ \\
& Imposto de Renda & $\begin{array}{c}\text { Impostos sobre } \\
\text { o capital }\end{array}$ & $\begin{array}{c}\text { Relação de } \\
(3) /(2)\end{array}$ & $\begin{array}{c}\text { Impostos sobre } \\
\text { o PNB }\end{array}$ \\
1950 & 39,4 & 10,4 & 0,26 & 0,13 \\
1960 & 92,5 & 21,5 & 0,23 & 0,17 \\
1970 & 192,8 & 32,8 & 0,17 & 0,18 \\
1980 & 517,1 & 64,6 & 0,12 & 0,18 \\
Variação & 13,1 & 6,2 & $\ldots$ & $\ldots$ \\
$1950-1980$ & & & & \\
\hline
\end{tabular}

Fonte: Economic Report of the President, 2006, Tabela B-81, Federal receipts, outlays, surplus or deficit, and debt, fiscal years, 2002-2007.

Gráfico 11. Estados Unidos. Impostos recebidos pelo governo federal e PIB. Calculado a partir de séries em bilhões de dólares correntes. 1940-1979.

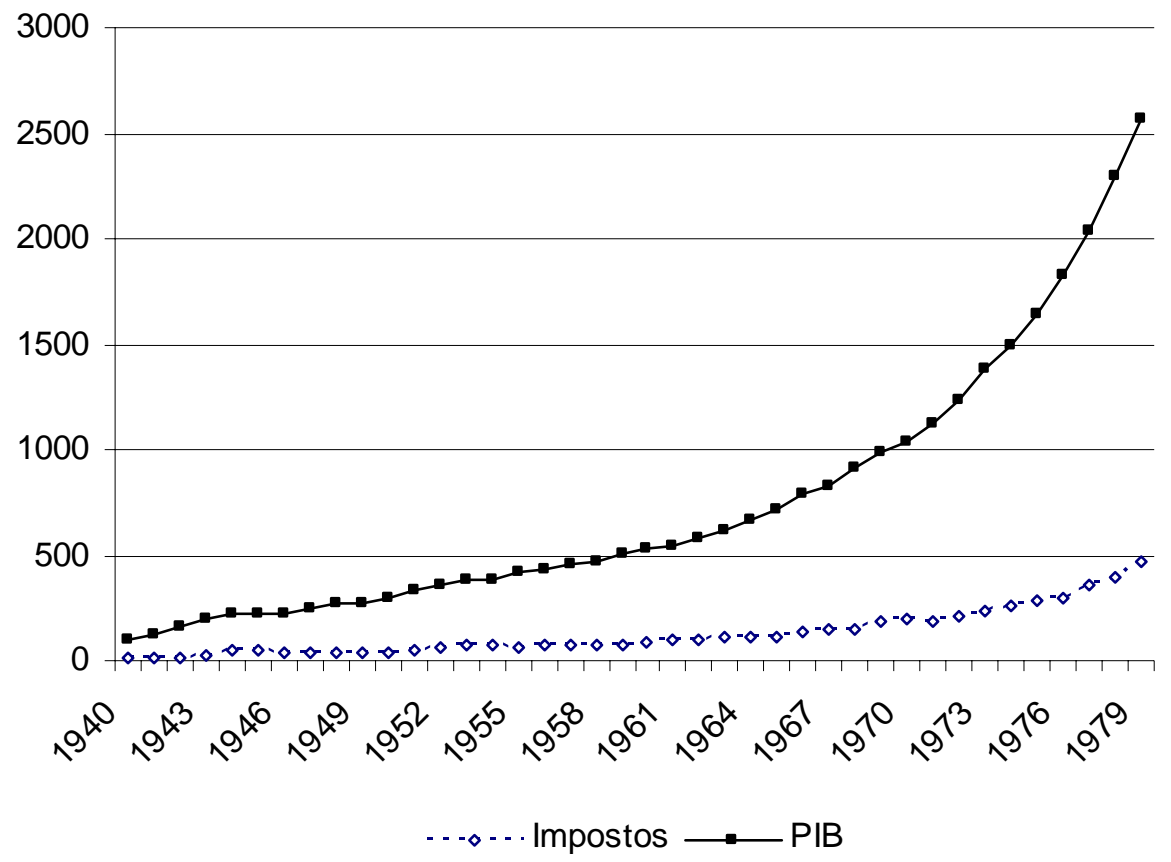

Fonte: Economic Report of the President, 2008, Table B-78.-Federal receipts, outlays, surplus or deficit, and debt, fiscal years, 1940-2009. Observação: todos os Economic Report of the President informam o produto sob o conceito de PIB e não mais de PNB.

b) Os impactos das inversões na indústria de guerra

Tal como visto, o principal ingrediente do Reaganomics foi o alento à indústria de guerra. Os gastos com defesa somaram sozinhos quase $30 \%$ dos gastos totais do governo federal neste período. Porém, quantificados apenas os déficits orçamentários, isto é, o elemento "contracíclico" das políticas do governo, a importância dos gastos militares assumiu uma posição qualitativamente superior. Os déficits orçamentários serviram cada vez mais para expansões no setor militar, em proporções maiores que $50 \%$ do total. Isto é, o endividamento do 
governo foi ampliado quase que exclusivamente para as inversões no complexo industrialmilitar. Pode-se verificar esta proporção caso se comparem apenas os déficits anuais do orçamento com os gastos de defesa: em 1983, para 207,8 bilhões em déficits federais, houve 209,9 bilhões de gastos com setor militar; em 1984, houve 185,4 bilhões em déficits em relação a 227,4 bilhões de gastos militares, etc..

Isto é, em termos de política anti-cíclica, pode-se admitir que os investimentos na indústria de guerra assumiram o "carro-chefe" da função de compensar os gastos privados em queda. Os investimentos em capital fixo e demanda por bens finais por parte do governo ficaram todos a cabo do gasto com desenvolvimento em manutenção de recursos bélicos, gastos tais que quase superaram todas as outras despesas do governo. Entre 1981 e 1984, o governo elevou despesas nominais com saúde em 7 bilhões, com o programa Medicare 24 bilhões, com os gastos de seguro desemprego 27 bilhões, e 60 bilhões com segurança social, num total de 118 bilhões. Por seu turno, as despesas militares apenas elevaram-se 93 bilhões de dólares no mesmo período 1981-1984 (ver tabela na seqüência).

Em tal tabela, que discrimina os gastos do governo federal, vê-se que os gastos com saúde praticamente estagnaram: se deflacionados, os gastos em 1984 ficam num patamar abaixo do que estavam em 1981 (23,2 / 1,26, usando-se o deflator a partir de 1980). Os gastos com segurança social se elevam em 1,5, e os com "defesa" 1,7. A coluna "Outros", que inclui despesas sociais, reduzem-se absolutamente.

Veja-se a importância dos déficits com o setor militar sob a perspectiva da funçãoconsumo, cuja forma adotada aqui é $C=a+b Y$ (sendo: $\mathrm{C}=$ consumo; a $=$ consumo autônomo; $\mathrm{b}=$ propensão marginal a consumir; $\mathrm{Y}=$ renda). A função-consumo para um período específico é obtida pela regressão do consumo das famílias em função da renda das famílias. (Sua forma adotada aqui é $c=a+b y$ ). Para o período em questão, ela tem a seguinte forma: $\mathrm{C}=72,89+$ 0,83 Y.

\begin{tabular}{ccc}
\hline$(1)$ & $(2)$ & $(3)$ \\
Anos & Consumo & Renda \\
1976 & 1151 & 1302 \\
1977 & 1278 & 1436 \\
1978 & 1428 & 1607 \\
1979 & 1592 & 1798 \\
1980 & 1758 & 2004 \\
1981 & 1943 & 2246 \\
1982 & 2078 & 2421 \\
1983 & 2292 & 2608 \\
1984 & 2503 & 2912 \\
\hline
\end{tabular}

Tabela 8. Consumo das Famílias e Renda Disponível em bilhões de dólares correntes, e resultados da regressão (I) do consumo em função do investimento. 1984-1979. Fonte (séries): Bureau of Economic Analysis. 
Regressão (I): consumo (C) em função da renda disponível (Y)

Observações: 9

$\mathrm{C}=72,89+0,83 \mathrm{Y}$

$\mathrm{R}^{2}: 0,99$

valor-p $=2,8839 \mathrm{E}-11$

Durbin Watson: 2,52

Tabela 9. Estados Unidos. Despesas e receitas do governo federal. 1980-1984. Em bilhões de dólares correntes. 1980-1984.

Despesas do governo federal

$\begin{array}{cccccc} & \text { Total } & \text { Defesa } & \begin{array}{c}\text { Compromissos } \\ \text { Internacionais }\end{array} & \text { Saúde } & \text { "Medicare" } \\ 1980 & 590,9 & 134 & 12,7 & 23,2 & 32,1 \\ 1981 & 678,2 & 157,5 & 13,1 & 26,9 & 39,1 \\ 1982 & 745,7 & 185,3 & 12,3 & 27,4 & 46,6 \\ 1983 & 808,4 & 209,9 & 11,8 & 28,6 & 52,6 \\ 1984 & 851,9 & 227,4 & 15,9 & 30,4 & 57,5 \\ & & & & \\ & & & & & \text { Déficit (-) ou } \\ 1980 & \text { Seguro } & \text { Segurança } & \text { Juros } & & \text { superávit (+) } \\ 1981 & \text { Desemprego } & \text { Social } & \text { líquidos } & & -73,8 \\ 1982 & 106,6 & & & & -79 \\ 1983 & 100,3 & 118,5 & 52,5 & 131,1 & -128 \\ 1984 & 108,2 & 139,6 & 68,8 & 125 & -207,8 \\ & 123 & 156 & 85 & 121,8 & -185,4\end{array}$

Receitas do governo federal

\begin{tabular}{|c|c|c|c|c|c|}
\hline & $\begin{array}{l}\text { Imposto de } \\
\text { renda }\end{array}$ & $\begin{array}{c}\text { Tributos sobre } \\
\text { empresas }\end{array}$ & $\begin{array}{l}\text { Previdência e } \\
\text { seguro social }\end{array}$ & Outros & $\begin{array}{c}\text { Dívida federa } \\
\text { total }\end{array}$ \\
\hline 1980 & 244,1 & 64,6 & 157,8 & 50,6 & 711,9 \\
\hline 1981 & 285,9 & 61,1 & 182,7 & 69,5 & 789,4 \\
\hline 1982 & 297,7 & 49,2 & 201,5 & 69,3 & 924,6 \\
\hline 1983 & 288,9 & 37,1 & 209,1 & 65,6 & 1137,3 \\
\hline 1984 & 298,4 & 56,9 & 239,4 & 71,8 & 1307,2 \\
\hline
\end{tabular}

$\begin{array}{cccccc}\text { Déficit ou } & \begin{array}{c}\text { Aumento do } \\ \text { superávit total } \\ \text { do gov. federal }\end{array} & \begin{array}{c}\text { Dívida externa } \\ \text { do gov. federal }\end{array} & \begin{array}{c}\text { Aumento da } \\ \text { dív. externa }\end{array} & \begin{array}{c}\text { Déficit financiado } \\ \text { localmente * }\end{array} \\ 1980 & 73,8 & \ldots & 147 & \ldots & \\ 1981 & 79,1 & 8 & 156 & 9 & (-1) \\ 1982 & 128,3 & 49 & 171 & 15 & 34 \\ 1983 & 207,8 & 79 & 185 & 14 & 65 \\ 1984 & 185,4 & -22 & 215 & 30 & (-8)\end{array}$

Fonte: Economic Report of the President, vários números. ${ }^{148}$

148 Os dados foram retirados das seções "Government Finance", principalmente das Tabelas "Federal
Receipts and Outlays by major category". Para as séries sobre dívida externa do governo federal, ver as
Tabelas "International Investment Position of United States" no apêndice estatístico do Economic Report
de 1984, 1985 e 1986, nas linhas "US government securities and liabilities" e "US Treasury Securities". 
O efeito multiplicador, alvo da teoria das "expectativas racionais", serve aqui como bom instrumento de análise. É calculado como sendo: 1/1-0,83 (propensão marginal a consumir), o que dá 5,88 . Para que se avalie qual foi o impacto potencial na renda a partir dos déficits com defesa, deve-se multiplicar tais déficits pelo multiplicador. Isto está disposta na tabela a seguir. Em média, $40 \%$ dos gastos totais na economia norte-americana sofreram o impacto direto e indireto das despesas militares.

Tabela 10. Estados Unidos. Hipóteses sobre o efeito multiplicador. (1) Gastos com defesa do governo federal; (2) gastos com defesa vezes o multiplicador da renda $(5,88)$ calculado; (3) renda disponível. 1981-1984 (dados trimestrais).

\begin{tabular}{cccc}
\hline (1) & $(2)$ & $(3)$ & $(4)$ \\
& Gastos com defesa - gov. federal & $\begin{array}{c}\text { Gastos com defesa vezes o } \\
\text { multiplicador }(5,88)\end{array}$ & Renda Disponível \\
1981/I & 184,9 & 1087,2 & 2866,6 \\
II & 193,8 & 1139,5 & 2912,5 \\
III & 197,8 & 1163,1 & 3004,9 \\
IV & 208,6 & 1226,5 & 3032,2 \\
1982/I & 213,8 & 1257,1 & 3021,4 \\
II & 222,7 & 1309,4 & 3070,2 \\
III & 228,6 & 1344,1 & 3090,7 \\
IV & 238,6 & 1402,9 & 3109,6 \\
1983/I & 241,3 & 1418,8 & 3171,5 \\
II & 248,8 & 1462,9 & 3272,1 \\
III & 252,5 & 1484,7 & 3362,2 \\
IV & 260,1 & 1529,3 & 3432,3 \\
1984/I & 274,2 & 1612,2 & 3553,3 \\
II & 279,5 & 1643,4 & 3644,7 \\
III & 280,2 & 1647,5 & 3694,6 \\
IV & 292,7 & 1721,3 & 3752,5 \\
\hline
\end{tabular}

Fonte: Economic Report of the President, vários anos. Para gastos trimestrais do governo com defesa, ver as tabelas "Federal and State and local government current receipts and expenditures, national income and product accounts (NIPA), by major type", na seção do apêndice estatístico, "Government Finance". Para valores trimestrais de renda disponível, ver as tabelas "Disposition of personal income", na seção 1 do apêndice estatístico, "National Income or Expenditure".

Outra maneira de ver a questão é estimar a regressão da renda disponível (variável dependente ou " $y$ " na coluna 4 acima) explicada pelos gastos com defesa vezes o multiplicador de renda (variável independente ou " $x$ " na coluna 3). Obtém-se a expressão $y=1252,71+1,42$ $x$. Tem-se um valor muito baixo para o estatístico Durbin Watson, sugerindo alta correlação para os resíduos e talvez uma subestimação da significância deste teste. Em tese, ela indica que a cada variação de um dólar nos gastos com defesa, a renda disponível irá elevar-se em média 1,42 dólares - levando-se em consideração o efeito multiplicador dada a propensão marginal ao

O número das tabelas pode variar (B-107, B-106) etc., de acordo com o ano da publicação. * O cálculo do financiamento local do déficit federal dá-se pelo aumento da dívida externa menos o aumento do déficit do governo federal. 
consumo estimada. Talvez os impactos dos gastos com defesa sejam um pouco menores. Porém, levando-se em consideração que são dados oficiais, e os únicos disponíveis, não se pode tornar vítima aqui deste regressor específico, a troco de não compreender a função da indústria de guerra para o produto. Aqui parece ser o caso para aplicar "métodos imperfeitos, porém eficazes", de que fala Joan Robinson.

\section{Regressão (II)}

Regressão II: renda disponível (Y) explicada pelos gastos de defesa do governo federal (Gd) multiplicados pelo multiplicador

Observações: 16

$\mathrm{Y}=1.252,7+1,42 \mathrm{Gd}$

$\mathrm{R}^{2}: 0,93$

Valor-p: 4,98693E-10

Durbin Watson: 0,40

Gráfico 12. Estados Unidos. Renda disponível e gastos multiplicados a partir de gastos do governo federal com despesas militares. 1980-1984 (dados trimestrais). Em bilhões de dólares correntes.

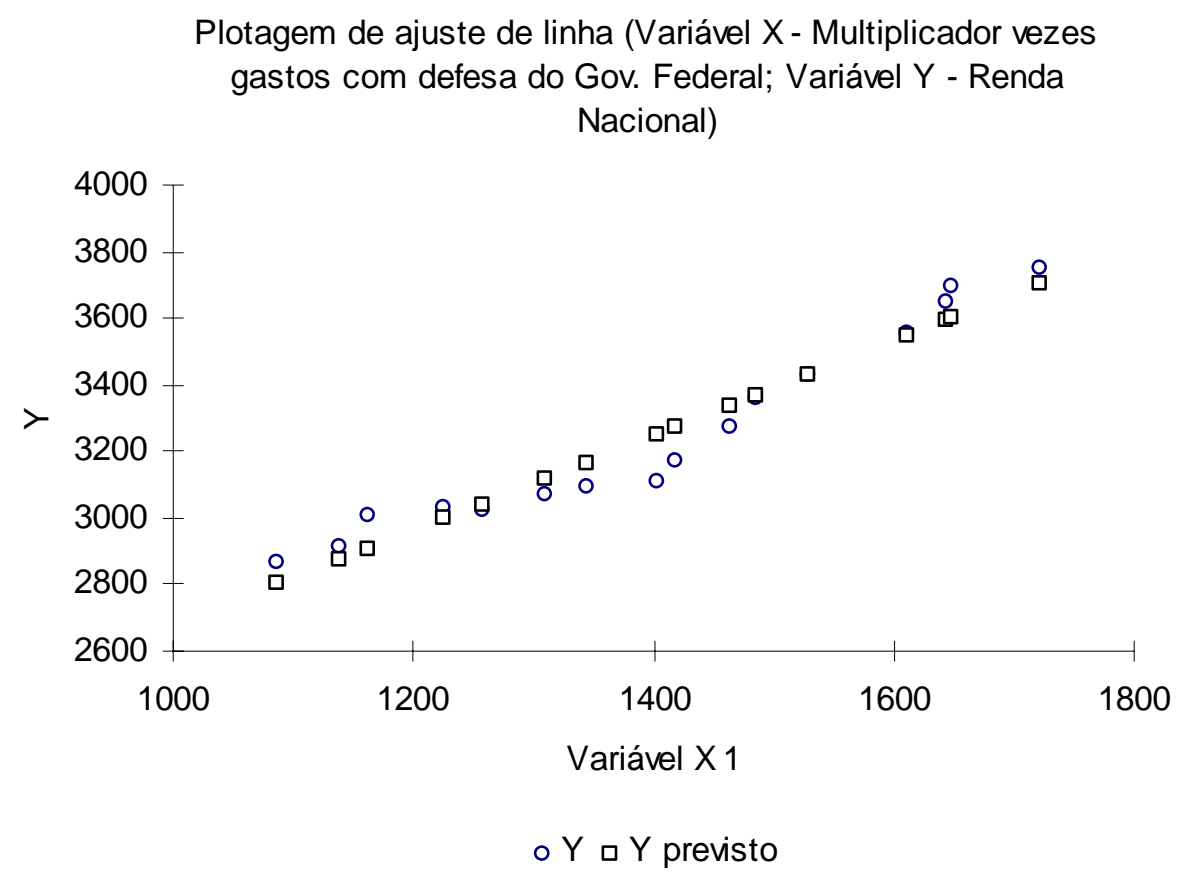

Fonte: cálculo do autor a partir de dados da Tabela 10.

c) Evitando a monetização da dívida

Afirmou Tinbergen:

"Se durante um período de baixos dispêndios privados, o emprego deve ser mantido pelo aumento das despesas governamentais e se o déficit daí resultante é 
financiado pela criação de crédito, isto poderia introduzir o perigo de uma inflação potencial, isto é, a possibilidade de uma inflação futura. Os saldos maiores de dinheiro deixados nas mãos do público podem ser gastos por ele mais tarde, em acréscimos a suas rendas. Isto torna preferível financiar o déficit orçamentário com o auxílio de empréstimos." 149

Foi exatamente esta a opção da administração Reagan: diante das pressões inflacionárias conjugadas com uma queda dos investimentos privados, o governo preferiu financiar o déficit com aumento de seus empréstimos, ao invés de elevar a base monetária. Caso assim o fizesse (elevar a base monetária), o Banco Central estaria comprando títulos do Tesouro, e assim indiretamente criando crédito, segundo os termos de Tinbergen.

No âmbito interno, este processo de altos gastos do governo federal explicitava um conflito com a direção do Fed. De um lado estava Volcker, na presidência do banco, com suas demandas monetaristas de contenção do crédito, dos meios de pagamentos, dos gastos do governo e estabilização dos preços. De outro, Reagan, no poder executivo, expressando retoricamente a posição de que o governo, em seus próprios termos, "atrapalhava com suas taxas", mas apenas para justificar publicamente os benefícios fiscais concedidos ao capital.

Daí que o financiamento da dívida do governo não foi feito à custa da criação de mais base monetária, caso em que o Fed teria se responsabilizado pelo financiamento do Tesouro, "monetizando a dívida": o Fed compraria os títulos do Tesouro, com emissão de dinheiro adicional e aumento da base monetária. Pelo gráfico abaixo, vê-se que foi o "público" que se engajou na compra da maior parte dos Títulos do Tesouro necessários à expansão dos gastos do governo federal: mais empréstimos do governo, menor emissão de moeda. O Tesouro emitiu títulos para converter a poupança inativa - sob forma de dinheiro já existente, portanto - em recursos diretamente utilizáveis pelos gastos do governo federal. Assim, houve uma pequena elevação da base monetária, que não acompanhou a brusca ascensão do déficit federal. Se o Fed tivesse financiado o Tesouro, a base monetária acompanharia mais de perto o próprio déficit federal.

${ }^{149}$ Política Econômica: princípios e planejamento, p.180. 
Gráfico 13. Estados Unidos. Aumento do déficit do governo federal financiado localmente (aumento do déficit federal menos aumento da dívida em mãos de estrangeiros) e base monetária. Em bilhões de dólares correntes. 1981-1984.

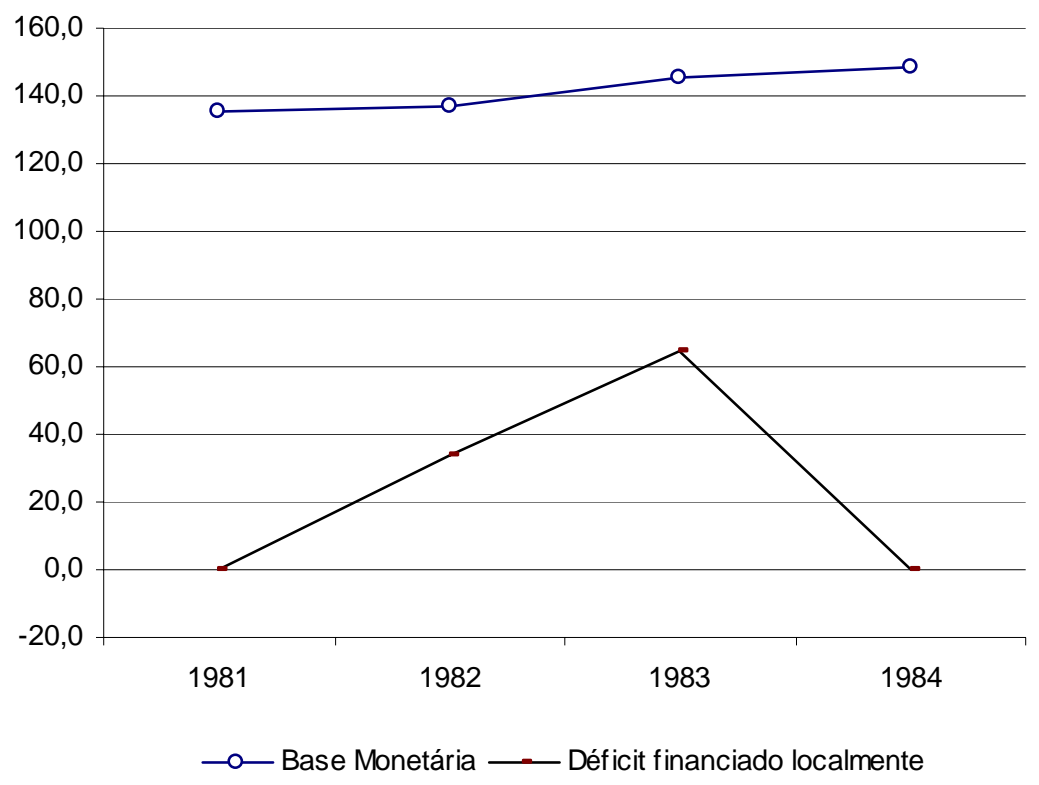

Fonte: calculado a partir dos dados do Economic Report of the President. Em bilhões de dólares correntes. Para cálculo do déficit financiado localmente, os dados são o da tabela 19. Para meios de pagamento, ver a primeira tabela "Money, Stock and Debt Measures" da seção "Money Stock, Credit, and Finance". Onde: M1 = soma de moeda, depósitos à vista, travelers checks e outros depósitos. M2 = M1 mais Money Market Mutual Funds (MMMFs), e depósitos de curto prazo (small time deposits). M3 = depósitos de longo prazo, Euro-dólares, e Money Market Mutual Funds (MMMFs) institucionais.

Enquanto as pressões inflacionárias eram recriadas na produção de mercadorias improdutivas, elas eram contidas com uma extensa diminuição da produção e do poder de compra. Logo, os resultados econômicos de ambas as políticas, monetária e fiscal, caminhavam em trilhas que, neste sentido, poder-se-ia classificar de opostas. Enquanto o Fed "apertava o crédito", o governo despejava bilhões em dólares emprestados no setor bélico, colhidos internamente pela enorme poupança de todos os "detentores de riqueza" que não investiram seus recursos excedentes de forma produtiva. Neste ínterim, por mais que os recursos que o governo tivesse tomado no exterior apresentassem aumento significativo, eles permaneceram menores que o endividamento interno do governo federal.

Por isso também dá-se a alteração entre a composição dos agregados monetários, na qual a proporção de M3 cresce vertiginosamente sobre a de M1, indicando a contração da renda monetária e fuga para papéis dos indivíduos e famílias mais bens posicionados. A proporção de M3 para M1 cairia no segundo governo Reagan. Isto expressaria o "alívio" da política monetária face à queda da inflação, mediante a queda parcial das taxas de juros dos títulos do Tesouro e das taxas de desconto do Fed aos bancos privados. 
Tabela 11. Estados Unidos. Agregados Monetários e relação de M3 sobre M1. 1978-1988. Em bilhões de dólares.

\begin{tabular}{ccccc}
\hline Anos & M1 & M2 & M3 & M3/M1 \\
1978 & 357,3 & 1366,1 & 1644,5 & 4,65 \\
1979 & 381,8 & 1473,7 & 1808,7 & 4,72 \\
1980 & 408,5 & 1599,8 & 1995,5 & 4,88 \\
1981 & 436,7 & 1755,4 & 2254,5 & 5,16 \\
1982 & 474,8 & 1910,3 & 2460,6 & 5,18 \\
1983 & 521,4 & 2126,5 & 2697,4 & 5,17 \\
1984 & 551,6 & 2310,1 & 2990,6 & 5,42 \\
1985 & 619,8 & 2495,7 & 3208,1 & 5,17 \\
1986 & 724,7 & 2732,3 & 3499,1 & 4,82 \\
1987 & 750,2 & 2831,5 & 3686,5 & 4,91 \\
1988 & 786,7 & 2994,5 & 3928,8 & 4,99 \\
\hline
\end{tabular}

Fonte: Economic Report of the President, 2006. As definições e tabelas do Economic Report para estes dados anuais são as mesmas do Gráfico 13.

\subsubsection{O papel do endividamento externo}

Como se apontou no início, no terceiro ano da primeira administração Reagan os Estados Unidos tornaram-se devedores líquidos do exterior. A enorme elevação dos juros a partir de 1979 fora o estopim que desencadeou a enorme enxurrada de recursos forâneos. O Japão e a Alemanha foram os principais países a cooperarem na valorização da moeda dos Estados Unidos, já que seus setores exportadores colheriam as vantagens desta valorização no plano do comércio internacional. Ainda que os níveis de endividamento só fossem se acelerar no início do segundo mandato de Reagan, pode-se medir os impactos já benéficos na economia desta transformação qualitativa.

Abaixo está discriminada a captação de poupança externa dos Estados Unidos, vinda de agentes "oficiais" - recursos vindos de governos, instituições multilaterais estrangeiros etc. - e "privados", concedidos aos agentes norte-americanos por bancos, empresas, e pessoas físicas do exterior. As compras de ações e bônus no mercado financeiro passam de 68 bilhões a 159 bilhões; os títulos emitidos pelos bancos, de 121 a 312. Somados, a atração de Investimento Estrangeiro Direto e de recursos pelos bancos totaliza 282 bilhões de dólares no período.

De fato, vê-se que os investimentos locais superaram nos quatro anos a poupança agregada. Segundo o Economic Report of the President de 2006, o investimento líquido na economia como um todo caiu vertiginosamente entre 1980 e 1983, passando de 236 bilhões em 1980 a 173 em 1982, e a 201 bilhões em 1983. Para 1983, os economistas responsáveis pelo Economic Report calculam que 15\% dos investimentos líquidos efetuados na economia foram financiados com empréstimos ao exterior. Para 1984, 27\%. Este é o início da tendência que culminará com $75 \%$ dos investimentos líquidos domésticos, em 2004, sendo financiados com poupança externa. 
Tabela 12. Estados Unidos. Investimento doméstico bruto e líquido, empréstimos líquidos (do exterior) para o investimento doméstico bruto, e poupança agregada. 1980-1984. Em bilhões de dólares correntes. 1980-1984.

\begin{tabular}{cccccc}
\hline (1) & $\begin{array}{c}(2) \\
\text { Empréstimos } \\
\text { líquidos do } \\
\text { exterior }\end{array}$ & $\begin{array}{c}\text { Investimento } \\
\text { líquido }\end{array}$ & $\begin{array}{c}\text { Investimento } \\
\text { bruto }\end{array}$ & $\begin{array}{c}\text { Poupança } \\
\text { agregada }\end{array}$ & $\begin{array}{c}(6) \\
\text { Poupança } \\
\text { Doméstica }\end{array}$ \\
1980 & $-11,4$ & 236,6 & 479,3 & 549,4 & 560,8 \\
1981 & $-6,3$ & 264,7 & 520,3 & 654,7 & 660,3 \\
1982 & 0 & 173,1 & 442,1 & 629,1 & 629 \\
1983 & 31,8 & 201,1 & 466,3 & 609,4 & 577,6 \\
1984 & 86,7 & 319,3 & 583,8 & 773,4 & 686,7 \\
\hline
\end{tabular}

Fonte: Economic Report of the President, 2006. Tabela B-32, Gross saving and investment, 1959-2005.

O papel preponderante do endividamento deu-se pelas corporações e pelo sistema financeiro privado. Muitas corporações continuaram seus investimentos durante a crise, elevando a captação de recursos no exterior, mesmo durante a cadente trajetória dos lucros, e o conseqüente aperto da poupança e da liquidez local, provocada pela crise e pelas políticas de Volcker. Evidentemente, o desempenho durante a crise não foi similar para todas as corporações, de modo que muitas continuaram a adquirir empréstimos ou emitir ações. Tal atesta o desempenho de muitas empresas com capital aberto, cujas ações pouco ou nada oscilaram durante o período. ${ }^{150} \mathrm{O}$ desempenho médio dos preços das ações listadas nos índices do Nova York Stock Exchange foi ascendente durante toda a crise entre 1976-1984, o que permite inferir que muitas empresas mantiveram sua lucratividade corrente. O mesmo se deu para Standard\&Poor's. O desempenho das ações listadas no Dow Jones foi um pouco pior, mas mesmo assim foi ascendente e contrastou com a tendência para a queda dos lucros na economia como um todo. Mesmo considerando a formação da bolha que iria estourar em 1987, deve-se considerar a valorização real das ações das empresas beneficiadas pela política do governo.

Isso significa que se deve atentar para a diferença entre o comportamento dos oligopólios ou empresas mais dinâmicas que lograram sobreviver à crise, muitas vezes aumentando seus lucros pelas fusões, favorecimentos pelo governo etc., e um grande conjunto de empresas menores. Estas, menos oligopolizadas, com capital não aberto, cuja trajetória foi mais tortuosa, tiveram que demitir trabalhadores, enfrentar quebras, falências, etc.. Como observa Robert Brenner, o endividamento externo das firmas que conseguem sobreviver muitas vezes aumenta também por suas estratégias de recompras maciças de suas próprias ações, no sentido de valorizá-las. ${ }^{151}$

\footnotetext{
${ }^{150}$ Isto demonstrava como a estrutura acionária refletia a divisão das corporações norte-americanas entre os setores "competitivo", "oligopólico" e "estatal", tal como caracterizado por James O'Connor em 1977. Os setores oligopólicos escaparam da crise em posição muito mais tranqüila, com suas ações valorizandose mesmo durante os "tempos difíceis". Mas mesmo os oligopólios não podem sustentar para sempre a valorização de seus papéis num contexto global instável.

${ }^{151}$ O boom e a bolha (2003).
} 
Tabela 13. Estados Unidos. Preços históricos das ações. 1976-1984. Médias anuais dos preços finais a cada dia. Nova York Stock Exchange Indexes, Dow Jones Industrial Average e Standard\&Poor's composite Index.

\begin{tabular}{cccc}
\hline$(1)$ & $(2)$ & $(3)$ & $(4)$ \\
& NYSE & Dow Jones & Standard\&Poor's \\
1976 & 54,46 & 974,92 & 102,1 \\
1977 & 53,69 & 894,63 & 98,2 \\
1978 & 53,7 & 820,23 & 96,02 \\
1979 & 58,32 & 844,4 & 103,1 \\
1980 & 68,1 & 891,41 & 118,78 \\
1981 & 74,02 & 932,92 & 128,05 \\
1982 & 68,93 & 884,36 & 119,71 \\
1983 & 92,63 & 1190,34 & 160,41 \\
1984 & 92,46 & 1178,48 & 160,46 \\
\hline
\end{tabular}

Fonte: Economic Report of the President, 2006. Tabela B-95, Historical stock prices and yields, 1949-2003. Índice do NYSE: $1965=50$. Índice do Standard\&Poor's: $1941=10$. Índice do Dow Jones: não informado. 1976-1984.

Tal movimento provocou um enorme aumento dos depósitos diretos nos bancos e no extenso sistema financeiro doméstico, devido à compra de ações e outros títulos privados, e títulos do Tesouro do governo norte-americano. Isto auxiliaria na diminuição relativa dos impactos das referidas políticas, devido ao aumento absoluto da oferta de dinheiro existente. Veja-se na tabela abaixo a discriminação do endividamento externo do setor privado nos Estados Unidos:

Tabela 14. Estados Unidos. Discriminação dos papéis emitidos pelos Estados Unidos a estrangeiros (dívidas contra os Estados Unidos): (1) recursos concedidos aos Estados Unidos por agentes oficiais estrangeiros (governos estrangeiros, instituições multilaterais e outros); recursos concedidos aos Estados Unidos por agentes privados (bancos, empresas e famílias). Em milhões de dólares correntes. 1980-1984.

(1)

(1) Oficiais

Títulos emitidos por bancos dos EUA

Outros ativos oficias

(2) Privados

Investimento Estrangeiro Direto

Ações e Bônus

Títulos emitidos por bancos, não incluídos em outro lugar

$\begin{array}{lllll}(2) & (3) & (4) & (5) & (6) \\ 1980 & 1981 & 1982 & 1983 & 1984\end{array}$

$30,4 \quad 26,9 \quad 24,9 \quad 25,5 \quad 26,2$

$\begin{array}{lllll}14,1 & 15,6 & 18 & 17,7 & 15,2\end{array}$

$68,4 \quad 90,4 \quad 101,8 \quad 137,1 \quad 159,6$

$\begin{array}{lllll}74,1 & 75,4 & 93,3 & 114,7 & 128,2\end{array}$

$121,1 \quad 165,3 \quad 229,6 \quad 280,6 \quad 312,3$

Fonte: Economic Report of the President, vários números. Tabelas intituladas "International investment position of the United States at year-end, 1997-2004".

Os títulos do governo foram então o principal indutor de atração de divisas do exterior pela economia, mas ela foi amplificada para todos os agentes privados financeiros e nãofinanceiros domésticos. Segundo as tabelas "International Investment Position of U.S." e "Federal Receipts and Outlays", do apêndice estatístico do Economic Report of the President 
aqui consultado, os títulos emitidos por bancos dos Estados Unidos a estrangeiros passaram de 121 milhões em 1980 para 165 milhões em 1981, e de 229 milhões em 1982 para 280 milhões em 1983. Chegaram a 312 milhões em 1984.

Os benefícios da captação de poupança externa no curto prazo, apesar de ainda estarem em seu início, foram importantes para tornar a crise menos impactante. No âmbito agregado, quanto maior for o financiamento externo da taxa de investimento doméstico, maior deve ser o espaço concedido ao consumo, com a oferta de recursos nos bancos. A diferença entre a poupança agregada e o investimento agregado doméstico coberto pelo exterior - de 86,7 bilhões, em 1984 - é justamente uma concessão ao aumento do consumo agregado das famílias da mesma magnitude.

Neste sentido, é particularmente relevante notar que o crédito total concedido aos consumidores pulou de $12 \%$ a 14\% em relação ao PNB em 1983, após permanecer naquela casa (12\%) ininterruptamente desde 1955. A Tabela B-77 do Economic Report de 2006 refere-se à série Consumer Credit Outstanding, ou crédito total remanescente aos consumidores em cada ano. Relacionando-se este crédito agregado anual concedido aos consumidores pelos bancos com o PNB, tem-se média de 12\% do PNB entre 1955 e 1980. Esta média se eleva para 14\% no início dos anos (19)80, até chegar a 17\% em 2004. Em relação a 1980, isto significa aproximadamente um aumento adicional de 116 bilhões de dólares em crédito ao consumo em 1984. Neste período, os depósitos estrangeiros a título de empréstimos aos bancos norteamericanos elevaram-se em 191 bilhões de dólares, como visto na tabela 14.

Tabela 15. Estados Unidos. Crédito remanescente aos consumidores e PNB. Crédito em milhões de dólares, e PNB em bilhões. 1960-1989.

\begin{tabular}{cccc}
\hline$(1)$ & $(2)$ & $(3)$ & $(4)$ \\
& Crédito ao consumo & PNB & Crédito em \% do PNB \\
1960 & 60025,30 & 526,4 & $11 \%$ \\
1965 & 95954,70 & 719,1 & $13 \%$ \\
1970 & 131551,60 & 1038,5 & $12 \%$ \\
1975 & 198917,80 & 1683,3 & $11 \%$ \\
1980 & 351920,10 & 2789,5 & $12 \%$ \\
1985 & 599711,20 & 4220,3 & $14 \%$ \\
1989 & 794612,20 & 5484,4 & $14 \%$ \\
\hline
\end{tabular}

Fonte: Economic Report of the President, 2006. Para produto, Tabela B-1, Gross Domestic Product, 1959-2005. Para crédito ao consumo, Tabela B-77, Consumer Credit Outstanding.

Veja-se agora a dívida externa do governo federal (as esferas municipais e estaduais não emitem títulos ao exterior). Do ponto de vista do governo, toda captação de recursos que se dê em relação à poupança ociosa, ou fora da economia, permite que parte do financiamento das despesas se dê sem tributação direta do consumo, porque justamente o financiamento destes gastos se dá sobre recursos dos setores mais ricos ou é externo à economia. Quanto maior é o financiamento externo, tanto melhor para o consumo dos trabalhadores como para os próprios 
investimentos das corporações domésticas. ${ }^{152}$ Pode-se neste caso estimar os impactos multiplicadores dos gastos federais a partir especificamente de seus recursos colhidos ao exterior. Os efeitos benéficos para a economia deste endividamento externo do governo são consideráveis. Nos anos em que os investimentos privados caíram, eles compensaram, mediante a provável impacto do multiplicador na renda agregada, tal queda; nos anos em que os investimentos privados aumentaram, os gastos do governo somaram-se a eles.

Observe-se tal por meio da função consumo já calculada anteriormente. Contabilizados em dólares de 1980, os investimentos privados (não-residenciais) oscilaram de 420 bilhões em 1981 a 426 bilhões em 1982. Em 1983 eles somariam 417 bilhões, e em 1984, 489 bilhões. A função-consumo para o período 1976-1984, a partir do consumo das famílias em função de sua renda disponível em dólares correntes, tem a seguinte forma, como visto acima:

$$
\mathrm{C}=72,89+0,83 \mathrm{Y}
$$

Estima-se daí o efeito multiplicador como sendo:

$$
\text { 1/1-0,83 (propensão marginal a consumir) }=5,88
$$

A partir da tabela de despesas do governo federal disposta acima, pode-se calcular, entre 1980 e 1984, os gastos totais hipotéticos na economia obtidos pelos gastos do governo a partir de seu endividamento externo no período, mediante o conhecimento do multiplicador: ${ }^{153}$

(1981) 9 bi US\$ [aumento da dívida externa face a 1980] x 5,88=52,9

(1982) 15 bi US\$ [aumento da dívida externa face a 1981] x 5,88 =88,2

(1983) 14 bi US $\$$ [aumento da dívida externa face a 1982] x $5,88=82,3$

(1984) 30 bi US\$ [aumento da dívida externa face a 1982] x 5,88=176,4

Para que se veja a hipótese de como os gastos com consumo a partir do endividamento externo do governo federal mais que compensaram o declínio dos investimentos privados, veja-

\footnotetext{
152 Nas palavras de Kalecki: "a despesa governamental, na medida em que é financiada por empréstimos, ou mesmo por tributos sobre os capitalistas, contribui para o problema da demanda efetiva, porque seu efeito não é contrabalançado por um declínio do investimento e do consumo, o que aconteceria se essa despesa fosse financiada por tributação direta ou indireta dos trabalhadores". Crescimento e Ciclo das Economias Capitalistas, p.9.

${ }^{153}$ É crucial que se enfatize que se deve levar aqui em consideração a variação dos títulos em mãos de estrangeiros. Pois, como o vencimento médio dos papéis é maior que um ano, parte dos recursos colhidos pela emissão de títulos ao exterior, que aparece nos valores totais de títulos em mãos de estrangeiros, já havia sido aplicado na economia pelo governo no ano anterior. Assim, se os papéis em mãos de estrangeiros num Ano 1 estavam em 100 bilhões e em 200 bilhões num Ano 2, 100 bilhões do ano 2 já tinham aplicados no ano anterior; o valor de 200 expressa assim o valor acumulado, ou total, de títulos do governo norte-americano que a economia internacional possui. $\mathrm{O}$ uso da variação de um ao outro é crucial também porque o governo paga, em cada ano, títulos emitidos em anos anteriores.
} 
se a seguinte relação a partir da função-investimento. A série, em bilhões de dólares correntes, de investimentos privados (não-residenciais) entre 1976 e 1984 é a seguinte:

Tabela 16. Estados Unidos. Investimentos privados fixos não-residenciais. Em bilhões de dólares correntes. 1976-1984.

\begin{tabular}{cc}
\hline (1) & $\begin{array}{c}(2) \\
\text { Investimentos } \\
\text { privados não- } \\
\text { residencias } \\
1976\end{array}$ \\
192,4 \\
1977 & 228,7 \\
1978 & 280,6 \\
1980 & 333,9 \\
1981 & 362,4 \\
1982 & 420 \\
1983 & 426,5 \\
1984 & 417,2 \\
\hline
\end{tabular}

Fonte: NIPA-BEA, Seção 5, Saving and Investment, Tabela 5.3.5. Private Fixed Investment by Type.

Sua regressão em função do tempo $(\mathrm{t})$ no período gera a equação III $(I=a+b t)$ :

$$
\begin{aligned}
& \text { Regressão (III) } \\
& \mathrm{I}_{\text {pnr }}=172,46+35,537 \mathrm{t} \\
& \mathrm{R}^{2}: 0,95 \\
& \text { Durbin Watson: } 1,41
\end{aligned}
$$

Os investimentos realmente verificados e os estimados a partir da equação estão dispostos abaixo, em bilhões de dólares correntes. Note-se que os hiatos entre a tendência e os investimentos reais no intervalo 1983-1984 são mais que compensados pelos impactos positivos nos gastos oriundos do financiamento do déficit com base nos recursos estrangeiros. Em 1981 e 1982, os gastos multiplicados a partir do déficit financiado externamente vêm somar-se, de qualquer modo, aos investimentos locais. 
Tabela 17. Estados Unidos. (a) Investimento bruto privado não-doméstico verificado e (b) estimado, a partir da função-investimento (investimentos em função do tempo entre 1976 e 1984); hiato entre eles (a-b) e (c) gastos estimados, a partir do efeito multiplicador, oriundos do aumento do endividamento externo federal a cada ano. 1981-1984.

$\begin{array}{lrrrr} & 1981 & 1982 & 1983 & 1984 \\ & 420,1 & 426,5 & 417,2 & 489,6 \\ \begin{array}{llrr}\text { (a) Verificado } \\ \text { (b) Estimado }\end{array} & 485,6 & 421,2 & 456,7 & 492,2 \\ \text { Resíduos (a-b) } & 34,32 & 5,29 & -39,5 & -2,6 \\ \begin{array}{l}\text { (c) Gastos a partir do } \\ \text { endividamento } \\ \text { exteno do gov. federal }\end{array} & 52,9 & 88,2 & 82,3 & 176,4\end{array}$

Fonte: cálculo do autor a partir dos dados do BEA e Economic Report of the President de vários anos. Para investimentos, NIPA-BEA, Seção 5, Saving and Investment, Tabela 5.3.5. Private Fixed Investment by Type. Para dados sobre endividamento do governo federal, ver tabela 9 acima.

Gráfico 13. Estados Unidos. Investimentos privados não-residenciais e tendência estimada (investimentos em função do tempo). 1976-1984. Em bilhões de dólares correntes.

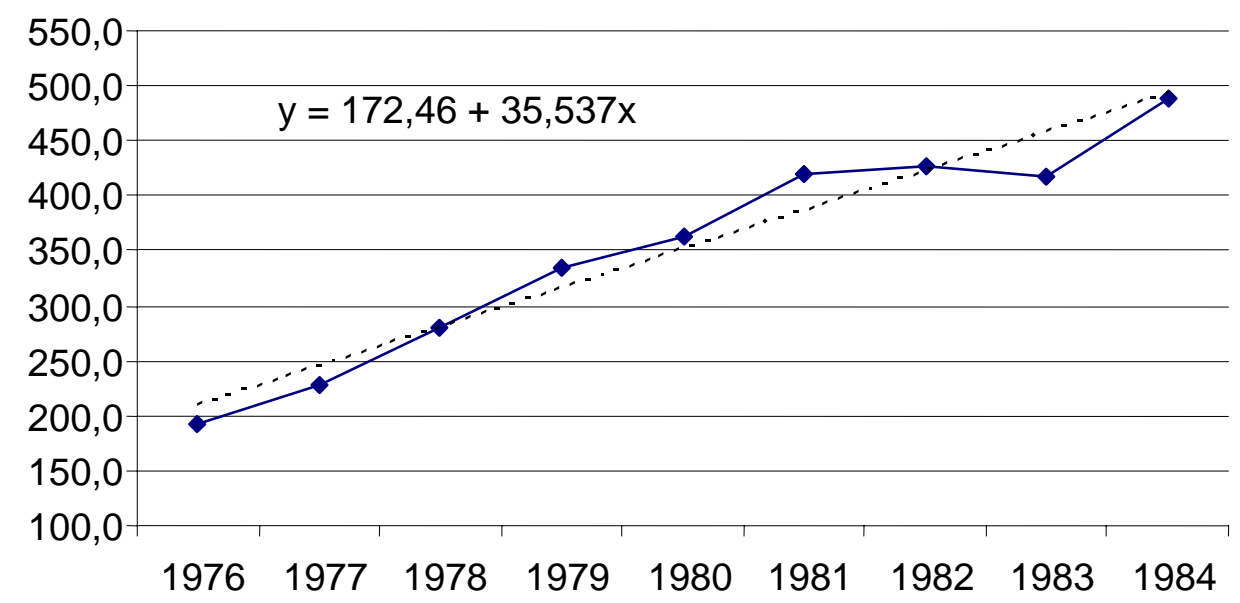

Fonte: ver tabela 17 acima. 
Tabela 18. Estados Unidos. Empréstimos por setores. Famílias - hipotecas (casas) e crédito ao consumo -, corporações e setores financeiros. 1972-1984. Em bilhões de dólares correntes.

Empréstimos por setor

\begin{tabular}{|c|c|c|c|}
\hline $\begin{array}{l}\text { Hipotecas } \\
\text { (famílias ) }\end{array}$ & $\begin{array}{l}\text { Crédito ao } \\
\text { consumo }\end{array}$ & Corporações & $\begin{array}{c}\text { Setores } \\
\text { financeiros }\end{array}$ \\
\hline
\end{tabular}

$\begin{array}{ccccccccc}{[1]} & {[2]} & {[3]} & {[4]} & {[5]} & {[6]} & {[7]} & {[8]} & {[9]} \\ 1972 & 34,1 & \Delta & 19,5 & \Delta & 39,4 & \Delta & 23,9 & \Delta \\ 1973 & 39,5 & 1,15 & 22,5 & 1,15 & 76 & 1,94 & 47 & 2,04 \\ 1974 & 37,3 & 0,94 & 8,9 & 0,39 & 56,4 & 0,74 & 49,6 & 1,04 \\ 1975 & 39,7 & 1,06 & 7,8 & 0,87 & 18 & 0,32 & 2,1 & 0,04 \\ 1976 & 57,6 & 1,45 & 22 & 2,82 & 43,4 & 2,38 & 23,5 & 11,1 \\ 1977 & 85,9 & 1,49 & 35,5 & 1,61 & 73,3 & 1,69 & 53,6 & 2,3 \\ 1978 & 105,7 & 1,23 & 46,4 & 1,3 & 88,7 & 1,2 & 74,7 & 1,39 \\ 1979 & 116,5 & 1,1 & 43,3 & 0,93 & 83,1 & 0,94 & 91,1 & 1,22 \\ 1980 & 90,2 & 0,77 & 3,4 & 0,07 & 70,2 & 0,84 & 73,2 & 0,8 \\ 1981 & 67 & 0,74 & 19,8 & 5,82 & 123,4 & 1,75 & 105,1 & 1,43 \\ 1982 & 47,4 & 0,7 & 18,8 & 0,94 & 93,4 & 0,75 & 93 & 0,88 \\ 1983 & 105,1 & 2,21 & 48,2 & 2,56 & 90,1 & 0,96 & 104,4 & 1,11 \\ 1984 & 127,2 & 1,21 & 81,7 & 1,68 & 204,9 & 2,26 & 157,8 & 1,5\end{array}$

Fonte: Federal Reserve Statistical Release. Flow of Funds Accounts of the United States 2007, Tabela D.2, Borrowing by Sector, p.7. $\Delta$ = Taxas de variação.

A tabela acima deixa ver como os empréstimos das famílias, tanto no conceito de hipotecas como de empréstimos ao consumo, mais que dobram entre 1982 e 1983. Isto se dá mesmo após o aperto das políticas do Fed desde 1979, refletido na grande queda nos meios de pagamento e nos juros ainda altos até 1984. Os empréstimos corporativos variam 2,26 vezes de 1983 a 1984, após sucessivas quedas desde 1978. Os setores financeiros também elevaram seu endividamento em 1984. Não se pode, portanto, desconectar o brusco reflexo do aumento geral de "liquidez" em toda a economia do aumento da atração de poupança externa neste momento.

Estes eram objetivos não-declarados por Volcker, já que importava, oficialmente, conter o crédito e a inflação. Mas, como se pode notar em suas próprias declarações (ver página 24 acima), tornava-se essencial para os Estados Unidos financiar parte do consumo e do investimento com recursos estrangeiros, para evitar uma recessão ainda mais forte. Amiúde os objetivos perseguidos pela política econômica devem ser atingidos com medidas que podem ser contraditórias entre si, mas que não podem ser evitadas quando se assume a importância de tais objetivos em conjunto. Este foi o caso no seio dos dirigentes norte-americanos: a política antiinflacionária de Volcker levou à contenção do crédito e aos altos juros, que por seu turno culminaram numa avalanche de capital externo que dinamizou parte da demanda agregada anulada por aquelas mesmas políticas - demanda agregada esta estimulada diretamente pelo governo "perdulário" de Reagan.

A análise dos impactos benéficos deste início de processo de endividamento externo acima feita foi desagregada, e para ela não se levou em conta a propensão marginal a importar. Incorporemo-la agora para uma estimativa do impacto global do endividamento sobre a 
economia como um todo. $\mathrm{O}$ mesmo tipo de regressão simples $(y=a+b x)$ que acima gerou a propensão marginal ao consumo $(5,88)$ agora serve para gerar a propensão marginal a importar aproximada: a regressão entre o consumo das famílias (variável explicativa ou $\mathrm{x}$, coluna 2 abaixo) e as importações totais (variável explicada ou y, coluna 3 abaixo) dá uma propensão marginal a consumir de 0,13 (coeficiente b). Então o multiplicador torna-se 1/1-0,83+0,13, ou 3,33 .

Tabela 19. Estados Unidos. Dados selecionados. 1976-1984. Em bilhões de dólares.

\begin{tabular}{cccccc}
\hline$(1)$ & $(2)$ & $(3)$ & $(4)$ & $(5)$ & $\begin{array}{c}\text { (6) } \\
\text { Impactos na renda } \\
\text { local da } \\
\text { dívida a partir do } \\
\text { multiplicador }\end{array}$ \\
1976 & 1151 & 124 & - & - & \\
1977 & 1278 & 151 & - & - & \\
1978 & 1428 & 176 & - & - & \\
1979 & 1592 & 212 & - & - & \\
1980 & 1757 & 249 & - & - & \\
1981 & 1941 & 265 & 9 & 3.128 & 29 \\
1982 & 2077 & 247 & 15 & 3.255 & 49 \\
1983 & 2290 & 268 & 14 & 3.536 & 46 \\
1984 & 2503 & 332 & 30 & 3.933 & 100 \\
\hline
\end{tabular}

Fonte: Economic Report of the President de vários anos.

Os resultados de 1981 e 1982 não são significativos porque a economia ainda era credora do exterior. Mas o valor de 100 bilhões em impactos na renda local somava $20 \%$ dos investimentos não-residenciais nos Estados Unidos em 1984 (cujo valor somou 489 bilhões de dólares).

\subsection{Lógica do endividamento}

A administração Reagan assumiu o país no contexto da segunda crise do petróleo, na qual se deu a conjunção de alta inflação e investimentos em queda, trazendo abaixo o emprego e o crescimento. A política econômica buscou paralelamente dois objetivos: em primeiro lugar, a estabilização dos preços. Isto se deu com uma enorme restrição à oferta de crédito, mediante a manutenção de juros elevados, alçados entre 10 e 14 porcento ao ano nos títulos do Tesouro, no interlúdio 1981-1983. Mas, para contrabalançar os impactos da crise e da política de estabilização, o governo federal usou um leque de políticas que uniu (a) concessões ao capital e ataque aos trabalhadores, mediante diminuição dos impostos às corporações e às famílias mais ricas, com cortes em gastos na assistência social, e (b) militarismo crescente. As perdas no emprego para os trabalhadores foram compensadas por mais consumo dos ricos e gastos bélicos do governo. O governo então mesclou uma política monetarista, de contração do crescimento da 
base monetária - devido à inflação - com uma política de keynesianismo bastardo, devido à recessão e às suas opções ideológico-políticas.

Manter a base monetária estável foi fundamental para coadunar a política do Fed de enxugamento dos meios de pagamento com a política do governo federal para favorecer os investimentos privados com vistas a uma futura recuperação. Particularmente, o governo federal conduziu a poupança doméstica e seu endividamento externo com o objetivo de tornar a indústria da guerra o carro chefe da saída da crise. Ao mesmo tempo, o desemprego elevado e a postura do governo face aos trabalhadores - cortando gastos, punindo mobilizações etc. elevou a taxa de lucro média, mantendo os salários estagnados mesmo quando os níveis de produtividade do capital se elevaram.

Esta política foi conjugada, no plano externo, com uma aceleração do endividamento. Tanto o governo como os agentes privados aumentaram seu endividamento no exterior, fato central à resolução da crise.

O enorme encarecimento dos custos de produção refletiu-se numa queda abrangente da taxa de lucro, só minorada pela estagnação dos salários. A queda na taxa de lucro desestimulou o crescimento pela queda das inversões. Com um crescimento menor, caiu a demanda efetiva e o montante dos lucros auferidos foi também menor. A poupança doméstica caiu no mesmo montante. $\mathrm{O}$ endividamento externo permitiu à economia investir e consumir com recursos maiores do que os que efetivamente a economia doméstica gerou.

"A inversão, uma vez que se a leva a cabo, cria automaticamente a poupança necessária para financiá-la." ${ }^{154}$ De fato, a perspectiva kaleckiana pontua que os investimentos geram a própria poupança que os financia, invertendo a perspectiva clássica da necessidade da poupança para investir. Porém, tal poupança pode ser maior, com o endividamento externo, caso no qual o mecanismo de financiar uma inversão inicial torna-se menos custoso. De fato, o investimento gera poupança; mas gera um volume determinado de poupança. Não pode gerar mais do que a poupança que lhe é proporcional, dada a taxa de lucros. Esta poupança pode ser incrementada, porém, com o recurso ao financiamento externo.

Mesmo o baixo crescimento somado entre 1981 e 1984 não foi obtido somente com recursos domésticos. Os Estados Unidos tornaram-se neste momento importadores líquidos de capital. Muitas corporações financiaram seus investimentos, durante a crise, com recursos alavancados no mercado internacional de capitais. Elas se endividaram no exterior, literalmente. Parte da poupança doméstica pôde ser mantida em termos relativos, porque sobraram mais recursos para o consumo. Ao mesmo tempo, a avalanche de depósitos no sistema financeiro norte-americano demonstrava que a economia mundial não hesitava em ter nos Estados Unidos um porto-seguro num ambiente de crise - mesmo que a economia dos Estados Unidos não estivesse, absolutamente, imune a esta crise.

A liquidez no sistema financeiro conseqüentemente se tornou mais alta do que teria sido, se não houvesse um fluxo enorme de recursos externos aportando no país. Os juros talvez

${ }^{154}$ KALECKI, Michal. Teoría de la dinámica económica, p.52. 
tivessem se elevado ainda mais, o endividamento e o consumo das famílias e do governo crescido menos. A demanda agregada conseqüentemente teria ficado num patamar ainda menor. Não tivesse o dólar recobrado valor em 1979, a crise do petróleo teria impactado com mais força. A administração dos Estados Unidos preferiu então colher os custos menores do impacto dos juros altos na demanda para ficar com as benesses de manter a posição do dólar do mundo, com a subseqüente demanda por ativos denominados em dólar e o endividamento externo possível a partir disso.

Assim, através da política econômica de altos juros e dólar valorizado, o endividamento externo tornou-se um elemento estrutural de remédio à crise. Quando o valor do dólar se elevou no exterior, houve um aumento da demanda por títulos denominados nele. Isto implicou um aumento da disponibilidade de recursos aos agentes da economia que compensou as políticas recessivas adotadas por Volcker. $\mathrm{Na}$ ausência da possibilidade do endividamento, a política de Volcker traduzir-se-ia em recessão muito maior na economia, situação na qual a elevação dos juros e do dólar levariam não a uma crise, mas sim a uma catástrofe. Naturalmente, era impossível que a política econômica desse conta de todas as variáveis econômicas ao mesmo tempo. Houve então um impacto direto da política monetária recessiva, sob forma de contenção dos salários e do crédito levando à queda dos preços, e outros impactos indiretos advindos da valorização do dólar e do endividamento dos agentes no exterior, que sustentou parte da demanda efetiva anulada pela ação anterior. Isto era natural, dado que os objetivos do governo eram ao mesmo tempo segurar o aumento dos preços em âmbito doméstico e revigorar o valor do dólar como divisa internacional. Este último teve como resultado um conjunto de conseqüências que até certo ponto iam de encontro ao primeiro.

No gráfico a seguir, pode-se perceber que o início do endividamento externo líquido da economia se inicia no primeiro governo de Reagan. Vê-se que desde os anos (19)60 até aproximadamente 1980, há uma relação muito próxima entre os saldos em conta corrente e os saldos em conta de capitais do balanço de pagamentos. Esta proximidade desapareceu durante o primeiro governo Reagan, dando lugar a um crescimento "perverso" baseado em taxas de investimento maiores do que de poupança. Por sua vez, os saldos em conta corrente do balanço de pagamentos se tornaram mais negativos pelo estrondoso crescimento dos pagamentos de rendas ao exterior e das importações. Os pagamentos de renda ao exterior cresceram 2,24 vezes entre 1981 e 1984, ao passo que os recebimentos apenas 1,7.

Particularmente, o fato de que a economia tornar-se-ia devedora líquida ao exterior neste primeiro governo Reagan deve ser melhor esclarecido. Ele indica, naturalmente, que o montante global de recursos que o país recebeu superou o montante de recursos que enviou ao exterior, nas diversas formas que as importações e exportações de capital podem assumir: empréstimos do governo federal no exterior, empréstimos interbancários, investimento estrangeiro direto. Como visto, o papel da elevação dos juros foi determinante para esta inversão. Mas isto não indica que agentes norte-americanos não se endividassem no exterior no 
período anterior, especialmente o governo federal - cuja dívida em dólares com o exterior existe praticamente desde que o dólar tornou-se a moeda de aceitação universal a partir de 1945.

Gráfico 14. Estados Unidos. Ativos estrangeiros nos Estados Unidos menos ativos dos Estados Unidos no exterior, e saldo em conta corrente do Balanço de Pagamentos. Em milhões de dólares de 1980. 1960-2004.

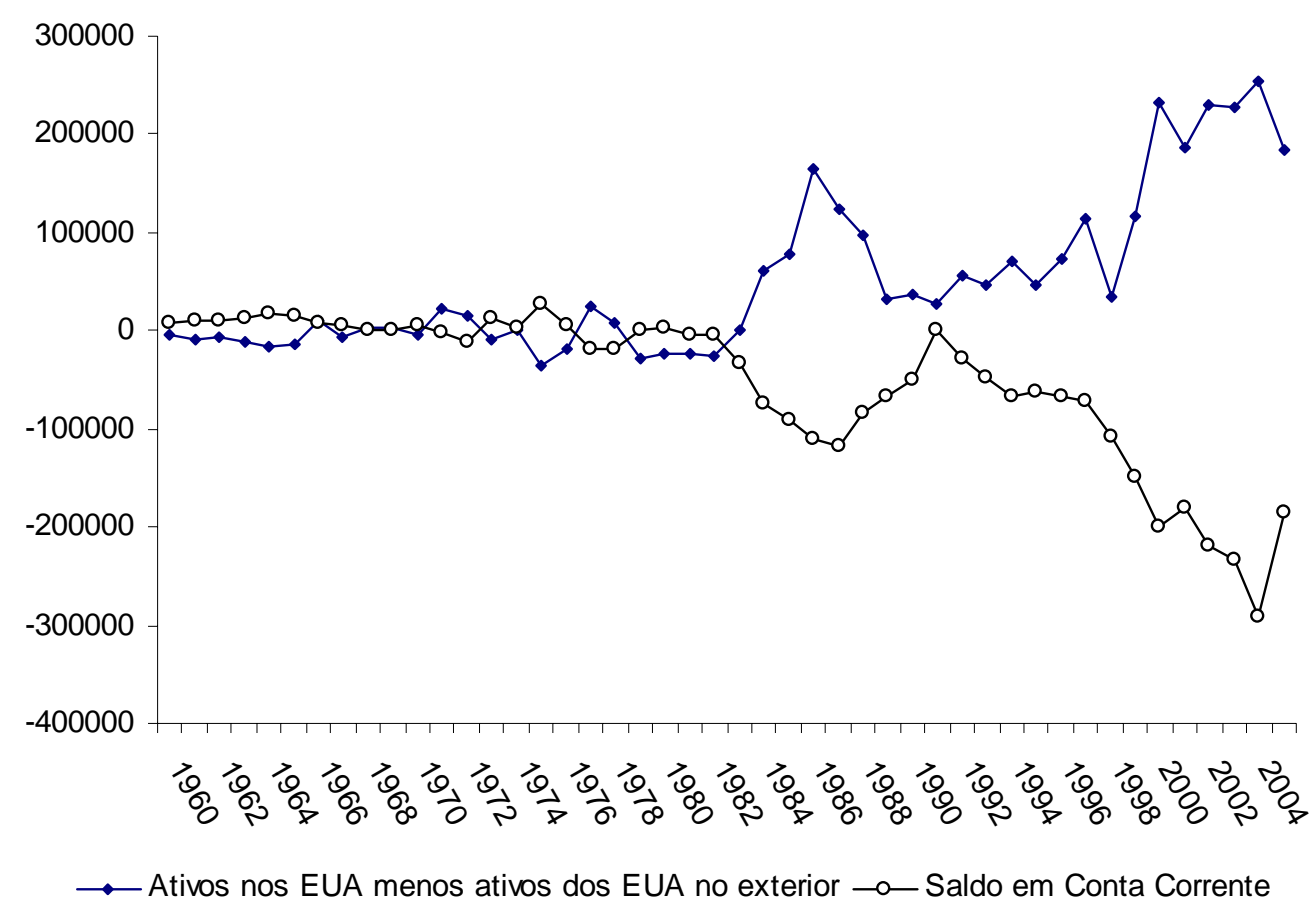

Fonte: Economic Report of the President, 2006. Para Conta Corrente: Tabela B-103, U.S. International Transactions, 1946-2005. Para resultados líquidos de Conta de Capitais: Tabela B-103, U.S. International Transactions, 1946-2005, subtraindo-se a coluna U.S. owned assets abroad da coluna Foreign-owned assets in the U.S. .

Desde 1945, o governo norte-americano sistematicamente pagou parte de seus gastos no exterior com endividamento de curto e médio prazos em dólares, ao invés de valer-se das reservas de ouro unicamente. Naquele contexto de grandes déficits globais do balanço de pagamento pelo lado da conta de capitais, o Economic Report of the President de 1962 observava: "Os déficits no balanço de pagamentos dos Estados Unidos são financiados ou pela diminuição de nossas reservas de ouro ou aumentando os direitos estrangeiros contra eles na forma de papéis em dólar a estrangeiros, oficiais e privados." ${ }^{155}$ Tais déficits eram causados por crescentes gastos em forma de agressões imperialistas, manutenção de tropas no exterior, investimentos diretos na Europa ocidental, entre outros. Agora, a diferença com a situação pré1973 era de que os direitos futuros contra os Estados Unidos passaram a existir apenas sob

155 "Deficits in the U.S. balance of payments are financed either by drawing down our gold reserves or by increasing the potential foreign claims against them in the form of liquid dollar liabilities to foreigners, official and private." Economic Report of the President de 1962, Capítulo 3, The Balance of International Payments, p.148. 
forma de dólares, com exclusão do ouro. Continuam tendo, porém, os maiores depósitos em ouro do mundo em seus bancos, fato consolidado pelo fim da conversibilidade em 1971-1973.

Gráfico 15. Estados Unidos. Proxy de taxa de lucro no setor manufatureiro. 1978-1985.

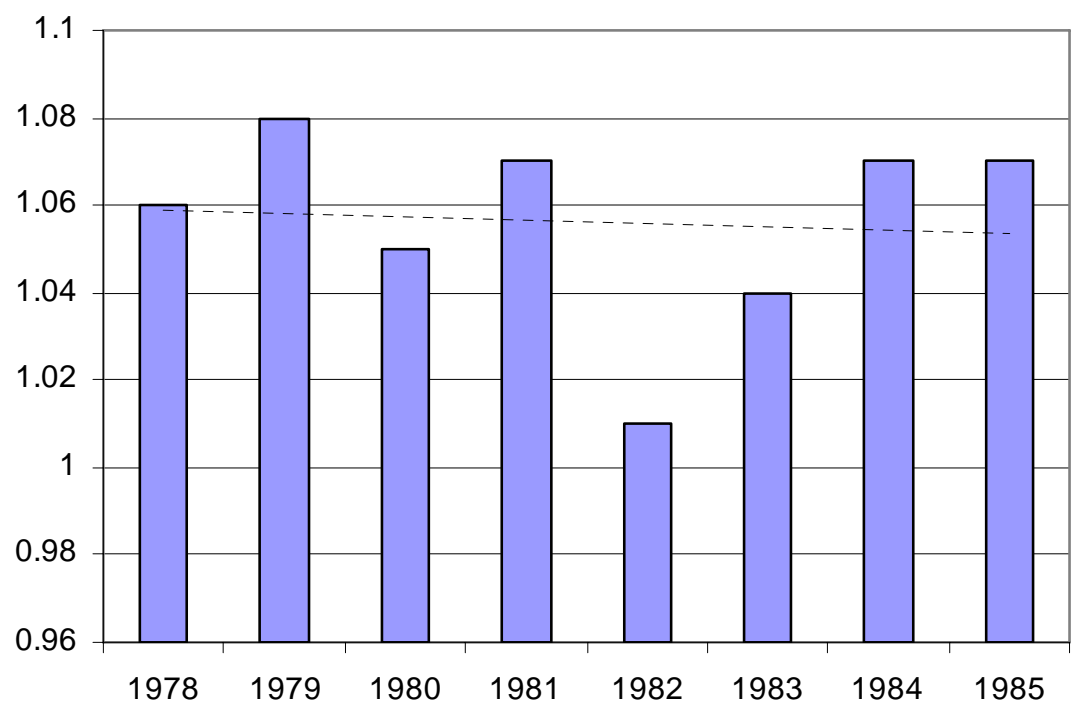

Fonte: mesma do gráfico 3 do capítulo 4 (referente ao cálculo de proxy de taxa de lucro).

Ocorre, todavia, que o montante relativo deste artifício nunca ultrapassou mais que 5\% de suas despesas totais do governo federal dos Estados Unidos. Com o fim do padrão dólar-ouro em 1971-1973, num contexto de elevados gastos de guerra com a agressão ao Vietnã, as administrações norte-americanas encontraram facilidade em aumentar o financiamento externo de seus gastos a partir do momento em que o dólar se tornou a única divisa internacional de reserva. Tal financiamento externo às contas do governo federal chegou a quase $25 \%$ no fim da década de (19)70 (gráfico 13, a seguir).

Isto fica claro a partir da figura abaixo, onde se pode ver o expediente sendo utilizado tanto pelas administrações de Ford (1974-1977) como de Carter (1977-1981). Note-se que aparentemente a administração Reagan não se valeu do endividamento externo mais do que suas antecessoras, e que o endividamento externo progressivo do governo federal remete aos anos (19)70, e não (19)80. Porém, as políticas de Reagan serviram para induzir o endividamento externo das instituições financeiras e oligopólios, atraídos pelos elevadíssimos juros desde 1979 e pela valorização do dólar. É isto que confere a elas a particularidade do uso do expediente do endividamento externo como remédio parcial à crise.

Por que a atração de recursos exteriores não vai gerar nos próximos anos investimentos suficientes para gerar propiciar um crescimento que permita diminuir o endividamento global da economia? No âmbito estrutural, isso se daria se fosse possível à economia estar expandindo a taxa de acumulação produtiva. Mas tal não foi o caso para a economia dos Estados Unidos: a participação do setor manufatureiro no produto iria cair ao longo de toda a década, dando o sinal inequívoco da ultrapassagem de sua lucratividade corrente pelas das outras atividades que 
expressavam a etapa da financeirização. Neste caso, o crescimento dos lucros nos outros setores (não produtivos) estará se dando à custa dos excedentes totais produzidos na economia, e não se somando a eles. Isto porque o crescimento "real" da economia só se poderia dar com mais produção realizada a lucros crescentes, processo que a estagnação dos lucros no setor manufatureiro impede que ocorra. O país exporta aumenta suas exportações de capital produtivo para outras regiões (México, China). Arrighi está corretos, portanto, quando falam da grande diminuição da acumulação produtiva nos Estados Unidos, e sua passagem para o Leste Asiático. ${ }^{156} \mathrm{Se}$ a acumulação produtiva estivesse se expandindo, a busca do nível médio de crescimento buscado pelas autoridades poderia prescindir do endividamento externo.

Gráfico 16. Estados Unidos. Porcentagem (\%) da dívida federal detida por estrangeiros (oficiais e privados). 1970-2003.

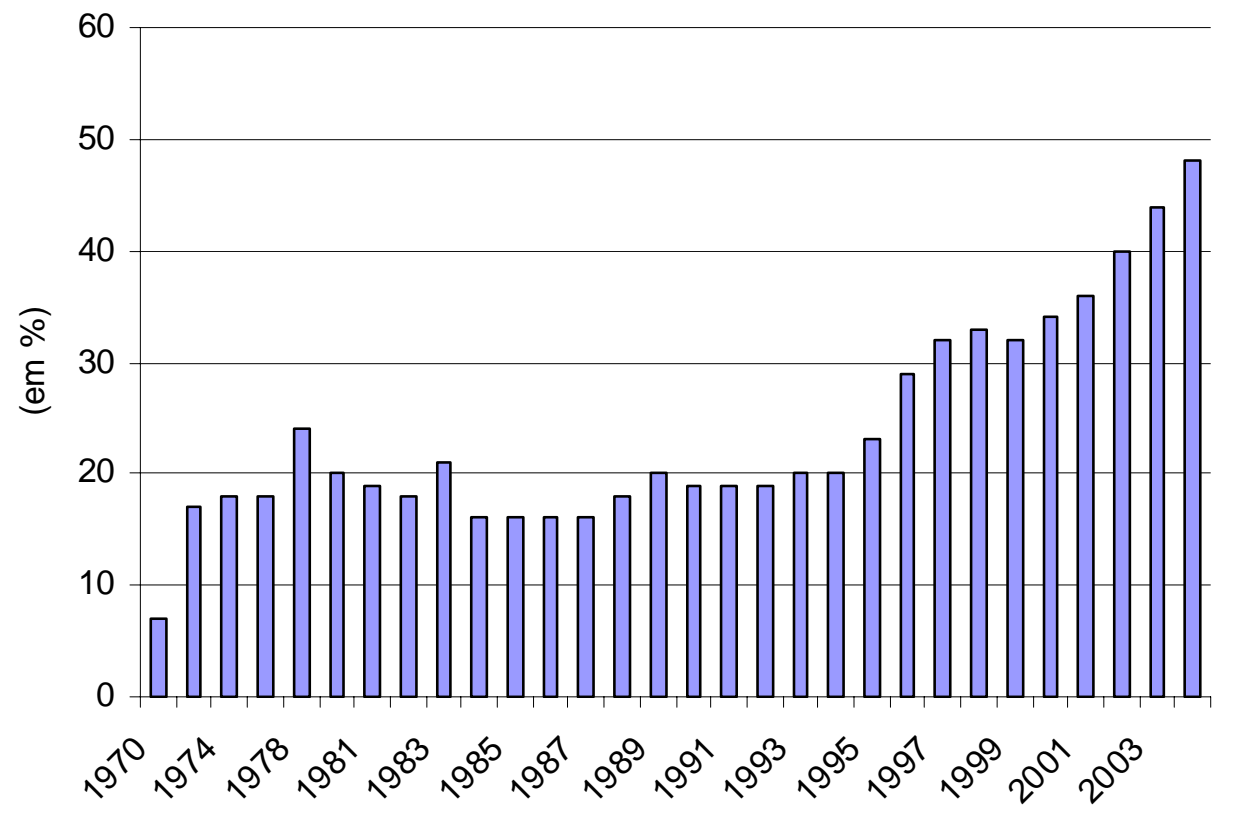

Fonte: Economic Report of the President, vários números. A tabela é International Investment Position of the United States at year-end, na seção International Statistics. Calculados a partir das linhas "Government Securities" e "Other U.S. government liabilities" na sub-seção "Foreign official assets in the United States" (Ativos oficiais estrangeiros nos Estados Unidos) e da linha "U.S. Treasury Securities" na sub-seção "Other Foreign Assets" (Ativos privados estrangeiros nos Estados Unidos).

O fato de que o endividamento externo se elevará nos próximos anos indica a dificuldade crescente de os lucros corporativos dos setores produtivos conduzirem a um crescimento que seja suficiente para que a economia diminua o nível de endividamento externo. O crescimento a uma taxa mais moderada dos lucros indica então uma estagnação do crescimento da demanda efetiva em todos os níveis. Se a taxa de luro nos setores produtivos tende a não crescer, os investimentos caem. O consumo das famílias, que depende dos investimentos corporativos, já que "os trabalhadores gastam o que ganham", é estancado no 
mesmo montante dos investimentos privados. Os gastos do Estado também dependem do desempenho dos investimentos privados; se eles cessam, a arrecadação cai. Mas o Estado pode financiar o consumo e estimular o investimento com emissão de títulos externos, atribuindo mais um componente à demanda efetiva não efetivamente gerado na economia. Se as empresas aumentam suas captações externas para investir, elas demandam mais que seus lucros passados permitem. O Estado também colhe mais tributos quando as empresas se endividam.No contexto que aqui se descreve, o artifício das autoridades econômicas é o próprio recurso à poupança externa, que permite manter a demanda efetiva global adequada à capacidade instalada à custa do endividamento externo da economia.

Quando os preços dos bens de capital se elevaram depois da segunda crise do petróleo, a composição orgânica média dos capitais se elevou (como demonstrado na tabela 2 do capítulo 4, de lucros não distribuídos, gastos com salários e capital fixo, e taxa de lucro, por setor econômico), e os ganhos reais dos trabalhadores regrediram. Os dispêndios com capital constante aumentaram, como mostra as séries referentes à relação entre capital fixo e salários para manufatura, mineração e transportes. As taxas de mais-valia cresceram, mas junto da queda das taxas de lucro. De fato, a taxa de lucros e o montante de lucros auferidos se recuperariam em 1984, com uma vigorosa política de ataque aos trabalhadores, déficits fiscais e crédito farto. Mas a recuperação não foi suficiente para dar margem a um crescimento sustentado ao longo dos anos subseqüentes. A recuperação até 1987 permitiria diminuir um pouco a taxa de endividamento externo, mas como a economia continuava sob a ação das dificuldades dos setores industriais para ultrapassarem uns aos outros em lucratividade, a tendência à estagnação levava à captação de recursos externos como meio de evitar uma instalação mais nítida de seus resultados. Tratava-se aí da ação da lei tendencial da queda da taxa de lucros não completamente debelada pelas políticas de Reagan, levando a pressões desacumulativas sobre a variação relativa da produção física, e assim à demanda da política econômica pelos estabilizadores dos recursos em dólar vindos de uma economia internacional disposta a aceitar papéis norte-americanos.

O fato de que a economia irá elevar os níveis de endividamento externo - com pequenas diminuições de sua taxa devido a aumentos conjunturais das condições de inversões produtivas domésticas e das exportações - indica que a dificuldade de manutenção da demanda efetiva em forma de investimento, consumo e impostos recolhidos, teve de ser compensada com aporte de poupança externa, para evitar uma desaceleração maior. $\mathrm{O}$ aumento absoluto e relativo do endividamento externo ao longo do tempo sugere que os fatores que permitiriam reativar a taxa de lucro relativa nos setores produtivos iriam atuar com efeito cada vez menor. A tendência para a "reprodução simples" apresentar-se-ia com cada vez mais força, o que seria respondido pelo aumento paralelo do endividamento externo da economia. 
A segunda administração Reagan (1985-1988)

"O influxo de capital externo levou a um dólar forte. O dólar forte, por sua vez, contribui significativamente para o grande e crescente déficit comercial. Nosso dilema político é simples, mas talvez ainda não completamente compreendido. Logicamente não podemos dar boas vindas ao capital externo e reclamar depois do déficit comercial. Eles são dois lados da mesma moeda." 157

Paul Volcker

\subsection{Introdução}

A segunda administração de Ronald Reagan iniciou-se no bojo da forte expansão de 1984, e durante ela o desempenho do produto ver-se-ia mais estável do que em seu primeiro governo, com média quadrienal de $3,8 \%$ de crescimento. Por outro lado, o aumento rápido dos déficits fiscais e das importações norte-americanas entre 1981 e 1984, decorrentes da política do dólar forte iniciada em 1979, suscitaram a lei dos limites dos déficits orçamentários e o acordo do Plaza, ambos de 1985. A primeira buscou impor controle e depois eliminar os déficits orçamentários, e a segunda visava desvalorizar o dólar, a fim de diminuir os déficits comerciais. O capítulo analisa, então: (1) as condições em que se deu a recuperação da economia norteamericana depois da crise de 1981-83; (2) os impactos benéficos da aplicação do Acordo do Plaza em 1985; (3) as condições em que se deu a atuação da lei sobre os limites dos déficits orçamentários, também de 1985; (4) como a recuperação não evitou de todo a crise do setor industrial, iniciado no fim da década de (19)70. O capítulo ainda aborda os efeitos estabilizadores do endividamento, mostrando, por outro lado, como o crescimento com base na recuperação da lucratividade e no aumento das exportações resultou numa maior expansão que permitiu à diminuição do ritmo do endividamento em 1987 e 1988.

\footnotetext{
157 "The inflow of funds has encouraged a very strong dollar. The strong dollar, in turn, contributes importantly to the huge and growing trade deficit. Our police dilemma is simple but perhaps not fully understood. We cannot logically welcome the capital inflow from abroad in one breath and complain about the trade deficit in the next. They are two sides of the same coin." Statement by Paul Volcker, Chairman, Board of Governors of the Federal Reserve System, before the Committee on Banking, Housing and Urban Affairs - U.S.Senate. 20 de Fevereiro de 1985. Este e outros documentos referentes aos presidentes do Fed estão disponíveis no Endereço do Fed St. Louis: http://fraser.stlouisfed.org/historicaldocs /.
} 


\subsection{A continuação do Reaganomics}

Grande parcela do forte crescimento do produto ${ }^{158}$ em 1984 deu-se com utilização da capacidade instalada ociosa deixada pela conjuntura ruim anterior. A inflação estabilizou-se e o nível de emprego cresceu, com grande elevação das importações. Todavia, o déficit fiscal do governo federal atingia agora níveis altos, assim como os déficits comerciais. Mesmo assim, as autoridades enfatizavam para os próximos quatro anos a necessidade da manutenção do mesmo padrão de política econômica encontrado no Economic Recovery Act de 1981. Quais sejam: (a) manutenção de preços estáveis como prioridade principal da política econômica, com forte controle da política monetária sobre o comportamento dos meios de pagamento; (b) favorecimentos tributários às firmas como expediente principal da elevação da taxa de investimentos e da demanda por trabalho; (c) inversões na indústria da guerra como componente contra-cíclico; (d) ênfase na desregulação da economia; (e) cortes de direitos sociais.

Podia-se ler no Economic Report de 1985:

"O país acabou de passar por um período de ajuste difícil rumo a uma mais baixa inflação - no entanto, o ajuste está incompleto. É importante que os ganhos conquistados na redução da inflação não sejam perdidos. O sucesso vai requerer um crescimento suficiente dos meios de pagamento para permitir uma vigorosa expansão, enquanto que, ao mesmo tempo, vai requerer manter uma pressão baixista sobre a taxa de inflação para fornecer confiança para a obtenção de uma estabilidade dos preços no longo prazo. Para obter estes objetivos, a administração leva à frente uma política de redução gradual da taxa de crescimento dos meios de pagamento ao longo do tempo, e de estabilização da emissão monetária no curto prazo ao máximo possível." 159

Consoante sua perspectiva anti-keynesiana, a administração considerava infrutífera uma manipulação da política tributária em favor de uma elevação dos gastos das famílias como medida de estabilização da atividade econômica. Classificavam-se, surpreendentemente, os gastos públicos como capazes apenas no curto prazo de interferirem na atividade econômica,

\footnotetext{
${ }^{158}$ Nota explicativa: o sistema de Contas Nacionais norte-americanas abandonou a classificação de Produto Nacional Bruto (Gross National Product) pela de Produto Interno Bruto (Gross Domestic Product) em 1991. Neste capítulo, feito com dados de edições do Economic Report of the President da década de 1980, adota-se então a noção de PNB - Produto Nacional Bruto, correspondente a GNP. Esta convenção servirá até o capítulo que estuda a administração de George Bush, depois do qual a noção de PIB é então adotada, em consonância com o BEA e o Economic Report of the President.

159 "The Nation has just gone through a difficult period of adjustment to lower inflation - indeed, the adjustment is still incomplete. It is important that gains achieved in reducing inflation not be lost. Success will require permitting enough money growth to allow vigorous economic expansion, while at same time maintaining downward pressure on the inflation rate to build confidence in the achievement of long-run price stability. To achieve these goals, the Administration supports a policy of gradually reducing the average rate of money growth over time and of stabilizing short-run money growth to the maximum extent possible." Economic Report of President, 1985, p.56.
} 
ainda que seus impactos fossem considerados maiores do que as diminuições no imposto de renda. Neste momento, a insistência quanto ao controle dos gastos federais insurgia-se contra os próprios resultados da política adotada anteriormente.

"A política fiscal não parece ter muitos impactos na atividade econômica agregada pelo lado da demanda, que uma vez supunha-se existir. Pelo fato de que o comportamento dos consumidores depende da renda média, mudanças nos impostos para propósitos contra-cíclicos parecem ter efeito reduzido. Se os contribuintes esperam mudanças apenas temporárias na cobrança de impostos - e tais mudanças deveriam ser tomadas num contexto temporário porque recessões e booms não são permanentes - então as mudanças advindas da alteração nos impostos vão provavelmente impactar muito pouco no comportamento do consumo. Mudanças temporárias nas transferências do governo também têm pouco valor para propósitos de estabilização, pelos mesmos motivos das mudanças nos impostos de renda. A evidência sugere, no entanto, que mudanças temporárias nos gastos do governo para bens e serviços talvez tenham um influência um pouco maior no PIB no curto prazo, por mais que relativamente ainda bem pequena." 160

Desde 1981, um dos pilares da política da administração Reagan foi implementar a desregulamentação da economia, mediante "remoção de barreiras à inovação, investimento, trabalho e poupança nos sistemas tributário, legal e regulatórios." Basicamente, com (1) eliminação de leis restritivas ao ingresso de mais empresas em cada setor econômico e (2) retirada da participação do Estado em setores em que o capital privado pudesse atuar. Oficialmente, esperava-se que a taxa de investimento agregado aumentasse, segundo a ótica de que "os mercados geram e usam enormes quantidades de informação especializada que são extremamente difíceis e custosas de o governo obter [de modo que] quando o governo substitui os mercados, tanto pela regulação como pela propriedade, esta informação é geralmente perdida e o comportamento econômico é sacrificado". ${ }^{161}$

Eram vários os setores visados pela desregulamentação. $\mathrm{O}$ setor financeiro foi autorizado a alavancar parcelas maiores de seu capital, reduzindo suas reservas. Novas instituições, com funções e práticas de operações financeiras - como os derivativos - foram

\footnotetext{
160 "Fiscal policy does not appear to have large impacts on aggregate economic activity through demand side effects that were once thought to exist. Because consume behaviour depends on household's average income, changes in individual income taxes for countercyclical purposes seem to have especially small effects. If taxpayers expect income tax changes to be temporary - and changes for countercyclical stabilization should be interpreted in a temporary context because recessions and booms are not permanent - then the tax changes are likely to have relatively little effect on consumption behaviour. Temporary changes in transfer payments seem to have little value for stabilization purposes, for the same reason that temporary tax changes have little value. The evidence suggests, however, that temporary changes in government purchases of goods and services may have somewhat greater, though still relatively small, effects on total GNP in the short run." Ibid., p.58.

${ }^{161}$ Economic Report of the President, 1986, p.159.
} 
autorizadas a operar. Nos transportes, as restrições pela entrada de mais companhias no setor rodoviário e aéreo tinham levado, segundo a perspectiva oficial, a maiores ganhos de corte monopolístico, tanto às empresas como a seus empregados "sindicalizados". No transporte ferroviário, segundo esta ótica, os preços estariam desconectados com a demanda real pelo serviço, superando-a. Daí que o governo tivesse cancelado os impedimentos à entrada de mais empresas em cada setor, o que supostamente teria conduzido a preços menores no sistema como um todo.

No setor de gás natural, o governo liberara os controles do preço do insumo em (19)81, explicando, entre outros, que as importações de petróleo, um substituto direto, estavam artificialmente grandes porque a produção doméstica de gás era mantida baixa. Dizia-se que o controle de preços impedia aumento da concorrência, pondo-se assim a produção abaixo da demanda doméstica. Na ótica oficial, a liberalização dos preços, junto da oportunidade para mais concorrência, iria conduzir ao melhor dos mundos possíveis, com queda dos preços e aumento da produção.

Outra área onde atuou a desregulamentação refere-se à política ambiental. Substituiu-se a antiga legislação de "comando e controle", que impunha padrões uniformes aplicáveis a todas firmas de uma determinada categoria, por aquilo que se chamou de "vendas de emissões" (emissions trading). Tal foi definido com "um método de controle da poluição baseado no mercado". A ideia era de que as firmas enfrentavam diferentes graus de dificuldade para atingirem os níveis de redução de emissões exigidos. Daí que "um método mais eficiente é pedir às firmas onde a redução da poluição pode ser obtida sob custos mais baixos para reduzirem as emissões em maior escala do que naquelas onde isto não é possível". ${ }^{162}$ As empresas onde a redução das emissões fossem mais baratas poderiam assim vender créditos da redução de seus níveis de poluição abaixo dos níveis exigidos para as empresas onde tais reduções se vissem mais difíceis.

Com a continuidade do acento na desregulação e no controle estrito dos meios de pagamento, assim como na diminuição dos impostos às firmas, a administração sinalizava que o leque de políticas do segundo governo Reagan não diferiria daquele referente ao primeiro, modificando-se apenas a conjuntura onde elas iam ser aplicadas. No caso, a economia apresentar-se-ia mais estável a partir de 1985, o que de fato permitiria uma diminuição dos déficits e evitaria elevação do nível de impostos.

\section{3. $O$ acordo do Plaza de 1985}

Em 1985, Paul Volcker continuava sendo o presidente do Fed, com mandato renovado por Reagan ainda em 1983. Viu-se como Volcker implementou políticas de contenção do crédito e de metas estáveis de inflação que, se foram politicamente difíceis de aceitar num primeiro momento, terminaram por auxiliar o governo quando o nível de desemprego tornasse a

${ }^{162}$ Economic Report of the President, 1986, p.180. 
taxa de lucro de novo compensadora para a retomada de parte dos investimentos. A contração dos meios de pagamento e o aumento dos juros, mesmo que altamente recessivos em seu impacto direto, sinalizaram positivamente para o Executivo que os déficits fiscais federais poderiam ser feitos em parte sobre a base da poupança inativa dos detentores de riqueza. Assim, ao não monetizar a dívida federal, o Fed assegurou uma baixa inflação e evitou que os posteriores gastos "perdulários" do governo se fizessem por meios supostamente inflacionários - isto é, pelo crescimento de M1.

Neste mesmo 1985 o produto voltou a apresentar comportamento menos errático, e o governo colheu os louros da situação melhorada. Chamou atenção o fato de que este crescimento tinha se dado com base na venda dos bens de luxo e na concentração da renda, sem eliminar os males que o "remédio" de 1981/82 havia infligido aos trabalhadores. Ao mesmo tempo, os níveis de inflação diminuíram, indo a 3,8\% em média. Isso permitiu uma queda da taxa de juros de longo prazo, Os juros ainda se encontrava num patamar alto (10,62\%), mas haviam deixado a marca dos $13,90 \%$ de 1981 .

Tabela 1. Estados Unidos. Taxas de crescimento semestrais e anuais do PNB (\%). 1985-1988.

\begin{tabular}{cc}
\hline Trimestres/anos & $(2)$ \\
$1985 \mathrm{q} 1$ & Taxas de crescimento do PNB (\%) \\
$1985 \mathrm{q} 2$ & 3.8 \\
$1985 \mathrm{q} 3$ & 3.5 \\
$1985 \mathrm{q} 4$ & 6.4 \\
1985 & 3.1 \\
$1986 \mathrm{q} 1$ & 4.1 \\
$1986 \mathrm{q} 2$ & 3.9 \\
$1986 \mathrm{q} 3$ & 1.6 \\
$1986 \mathrm{q} 4$ & 3.9 \\
1986 & 2.0 \\
$1987 \mathrm{q} 1$ & 3.5 \\
$1987 \mathrm{q} 2$ & 2.7 \\
$1987 \mathrm{q} 3$ & 4.5 \\
$1987 \mathrm{q} 4$ & 3.7 \\
1987 & 7.2 \\
$1988 \mathrm{q} 1$ & 3.4 \\
$1988 \mathrm{q} 2$ & 2.0 \\
$1988 \mathrm{q} 3$ & 5.2 \\
$1988 \mathrm{q} 4$ & 2.1 \\
1988 & 5.4 \\
& 4.1 \\
\hline
\end{tabular}

Fonte: dados obtidos no endereço eletrônico do BEA: a tabela intitula-se "Gross Domestic Product, percent change from preceding period, 1930-2006". ${ }^{163}$

Durante todo o ano o produto manteve-se estável, estimulado pelos juros mais baixos dos Títulos do Tesouro e da taxa de desconto do Fed, e pelos crescentes déficits fiscais. Estes foram de 99 bilhões para 151 bilhões nos dois primeiros trimestres do ano, ao passo que os juros

${ }^{163}$ Como explicado no Apêndice, todos os dados do Bureau of Economic Analysis podem ser obtidos em www.bea.gov. 
dos Títulos do Tesouro permaneceram entre 7 e 7,5\%. As taxas privadas custaram a cair, porém. A taxa Moody's, que remunera os títulos corporativos, estava a $12 \%$ e ficou neste patamar o ano todo. Sem embargo, os níveis de endividamento externo da economia cresceram na mesma medida do PNB. O aporte de capitais estrangeiros somou aproximadamente 150 bilhões de dólares em 1985, número bem superior aos 50 bilhões em capitais que os Estados Unidos enviaram ao exterior. $\mathrm{O}$ valor importado representava um terço da poupança agregada de famílias, empresas e governo.

O ano de 1985 foi marcado por uma decisão crucial para o comércio exterior norteamericano: o acordo do Plaza, para a desvalorização do dólar face ao iene e ao marco. Em tempo: se em fins de 1979 as autoridades buscaram restaurar o valor do dólar, em queda desde os anos sessenta, agora parecia ser o momento de conter o movimento, e forçá-lo à direção oposta. Como dizia Volcker, o capital externo havia sido tão "generoso" com a economia dos Estados Unidos, auxiliando-a a suprir a falta de poupança doméstica, que a demanda por títulos em dólar havia levado a uma valorização excessiva da moeda. Mas esta colocou o comércio exterior norte-americano, e a própria produção doméstica, sob a exposição das manufaturas japonesas.

Tabela 2. Estados Unidos. Taxas de juros selecionadas e déficits fiscais do governo federal (em bilhões de dólares correntes).

\begin{tabular}{ccccc}
\hline$(1)$ & $(2)$ & $(3)$ & $(4)$ & $(5)$ \\
& Taxa de & Moody's & Treasury Bonds - & Déficits fiscais \\
& desconto do Fed & 12,08 & 3 meses & -96 \\
1985/Janeiro & 8,35 & 12,23 & 7,01 & -155 \\
Junho & 7,53 & 11,05 & 7,18 & -138 \\
Agosto & 7,90 & 10,06 & 7,07 & -155 \\
Dezembro & 8,27 & & \\
\hline
\end{tabular}

Fonte: Economic Report of the President, 1987. Para taxas de juros, Tabela B-68, Bonds yields and interest rates, 1929-86. Para déficits fiscais, Tabela B-73, Federal Receipts, outlays, surplus or déficit, and debt.

No evento do Acordo do "Plaza", nome do hotel em Nova York em que se deu o evento, estiveram os ministros das finanças do Reino Unido, França, Japão e Alemanha Ocidental. No início do documento que oficializou o evento, "Announcement of the Ministers of Finance and Central Bank Governors of France, Germany, Japan, the United Kingdom, and the United States (Plaza Accord)", elogiava-se a retomada do crescimento das economias industriais a partir de 1984, assim como a referida queda dos juros e da inflação. Entretanto, o ponto 10 apontava como questão fundamental a deterioração da conta corrente do balanço de pagamentos dos Estados Unidos. Não à toa, o documento enfatizava que a queda das exportações dos Estados Unidos era intensificada pelo crescente bloqueio das importações dos países submetidos às políticas de ajuste do Fundo Monetário, durante a deflagração da crise da 
dívida externa que devastou as economias periféricas. No documento que registrou o Acordo, pode-se ler:

"Não obstante estes desenvolvimentos econômicos positivos [o crescimento com baixa inflação a partir de 1984], há grandes instabilidades nas posições externas que colocam problemas potenciais, e que refletem um amplo leque de problemas. Entre eles há: a deterioração das contas externas que os Estados Unidos experimentaram desde seu período de crescimento rápido; o particularmente grande impacto na conta corrente dos Estados Unidos oriundos das dificuldades e dos esforços de ajuste de alguns dos principais países em desenvolvimento; a dificuldade das vendas externas em acessar certos mercados; e a apreciação do dólar. A interação destes dois fatos - taxas de crescimento relativo, os problemas externos dos países em desenvolvimento, e os desenvolvimentos da taxa de câmbio - contribuíram para enormes instabilidades externas, potencialmente desestabilizadoras em relação aos principais países industriais. Particularmente, os Estados Unidos passam por um grande e crescente déficit na conta corrente, e o Japão, e numa menor medida a Alemanha, por um grande superávit." 164

O argumento para a desvalorização do dólar era o de que a continuidade dos déficits dos Estados Unidos poderia potencializar uma guerra comercial de prejuízos mútuos, na medida em que os Estados Unidos enveredassem por medidas protecionistas. De acordo com esta ótica, tais medidas poderiam desencadear um disputa global que levaria a menores taxas de crescimento e emprego. A desvalorização do dólar permitiria que a nação "desbalanceada", a virtual origem dos problemas potenciais, se estabilizasse. Mas não se fazia uma análise da condição estrutural deficitária do comércio exterior dos Estados Unidos à qual levava a posição do dólar na economia mundial. $\mathrm{O}$ documento, com forte ênfase na abertura, desregulamentação $\mathrm{e}$ privatização, assegurava a melhoria do comércio exterior dos Estados Unidos mediante a aplicação das seguintes medidas conjuntas:

\footnotetext{
164 "These positive economic developments notwithstanding, there are large imbalances in external positions which pose potential problems, and which reflect a wide range of factors. Among these are: the deterioration in its external position which the U.S.experienced from its period of very rapid relative growth: the particularly large impact on the U.S. current account of the economic difficulties and the adjustment efforts of some major developing countries; the difficulty of trade access in some markets; and the appreciation of the U.S. dollar. The interaction of these factors-- relative growth rates, the debt problems of developing countries, and exchange rate development-- has contributed to large, potentially destabilizing external imbalances among major industrial countries. In particular, the United States has a large and growing current account deficit, and Japan, and to a lesser extent Germany, large and growing current account surpluses." Este documento foi disponibilizado pelo Munk Centre for International Studies da Universidade de Toronto (Canadá). O endereço é: http://www.g8.utoronto.ca /.
} 
- resistência generalizada ao protecionismo das nações parceiras dos Estados Unidos;

- aumento da demanda agregada de Japão, Alemanha e França, via extensão do crédito às famílias e empresas privadas;

- para o Japão especificamente: implementação do Action Program, anunciado em 30 de Junho de 1985, que visava maior abertura do mercado doméstico japonês às importações; flexibilização da política monetária com a "devida atenção" à taxa de câmbio do yen (flexible management of monetary policy with due attention to the yen rate); e redução do déficit fiscal do governo federal;

- quanto aos Estados Unidos, elencavam-se medidas de redução do déficit público para "liberar recursos para os setores privados" (que, se cumpridas à risca, somente culminariam numa maior valorização do dólar), além do inócuo "resistir a medidas protecionistas".

Não é necessário enfatizar que estas medidas excluíam qualquer modificação da estrutura do padrão monetário internacional dominado pelo dólar, que era afinal a razão explicativa dos déficits comerciais. Porém, as ações das autoridades não se restringiram às medidas acima citadas, envolvendo já no dia seguinte uma ampla participação dos Bancos Centrais na venda de dólares e compra de outras moedas. O fato é que simplesmente tais medidas "intervencionistas" não eram explicitadas no corpo do texto, dado o natural "retraimento" em admitir a intervenção aberta pelos administradores liberais. Robert Solomon que pertenceu ao quadro de economistas do Fed e participara da Comissão de Reformas do Sistema Monetário Internacional no início dos anos setenta - assim descreve as ações conjuntas dos Bancos Centrais para desvalorizar o dólar:

"Em 23 de Setembro de 1985, pela primeira vez em seis meses, as autoridades monetárias americanas intervieram nos mercados de divisas. Venderam um volume moderado de dólares - 149 milhões - para comprar marcos alemães e ienes. $\mathrm{Na}$ semana seguinte ao anúncio do Plaza, os países do G-5 intervieram num total de 2,7 bilhões. Durante o mês seguinte, os países do G-10 venderam 7 bilhões para comprar moedas Europeias e ienes. A parcela da intervenção dos EUA em Outubro foi de 2,8 bilhões de dólares. Após vender apenas 102 milhões em Novembro, as autoridades americanas permaneceram fora dos mercados de divisas até o fim de 1986 enquanto o dólar se desvalorizava. O volume da intervenção feita pelo G-5 foi menor que o previsto, mas não divulgado, no Plaza: um total de 18 bilhões de dólares ao longo de um mês e meio." 165

${ }^{165}$ Dinheiro em movimento, p.47. 
Entrementes, o déficit fiscal também suscitou uma medida de política econômica a fim de contê-lo. O alarde quanto ao crescimento dos déficits fiscais gerou o "Decreto pelo Orçamento Equilibrado e Controle Emergencial do Déficit de 1985", chamado no original de Balanced Budget and Emergency Deficit Control Act of 1985. Foi formulado no fim de 1985 pelos senadores Phill Gramm do Texas, Ernest Hollings da Carolina do Sul e Warren Rudman, de New Hampshire. A lei foi aprovada em Dezembro de 1985, e era um exemplo de "medida corretiva" que Volcker dizia ser necessária para aumentar no curto prazo a poupança (doméstica). Mas era mais do que isto. Era uma reação por parte do Congresso ao aumento rápido dos déficits.

A lei, aprovada pelo Congresso, visava limitar os déficits fiscais do governo federal, criando mecanismos automáticos de cortes de gastos pelo Executivo. Tais gastos seriam implementados e fiscalizados pelo que se chamou de o "Controlador Geral" (Comptroller General) - o chefe do General Accounting Office, entidade responsável pelas análises e investigações econômicas do Congresso. A lei propunha cortes paulatinos até que se chegasse a um superávit no início da próxima década de (19)90. Mediante uma extensa investigação das despesas do governo federal, propunha-se um corte de $50 \%$ nos gastos com defesa e de $50 \%$ nos outros tipos de gastos.

Pode-se ler o miolo da proposta no documento do próprio Congresso norteamericano, "Explanation of the Balanced Budget and Emergency Deficit Control Act of 1985 Public Law 99-177." 166

“O Decreto do 'Orçamento Equilibrado e Controle Emergencial do Déficit de 1985', Lei Pública número 99-177, requer reduções anuais nos déficits orçamentário de 171 bilhões no ano fiscal de 1986 para zero no ano fiscal de 1991. O Ato propõe procedimentos para reduzir os déficits para os máximos níveis anuais mediante confisco obrigatório dos fundos. A quantia e o percentual da redução requerida são determinados [levando-se em conta] o déficit do ano, as condições econômicas esperadas, e a base orçamentária dos gastos e programas. O Controlador Geral [Comptroller General] emite um parecer determinando a quantia da redução a ser feita tanto nos gastos, projetos e atividades com defesa e com não-defesa. A redução total é igualmente dividida entre os programas de defesa e de não-defesa [...].

Com exceção dos programas com regras especiais, as mesmas percentagens de redução são feitas dentro de ambas categoriais, de modo que todos os programas

\footnotetext{
166 "Explanation of the Balanced Budget and Emergency Deficit Control Act of 1985 - Public Law 99177. Congressional Research Service - The Library of congress". Pode ser acessado no seguinte endereço eletrônico da University of North Texas: http://digital.library.unt.edu/govdocs/crs/permalink/meta-crs$\underline{8715: 1}$
} 
de defesa e de não-defesa são reduzidos por suas próprias percentagens uniformes." 167

Originalmente, o decreto determinava que o presidente estivesse obrigado a implementar, mediante ordem de confisco [sequestration], as reduções especificadas pelo "Controlador Geral", não podendo alterá-las em hipótese alguma. Porém, postulava que o decreto poderia (1) ser suspendo pelo Congresso em caso de recessão, e (2) que ele não se aplicaria em tempos de guerra. Barrava-se também o presidente quanto a submeter uma proposta de maior déficit do que o nível permitido pelo Decreto para o determinado ano em questão. Por outro lado, estipulava-se que mesmo em caso de recessão não haveria cortes automáticos:

"Não há suspensão automática da redução do déficit no caso de recessão. Entretanto, se o Office of Management and Budget e o Congressional Budget Office projetarem crescimento econômico real negativo em dois trimestres consecutivos, ou se o Departamento de Comércio notar que o crescimento esteve abaixo de um porcento em dois trimestres consecutivos, o Congresso expedirá procedimentos para suspender os confiscos e outros determinados processos referentes ao orçamento." 168

Os níveis de déficits aprovados pelo decreto para os anos subseqüentes eram:

Ano fiscal de 1986 171,9 bilhões

Ano fiscal de 1987 144 bilhões

Ano fiscal de 1988 108 bilhões

Ano fiscal de 1989 .72 bilhões

Ano fiscal de 1990 36 bilhões

Ano fiscal de 1991 fim dos déficits

\footnotetext{
167 "The Balanced Budget and Emergency Deficit Control Act of 1985 (the Gramm-Hudman-Hollings Act), Public Law 99-177, provides for annual reductions in the budget deficit from \$171.9 billion in fiscal year 1986 to zero in fiscal year 1991. The Act establishes procedures to reduce deficits to the annual maximum levels through the mandatory sequestration of funds. The amount and percentage of required reduction is determined by the Comptroller General on the basis of a joint OMB/CBO report estimating the fiscal year's deficit, expected economic conditions, and the budget base of accounts and programs. The Comptroller General issues a report setting forth the amount of reduction to be made in each nondefense account and in each defense program, project, and activity. The total reduction is equally divided between defense and nondefense programs (with half of reductions in retirement cost-of-living increases listed as defense reductions). Except for programs with special rules, equal percentage reductions are made within each of these categories, so that all defense programs are reduced by a uniform percentage and nondefense programs are reduced by their own uniform percentage", p.4.

168 "There is no automatic suspension of deficit reduction in the event of a recession. However, if CBO or OMB projects negative real economic growth in two consecutive quarters, or if the Commerce Department reports that actual real growth was below one percent in two consecutive quarters, Congress would have expedited procedures for suspending sequestration procedures and certain other budget procedures", p.27.
} 
O decreto expressava que se o "Controlador Geral" tivesse identificado um déficit em excesso, o presidente deveria emitir uma nota em 1 de Setembro, que o eliminasse, de acordo com as determinações do fisco expressas na letra da lei. Isso com exceção do ano fiscal de 1986, que já estava em curso em Dezembro de 1985, quando o decreto fora aprovado. Com efeito, o decreto estipulou um calendário anual para as atividades de inspeção do déficit, e fez uma análise detalhada do orçamento do governo naquele ano, em relação a todas as agências (ministérios) do governo federal. Relevava-se o fato de que havia menos tempo para implementar as mudanças do que se teria nos próximos anos, mas se enfatizava a necessária queda aos níveis previstos pelo documento original.

Para 1986, considerava-se que o déficit total permitido seria de 171 bilhões, para uma arrecadação de 776 bilhões e para uma projeção de déficit total - sem que se levasse em conta o decreto - de 220 bilhões. Contudo, requerer-se-ia para 1986 uma diminuição total de apenas 11 bilhões, e não de 48 bilhões, com o argumento de que o ano fiscal já começara. Assim, o déficit total permitido para 1986 seria de 220 bilhões menos 11 bilhões, gerando um total de 209 bilhões.

Estes eram os dados referentes ao orçamento e à redução dos déficits requerida para 1986:

Arrecadação..........................976,0 bilhões
Gastos...........................996,5 bilhões
Déficit previsto.................220,5 bilhões
Déficit permitido..............171,9 bilhões
Déficit em excesso..............48,6 bilhões
Redução requerida.............11,7 bilhões

O caso, porém, era mais difícil do que julgavam os autores da lei. Isto porque a Suprema Corte dos Estados Unidos considerou-a inconstitucional, no ponto específico de não se poder permitir que o "Controlador Geral" pudesse exercer uma restrição que somente o Poder Executivo poderia desempenhar. Desde modo, a lei fora aprovada, mas o poder do "Controlador Geral" de cancelar os aumentos dos déficits foi cerceado, criando-se deste modo impasse, no qual os aumentos dos déficits foram proibidos, mas não puderam ser efetivamente levados a cabo. Neste caso, a influência do Decreto ficou limitada, o que explica que, não obstante seu impacto político, o déficit em 1986 tivesse de fato chegado aos 220 bilhões originalmente previstos. Em 1987, uma nova lei sobre o déficit seria aprovada, com o mesmo espírito da de 1985. Mas padecia do mesmo limite que a primeira, com o agravante de que os prazos para a aplicação dos ajustes se tornaram maiores.

\subsection{O aumento do endividamento externo em 1986}

À medida que 1985 passava, ficava mais nítido para Volcker que a economia se recuperava às custas do aumento do endividamento externo. Em declaração de Fevereiro de 
1985 perante o Comitê de Política Bancária, Habitação e Assuntos Urbanos do Senado (Committee on Banking, Housing and Urban Affairs - U.S. Senate), afirmou que os Estados Unidos tinham conseguido "conciliar altos déficits, aumento enorme das importações, e forte investimento, apenas por uma razão: [porque têm] sido capazes de atrair uma enorme quantidade de poupança externa para suplementar a nossa própria." ${ }^{169}$ E continuou:

"De fato, a estabilidade de nosso mercado de capitais e dinheiro é agora mais dependente como nunca da disponibilidade dos estrangeiros de continuarem colocando crescentes quantias de dinheiro em nossos mercados. Até aqui, eles não têm apenas querido mas têm estado ávidos para fazer isto. Mas nós estamos, realmente, vivendo com tempo e dinheiro emprestados. Em essência, este é o desafio para nós - para a política monetária e fiscal, e para todas as outras políticas que podem contribuir para obter uma economia produtiva e em crescimento." 170

O crescimento de 1986 fora pouco menor que o de 1985, com 3,4\% de variação. Durante o ano viu-se aumento rápido do nível de endividamento externo. A taxa de variação da colocação de capitais externos nos Estados Unidos atingiu a maior variação em todos os anos (19)80, crescendo 1,26 vezes. Entrementes, argumentava-se que era necessário que a taxa de poupança se elevasse, para diminuir a dependência dos recursos de fora. Todavia, um aumento da taxa de poupança das famílias e do Estado, no curto prazo - para que se liberassem mais capital para as empresas investirem, iria de início impactar negativamente na demanda agregada. E assim fazer cair a taxa média de investimentos pela atuação das forças desacumuladoras. Corrigir a rota de crescimento baseado na dívida externa requereria grande capacidade de modificação das políticas do governo, no sentido de suportar politicamente a queda inicial da demanda agregada com a redução do endividamento externo e o aumento da capacidade de poupança. Tudo isto para apenas num segundo momento reorganizar os agregados macroeconômicos no sentido de um crescimento a partir da poupança doméstica. Mas dado o modo pelo qual a economia estava se adequando à dívida externa, tais modificações se tornavam cada vez mais difíceis.

\footnotetext{
169 "We have been able to reconcile high deficits, sharply rising imports, and strong investment mainly for one reason: we have been able to attract an enormous amount of savings from abroad to supplement our own." Ibid, p.6. Statement by Paul Volcker, Chairman, Board of Governors of the Federal Reserve System, before the Committee on Banking, Housing and Urban Affairs - U.S.Senate. 20 de Fevereiro de 1985. Disponível em http://fraser.stlouisfed.org/historicaldocs /.

170 "Looking ahead, the stability of our capital and money market is now dependent as never before on the willingness of foreigners to continue to place growing amounts of money in our markets. So far, they have been not willing but eager to do so. But we are in a real sense living on borrowed money and time. It is up to all of us to make constructive use of both the money and the time. In essence, that is the challenge for all of us - for monetary and fiscal policy, and for all the other policies that can contribute to productive, growing economy." Statement by Paul Volcker, Chairman, Board of Governors of the Federal Reserve System, before the Committee on Banking, Housing and Urban Affairs - U.S.Senate. 20 de Fevereiro de 1985.
} 
Esta rota, que era sugerida por Volcker, conduziria a um crescimento menor. Um aumento da poupança das famílias e do Estado faria cair a demanda efetiva, fazendo depositar nos investimentos corporativos o elemento principal de manutenção da reprodução do capital social. Ora, tornar o crescimento fundamentalmente dependente da liberalização de mais recursos para as empresas implicava diminuir o consumo das famílias e o déficit federal. Mas o que se ganharia em investimentos perder-se-ia em gastos das famílias e do Estado. Diminuir o déficit fiscal e o consumo para diminuir o endividamento externo levaria a economia a um caminho mais sadio, de um ponto de vista dos "fundamentos". Todavia, isso exporia a economia a um comportamento mais parecido com o do Japão e Alemanha Ocidental, que não possuíam os correlatos mecanismos de endividamento externo. E que por conseqüência cresciam menos.

No transcorrer dos meses, Volcker recrudesceu seu parecer. Em suas últimas declarações públicas, o endividamento externo tornou-se o centro de suas análises. Num encontro no Canadá, ele observava:

"Nós não seríamos capazes de financiar o déficit federal, no bojo de crescentes gastos com equipamentos, estruturas e casas, sem os influxos de capital externo. Mas é claramente não saudável para a maior e mais rica economia do mundo - para os nossos interesses e os dos outros - usar tanta poupança mundial para financiar um déficit orçamentário. Nossos empréstimos para fora do país praticamente cessaram, estamos nos tornando uma nação devedora, e nós temos menos investimentos do que do contrário seria possível. Cedo ou tarde, o processo é insustentável, e seria melhor que o abordássemos de modo construtivo, do que em crise." 171

\footnotetext{
171 "We would not have been able to finance the federal deficit, on top of rising expedintures for plant and equipment and housing, without that net capital inflow. But it is clearly not healhty for the largest and richest country in the world - in its own interest or that of others - to use up so much of the world's savings to finance a budget deficit. Our lending abroad has practically stopped, we are becoming a debtor nation, we have less investment and housing than would otherwise be possible, and our trading position is deteriorating. Sooner or later, the process is unsustainable, and it had better be approached constructively rather than in crisis." "Remarks by Paul Volcker at a Joint Dinner Meeting of the Empire Club of Canada and the Canadian Club of Toronto". Toronto, Canada, 28 de Outubro de 1985.
} 
Tabela 3. Estados Unidos. Ativos de estrangeiros nos Estados Unidos (I), PNB (II), ativos estrangeiros sobre PNB (III) e variação da atração de ativos estrangeiros sobre o PNB (IV). 1981-1988. Em milhões de dólares correntes.

\begin{tabular}{|c|c|c|c|c|}
\hline (1) & (2) & (3) & (4) & (5) \\
\hline Anos & $\begin{array}{c}\text { Capitais } \\
\text { estrangeiros nos } \\
\text { EUA }\end{array}$ & PNB & $(2) /(3)$ & Variação de (4) \\
\hline 1980 & 500.8 & 2732.0 & 0.18 & - \\
\hline 1981 & 578.7 & 3052.6 & 0.18 & 1.0 \\
\hline 1982 & 688.1 & 3166.0 & 0.21 & 1.16 \\
\hline 1983 & 784.5 & 3405.7 & 0.23 & 1.09 \\
\hline 1984 & 892.6 & 3772.2 & 0.23 & 1.0 \\
\hline 1985 & 1061.0 & 4014.9 & 0.26 & 1.13 \\
\hline 1986 & 1340.7 & 4240.3 & 0.31 & 1.14 \\
\hline 1987 & 1536.0 & 4526.7 & 0.33 & 1.06 \\
\hline 1988 & 1786.2 & 4880.6 & 0.36 & 1.09 \\
\hline
\end{tabular}

Fonte: Economic Report of the President, 2006. Para PNB, ver Tabela B-1, Gross Domestic and Saving; para capitais estrangeiros nos Estados Unidos, Tabela B-107, Internation Investment Position of the United States at year-end, 1997-2004.

A variação do crescimento dos níveis de endividamento seria menor em 1987 e 1988, na medida em que cairiam os déficits em conta corrente pelo aumento das exportações, depois dos efeitos do Acordo do Plaza. Pode-se verificar tal queda também para o ano de 1984, de crescimento rápido, e seu desempenho oposto para 1982 e 1986, onde o crescimento fora menor.

Tabela 4. Estados Unidos. Variações mensais (\%) dos índices de preços ao consumidor. 19851986.

\begin{tabular}{ccc}
\hline$(1)$ & $(2)$ & $(3)$ \\
Meses & Variação $(\%)$ de todos itens & Todos itens menos alimentos \\
1985/Janeiro & 0,2 & 0,2 \\
Abril & 0,3 & 0,5 \\
Julho & 0,2 & 0,4 \\
Setembro & 0,2 & 0,2 \\
Dezembro & 0,4 & 0,3 \\
& 0,3 & 0,4 \\
1986/Janeiro & $-0,3$ & $-0,4$ \\
Abril & 0,0 & $-0,2$ \\
Julho & 0,3 & 0,3 \\
Setembro & 0,2 & 0,3 \\
Dezembro & & \\
\hline
\end{tabular}

Fonte: Economic Report of the President, 1987, Tabela B-58, Changes in special consumer prices indexes, major expenditure classes, 1946-86.

Em 1986, com um avanço mais moderado do produto, cresceu o consumo das famílias, assim como o emprego no setor de serviços. A indústria caminhou a passos mais lentos, assim 
como algumas áreas agrícolas dos "belts". ${ }^{172}$ Os lucros da manufatura em 1986 mostraram-se os mais baixos durante toda a administração Reagan e a taxa de investimento bruto (nãoresidencial) oscilou quase estagnada bem próxima à casa dos 520 bilhões anuais. As exportações progrediam com vagar mesmo depois da desvalorização do dólar. Como se vê na tabela a seguir, a relação entre o cômputo das exportações e das importações chegou a piorar entre 1985 e 1986.

Tabela 5. Estados Unidos. Exportações e importações de bens e serviços. E/I = exportações/importações. Em bilhões de dólares correntes. 1985-1986.

\begin{tabular}{cccc}
\hline (1) & $(2)$ & $(3)$ & $(4=2 \div 3)$ \\
Trimestres & Exportações & Importações & E/Ix 100 \\
1985/I & 305,4 & 397,3 & 76 \\
II & 303,1 & 418,6 & 72 \\
III & 295,6 & 414,2 & 71 \\
IV & 304,1 & 438,9 & 69 \\
1986/I & 312,2 & 439,8 & 71 \\
II & 314,4 & 444,4 & 70 \\
III & 320,4 & 459,8 & 69 \\
IV & 335,2 & 469,3 & 71 \\
\hline
\end{tabular}

Fonte: Economic Report of the President, 1987, Tabela B-99, U.S. International Transactions, 1946-86.

\subsection{O acordo do Louvre em 1987 e a crise acionária}

A taxa de variação do produto em 1987 foi similar à de 1986, atingindo 3,4\%. Agora os déficits na conta corrente seriam diminuídos pelo aumento das vendas ao exterior. No primeiro semestre, a conjuntura era estável. Os pedidos de novas encomendas na indústria elevaram-se de 186 bilhões em Janeiro para 209 bilhões até o fim do ano. A taxa de utilização de capacidade variou positivamente e de modo estável de $79 \%$ para $82 \%$ entre estes mesmos meses. A taxa de variação global do índice de preços ao consumidor, que tinha sido de 2\% entre 1985 e 1986, dobrou para 4,4\% em 1987, variando mais 4,4\% depois em 1988. Além do aumento das atividades, também explicavam esta variação preponderantemente um novo repique para cima do preço do petróleo, que fora de 14 a 17 dólares por barril, e a continuação da queda do dólar face ao iene e ao marco.

Neste momento, o desemprego em nível nacional para trabalhadores com mais de dezesseis anos atingiu a menor taxa da década, de 5,5\%, segundo o Bureau of Labor Statistics. E dada a recuperação em curso dos investimentos privados, os déficits orçamentários do

\footnotetext{
${ }^{172}$ Sobre a indústria norte-americana neste momento, comentaria Robert Brenner: "A 'grande máquina de empregos' da década de 1980 representou quase literalmente apenas isto: o rápido crescimento do emprego se dando sem a vantagem de um aumento paralelo nas instalações e equipamentos disponíveis a cada trabalhador. A gigantesca expansão do setor de não-manufaturados foi com efeito um sintoma do amplo declínio econômico que acompanhou a crise do setor de manufaturados na economia dos Estados Unidos, e que pode de maneira útil ser chamada de uma 'des-industrialização', com todas suas conotações negativas." O boom e a bolha, p.128.
} 
governo federal iriam ficar relativamente menores, caindo de 140 bilhões de dólares no primeiro trimestre de 1987 para 82, 85 e 110 bilhões nos três trimestres consecutivos (em dólares correntes). Tal como determinava a lei sobre os déficits, os gastos com defesa do governo, que somavam $26 \%$ do total em 1986, continuavam somando $26 \%$ do total em 1988 . Quer dizer, o declive dos déficits manteve constantes, em termos proporcionais, os gastos com defesa e os gastos com áreas não-relacionadas à defesa.

Quanto aos salários no período considerado, continuaram estagnados. Volcker observou, em Julho de 1987:

"De importância central, tem havido evidência contínua de contenção e disciplina nos custos e salários em grande parte da indústria [norte-] americana, oferecendo a perspectiva de taxas mais baixas de inflação nos meses à frente. No meio tempo, isto deve ser um elemento essencial na manutenção de nossa competitividade internacional assim como em restaurar nossa estabilidade doméstica depois do salto dos preços neste ano." 173

Como se notou, até 1987 a relação entre o total de exportações e importações norteamericanas, em dólares correntes, avançou de modo muito lento. Mas, a partir deste ano, as exportações passaram a crescer mais rapidamente. Isto explica porque um crescimento do produto similar ao do ano anterior refletiu-se em queda do endividamento externo. Na verdade, as importações cresceram mais rápido que as exportações depois do acordo do Plaza. Como se pode ver na tabela abaixo, que dá os termos de intercâmbio, a relação entre as exportações e importações (vezes cem) era 72 em 1985 e 70 em 1986. Isto se explica pelo crescimento estável da economia, que fez elevar as compras fora do país. Se estava em 70 em 1986 e passara a 66 no segundo trimestre de 1987, o nível das importações não havia ainda sido alterado substancialmente pelo Acordo do Plaza, tendo inclusive piorado de 1986 a 1987. Deste modo, os impactos sobre o comércio exterior do Acordo ocorreram só depois de quase dois anos. Foi somente no terceiro trimestre de 1987 que as exportações começaram a crescer mais rapidamente do que as importações, seguindo a partir daí um caminho ascendente.

\footnotetext{
173 "Of central importance, there has been continuing evidence of restraint and discipline on costs and wages in much of American industry, offering the prospect of lower rates of inflation in the months ahead. Over time, that must be an absolutely essential element in maintaining our international competitiveness as well in restoring domestic stability after the bulge in prices this year." Testimony by Paul A. Volcker. Chairman, Board of Governors of the Federal Reserve System, before the Committee on Banking, Finance, and Urban Affairs. House of Representatives. Julho de 1987.
} 
Tabela 6. Estados Unidos. Exportações e importações de bens e serviços. E/I = exportações/importações. Em bilhões de dólares correntes. 1989-1988.

\begin{tabular}{cccc}
\hline$(1)$ & $(2)$ & $(3)$ & $(4=2 \div 3)$ \\
Trimestres & Exportações (E) & Importações (I) & E/Ix 100 \\
1985 & 302,0 & 417,2 & 72 \\
1986 & 320,5 & 453,3 & 70 \\
1987/I & 336,8 & 517,7 & 64 \\
II & 355,1 & 537,9 & 66 \\
III & 371,7 & 543,2 & 68 \\
IV & 392,1 & 546,6 & 71 \\
1988/I & 418,5 & 553,3 & 75 \\
II & 439,1 & 574,8 & 76 \\
III & 452,9 & 582,3 & 77 \\
IV & 465,8 & 597,3 & 77 \\
\hline
\end{tabular}

Fonte: NIPA-BEA. Seção 4, Foreign Transactions, Tabela 4.1., Foreign Transactions in the National Income and Product Accounts.

Esta dificuldade para as exportações elevarem-se frente às importações foi intensificada pela assinatura do Acordo do Louvre, em 22 de Fevereiro de 1987. Realizado pelas mesmas nações que assinaram o Acordo do Plaza em 1985, com exceção da Itália, buscava impedir uma desvalorização ainda maior do dólar. Considerava-se que o ajuste obtido até ali fora suficiente para impedir um aguçamento da crise nas transações correntes norte-americanas, ou mesmo para evitá-la de todo. Realmente, como o dólar havia se desvalorizado muito rapidamente desde 1985, colocou-se pouco depois o problema inverso, de novo, de impedir seu virtual colapso. Uma desvalorização ainda maior do dólar, que se descrevia eufemisticamente de "futuras mudanças cambiais substanciais entre as moedas" poderia comprometer a estabilidade do sistema financeiro pela pressão sobre o dólar.

"Os Ministros e Diretores concordam que as mudanças cambiais desde o Acordo do Plaza vão contribuir fortemente para reduzir os desequilíbrios externos e que elas trouxeram as taxas de câmbio para dentro de margens bem consistentes com os fundamentos econômicos subjacentes, dados os compromissos políticos resumidos nesta declaração. Posteriores variações cambiais entre suas moedas poderiam prejudicar o crescimento e as perspectivas de ajuste em seus países.” 174

\footnotetext{
174 "The Ministers and Governors agreed that the substantial exchange rate changes since the Plaza Agreement will increasingly contribute to reducing external imbalances and have now brought their currencies within ranges broadly consistent with underlying economic fundamentals, given the policy commitments summarized in this statement. Further substantial exchange rate shifts among their currencies could damage growth and adjustment prospects in their countries." Statement of the G6 Finance Ministers and Central Bank Governors (Louvre Accord). Canada, France, Germany, Japan, United Kingdom and United States. Paris, 22 de Fevereiro de 1987.
} 
Tabela 7. Estados Unidos. Dados Selecionados. 1987. Variações (\%) mensais do índice de preços ao consumidor (2). Utilização de capacidade instalada no setor manufatureiro (\%)(3). Novos pedidos (encomendas) na indústria (milhões de dólares correntes) (4).

\begin{tabular}{|c|c|c|c|}
\hline (1) & $\begin{array}{c}(2) \\
\text { Preços (\% a.a.) }\end{array}$ & $\begin{array}{c}(3) \\
\text { Capacidade instalada } \\
(\%)\end{array}$ & $\begin{array}{c}\text { (4) } \\
\text { Encomendas } \\
\text { (em US\$) }\end{array}$ \\
\hline 1985 & 3,8 & - & - \\
\hline 1986 & 1,1 & - & - \\
\hline 1987 & 4,4 & - & - \\
\hline 1987 - Jan. & 0,6 & 79,2 & 186,765 \\
\hline Fev. & 0,4 & 79,7 & 194,562 \\
\hline Mar. & 0,4 & 79,7 & 196,911 \\
\hline Abr. & 0,5 & 79,6 & 200,142 \\
\hline Mai. & 0,4 & 79,9 & 203,429 \\
\hline Jun. & 0,4 & 80,3 & 205,490 \\
\hline Jul. & 0,3 & 81,1 & 202,358 \\
\hline Ago. & 0,5 & 81,4 & 205,340 \\
\hline Set. & 0,5 & 81,1 & 208,602 \\
\hline Out. & 0,3 & 81,9 & 208,602 \\
\hline Nov. & 0,1 & 82,1 & 209,258 \\
\hline Dez. & 0 & 82,4 & 209,564 \\
\hline
\end{tabular}

Fonte: Economic Report of the President, 1989. Para preços: Tabela B-58, Consumer Prices Indexes, major expenditure classes, 1946-86; para capacidade instalada, página B-51, Capacity Utilization Rates, 1948-86; para encomendas, Tabela B-57, Manufacturer's new and unfilled orders.

Como se vê na figura abaixo, a ação coordenada dos Bancos Centrais resultou primeiramente (1) numa interrupção da desvalorização do dólar face ao marco e ao iene que vinha desde 1985; e (2) numa própria desvalorização do iene e o marco mais à frente. Vê-se que se concedeu ao marco praticamente a volta à posição que ocupava no início da década, ao passo que o iene, mesmo valorizando-se, não chegaria mais à condição bastante favorável que ocupara no mesmo início da década de 1980. É evidente que o acordo visava principalmente a concorrência com as firmas do país asiático, dado que o cômputo de importações provenientes dali era mais do que o dobro da proveniente da Alemanha Ocidental: para ter-se ideia, em 1986 os Estados Unidos importaram 39 bilhões em mercadorias e serviços alemães, e 100 bilhões do Japão. 
Gráfico 1. Estados Unidos. Taxa de câmbio do dólar face ao iene e ao marco. Iene: eixo esquerdo; marco: eixo direito. 1980-1990.

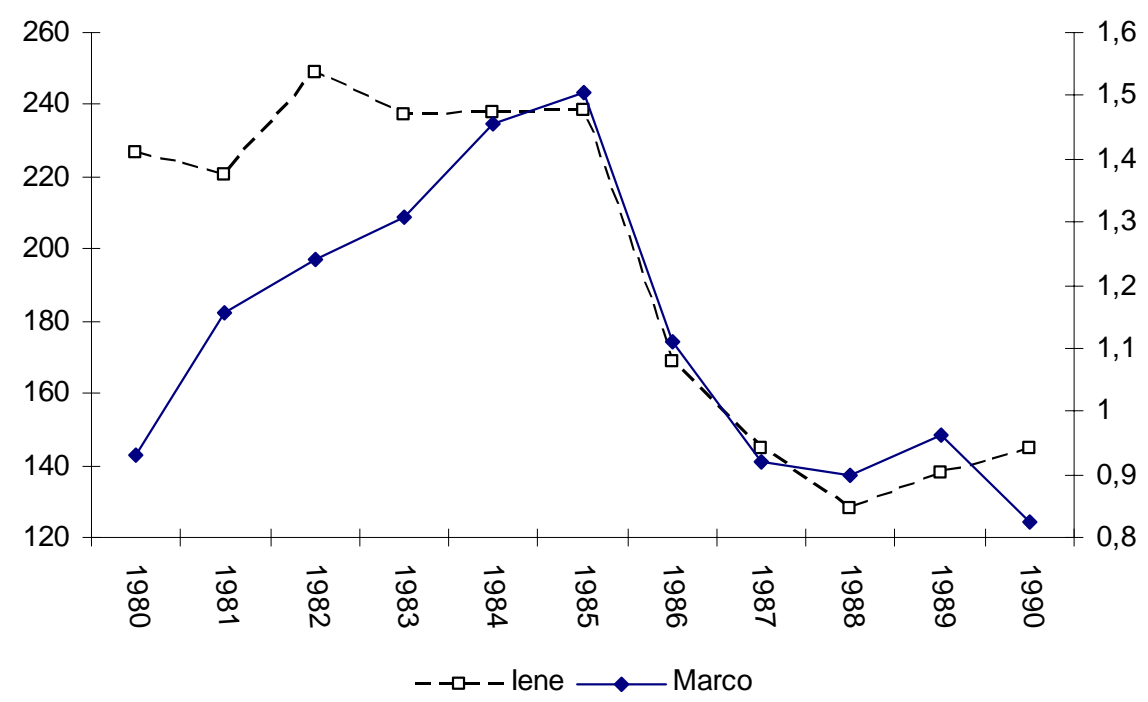

Fonte: OCDE. (http://stats.oecd.org)

Em 1987, assim como anos anteriores, o produto nacional bruto não teve um desempenho ruim, chegando a $3,4 \%$ de variação. Todavia, um desempenho mais ou menos razoável do comportamento do PNB e das exportações não indicava ausência de problemas pendentes. Estes envolviam a formação progressiva de uma crise bancária, que irromperia com mais força no governo Bush, e uma crise acionária, dada em 1987. A primeira delas tornou-se conhecida como a crise dos Savings\&Loans, que se avizinhava aos poucos. A segunda foi a crise acionária em Wall Street, desencadeada já no fim de 1987.

A crise dos Savings\&Loans se delineava a partir do fim da década de (19)70 e se intensificou no decorrer da década. Os documentos oficiais já falavam nela no início dos anos (19)80. Os Savings\&Loans formavam um amplo conjunto de bancos locais, com tradição de recolher depósitos de particulares para financiamentos hipotecários, desde os anos (19)70. As perdas para os bancos vinham da conjunção da (1) política de juros altos e (2) desregulamentação financeira. Em primeiro lugar, o aumento dos juros no fim da década expôs o sistema de bancos a maiores obrigações para com seus credores. Em segundo lugar, a desregulamentação do sistema financeiro permitiu a criação de novas oportunidades de investimentos financeiros mais rápidos, o que drenou dos Savings\&Loans muitos depósitos. A ocorrência dos dois fatores levou o sistema a xeque. Deste modo, os bancos viram-se num dilema causado pelo aumento da inflação e pelas altas taxas de juros. Se mantinham juros baixos, não atraíam depósitos. Mas se os elevavam, os juros que recebiam dos empréstimos de longo prazo feitos para as famílias que iriam adquirir seus imóveis não pagavam os custos dos juros que agora iam dever. A desregulação do sistema financeiro, com o crescimento de outros 
tipos de casas financeiras, drenou ainda mais recursos nos (19)80. Abriu-se um descompasso crescente entre (a) depósitos e recebimentos novos e (b) os compromissos. ${ }^{175}$

A solução via oferta de liquidez às casas quebradas iria custar mais ou menos 90 bilhões de dólares às autoridades monetárias norte-americanas no fim da década, já no governo Bush. Um quarto dos bancos existentes desapareceria. E as quebras impactariam no PNB a ponto de converterem-se mesmo numa das causas da recessão de 1991.

A segunda crise, estalada já neste momento, foi a crise acionária de Setembro. Durante esta, Alan Greenspan já havia assumido o Fed, depois da recusa de Volcker em continuar. Economista conservador, Greenspan era filiado desde os anos (19)60 ao Partido Republicano e havia cooperado com o presidente Nixon e Ford, tendo apoiado a eleição de Ronald Reagan. Seu primeiro momento no Fed, em Agosto, não foi fácil. Paralelamente à crise bancária, o setor corporativo também enfrentava dificuldades. Estas incluíam (a) maquinações financeiras - via sucessivas recompras corporativas de suas próprias ações, com intuito de valorizá-las artificialmente; (b) altos níveis de endividamento das empresas, e (c) continuidade da política de desregulamentação no sistema bancário. ${ }^{176} \mathrm{O}$ valor do dólar caía, e as transações correntes norte-americanas teimavam em permanecer deficitárias, fato auxiliado pelo Acordo do Plaza de 1987.

Isto conduziu a um acúmulo de expectativas negativas sobre o mercado financeiro, que levaram à crise de 1987. As perdas em papéis somaram quase um trilhão de dólares, mais ou menos um sexto do valor do PNB em 1987, com perdas acumuladas no Dow Jones de 215 pontos. Como Greenspan comentou, "quase um trilhão de dólares em papéis evaporaram apenas no mercado de ações - para não mencionar as perdas em dinheiro e nos outros mercados". 177 Para ter-se ideia do tamanho das perdas, o PNB de 1987 somou aproximadamente 6 trilhões e 400 bilhões de dólares. Quer dizer, quase um sexto do PNB desaparecera na desvalorização dos papéis. O Dow Jones registrou perda líquida acumulada de 215 pontos no fim do ano, encerrando um ano de perda líquida total que desde 1983 não ocorria.

\footnotetext{
${ }^{175}$ Ratner, Soltow e Sylla assim explicam a origem da crise dos Savings\&Loans: "As associações de empréstimos e poupança norte-americanas, assim chamadas de instituições de parcimônia ou 'S\&L', durante décadas tomaram empréstimos de poupadores e os empregaram para fazer empréstimos hipotecários para os que iam comprar sua casa. Muitos deles eram instituições de orientação local [...]. A principal característica deles era que seus depósitos podiam ser sacados no curto prazo mas seus empréstimos hipotecários eram feitos por prazos muito longos, quase sempre trinta anos. Quando a grande inflação depois de 1965 levou a taxas de juros muito mais altas, muitos deles foram levados à insolvência. As taxas de juros mais altas reduziram o valor de seus empréstimos feitos sob taxas menores de juros no passado. Ao mesmo tempo, as taxas sob as quais o governo federal regulou os empréstimos que os S\&L podiam pagar tornaram-se cada vez mais baixas face aos mercados desregulados, que estavam aumentando como uma resposta à inflação. O mercado desregulado - incluindo-se o mercado de fundos mútuos (mutual funds) que surgiu nos anos (19)70 oferecendo aos poupadores taxas mais altas e menos reguladas - drenou depósitos dos S\&L." Sidney RATNER, James H. SOLTOW e Richard SYLLA. The Evolution of American Economy, p.571.

${ }^{176}$ Cf. BRENNER, O boom e a bolha, capítulos 3 e 4 .

177 "Half a trillion dollars of paper wealth had evaporated 6,73in the stock market alone - not to mention the losses in currency and other markets". The Age of Turbulence, p.104.
} 


\subsection{Fim da administração Reagan}

$\mathrm{Na}$ área econômica, esperava-se que o ano de 1988 fosse refletir as instabilidades do ano anterior. A taxa de crescimento dos estoques foi mais alta do que no mesmo período anterior de 1987. ${ }^{178}$ No primeiro trimestre de 1987, os estoques estagnaram em 317 bilhões entre Janeiro e Abril, e pararam em 319 bilhões até Julho. Nos primeiros seis meses do ano, os estoques cresceram sem parar, saindo de 333 bilhões em Janeiro, indo a 336 em Março e a 341 bilhões em Junho, indicando assim vendas mais fracas. Por sua vez, as novas encomendas pedidas pelas corporações, que foram de 186 a 196 bilhões entre Janeiro e Março de 1987, agora estagnavam, pulando de 210 para apenas 211 bilhões.

Dado o cenário, o Federal Reserve tratou de manipular os agregados no sentido de inverter a rota anteriormente traçada, dadas as expectativas de alta da inflação. A taxa de desconto do Fed, que fora aumentada em $0,5 \%$ quando Greenspan ascendeu ao banco. Foram mantidas em 6\% durante oito meses. As taxas de 3 meses dos Títulos do Tesouro, que vinham crescendo desde Fevereiro de 1987; caíram de 6,4\% em Outubro para 5,8\% em Dezembro de 1987. Esta política começou a funcionar em meados do ano, dando resultados mais positivo a partir do segundo trimestre. O crescimento do produto no primeiro alcançou $2 \%$, e no segundo mais que $5 \%$. O ano fechou então com $4,1 \%$ de crescimento e com a utilização de capacidade instalada mais alta da década de 1980 , de $84 \%$ no setor industrial. Neste contexto, evitou-se uma flutuação mais intensa também por um desempenho crescentemente melhor das exportações. Como visto acima, estas passaram a caminhar mais rapidamente que as importações desde meados de 1987.

Assim que as perspectivas melhoraram, e os preços aumentaram um pouco como indício da melhoria conjuntural, "o Fed levou a cabo uma sucessão de medidas restritivas desde o fim de Março até meados de Junho". Assim Greenspan mesmo descreveu. ${ }^{179}$ Ao mesmo tempo, a melhoria da conta corrente do B.P., devido ao crescimento das exportações, influiu na atração de capitais externo, no sentido de diminuí-la absolutamente, face aos anos anteriores. Pela primeira vez desde 1983, o aporte de dólares vindos do exterior num ano não era maior do que no anterior. Em 1987 ele atingiu 248 bilhões; e em 1988, 246 bilhões de dólares. Isto evidenciava a relação inversa entre o desempenho das exportações e a necessidade de recursos para o consumo e investimentos internos.

Em 1988 houve eleições para presidência. Reagan apoiou a candidatura de seu vice, George Bush. A campanha Republicana novamente derrotou os Democratas.

\footnotetext{
178 Segundo o Apêndice Estatístico do Economic Report of the President de 1989.

179 "The System took a succession of restraining steps from Late March through late June." Statement by Alan Greenspan. Chairman, Board of Governors of the Federal Reserve System before the Subcommittee on Domestic Policy. Committee of Banking, Finance and Urban Affairs. U.S. House of Representatives. July. 1988.
} 


\subsection{Uma análise de dados}

Esta divide-se em: a) análise do papel da ingerência pública durante o Reaganomics; b) os fatores que levaram à recuperação no segundo quadriênio 1985-1988; c) análise da crise acionária de 1987; d) a tendência à financeirização.

a) O Estado e a política contra-cíclica

Contrariamente a seu discurso anti-keynesiano, o Reaganomics não levou a uma queda da participação do Estado na economia, nem se desfez dos déficits federais como elemento estabilizador dos pontos de viragem cíclica. Particularmente, a atuação da política orçamentária representou o caso clássico de "keynesianismo bastardo" (Joan Robinson), na qual as políticas anticíclicas não se caracterizam pela manipulação dos agregados de acordo com as predições tradicionais da orientação keynesiana. Tal favoreceu, por exemplo, faixas de consumo de maior propensão marginal a consumir. No caso, os recursos públicos foram canalizados para os setores de maior influência dentro da administração federal, principalmente os oligopólios do petróleo, energia e da indústria de guerra. Assim, grande parte da roupagem liberal presente nas declarações do governo encobria apenas a influência dos oligopólios na política econômica por mais e mais recursos e favorecimentos do Estado. Unia-se então (i) uma política fiscal e tributária de corte liberal, com concessões aos ricos e às corporações, a (ii) uma política orçamentária fortemente intervencionista, sob influência do círculo oligopolista privilegiado.

A arrecadação do governo federal sobre o produto nacional bruto inclusive se elevou no início da administração de Reagan, terminando no mesmo patamar do início da década. A arrecadação do governo federal somava 18\% do PNB em 1980, e passou a 19\% em 1981 e 1982. Reduziu-se, de fato, a $17 \%$ nos próximos três anos, para apenas elevar-se novamente ao mesmo patamar em que se encontrava no início da década. Trata-se de estabilidade notável dado o alarde da propaganda do governo sobre a suposta necessidade da queda dos impostos, e, mais particularmente, dado o nível de flutuações pelo qual a economia passou no período. 
Tabela 8. Estados Unidos. Compras do governo federal em bens e serviços. Em bilhões de dólares correntes.

\begin{tabular}{cccc}
\hline$(1)$ & $\begin{array}{c}(2) \\
\text { Compras do } \\
\text { governo }\end{array}$ & $\begin{array}{c}(3) \\
\text { PNB }\end{array}$ & $\begin{array}{c}(4) \\
(2 \div 3)\end{array}$ \\
1985/I & 777 & 3.909 & 0,19 \\
II & 799 & 3.965 & 0,20 \\
III & 829 & 4.030 & 0,20 \\
IV & 855 & 4.087 & 0,20 \\
1986/I & 836 & 4.149 & 0,20 \\
II & 860 & 4.175 & 0,20 \\
III & 874 & 4.240 & 0,20 \\
IV & 889 & 4.268 & 0,20 \\
1987/I & 903 & 4.391 & 0,20 \\
II & 915 & 4.484 & 0,20 \\
III & 932 & 4.568 & 0,20 \\
IV & 947 & 4.662 & 0,20 \\
1988/I & 945 & 4.724 & 0,20 \\
II & 961 & 4.823 & 0,19 \\
III & 955 & 4.909 & 0,19 \\
\hline
\end{tabular}

Fonte: Economic Report of the President, 1988-89. Para ambas as fontes, em ambos os documentos, Tabela B-1, Gross National Product.

Observando-se as fontes da arrecadação do governo federal, vê-se que no início da crise do início dos (19)80 os impostos sobre as corporações foram diminuídos quase que em sua metade, contrariamente a um pequeno aumento dos impostos sobre as famílias. Neste caso, o governo foi coerente: levou-se à frente o princípio de rebaixar impostos ao capital como medida de reativação, recusando-se a aproveitar as faixas de maior propensão marginal ao consumo como opção de medida de elevação da demanda agregada (ou contra-cíclica). Vê-se que para o quadriênio 1985-1988, os impostos corporativos voltaram a elevar-se, dada a recuperação dos investimentos.

Tabela 9. Estados Unidos. Compras do governo federal em bens e serviços. Em bilhões de dólares correntes.

\begin{tabular}{|c|c|c|c|c|c|c|}
\hline (1) & (2) & (3) & (4) & (5) & (6) & (7) \\
\hline Anos & $\begin{array}{l}\text { Arrecadação do } \\
\text { governo federal } \\
\text { (em bilhões) }\end{array}$ & $\begin{array}{c}\text { Produto } \\
\text { nacional } \\
\text { Bruto (em } \\
\text { bilhões) }\end{array}$ & $\begin{array}{c}\text { Arrecadação } \\
\text { sobre o } \\
\text { PNB }\end{array}$ & $\begin{array}{l}\text { Gastos com } \\
\text { defesa } \\
\text { sobre a } \\
\text { arrecadação } \\
\text { total }\end{array}$ & $\begin{array}{c}\text { Imposto } \\
\text { sobre as } \\
\text { famílias } \\
\text { sobre a } \\
\text { arrecadação } \\
\text { total }\end{array}$ & $\begin{array}{c}\text { Imposto } \\
\text { sobre as } \\
\text { empresas } \\
\text { sobre a } \\
\text { arrecadação } \\
\text { total }\end{array}$ \\
\hline 1980 & 517 & 2732 & 0,18 & - & - & - \\
\hline 1981 & 599 & 3052 & 0,19 & 0,26 & 0,47 & 0,10 \\
\hline 1982 & 617 & 3166 & 0,19 & 0,29 & 0,48 & 0,07 \\
\hline 1983 & 600 & 3405 & 0,17 & 0,34 & 0,48 & 0,06 \\
\hline 1984 & 666 & 3772 & 0,17 & 0,34 & 0,44 & 0,08 \\
\hline 1985 & 734 & 4104 & 0,17 & 0,34 & 0,45 & 0,08 \\
\hline 1986 & 769 & 4240 & 0,18 & 0,35 & 0,45 & 0,08 \\
\hline 1987 & 854 & 4526 & 0,18 & 0,32 & 0,45 & 0,09 \\
\hline 1988 & 908 & 4880 & 0,18 & 0,31 & 0,44 & 0,10 \\
\hline
\end{tabular}

Fonte: Economic Report of the President, 1988-89. Tabelas Federal Receipts, Outlays, and debt, fiscal years, 1980-90. 
Do ponto de vista da demanda final sobre o PNB, as compras totais do governo, em termos de bens e serviços, longe de diminuírem também, permaneceram no mesmo patamar de $20 \%$ do produto doméstico, durante todo o período de 1985 a 1988. Não poderia ser diferente, com o aumento dos déficits federais visto no período. Dentro de tal demanda, os gastos com defesa assumiram posição de destaque, com forte elevação, desde 1981. É evidente que a participação do Estado, longe de cair, foi redirecionada, segundo outros tipos de gastos condizentes com as opções acumulativas daquela administração.

Veja-se agora o papel da política anti-cíclica mediante análise de regressão simples $(y=$ $a+b x)$ a seguir. Por meio de duas regressões de (1) déficits fiscais (Y1) em função do tempo (X1), e (2) investimentos privados (Y2) em função do tempo (X1), obtêm-se os seguintes regressores, valores estimados e suas diferenças residuais:

Regressão I: déficit fiscal (Y1) em função do tempo (X1)

$\mathrm{Df}=+217,1-4.7912 \mathrm{t}$

$\mathrm{R}^{2}: 0,47$

Durbin Watson: 1,39

Regressão II: investimentos privados (Y2) em função do tempo (X1)

$\mathrm{Df}=+508,78+2.8193 \mathrm{t}$

$\mathrm{R}^{2}=0,49$

Durbin Watson: 0,7

Tabela 10. Estados Unidos. Déficits fiscais e investimentos privados, resultados previstos em função do tempo e resíduos. Em bilhões de dólares correntes.

\begin{tabular}{ccccccc}
\hline (1) & $(2)$ & $\begin{array}{c}\text { Déficits fiscais (Y1) } \\
(3)\end{array}$ & $\begin{array}{c}(4) \\
\text { Diferença }\end{array}$ & $\begin{array}{c}\text { Investimentos privados (Y2) } \\
\text { Observado }\end{array}$ & $\begin{array}{c}\text { Previsto } \\
\text { residual }\end{array}$ & $\begin{array}{c}\text { Diferença } \\
\text { residual }\end{array}$ \\
& Observado & Previsto & 520.5 & 511.59 & 8.90 \\
1985/I & 162 & 212.30 & -50.30 & 520.5 & 514.41 & 14.08 \\
II & 214 & 207.51 & 6.482 & 528.5 & 517.23 & 4.96 \\
III & 197 & 202.72 & -5.72 & 522.2 & 520.05 & 13.54 \\
IV & 217 & 197.93 & 19.06 & 533.6 & 522.87 & 4.32 \\
1986/I & 198 & 193.14 & 4.85 & 527.2 & 525.69 & -8.19 \\
II & 234 & 188.35 & 45.64 & 517.5 & 528.51 & -15.01 \\
III & 206 & 183.56 & 22.43 & 513.5 & 53.33 & -10.13 \\
IV & 183 & 178.77 & 4.22 & 521.2 & 531.33 & -27.35 \\
1987/I & 188 & 173.97 & 14.02 & 506.8 & 534.15 & -18.77 \\
II & 144 & 169.18 & -25.18 & 518.2 & 536.97 & -5.59 \\
III & 138 & 164.39 & -26.39 & 534.2 & 539.79 & -5.41 \\
IV & 160 & 159.60 & 0.39 & 537.2 & 542.61 & 146 \\
1988/I & 151 & 154.81 & -3.81 & 546.2 & 545.43 & 54.05 \\
II & 141 & 150.02 & -9.02 & 562.3 & 548.24 & 16.23 \\
III & 122 & 145.23 & -23.23 & 567.3 & 551.06 & 13.61 \\
IV & 167 & 140.44 & 26.55 & 567.5 & 553.88 & \\
\hline
\end{tabular}

Fonte: Economic Report of the President, 1988-89. Para investimentos privados, Tabela B-1, Gross Domestic Product; para déficits, Federal and State and Local Government receipts and expenditures, national income and product accounts.

A plotagem das diferenças residuais das duas séries em função tempo mostra que os déficits fiscais atuaram como elementos estabilizadores durante o período da segunda 
administração. Vê-se (i) elevação dos déficits fiscais entre 1985 e 1987, momento no qual os investimentos privados tendem a cair, e (ii) diminuição dos déficits a partir da recuperação dos investimentos privados. De fato, o nível de associação entre as duas variáveis observadas é baixo ( $\mathrm{R}^{2}$ é 0,32$)$, o que justamente sugere o caráter estabilizador dos déficits, crescendo quando os investimentos caem.

Neste sentido, foi a recuperação dos investimentos privados que permitiu uma queda dos déficits federais. Isto aparentemente sugere a efetividade da lei dos limites dos déficits orçamentários de 1985. Porém, deve-se enfatizar que a lei não foi seguida à risca. Em 1986, o ano encerrou-se com 221 bilhões de dólares em déficits fiscais do governo federal, para um total máximo aprovado na lei de 209 bilhões. No fim de 1987, o governo federal terminou com déficit de 160 bilhões, contrariamente ao valor de 144 bilhões que determinava a lei; em 1988 o déficit fiscal federal atingiu 167 bilhões, para 108 bilhões previstos. Destarte, o próprio nãocumprimento da lei de 1985 num momento onde os investimentos privados recuperavam-se (assim como o não cumprimento da lei complementar feita em 1987) mostra que numa virtual manutenção da estagnação dos investimentos privados, a discrepância entre os valores máximos estabelecidos pela lei e os realmente obtidos seria ainda muito maior. Isto pela necessidade de aumentar os déficits.

Gráfico 2. Estados Unidos. Resíduos das regressões de déficits fiscais (Y1) e investimentos privados (Y2) em função do tempo (X1). Em bilhões de dólares correntes.

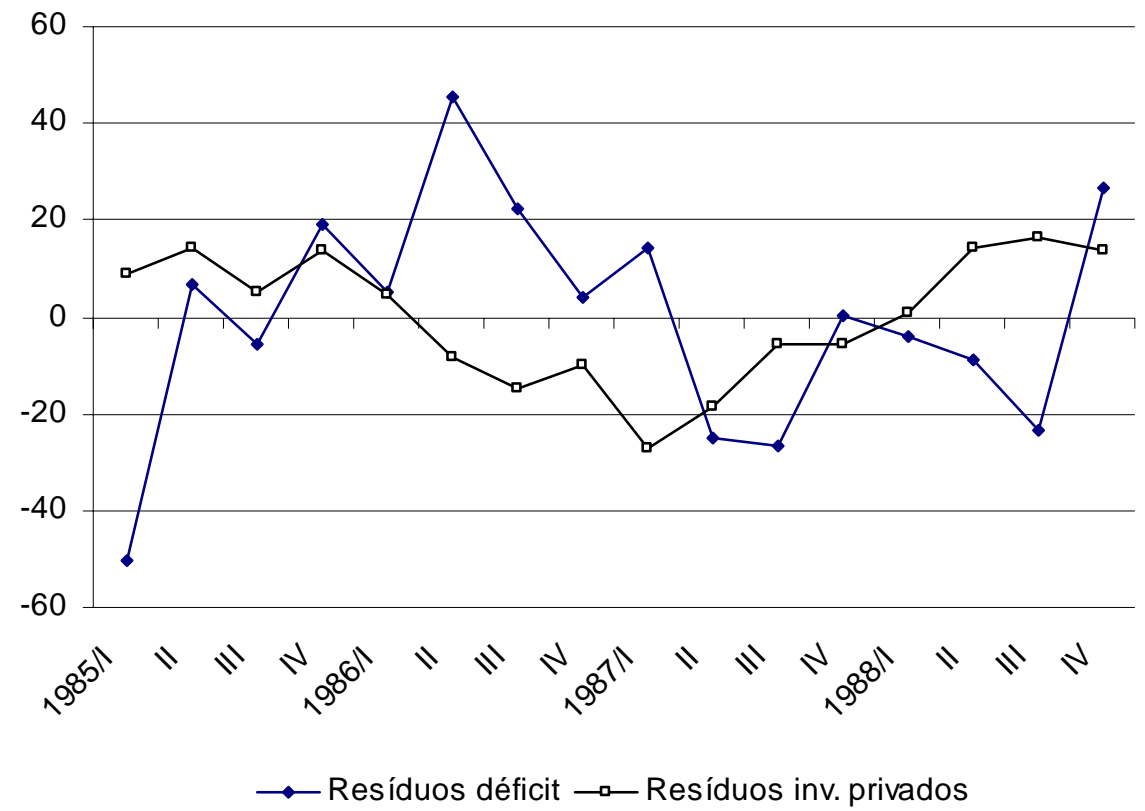

Fonte: ver tabela 10.

No caso, merecem atenção as declarações oficiais sobre a possibilidade de eliminar os déficits fiscais do governo federal. Elas os classificam como negativos por seus efeitos colaterais sobre as taxas de juros e sobre as contas do governo. O caso, todavia, é que (1) os gastos com juros do governo federal juntos do (2) aumento dos juros para o capital privado 
advindos do "deslocamento da poupança" disponível das empresas [assim chamado efeito “crowd out”] para o governo são compensados pelos impactos multiplicadores dos gastos do governo. Não exatamente em termos numéricos, mas sim pelo fato de que na baixa cíclica as corporações não investem e o crescimento do consumo se vê bloqueado.

Tabela 11. Estados Unidos. Dados selecionados. Coluna 2. Investimento privado doméstico não-residencial. Coluna 3. Consumo das famílias. Coluna 4. Gastos do governo federal com defesa. Coluna 5. Gastos do governo federal com exceção de defesa. Coluna 6. Ativos estrangeiros nos EUA. 1981-1986. Em bilhões de dólares correntes.

\begin{tabular}{|c|c|c|c|c|c|}
\hline (1) & (2) & (3) & (4) & $(5)$ & (6) \\
\hline Anos/trimestres & $\begin{array}{l}\text { Investimentos } \\
\text { privados (Y1) }\end{array}$ & $\begin{array}{c}\text { Consumo } \\
\text { das } \\
\text { famílias }\end{array}$ & $\begin{array}{l}\text { Gastos do } \\
\text { governo } \\
\text { federal } \\
\text { (defesa) } \\
\text { (X1) }\end{array}$ & $\begin{array}{c}\text { Gastos do } \\
\text { governo } \\
\text { federal } \\
\text { (exceto } \\
\text { defesa) }\end{array}$ & $\begin{array}{c}\text { Ativos } \\
\text { estrange } \\
\text { iros nos } \\
\text { EUA }\end{array}$ \\
\hline $1981 / \mathrm{I}$ & 393,1 & 1893,7 & 184,9 & 81,7 & 8,437 \\
\hline II & 410,8 & 1925,5 & 193,8 & 84,9 & 13,959 \\
\hline III & 428,4 & 1965,1 & 197,8 & 83,6 & 16,731 \\
\hline IV & 447,8 & 1979,9 & 208,6 & 85,6 & 41,551 \\
\hline 1982/I & 443,1 & 2018,0 & 213,8 & 84,9 & 27,124 \\
\hline II & 432,1 & 2044,4 & 222,7 & 82,4 & 31,612 \\
\hline III & 419,5 & 2092,4 & 228,6 & 83,8 & 17,613 \\
\hline IV & 411,3 & 2154,2 & 238,6 & 88,5 & 11,517 \\
\hline 1983/I & 400,5 & 2194,1 & 241,3 & 91,6 & 15,158 \\
\hline II & 402,9 & 2258,2 & 248,8 & 93,3 & 15,608 \\
\hline III & 419,5 & 2328,6 & 252,5 & 101,7 & 19,539 \\
\hline IV & 446,0 & 2381,3 & 260,1 & 82,4 & 34,017 \\
\hline 1984/I & 460,1 & 2427,6 & 274,0 & 85,3 & 19,277 \\
\hline II & 484,4 & 2486,3 & 279,5 & 94,5 & 41,592 \\
\hline III & 500,7 & 2524,9 & 280,2 & 95,1 & 3,14 \\
\hline IV & 513,3 & 2574,3 & 292,7 & 96,1 & 33,31 \\
\hline 1985/I & 520,5 & 2645,7 & 298,3 & 99,8 & 14,247 \\
\hline II & 528,5 & 2690,1 & 306,1 & 101,6 & 25,358 \\
\hline III & 522,2 & 2758,7 & 318,1 & 102,7 & 35,665 \\
\hline IV & 533,6 & 2786,7 & 322,5 & 102,2 & 51,837 \\
\hline 1986/I & 527,2 & 2830,3 & 318,4 & 103,1 & 39,05 \\
\hline II & 517,5 & 2862,0 & 329,4 & 105,4 & 50,128 \\
\hline III & 513,5 & 2933,5 & 342,4 & 109,7 & 69,884 \\
\hline IV & 521,2 & 2973,2 & 333,3 & 112,9 & 62,192 \\
\hline $1987 / \mathrm{I}$ & 506,8 & 3008,0 & 340,7 & 111,2 & 33,1 \\
\hline II & 518,2 & 3075,3 & 349,3 & 109,8 & 50,66 \\
\hline III & 534,2 & 3141,6 & 355,4 & 105,6 & 71,658 \\
\hline IV & 537,2 & 3176,0 & 354,7 & 113,5 & 56,072 \\
\hline $1988 / \mathrm{I}$ & 546,2 & 3256,8 & 354,6 & 106,3 & 26,066 \\
\hline II & 562,3 & 3316,4 & 354,0 & 105,7 & 65,495 \\
\hline III & 567,3 & 3384,0 & 350,9 & 105,9 & 48,027 \\
\hline IV & 567,5 & 3457,2 & 360,0 & 111,8 & 80,759 \\
\hline
\end{tabular}

Fonte: NIPA-BEA e Economic Report of the President, vários números. Para 1 e 2, ver NIPA-BEA, ver Seção 1, Domestic Product and Income, Tabela 1.1.5., Gross Domestic Product; para 4 e 5, ver NIPABEA, Tabela 3.9.5., Government Consumption Expenditures and Gross Investment. Para 6, ver as Tabelas de vários números do Economic Report, International Investment Position of the United States, at year-end.

De fato, este ponto nem remete a uma comparação numérica de juros pagos versus impactos multiplicadores. O problema é de outra natureza. A crise expressa a queda dos investimentos das firmas, dando-se queda da demanda agregada e queda do consumo das famílias. O aumento dos déficits, mediante o endividamento doméstico ou externo, compensa a flutuação negativa. De modo a haver sempre uma relação inversa entre os déficits fiscais e a 
baixa dos investimentos, quando o governo atua de modo anticíclico. Certamente, não se trata de "má administração".

Dentro dos gastos do governo, os de defesa envolvem as maiores despesas, com quase $40 \%$ dos gastos totais sobre o orçamento federal. Os gastos com defesa estipulados dentro do próprio orçamento ("on budget") tiveram forte impacto nos investimentos privados nãoresidenciais, constituindo o carro-chefe da influência dos gastos do governo sobre a economia. Isto pode ser analisado sob o modelo de regressão linear de forma $y=a+b x$. Para ver mais de perto a relação, tomem-se os dados da tabela na seqüência. Na coluna 1 estão dispostos os dados observados de investimento privado entre 1985 e 1988, e na coluna 3 os gastos com defesa do governo federal no mesmo período, numa base trimestral. Os investimentos privados são Y1 e os gastos com defesa X1.

A regressão de $\mathrm{Y} 1$ explicada por $\mathrm{X} 1$ gera os seguintes estatísticos dispostos na seqüência, e a seguinte plotagem dos dados estimados e verificados:

Regressão III: Investimentos privados (Y1) em função de gastos com defesa (X1):

32 observações (1981-1988, dados trimestrais)

$\mathrm{IP}=227,03+0,898 \mathrm{GD}$, em que...

IP = investimentos privados não-residenciais;

$\mathrm{GD}=$ gastos do governo federal com defesa;

$\mathrm{R}^{2}: 0,89$

Valor-p para $\beta: 1,66015 \mathrm{E}-13$

Durbin Watson: 0,33

t-estatístico para $\beta: 12,59181$

Pelo modelo infere-se que a cada dólar gasto em defesa pelo governo federal, os investimentos privados elevam-se em quase noventa centavos. A regressão traz coeficiente explicativo $\mathrm{R}^{2}$ de $89 \%$, sugerindo-se grande impacto “acelerador" dos gastos com a indústria da guerra nas taxas de investimento agregado. Para a hipótese nula de $\mathrm{H}_{\mathrm{o}}: \beta=0$, o Estatístico $t$ cai na área de rejeição (a $\mathrm{T}-2=30$ graus de liberdade, o valor crítico é 2,042, a 5\% de significância), podendo-se considerar que a relação entre as variáveis é diferente de zero. O baixo valor de Durbin Watson, com alto índice de correlação serial, sugere forte correlação das séries, pelo padrão cíclico.

Com efeito, o modo pelo qual a ingerência pública manipulou os gastos com defesa no período considerado, no sentido de centrar nela a política anti-cíclica, mostra como o discurso das autoridades de ênfase no livre mercado e de restrições à participação do Estado na economia não passava de uma roupagem eufemística, ou mesmo enganadora, na caracterização da atuação de um Estado cuja participação direta na demanda efetiva continuou fundamental. 
Gráfico 3. Estados Unidos. Plotagem de ajuste de linha. Variável X (gastos com defesa) e variável Y (investimentos privados não-residenciais). Em bilhões de dólares. 1981-1988.
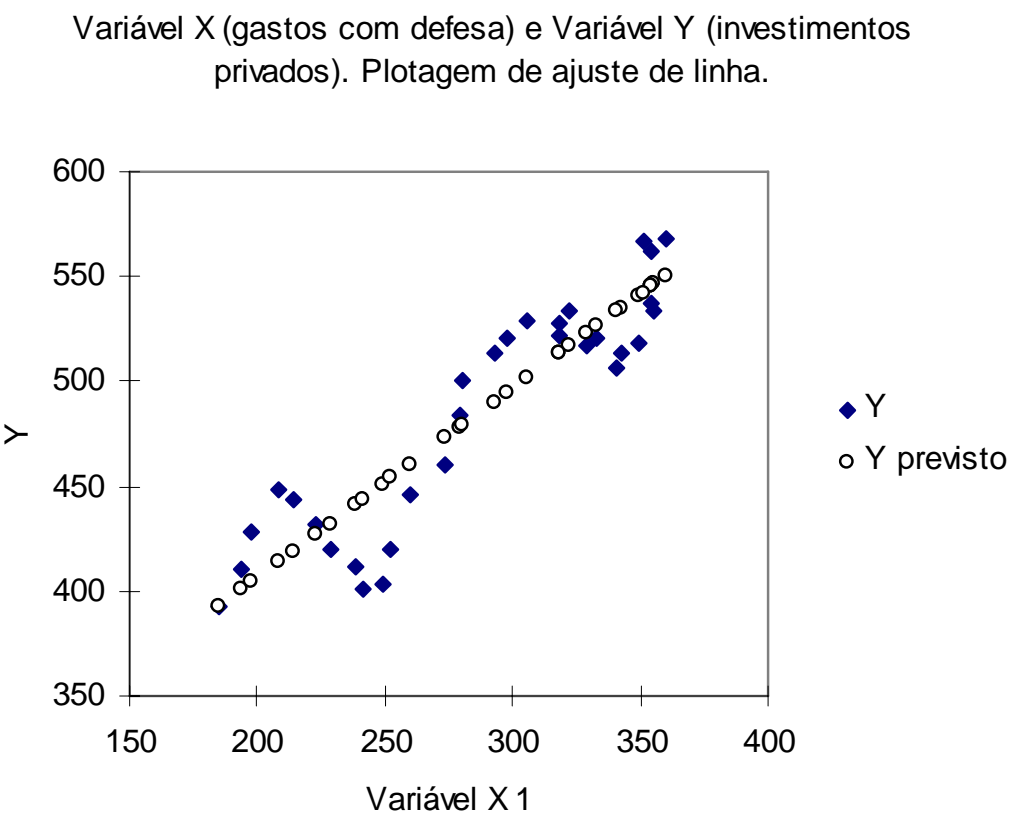

Fonte: ver tabela 11.

b) Fatores da recuperação

b.1) Salários, capacidade instalada e juros

O desempenho mais estável da economia entre 1985 e 1988 pode ser atribuído à seguinte conjunção de fatores: (a) aumento da lucratividade dos investimentos privados, com base em: (i) desvalorização de parte do capital existente pela crise anterior; (ii) queda dos juros, permitida pela estabilização dos preços; (iii) aumento da utilização da capacidade ociosa; e (iv) estagnação dos salários, cujas variações ficaram atrás dos índices de produção; (b) aumento das exportações norte-americanas a partir de 1987, dadas as conseqüências do Acordo do Plaza.

A tabela abaixo mostra a contínua discrepância entre a variação dos ganhos salariais reais e dos níveis de produção, para os salários referentes aos setores privados não-agrícolas. De fato, a soma das variações anuais dos salários reais, desde 1981, não chega a um terço da variação total dos níveis de produção, o que permite obter a formação de taxas de lucros novamente favoráveis aos investimentos corporativos, propiciando assim ascensão dos investimentos depois da grande crise no início da década. Segundo método de cálculo de uma proxy de taxa de lucro no setor industrial, ${ }^{180}$ ela sobe entre 1986 e 1988 (ver gráfico na seqüência).

${ }^{180}$ Ver capítulo 4. 
Tabela 12. Estados Unidos. Salários e produção - variação anual (\%). Setores não-agrícolas.

\begin{tabular}{ccc}
\hline 1$)$ & $(2)$ & $(3)$ \\
Anos & Salários & Produção \\
1981 & 0,4 & 2,1 \\
1982 & 1,1 & $-3,2$ \\
1983 & 0 & 6,5 \\
1984 & 0,2 & 8,2 \\
1985 & 1,2 & 4,2 \\
1986 & 3,3 & 3,9 \\
1987 & 0,3 & 3,6 \\
1988 & 1,2 & 4,6 \\
Soma & 7,7 & 29,9 \\
\hline
\end{tabular}

Fonte: Economic Report of the President, 2008. Tabela B-49, Productivity and Related Data, Business Sector, 1959-2005.

Abaixo podem-se ver os níveis de utilização de capacidade industrial desde o início da década. Percebe-se a forte retração da produção industrial, com correspondente aumento da capacidade ociosa, entre 1981 e 1983. Como se vê, a expansão a partir de 1984 gera um contínuo aumento da produção global. A produção referente aos serviços públicos tem uma utilização de capacidade em média $8 \%$ maior do que a existente no setor manufatureiro. Isto sugere maior elasticidade da produção da última, face às flutuações do produto como um todo.

Gráfico 4. Estados Unidos. Proxy de taxa de lucro no setor manufatureiro. 1985-1990.

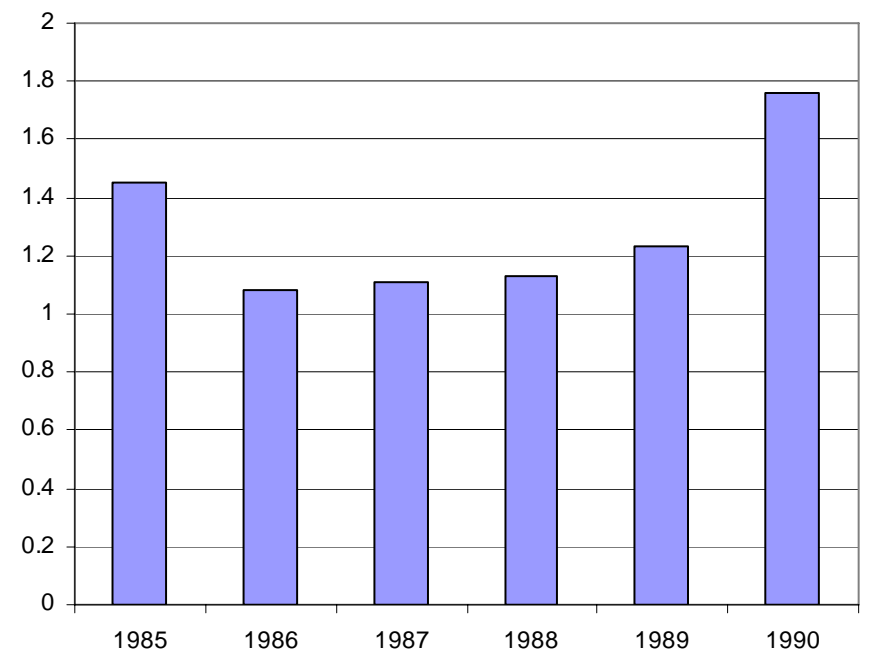

Fonte: cálculo do autor a partir dos dados do NIPA-BEA. Ver gráfico 2 do capítulo 4 .

A tabela ainda traz o número aproximado das falências ocorridas entre 1981 e 1988. Elas crescem enormemente entre 1981 e 1985, espelhando a grande recomposição dos capitais durante o período. Percebe-se que a diminuição do crescimento das falências somente se dá depois de 1987. Isto é, no auge da recuperação cíclica, o número de falências chegava ao seu número mais alto. Tal sugere forte correlação da recuperação dos capitais com as próprias falências. A recuperação de parte das firmas só se deu às custas da desvalorização de parte do próprio capital instalado. 
Tabela 13. Estados Unidos. Utilização de capacidade ociosa (\%) e número de empresas falidas. 1981-1988.

\begin{tabular}{|c|c|c|c|c|}
\hline (1) & (2) & $\begin{array}{c}\text { (3) } \\
\text { Capacidade utilizada (\%) }\end{array}$ & (4) & (5) \\
\hline Anos & Total da indústria & Serviços públicos & Manufatura & $\begin{array}{l}\text { Número de } \\
\text { empresas } \\
\text { falidas }\end{array}$ \\
\hline 1981 & 79,7 & 84,3 & 77,1 & 16794 \\
\hline 1982 & 73,7 & 80,4 & 71,0 & 24908 \\
\hline 1983 & 74,7 & 79,7 & 73,4 & 31334 \\
\hline 1984 & 80,4 & 82,9 & 79,4 & 52078 \\
\hline 1985 & 79,4 & 83,1 & 78,3 & 57253 \\
\hline 1986 & 78,6 & 82,3 & 78,3 & 61616 \\
\hline 1987 & 81,2 & 83,9 & 81,0 & 61622 \\
\hline 1988 & 84,2 & 86,1 & 84,0 & 57099 \\
\hline
\end{tabular}

Fonte: Economic Report of the President, 1989. Tabela B-51, Capacity Utilization Rates, 194888 .

A eficiência marginal do capital não foi apenas alterada pelo grau de utilização da capacidade instalada ou pelo nível dos salários, mas sim pelo nível das taxas de juros. Neste caso, assim que os preços foram estabilizados mediante a política de contenção dos meios de pagamento entre 1981-1983, as taxas de juros indicadas pelo Fed puderam cair aos poucos, o que trouxe abaixo o restante das taxas de juros privadas. Provocou-se uma queda sustentada, ao longo deste período, das taxas em nível global, com impactos benéficos nos financiamentos e empréstimos.

Tabela 14. Estados Unidos. Taxas de juros selecionadas (\% anual). 1981-1988.

\begin{tabular}{cccc}
\hline$(1)$ & $\begin{array}{c}(2) \\
\text { Taxa de desconto do }\end{array}$ & $\begin{array}{c}(3) \\
\text { Moody's }\end{array}$ & $\begin{array}{c}(4) \\
\text { Prime Rate }\end{array}$ \\
Anos & Fed & & 18,87 \\
1981 & 16,38 & 14,17 & 14,86 \\
1982 & 12,26 & 13,79 & 10,79 \\
1983 & 9,09 & 12,04 & 12,04 \\
1984 & 10,23 & 12,71 & 9,93 \\
1985 & 8,10 & 11,37 & 8,33 \\
1986 & 6,81 & 9,02 & 8,21 \\
1987 & 6,66 & 9,38 & 9,32 \\
1988 & 7,57 & 9,71 & \\
\hline
\end{tabular}

Fonte: Economic Report of the President, 1989. Tabela B-71, Bond yields and interest rates, 1929-88.

b.2) Exportações

O aumento das exportações contribuiu parcialmente para a formação de poupança e queda dos déficits em conta corrente do balanço de pagamentos, levando à desaceleração do crescimento do endividamento. Enquanto os investimentos variaram 1.11 vezes, as exportações 
variaram 1.48 vezes. Porém, vê-se pela figura na seqüência abaixo que o reajuste das taxas de câmbio de 1985 levou aproximadamente dois anos para surtir efeitos visíveis sobre as vendas ao exterior, tendo antes funcionado como elemento que impediu maiores resultados negativos dos déficits na conta corrente do balanço de pagamentos, até ali. Pode-se localizar mais especificamente o início de 1987 como o momento no qual as exportações norte-americanas ganharam mais impulso. Isto não obstante o fato de que somente no fim deste ano elas ascendessem acima de sua média, para iniciar uma trajetória que iria pôr grande fardo à manufatura japonesa neste fim de década, e no início dos anos (19)90.

Interessa notar também, como se vê no gráfico 5, que as importações apresentam maior estabilidade do que as exportações, sendo explicadas em primeiro lugar pelo comportamento estável do produto neste momento. Isto pode ser percebido por um $\mathrm{R}^{2}$ maior para a reta de importações, dentre as duas retas estimadas de importações e exportações em função do PNB, que dão as duas linhas de tendência. As menores variações das importações em torno de sua tendência deixam ver justamente a dificuldade em ajustar a balança comercial, nas condições de superávit na conta de capitais.

A tabela abaixo, com as exportações e importações dos Estados Unidos referentes ao Japão e à Europa ocidental, mostra (1) o crescimento mais rápido das importações frente às exportações feitas às duas regiões até 1986; e (2) a posterior ultrapassagem das exportações norte-americanas em relação a suas importações, a partir de 1986. Vê-se o impacto do Acordo do Plaza particularmente mais claro na queda das importações oriundas do Japão.

Tabela 15. Estados Unidos. Taxas de crescimento anuais das exportações e importações da Europa ocidental e Japão. 1981-1988.

\begin{tabular}{|c|c|c|c|c|}
\hline \multirow{4}{*}{ (1) } & \multicolumn{4}{|c|}{ Estados Unidos: taxas de crescimento anuais das importações e exportações } \\
\hline & \multicolumn{2}{|c|}{ Europa ocidental } & \multicolumn{2}{|c|}{ Japão } \\
\hline & (2) & (3) & (4) & (5) \\
\hline & Exportações dos & Importações pelos & Exportações dos & Importações pelos \\
\hline & EUA & EUA & EUA & EUA \\
\hline 1981 & 0,96 & 1,12 & 1,04 & 1,20 \\
\hline 1982 & 0,91 & 1,00 & 0,94 & 1,00 \\
\hline 1983 & 0,92 & 1,05 & 1,05 & 1,13 \\
\hline 1984 & 1,02 & 1,29 & 1,06 & 1,40 \\
\hline 1985 & 0,98 & 1,07 & 0,95 & 1,09 \\
\hline 1986 & 1,07 & 1,14 & 1,19 & 1,22 \\
\hline 1987 & 1,13 & 1,07 & 1,04 & 1,04 \\
\hline 1988 & 1,25 & 1,06 & 1,34 & 1,04 \\
\hline
\end{tabular}

Cálculo do autor a partir das séries fornecidas pelo Economic Report of the President, 1989. Tabela B-104, U.S. Merchandise Exports and Imports by Area. 
Gráfico 5. Estados Unidos. Exportações e importações de bens e serviços. Em bilhões de dólares correntes. 1985-1988.

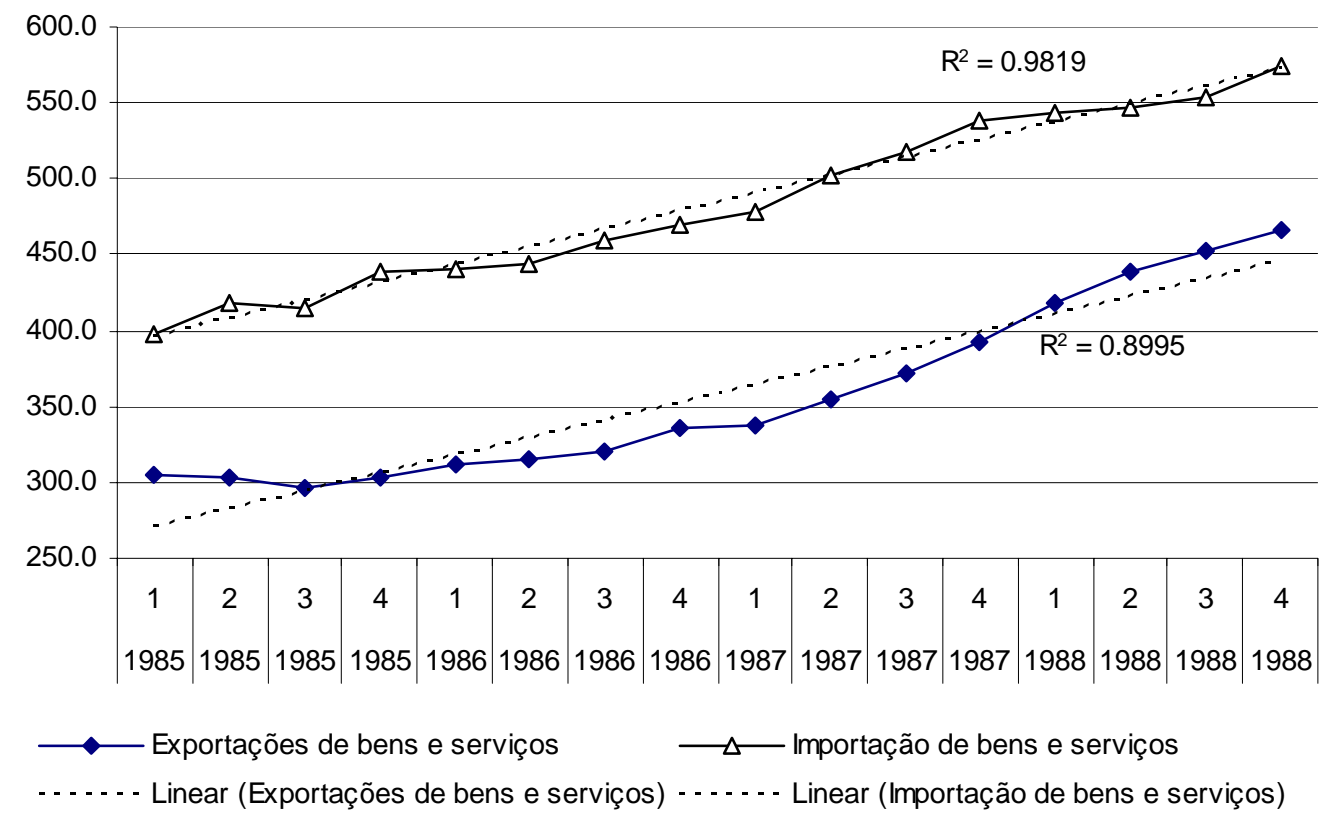

Fonte: Economic Report of the President, 1989. Tabela B-102, U.S. International Transactions.

O aumento das exportações evitou desempenho ainda pior do setor manufatureiro norteamericano no fim da década. Ora, a comparação intertemporal entre duas regressões de "lucros na manufatura" em função dos resultados de "exportação de bens e serviços", uma para o período 1960-1980, e outra para o período 1970-1990, não deixa dúvidas sobre as perdas externas às quais o setor exportador norte-americano foi levado ao longo da política do dólar forte e do processo de endividamento externo. Apresenta-se uma associação mais estreita entre os lucros manufatureiros e as exportações de bens e serviços no primeiro período do que no segundo.

Somente $49 \%$ das variações das exportações explicam as variações dos lucros auferidos pelo setor durante o período 1970-1990. A relação explicativa mostra-se mais presente no período 1960-1980. O montante não explicado (51\%) para o segundo momento aponta as perdas de posição no comércio internacional norte-americano desde fins dos anos (19)70. Infere-se a perda de mais da metade dos lucros da indústria em função das exportações no decorrer da década de (19)70 e (19)80, comparando-se tal com o momento anterior, referente a 1960-1980. De fato: 
Tabela 16. Estados Unidos. Lucros nos setores manufatureiros e exportações de bens e serviços. Em bilhões de dólares correntes. 1960-1990.

\begin{tabular}{cccccc}
\hline$(1)$ & $(2)$ & $(3)$ & $(4)$ & $(5)$ & $(6)$ \\
Anos & Lucros/manufatura & $\begin{array}{c}(3) \\
\text { Exportações }\end{array}$ & Anos & $\begin{array}{c}\text { Lucros/manufatura } \\
(\text { Y1) }\end{array}$ & $\begin{array}{c}\text { Exportações } \\
(\text { X1) }\end{array}$ \\
1960 & 12.6 & 27.0 & 1970 & 16.1 & 59.7 \\
1961 & 11.8 & 27.6 & 1971 & 20.1 & 63.0 \\
1962 & 14.1 & 29.1 & 1972 & 24.5 & 70.8 \\
1963 & 15.8 & 31.1 & 1973 & 32.2 & 95.3 \\
1964 & 18.4 & 35.0 & 1974 & 36.1 & 126.7 \\
1965 & 23.3 & 37.1 & 1975 & 34.8 & 138.7 \\
1966 & 25.1 & 40.9 & 1976 & 43.8 & 149.5 \\
1967 & 23.1 & 43.5 & 1977 & 49.1 & 159.4 \\
1968 & 23.4 & 47.9 & 1978 & 58.8 & 186.9 \\
1969 & 21.1 & 51.9 & 1979 & 65.4 & 230.1 \\
1970 & 16.1 & 59.7 & 1980 & 55.2 & 280.8 \\
1971 & 20.1 & 63.0 & 1981 & 62.8 & 305.2 \\
1972 & 24.5 & 70.8 & 1982 & 42.4 & 283.2 \\
1973 & 32.2 & 95.3 & 1983 & 44.1 & 277.0 \\
1974 & 36.1 & 126.7 & 1984 & 52.1 & 302.4 \\
1975 & 34.8 & 138.7 & 1985 & 49.2 & 302.0 \\
1976 & 43.8 & 149.5 & 1986 & 19.5 & 320.5 \\
1977 & 49.1 & 159.4 & 1987 & 47.4 & 363.9 \\
1978 & 58.8 & 186.9 & 1988 & 75.6 & 444.1 \\
1979 & 65.4 & 230.1 & 1989 & 64.1 & 503.3 \\
1980 & 55.2 & 280.8 & 1990 & 65.4 & 552.4 \\
\hline
\end{tabular}

Fonte: NIPA-BEA. Para lucros, Seção 6, Income and Employment by Industry, Tabela 6.16A., Corporate Profits by Industry; para exportações, Seção 4, Foreign Transactions, Tabela 4.1., Foreign Transactions in the National Income and Product Accounts.

Regressão IV. Lucros no setor manufatureiro (Y1) em função das exportações de bens e serviços $(\mathrm{X} 1)$

21 observações (1960-1980, dados anuais).

Lm: lucros no setor manufatureiro

Exp: exportações de bens e serviços

$\mathrm{Lm}=10,87+0,20 \mathrm{Exp}$

$\mathrm{R}^{2}=0,94$

Durbin Watson: 1,12

valor-p: $1.18 \mathrm{E}-13$

Erro padrão: 3.509369901

Regressão V. Lucros no setor manufatureiro (Y1) em função das exportações de bens e serviços (X1)

21 observações (1970-1990, dados anuais).

Lm: lucros no setor manufatureiro

Exp: exportações de bens e serviços

$\mathrm{Lm}=24,7+0,08 \operatorname{Exp}$

$\mathrm{R}^{2}=0,49$

Durbin Watson: 1,10

Valor-p: 0.000348

Erro-padrão: 12.2745

$\mathrm{O}$ aumento das exportações norte-americanas não representou apenas um desafogo ao setor manufatureiro norte-americano, mas sim a toda produção doméstica - através de seus efeitos multiplicadores -, constituindo elemento central da expansão no segundo governo pós- 
Reagan que permitiu a queda dos níveis de endividamento externo. Podem-se notar através da análise de regressão múltipla $\left(y=a+b x_{1}+c x_{2}\right)$ os impactos adicionais que a variável "exportações totais de bens e serviços" (X2) tem sobre a variável dependente "poupança bruta" (Y1), quando se contrapõe a formação de poupança bruta explicada apenas pelos "investimentos em capital fixo privados" (X1). A regressão simples da formação de "poupança bruta" (Y1) em função dos "investimentos em capital fixo" (X1), aqui em função de um modelo dinâmico com a série de poupança adiantada em um trimestre em relação aos investimentos, gera os seguintes regressores:

Regressão VI: Poupança Bruta adiantada em um trimestre $\left(\mathrm{Y}_{\mathrm{t}+1}\right)$ em função dos investimentos em capital fixo (X1):

15 observações (1985/I - 1988/III para (X1) e 1985/II - 1988/IV para Y1)

Pou $_{\mathrm{t}+1}=-1309,76+3,98 \mathrm{INK}_{\mathrm{t}}$, em que...

Pou ${ }_{\mathrm{t}+1}=$ poupança bruta adiantada em um trimestre

INK = investimentos privados em capital fixo

$\mathrm{R}^{2}: 0,75$

Durbin-Watson: 0,70

Valor-p para $\beta: 0,0018$

t-estatístico para $\beta:-3,9207$

De fato, a regressão múltipla da formação de "poupança bruta" (Y1) num tempo $t+1$, em função dos "investimentos em capital fixo" (X1) num tempo t e em função das "exportações totais de bens e serviços" (X2) num tempo t gera os seguintes valores preditivos, de maior poder explicativo:

Regressão VII: Poupança Bruta adiantada em um trimestre $\left(\mathrm{Y}_{\mathrm{t}+1}\right)$ em função dos investimentos em capital fixo (X1) e das exportações totais de bens e serviços (X2):

15 observações (1985/I - 1988/III para (X1 e X2) e 1985/II - 1988/IV para Y1)

Pou $_{\mathrm{t}+1}=-594,7+2,248 \mathrm{INK}_{\mathrm{t}}+0,55 \mathrm{EXP}_{\mathrm{t}}$, em que...

$\mathrm{Pou}_{\mathrm{t}+1}=$ poupança bruta adiantada em um trimestre

$\mathrm{INK}_{\mathrm{t}}=$ investimentos privados em capital fixo adiantados em um trimestre

EXP $_{\mathrm{t}}=$ exportações totais de bens e serviços

$\mathrm{R}^{2}: 0,89$

Durbin-Watson: 1,5

Valor-p para EXP: 0,02

F-estatístico: 50,649

O valor de F-estatístico não cai na região crítica de 4,67, com 13 graus de liberdade no denominador e 1 no numerador $(\mathrm{J}=1)$, indicando assim que os regressores são significativos. $\mathrm{O}$ valor-p para a variável "exportações” é menor do que o nível de significância de 5\% adotado, de modo que se pode considerar descartada a hipótese nula de que seja zero; de fato as exportações influíram significativamente na formação da poupança bruta, o que se revela por um $\mathrm{R}^{2}$ maior quando se leva em consideração a formação de poupança futura explicada não só pelos investimentos mas pelas exportações. Importa ver também como o estatístico Durbin Watson acusa uma melhora. 
Tabela 17. Estados Unidos. Lucros nos setores manufatureiros e exportações do setor manufatureiro. Em bilhões de dólares correntes. 1981-1988.

\begin{tabular}{cccc}
\hline (1) & $\begin{array}{c}(2) \\
\text { Poupança Bruta (Y1) }\end{array}$ & $\begin{array}{c}(3) \\
\text { Investimentos privados } \\
\text { em capital fixo (X1) }\end{array}$ & $\begin{array}{c}(4) \\
\text { Exportações de bens e } \\
\text { serviços (X2) }\end{array}$ \\
1985/I & 783.6 & 520.5 & 305.4 \\
II & 779.6 & 528.5 & 303.1 \\
III & 748.2 & 522.2 & 295.6 \\
IV & 758.5 & 533.6 & 304.0 \\
1986/I & 771.5 & 527.2 & 312.2 \\
II & 744.4 & 517.5 & 314.4 \\
III & 705.8 & 513.5 & 320.4 \\
IV & 712.4 & 521.2 & 335.2 \\
1987/I & 754.6 & 506.8 & 336.8 \\
II & 773.6 & 518.2 & 355.1 \\
III & 803.6 & 534.2 & 371.7 \\
IV & 855.4 & 537.2 & 392.0 \\
1988/I & 872.8 & 546.2 & 418.5 \\
II & 909.9 & 562.3 & 439.1 \\
III & 933.7 & 567.3 & 452.9 \\
IV & 943.7 & 567.5 & 465.8 \\
\hline
\end{tabular}

Fonte: NIPA-BEA. Para lucros, Seção 6, Income and Employment by Industry, Tabela 6.16A., Corporate Profits by Industry; para exportações, Seção 4, Foreign Transactions, Tabela 4.1., Foreign Transactions in the National Income and Product Accounts.

b.3) Papel do endividamento externo

O alto nível de atração de recursos externos pela economia norte-americana representou no período um elemento determinante para um comportamento mais estável, principalmente durante a crise de 1980-1983, atendendo, por sua vez, a um comportamento cíclico. O endividamento externo elevou-se na segunda administração Reagan, com ênfase nos dois primeiros anos da administração. Em 1987 e 1988, quando as exportações aceleraram-se, a poupança doméstica cresceu conjuntamente, com queda nos déficits nas transações correntes, fazendo com que o nível de endividamento caísse. Mostrava-se assim que o aumento da formação de poupança doméstica gerava menor pressão sobre o mercado de capitais doméstico, o que se refletiu em menor endividamento externo.

A estrutura do endividamento externo durante o quadriênio em questão está resumida no quadro abaixo, em bilhões de dólares correntes. 
Tabela 18. Estados Unidos. Estrutura do endividamento externo. Em bilhões de dólares correntes. 1985-1988.

\begin{tabular}{|c|c|c|c|c|}
\hline \multicolumn{5}{|c|}{ Estados Unidos: estrutura do endividamento externo } \\
\hline (1) & (2) & (3) & (4) & (5) \\
\hline & 1985 & 1986 & 1987 & 1988 \\
\hline $\begin{array}{l}\text { Títulos norte-americanos em mãos } \\
\text { de estrangeiros }\end{array}$ & 1061 & 1341 & 1548 & 1786 \\
\hline $\begin{array}{l}\text { Taxa de crescimento do } \\
\text { endividamento externo face ao ano } \\
\text { anterior }\end{array}$ & 1,18 & 1,26 & 1,15 & 1,15 \\
\hline \multicolumn{5}{|l|}{$\begin{array}{l}\text { a) Papéis do governo norte- } \\
\text { americano em mãos de } \\
\text { estrangeiros }{ }^{181}\end{array}$} \\
\hline $\begin{array}{l}\text { a.1) Por agentes oficiais (Bancos } \\
\text { Centrais) }\end{array}$ & 143,4 & 177,3 & 218,9 & 259,2 \\
\hline a.2) Por agentes privados & 83,6 & 91,5 & 78,3 & 96,6 \\
\hline $\begin{array}{l}\text { a.3.) Outros títulos em mãos de } \\
\text { estrangeiros }\end{array}$ & 15,9 & 18 & 15,5 & 14,2 \\
\hline a.4) Total & 242 & 286 & 311 & 369 \\
\hline $\begin{array}{l}\text { Total arrecadado pelo governo } \\
\text { com impostos domésticos }\end{array}$ & 1,270 & 1,347 & 1,464 & 1,562 \\
\hline $\begin{array}{l}\text { \% dos empréstimos externos totais } \\
\text { (a.4) sobre arrecadação doméstica }\end{array}$ & $19 \%$ & $21 \%$ & $21 \%$ & $23 \%$ \\
\hline \multicolumn{5}{|l|}{$\begin{array}{l}\text { b) Depósitos nos bancos dos EUA } \\
182\end{array}$} \\
\hline b.1.) Por agentes oficiais & 26,7 & 27,9 & 31,8 & 31,5 \\
\hline b.2) Por agentes privados & 354,5 & 451,6 & 540,6 & 609,5 \\
\hline $\begin{array}{l}\text { Taxa de variação de (b) face ao } \\
\text { ano anterior }\end{array}$ & 1,12 & 1,27 & 1,19 & 1,12 \\
\hline \multicolumn{5}{|l|}{$\begin{array}{l}\text { c) Compras de ações e bonds de } \\
\text { corporações dos EUA }\end{array}$} \\
\hline c.1) Ações & 123,7 & 166,7 & 173,4 & 198,4 \\
\hline c.2) Bonds & 82,5 & 142,1 & 170,8 & 195,2 \\
\hline $\begin{array}{l}\text { Variação de (c) face ao ano } \\
\text { anterior }\end{array}$ & 1,62 & 1,50 & 1,11 & 1,14 \\
\hline \multirow{2}{*}{$\begin{array}{l}\text { d) Investimento direto nos EUA } \\
\text { Variação do investimento direto } \\
\text { face ao ano anterior }\end{array}$} & 184,6 & 220,4 & 217,8 & 328,9 \\
\hline & 1,13 & 1,19 & 0,98 & 1,51 \\
\hline Investimento agregado doméstico & 643,1 & 659,4 & 700 & 750,3 \\
\hline
\end{tabular}

Fonte: Economic Report of the President, 1989. Tabela B-106, International investment position of the United States at year-end, 1980-89.

\footnotetext{
${ }^{181}$ No Apêndice Estatístico do Economic Report of the President a linha (a) corresponde - na tabela "International Investment Position of the United States at year-end" da Seção "International Statistics" - à seção "Foreign Official Assets in the United States - U.S.government securities"; a linha (b) corresponde a "US treasury securities", em "Other Foreign Assets in the United States"; e a linha (c) corresponde a "Other foreign official assets", de novo em "Foreign Official Assets in the United".

${ }^{182}$ Correspondem respectivamente a ambas linhas "U.S. Liabilities reported by U.S. Banks, not included elsewhere", estando uma na sub-seção "Foreign Official Assets in the United States" e outra na sub-seção "Other Foreign Assets in the United States".
} 
Vê-se em primeiro lugar que a taxa de variação do endividamento externo total caiu entre 1987 e 1988, face aos dois primeiros anos de 1985 e 1986. Desagregando-se os itens do endividamento, nota-se, quanto ao endividamento externo do governo federal (a), que a pequena diminuição da arrecadação (vista na seção acima) foi compensada por um aumento do endividamento externo do próprio. Em terceiro lugar, quanto aos depósitos bancários nos Estados Unidos (b), vê-se que o aumento da poupança local se expressou numa menor emissão de títulos ao exterior. O mesmo se deu para a emissão de bonds e ações pelas empresas norteamericanas no biênio mais expansivo de 1987 e 1988. O crescimento, levando a maiores disponibilidades de financiamento doméstico, com conseqüente menor pressão sobre o mercado de capitais, diminuiu a emissão de títulos ao exterior.

A série de Investimentos Diretos em aumento da capacidade instalada - da qual se excluem as compras de ações e bonds - expressa uma relação distinta. Os investimentos diretos na economia são um modo de a economia investir com recursos externos. Mas contrariamente aos outros componentes do endividamento, eles tendem a crescer justamente quando o mercado doméstico cresce, não expressando, assim, um desafogo similar ao representado pela emissão de títulos e ações ao exterior ou o próprio endividamento externo do governo. Ele se comporta como o próprio investimento das firmas instaladas nos Estados Unidos, quando a taxa de eficiência do capital sobe: seu crescimento evidencia o próprio crescimento da eficiência do capital doméstica.

A função do endividamento tem de ser bem delineada. O endividamento externo é parte da poupança agregada (definiu-se antes a poupança doméstica como sendo a poupança agregada menos o endividamento externo). Faz parte, assim, da poupança agregada; esta é definida como o resultado da formação bruta de capital menos a poupança bruta. No caso dos Estados Unidos, a poupança agregada tem sido superada sempre pelos investimentos, o que gera a necessidade do endividamento. Se, no curto prazo, o endividamento externo elevou-se enquanto a poupança doméstica caía, ele compensou tal queda. Quer dizer, caem os componentes principais da poupança, mas se dá a elevação do componente externo nela. Isto se deu até a metade do segundo mandato Reagan. Depois, foi possível diminuir o ritmo de endividamento porque as vendas externas cresceram, junto da acumulação produtiva.

A relação entre a formação de poupança agregada e o endividamento externo pode ser vista a partir do procedimento quantitativo que se segue. Primeiramente, façam-se duas regressões, sendo a primeira de poupança agregada (Y1) em função do tempo, e a segunda de empréstimos externos (Y2) em função também do tempo (X1). Obtêm-se os resultados estimados e os resíduos dispostos na tabela abaixo. A plotagem dos resíduos de ambos os resultados, verificados em relação à tendência estimada, revela a alternância entre: (1) a elevação dos níveis de poupança agregada e a diminuição dos empréstimos externos entre 1985 e 1986; e (2) a queda da poupança agregada acompanhada do aumento dos níveis de endividamento, entre 1987 e 1988. 
A regressão dos empréstimos externos (Y1) em função da poupança agregada, agora tomada como variável explicativa (X1), revela baixa associação entre as variáveis, com um $\mathrm{R}^{2}$ de 0,49 indicando que a elevação da poupança agregada (expressando crescimento com base nos investimentos privados) leva à diminuição do endividamento externo. Se se encontrasse correlação positiva estaria havendo relação direta entre formação de poupança doméstica e endividamento externo. Ou que, ao contrário, os níveis de endividamento externo em queda expressariam aumento da poupança agregada com base no crescimento com recursos de capitais domésticos. Mas só há necessidade do endividamento externo porque a economia cresce além do que permite sua própria formação de poupança.

O gráfico 6 abaixo mostra então a correlação inversa existente entre a capacidade de formação de poupança da economia e o crescimento do endividamento externo. Quando os investimentos privados permitem, a partir de uma taxa de lucro mais favorável e maiores exportações, uma maior taxa de formação de poupança, os níveis de endividamento externo caem. Porém, quando a formação de poupança é menor, o endividamento externo compensa a dificuldade local de expandir a própria formação de poupança doméstica e a menor disponibilidade relativa de recursos no mercado de capitais. A presença do endividamento externo atua assim como estabilizador da flutuação negativa. Ele é parte da poupança agregada; mas aumenta quando a poupança doméstica cai - definida aqui como a poupança agregada menos o endividamento externo -, e vice-versa.

Gráfico 6. Estados Unidos. Resíduos de poupança agregada e de empréstimos externos. Em bilhões de dólares correntes. 1985-1988.

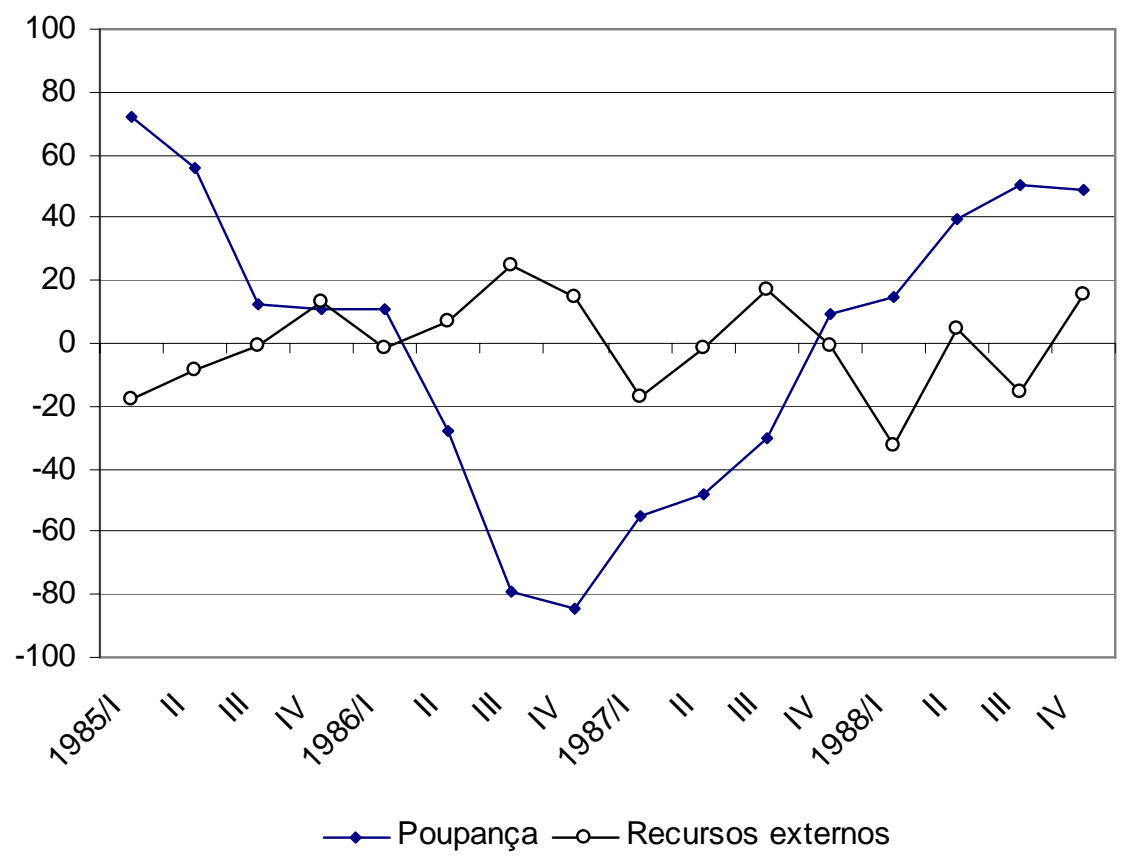

Fonte: NIPA-BEA e Economic Report of the President de 1987, 1988 e 1990. Para poupança agregada, Seção 5, Saving and Investment, Tabela 5.1., Saving and Investment. Para empréstimos externos, ver coluna Foreign Assets in U.S., na Tabela U.S. International Transactions, na Seção International Statistics do Economic Report. 
De qualquer maneira, a presença do endividamento externo mesmo num momento de crescimento mais rápido constituiu então um mecanismo que permitiu crescer mais do que se poderia na ausência dela, sendo um facilitador da acumulação adicional de ativos mesmo quando tal acumulação se viu impulsionada por uma elevação das exportações e da lucratividade geral do capital. Com efeito, é na dificuldade de inúmeros ramos da produção norte-americana para elevarem sua lucratividade em relação às economias externas que se gera a insuficiência de investimento doméstico, e, conseqüentemente, de expansão da poupança bruta. Isto denota: (a) queda da participação dos setores industriais no produto e seus efeitos estagnativos por todo o sistema contraposto a (b) uma demanda crescente de recursos por parte dos agentes que não pode ser atendida por um sistema que tende a estagnar.

Tabela 19. Estados Unidos. Poupança agregada e empréstimos externos, e resíduos em função do tempo. Em bilhões de dólares correntes. 1985-1988.

\begin{tabular}{|c|c|c|c|c|c|c|}
\hline \multirow[b]{2}{*}{ (1) } & \multicolumn{3}{|c|}{ Poupança agregada (Y1) } & \multicolumn{3}{|c|}{ Empréstimos externos (Y2) } \\
\hline & (2) & (3) & (4) & (5) & (6) & (7) \\
\hline & Observado & Estimado & $\begin{array}{l}\text { Resíduos em } \\
\text { função do } \\
\text { tempo }\end{array}$ & Observado & Estimado & $\begin{array}{l}\text { Resíduos } \\
\text { em função } \\
\text { do tempo }\end{array}$ \\
\hline 1985/I & 783.6 & 711.2088 & 72.39118 & 14.247 & 31.90295 & -17.6559 \\
\hline II & 779.6 & 723.4751 & 56.12485 & 25.358 & 34.1509 & -8.7929 \\
\hline III & 748.2 & 735.7415 & 12.45853 & 35.665 & 36.39885 & -0.73385 \\
\hline IV & 758.5 & 748.0078 & 10.49221 & 51.837 & 38.64679 & 13.19021 \\
\hline 1986/I & 771.5 & 760.2741 & 11.22588 & 39.051 & 40.89474 & -1.84374 \\
\hline II & 744.4 & 772.5404 & -28.1404 & 50.128 & 43.14269 & 6.985309 \\
\hline III & 705.8 & 784.8068 & -79.0068 & 69.884 & 45.39064 & 24.49336 \\
\hline IV & 712.4 & 797.0731 & -84.6731 & 62.192 & 47.63859 & 14.55341 \\
\hline 1987/I & 754.6 & 809.3394 & -54.7394 & 33.101 & 49.88654 & -16.7855 \\
\hline II & 773.6 & 821.6057 & -48.0057 & 50.661 & 52.13449 & -1.47349 \\
\hline III & 803.6 & 833.8721 & -30.2721 & 71.658 & 54.38243 & 17.27557 \\
\hline IV & 855.4 & 846.1384 & 9.261618 & 56.072 & 56.63038 & -0.55838 \\
\hline 1988/I & 872.8 & 858.4047 & 14.39529 & 26.066 & 58.87833 & -32.8123 \\
\hline II & 909.9 & 870.671 & 39.22897 & 65.495 & 61.12628 & 4.368721 \\
\hline III & 933.7 & 882.9374 & 50.76265 & 48.027 & 63.37423 & -15.3472 \\
\hline IV & 943.7 & 895.2037 & 48.49632 & 80.759 & 65.62218 & 15.13682 \\
\hline
\end{tabular}

Fonte: ver gráfico 6 acima.

De modo menos agregado, podem-se estimar os efeitos estabilizadores do endividamento externo sob (i) seu papel para a administração dos recursos do Estado, (ii) seu papel para as corporações; e (iii) para o sistema financeiro. Comece-se por (i).

$\mathrm{O}$ fato de que quase um quarto de todos os gastos do governo federal tenham sido financiados desde o exterior teve óbvio efeito benéfico sobre a capacidade de consumo e investimento domésticos, representando tributos $20 \%$ menores no curto prazo. Analisem-se, pela perspectiva do multiplicador da renda, os efeitos expansivos na renda local do endividamento externo do governo. 
A regressão do consumo em função da renda das famílias entre 1984 e 1988 (em base trimestral - ver tabela 21 abaixo) gera uma função-consumo de tipo $\mathrm{C}=-250,77+0,96 \mathrm{Y}$, a partir da qual se pode estimar o multiplicador como sendo: $1 / 1-0,96=25$. Para um modelo mais realista, incorpore-se a propensão marginal a importar neste valor. A propensão marginal a importar é dada pelos resultados da regressão das importações no período em função da renda, de modo que Imp = -89,1 + 0,13 Y. Daí o multiplicador torna-se 1/1-0,96+0,13=5,88. Logo, uma diminuição de $22 \%$ da arrecadação do governo federal com base na economia norteamericana, em função do endividamento externo, significa, a partir dos dados de arrecadação total do governo no período, uma hipótese da liberalização de recursos da ordem da arrecadação economizada vezes o efeito multiplicador.

A porcentagem da arrecadação total do governo federal mediante endividamento externo multiplicada pela hipótese de um multiplicador da renda torna-se: ${ }^{183}$

1986: $21 \%$ de 769 bilhões $=44$ [aumento da emissão de títulos públicos do governo ao exterior de 1986 em relação a 1985] x 5,88 [multiplicador] $=258$ bilhões

1987: $21 \%$ de 854 bilhões $=25$ [aumento de 1986 a 1987] x 5,88 [multiplicador] $=147$ bilhões

1988: $23 \%$ de 909 bilhões $=58 \times 5,88$ [multiplicador] $=341$ bilhões

Estes valores finais representam a hipótese de uma quantia notável em forma de consumo das famílias e lucros corporativos que o governo libera quando colhe tais recursos do exterior, justamente não tributando os agentes domésticos. Ou representa, sob uma outra abordagem, a renda formada pelos gastos do governo na economia a partir especificamente do endividamento externo. Tais resultados representavam aproximadamente $50 \%$ da taxa de investimento não-residencial em 1986 e 60\% dela em 1988.

Tabela 20. Estados Unidos. Arrecadação do governo, renda e consumo das famílias, e importações. Em bilhões de dólares correntes.

\begin{tabular}{ccccccc}
\hline$(1)$ & $\begin{array}{c}(2) \\
\text { Arrecadação } \\
\text { total do } \\
\text { governo } \\
\text { federal }\end{array}$ & $\begin{array}{c}(3) \\
\% \text { da } \\
\text { arrecadação } \\
\text { com recursos } \\
\text { externos }\end{array}$ & Renda & Consumo & Importações & PNB \\
1984 & 666 & $20 \%$ & 3109 & 2720 & 332 & 3.933 \\
1985 & 734 & $19 \%$ & 3285 & 2899 & 338 & 4.220 \\
1986 & 769 & $21 \%$ & 3458 & 3100 & 368 & 4.462 \\
1987 & 854 & $21 \%$ & 3748 & 3353 & 409 & 4.739 \\
1988 & 909 & $23 \%$ & 4021 & 3598 & 447 & 5.103 \\
\hline
\end{tabular}

Fonte: Economic Report of the President, 1989. Para arrecadação (1), Tabela B-76, Federal Receipts, Outlays, surplus or deficit, and debt, selected fiscal years, 1929-90. Para (2), ver tabela 18 acima; para (4), (5) e (7), Tabela B-1, Gross National Product. Para importações, B-102, U.S. International transactions, 1946-88.

${ }^{183}$ Tal como no capítulo passado, deve-se levar em consideração a variação da dívida (conferir nota 152). 
Quanto a (ii), basta notar que as emissões de ações e bonds ao exterior representaram um valor que somou, em 1985, 31\% do investimento agregado doméstico; em 1986, 49\%; e em 1987 e 1988, 52\%. Das próprias inversões mais lucrativas do setor privado neste momento, metade delas foi financiada com recursos externos, e a um passo acelerativo. Neste sentido, as variações de compras de ações caíram em 1987 e 1988, como resultado do aumento do financiamento corporativo com base em emissões domésticas. Quando a economia cresce mais, há mais compra de títulos pelos agentes locais. Assim, o papel das exportações foi determinante que a recuperação dos investimentos. Ora, como se notou, no período em questão a variação dos investimentos privados, de 1,11 vezes, foi menor que a variação das exportações, de 1,48 vezes. O consumo variou 1.23 vezes e os gastos do governo 1,18. Daí a diminuição do endividamento externo, mas sua própria elevação em relação ao cômputo total das inversões privadas. O que deixa ver o caráter frágil da recuperação.

Quanto ao financiamento do consumo das famílias mediante o sistema financeiro (iii), pode-se notar como o endividamento externo correlaciona-se com o crescimento, facilitando-o. Note-se que se trata antes de mais nada de efeito distribuidor de renda, via mercado financeiro, que minora os efeitos depressivos da política salarial do governo. Um modelo pode ser formulado a partir do consumo das famílias (Y1) explicado parcialmente pela entrada de ativos estrangeiros na economia (X1). Tomem-se como exemplo os gastos com bens duráveis (os dados estão também na tabela acima) explicados pela entrada de recursos externos, ambos em escala semestral. A regressão é feita entre a entrada de recursos no país como variável explicativa e o consumo pelas famílias de bens duráveis no mesmo período 1981-1988. O testatístico mostra que o coeficiente angular é diferente de zero. Há certa correlação entre as importações de capital e o consumo doméstico, que sugere impacto benéfico no crédito ao consumo das famílias dos crescentes aportes de capital estrangeiro. Os resultados da expressão e da plotagem dos dados que quantificam o modelo são:

Regressão VIII: ativos estrangeiros (X1) explicando consumo de bens duráveis (Y1) 32 observações (1981-1988, dados trimestrais)

$\mathrm{C}=229,4+2,93 \mathrm{AE}$, em que...

$\mathrm{C}=$ Consumo de bens duráveis

$\mathrm{AE}=$ ativos estrangeiros na economia norte-americana

$\mathrm{R}^{2}: 0,54$

Durbin-Watson: 1,001

Valor-p para $\beta: 1,63 \mathrm{E}-06$

t-estatístico para $\beta: 5,944021$ 
Tabela 21. Estados Unidos. Consumo de bens duráveis e ativos estrangeiros na economia. Em bilhões de dólares correntes. 1981-1988.

\begin{tabular}{|c|c|c|c|c|c|}
\hline & \multicolumn{2}{|c|}{ Valores observados } & & \multicolumn{2}{|c|}{ (continuação de dados observados) } \\
\hline & $\begin{array}{l}\text { Consumo de bens } \\
\text { duráveis (Y1) }\end{array}$ & $\begin{array}{l}\text { Ativos estrangeiros } \\
\text { nos EUA (X1) }\end{array}$ & & $\begin{array}{l}\text { Consumo de bens } \\
\text { duráveis (Y1) }\end{array}$ & $\begin{array}{l}\text { Ativos estrangeiros } \\
\text { nos EUA (X1) }\end{array}$ \\
\hline 1981/I & 223,8 & 8,437 & 1985/I & 337,7 & 14,247 \\
\hline II & 233,5 & 13,959 & II & 351,7 & 25,358 \\
\hline III & 228,3 & 16,731 & III & 356,6 & 35,665 \\
\hline IV & 239,2 & 41,551 & IV & 379,5 & 51,837 \\
\hline 1982/I & 224,3 & 27,124 & 1986/I & 366,2 & 39,05 \\
\hline II & 234,1 & 31,612 & II & 373,8 & 50,128 \\
\hline III & 236,6 & 17,613 & III & 388,8 & 69,884 \\
\hline IV & 239,1 & 11,517 & IV & 426,8 & 62,192 \\
\hline 1983/I & 251,2 & 15,158 & 1987/I & 422,5 & 33,109 \\
\hline II & 255,3 & 15,608 & II & 398,9 & 50,66 \\
\hline III & 275,5 & 19,539 & III & 419,1 & 71,658 \\
\hline IV & 287,9 & 34,017 & IV & 439,9 & 56,072 \\
\hline 1984/I & 304,5 & 19,277 & 1988/I & 428,7 & 26,066 \\
\hline II & 316,3 & 41,592 & II & 449,3 & 65,495 \\
\hline III & 325,7 & 3,140 & III & 451,8 & 48,027 \\
\hline
\end{tabular}

Fonte: Economic Report of the President, 1989.

Outra regressão segundo a mesma lógica dá um melhor resultado. Tome-se, pela tabela abaixo, o aporte (desta vez anual) de recursos estrangeiros ao país, explicando os créditos concedidos às famílias para hipotecas. Tal gera um $\mathrm{R}^{2}$ muito mais alto, com $90 \%$ de correlação entre as duas séries. $\mathrm{O}$ índice Durbin Watson mostra-se melhor, também. A hipótese de o coeficiente angular ser zero é descartada (teste $T$ para $H_{0}: \beta=0$ supera o valor crítico de 2,228 para $\mathrm{T}=12$-2 graus de liberdade, caindo na área de rejeição). De fato, sugere-se que a construção e aquisição de imóveis é financiada pelo sistema financeiro doméstico em parte muito maior que o consumo de bens não-duráveis. As séries e os resultados estatísticos da última regressão citada são:

Tabela 22. Estados Unidos. Empréstimos das famílias - hipotecas. Em bilhões de dólares correntes. 1981-1988.

\begin{tabular}{ccc}
$(1)$ & $(2)$ & $(3)$ \\
& Hipotecas (Y1) & Ativos estrangeiros nos EUA \\
1977 & 603,1 & 51,3 \\
1978 & 708,6 & 64,1 \\
1979 & 826,7 & 38,7 \\
1980 & 926,5 & 58,1 \\
1981 & 998,2 & 83,1 \\
1982 & 1031,1 & 93,7 \\
1983 & 1116,2 & 84,8 \\
1984 & 1242,8 & 102,6 \\
1985 & 1448,3 & 130,1 \\
1986 & 1647,1 & 221,6 \\
1987 & 1826,6 & 218,1 \\
1988 & 2052,8 & 219,2 \\
\hline
\end{tabular}

Fonte: Federal Reserve Statistical Release - Flow of Funds Accounts e Economic Report of the President. Tabela D.2, Borrowing by Sector. Billions of dollars; quarterly figures are seasonally adjusted annual rates, p.7. 
Regressão IX: ativos estrangeiros (X1) explicando empréstimos hipotecários (Y1) 12 observações (1977-1988, dados anuais)

$\mathrm{F}_{\mathrm{h}}=483.7+6.31 \mathrm{AE}$, em que...

$\mathrm{F}_{\mathrm{h}}=$ Financiamento de Hipotecas

$\mathrm{AE}=$ ativos estrangeiros na economia norte-americana

$\mathrm{R}^{2}: 0,90$

Durbin-Watson: 1,51

Valor-p para $\beta: 2.45 \mathrm{E}-06$

t-estatístico para $\beta: 9.535378$

A partir do que foi dito, é-se levado à seguinte observação final, à guisa de conclusão e resposta a uma possível dúvida conceitual: é difícil separar em termos quantitativos e teóricos a (1) poupança doméstica formada exclusivamente pelos investimentos feitos sem a participação do capital estrangeiro da (2) poupança agregada total formada pelos investimentos domésticos mais a poupança externa. Em hipótese, a primeira seria "natural" e a segunda "artificial". Na vida real, o que importa de fato é verificar a relação poupança/investimento ou o desempenho do setor industrial no produto; se ambos crescem, cairá a necessidade de endividar-se no exterior.

c) A crise acionária de 1987

É importante comentar o que levou à crise acionária de 1987, porque, mesmo não tendo tido um impacto tão recessivo, representou perdas consideráveis para acionistas da ordem quase um sexto do produto. A análise do evento é ademais interessante por desvelar como surge uma crise acionária.

Assim que Greenspan assumiu o Fed, focou atenção na inflação, que de fato era maior. A variação de 1986 para os índices de preço ao consumidor tinha sido de 1,1\%; a de 1987 caminhou para 4,4\%. Deste modo, sugeriu já em sua primeira reunião a elevação da taxa básica de desconto - a taxa sob a qual o Fed empresta aos outros bancos. O Fed não o fazia desde 1984. Na segunda reunião, em 4 de Setembro, concordou-se com uma elevação de 0,5\%.

$\mathrm{O}$ aumento dos juros provocou tensão. Recentemente a economia tinha enfrentado a maior recessão das últimas décadas, e temia-se que o aumento dos juros expressasse mais uma baixa cíclica. Ao mesmo tempo, via-se que o aumento nos juros podia desencadear uma crise acionária. Com efeito, segundo o índice da Standard\&Poor's, a relação entre os ganhos e os preços das ações (earnings/price ratio) atingia os níveis mais baixos desde o início da queda a partir dos anos (19)80. No entanto, os índices de frenesi só se elevavam: o composite index das empresas listadas no Standard... evoluiu continuamente desde 1982, indo de 119,71 em 1982 para 160,41 em 1984; em 1985 estava em 186,84, e em 1987 286,83. Como se vê no gráfico a seguir, os níveis de ganho por ação em 1987 remontavam aos valores do momento da primeira crise do petróleo (1974). 
Vários mecanismos somaram-se para projetar a crise acionária. Além da (1) contradição entre o aumento do valor das ações - refletido na elevação dos índices do Dow e Standard -, (2) do aumento dos juros, e (3) da queda dos ganhos por preço das ações (que refletia lucros subjacentes estagnados), houve (4) a progressiva queda do dólar frente ao marco e iene. Tal pressionava pela diminuição da atratividade dos papéis denominados em dólar para os investidores estrangeiros. A elevação dos juros na Alemanha Ocidental, como resposta à elevação nos Estados Unidos, a partir de Agosto de 1987, também contribuiu para a fuga desde os papéis norte-americanos.

Tabela 23. Estados Unidos. Dados selecionados. Taxas de juro dos Títulos do Tesouro (3 meses) e Federal Funds Rate (taxa de desconto do Fed anual). 1987.

\begin{tabular}{ccc}
\hline (1) & $(2)$ & $(3)$ \\
1987 & US Treasury Securities - & Federal Funds Rate \\
& 3 meses & \\
Jan. & 5,45 & 6,43 \\
Fev. & 5,59 & 6,1 \\
Mar. & 5,56 & 6,13 \\
Abr. & 5,76 & 6,37 \\
Mai. & 5,75 & 6,85 \\
Jun. & 5,69 & 6,73 \\
Jul. & 5,78 & 6,58 \\
Ago. & 6,0 & 6,73 \\
Set. & 6,32 & 7,22 \\
Out. & 6,4 & 7,29 \\
Nov. & 5,81 & 6,69 \\
Dez. & 5,8 & 6,77 \\
\hline
\end{tabular}

Fonte: Economic Report of the President, 1989. Tabela B-71, Bond yields and interest rates, 1929-86.

Para a crise de 1987, a análise posterior permite ver os crescentes preços das ações ultrapassarem os ganhos das corporações às quais se referiam. Como mostra o gráfico abaixo, os preços das ações evoluíram mais rapidamente que os lucros subjacentes. Ao mesmo tempo em que a relação entre os lucros e os ganhos acionários nos setores manufatureiros era praticamente a mesma do início da década, os índices Dow Jones e Standard and Poor's elevavam-se sem parada desde 1984 (ver gráfico a seguir). O avanço dos índices do Dow Jones e do Standard and Poor's, se contrapuseram à estagnada relação de ganhos por ação em relação ao seu preço. Isto iria frutificar num estouro de uma típica "bolha". Bastou para tanto a confluência da desvalorização do dólar e do aumento dos juros, nos Estados Unidos e no exterior.

Assistindo às perdas, Greenspan e o Fed iniciaram intenso trabalho de convencimento das grandes corporações e acionistas, para que continuassem fazendo negócios, via comunicação direta. E para evitar uma crise de liquidez e fuga maior das ações, rebaixaram-se de Outubro para Novembro as taxas de desconto e dos Títulos do Tesouro. Sem embargo, a trajetória mais ou menos firme do PNB em 1987, mesmo com a crise acionária, pode ser 
explicada pela atuação conjunta de alguns dos mesmos fatores responsáveis pela eliminação da crise no início da década. Foram eles: (a) exportações passando a crescer mais rápido que as importações a partir de meados do ano; (b) salários reais estagnados; (c) manutenção dos déficits orçamentários com base nas inversões no setor de defesa. Estas, apesar da diminuição relativa, continuaram altas, somando 104 bilhões ao fim do ano (atingiu 144 bilhões em 1986); (d) taxa de endividamento externo diminuída, mas não eliminada. Apesar da queda da atração de recursos do exterior de 221 para 211 bilhões entre 1986 e 1987, e do aumento da poupança agregada por parte do governo federal, esta soma continuava alta e era essencial para compensar o déficit em transações correntes de 153 bilhões em 1987.

Tabela 24. Estados Unidos. Índices selecionados. 1. Relação dos lucros manufatureiros com os ganhos acionários em todas as manufaturas. 2. Relação dos lucros manufatureiros com os ganhos acionários nas empresas fabricantes de bens duráveis. 3. Standard and Poor's composite index. 4. Earnings-price ratio Standard and Poor's (em centavos).

\begin{tabular}{ccccc}
\hline$(1)$ & $(2)$ & $(3)$ & $(4)$ & $(5)$ \\
Anos & $\begin{array}{c}\text { Todas as } \\
\text { manufaturas (\%) }\end{array}$ & $\begin{array}{c}\text { Bens } \\
\text { Duráveis (\%) }\end{array}$ & $\begin{array}{c}\text { Standard and Poor's } \\
\text { composite index }\end{array}$ & $\begin{array}{c}\text { Earnings-price ratio Standard } \\
\text { and Poor's (centavos) }\end{array}$ \\
1980 & 13,9 & 11,2 & 118,78 & 12,66 \\
1981 & 13,6 & 11,9 & 128,05 & 11,96 \\
1982 & 9,2 & 6,1 & 119,71 & 11,6 \\
1983 & 10,6 & 8,1 & 160,41 & 8,03 \\
1984 & 12,5 & 12,4 & 160,46 & 10,02 \\
1985 & 10,1 & 9,2 & 186,84 & 8,12 \\
1986 & 9,5 & 7,5 & 236,34 & 6,09 \\
1987 & 12,8 & 11,9 & 286,83 & 5,48 \\
\hline
\end{tabular}

Fonte: Economic Report of the President, 2007. Tabela B-95, Historical stock prices and yields, 1949-2003.

Gráfico 7. Estados Unidos. Ganhos por ação em relação ao preço das ações (earnings/price ratio, em \%). Standard\&Poor's composite index. 1980-1990.

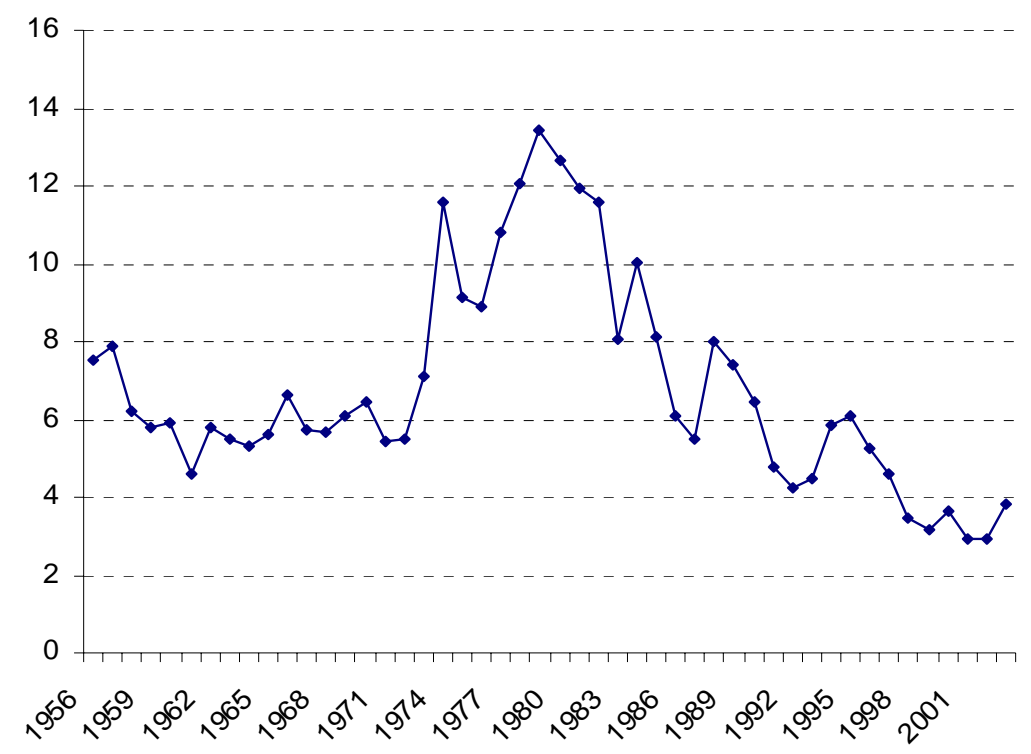

Fonte: Economic Report of the President. 2006. Ver tabela 24. 
O expediente do endividamento externo não pôde evitar de todo as conseqüências da queda das taxas de lucratividade no setor industrial e de sua participação no produto. Por isto, justamente, o endividamento externo cresceu. Note-se que, por mais estáveis que tenham sido as variações do produto nesta segunda administração Reagan, e por mais que a economia investisse e consumisse com recursos externos, as taxas de crescimento já estavam muito abaixo das taxas de crescimento históricas verificadas nas décadas precedentes. Mais especificamente, a política econômica do Reaganomics, na medida em que deixava instalarem-se os déficits comerciais, representava perdas para a produção local no médio prazo. Uma maior produção substitutiva no exterior também representou uma queda de oportunidades para a produção norte-americana, cuja participação no mercado internacional caiu bastante, face ao que chegara a ser em fins dos anos (19)70. Por fim, o acento na indústria de guerra evitou a conformação de um tipo de vendas ao exterior mais calcadas numa lógica de mercado, podendo ser interpretada como outro fator complicador do desempenho do comércio exterior no longo prazo.

$\mathrm{O}$ acordo do Plaza representou auxílio à produção norte-americana, justamente para evitar maiores perdas no mercado exterior. Num âmbito mais amplo deu alento ao próprio crescimento industrial, cujas taxas de crescimento vinham caindo face a outros setores, com acento particular na primeira metade da década de (19)80. Veio tarde, porém, para impedir a consolidação de uma tendência à financeirização, provocada pela queda da taxa de lucro no fim dos anos (19)70, e pela política de aumento de juros conjugada com um dólar valorizado. Com menores oportunidades no setor real, os maiores juros, conjugados com uma desregulamentação do setor financeiro, iriam culminar num aumento da financeirização da economia como um todo.

As duas primeiras regressões lineares abaixo expressam tal crise do setor industrial norte-americano desde o fim dos anos (19)70, que a retomada das exportações a partir de 1987 não debelou totalmente. As duas regressões abaixo estimam (i) os lucros do setor financeiro (Y1) a partir do produto nacional bruto (X1); e (ii) os lucros do setor manufatureiro (Y2), estimados a partir do mesmo produto nacional bruto (X1). Os dois modelos de regressão linear dão os valores numéricos, e foram estimados a partir das séries da tabela na seqüência:

Regressão X: Lucros financeiros (Y1) em função do PNB (X1):

32 observações (1981-1988, dados trimestrais)

$\mathrm{L}_{\mathrm{f}}=-19,6027+0,015 \mathrm{PNB}$, em que...

$\mathrm{L}_{\mathrm{f}}=$ lucros no setor financeiro

$\mathrm{PNB}=$ produto nacional bruto

$\mathrm{R}^{2}: 0,73$

Valor-p para $\beta: 3,2339 \mathrm{E}-10$

t-estatístico para $\beta: 9,17919607$

Durbin Watson: 0,28 
A série de lucros financeiros apresenta maior aderência ao crescimento do PNB ao longo dos dois governos Reagan, com menores flutuações e taxa de crescimento mais rápida e estável. Mostra-se a ascensão das finanças como o setor onde progressivamente se apresentam as taxas de lucro mais atrativas da economia, tradução do estancamento no longo prazo do setor industrial. Enquanto a série de lucros dos setores manufatureiros pouca adesão teve ao crescimento do PNB, a série de lucros financeiros mostrou uma adesão ou estabilidade muito maiores. A maior aderência dos lucros financeiros ao PNB é evidenciada por um maior coeficiente "b" na equação estimada, visto em (I), assim como por um $\mathrm{R}^{2}$ muito superior ao da equação estimada para os lucros na indústria. E também por um erro-padrão para a série de empresas financeiras $(0,001733)$ bem menor do que para as séries da indústria $(0,00534)$. De fato, em (I), a hipótese nula $\mathrm{H}_{0}: \beta=0$ é rejeitada ao nível de significância de $5 \%$. Já no caso da manufatura (II), não se pode rejeitar a hipótese de $\operatorname{ser} \beta=0$, pois o valor da estatística de teste para esta hipótese $(\beta=0)$, não cai na área de rejeição. Isto só mostra como os lucros financeiros se ajustam melhor em função do PNB do que os lucros manufatureiros, já que o coeficiente de (II) se mostra mais próximo de zero.

Regressão XI: Lucros manufatureiros (Y2) em função do PNB (X1): 32 observações (1981-1988, dados trimestrais)

$\mathrm{L}_{\mathrm{m}}=47,609+0,009 \mathrm{PNB}$, em que...

$\mathrm{L}_{\mathrm{m}}=$ lucros no setor manufatureiro

$\mathrm{PNB}=$ produto nacional bruto

$\mathrm{R}^{2}: 0,10$

t-estatístico para $\beta: 1,837$

Valor-p para $\beta: 0,07604$

Durbin Watson: 0,33

A ascensão das exportações de 1987-1988 representou portanto uma viragem apenas parcial de uma tendência ao crescimento das finanças cuja origem remontava pelo menos desde o final da década de (19)70. A tendência crescente dos lucros nos setores financeiros iria ignorar todas as flutuações do produto deste período, podendo-se, como faz Chesnais, falar-se num predomínio da financeirização na economia norte-americana para o período ora considerado. 
Tabela 25. Estados Unidos. Dados observados: lucros nas empresas do setor financeiro, na do setor manufatureiro e PNB. Em bilhões de dólares correntes. 1981-1988.

\begin{tabular}{|c|c|c|c|c|c|c|c|}
\hline \multicolumn{5}{|c|}{ Valores observados } & \multicolumn{3}{|c|}{ (continuação) } \\
\hline (1) & (2) & (3) & (4) & (5) & (6) & (7) & (8) \\
\hline Trimestres & $\begin{array}{l}\text { PNB } \\
\text { (X1) }\end{array}$ & $\begin{array}{l}\text { Financeiras } \\
\text { (Y1) }\end{array}$ & $\begin{array}{c}\text { Manufatureiras } \\
\text { (Y2) }\end{array}$ & Trimestres & $\begin{array}{l}\text { PNB } \\
(\mathrm{X} 1)\end{array}$ & $\begin{array}{c}\text { Financeiras } \\
\text { (Y1) }\end{array}$ & $\begin{array}{l}\text { Manufatureiras } \\
\text { (Y2) }\end{array}$ \\
\hline 1981/I & 2725.3 & 37,7 & 93,0 & 1985/I & 3809.6 & 35,4 & 78,7 \\
\hline II & 2729.3 & 33,8 & 92,0 & II & 3908.6 & 35,4 & 79,7 \\
\hline III & 2786.6 & 31,4 & 100,7 & III & 3978.2 & 31,2 & 92,8 \\
\hline IV & 2916.9 & 33,0 & 78,6 & IV & 4036.3 & 35,6 & 86,2 \\
\hline $1982 / \mathrm{I}$ & 3052.7 & 33,5 & 67,3 & $1986 / \mathrm{I}$ & 4119.5 & 42,6 & 63,4 \\
\hline II & 3085.9 & 29,1 & 70,7 & II & 4178.4 & 46,9 & 57,5 \\
\hline III & 3178.7 & 27,7 & 74,2 & III & 4261.3 & 46,8 & 46,6 \\
\hline IV & 3196.4 & 26,2 & 56,0 & IV & 4321.8 & 47,2 & 64,3 \\
\hline $1983 / \mathrm{I}$ & 3186.8 & 20,5 & 60,9 & $1987 / \mathrm{I}$ & 4385.6 & 54,9 & 62,9 \\
\hline II & 3242.7 & 23,1 & 69,8 & II & 4425.7 & 59,0 & 79,9 \\
\hline III & 3276.2 & 27,5 & 81,8 & III & 4493.9 & 56,3 & 100,0 \\
\hline IV & 3314.4 & 33,1 & 92,3 & IV & 4546.1 & 56,9 & 102,3 \\
\hline 1984/I & 3382.9 & 35,3 & 101,2 & 1988/I & 4613.8 & 55,0 & 112,2 \\
\hline II & 3484.1 & 37,5 & 96,1 & II & 4690.0 & 59,7 & 116,9 \\
\hline III & 3589.3 & 35,1 & 86,0 & III & 4767.8 & 60,6 & 121,8 \\
\hline IV & 3690.4 & 34,2 & 84,0 & IV & 4886.3 & 63,9 & 133,8 \\
\hline
\end{tabular}

Fonte: NIPA-BEA. Seção 6, Income and Employment by Industry, Tabela 6.16A, Corporate Profits by Industry.

De fato, a regressão das duas séries em função do tempo gera um coeficiente explicativo $\mathrm{R}^{2}$ muito pequeno para a série de manufaturas (12\%), a expressar flutuações marcantes, com enormes discrepâncias entre o comportamento previsto e o verificado. Já para a série de lucros financeiros, o comportamento mais estável, com menores resíduos, é expresso por um ajustamento muito maior da série de dados observados face aos previstos, tal como se vê nas figuras abaixo. $\mathrm{O} \mathrm{R}^{2}$ para a regressão dos lucros financeiros em função do tempo é de $72 \%$. O crescimento dos lucros manufatureiros no período é de 1,43 vezes; já os lucros financeiros cresceram 1,69 vezes.

Regressão XII: lucros manufatureiros em função do tempo

$\mathrm{Lm}=72,001+0,75 \mathrm{t}$

Onde: $\mathrm{Lm}=$ lucros no setor manufatureiro

$\mathrm{t}=$ tempo

$\mathrm{R}^{2}: 0,12$

Erro padrão: 19,45

Regressão XIII: lucros financeiros em função do tempo

$\mathrm{Lf}=21,82+1,11 \mathrm{t}$

Onde: $\mathrm{Lf}=$ lucros no setor financeiro

$\mathrm{t}=$ tempo

$\mathrm{R}^{2}: 0,72$

Erro padrão: 6.52 
Gráfico 8. Estados Unidos. Lucros financeiros e lucros financeiros e suas respectivas previsões a partir do tempo. 1981-1988 (dados semestrais).

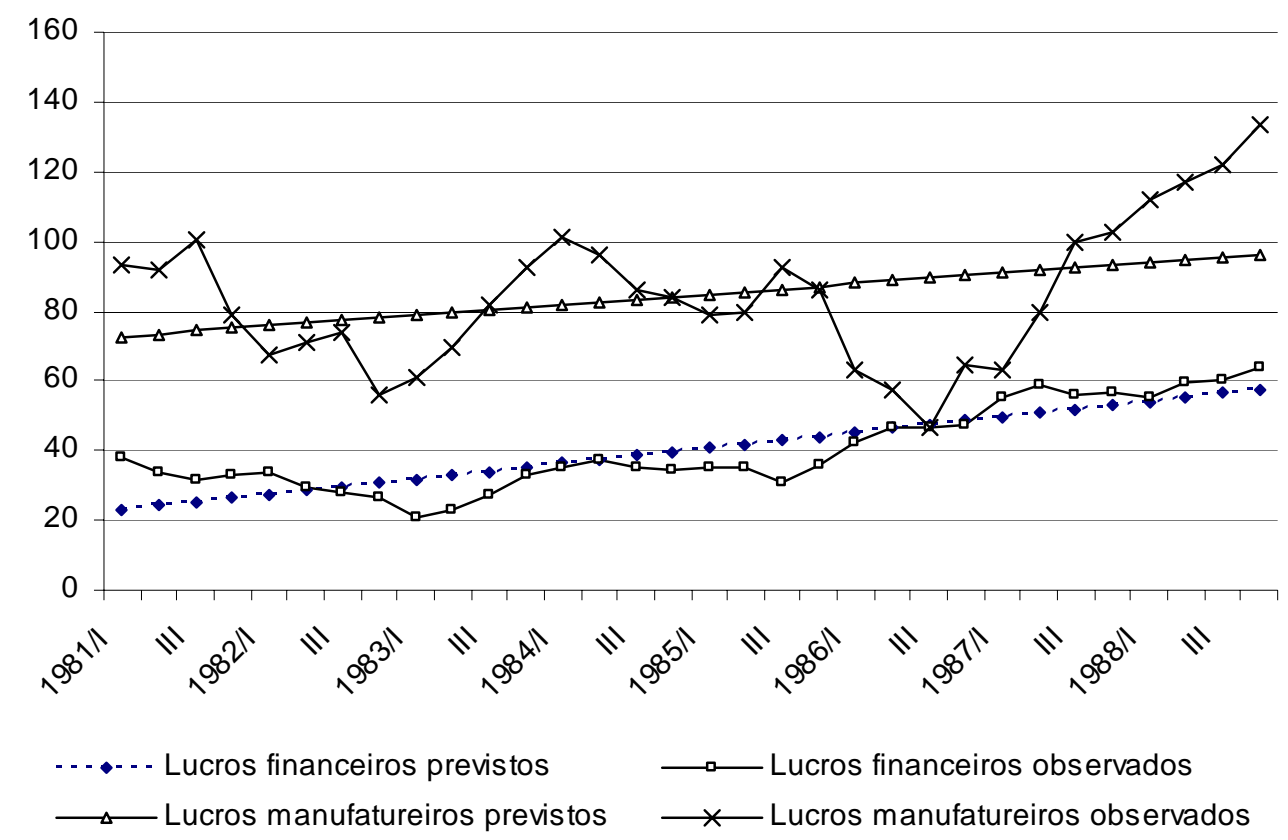

Fonte: NIPA-BEA. Ver tabela 25 acima.

\subsection{Conclusão}

As opções da administração Reagan por (1) um dólar forte no início da década; (2) firme restrição ao crescimento dos meios de pagamento; (3) tributação regressiva; (4) eleição da indústria da guerra como setor-chave para a acumulação; e (4) recurso ao endividamento externo, de fato conduziram a economia à: (i) queda da inflação no início da década; (ii) recomposição das taxas de lucro para o capital local; (iii) manutenção do dólar como divisa de reserva internacional; e (iv) amortecimento dos impactos da crise vinda dos anos (19)70. Porém, trouxeram como conseqüências outras variantes menos desejadas, tais como (a) rápido aumento dos déficits fiscais, (b) queda relativa do poder de demanda das famílias; (c) queda da participação da indústria no produto, (d) perdas no mercado internacional, aguçadas pela ênfase na indústria da guerra, e (e) elevação da financeirização.

Logo no início da segunda administração de Reagan, estes efeitos já eram notados, sendo o Acordo do Plaza e a lei sobre os déficits fiscais respostas a isto. Porém, enquanto que o Acordo do Plaza remediou a situação do comércio exterior e dos déficits em conta corrente, a lei sobre os limites dos déficits na verdade se insurgia contra um dos princípios básicos da administração de Reagan. Como tal, não pôde ser implementada a contento, mesmo com o crescimento entre 1987 e 1988.

A queda dos níveis de endividamento externo em 1987 e 1988 mostrou como ele (endividamento externo) se ligava fundamentalmente a uma taxa de crescimento da acumulação produtiva menor do que a necessária para obter o crescimento almejado pelas autoridades. Isto 
era aguçado particularmente pelos déficits na conta corrente do balanço de pagamentos, na medida em que caiu com a recuperação da lucratividade e o aumento das exportações. Neste caso, a relação inversa entre (a) um maior crescimento doméstico e das exportações e (b) a queda do endividamento externo mostrou que somente uma recuperação sustentada da lucratividade nos setores industriais e/ou maiores ganhos via exportações poderiam levar a economia norte-americana a um aumento da acumulação que fosse suficiente para prescindir do endividamento externo.

Mas dentro deste modelo de política econômica, esta possibilidade mais alvissareira se avizinhava difícil, primeiramente porque, nas condições de livre mobilidade dos capitais, o papel que a administração conferiu ao dólar no mundo acarretava, necessariamente, um crescente saldo na conta de capitais, com conseqüente déficit nas transações correntes. Em segundo lugar porque jogava parte do setor industrial sob o fardo dos déficits comerciais consolidados. Este setor industrial, com taxas de lucro crescendo pouco, assistia o crescimento mais rápido dos setores financeiros e de serviços. Realmente, tendo diminuindo sua participação relativa no produto, o setor industrial seria cada vez menos capaz de induzir a um crescimento sustentado da economia, mesmo quando suas taxas de lucro se mostrassem ascendentes.

Deste modo, as vantagens trazidas pelas opções acumulativas escolhidas no início da década de (19)80 trouxeram outros tipos de decorrências negativas, inevitáveis quando os administradores se defrontaram com um leque de escolhas a tomar. Manteve-se o papel do dólar como divisa referencial principal no mundo e lançou-se o endividamento externo como mecanismo de estabilização das flutuações. Mas isto foi feito às custas de perdas no comércio internacional e de diminuição relativa da produção doméstica. 
A administração Bush (1989-1992)

\begin{abstract}
"Nos tempos modernos, durante uma depressão ou quando a economia é ameaçada por um estancamento em virtude do monopólio crescente e do debilitamento do impulso para acumular, os gastos suntuários, como um remédio para a desocupação, são preferíveis aos gastos em armamentos, mas obviamente são menos benéficos que a inversão em capacidade produtiva industrial ou em serviços públicos.”
\end{abstract}

Joan Robinson, A Acumulação de Capital, 1955.

\subsection{Introdução}

$\mathrm{N}$

o início da década de (19)90 a economia dos Estados Unidos voltaria a apresentar forte flutuação, entrando na pendente decrescente da viragem cíclica após a expansão entre 1984 e 1989. Esta flutuação cíclica foi aguçada (a) pela política monetária restritiva do Fed em 1988, ainda na administração anterior; (b) por uma crise no sistema de crédito; e (c) pelo "engessamento" da política fiscal do governo federal, dada a aprovação da lei orçamentária de 1990, que restringia os déficits orçamentários. Um aumento nos preços do petróleo devido aos acontecimentos no Golfo Pérsico também contribuiu para a instabilidade, pressionando os níveis de consumo das famílias e elevando custos produtivos intersetoriais. A média do crescimento do produto somou $2,1 \%$ nos quatro anos, com uma recessão de 0,2\% em 1991, tal conformou cenário pouco animador, a explicar o fim de doze anos de governo Republicano. A economia continuou devedora do exterior, como meio de atenuar a crise. Este capítulo estuda então: (a) as causas da crise de 1990-1991; (b) o auxílio do governo norte-americano ao sistema financeiro; (c) as alterações no sistema fiscal em 1990 e como a política econômica adotada durante a crise foi prejudicada pela lei. No fim, comenta-se o comportamento do endividamento externo durante o período.

\subsection{Um novo presidente republicano}

Como se pôde observar nos capítulos precedentes, o Program for Economic Recovery da primeira administração de Reagan, lançado logo no início de seu primeiro mandato, concentrava-se na eliminação dos direitos sociais dos pobres e na queda dos índices de inflação, combinando isto com (a) diminuição de impostos aos setores mais ricos e às corporações e (b) com altos investimentos na indústria da guerra. Evidentemente, tal levou a enorme aumento dos déficits fiscais do governo federal. Este, conjugado com uma grande retração da demanda agregada e elevação dos juros, fez com que os índices de inflação caíssem. Assim, os índices de endividamento externo cresceram. A queda dos salários ajudou a taxa de lucros a recompor-se, 
e, não obstante o crescimento rápido dos ganhos financeirizados, a economia voltaria a crescer a partir de 1984. É claro que parte importante do crescimento em 1984 dava-se apenas pela recuperação dos espaços deixados pela recessão dos anos anteriores - notadamente muitas falências e capacidade ociosa -, mas ele teve um componente de gastos militaristas crucial. E este crescimento agora se dava cada vez mais à base de um aumento da dívida externa.

Nos anos seguintes, já durante o segundo mandato de Reagan, a economia norteamericana recuperaria crescimento, com base, como também se viu, em enorme elevação do endividamento externo. Isto veio conjugado com mais investimentos na indústria de guerra. Os Estados Unidos endividavam-se rapidamente e o déficit público crescia vertiginosamente; mas a União Soviética era derrotada, em contrapartida. Viu-se também como o Acordo do Plaza em 1985 forçaria o Japão e a Alemanha a desvalorizar suas moedas face ao dólar, exercendo posteriormente pressão sobre os parques manufatureiros destas grandes potências.

De fato, a eleição do novo presidente em 1988, George W. Bush, parecia manter a perspectiva do complexo industrial-militar no comando da nação. Quando jovem, Bush prestara serviço militar no Pacífico, como aviador durante a Segunda Guerra Mundial. Em 1944, numa missão em Chichi Jima (Japão) sua aeronave fora abatida e dois dos três tripulantes morreram. Foi então condecorado com três medalhas pelos serviços à força aérea norte-americana. Depois de estudar economia na Universidade de Yale, começou a investir no setor de exploração de petróleo no Texas. Ingressou no Partido Republicano em 1963, e foi eleito deputado em 1966, pelo mesmo Estado do Texas. Foi reeleito quatro anos depois.

Após o término de seus dois mandatos como deputado, Bush serviu ao governo dos Estados Unidos em várias outras funções, como embaixador, e chegou até a deslocar-se para a China, ainda trabalhando para o governo, durante dois anos. Em 1976 tornou-se diretor da Central de Inteligência norte-americana (CIA). Em 1979 anunciou sua candidatura à presidência dos Estados Unidos, candidatura esta que, como se viu, fora sobrepujada pela de Ronald Reagan. Foi então à Casa Branca na condição de vice de Reagan, e ali permaneceu até o fim dos dois mandatos. Suas funções como vice concentravam-se nos compromissos diplomáticos do governo norte-americano; nos relativos à Otan; e no que o governo dos Estados Unidos estava chamando já de "combate ao terrorismo". Em 1988, foi o candidato do Partido Republicano para as eleições presidenciais. No bojo da expansão econômica do segundo governo Reagan, foi eleito.

\subsection{O Financial Institutions Reform Recovery and Enforcement Act (FIRREA) de 1989}

Viu-se como (1) a elevação dos juros no fim dos anos (19)70 e (2) o surgimento de novas oportunidades de aplicação financeira, além da (3) política de desregulação da administração Reagan, conduziram a desajustes interssetoriais no sistema financeiro. Estes culminaram com um hipertrofiamento de alguns setores e com a insolvência de outros - caso dos bancos que compunham o sistema de Savings\&Loans. No fim da década de 19(80), a crise 
agravou-se, com acúmulo de quebras de bancos regionais, causando retração nos empréstimos bancários. Inclusive, não só o sistema de Savings\&Loans passava por problemas. Muitos bancos comerciais que haviam emprestado aos países periféricos na década anterior viam-se diante da possibilidade do crack. Isto mesmo no fim da década, após anos de pagamento do principal e dos juros.

Observou Greenspan sobre este período:

"Os bancos comerciais estavam também com sérios problemas. Isto foi uma dor de cabeça ainda maior do que a dos Savings\&Loans porque os bancos representam um setor muito maior e mais importante da economia. Os anos finais da década de (19)80 marcaram seu pior período desde a Grande Depressão; centenas de pequenos e médios bancos faliram, e gigantes como o Citibank e Chase Manhattan estavam aflitos. Seu problema, assim como com os $S \& L s$, foram muitos empréstimos especulativos. No início dos anos (19)80, os principais bancos tinham se aventurado com a dívida externa da América Latina, e então, quando aqueles empréstimos complicaram-se, como apostadores amadores tentando se ajustar, eles apostaram ainda mais, levando todo o setor a uma farra de empréstimos imobiliários." 184

É verdade que antes das políticas de Reagan já havia um ambiente instável para o sistema de Savings\&Loans. Vela pena comentar rapidamente um pouco a cronologia dos fatos. ${ }^{185}$ Pelo menos desde os anos (19)70, reiterações do processo de "desintermediação" - pelo qual o teto das taxas de juros de tais bancos levava a uma maciça fuga de recursos para instrumentos com retornos mais atrativos - dificultavam sua administração. $O$ sistema passava a enfrentar a concorrência de mercados financeiros cada vez maiores e dinâmicos. Ao mesmo tempo, era inicialmente proibido aos Savings\&Loans participar investindo em tais novos mercados. Posteriormente, foram seguindo-se medidas parciais de liberalização para que tais pressões inibidoras fossem relaxadas, como o Financial Institutions Regulatory and Interest Rate Control Act of 1978. Este permitia que os $S \& L s$ investissem 5\% de seus ativos em áreas como construção civil e empréstimos para educação. Depois, o Depository Institutions Deregulation and Monetary Control Act (DIDMCA), de 1980 - portanto ainda na administração Carter removeu o teto de taxas de juros pagas por tais bancos aos seus depositantes.

\footnotetext{
184 "Commercial banks were also in serious trouble. This was an ever bigger headache than the $S \& L S$ because banks represent a far larger and more important sector of the economy. The late 1980s was their worst period since the Depression; hundreds of smalls and medium-size banks failed, and giants like Citibank and Chase Manhattan were in distress. Their problem, as with the $S \& L s$, was too much speculative lending: in the early eighties, the major banks had gambled on Latin American debt, and then, as those Loans went bad, like amateur gamblers trying to get square they'd bet even more by leading the whole industry into a binge of commercial real state lending." GREENSPAN, Alan. The Age of Turbulence, p.117.

${ }^{185} \mathrm{O}$ endereço eletrônico do Federal Deposit Insurance Corporation, o órgão Federal responsável pela administração do sistema de financiamento de casas e imóveis, traz uma cronologia completa, além de uma extensa bibliografia, sobre a sucessão de crises. Cf.: www.fdic.gov/ .
} 
Já no governo Reagan, em 1981 o Tax Reform Act of 1981 incentivava investimentos em imóveis, com isenções diversas para que a demanda por empréstimos dos $S \& L s$ aumentasse; ainda em 1981, o Federal Home Loan Bank Board, emitiu títulos adquiridos pelos $S \& L s$ que passaram a contar como aumento de seu capital, postergando, e mesmo mascarando, a situação insolvente de muitos. A contrapartida foi um aumento do endividamento federal.

Não obstante seguirem-se políticas de desregulamentação e aumento de oportunidades para investimentos dos $S \& L s$ em outras áreas do sistema financeiro, além da própria queda da taxa de juros no desenrolar da década, crises e falências sucederam-se. Em Março de 1985 o governador do estado de Ohio ordenou o fechamento dos $S \& L s$, diante da iminência do colapso do sistema bancário. Em Maio, a sucessão de crises em Maryland levou a perdas que chegariam a quase 200 milhões de dólares para os depositantes dos $S \& L s$, que haviam falido. Seguiram-se investigações dos órgãos federais, com trocas de chefes de tais instituições e intimações a dirigentes de bancos falidos. O governo Reagan permitiu que instituições praticamente falidas continuassem operando. Em 1987, a crise impactou no estado do Texas, cujas perdas avolumadas chegaram praticamente à metade das perdas do país. Com isso, a economia texana entrou em forte recessão, com aumento rápido do desemprego e queda dos preços de imóveis e do petróleo.

Então a crise dos Savings\&Loans, desde os últimos anos da administração Reagan, havia se ampliado, pondo em xeque a solvência do sistema. Uma sucessão de medidas paliativas fora tomada ao longo da década, em âmbito estadual e federal, como revisões dos padrões de empréstimos, repasses dos bancos quebrados a instituições maiores, e limitações às políticas de investimentos dos Savings\&Loanss. Elas haviam sido relaxadas no início da década. Mas os crescentes desequilíbrios nos diversos bancos estaduais se avolumavam, com conseqüentes desdobramentos para os bancos comerciais e pressão nos perfis correntes de concessão de crédito. As agências federais - principalmente o Federal Home Loan Bank Board, responsável pelo seguro de parte importante dos depósitos dos $S \& L$ 's - viram suas obrigações crescerem, por conseqüência. O mandato de Reagan terminou sem que esta questão tivesse ganhado resolução, de que modo que o debate presidencial de 1988 a teve como um dos temas principais.

Foi após a eleição de Bush que o governo federal interviu para dar cabo de uma situação que ameaçava o próprio sistema financeiro norte-americano, o que geraria virtuais conseqüências catastróficas para o papel do dólar. E, por decorrência, para a estratégia do crescimento com endividamento externo. Logo em Fevereiro o presidente assinou decreto, aprovado pelo Congresso um pouco antes, de reformulação do sistema sobre o qual se estruturavam os bancos do sistema Savings\&Loans. O chamado Financial Institutions Reform Recovery and Enforcement Act (FIRREA) constituía-se basicamente da abolição de algumas agências por outras agora mais capitalizadas. Elas teriam recursos novos iniciais de 50 bilhões. Estas agências seriam um novo centro realinhador de empréstimos às casas ainda em dificuldades, e supervisionariam uma legislação agora mais restritiva sobre os bancos. As instituições quebradas iriam literalmente ser salvas pelas novas agências. A principal alteração 
foi a substituição do falido Federal Savings and Loans Insurance Corporation, principal instituição responsável por supervisionar os seguros sobre os depósitos dos S\&L's, e que existia desde 1934, pela nova Federal Deposit Insurance Corporation (FDIC). A insolvência da instituição ocorrera pelo aumento rápido dos seguros pagos às casas quebradas, já que elas haviam usado os depósitos segurados em investimentos pouco lucrativos.

Observaram os autores do Economic Report of the President de 1989, escrito um pouco antes de Bush assinar o FIRREA:

“A rápida ascensão das falências [dos $S \& L$ 's] colocou o peso principal nas instituições seguradoras de depósitos. O Federal Savings and Loans Insurance Corporation (FSLIC), que provê seguros de depósitos para associações de poupança e empréstimos, está insolvente desde 1986. O Federal Deposit Insurance Corporation (FDIC), que garante seguros a bancos comerciais e alguns bancos de depósitos, ainda está solvente, mas vai ter perdas líquidas em 1988. Estimativas dos custos totais para o FSLIC em relação ao fechamento bancos de depósitos insolventes têm crescido rápido. O Federal Home Loans Bank Board, que regula estas instituições, agora estima que estes custos cheguem à casa de 50 bilhões de dólares." 186

A intervenção de resgate aos bancos falidos dar-se-ia do seguinte modo: as novas agências federais seguradoras - como a Resolution Trust Corporation ou a própria Federal Deposit Insurance Corporation (FDIC) - adquiriria por 100 milhões, por exemplo, um banco com depósitos e ativos segurados no valor total corrente de 85 milhões. A agência emprestaria do orçamento federal 100 milhões para adquirir tais ativos e assegurar os recursos aos clientes do banco. Estaria assim assegurando que estes clientes mantivessem seus recursos no sistema. Os 15 milhões excedentes seriam o resultante aumento da dívida Federal advindo desta transação.

Mas além do resgate dos bancos quebrados, a lei continha novos elementos legais intervenientes. Como se lê no Survey of Current Business de Dezembro de 1989, a lei "aumentou os valores a serem pagos pelas instituições seguradas pelos seguros de depósitos e aumentou os requerimentos tangíveis de capital - isto é, a taxa entre o capital e os ativos - que as casas precisam manter". ${ }^{187}$ Por decorrência, o FIRREA sinalizava uma parcial volta atrás no

\footnotetext{
186 "The sharp rise in failures has placed a major burden on the deposit insurance systems. The Federal Savings and Loans Insurance Corporation (FSLIC), which provides deposit insurance for Savings and Loans associations, has been insolvent since 1986. The Federal Deposit Insurance Corporation (FDIC), which insures commercial banks and some Savings banks, is still solvent, but will run a loss for 1988. Estimates of the costs to the FSLIC of closing insolvent thrifts have risen steadily. The Federal Home Loans Bank Board, which regulates these institutions, now estimates this cost to be in the range of $\$ 50$ billion."

187 "The act increased the premium to be paid by insured institutions for deposit insurance and increased the tangible capital requirements - that is, the ratio of capital to assets - that institutions must maintain in business." Survey of Current Business, v.12, Dezembro de 1989, p.2. Disponível em: http://fraser.stlouisfed.org/
} 
processo de desregulação do sistema: limitava os $S \& L s$ a suas atividades costumeiras, e permitia seus investimentos em outras atividades desde que tais investimentos não fossem aqueles segurados pelas agências federais. Por fim, o FIRREA alterou também - tornando-as mais rígidas - as regras para punições de executivos envolvidos com processos de investimentos arriscados, considerados responsáveis pelas quebras de algumas casas.

Tal regulamentação de parte do sistema bancário era, no entanto, apenas uma medida de contenção conjuntural. Uma nova onda de desregulamentação estaria por vir com o governo democrata de Clinton.

\subsection{O Omnibus Budget Reconciliation Act of 1990}

O primeiro semestre de 1990 espelhava o surgimento das condições da recém criada unipolaridade mundial. O presidente anunciava no início do ano um plano de tratado de livre comércio para a América do Norte, o North American Free Trade Agreement (NAFTA), e no fim de Junho, de modo megalomaníaco, o Enterprise for the Americas Initiative, que visava englobar todo o hemisfério ocidental sob a égide do livre comércio, com liderança norteamericana. Ao passo que mais à frente Clinton conseguiria aprovar o primeiro, o segundo nunca deixaria o papel, em parte pela sua pouca viabilidade real.

Tabela 1. Estados Unidos. Variações trimestrais do PIB (\%). 1989-1990.

\begin{tabular}{cccc}
\hline Trimestres & PIB (\%) & Trimestres & PIB (\%) \\
1989q1 & 4,1 & $1991 \mathrm{q} 1$ & $-2,0$ \\
$1989 \mathrm{q} 2$ & 2,6 & $1991 \mathrm{q} 2$ & 2,6 \\
$1989 \mathrm{q} 3$ & 2,9 & $1991 \mathrm{q} 3$ & 1,9 \\
$1989 \mathrm{q} 4$ & 1,0 & $1991 \mathrm{q} 4$ & 1,9 \\
$1990 \mathrm{q} 1$ & 4,7 & $1992 \mathrm{q} 1$ & 4,2 \\
$1990 \mathrm{q} 2$ & 1,0 & $1992 \mathrm{q} 2$ & 3,9 \\
$1990 \mathrm{q} 3$ & 0,0 & $1992 \mathrm{q} 3$ & 4,0 \\
1 1990q4 & $-3,0$ & $1992 \mathrm{q} 4$ & 4,5 \\
\hline
\end{tabular}

Fonte: NIPA-BEA. Seção I, Domestic Product and Income, Tabela 1.1.1., Percent Change From Preceding Period in Real Gross Domestic Product.

O orçamento do governo federal, cuja situação melhorava desde 1987, com progressiva queda absoluta dos déficits até este ano de 1989, ver-se-ia pressionado pelo FIRREA. Os custos estimados de 50 bilhões iniciais para criação das novas agências foram alterados para um valor muito maior, depois de assinada a lei. Em 1991, a equipe econômica declarava, no Economic Report, que os custos totais para o orçamento federal do FIRREA seriam muito maiores, chegando a quase 180 bilhões. 
A pendente negativa do ciclo que se iniciava determinaria que tal peso adicional sobre o orçamento, vindo da criação das novas agências de seguros dos $S \& L s$, fosse ainda maior. O produto variou 3,5\% em 1989. Tal desempenho foi auxiliado por uma elevação das exportações sem precedente na década anterior, com o país recuperando posições internacionais via principalmente o rebaixamento do preço do dólar. Mesmo assim, o perfil do comportamento do PIB mostrou-se cadente, com variações trimestrais decrescentes de 4,1\%, 2,6\%, 2,9\% e 1\% no fim do ano. No segundo semestre do ano, já se percebia que havia nítida desaceleração em curso. Em 1990, as forças desacumuladoras continuaram crescendo, com variações decrescentes do produto de $4,7 \%, 1,0 \%, 0$ e $-3 \%$ nos quatro trimestres. Com a crise avolumando-se, era claro que o FIRREA assumiria uma carga relativa mais difícil para o orçamento, acirrando ânimos entre (1) os defensores da necessidade de zerar os déficits e diminuir impostos e () os favoráveis a uma política mais intervencionista.

De fato, o discurso de Bush logo depois de sua eleição, para o tradicional State of Union no início de 1989, enfatizava tais pontos tradicionalmente defendidos publicamente pelos Republicanos. Sua aplicação sempre resultara difícil, pelo trade off existente entre a diminuição dos impostos e a diminuição dos déficits. Ao longo da campanha presidencial, Bush colocara acento particularmente grande no mote de não elevar tributos. Ficara famosa a sentença proferida em frente às câmeras: "Leiam meus lábios: sem mais impostos". No início de 1989, apresentando as propostas de governo, junto da política orçamentária, comentou:

"Meu plano tem quatro principais características: atenção a prioridades urgentes, investimento no futuro, um ataque ao déficit, e não mais impostos. Este orçamento representa meu melhor juízo sobre como podemos levar à frente nossas prioridades. Há muitas áreas nas quais gostaríamos de gastar mais do que proponho; eu entendo isto. Mas não podemos até que ponhamos nossa situação fiscal em ordem." 188

Portanto, a situação orçamentária do governo federal, mesmo depois da pendente cíclica ascendente de 1984-1988, e das leis sobre os limites dos déficits de 1985 e 1987, continuava a pautar o debate sobre a política econômica, geralmente com um viés crítico acerca dos déficits. A conjunção dos gastos com o FIRREA e a desaceleração do produto ao longo do ano forçaram o governo a uma outra abordagem. Decidiu-se por uma elevação dos impostos, contrariamente ao que prometera Bush na campanha. A medida lhe traria altos custos políticos com o eleitorado e com a ala mais à direita do Partido Republicano. Ela evidenciava-se necessária diante da

\footnotetext{
188 "My plan has four broad features: attention to urgent priorities, investment in the future, an attack on the deficit, and no new taxes. This budget represents my best judgment of how we can address our priorities. There are many areas in which we would all like to spend more than I propose; I understand that. But we cannot until we get our fiscal house in order." Discurso para o State of Union de 1989. Pode ser encontrado em: http://www.let.rug.nl/usa/P/gb41/speeches/su89ghwb.htm
} 
pressão do FIRREA sobre o orçamento federal. A necessidade do financiamento externo das contas do governo apareceu como ainda mais útil, diante de tais barreiras internas.

Este aumento dos impostos foi consubstanciado na lei que se chamou de Omnibus Budget Reconciliation Act of 1990, aprovado em 5 de Novembro. Ela estabelecia limites máximos de gastos no exterior, de defesa e de consumo doméstico do governo, sob o expediente do que se definiu de sistema "pay-as-you-go". A saber: quaisquer novas propostas de redução de taxas ou de aumento de gastos em algum dos itens do consumo da administração pública teriam de ser compensados por uma diminuição correspondente em algum outro item. Ou por um novo aumento de impostos.

O miolo da lei envolvia o seguinte leque de mudanças: (i) diminuição de gastos em itens específicos do orçamento; (ii) eliminação paulatina das isenções fiscais aos contribuintes cuja renda bruta reajustada de um ano para o outro ultrapassasse a respectiva faixa máxima de isenções para tal renda; (iii) aumento de impostos sobre o tabaco, álcool e gasolina. Por outro lado, a lei previa, mediante uma diminuição de impostos sobre os ganhos de capital, (iv) aumentar a arrecadação pelo (supostamente) conseqüente aumento dos ganhos de capital dos contribuintes que investissem. Por fim, também como medida compensatória, (v) a lei estendeu a cobertura de seguro médico para todos os funcionários da administração pública estadual e local.

Lia-se no Economic Report de 1991 um resumo das propostas da lei:

"Primeiramente, o Budget Reconciliation... contém mecanismos críveis de contenção [de gastos federais], introduzindo limites máximos para os gastos e regras de 'pay-as-you-go', para impedir que as futuras legislações permitam com que o déficit cresça de novo. Os limites [caps] colocaram em ação o conceito de 'congelamento flexível' [flexible freeze]: dentro de cada categoria de gasto específica, qualquer aumento de gastos deve ser contrabalançado por cortes para permanecer dentro do limite.

Em segundo lugar, novos procedimentos sistemáticos melhoram a capacidade dos estabilizadores automáticos de minorar as flutuações negativas no curto prazo. Sob a nova lei, os alvos de déficit são ajustados para mudanças nas condições econômicas, tal como refletido nas previsões das autoridades. [...] Contrariamente, a lei anterior não tinha nenhum expediente para ajustar os alvos de déficit sem suspender todo o mecanismo de controle.

Outro elemento importante da política fiscal desta Administração é um compromisso com um sistema fiscal com baixas taxas marginais de impostos e as menores barreiras possíveis em relação ao crescimento. A administração propôs uma redução na taxa de imposto sobre ganhos de capital de longo prazo. Uma redução deste imposto afetaria o setor imobiliário e outros ativos fixos favoravelmente, aliviando assim problemas de capital e de balancetes tanto nos 
setores financeiros e não financeiros. [...] Tal encorajará o empreendedorismo, tão essencial para a criação de novos empregos e para a comercialização de novas ideias." 189

Seguia-se daí um comentário sobre o Omnibus Budget Reconciliation Act of 1990. Ele continha, segundo o documento, a maior proposta de redução de déficit fiscal da história do país, prevendo diminuir ao longo dos próximos cinco anos um total de 500 bilhões de dólares deste déficit. Segundo tal, o aumento da poupança iria favorecer o investimento. Por outro lado, dizia-se que a arregimentação do orçamento agora trazia embutida um procedimento sistemático para ajuste automático dos gastos do governo, com vistas a diminuir os efeitos de cada declínio no curto prazo. Porém, não se fazia menção aos itens sobre os quais incidiriam os aumentos de impostos, nem sobre os novos limites de isenção para os contribuintes. Enfatizava-se apenas que as taxas sobre os ganhos de capital seriam diminuídas.

Tal ação dos estabilizadores automáticos, "sem que o sistema inteiro da lei fosse suspenso", seria de fato utilizado a partir do segundo trimestre de 1991 e levado à frente até 1992. Tal utilização dos déficits sem que a lei fosse cancelada certamente seria uma característica que impediu que os déficits fossem maiores do que efetivamente foram. Isto dada a dimensão da crise. Ela desfavoreceria, portanto, uma administração mais efetiva. Havia aí uma exigência de rigor no cumprimento da lei não existente na administração de Reagan.

\subsection{A crise de 1990-1991}

Depois da estabilização no interlúdio 1982-1985, a taxa de inflação voltou a apertar passo a partir de 1986, com variações de 4\% e depois 5\%, em 1987 e 1988. Em 1989, os juros subiram bastante, mas a variação dos preços caiu pouco, tendo sido de $6 \%$. No quarto trimestre, o produto variou apenas $1 \%$. Como não poderia deixar de ser, os indícios da crise provocaram uma nítida mudança de perspectiva do presidente do Fed.

\footnotetext{
189 "First, it contains credible enforcement mechanisms, using caps on spending and pay-as-you-go rules, to prevent new legislation from increasing the budget deficit. The caps put into effect the concept of a "flexible freeze": within each discretionary spending category, any spending increases must be offset by spending cuts to stay within the caps. Second, new systematic procedures enhance the ability of the automatic stabilizers to cushion downturns in the short run. Under the new law, deficit targets are adjusted for changes in economic conditions, as reflected in the Administration forecast. [...] In contrast, the previous law had no procedure for adjusting the deficit targets without suspending the entire enforcement mechanism. Another important element of Administration's fiscal policy is a commitment to a tax system with low marginal tax rates and the lowest possible barriers to economic growth. The Administration has proposed a reduction in the tax rate on long-term capital gains. A capital gains tax cut would affect real state and other asset values favourably, thereby alleviating capital and balance sheet problems in both financial and non-financial corporations. [...] And it would encourage entrepreneurship so essential for the creation of new jobs and the commercialization of new ideas." Economic Report of the President, 1991, p.27.
} 
Tabela 2. Estados Unidos. Índice de Preços ao Consumidor para todos os itens e taxa de variação percentual de um ano a outro. 1986-1993.

\section{(1)}

Anos

1986

1987

1988

1989

1990

1991

1992

1993
(2)

Índice de Preços ao Consumidor para todos os itens

109,6

113,6

118,3

124,1

130,7

136,2

140,3

144,5
(3)

Taxa de variação percentual de um ano a outro

2

4

5

6

6

6

4

Fonte: Economic Report of the President, 2006. Tabela B-60, Consumer Price Indexes for major expenditure classes, 1959-2005, e Tabel B-63, Changes in special consumer price indexes, 1960-2005.

Em Janeiro de 1989, Greenspan observava otimista:

"Ao começar o ano de 1989, parece haver poucos sinais de qualquer impedimento para uma expansão continuada. A história dos ciclos nos indica alguns lugares para que busquemos problemas. Um deles é uma acumulação excessiva de inventários. No momento, o acúmulo de estoques é, no entanto, isolado e administrável. Um outro é o excesso de construção de capacidade instalada; mesmo que saibamos que há claramente muitas empresas com capacidade ociosa no país, a capacidade de utilização industrial está relativamente bem utilizada, apertada mesmo em alguns setores. [...] O mercado de trabalho está mostrando claros sinais de aperto. As taxas de utilização da capacidade no mercado de trabalho moveram-se rapidamente nos últimos quatro anos." 190

Para este Greenspan do início de 1989, a taxa de desemprego se aproximava da situação que a economia "neokeynesiana" (ou neoneoclássica?) definia como a de Non-Accelerating Inflation Rate of Unemployment (NAIRU) - isto é, a suposta máxima taxa de emprego da força de trabalho que se pode obter sem que não se pressionem para cima os índices de inflação. Estava-se aí no zênite da expansão da segunda administração Reagan. O diagnóstico que Greenspan vinha fazendo desde 1988 era de que de fato se mostrava necessário exercer uma contenção sobre o crescimento dos meios de pagamento e sobre as taxas de juros.

\footnotetext{
190 "As we enter 1989, there are few signs of any significant impediments to continued expansion. Business cycle history tells us some places to look for danger signals. One of them is excessive accumulation of inventories. At present, overhangs of stocks are rather isolated and manageable. Another is overbuilding of capacity, while there clearly are a good many empty office buildings around the country, industrial capacity is relatively fully utilized-indeed, tight in some industries. [...] The labor market is showing clear signs of tightening. [...] Utilization rates for plants and equipment, as in the labor market, have moved up sharply over the past few years." GREENSPAN, Alan. "Chairman, Board of Governors of the Federal Reserve System before the Committee on Banking, Finance, and Urban Affairs. U.S. House of Representatives." 24 de Janeiro de 1989.
} 
Tabela 3. Estados Unidos. Taxas de juros selecionadas (\%).

\begin{tabular}{|c|c|c|c|}
\hline \multirow[t]{3}{*}{ (1) } & $(2)$ & (3) & (4) \\
\hline & Treasury & & \\
\hline & $\begin{array}{l}\text { Securities - } \\
3 \text { meses }\end{array}$ & $\begin{array}{c}\text { Fed Funds Rate } \\
\text { - anual }\end{array}$ & Moody's Aaa \\
\hline 1988./Jan. & 5,9 & 6,83 & 9,88 \\
\hline Fev. & 6,69 & 6,58 & 9,40 \\
\hline Mar. & 5,69 & 6,58 & 9,39 \\
\hline Abr. & 5,92 & 6,87 & 9,67 \\
\hline Mai. & 6,27 & 7,09 & 9,90 \\
\hline Jun. & 6,5 & 7,51 & 9,86 \\
\hline Jul. & 6,73 & 7,75 & 9,96 \\
\hline Ago. & 7,02 & 8,01 & 10,11 \\
\hline Set. & 7,23 & 8,19 & 9,82 \\
\hline Out. & 7,34 & 8,3 & 9,51 \\
\hline Nov. & 7,68 & 8,35 & 9,45 \\
\hline Dez. & 8,09 & 8,76 & 9,57 \\
\hline Jan./1989 & 8,29 & 9,12 & 9,62 \\
\hline Fev. & 8,48 & 9,36 & 9,64 \\
\hline Mar. & 8,83 & 9,85 & 9,8 \\
\hline Abr. & 8,70 & 9,84 & 9,79 \\
\hline Mai. & 8,40 & 9,81 & 9,57 \\
\hline Jun. & 8,22 & 9,53 & 9,10 \\
\hline Jul. & 7,92 & 9,24 & 8,93 \\
\hline Ago. & 7,91 & 8,99 & 8,96 \\
\hline Set. & 7,72 & 9,02 & 9,01 \\
\hline Out. & 7,63 & 8,84 & 8,92 \\
\hline Nov. & 7,65 & 8,55 & 8,89 \\
\hline Dez. & 7,64 & 8,45 & 8,86 \\
\hline 1990 & 7,51 & 8,11 & 9,32 \\
\hline 1991 & 5,42 & 5,69 & 8,77 \\
\hline 1992 & 3,45 & 3,52 & 8,14 \\
\hline
\end{tabular}

Fonte: Economic Report of the President, 1993. Tabela B-69, Bond yields and interest rates, 1929-92.

Como mostram as variações do PIB, no segundo semestre de 1989 já se podia perceber a desaceleração em curso. Neste ínterim, o acúmulo dos fatores depressivos impactaram no produto a ponto de Greenspan e o Fed terem de rever sua posição otimista sobre a capacidade de a economia estender por mais tempo a ascensão iniciada em meados da década. De modo que Greenspan, em Agosto de 1989, já mudara seu tom, afirmando que...

"Ao longo do curso deste ano, os contornos do cenário econômico mudaram. Como conseqüência, os parâmetros da política monetária também mudaram um pouco, apesar da manutenção dos objetivos fundamentais de nossa política. Este objetivo continua sendo maximizar crescimento econômico sustentável, que por sua vez requer a manutenção de preços estáveis ao longo do tempo. No início do ano, o Fed continuou no caminho em direção à contínua restrição na qual embarcou na primavera de 1988. [Mas] no início do segundo trimestre, o panorama para os gastos e para os preços tornou-se mais turvo. Alguns sinais 
espalhados de que a atividade econômica havia diminuído começaram a aparecer, forçando as taxas de juro do mercado a voltar atrás." 191

Portanto, em 1989, a política econômica via-se então premida entre tentar debelar os impactos da viragem cíclica e do "credit crunch" da crise do Savings\&Loans - via uma virtual diminuição dos juros - ou justamente encarar o aumento da inflação, pressionada pelos preços em alta do petróleo, elevando os juros. Antes dos sinais da crise, esta última opção foi escolhida pelo Fed, e os juros foram aumentando. Os juros dos Títulos do Tesouro de 3 meses foram de 8,09 a 8,80, de Dezembro de 1988 a Março de 1989. Subiram também as outras taxas importantes. A inflação aumentou um ponto percentual a cada três meses.

$\mathrm{O}$ aumento dos juros ajudaram a desacelerar um pouco a inflação, mas também o crescimento. No segundo semestre de 1989, depois do início do movimento depressivo do PIB, iniciava-se o movimento oposto da taxa de juros, com quedas sucessivas até Dezembro. No início de 1990, Greenspan já traçava um panorama conjuntural completamente diferente:

"Nos meses recentes, segmentos da indústria da construção relataram dificuldades na obtenção de crédito no bojo das novas restrições impostas pelas instituições de poupança. [Além disso] as instituições de empréstimos - exauridas por uma longa série de empréstimos questionáveis - estão mais cuidadosamente selecionando seus empréstimos do que no passado, de modo que os projetos de mais alto risco não estão sendo financiados como deveriam." 192

Destarte, à medida que a pendente descensional iniciava-se em 1990, Greenspan poria o combate à inflação em segundo plano, diante dos impactos da crise no mercado de crédito na economia real. Como se vê na tabela acima, já a partir de meados de 1989, o Fed procedeu a um radical rebaixamento da taxa de juros. Tal queda estendeu-se até 1992, o que por seu turno realinhou as taxas de juros no setor privado, como a Prime Rate e outras taxas do mercado. Todavia, mesmo neste ambiente depressivo - já que a desaceleração naturalmente forçava um pouco os preços abaixo - não foi fácil contornar a inflação em alta. Os preços ao consumidor

191 "Chairman, Board of Governors of the Federal Reserve System before the Committee on Banking, Finance, and Urban Affairs. U.S. House of Representatives." 01 de Agosto de 1989. "Over the course of this year, the contours of the broad economic setting have changed. As a consequence, the stance of monetary policy also have shifted somewhat, although the fundamental objective of our policy has not. That objective remains to maximize sustainable economic growth, which in turn requires the achievement of price stability over time. Early in the year, the Federal Reserve continued on the path toward increased restraint upon which it had embarked in the spring of 1988. [...] By the beginning of the second quarter, the outlook for spending and prices was beginning more mixed. Scattered indications of an emerging softening in economic activity began to appear, prompting market interest rates to pull back."

192 "In recent months, however, segments of the construction industry have reported difficulty in obtaining credit in the wake of newly imposed restrictions on lending by thrift institutions. [...] Moreover, lending institutions - stung by a long series of questionable investments - are more carefully scrutinizing Loans applications than in the past, so that high riskly projects are not getting funded as readily". "Testimony by Alan Greenspan before The Joint Economic Committee - United States Congress", p.4-5. 30.01.1990. 
variaram 6\% em 1990 e 6\% 1991. Eram as mesmas taxas que as que incomodavam Greenspan em 1987. Por sua vez, a variação do crescimento do PIB em 1990 cairia para 1,9\%, numa extensão dos efeitos desaceleradores iniciados no ano anterior. E para complicar ainda mais o comportamento macroeconômico, o preço do petróleo subiu de 1989 a 1990. Subiria mais entre 1990 e 1991. Neste caso, pela reação dos mercados dada a ocupação do Kwait pelo Iraque e depois pela subseqüente guerra norte-americana às forças de Hussein.

Gráfico 1. Estados Unidos. Preços de importação do barril do petróleo, em dólares correntes. 1974-1999.

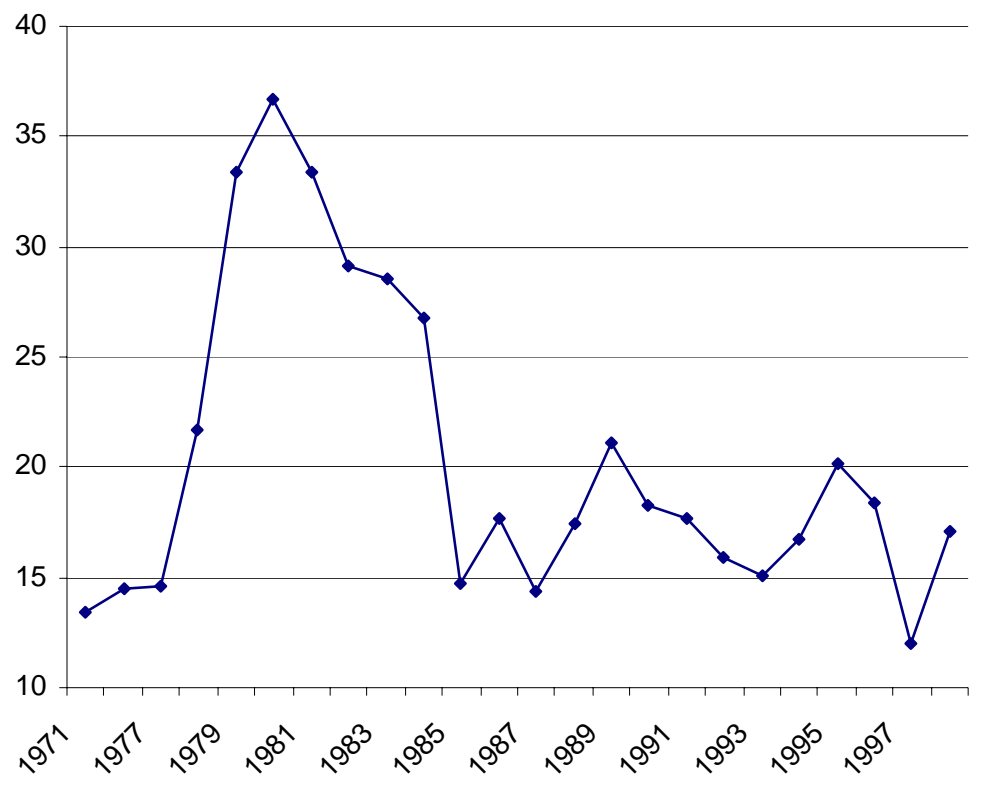

Fonte: OCDE. Ver www.stats.oecd.org/.

Com efeito, após as hostilidades com o Irã, as autoridades iraquinanas tiveram de enfrentar o enorme endividamento do país. Julgaram poder debelá-lo com a ocupação dos poços de petróleo do Kwait, com o argumento oficial de que as políticas deste país estavam destruindo os preços do petróleo no mundo. Como sugere Moniz Bandeira, Saddam Hussein parecia julgar que os Estados Unidos não interfeririam em seu movimento rumo ao Kwait. Isto porque até ali fora aliado de Washington. Mas "os Estados Unidos temeram que Saddam Hussein, desenfreado, avançasse contra a Arábia Saudita e se colocasse em posição de controlar os preços do petróleo no Oriente Médio". ${ }^{193}$

A partir da invasão do Kwait pelo Iraque, iniciaram-se então conversações na Casa Branca e no Pentágono sobre a posição dos Estados Unidos face ao ocorrido. Foi decidida no fim de 1990 a retaliação da ação de Hussein. A guerra foi iniciada em Janeiro de 1991 e finalizada com sucesso em Fevereiro. A agressão ao Iraque foi autorizada pela ONU e realizada sob a bandeira de mais de vinte nações, que arcaram com a maior parte dos custos, favorecendo

${ }^{193}$ Conferir p.508 e subseqüentes de Formação do Império Americano. 
os Estados Unidos. De qualquer modo, a Operação Desert Storm não estava constrangida pelo Budget Reconciliation Act.

Com isto, o setor automobilístico estadunidense desacelerou, com diminuição dos créditos para compra de veículos, de 290 para 284 bilhões de 1989 a 1990. O mesmo se deu junto da construção civil, cujos créditos para novas casas caíram de 1.931 para 1.913 bilhões, no mesmo período. Como mostra o apêndice estatístico do Economic Report de 1992, a taxa de desemprego subiu de 5,2\% para 5,3\% no primeiro semestre de 1990 , e de $5,6 \%$ para $6 \%$ no segundo. Em 1991 a taxa de desemprego para todos os trabalhadores chegou a 6,8\%, e a 7\% em 1992. A taxa de falência de novas empresas, medida sobre cada grupo de dez mil empresas listadas pelo governo, ascendeu a uma variação de 75\% em 1990. Chegaria a 98\% em 1991 (estava em 65\% em 1989). O número de empresas falidas, que em 1988 havia baixado para 57 mil, em 1989 caía ainda mais para 50 mil. Subiu a 60 mil em 1990.

\subsection{Uma recuperação tardia para evitar a derrota republicana}

Tal como observava Greenspan, "a variedade das forças que conformam o que estamos chamando de credit crunch não é o único motivo explicativo para o desempenho ruim da economia. Há muitos outros fatos afetando o panorama econômico atual." ${ }^{194}$ Consoante esta perspectiva, o Fed relaxava os juros e descomprimia a concessão de crédito, como medidas compensatórias. Além disso, ouviam-se no Congresso pedidos para que as alterações orçamentárias trazidas pelo Budget Reconciliation Act fossem temporariamente canceladas. Isto devido à crise. Greenspan e o Fed publicamente respondiam que tal revogação antecipada era errônea, pois supostamente não se podia prever exatamente qual seria o tamanho da recessão.

Como reflexo da lei, de 1990 a 1991 o déficit federal fora diminuído de 179 bilhões, no último trimestre, para 139 bilhões, no primeiro semestre do ano seguinte (1991). Mas com a crise em curso, tornou-se evidente a impossibilidade de manter tal política suicida, de modo que as regras de exceção entraram em vigor. Então, os déficits passaram a crescer de novo. Eles foram aumentando, em porcentagem do produto, de $0,02 \%$ no primeiro trimestre para $0,03 \%$ no segundo e terceiro; e para $0,04 \%$ no último. O fato, porém, é que tais concessões a aumentos do déficit teriam de ter sido muito maiores para evitar efetivamente a recessão que ocorreu.

Em 1992, depois de o comportamento errático do produto atravessar todo o triênio 1989-1991, a economia voltaria a apresentar maiores taxas de crescimento, de 4\% aproximadamente. E uma variação da inflação um pouco mais baixa, de 4\% (mesmo com recessão, fora de $6 \%$ no ano entre 1990 e 1991). O Fed continuou a relaxar a oferta de dinheiro,

\footnotetext{
194 "The variety of forces that make up what we have been calling the credit crunch is not the only reason for the disappointing performance of the economy. There are many other significant factors affecting the economic outlook. But the state of bank loan markets certainly is a key element." "Remarks of Alan Greenspan, Chairman, Board of Governors of the Federal Reserve System. $55^{\text {th }}$ Annual Dinner of the Tax Foundation." Nova York. 18 de Novembro de 1992.
} 
com as taxas dos Títulos do Tesouro e de desconto do Fed estando menores ainda ${ }^{195}$. O déficit federal, porém, praticamente não voltou a crescer em termos do PIB, estabilizando-se durante todos os trimestres em 4,9\% do produto. Certamente, uma variação maior dos gastos teria influído positivamente nas eleições do fim do ano. Mas os primeiros sinais da recuperação impediram a continuidade da atuação dos dispositivos de exceção da lei orçamentária, de modo a ter tornado a administração das contas federais novamente próxima do princípio pay-as-yougo.

Infelizmente, para os Republicanos, a taxa de desemprego chegava ao zênite justamente no momento das eleições presidenciais, no fim de 1992. Para o montante de trabalhadores em atividade, os impactos da crise mostraram-se mais agudos justamente no fim deste ano: a taxa de desemprego total chegava a 7,4\% da força de trabalho. Era ela a mais alta desde 1984 . Desagregada, a taxa média de desemprego para trabalhadores negros foi 14,1\% em 1992, e para os trabalhadores brancos, $6,5 \%$. Ambas não diminuíram ao longo do ano. A recuperação cíclica do produto gerou efeitos apenas em 1993, depois das eleições. Tal determinou a sorte de Bush.

Tabela 4. Estados Unidos. Taxas de desemprego entre trabalhadores brancos e negros (em \%).

\begin{tabular}{ccc}
$(1)$ & $(2)$ & $(3)$ \\
& Taxa de desemprego (em \%) & \\
& Negros & Brancos \\
1989 & 11,4 & 4,5 \\
1990 & 11,3 & 4,7 \\
1991 & 12,4 & 6,0 \\
$992 /$ Jan. & 13,6 & 6,3 \\
Mar. & 13,9 & 6,5 \\
Mai. & 14,6 & 6,5 \\
Jul. & 14,4 & 6,6 \\
Set. & 13,8 & 6,6 \\
Out. & 14,0 & 6,4 \\
Dez. & 14,2 & 6,4 \\
\hline
\end{tabular}

Fonte: Economic Report of the President, 1994. Tabela B-36, Unemployment by demographic characteristics, 1954-93.

Não deixa de ser curioso que a administração que estava à testa do governo norteamericano durante o fim do campo socialista mundial tivesse o destino, justamente, de perder as primeiras eleições realizadas no agora "mundo unipolar". Isto não pode ser explicado senão pelo relativo isolamento da vida política norte-americana face ao resto do mundo. A vitória de Bill Clinton, pelo Partido Democrata, demonstrava que as taxas de desemprego eram mais importantes para a maior parte dos eleitores do que a imposição da hegemonia norte-americana num mundo agora sem inimigos à altura. A rápida ação contra o Iraque em 1991, praticamente

195 Diferentemente, todavia, era o estado das taxas privadas neste momento. Estas se viam mais altas devido à crise financeira em curso. A Moody's Aaa fecharia o ano com média 8,14\%, e a Prime Rate a $6,25 \%$. 
um passeio das forças norte-americanas, era uma demonstração do tipo de poderio militar que a "nova guerra fria" de Reagan havia legado. Mas não fora suficiente para que a administração de George Bush fosse aprovada para um segundo termo. Não à toa, Bill Clinton vencera com o mote de "É a economia, burro!", pondo fim a doze anos de administração republicana nos Estados Unidos.

\subsection{Uma análise de dados}

a) O orçamento federal

Como se notou, as leis orçamentárias de 1990 foram formuladas de acordo com o princípio "pay-as-you-go", no qual um aumento nos gastos em um determinado item do orçamento teria de ser compensado. Ou por (1) uma diminuição de gastos em outro item, ou por (2) um aumento correspondente da arrecadação. O objetivo da lei, que elevou impostos sobre consumo e os diminuiu para os detentores de capital, era conter o aumento dos déficits e controlar a situação orçamentária, pressionada pelos gastos do FIRREA. Privilegiava-se assim os detentores de riqueza, jogando-se o peso do aumento sobre a maioria dos trabalhadores.

Tabela 5. Estados Unidos. Recebimentos, gastos, gastos com defesa e déficits do governo federal. Em porcentagem do PIB e em bilhões de dólares correntes. 1989-1992.

Contas selecionadas do orçamento federal em $\%$ do PIB

(1)

1989

1990

1991

1992
(2)

Receitas

19,2

18,9

18,7

18,6
(3)

Gastos

22,9

23,5

23,5

23,9
(4)

Gastos com

defesa

$\begin{array}{ll}5,9 & 2,9\end{array}$

$5,5 \quad 4,0$

$4,9 \quad 4,8$

$5,1 \quad 4,9$
(5)

Déficit

$$
\text { , } 8
$$$$
4,0
$$

Contas selecionadas do orçamento federal em milhões de dólares correntes

(1)

1989

1990

1991

1992
(2)

Receitas

$$
990,6
$$

1031,3

1054,2

1091,6
(3)

Variação

1,08

1,04

1,02

1,10
(4)

Gastos

1143, 1

1252,1

1323, 1

1381, 1
(5)

Variação

1,07

1,09

1,05

1,20
(6)

Déficits

152,4

221,3

269,5

290,1
(7)

Variação

0,98

1,45

1,21

1,90

Fonte: Economic Report of the President, 1993. Tabela B-74, Federal Receipts, outlays, surplus or deficit, and debt, selected fiscal years. 
Tabela 6. Estados Unidos. Orçamento do governo federal: recebimentos e gastos discriminados. Em milhões de dólares correntes.

\begin{tabular}{|c|c|c|c|c|}
\hline \multicolumn{5}{|c|}{ Gastos discriminados do orçamento do governo federal } \\
\hline & & Receita & & \\
\hline \multirow[b]{3}{*}{ Imposto de renda (famílias) } & (1) & (2) & (3) & (4) \\
\hline & 1989 & 1990 & 1991 & 1992 \\
\hline & 445,690 & 466,884 & 467,827 & 476,465 \\
\hline \multirow{3}{*}{$\begin{array}{l}\text { Impostos sobre as } \\
\text { corporações } \\
\text { Impostos sobre consumo } \\
\text { Impostos sobre imóveis }\end{array}$} & 103,291 & 93,507 & 98,086 & 100,27 \\
\hline & 34,386 & 35,345 & 42,402 & 45,569 \\
\hline & 8,745 & 11,500 & 11,138 & 11,143 \\
\hline & (1) & $\begin{array}{l}\text { Gastos } \\
\text { (2) }\end{array}$ & (3) & (4) \\
\hline Defesa & 303,559 & 299,331 & 273,292 & 298,361 \\
\hline Compromissos Internacionais & 303,559 & 299,331 & 273,292 & 298,361 \\
\hline Ciência, espaço, tecnologia & 303,559 & 299,331 & 273,292 & 298,361 \\
\hline $\begin{array}{l}\text { Comércio e crédito } \\
\text { imobiliário }\end{array}$ & 29,211 & 67,142 & 75,639 & 9,514 \\
\hline Educação & 36,674 & 38,755 & 43,354 & 45,248 \\
\hline Saúde & 48,390 & 57,716 & 71,183 & 89,570 \\
\hline Medicare & 84,964 & 98,102 & 104,489 & 119,204 \\
\hline Seguridade Social & 232,542 & 248,623 & 269,015 & 287,545 \\
\hline
\end{tabular}

Fonte: Economic Report of the President, 1993. Tabela B-75, Federal Receipts, outlays, and debts, fiscal years, 1981-83.

]

Os efeitos da lei orçamentária de 1990 sobre os gastos discriminados e a arrecadação do governo federal norte-americano podem ser vistos a partir das tabelas acima. Primeiramente, nota-se que já tinha havido uma queda na arrecadação sob a rubrica de impostos sobre os lucros das corporações de 1989 a 1990, que caiu de 103 bilhões a 93 bilhões. Os impostos sobre as famílias ascenderam 22 bilhões, no mesmo período. No ano em que a lei entrou em vigor (1991), os impostos sobre as corporações praticamente ficaram na mesma marca (caem em valor real, descontada a inflação), ao passo que os impostos de renda sobre as famílias cresceram cinco bilhões. Por sua vez, o aumento dos impostos sobre consumo - álcool, tabaco, gasolina foi significativo, a ponto de a arrecadação desta rubrica ter crescido 1,2 vezes num período de retração de $0,2 \%$ do PIB: como se vê na tabela, a captação passou de 35 para 42 bilhões de dólares entre 1990 e 1991. Esse aumento, pequeno por si mesmo, indica no entanto que o governo, ao não manipular a política fiscal no sentido de favorecer o consumo das famílias, agravou a crise, pelo lado da política tributária.

O comportamento do elemento principal, naquele momento, que obrigou o governo a elevar os impostos quanto ao consumo das famílias, foram os gastos com as operações de resgate dos bancos imobiliários falidos na crise dos Savings\&Loans. A rubrica de gastos com "Comércio e Crédito Imobiliário" acusou um crescimento inicial de 37 bilhões das operações do governo de 1989 a 1990. De 1990 a 1991, tais gastos elevam-se em mais oito bilhões de dólares, constituindo - de longe - o maior aumento absoluto e relativo das contas do governo naquele momento. 
Por outro lado, não se pode deixar de notar (i) os impactos do fim da Guerra Fria sobre os gastos com defesa do governo federal; assim como (ii) a elevação dos gastos sociais, sob o conceito de saúde, educação, do programa Medicare, e de Seguridade Social. Quanto a (a), tal diferencia o contexto da administração Bush face a de Reagan: a Guerra Fria terminara, não sendo mais viável - pelo menos naquele contexto - justificar crescentes inversões no complexo industrial-militar. Poder-se-ia indagar: e quanto à guerra contra o Iraque? Ora, os custos totais da operação no Golfo Pérsico chegaram a aproximadamente 63 bilhões de dólares, mas 52 bilhões ficaram sob o encargo das outras nações envolvidas. O fim próximo da União Soviética permitiu aos Estados Unidos manejar a guerra em condições de potência hegemônica no mundo, articulando a operação, garantindo seus interesses geopolíticos e repassando os custos da mobilização.

Neste sentido, diante da inevitável queda das despesas com a indústria de guerra, o governo Bush elevou os gastos com diversos setores econômicos, atendendo a outros interesses oligopolistas - no caso, no setor da saúde social - mas também refletindo outras demandas sociais. Estas, na década anterior, haviam sido mais abafadas. Como se vê na tabela, todos gastos com saúde cresceram relativamente mais do que os outros gastos, com exceção do auxílio ao sistema de crédito imobiliário. Em tempo: os gastos totais do governo entre 1989 e 1992 cresceram 1,20 vezes; mas os gastos com educação, particularmente, cresceram 1,25 vezes; com saúde, 1,85 vezes; com o programa Medicare, 1,33 vezes; e com Seguridade Social, 1,23 vezes. A diminuição das inversões na indústria de guerra favoreceu a diversificação dos gastos setoriais do governo, e, porque não dizer, a maioria das pessoas cujo emprego não dependia diretamente das indústrias de guerra.

b) A condução da crise

A tabela acima deixa ver que, regra geral, o objetivo da lei orçamentária de 1990, de diminuir o déficit do governo, não foi cumprido. Este aumentou em proporção do PIB ao longo de 1991 e 1992. Todavia, se observada a taxa do crescimento do déficit de 1989 a 1990, pode-se afirmar que a lei minorou sua expansão face à tendência herdada. Isto se pode notar na diminuição do crescimento verificada entre 1991 e 1990, comparada à de 1990 e 1989. A lei representou assim um limite à atuação mais livre da política fiscal. Desfavorecendo uma ação mais imediata e pontual da política econômica, certamente aguçou a crise, com uma queda trimestral no início de 1991, logo depois de aprovada a lei. Neste momento a crise já mostrava gravidade. A interrupção da diminuição do crescimento dos déficits em 1992 mostra como os mecanismos de exceção foram atenuados assim que alguns agregados recuperavam desempenho. Portanto, os déficits aumentaram em 1991, mas os arranjos da lei impediram que tal movimento se desse de um modo imediato e proporcional à dimensão da flutuação do produto. 
A observação dos déficits orçamentários como neutralizadores das flutuações do capital fixo privado mediante a contraposição dos resíduos das duas séries em função do tempo, eliminando-se o componente tendencial, permite ver os tipos respostas de curto prazo dos déficits como resposta ao movimento acumulativo. Mais especificamente, vê-se como a lei orçamentária modificou o padrão de atuação das políticas no início de 1991. A análise de regressão dos déficits federais (Y1) e das inversões líquidas em capital fixo (eliminados os dispêndios com amortização) (Y2) em função do tempo (X) gera os resíduos em torno da tendência estimada, plotados conjuntamente na figura a seguir.

Vê-se que até o fim de 1990 os déficits federais contrapunham-se como bons estabilizadores das flutuações dos investimentos em capital fixo. $\mathrm{Na}$ seqüência, depois da aprovação da lei no fim de 1990, nota-se que os déficits caem justamente na conjuntura em que os investimentos também estão caindo desde o terceiro trimestre. Esteve exatamente aí, portanto, o estímulo do governo ao próprio aprofundamento da crise, dado que os déficits precisariam ter sido aumentados para diminuir os processos desacumulativos em curso. Ao longo de 1991, os déficits cresceram para "correr atrás do prejuízo"; mas, em meados de 1992, quando a crise parecia ter já sido afastada, mergulharam novamente. Sugere-se assim uma obediência à volta da "normalidade" da lei pela equipe de Bush bem distinta da postura que marcara administração passada, de Reagan. Isto ajuda, afinal, a explicar a lenta recuperação do emprego ao longo do último ano do mandato presidencial.

Gráfico 2. Estados Unidos. Resíduos de déficits orçamentários federais (Y1) em função do tempo $(\mathrm{X})$ e resíduos de investimentos líquidos em capital fixo privado (Y2) em função do tempo (Y). Em bilhões de dólares correntes.

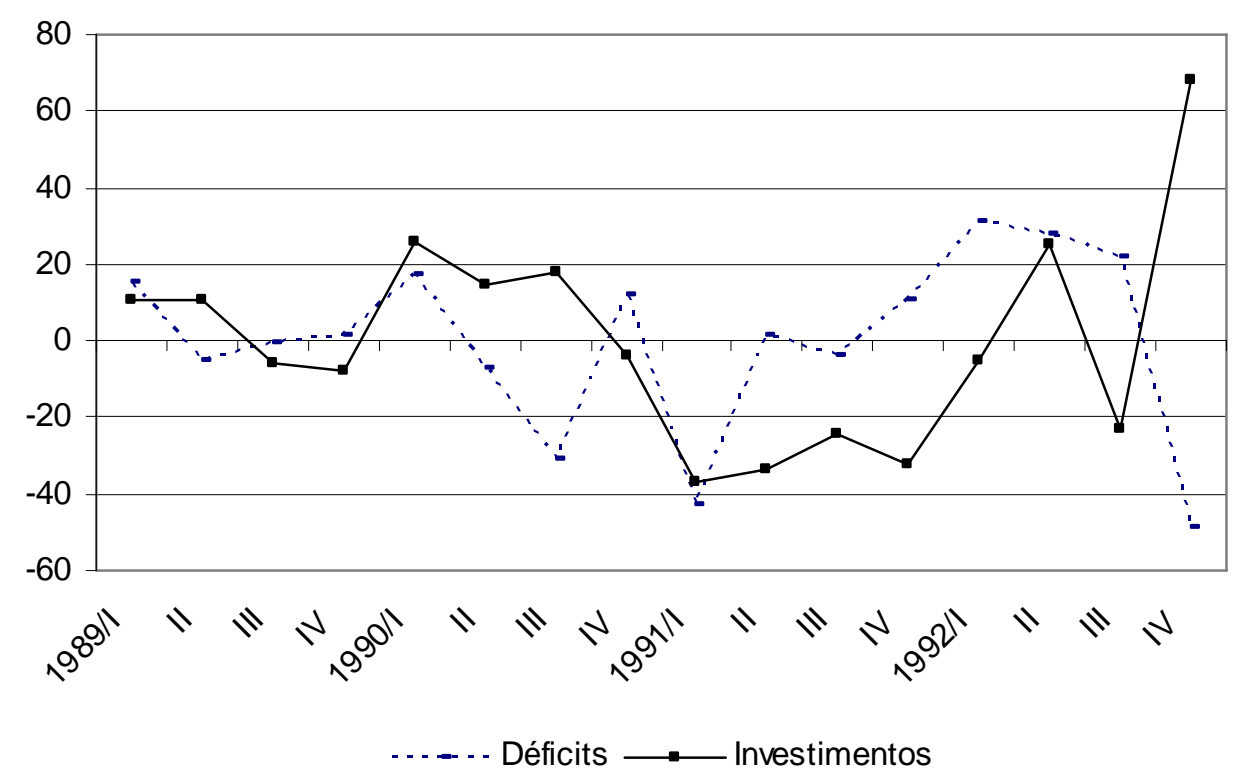

Fonte: Economic Report of the President, 1993. Para investimentos, ver Tabela B-14, Gross and net private domestic investment, 1959-92. Para déficits orçamentários, ver Tabela B-74, Federal receipts, outlays, surplus or deficit. 
Do ponto de vista do consumo das famílias, a manipulação tributária em favor do capital e das famílias mais ricas (para as quais os impostos indiretos custam relativamente menos) certamente atuou como elemento pró-cíclico à viragem do produto naquele momento. Para ficar mais claro, proceda-se com o seguinte exercício. Suponha-se que anteriormente citados cinco bilhões adicionais em impostos sobre as rendas das famílias, mais os oito bilhões arrecadados em forma de impostos adicionais sobre o consumo, tivessem sido cobrados sobre os lucros corporativos, que não foram investidos durante a crise de 1991. Os investimentos líquidos em capital fixo caíram de 115 bilhões no primeiro trimestre de 1991 para 108 bilhões no segundo, e de 107 bilhões no terceiro para 89 bilhões no segundo.

Tabela 7. Estados Unidos. Déficits orçamentários federais (Y1) em função do tempo (X) e resíduos, e investimentos líquidos em capital fixo privado (Y2) em função do tempo (X) e seus resíduos. Em bilhões de dólares correntes.

\begin{tabular}{|c|c|c|c|c|}
\hline (1) & (2) & (3) & (4) & (5) \\
\hline Anos & Déficits & $\begin{array}{l}\text { Inv. } \\
\text { líquido }\end{array}$ & $\begin{array}{c}\text { Resíduos } \\
\text { de } \\
\text { déficits }\end{array}$ & $\begin{array}{l}\text { Resíduos } \\
\text { de invest. }\end{array}$ \\
\hline 1989/I & 66,1 & 242,4 & 21,454 & 1,668 \\
\hline II & 61,5 & 232,1 & $-0,395$ & 3,286 \\
\hline III & 82.3 & 205,7 & 3,154 & $-11,196$ \\
\hline IV & 100,2 & 194,2 & 3,805 & $-10,778$ \\
\hline 1990/I & 131,7 & 217,5 & 18,055 & 24,439 \\
\hline II & 123,1 & 196,2 & $-7,794$ & 15,057 \\
\hline III & 115,3 & 189,5 & $-32,843$ & 20,275 \\
\hline IV & 174,4 & 158,3 & 9,006 & 0,993 \\
\hline 1991/I & 135,5 & 115,1 & $-47,143$ & $-30,288$ \\
\hline II & 195,6 & 108,5 & $-4,292$ & $-24,971$ \\
\hline III & 205,6 & 107,7 & $-11,542$ & $-13,853$ \\
\hline IV & 236,6 & 89,8 & 2,208 & $-19,835$ \\
\hline $1992 / \mathrm{I}$ & 272,6 & 106,8 & 20,958 & 9,082 \\
\hline II & 285,2 & 126,9 & 16,308 & 41,100 \\
\hline III & 295,2 & 68,9 & 9,059 & $-4,981$ \\
\hline IV & 240,6 & 150,1 & $-48,477$ & 68,046 \\
\hline
\end{tabular}

Fonte: ver gráfico 2.

Se o governo tivesse aumentado a tributação sobre os lucros do capital (o aumento sobre a poupança das famílias ricas teria efeito similar), a poupança das famílias teria então se elevado em 13 bilhões, de forma direta. Sendo a função-consumo $(C=a+b Y)$ para $1991 \mathrm{e}$ 1992 de forma $\mathrm{C}=315,6+0,76 \mathrm{Y}$, calculada a partir da regressão do consumo das famílias (Y) explicado pela renda disponível $(\mathrm{X})$ no período, estes treze bilhões em aumento da renda das famílias teriam então, na hipótese keynesiana, se tornado 13 x 0,76 $=9,88$ bilhões em consumo de forma direta, aproximadamente. Dado o multiplicador de 1/1-0,76 $=4,16$, estes 9,88 bilhões de gastos adicionais que as famílias teriam da inversão da política tributária teriam então gerado, na mesma hipótese, aproximadamente 42 bilhões de dólares adicionais na economia, que não foram gerados porque, mesmo com a política tributária favorável, as firmas não 
investiram, resultando num aumento adicional dos lucros não distribuídos de 95 bilhões em 1990 para 103 bilhões em 1991.

Regressão I: consumo das famílias (Y) em função da renda disponível (X)

$\mathrm{R}^{2}=0,98$

Erro padrão $=16,10$

valor-P $=4,3 \mathrm{E}-07$

Tabela 8. Estados Unidos. Renda disponível e consumo das famílias, e investimento líquido privado em capital fixo. Em bilhões de dólares correntes.

\begin{tabular}{cccc}
\hline (1) & $(2)$ & $(3)$ & $(4)$ \\
& Renda (X) & Consumo (Y) & Investimento \\
1991/I & 4783,9 & 3966,1 & 115,1 \\
II & 4833,4 & 4010,7 & 108,5 \\
III & 4858,8 & 4052,3 & 107,7 \\
IV & 4927,5 & 4087,1 & 89,8 \\
1992/I & 5017,8 & 4169,4 & 106,8 \\
II & 5093,8 & 4221,3 & 126,9 \\
III & 5139,8 & 4277,3 & 68,9 \\
IV & 5328,3 & 4377,9 & 150,1 \\
\hline
\end{tabular}

Fonte: Economic Report of the President, 1994. Para renda, ver tabela B-24, Disposition of personal income, 1959-92. Para consumo, ver tabela Personal consumption expenditures, 195992. Para investimentos, ver Tabela B-14, Gross and net private domestic investment, 1959-92.

Poder-se-ia argumentar do ponto de vista oficial que, sem os favorecimentos fiscais, as empresas teriam aumentado ainda mais suas desinversões. Ora, em tese isto podia ter ocorrido. Mas é de fato difícil crer que tivessem aumentado a acumulação mesmo com uma maior concessão tributária, a julgar pela dimensão das forças desacumulativas em operação no momento, que não eram de natureza fiscal, mas sim de demanda agregada e financiamento. Num ambiente depressivo, o comportamento das famílias é mais previsível do que o das firmas. Podendo ser estimado a partir do valor previsível inferido da relação conhecida entre renda e consumo, a propensão marginal a consumir revela um aumento de gastos muito mais provável de ocorrer se o governo tivesse liberado os recursos às famílias. Já a taxa de investimento é mais elástica, sendo influenciada por mais fatores do que o consumo corrente. Isto é: taxar lucros teria sido mais certeiro para equilibrar o orçamento nesse caso, liberando demanda agregada em forma de consumo, cujos gastos teriam potencialmente gerado efeitos multiplicadores mais imediatos. O aumento dos lucros não distribuídos mostra, por sua vez, que a política físcal foi inoperante em influenciá-los. Um aumento dos gastos das famílias teria certamente puxado para cima o efeito acelerador, independentemente da oposição oficial a uma política deste tipo pelas corporações. Certamente elas não se recusariam a investir quando os novos pedidos começassem a chegar. 
A arrecadação do governo teria sido a mesma, no caso, cobrando das empresas ou das altas rendas, mas com impactos subseqüentes mais positivos de acordo com os fins que oficialmente se dizia perseguir. E o maior aumento do produto à frente permitiria ao governo colher parte das concessões tributárias antes feitas às famílias etc..

Portanto, expressando os interesses corporativos dominantes nas esferas da administração pública, a diminuição de impostos sobre os lucros corporativos refletiu a perspectiva neoneoclássica de privilegiar o "lado da oferta", elevando a eficiência marginal do capital, mas estancando um possível crescimento maior da demanda agregada na forma de consumo liberado por impostos menores. Uma atuação oposta neste curto prazo, diminuindo os impostos às famílias e aumentando-os sobre os lucros corporativos, certamente teria exercido um efeito mais benéfico, sob a atuação do efeito acelerador. Mas isto dependia de uma decisão política sem apoio na esfera decisória. Mantido o cumprimento da lei, poder-se-ia criticar melhor a administração por ter dividido os custos da operação de forma desigual, de modo a bloquear outras alternativas que se revelassem mais favoráveis à coletividade, de um ponto de vista do próprio crescimento. Aumentar a demanda agregada com diminuição dos impostos sobre bens de consumo de massa, elevando os tributos sobre as rendas mais altas certamente teria induzido a ganhos acumulativos provavelmente mais expansivos, distintos daqueles originados dos favorecimentos aos detentores de capital. Mas a prevalência inconteste dos interesses corporativos e de uma postura anti-keynesiana nas esferas decisórias naquele momento impediu este tipo de saída. Tratava-se então de levar a cabo um raciocínio de aparência keynesiana, mas de fundo bastardo, porque a persecução de uma política de crescimento era vista quase sempre como capaz de pôr em xeque o "primado da propriedade".

c) Causas da crise de 1990-1991

c.1.) Viragem cíclica

A crise de 1991 deve ser atribuída ao seguinte conjunto de fatores: i) momento de viragem cíclica dos investimentos privados; ii) política monetária restritiva do Fed entre $1988 \mathrm{e}$ o início de 1989; iii) impactos da crise no sistema Savings\&Loans; iv) decorrências do aumento dos preços, estimulados pela alta do petróleo, para o consumo relativo das famílias.

Abaixo se encontra o comportamento dos investimentos líquidos em capital fixo, assim como a plotagem dos resíduos em função do tempo. Reconhece-se que o aumento do endividamento corporativo ao longo dos anos (19)80 - reflexo indireto do aumento do endividamento externo da economia - levou a um acúmulo de estoques de capital físico que pressionaram seus preços para baixo no fim da década. Este movimento, particularmente grande no setor imobiliário comercial, foi responsável por pressões adicionais no sistema financeiro. Certamente, à luz das flutuações de 1979-1983 e 1983-1987 no comportamento dos investimentos privados, podia-se inferir uma viragem cíclica a partir de 1989. A observação dos 
picos e fendas do trajeto do investimento deixava prever o zênite acumulativo para 1989, auge este que deveria estar pelo menos na mesma marca que o último pico de 1985. Após tal auge, uma baixa natural deveria seguir-se, por si mesma suficiente para diminuir a expansão do PIB.

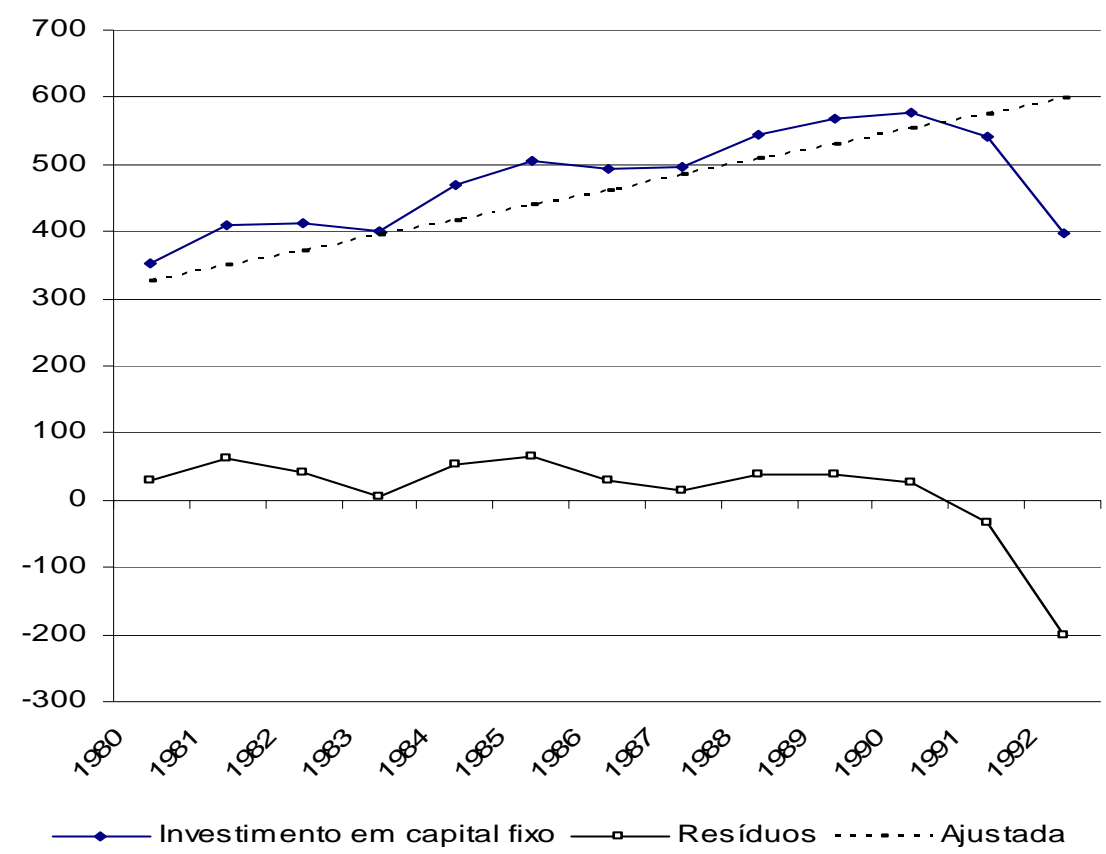

Gráfico 3. Estados Unidos. Resíduos de investimentos líquidos em capital fixo (Y) em função do tempo (Y). Em bilhões de dólares correntes. Fonte: Economic Report of the President, 1993.

Porém, vê-se que o perfil cíclico da série foi pressionado para baixo por forças que estavam além de seu comportamento esperado, trazendo-a - em dólares correntes! - para a mesma casa onde estava em 1981. Logo, a crise de 1990-1991 não pode ser entendida apenas como um momento de viragem previsto, para baixa, do comportamento do investimento em capital fixo, e sim como uma inversão de comportamento que, sofrendo acúmulo de outros condicionantes, culminou com grande desvio da tendência original, para a qual já se previa uma queda. Cabe então ver mais de perto a atuação destes fatores adicionais ao perfil cíclico.

\section{c.2) Política monetária}

O primeiro destes condicionantes foi certamente a política monetária restritiva do Fed, durante 1988 e o início de 1989, a impactar negativamente na variação dos meios de pagamento, (i) sob o conceito de empréstimos, elevando ao mesmo tempo (ii) a demanda por títulos indexados aos juros. Caíram os empréstimos e se dirigiu maior parte da renda corrente aos papéis que pagavam juros. Os juros foram mantidos elevados durante todo este período, dada a luta das autoridades por manter baixa a inflação. Tal política conduziu naturalmente a um desestímulo adicional às inversões, na transição de 1988 a 1989, com conseqüências negativas em 1990 e 1991 para a variação de estoques, para a implementação de projetos, para o emprego e renda etc.. 
Abaixo está disposto o comportamento dos meios de pagamento no período 1989-1992, em termos de sua variação (expressa aqui em porcentagem). Vê-se primeiramente a contínua queda conjunta das variações de M1, M2 e M3 de 1980 a 1988, com exceção da brusca elevação em 1984 de M1, que indicava o alto crescimento deste ano. Como se viu nos capítulos passados, esta queda conjunta de M2 e M3 foi o resultado da gradual queda dos juros, desde o início da década. Não obstante, após 1988, depois do aperto de juros do Fed, vê-se clara discrepância nas taxas de variação, com M2 e M3 mantendo taxas regulares de crescimento durante todo o ano de 1989, ao passo que M1 - refletindo os juros altos até o primeiro semestre deste ano - tem sua variação em queda até Junho daquele ano. Isto refletiu, justamente, uma fuga dos ingressos corporativos, da moeda corrente e dos depósitos à vista em direção aos papéis que pagavam juros, até o fim do primeiro semestre de 1989.

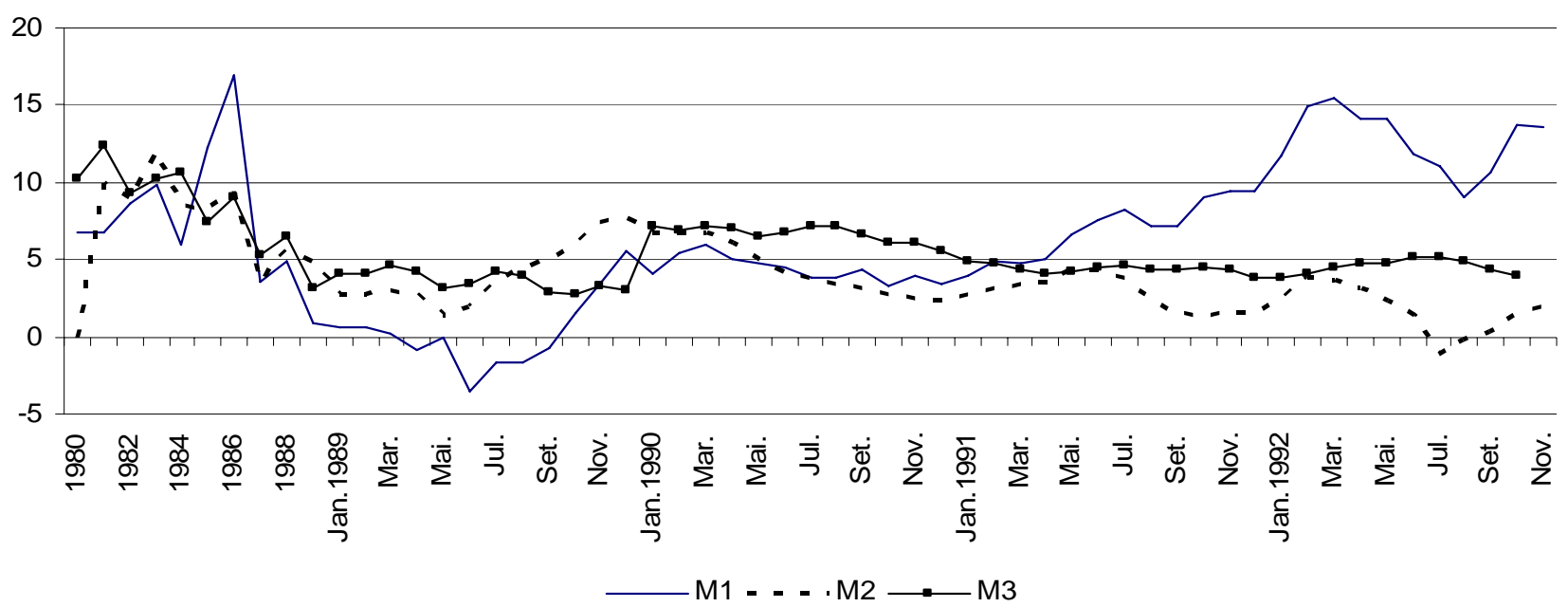

Gráfico 4. Estados Unidos. Variação (\%) dos meios de pagamento. 1980-1989. Fonte: Economic Report of the President, 1993.

Em seguida, com a diminuição dos juros a partir do segundo semestre de 1989, nota-se aumento de M1, e queda de M2, a denotar justamente o movimento oposto: relativo aumento da moeda corrente e depósitos à vista, com diminuição das inversões financeiras, como respostas aos juros menores. Percebe-se, é claro, que esta retomada expansiva induzida pela política monetária, no segundo semestre do ano, não foi suficiente para criar as condições de que um novo ciclo ascendente fosse iniciado. Deu-se uma queda geral da variação do crescimento dos três grandes agregados monetários desde 1990. Esta queda conjunta indicou justamente a queda geral das atividades induzida pelos outros processos desacumulativos supracitados. Houve diminuição tanto do crescimento do papel-moeda e depósitos à vista, como da própria demanda por papéis que rendem juros.

Interessa observar ainda como os juros continuaram baixos durante todo o ano de 1992. Isto depois de terem sido rebaixados, como se viu antes, a partir do segundo semestre de 1989. Vê-se que o crescimento de M1 foi mais rápido que o de M2 e M3, que continuaram estagnados (M3 de fato desacelerou ao longo do ano). Ora, pelas variações do PIB acima dispostas, viu-se 
que de fato a desaceleração começou em meados de 1989, podendo ser atribuída então, em parte, à política restritiva do Fed. Tem-se, pelo gráfico, que as variações de M1, mesmo no segundo semestre de 1989, nunca ultrapassaram as variações dos anos anteriores. Vê-se o peso que a política monetária tinha imprimido sobre o crescimento deste agregado monetário. Isto é, sobre as decisões de inversão dos detentores de riqueza, da concessão de empréstimos pelo setor financeiro, com conseqüentes impactos sobre a trajetória da moeda corrente e dos depósitos à vista.

c.3) A crise no sistema bancário

A taxa de juros, porém, esteve longe de ser o único elemento importante nas decisões acumulativas. A crise no sistema de Savings\&Loans foi certamente determinante, conferindo a especificidade da crise de 1991. A partir da observação da tabela abaixo, sugere-se que seu impacto foi geral para todo o sistema de crédito imobiliário norte-americano: representou perdas intra-setoriais e diminuição de concessão de créditos. A tabela deixa ver o surpreendente declínio nos perfis de concessão não somente de empréstimos sob o conceito de hipotecas, mas sim de crédito ao consumo às famílias, que durante 1991 foi praticamente eliminado. O endividamento doméstico das corporações e dos setores financeiros também decresceu absolutamente, interrompendo uma trajetória de ascensão desde o início dos anos (19)80.

Tabela 9. Estados Unidos. Endividamento de setores selecionados. Em bilhões de dólares correntes.

\begin{tabular}{|c|c|c|c|c|c|c|c|c|}
\hline \multirow[t]{3}{*}{ (1) } & \multirow{2}{*}{\multicolumn{2}{|c|}{$\begin{array}{c}\text { (2) } \\
\text { Hipotecas } \\
\text { (famílias) }\end{array}$}} & \multirow{2}{*}{\multicolumn{2}{|c|}{$\begin{array}{c}\text { (3) } \\
\text { Crédito } \\
\text { (consumo) }\end{array}$}} & \multirow{2}{*}{\multicolumn{2}{|c|}{$\begin{array}{c}\text { (4) } \\
\text { Corporações }\end{array}$}} & \multirow{2}{*}{\multicolumn{2}{|c|}{$\begin{array}{c}\quad(5) \\
\text { Financeiros }\end{array}$}} \\
\hline & & & & & & & & \\
\hline & [1] & Variação & {$[2]$} & Variação & {$[4]$} & Variação & [5] & Variação \\
\hline 1987 & 221,6 & 1,11 & 32,3 & 0,57 & 162,7 & 0,72 & 290,6 & 0,88 \\
\hline 1988 & 215,6 & 0,97 & 46,6 & 1,44 & 222,4 & 1,36 & 250,2 & 0,86 \\
\hline 1989 & 224,9 & 1,04 & 47 & 1 & 160 & 0,71 & 225 & 0,9 \\
\hline 1990 & 198,6 & 0,88 & 15,1 & 0,32 & 136,4 & 0,85 & 211,2 & 0,93 \\
\hline 1991 & 174,1 & 0,87 & 8,8 & $-0,58$ & 52,9 & 0,38 & 156 & 0,73 \\
\hline 1992 & 171,3 & 0,98 & 9,2 & 1,04 & 24,3 & 0,45 & 238,9 & 1,53 \\
\hline 1993 & 156,8 & 0,91 & 61,4 & 6,67 & 32,5 & 1,33 & 291,5 & 1,22 \\
\hline
\end{tabular}

Fonte: Flow of Funds Accounts of the United States 2007, Tabela D.2, Borrowing by Sector, p.7. 
Tabela 10. Estados Unidos. Crédito a hipotecas por tipo de instituição. 1986-1990.

\begin{tabular}{ccccc}
\hline$(1)$ & $(2)$ & $(3)$ & $(4)$ & $(5)$ \\
& Total & $\begin{array}{c}\text { Savings } \\
\text { Institutions }\end{array}$ & $\begin{array}{c}\text { Bancos } \\
\text { Comerciais }\end{array}$ & $\begin{array}{c}\text { Instituições de } \\
\text { seguro }\end{array}$ \\
1986 & 2663,3 & 778,1 & 504,7 & 193,8 \\
1987 & 3000,1 & 860,5 & 594,8 & 212,4 \\
1988 & 3319,6 & 924,5 & 676,9 & 232,9 \\
1989 & 3591,3 & 910,3 & 770,7 & 254,2 \\
1990 & 3807,4 & 801,6 & 849,3 & 267,9 \\
1991 & 3952,9 & 705,4 & 881,3 & 259,5 \\
1992 & 4062,5 & 627,9 & 900,5 & 242,0 \\
1993 & 4195,7 & 598,4 & 947,8 & 223,9 \\
\hline
\end{tabular}

Fonte: Economic Report of the President, 2006. Tabela B-76, Mortgage debt outstanding by holder, 1949-2005.

Já a segunda tabela acima mostra a enorme queda dos créditos hipotecários concedidos às famílias pelo sistema das "thrift institutions" como um todo. As instituições de seguro também diminuíram seus créditos a hipotecas a partir de 1990, em valores absolutos. Os bancos comerciais não chegaram a interromper um crescimento absoluto. Porém, a velocidade com que forneceram recursos nitidamente também caiu, face à década anterior. A taxa de crescimento de 1987 a 1988 fora 1,17 vezes; de 1989 a 1988, 1,13; de 1990 a 1989, 1,10; seguem-se daí 1,03 e 1,02, respectivamente de 1991 a 1990 e de 1992 a 1991.

Pelo gráfico abaixo, percebe-se a inversão dos investimentos residenciais já em 1988, reflexo do acúmulo de falências dos bancos à medida que a década se finalizava. A partir de 1989, tal inversão transforma-se em queda, cujo limite deu-se justamente em meados de 1991. Evidentemente, a diminuição das inversões no setor imobiliário tem se originado, além da própria diminuição dos créditos e das perdas de poupança pelas quebras das instituições creditícias. Ou seja, da própria crise, em seu sentido mais amplo: uma menor taxa de emprego desestimula e de fato muitas vezes impede a consolidação de planos familiares. A crise na construção de residências impacta diretamente nas indústrias de base - siderúrgica, química, construção civil - de modo a tornar a desaceleração um processo onde os efeitos desacumulativos se alimentam mutuamente. 
Gráfico 5. Estados Unidos. Investimentos em capital fixo privados (com exceção dos investimentos em residências) e investimentos em capital fixo privados em forma de residências. Em milhões de dólares correntes.

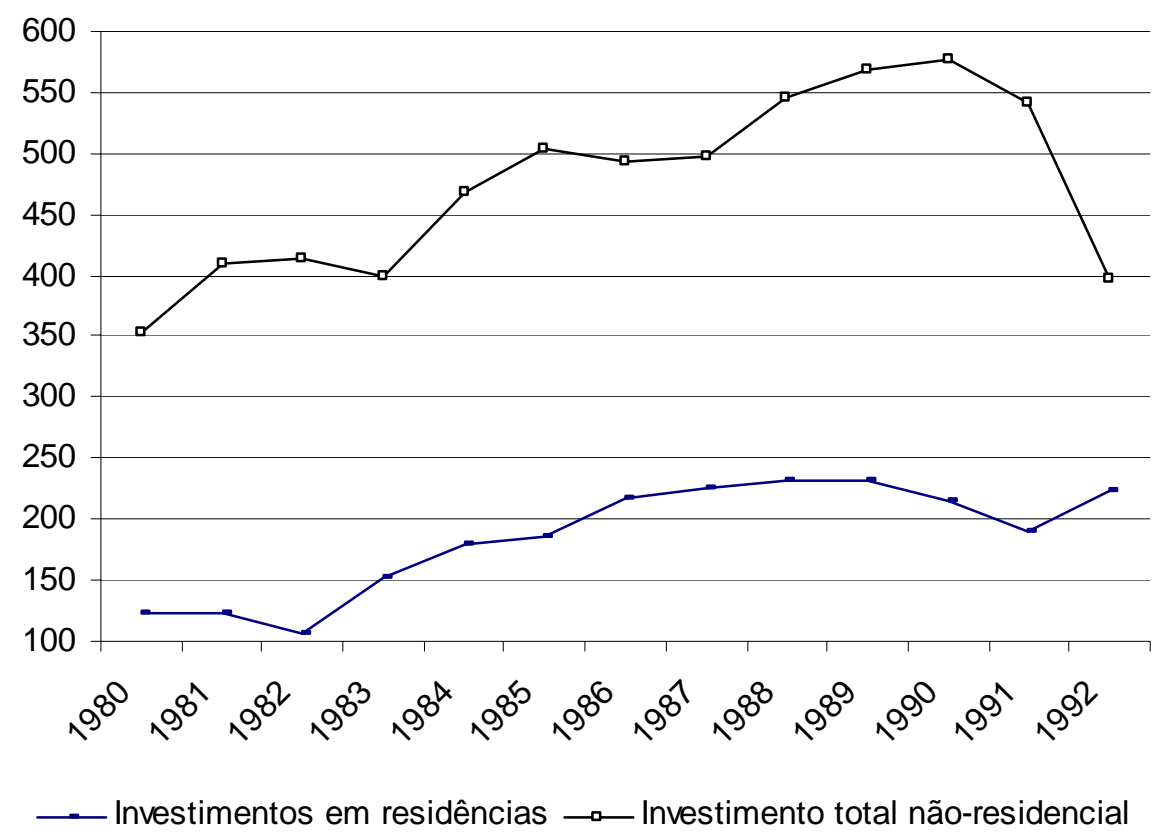

Fonte: Economic Report of the President, 1993. Tabela B-1, Gross Domestic Product, 1959-92.

Porém, o lado da oferta de créditos teve um papel fundamental para a abertura da crise. A queda dos níveis de endividamento do sistema financeiro como um todo mostrou como a crise bancária não pôde ser vista apenas como um resultado da queda de demanda por empréstimos bancários pelas famílias e pelas empresas. Antes, se trata de um fenômeno originado pelo lado da oferta de tais créditos, dado o desaparecimento de grande parte dos ativos até então existentes, na forma de haveres detidos pelas famílias contra os bancos, nunca mais ressarcidos. Deu-se assim um "efeito riqueza ao contrário", similar ao que ocorre nas crises do mercado acionário, onde as perdas para as famílias implicaram em queda do volume de consumo corrente, já que os créditos contra os bancos não recuperados naturalmente impediram o aumento de seus gastos. As falências trouxeram naturalmente um efeito em cadeia, não remediado completamente pela política econômica, sem ter podido evitar de todo uma crise amplificada para todas as instituições creditícias, dada a interconexão das obrigações. A crise então cresceu por seus próprios aspectos auto-alimentadores: quedas da atividade levaram a menores depósitos, e depois a menores demandas por planos de inversão, que por sua vez geraram uma diminuição da poupança corrente dos bancos etc.. Importa ressaltar, porém, o acúmulo de quebras financeiras e a desvalorização de papéis como um estopim central da crise econômica como um todo, no período em questão. 
d) Preços, renda e produção

O fato de que os salários estivessem defasados face à produção em todo o período não ajudou, naturalmente, a diminuir a queda da demanda agregada na forma de consumo das famílias. Além disso, os salários estiveram defasados face ao índice de inflação. O resultado foi uma queda sustentada da renda per capita.

A partir dos dados abaixo, vê-se retração da renda e do consumo pessoal per capita durante o biênio 1990-1991. Vê-se também o baixo crescimento da renda entre 1989 e 1990, comparado com a recuperação a partir de 1992. Comparando-se as variações de salários e produção, ${ }^{196}$ percebe-se um constante atraso das primeiras face às segundas, durante todo o período considerado. Por outro lado, a comparação dos salários face ao deflator calculado no Economic Report deixa ver, também, grande discrepância do poder de compra dos trabalhadores face ao crescimento da inflação. A defasagem do salário face à variação da produção e a substancial variação dos preços no quadriênio da administração Bush, tudo isto aguçado pelo aumento do preço do petróleo, fizeram cair então o nível dos ingressos e salários reais.

Tal deflator foi calculado simplesmente pela divisão dos preços correntes pelo índice de produção física, com o aumento do numerador face ao denominador expressando os preços crescentes. Com a exceção de 1992, durante o período deu-se maior aumento de preços do que de salários. Isso expressou-se como queda dos salários reais. Aliada a queda dos salários reais à diminuição do crédito ao consumo e em forma de hipotecas, tem-se assim que a queda do consumo das famílias foi atingida em cheio pelas manifestações da crise de 1990-1991.

Tabela 11. Estados Unidos. Dados selecionados de renda e salário.

\begin{tabular}{cccccc}
\hline$(1)$ & $(2)$ & $(3)$ & $(4)$ & $(5)$ & $(6)$ \\
& $\begin{array}{c}\text { Renda } \\
\text { per capita }\end{array}$ & $\begin{array}{c}\text { Consumo } \\
\text { per capita }\end{array}$ & Produção & Salário & Deflator \\
1989 & 21120 & 18898 & 0,7 & $-1,6$ & 3,6 \\
1990 & 21281 & 19067 & 1,9 & 1,1 & 3,7 \\
1991 & 21109 & 18848 & 1,7 & 1,4 & 3,4 \\
1992 & 21548 & 19208 & 4,1 & 2,7 & 1,9 \\
\hline
\end{tabular}

Onde:

[1]: Renda disponível per capita, em dólares, deflacionada pelo dólar de 2000.

[2]: Consumo pessoal per capita, em dólares, deflacionado pelo dólar de 2000.

[3]: Variação (em \%) da produção por hora nos setores não-agrícolas.

[4]: Salário real (em \%) por hora nos setores não-agrícolas.

[5]: Deflator implícito (produção em dólares correntes dividida pelo índice de produção).

Fonte: Economic Report of the President, 2006. Para renda e consumo disponível per capita, ver Tabela B-31, Total and per capita disposable personal income and personal consumption expenditures, and per capita gross domestic product, in current and real dollars, 1959-2005. Para produção, salário real e deflator, ver Tabela B-49, Productivity and related data, business sector, 1959-2005.

${ }^{196}$ Dispostos na tabela B-50 do Economic Report of the President de 2006. 
Outra questão, certamente mais difícil, seria avaliar o impacto inflacionário da elevação do preço do petróleo sobre a estrutura de custos das firmas. É evidente que um custo maior do petróleo é por si mesmo prejudicial a quase todos produtores que dele necessitam. Mesmo que se possa repassar o aumento dos custos fixos, um aumento súbito de preços não é mercadologicamente atrativo para os produtores, despertando sempre certa resistência mesmo em condições de monopólio. Como a alta da inflação neste momento foi pressionada principalmente pelo aumento do preço do petróleo, a estrutura de custos foi afetada pela (i) proximidade e dependência de cada firma em relação aos fornecedores de bens energéticos e (ii) pelo grau de monopólio, ou seja, a capacidade maior ou menor das corporações para repassar o aumento de custos a seus compradores. Um aumento dos preços do petróleo significava um aumento dos ingressos das firmas que o produziam, em detrimento das que deles dependiam.

É complicada a teia de relações nesta situação específica. Quanto maior fosse a dependência quanto aos bens derivados do petróleo e maior a proximidade para com os produtores e fornecedores do insumo, maior seria a pressão nos custos relativos, para uma firma dada. Um monopsônio poderia tentar rebaixar tais custos de seu fornecedor, assim como um monopólio transferir melhor o aumento de custos aos consumidores ou aos compradores na subseqüente etapa da cadeia produtiva. Um maior grau de concorrência podia impedir tal expediente, pela impossibilidade de manter um "mercado de vendedores" (Joan Robinson). E assim fazer com que a taxa de lucro caísse, dado o aumento dos preços das matérias-primas. Assim, tudo depende do tipo de concorrência em que cada firma estava inserida. Pode-se afirmar que quanto maior fosse o grau de concorrência, maiores seriam as dificuldades para repassar os custos aos compradores. Isto culminaria numa pressão maior sobre o nível da taxa de lucros do ramo em questão. Neste caso, a economia seria afetada fosse pelas desinversões que se fariam quando os lucros e as vendas eram menores, fosse pela diminuição do poder de compra, pelos custos finalmente repassados às famílias.

Tabela 12. Estados Unidos. Índice de preços ao produtor por grupos majoritários de tipos de produção. $1982=100$.

\begin{tabular}{rrrrrr}
\hline \multicolumn{6}{c}{ Variação de Preços: $1982=100$} \\
$(1)$ & $(2)$ & $(3)$ & \multicolumn{1}{c}{$(4)$} & \multicolumn{1}{c}{$(5)$} & \multicolumn{1}{c}{$(6)$} \\
& Agrícolas & Químicos & Metais & Plásticos & Têxteis \\
1988 & 110,0 & 116,3 & 118,7 & 118,9 & 109,2 \\
1989 & 115,4 & 123,0 & 124,1 & 126,7 & 112,3 \\
1990 & 118,6 & 123,6 & 122,9 & 129,7 & 115,0 \\
1991 & 116,4 & 125,6 & 120,2 & 132,1 & 116,3 \\
1992 & 115,9 & 125,9 & 119,2 & 146,6 & 117,4 \\
\hline
\end{tabular}

Fonte: Economic Report of the President, 2006. Tabela B-67, Producer price indexes for major commodity groups, special groups, 19742-2005. 
A tabela abaixo, que traz alguns dados retirados da ampla quantidade de indicadores de variação de preços do Economic Report of the President, mostra a variação dos preços ao produtor, por bens divididos segundo seu estágio de processamento. Percebe-se que, de fato, no período 1989-1993, a variação mais intensa dos preços se deu por pressão dos custos energéticos. Vê-se também que a produção primária e intermediária de alimentos, sementes e outros tipos de bens primários não foi afetada pela alta do petróleo, diferentemente da produção de bens finais. Os preços dos bens de energia em estágio primário - no caso, principalmente o petróleo - sofreram variação de nada menos que dez pontos percentuais, ao passo que a variação dos bens alimentícios e de "outros" em estágio primário foi de apenas dois pontos percentuais. Por sua vez, quando se passa aos produtos em estágio intermediário de processamento, vê-se novamente que a variação mais pronunciada é, de longe, a dos bens intermediários de energia, atingindo novamente quase $10 \%$, enquanto "outros" e "alimentos e sementes" têm variação de preços de $2 \%$ e $5 \%$ respectivamente.

Neste sentido, pode-se notar que tais variações bruscas dos preços dos bens energéticos chegaram aos produtores de bens finais, impactando assim no consumo das famílias. Sob a hipótese de concorrência menos oligopolizada, estes não teriam senão as opções de (i) elevar os preços aos consumidores finais, ou (ii) buscar mantê-los, sob pena de perder fatias de seu mercado. Dado o alto grau de monopolização/oligopolização vigente entre tais produtores de bens energéticos e derivados, os custos maiores foram sendo repassados de um produtor para outro, por todas as etapas das cadeias produtivas, até desembocarem nos produtores de bens finais. Como se vê abaixo, uma maior variação dos preços para os produtores de bens finais, entre 1989 e 1990 - 6\% para alimentos e 6\% para "outros" - mostra a dependência dos preços dos bens finais em relação à variação dos preços do petróleo, assim como o repasse dos custos maiores para os consumidores finais. É isto que explica a conseqüente diminuição relativa do poder de compra, já que os consumidores não podiam repassar adiante os preços em alta que lhe foram impostos.

Todavia, sob uma perspectiva mais agregada, e tomando-se ainda aqui como decisivo o comportamento dos setores industriais, pode-se ver que o cálculo de nossa proxy de taxa de lucro indica que ela (taxa de lucro) pouco foi afetada, como um todo, pelo aumento do preço do petróleo. Pouca coisa lembra neste período o impacto do aumento do preço do petróleo no setor manufatureiro das crises do petróleo de 1974-1979. Os impactos dos aumentos dos preços foram menores e mais facilmente absorvidos pelos produtores fora da área de energéticos, de modo que se pode dizer que a maior parte das taxas de lucro no setor industrial cresceram sem pausa, desconsiderando quedas intra-setoriais aqui e ali. Logo, tem-se aqui um caso em que o setor produtivo sofreu nitidamente com uma diminuição da demanda agregada ocasionada por outros fatores - excluindo a trajetória cíclica - que os concernentes à taxa de investimento. 
Visto de um outro ponto de vista, isto significa que os salários caíram mais do que as vendas, dentro do modelo de cálculo de taxa de lucro que se concebe aqui. ${ }^{197}$

Tabela 13. Estados Unidos. Índice de preços ao produtor por estágio de processamento. 1982 $=100$.

\begin{tabular}{|c|c|c|c|}
\hline \multicolumn{4}{|c|}{$\begin{array}{c}\text { Variação de preços: } 1982=100 \\
\text { Bens finais }\end{array}$} \\
\hline & Alimentos & Energia & $\begin{array}{l}\text { Equipamentos de } \\
\text { capital }\end{array}$ \\
\hline 1985 & 104,6 & 87,6 & 107,5 \\
\hline 1986 & 107,3 & 63 & 109,7 \\
\hline 1987 & 109,5 & 61,8 & 111,7 \\
\hline 1988 & 112,6 & 59,8 & 114,3 \\
\hline 1989 & 118,7 & 65,7 & 118,8 \\
\hline 1990 & 124,4 & 75 & 122,9 \\
\hline 1991 & 124,1 & 78,1 & 126,7 \\
\hline 1992 & 123,3 & 77,8 & 129,1 \\
\hline 1993 & 125,7 & 78 & 131,4 \\
\hline \multicolumn{4}{|c|}{ Bens intermediários } \\
\hline & Alimentos e sementes & Energia & Outros \\
\hline 1985 & 97,3 & 92,6 & 105,2 \\
\hline 1986 & 96,2 & 72,6 & 104,9 \\
\hline 1987 & 99,2 & 73 & 107,8 \\
\hline 1988 & 109,5 & 70,9 & 115,2 \\
\hline 1989 & 113,8 & 76,1 & 120,2 \\
\hline 1990 & 113,3 & 85,5 & 120,9 \\
\hline 1991 & 111,1 & 85,1 & 121,4 \\
\hline 1992 & 110,7 & 84,3 & 122,1 \\
\hline 1993 & 112,7 & 84,6 & 123,8 \\
\hline \multicolumn{4}{|c|}{ Bens primários } \\
\hline & Alimentos e sementes & Energia & Outros \\
\hline 1985 & 94,8 & 93,3 & 104,9 \\
\hline 1986 & 93,2 & 71,8 & 103,1 \\
\hline 1987 & 96,2 & 75 & 115,7 \\
\hline 1988 & 106,1 & 67,7 & 133 \\
\hline 1989 & 111,2 & 75,9 & 137,9 \\
\hline 1990 & 113,1 & 85,9 & 136,3 \\
\hline 1991 & 105,5 & 80,4 & 128,2 \\
\hline 1992 & 105,1 & 78,8 & 128,4 \\
\hline 1993 & 108,4 & 76,7 & 140,2 \\
\hline
\end{tabular}

Fonte: Economic Report of the President, 2006. Tabela B-65, Producer price indexes by stage of processing, 1959-2005.

Portanto, cabe explicar este comportamento mais vantajoso do setor industrial, à luz do que se passou nos anos (19)70. Já se notou no capítulo passado como no governo Reagan as taxas de lucro no setor manufatureiro foram recompostas pelas políticas do governo e pela queda dos salários, assim como pela queda do próprio preço do petróleo, de modo a reativar seu crescimento. Neste interlúdio entre 1989 e 1991, a pressão sobre a taxa de lucro vinda do aumento dos custos existiu. Contudo, foi de muito menor monta que a pressão exercida durante

197 A massa de lucros resulta da diferença entre vendas totais e gastos corporativos. Se as primeiras (vendas) caíram, e a taxa de lucro continuou crescendo, isto indica que os segundos (gastos) caíram ainda mais. 
os dois choques do petróleo (1974-1979). E isto porque: (a) o aumento do preço do petróleo foi, por si mesmo, muito menor do que no período 1974-1979; (b) a estrutura produtiva já era muito menos dependente do insumo, dadas as condições de prevalência da Terceira Revolução Industrial. Em tempo: os gastos totais com importação de petróleo nos EUA em 1980 somaram 79,5 bilhões de dólares, e em 1990 62,3 bilhões. Isto gerava um percentual de 31\% de importações do total de importações do país em 1980 e 13\% em 1990 (as importações eram respectivamente 249,8 e 498,4 bilhões). Por outro lado, a participação do setor manufatureiro norte-americano no PIB tinha caído de $20 \%$ a $15 \%$ entre 1980 e 1993, o que relativiza ainda mais o impacto do preço do petróleo para a produção corrente.

Gráfico 6. Estados Unidos. Proxy de taxa de lucro no setor manufatureiro. 1974-1995.

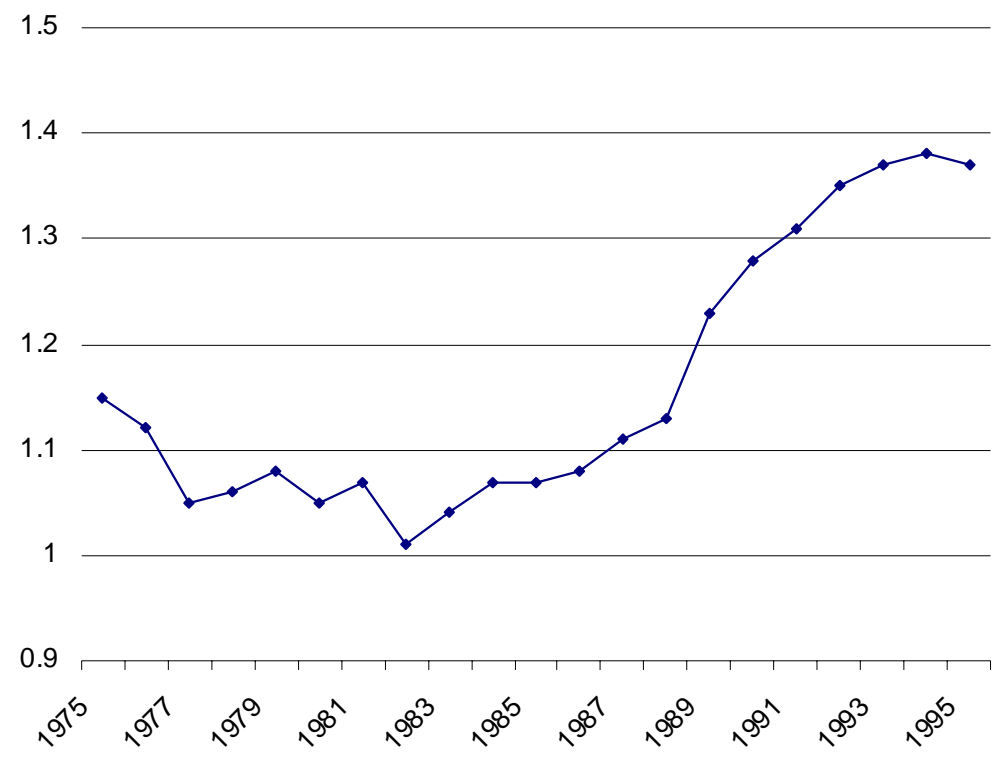

Fonte: ver gráfico 3 do capítulo 4.

A crise de 1990 aparece então como ocasionada por fatores distantes de um comportamento errático da lucratividade industrial. Trata-se de caso onde a lucratividade foi mantida, porém não a demanda agregada: mesmo uma relação entre salários e lucro tão favorável às corporações foi eliminada em seus efeitos pela queda geral das vendas, com conseqüências tácitas para o efeito acelerador, ocasionada pela conjunção dos processos supracitados.

e) O contraponto do bom desempenho das exportações

Não obstante, o conturbado panorama econômico da administração Bush foi minorado, em parte significativa, por um rápido crescimento das exportações norte-americanas, principalmente desde 1990. Como se vê pela figura abaixo, a partir daquele ano, o valor do dólar face ao iene e ao marco passou a cair rapidamente, numa trajetória decrescente que só iria 
encerrar-se em 1995. A recessão ajudou a diminuir o cômputo das importações em 1991; notase aí uma pendente ascendente das exportações bem maior do que a das importações, em queda. O setor exportador estava então recuperando ainda mais posições desde o segundo mandato de Reagan. E isto ainda que a situação geral da balança comercial norte-americana fosse de permanência dos déficits consolidados, refletindo o endividamento externo líquido da economia.

Gráfico 7. Estados Unidos. Exportações e importações de bens e serviços. Em bilhões de dólares correntes.

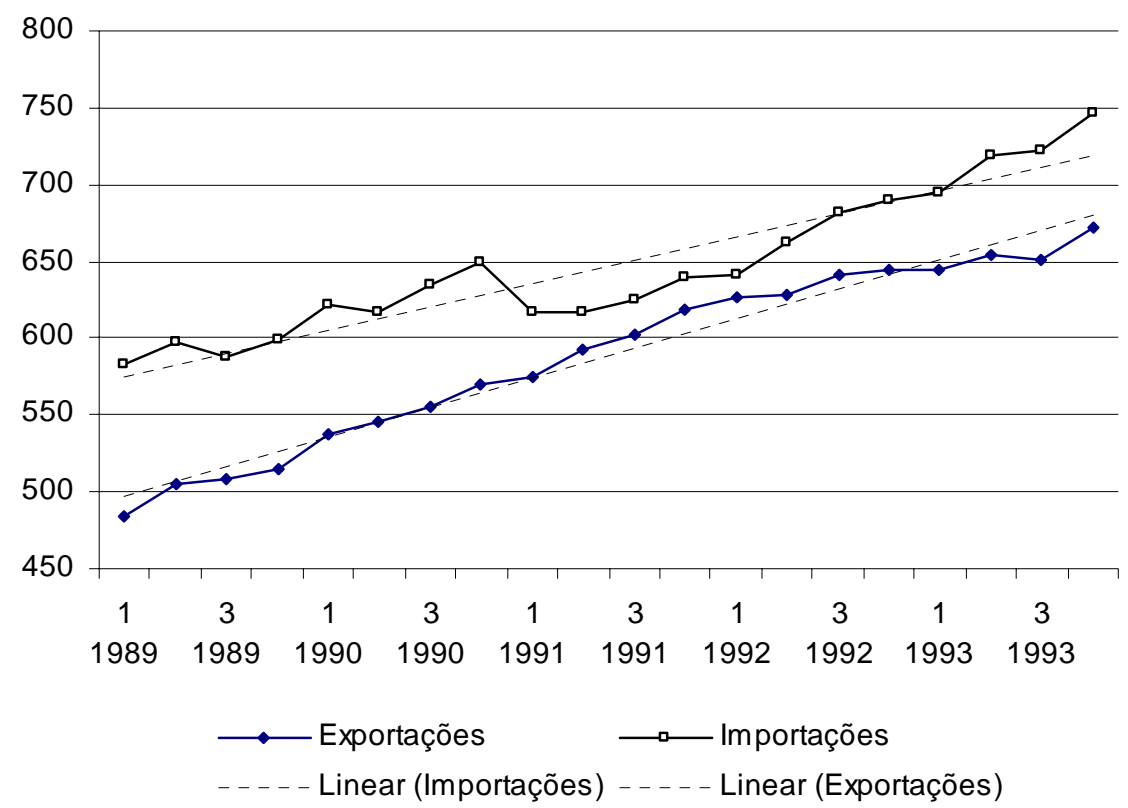

Fonte: NIPA-BEA. Seção 4, Foreign Transactions, Tabela 4.1., Foreign Transactions in the National Income and Product Accounts.

Estas exportações foram auxiliadas, sem dúvida, por uma queda do dólar face ao iene e ao marco, certamente atribuída ao rebaixamento dos juros desde o segundo semestre de 1989. Percebe-se então o impacto limitado do Acordo do Plaza Invertido de 1987 (o Acordo do Louvre) para conter a queda do dólar face às duas outras principais divisas, diante das modificações da política econômica doméstica norte-americana. Ou seja, tais ganhos de exportações não estavam se dando às custas de ganhos de produtividade na produção norteamericana, que se encontrava, desde o fim dos anos (19)70, bastante estagnada. Como se vê abaixo, os níveis de produção por hora na economia não-agrícola norte-americana encontravamse em trajeto cadente, não se podendo esperar que mesmo um certo aumento dos níveis de produtividade a partir de 1989 se refletissem de modo tão imediato no comportamento das vendas externas. Deste modo, o aumento das exportações deve ser atribuído em primeiro lugar às sucessivas desvalorizações do dólar que se seguiram ao rebaixamento dos juros, e à diminuição do crescimento do produto e renda domésticos. A diminuição do poder de compra doméstico induziu um aumento das vendas para o exterior e uma queda das compras no exterior. 
Gráfico 8. Estados Unidos. Taxa de câmbio do dólar em relação ao marco e ao iene (ienes no eixo esquerdo e marcos no eixo direito por unidade de dólar). 1980-2000.

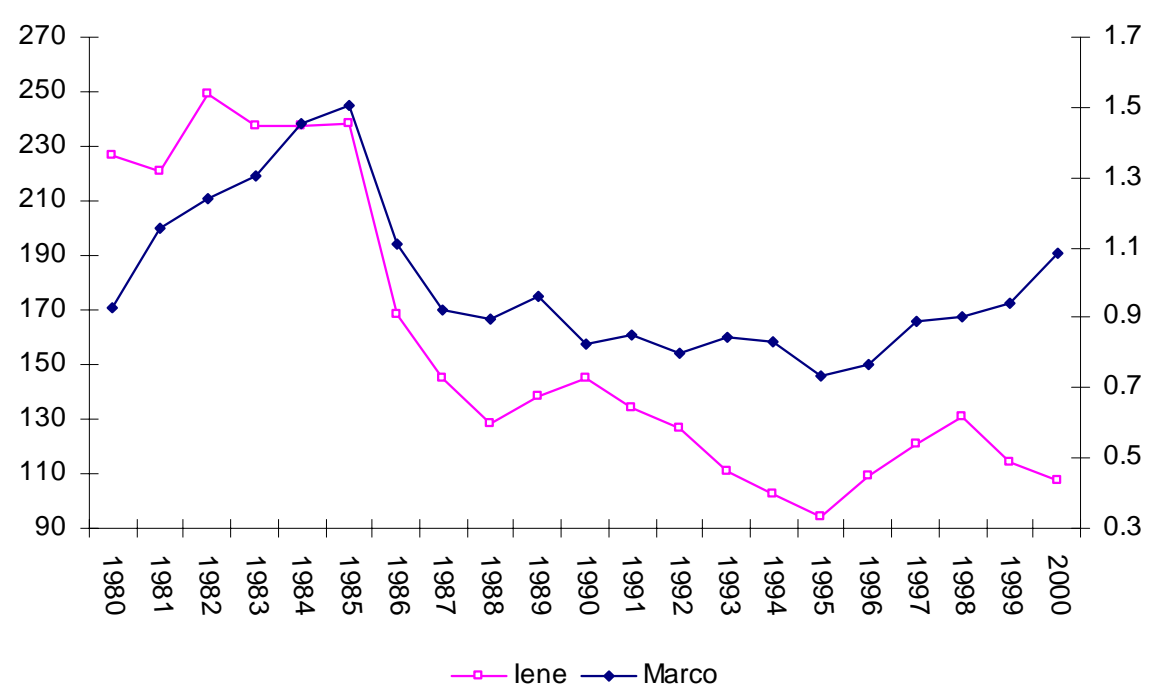

Fonte: OCDE. Ver www.oecd.stats.org /. (Pode ser encontrado também nos Economic Report of the President. Ver, para a edição de 2006, a Tabela B-110, Foreign Exchange Rates, 19842005.)

Assim, a crise de 1990-1991 foi minorada por uma taxa de lucro favorável no setor industrial e por um aumento das exportações norte-americanas no mundo, inclusive para Japão e Alemanha. Este aumento foi dado pelo radical rebaixamento do valor do dólar face ao iene e marco, e pelas decorrências que tal rebaixamento trouxe às outras moedas periféricas, atreladas ao dólar, ocasionado este pela vigorosa queda dos juros desde 1989. Justamente, os dois países viram-se pressionados em seus setores externos, componente crucial para elucidar suas respectivas desacelerações subseqüentes, ao longo dos (19)90. Tal deveu-se a suas dependências do setor externo.

Gráfico 9. Estados Unidos. Variação de produtividade (Output per hour - nonfarm business), em (\%). 1980-1994.

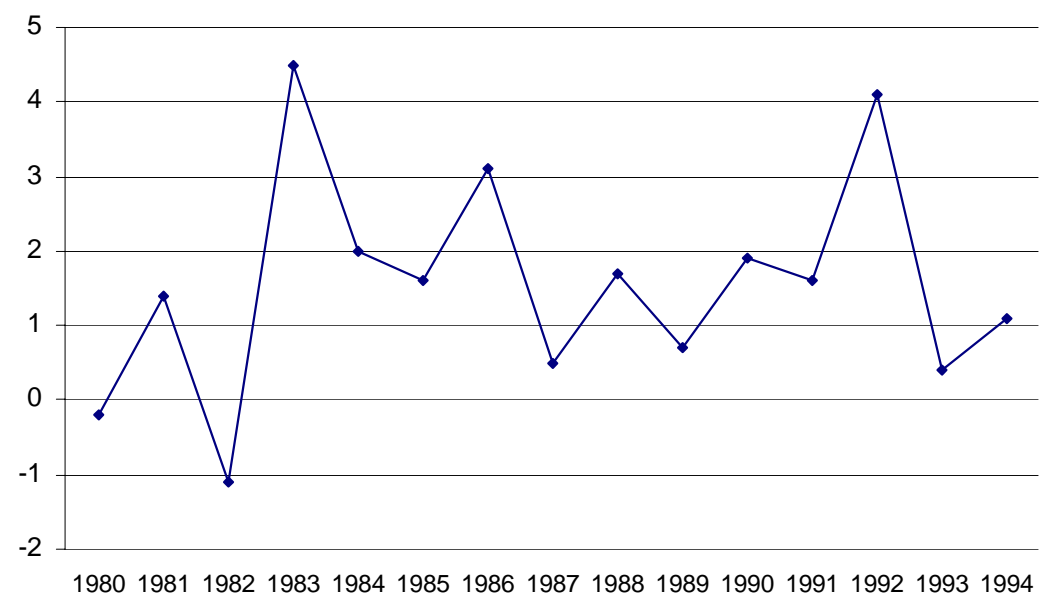

Fonte: Economic Report of the President, 2006. Tabela B-49, Productivity and related data, business sector, 1959-2005. 


\section{f) Endividamento externo}

Abaixo se encontram os dados sobre a posição externa da economia de forma menos desagregada. Vamos comentá-los brevemente, para a conclusão do capítulo.

Tabela 14. Estados Unidos. Estrutura do endividamento externo. Em bilhões de dólares correntes. 1989-1990.

\begin{tabular}{|c|c|c|c|c|}
\hline \multicolumn{5}{|c|}{ Estados Unidos: estrutura do endividamento externo } \\
\hline (1) & (2) & (3) & (4) & (5) \\
\hline & 1989 & 1990 & 1991 & 1992 \\
\hline $\begin{array}{l}\text { Títulos norte-americanos em } \\
\text { mãos de estrangeiros }\end{array}$ & 2145,5 & 2216,7 & 2363,2 & 2524,7 \\
\hline $\begin{array}{l}\text { Taxa de crescimento do } \\
\text { endividamento externo face ao } \\
\text { ano anterior } \\
\text { a) Compra de papéis do governo } \\
\text { norte-americano }\end{array}$ & 1,16 & 1,03 & 1,06 & 1,06 \\
\hline $\begin{array}{l}\text { a.1) Por agentes oficiais (Bancos } \\
\text { Centrais) }\end{array}$ & 263,7 & 295,0 & 315,9 & 335,7 \\
\hline a.2) Por agentes privados & 166,5 & 162,4 & 189,5 & 224,9 \\
\hline $\begin{array}{l}\text { a.3.) Outros títulos em mãos de } \\
\text { estrangeiros }\end{array}$ & 26,3 & 23,2 & 28,7 & 31,3 \\
\hline a.4) Total & 456,5 & 480,6 & 534,1 & 591,9 \\
\hline $\begin{array}{l}\text { Total arrecadado pelo governo } \\
\text { com impostos domésticos }\end{array}$ & 990,691 & $1.031,308$ & $1.054,264$ & $1.091,631$ \\
\hline $\begin{array}{l}\text { \% dos empréstimos externos } \\
\text { totais (a.4) sobre arrecadação } \\
\text { doméstica }\end{array}$ & $46 \%$ & $46 \%$ & $50 \%$ & $54 \%$ \\
\hline $\begin{array}{l}\text { b) Depósitos nos bancos dos EUA } \\
199\end{array}$ & 713,6 & 733,3 & 720,5 & 755,5 \\
\hline $\begin{array}{l}\text { b.1.) Por agentes oficiais } \\
\text { b.2) Por agentes privados }\end{array}$ & $\begin{array}{c}36,5 \\
677,1\end{array}$ & $\begin{array}{l}39,9 \\
693,4\end{array}$ & $\begin{array}{l}38,4 \\
682,1\end{array}$ & $\begin{array}{c}54,8 \\
700,7\end{array}$ \\
\hline $\begin{array}{l}\text { Taxa de variação de (b) face ao } \\
\text { ano anterior }\end{array}$ & 1,10 & 1,02 & 0,98 & 1,04 \\
\hline $\begin{array}{l}\text { c) Compras de ações e bonds de } \\
\text { corporações dos EUA }\end{array}$ & 482,9 & 469,0 & 556,3 & 617,3 \\
\hline c.1) Ações & 251,2 & 221,7 & 271,9 & 300,2 \\
\hline c.2) Bonds & 231,7 & 247,2 & 284,4 & 317,1 \\
\hline $\begin{array}{l}\text { Variação de (c) face ao ano } \\
\text { anterior }\end{array}$ & 1,23 & 0,97 & 1,18 & 1,11 \\
\hline d) Investimento direto nos EUA & 436,6 & 468,2 & 487,2 & 492,3 \\
\hline $\begin{array}{l}\text { Variação do investimento direto } \\
\text { face ao ano anterior }\end{array}$ & 1,16 & 1,07 & 1,04 & 1,01 \\
\hline
\end{tabular}

Fonte: Economic Report of the President, 1993. Tabela B-99, International Investment Position of the United States at year end.

\footnotetext{
${ }^{198}$ Tal como no capítulos anterior, no Apêndice Estatístico do Economic Report of the President a linha (a) corresponde - na tabela "International Investment Position of the United States at year-end" da Seção "International Statistics" - à seção "Foreign Official Assets in the United States - U.S.government securities"; a linha (b) corresponde a "US treasury securities", em "Other Foreign Assets in the United States"; e a linha (c) corresponde a "Other foreign official assets", de novo em "Foreign Official Assets in the United".

${ }^{199}$ Correspondem respectivamente a ambas linhas "U.S. Liabilities reported by U.S. Banks, not included elsewhere", estando uma na sub-seção "Foreign Official Assets in the United States" e outra na sub-seção "Other Foreign Assets in the United States".
} 
Os efeitos positivos à economia do expediente do endividamento já foram explicitados nos dois capítulos passados. De fato, a atração de recursos externos variou positivamente ano a ano; e, na verdade, não houve um ano em que sua taxa tenha caído a zero, no intervalo que está entre 1982 e 2009. Como se vê acima, o aumento da atração de recursos ano após ano indica que, de modo geral, todo o conturbado triênio de 1990-1992 foi menos conturbado pela presença das benesses do padrão dólar-dólar. Mas as posições no que toca ao endividamento externo devem ser tomadas em separado.

Especificamente, o governo norte-americano foi o agente que mais estrategicamente aumentou suas emissões de títulos a estrangeiros. De fato, o governo é o agente por excelência que pode emitir papel ao exterior, e com função contra-cíclica. A análise de como o governo consegue aumentar seu endividamento externo mostra que é elástica a demanda por títulos norte-americanos pela economia internacional, não sendo completamente correta a afirmação de Eatwell e Taylor de que "para a nação que toma emprestado, os movimentos de capital não são determinados completamente por sua vontade". ${ }^{200}$ Isto não é verdadeiro para o governo dos Estados Unidos em especial, dentro da vigência do padrão dólar-dólar. A administração Bush procedeu com o recurso do aumento das captações externas, num momento em que suas finanças estavam pressionadas por compromissos e determinações mais ou menos inevitáveis, de acordo com as regras do jogo impostas pela lei orçamentária de 1990. O agente que mais necessitava do endividamento continuou a fazê-lo, portanto. Os empréstimos externos sobre a arrecadação doméstica do governo federal subiram de $46 \%$ a $54 \%$. Não é demais notar também que os estrangeiros já possuíam papéis do Tesouro que somavam mais da metade da arrecadação do governo no país.

Veja-se o setor privado, começando pelos bancos. A desvalorização do dólar desde 1990, via rebaixamento dos juros, conduziu a uma menor colocação de recursos em moeda nos bancos norte-americanos, pelo mundo. A taxa de variação dos depósitos nos bancos norteamericanos caiu, durante o período (mantendo-se, no entanto, positiva, com exceção de 1991). Isto naturalmente tornou menor os efeitos redistributivos ao consumo das famílias oriundo do aumento das colocações em dólar no sistema financeiro norte-americano, pelo mundo. Esta flutuação das colocações de recursos do mundo na economia norte-americana pode ser classificada como sendo mais ou menos elástica à taxa de juros norte-americana e ao valor do dólar, portanto.

Por outro lado, não se pode dizer que a compra de ações e bonds de empresas norteamericanas tenha tido queda substancial. Pelo contrário, com exceção de 1990, deram-se variações positivas, que expressaram o aumento das captações externas como um recurso à contração do mercado de capitais local. Por sua vez, decresceu a participação dos investimentos diretos na economia, já que o mercado doméstico desacelerava. Os recursos obtidos pelo investimento direto, como já se viu, é muito elástico às flutuações do produto doméstico, e à taxa de lucro local. Diferentemente das emissões de papel ao exterior, o que o investimento

${ }^{200}$ Finanzas globales en riesgo, p. 150. 
direto busca é o lucro produtivo. Por isso, neste momento de desaceleração do PIB que marcou a maior parte da administração Bush, a taxa de crescimento do investimento direto caiu.

Assim, pode-se dizer que o governo e as empresas aumentaram suas captações no exterior, como maneira compensadora da flutuação. Por sua vez, neste momento de desaceleração e desvalorização do dólar, caiu o investimento direto e os depósitos diretos do mundo no sistema financeiro. Para tornar mais claro como especificamente os dois primeiros tipos de expediente relacionam-se com a poupança agregada norte-americana, vamos repetir a análise feita a partir da hipótese do multiplicador, no capítulo referente à primeira administração Reagan, para perceber o aumento do endividamento externo e sua relação com a renda nacional. Incorporemos agora ao multiplicador a propensão marginal a importar, para uma estimativa do impacto global do endividamento sobre a economia como um todo.

A propensão marginal a consumir e a propensão marginal a importar são dadas pelas duas regressões obtidas a partir dos dados das tabelas acima: o consumo das famílias (variável dependente ou y) em função da renda disponível (variável explicativa, ou x) dá a função consumo, cujo coeficiente b é a propensão marginal ao consumo das famílias no período adotado: $\mathrm{C}=-216+0,83 \mathrm{Y}$ (onde consumo é $\mathrm{C}$ e $\mathrm{Y}$ é renda). Do mesmo modo, a propensão a importar no período selecionado assume o valor de "b" em: $\mathrm{I}=-3,12+0,13 \mathrm{Y}$ (onde I são importações e Y renda). O multiplicador assim é: 1/1-0,83+0,13 =3,33. Percebe-se que, se em 1984 o endividamento externo era responsável por apenas $2 \%$ da renda nacional total formada tal como demonstrado naquele capítulo - em 1993 ele havia passado a aproximadamente 9\%.

Como dito, não se pode interpretar o aumento das emissões de bonds e ações das empresas norte-americanas ao exterior em 1991, neste ambiente depressivo, senão como uma estratégia de manter os níveis de capitalização internos. Estes eram herdados da década passada, driblando a contração dos mecanismos de crédito e financiamento domésticos. Neste caso, nota-se que se muitas taxas de endividamento corporativo não diminuíram mesmo na crise, isto se explica justamente pela presença marcante de uma situação de endividamento previamente já existente. Pode-se estimar que a situação de contração de vendas, num ambiente onde as dívidas já eram altas desde os anos (19)80, tenha forçado muitas firmas que sobreviveram à quebradeira a elevar seus níveis de endividamento, agora com o exterior. É a situação de tais corporações que se reflete num brusco aumento da emissão de papéis ao exterior. Igualmente, pode-se ver como esta emissão representou uma liberação de recursos locais, canalizados para outros fins, atenuando a flutuação do produto e a pressão sobre o mercado doméstico de capitais. 
Tabela 15. Estados Unidos. Dados selecionados. 1976-1984. Em bilhões de dólares.

\begin{tabular}{|c|c|c|c|c|c|c|}
\hline (1) & $\begin{array}{c}\text { (2) } \\
\text { Renda } \\
\text { disponível }\end{array}$ & Consumo das Famílias & $\begin{array}{l}\text { Importações totais } \\
\text { (bens e serviços) }\end{array}$ & $\begin{array}{c}\text { Aumento } \\
\text { do endividamento }\end{array}$ & PNB & $\begin{array}{c}(7) \\
\text { Impactos na } \\
\text { renda } \\
\text { local da } \\
\text { dívida a } \\
\text { partir do } \\
\text { multiplicador }\end{array}$ \\
\hline 1985 & 3526 & 2720 & 338 & - & - & - \\
\hline 1986 & 3722 & 2899 & 368 & - & - & - \\
\hline 1987 & 3947 & 3100 & 409 & - & - & - \\
\hline 1988 & 4253 & 3353 & 447 & - & - & - \\
\hline 1989 & 4587 & 3598 & 477 & - & - & - \\
\hline 1990 & 4878 & 3839 & 498 & - & - & - \\
\hline 1991 & 5051 & 3986 & 491 & 71 & 5995 & 236 \\
\hline 1992 & 5362 & 4235 & 536 & 147 & 6337 & 490 \\
\hline 1993 & 5558 & 4477 & 589 & 161 & 6657 & 536 \\
\hline
\end{tabular}

Fonte: Economic Report of the President, vários anos.

Em suma: não há como negar uma visão material do processo. Qualquer economia periférica que se endivide no exterior é vista como tal - como simples devedora que consumiu recursos alienígenas. Mas isto parece obscuro quando posto aos Estados Unidos, até o fim meados dos anos (19)70 "a maior fonte de poupança para a economia mundial", como diziam suas autoridades. $\mathrm{O}$ aumento do endividamento externo durante o período de crise traduzia a ajuda prestada pelo mundo à economia norte-americana, para que ela consumisse mais, e/ou investisse mais, num ambiente onde, em termos materiais, a poupança agregada estava em queda no médio prazo. Sem tal auxílio, os impactos seriam evidentemente mais disruptivos. No entanto, esta inversão ainda não era universalmente reconhecida como um sinal de mudanças subjacentes quanto ao desempenho dos agregados econômicos locais fundamentais. A Guerra Fria acabava e era um pouco difícil perceber que a economia "vencedora" também cambaleava - por outros motivos, mas cambaleava. Não era capaz de manter seus gigantescos níveis de consumo e investimento com seus próprios recursos.

Quando a União Soviética soçobrou, o Ocidente gabava-se da suposta superioridade do capitalismo sobre a economia socialista, retratada urbi et orbi como o pior dos sistemas sociais, em contraposição ao "mundo livre" sob égide dos Estados Unidos e de sua economia de "livre iniciativa". Mas neste mesmo momento, o mundo, por definição mais pobre, sancionava que a nação mais rica continuasse a mais rica, mesmo que artificialmente; o dreno do excedente permitia com que os perdulários norte-americanos não fizessem seus ajustes necessários. Os ajustes eram deixados para as nações periféricas, que padeciam da "escassez de divisas". A romantização de um mundo capitalista perfeitos só mostrava a decadência da análise social no Primeiro Mundo.

Um componente explicativo crucial da ideia geral deste trabalho é o que busca mostrar que, não obstante no longo prazo a presença do endividamento externo não evite a queda da acumulação produtiva, no médio prazo ele pode, como se esboçou na introdução, atenuar a 
pressão sobre a taxa de lucro, via barateamento da taxa de juros. No longo prazo, a conjunção de uma queda na propensão a investir com o aumento do endividamentoe externo culmina num aumento do consumo como modo de compensar a queda na demanda efetiva por parte das inversões. Isto por meio de uma menor pressão sobre o mercado de capitais e sobre a renda doméstica, conduzindo a juros menores e facilidades de financiamento. A uma maior "liquidez", na linguagem típica do economista. No limite, o endividamento externo conduz a um efeito distribuidor de renda, já que ele financia indiretamente empréstimos às famílias. Isto pode ser visto do modo inverso, por sua vez: as atuais (2008-2009) perdas nascidas no sistema imobiliário culminam em perdas para os bancos internacionais cujos capitais estavam nos Estados Unidos.

Tal como se definiu anteriormente, os empréstimos do exterior fazem parte da poupança agregada, por definição. O procedimento quantitativo abaixo deixa ver que justamente nos momentos onde a poupança agregada apresentou inversão negativa em relação a sua tendência, o cômputo do endividamento externo nela elevou-se, compensando, justamente, tal queda. $\mathrm{Na}$ figura abaixo, repete-se o estratagema de plotar apenas os resíduos de ambas variáveis poupança agregada líquida e ativos estrangeiros na economia norte-americana - para que suas flutuações possam ser vistas em sua inter-relação de modo mais exato. Mantém-se a linha do tempo, mas se retiram as variações de aumento ou queda. ${ }^{201}$

Com efeito, tal relação é encontrada com uma exatidão espantosa para o quadriênio da administração Bush. A figura deixa ver que justamente nos momentos onde a poupança agregada apresentou inversão negativa, o cômputo do endividamento externo (que faz parte dela) elevou-se, compensando, justamente, as deficiências. Pelo contrário, nos momentos em que a poupança doméstica crescia, a economia diminuía o nível de endividamento externo; ou seja, o cômputo do endividamento externo caía. Esta relação, já vista para o período da segunda administração Reagan, repetiu-se novamente no quadriênio de Bush.

\footnotetext{
${ }^{201}$ Como no capítulo passado, tais dados foram coletados nos apêndices estatísticos do Economic Report. Neste caso, os volumes são os de 1992, 1993 e 1994, novamente nas Tabelas "Gross Saving and Investment" e "International Investment Position of the United States at End of Year", respectivamente presentes nas Seções "National Income and Expenditure" e "International Statistics".
} 
Gráfico 10. Estados Unidos. Resíduos de poupança agregada em função do tempo e de ativos estrangeiros na economia norte-americana (dívida externa), em base trimestral. Em bilhões de dólares correntes. 1989-1990.

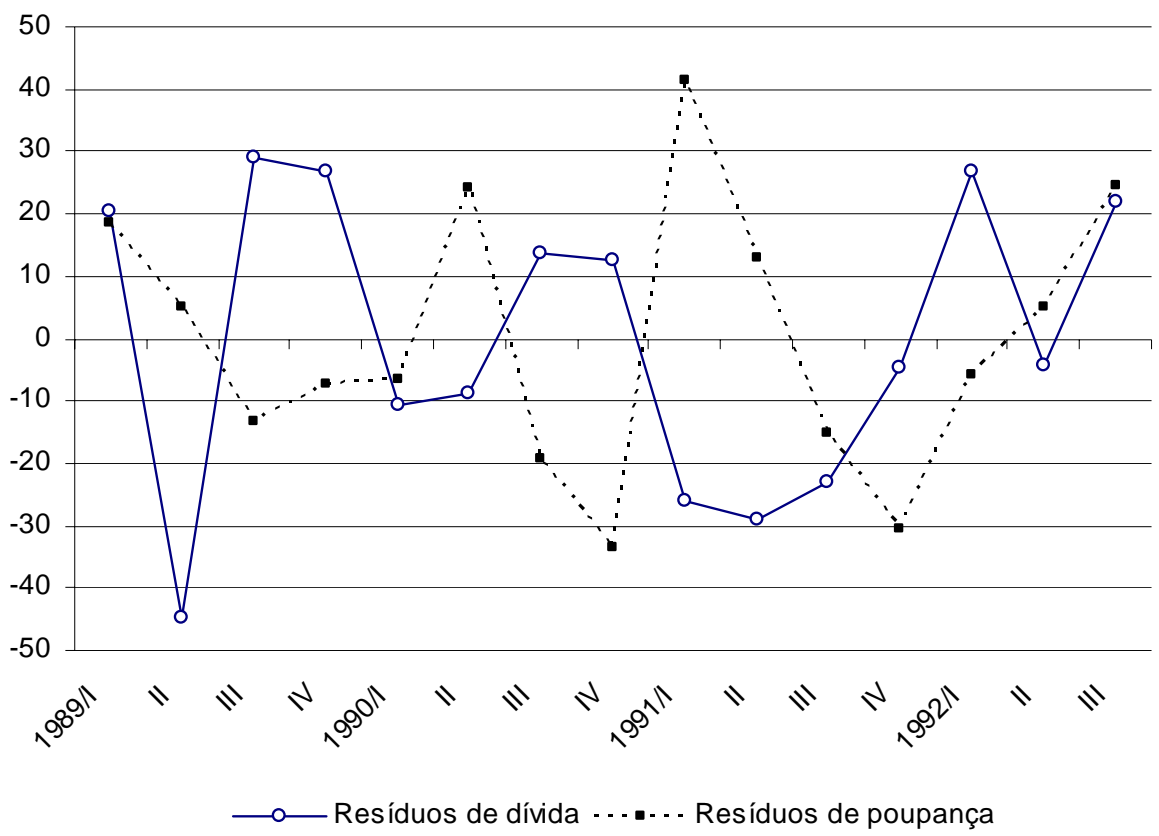

Fonte: Economic Report of the President, vários números. Fontes: para poupança agregada, Tabelas Gross Saving and Investment; para dívida externa, ver linha Foreign Assets in the U.S., na Tabela U.S. International Transactions, primeira tabela da Seção International Statistics do Economic Report.

Isto leva à conclusão de que todas as flutuações de curtíssimo prazo deste momento instável foram atenuadas por aumentos expressivos da poupança externa para a área norteamericana: aumento da poupança externa como cômputo da poupança agregada. É evidente que o aumento das emissões de papéis ao exterior, principalmente mediante os papéis do governo e das empresas (como se notou acima) tem então uma correlação com as mudanças imediatas nos perfis de custo de obtenção de crédito local, aparecendo o exterior como um elemento que diversifica a oferta de recursos ao mercado local, permitindo assim queda de custos. 
Tabela 14. Estados Unidos. Poupança agregada doméstica e ativos estrangeiros na economia norte-americana, em base trimestral. Em bilhões de dólares 1989-1990.

\begin{tabular}{ccc}
\hline$(1)$ & $(2)$ & $(3)$ \\
Trimestres & Poupança Agregada total & Ativos estrangeiros nos EUA \\
1989/I & 770 & 69,5 \\
II & 751 & 2,4 \\
III & 727 & 74,2 \\
IV & 727 & 70,2 \\
1990/I & 722 & 30,9 \\
II & 747 & 30,8 \\
III & 698 & 51,3 \\
IV & 678 & 48,1 \\
I991/I & 747 & 7,8 \\
II & 713 & 2,9 \\
III & 679 & 7,1 \\
IV & 658 & 23,5 \\
1992/I & 677 & 52,8 \\
II & 682 & 19,8 \\
III & 696 & 44,4 \\
\hline
\end{tabular}

Fonte: ver gráfico 10.

\subsection{Um balanço}

Pode-se inferir que o cenário econômico não se mostrou alvissareiro para a administração Bush, tendo ela a triste sorte de ter de encarar as conseqüências negativas da política do Reaganomics. Inicialmente herdou uma política monetária apertada, vinda do fim da administração passada. Seguiu-se a fase mais profunda da crise dos Savings\&Loans, também provocada pelas políticas do governo precedente. Teve-se de dar cabo dela, o que conduziu a gastos adicionais não previstos e à necessidade de ajuste do orçamento com déficit em aumento rápido. Os resultados foram (a) um politicamente difícil - ainda que sobre as famílias - aumento de impostos mediante uma nova lei orçamentária. Esta, se não impediu a ação do governo na crise econômica - mediante os mecanismos de exceção -, evidentemente a limitou. E (b), um aumento do endividamento externo do governo, agente que demandou mais recursos durante a crise. Por sua vez, os acontecimentos no Golfo Pérsico geraram um aumento do preço do petróleo também prejudicial no curto prazo, do ponto de vista da pressão sobre o consumo das famílias.

A invasão do Kwait pelo Iraque representou por si mesma uma elevação dos preços do petróleo. Certamente, a contenção norte-americana às forças de Hussein foi, economicamente, satisfatória para os vencedores. A guerra pouco impactou no orçamento (10 bilhões anuais em 1991) e o petróleo teve seus preços contidos. Mas a limitação da política físcal pela lei orçamentária e um acento demasiado na perspectiva do "lado da oferta" podem ser interpretados como impeditivos para que a administração minorasse a crise. Os déficits fiscais não estiveram 
à altura da dimensão da flutuação, não tendo impedido a retração em 1991, e as concessões às corporações só fizeram aprofundar a tendência negativa.

Com efeito, a guerra contra o Iraque não representou mais uma viragem rumo à militarização da economia como remédio à crise. Foi sim uma demonstração de poder norteamericano, dissuadindo de vez os últimos adversários da Guerra Fria e outros que poderiam aparecer num virtual contexto nebuloso de transição. De certo modo, o fim da Guerra Fria representou para o governo um momento onde as manipulações da indústria de guerra como elemento de resposta à crise já não eram politicamente fáceis de fazer-se aceitar. Tal fato ajuda a compreender melhor alguns dos elementos que impediam que os déficits fiscais crescessem mais do que deveriam, no sentido de minorar a flutuação. Não é errado crer que a lei orçamentária talvez tivesse virado "letra morta", no caso de uma suposta ameaça de agressão externa ou de algum fator que fosse o oposto daquele que estava ocorrendo: a queda da União Soviética. Neste caso, os mecanismos de exceção teriam dado lugar ao simples e puro aumento continuado dos déficits fiscais, com suspensão da lei propriamente dita. Como mostra o ambiente atual (2009), o aumento dos déficits fiscais pode ultrapassar tranqüilamente a casa de um trilhão, sem que nada ocorra. Então, o fim da Guerra Fria não significava apenas menos inversões, no curto prazo, na indústria de guerra: o novo contexto representava uma impossibilidade política de manipulações mais radicais do orçamento, para infelicidade do Partido Republicano e de Bush, que visavam a reeleição. Por isto mesmo num momento de triunfo da política externa a maior parte do eleitorado norte-americano rejeitou a reeleição. A partir daí, entende-se a necessidade objetiva para tais governos da existência de "inimigos externos", sendo eles (1) reais ou (2) criados pelas manipulações do próprio governo. É provável que (2) tenha sido e ainda hoje seja a hipótese mais correta.

Em tese, o conflito em torno dos déficits orçamentários se dava entre (1) os que adotavam uma perspectiva crítica dos déficits, geralmente defendida por políticos do Partido Republicano e seus think tanks munidos da teoria neoclássica, e (2) parte dos administradores de visão mais pragmática, para quem a política anti-cíclica era afinal o elemento mais importante da atuação da administração pública, a ser implementada às custas do sacrifício à ortodoxia. $\mathrm{O}$ Budget Reconciliation Act expunha uma dificuldade fiscal fundamental e também um conflito no interior do governo norte-americano referente à administração do orçamento federal. Tal dificuldade era a necessidade de aumentar a receita do Estado sob um ambiente politicamente difícil de fazê-lo, caso no qual o financiamento externo da economia aparecia como um cômodo modo de lograr tal objetivo sem que os custos políticos fossem muito pesados. De fato, o endividamento externo da economia já chamava a atenção de analistas, mas não representava um tema que politicamente expusesse o governo às dificuldades que provocava a elevação doméstica de impostos. Na verdade, boa parte do público via o endividamento externo da economia como um indício do continuado poder do dólar e dos Estados Unidos na economia mundial. Para este, podia ser encarado como um sinal de fortalecimento dos "fundamentos", e não como fraqueza deles - o que de fato era. 
Decerto, o Budget Reconciliation Act compunha-se de duas perspectivas principais: em primeiro lugar, era uma variante da administração econômica pelo "lado da oferta", rebaixando impostos ao capital e os elevando para a coletividade. Em segundo, continha alguns elementos de política de aparência keynesiana que o governo norte-americano sempre utilizou - como justamente o aumento de déficits orçamentários em situações de crise:

"Durante um declínio, os gastos do governo - como os de seguro-desemprego aumentam, e a arrecadação cai em relação ao que normalmente seria. Embora eles temporariamente aumentem o déficit público, estas mudanças nos impostos e gastos funcionam como 'estabilizadores automáticos' para reduzir quedas na renda e gastos e assim impulsionar a recuperação." ${ }^{202}$

Mas o cruzamento de duas posturas teóricas muito diversas conduzia a contradições internas. Em primeiro lugar, defendia-se a atuação dos estabilizadores automáticos - i.é, aumento dos gastos - mas se criticava tais gastos porque "diminuíam a taxa de poupança". Aceitava-se a ação dos estabilizadores automáticos, mas isso não parecia um princípio que contradizia a própria perspectiva do "lado da oferta". Ora, como podem existir estabilizadores automáticos que, aumentando a renda, não aumentem depois a poupança, pelo aumento dos gastos multiplicados? Para estes economistas, o governo só emprestava recursos, mas seus gastos nunca geravam efeitos multiplicadores. Tomava-se por certo que tais recursos que o governo efetivamente gastava - gerando poupança - seriam dispendidos por outros agentes, o que contradiz a própria noção de crise. Mas não indica a crise a taxa de poupança não efetivada? É evidente que, sem o uso da noção de multiplicador, um déficit orçamentário "apareceria" apenas como uma queda anterior da taxa de poupança, e não como um elemento que a dinamiza. Levando-se o argumento liberal à sua conclusão lógica, qualquer gasto - investimento ou consumo privado - remeteria a sua primeira fotografia, ou seja, a uma "queda da poupança". O que obrigaria a dizer, absurdamente, que qualquer investimento ou consumo nada mais seriam que impedimentos ao próprio crescimento: isto é, o crescimento impede o crescimento etc..

Para além do contra-senso, o déficit federal era o componente do consumo agregado mais fácil de reduzir, comparado, por exemplo, com o volume de consumo dos grupos mais ricos. Tal volume de consumo dos grupos dominantes era, num sentido agregado, muito maior do que os déficits do governo, merecendo assim, virtualmente, estar no centro da discussão sobre a capacidade de formação de poupança. ${ }^{203}$ Mas a preocupação era exclusiva com os

\footnotetext{
202 "During an economic downturn, government expenditures - such as unemployment compensation increase, and tax receipts fall relative to what they otherwise would be. Although they temporarily increase the budget deficit, these changes in taxes and expenditures work as 'automatic stabilizers' to reduce declines in income and spending and thus to hasten recovery". Economic Report of the President, 1991, p.26. As descrições citadas estão no capítulo 1 deste Economic Report of the President de 1991, intitulado "Foundations for Economic Growth".

${ }^{203}$ Formule-se o seguinte exemplo: em termos numéricos, o consumo total das famílias norte-americanas em 1992, na forma de bens de consumo duráveis, não-duráveis e serviços, chegava a quatro trilhões e
} 
déficits fiscais. "Por que não reduzir o consumo?", poder-se-ia perguntar, segundo a mesma lógica neoclássica de formação de poupança para o investimento. A pergunta envolveria uma discussão sobre a estrutura de gastos do excedente que no entanto não cabia para as autoridades e para os interesses dominantes.

"Para sustentar um crescimento robusto, os Estados Unidos precisam manter uma alta taxa de investimento em capital e em novas tecnologias. Isto, por sua vez, requer um adequado fluxo de poupança nacional. Os substanciais déficits federais dos anos recentes diminuíram a taxa nacional de poupança." 204

Além disso, a lei visava aumentar impostos e diminuir os déficits, num momento onde a economia precisava de menos impostos e mais gastos. Mas, ao invés de as autoridades declararem que a lei vinha justamente num momento onde diminuir impostos e aumentar gastos era politicamente difícil, definiam que o aumento de impostos e a queda dos gastos eram necessárias para que se obtivesse, justamente, mais crescimento. Esta postura da ingerência pública não era condizente com a administração da crise que se iniciava no fim de 1989, mas a pressão dos gastos com o FIRREA não deixava muitas alternativas, dado o "primado da propriedade".

Com efeito, a típica atitude do economista otimista era inclusive jactar-se dos crescentes haveres do exterior contra os Estados Unidos como um sinal claro da manifestação da "confiança" dos investidores e do capital internacional no dólar. ${ }^{205}$ Para além do raciocínio keynesiano, que é de curto prazo, tomavam a aparência do fenômeno como seu aspecto fundamental, ignorando que a taxa de investimento e consumo agregados não poderiam ser sempre maiores que a poupança gerada por eles no momento anterior. Por isso, mesmo na baixa, a manutenção do endividamento externo se revelou fundamental, como modo de contornar os efeitos da crise.

Uma posição mais lúcida acerca do endividamento externo, argumentada por muitos economistas conhecidos (Batra, Eatwell, Taylor, Stiglitz, Duncan, dentre outros), passou gradativamente a ser defendida inclusive por Alan Greenspan e outras autoridades da Reserva Federal. Mas o modo pelo qual esta defesa era feita não atingia o âmago do problema: sua

novecentos bilhões de dólares; se se supõe que dez porcento deste consumo representava consumo com bens de luxo das camadas mais ricas, tem-se que, em tese, aproximadamente quinhentos bilhões de dólares em consumo conspícuo eram passíveis de redução, a fim de conduzir tais gastos rumo a fins que "aumentassem a capacidade produtiva" da economia. Bem, este valor é quase duas vezes maior do que o déficit federal naquele momento, de 290 bilhões de dólares. Havia, então, outras maneiras de abordar o problema.

204 "To sustain robust economic growth, the United States must maintain a high rate of investment in new capital and new technology. That, in turn, requires an adequate flow of national Savings. The substantial Federal Budget deficits of recent years have decreased the national Savings rate.". Ibid, p.26.

${ }^{205}$ Esta posição está amplamente disseminada nos relatórios das várias sub-sedes do Fed. Mesmo autores que supostamente se inclinam por uma perspectiva kaleckiana parecem não ver contradições no aumento do endividamento, tal como Serrano, quando fala em tom de pilhéria sobre a "suposta tendência dos americanos de viverem acima de seus meios". Confunde ele assim hegemonia com ausência de contradições. O Mito do Colapso do Poder Americano, p.143. 
perspectiva neoneoclássica o levava a enxergar no Estado a fonte de todo o problema da taxa de poupança, e a desconsiderar todas outras alternativas de elevá-la, numa situação dada em que a economia já não obtinha grandes taxas de crescimento. Escreveu Greenspan:

"Quais são as atuais restrições ao crescimento e como elas podem ser manejadas? $\mathrm{Eu}$, e outros, temos há muito argumentado face a este Comitê que a questão essencial para esta economia é o hiato entre poupança e investimento. É aqui que nosso foco político principal deveria repousar. [...] Impulsionar a oferta de poupança disponível para apoiar investimentos privados produtivos deve ser uma prioridade para nossa política fiscal, e, em relação a isto, reduzir a demanda dos gastos federais na reserva de poupança nacional é essencial. A diminuição dos gastos do Estado é, neste sentido, crucial para esta meta." 206

Evidentemente, havia muitas maneiras de expandir a taxa de poupança doméstica para elevar a produtividade média da economia, e todas elas passavam pelo crivo das decisões políticas por detrás da política econômica. As inversões destinadas ao complexo industrial militar garantiam as opções estratégicas da política de segurança nacional e externa do governo norte-americano, mas indiretamente representavam um desestímulo às exportações como um todo, porque o cômputo principal das vendas do mercado internacional não é feito de bens para a economia de guerra. Por outro lado, uma enorme parte do consumo corrente das famílias norte-americanas mais abastadas significava, de um ponto de vista macroeconômico, simplesmente um desperdício de recursos que poderiam estar sendo invertidos na criação de maior capacidade produtiva. Não era este, afinal, o objetivo oficial perseguido pelas políticas de Greenspan? Isto ao invés, justamente, de simplesmente estarem sendo destinadas ao consumo luxuoso que não representava nada mais do que um componente de demanda efetiva que não alterava fundamentalmente as bases tecnológicas vigentes (e assim a taxa de produtividade).

Ora, a demanda representada pelos gastos do Estado era, neste sentido, muito mais eficiente do que o consumo perdulário, porque parte importante se destinava - incluídos inclusive os gastos com defesa - ao fomento à pesquisa e gastos sociais, importantes elementos "intangíveis" de crescimento da produtividade, inclusive o desempenho do fator trabalho. Daí ser a posição de Greenspan e dos que se voltavam contra o desequilíbrio das finanças públicas um mero reflexo de uma determinada posição - a de percepção da organização social vigente naquele momento como sendo a única possível, jogando para as esferas de atribuição do Estado um ajuste que poderia ser feito em outros setores, com resultados mais alvissareiros.

206 "What are the current restraints on growth and how can they be addressed? I and others, have long argued before this Committee that the essential shortcoming of this economy is the lack of saving and investment. It's here that our major policy focus should rest. [...] Bolstering the supply of saving available to support productive private investment must be a priority for fiscal policy, and in that regard, reducing the call of the federal government on nation's pool of saving is essential. Federal expenditure restraint is, in turn, crucial to this goal." Testimony by Alan Greenspan before the Committee on Ways and Means - House of Representatives. 18 de Dezembro de 1991. 
Não é errado dizer que a crise de 1990-1991 foi de natureza distinta da crise do fim dos anos (19)70, tendo tido decorrências muito menores. Ela não se mostrou tão catastrófica como previam alguns economistas no fim dos anos (19)80, ${ }^{207}$ mas certamente era um indício dos fatores que pressionavam pela estagnação. Neste momento, a política do governo baseou-se numa política tributária que não permitiu o aumento do consumo das famílias como medida compensatória. Ainda, viu a política fiscal anti-cíclica limitada pela lei orçamentária de 1990. Por outro lado, o impacto do aumento do preço do petróleo em 1989-1991 sobre as taxas de lucro pode ser relativizado seja (a) por suas próprias dimensões limitadas, quando comparado com o aumento da época anterior; seja (b) por uma economia tecnologicamente mais avançada, na qual utilização de tal insumo já era relativamente menor, nas condições do avanço da Terceira Revolução Industrial.

Gráfico 11. Estados Unidos. Valor real adicionado na indústria, em (\%). 1980-1992.

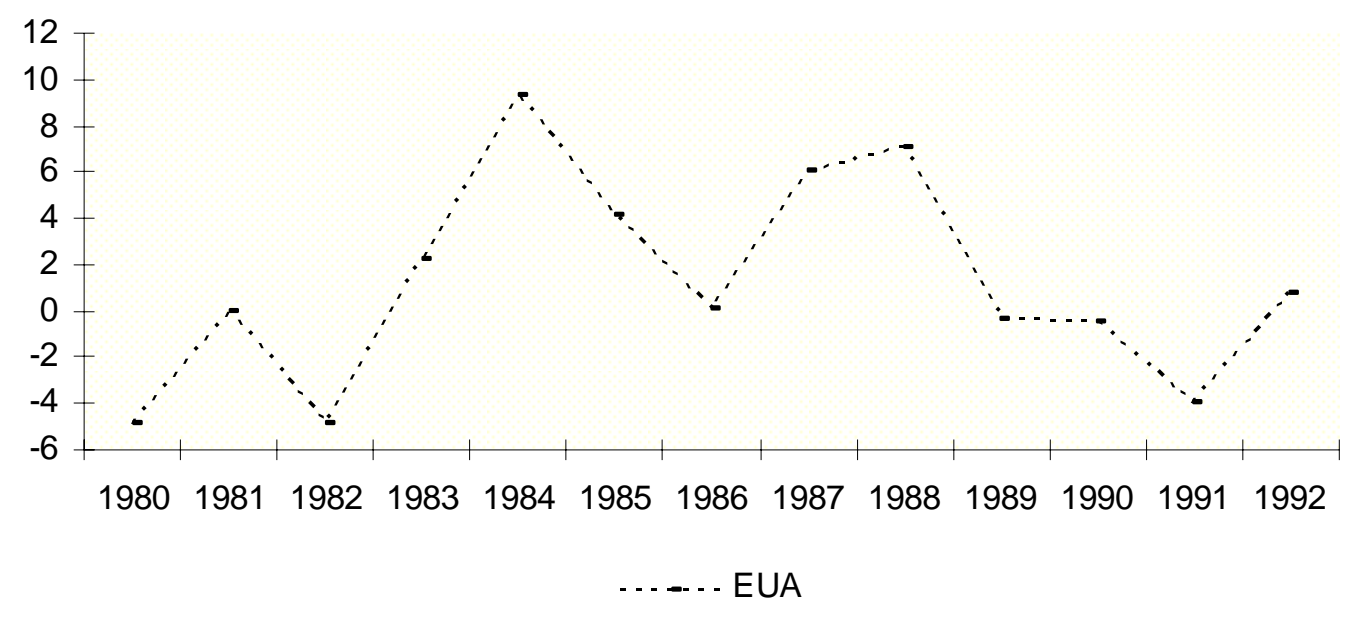

Fonte: OCDE. Ver www.oecd.stats.org/.

De modo geral, o comportamento da economia ao longo da próxima década será determinado por uma taxa de lucro em ascensão nos setores industriais, conjugada com um grande aumento das exportações, manutenção de salários estagnados e crescimento da produtividade média da economia. É importante ressaltar que tal crescimento se dará sem que o complexo industrial-militar fosse o centro acumulativo dinamizador da expansão, dada a então queda de sua importância relativa nas condições do fim da Guerra Fria. Estes fatores, porém, não vão impedir que o endividamento externo da economia tenha aumentado, e nem que os lucros no sistema financeiro tenham crescido ainda mais depressa. Os "exuberantes anos (19)90" não terão assim passado de um capítulo rápido e específico do caminho para taxas de crescimento cada vez menores, tal como se assiste hoje.

\footnotetext{
${ }^{207}$ A conclusão de "1990, A Grande Depressão", de Ravi Batra, é de que, "realmente, podemos indicar 1990 como o ano da maior depressão do mundo" (p.155), querendo com isto dizer a maior depressão já vista.
} 
Tal aumento do endividamento seria fundamental num momento onde a "maturidade" da economia estava se firmando cada vez mais, com uma elevação da taxa de lucro paralela à queda da participação da indústria no PIB. Isto indicava um desempenho ainda mais satisfatório de outras atividades econômicas, mormente o setor financeiro. Tais exuberantes anos (19)90, diferentemente de períodos anteriores de crescimento vigoroso, teriam um padrão de desempenho assentado não somente no crescimento das taxas de lucro no setor "real", mas sim no crescimento da financeirização, do endividamento externo, e de uma bolha acionária cujo rompimento se daria em 2001. Efetivamente, suas bases eram frágeis. Sua duração foi muito limitada, depois da qual a economia foi jogada novamente na tendência à estagnação. $O$ crescimento serviu, porém, para alimentar fantasias sobre um desempenho de uma economia livre dos ciclos, desfeitas logo depois de uma nova crise.

Tabela 18. Estados Unidos. Trabalhadores por setores. Em milhares de pessoas. 1980-1992.

\begin{tabular}{cccccc}
\hline$(1)$ & $(2)$ & $(3)$ & $(4)$ & $(5)$ & $(6)$ \\
Anos & Total & $\begin{array}{c}\text { Construção } \\
\text { Civil }\end{array}$ & $\begin{array}{c}\text { Manufatura } \\
\text { Serviços }\end{array}$ & Governo \\
1980 & 90528 & 4454 & 18733 & 66265 & 16375 \\
1981 & 91289 & 4304 & 18634 & 67172 & 16180 \\
1982 & 86677 & 4024 & 17363 & 67127 & 15982 \\
1983 & 90280 & 4065 & 17048 & 68171 & 16011 \\
1984 & 94530 & 4501 & 17920 & 71095 & 16159 \\
1985 & 97511 & 4793 & 17819 & 73926 & 16533 \\
1986 & 99474 & 4937 & 17552 & 76156 & 16838 \\
1987 & 102088 & 5090 & 17609 & 78618 & 17156 \\
1988 & 105345 & 5233 & 17906 & 81436 & 17540 \\
1989 & 108014 & 5309 & 17985 & 83969 & 17927 \\
1990 & 109487 & 5263 & 17695 & 85764 & 18415 \\
1991 & 108374 & 4780 & 17068 & 85787 & 18545 \\
1992 & 108726 & 4608 & 17799 & 86631 & 18787 \\
\hline
\end{tabular}

Fonte: Economic Report of the President, 2006. Tabela B-46, Employees on nonagricultural payrolls, by major industry, 1959-2005.

O centro da questão envolve a diminuição progressiva da participação do setor produtivo no produto doméstico. Esta não foi modificada estruturalmente nem nos anos mais expansivos na administração de Clinton. A contínua discrepância entre as taxas de lucro industriais e as financeiras é o que explica que a economia haja se tornado tão diversificada e tão mais complexa do que ela era em comparação, por exemplo, com os anos "áureos" de sua industrialização e vertiginoso crescimento da produção física. Mas isto é o que explica, também, seu menor crescimento. Neste sentido, a queda das taxas de crescimento do produto não seria por si mesma um "problema", se a lógica do sistema não fosse a de expandir sempre, seja por meio de mais investimento, seja por meio de mais consumo das famílias. É justamente a presença desta lógica, nas condições das pressões para a estagnação, que expressa as 
contradições que se refletem em última instância no aumento do endividamento externo da economia como expediente para sua atenuação.

Este panorama seria, todavia, agitado pelos acontecimentos da administração Clinton. Eles pareceram, por algum tempo, ofuscar os fatores subjacentes do movimento tendencial assinalado. 
A primeira administração Clinton (1993-1996)

"As verdades científicas são sempre paradoxais, se julgadas pela experiência de todos os dias, a qual somente capta a aparência enganadora das coisas."

Karl Marx, Salário, Preço e Lucro

\subsection{Introdução}

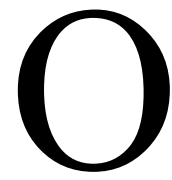

capítulo aborda a recuperação da economia norte-americana após a crise de 1990-1992, durante o primeiro mandato da administração Clinton (19931996). Discute-se como a recuperação esteve baseada num ciclo de inovações tecnológicas, e em que ambiente macroeconômico tal se deu. No âmbito da política econômica, abordam-se (a) o OBRA93, plano que visava conter os déficits fiscais e que conduziu a menores gastos com defesa; (b) o NAFTA, Tratado de Livre Comércio na América do Norte entre Estados Unidos, México e Canadá. Argumenta-se neste capítulo que a política econômica pôde conduzir a uma diminuição das inversões nos setores da economia de guerra e a uma redução dos déficits orçamentários federais, justamente pela elevação das inversões privadas e pelo aumento do endividamento externo. Sustenta-se também, neste sentido, que o crescimento das inversões produtivas com base numa taxa de lucro ascendente não levou à diminuição da atração de recursos externos, porque a elevação da poupança doméstica foi neutralizada pelo aumento do cômputo das importações e pela queda da taxa de poupança das famílias, além do fato de que só foi possível fazer o ajuste das contas do governo federal mediante aumento da dívida federal externa.

\subsection{O contexto da vitória do governo democrata}

Como se comentou no último capítulo, a crise econômica de 1990-1992 conduziu à derrota de George Bush. William Jefferson Clinton, ex-governador do Arkansas, e Albert Gore Jr., seu vice-presidente do Partido Democrata, foram eleitos com vitória em trinta e dois estados, contra a vitória de Bush em dezoito. O contexto de eleição do Partido Democrata, após doze anos de administrações republicanas sucessivas, envolvia, além do início da recuperação norte-americana, o reforço da hegemonia dos Estados Unidos no exterior e uma desaparição, na maior parte do mundo, de qualquer influência significativa do socialismo. Isso facilitou a influência de ideias liberais sobre as políticas de Clinton. Suas políticas refletiriam então (i) o modo específico pelo qual o Partido Democrata via determinadas questões de política econômica, junto de (ii) uma influência desta hegemonia das ideias liberais no início da década de (19)90. 
Com efeito, a liderança do Partido Democrata via de modo diferente, em comparação com o Partido Republicano, problemas tais como (i) os direitos das "minorias" (legalização das uniões entre homossexuais, p.e.); (ii) os dos chamados "direitos humanos" (menos policiamento, mais prevenção); (iii) a liberação da pesquisa com células-tronco; (iv) a reforma e ampliação do sistema de financiamento público de auxílio à saúde (MEDICARE, para idosos, e MEDICAID, para indivíduos com rendas baixas). A reforma do orçamento, representada pelo abaixo comentado Omnibus Budget Reconciliation Act of 1993, elevou impostos sobre as faixas mais ricas. Neste sentido, também se diferenciava das propostas republicanas de modificação dos orçamentos anteriores.

A política econômica de Clinton seguiria um corte de desregulamentação e promoção de maior competição em setores decisivos da vida econômica. Além disso, trazia favorecimentos ao livre comércio. A radicalidade na defesa dos interesses corporativos e norteamericanos no mundo seria similar a qualquer outra política republicana na década anterior. A atuação da política de desregulamentação de Clinton concentrou-se nas áreas referentes às telecomunicações, energia e finanças. E, por fim, tal como na administração Reagan, a equipe de Clinton permitiu um aumento do endividamento externo da economia como elemento crucial para o desempenho da economia.

A preocupação com o déficit fiscal federal, a desregulamentação do sistema financeiro e as propostas de liberalização do comércio exterior indicavam portanto várias continuidades, não obstante a mudança de perspectiva em outras áreas exteriores à política econômica. Conforme com isto, Alan Greenspan atravessará todos os dois mandatos de Clinton à frente da Reserva Federal, num bom relacionamento com o presidente. Clinton mesmo observou em sua autobiografia esta continuidade: "Eu sabia que Greenspan era um republicano conservador que provavelmente ficou desapontado com minha eleição, mas achei que poderíamos trabalhar juntos por [...] eu defender a independência do Banco Central, [e também porque, como ele,] eu também achava essencial diminuir o déficit [do orçamento federal]." 208

Cabe então discutir-se os seguintes tópicos: (a) o problema de uma viragem ascendente das inversões centrada nas tecnologias de informação; (b) a readequação da indústria de guerra; (c) a política econômica, com ênfase na reforma do orçamento, no comércio exterior e na política de liberalização.

\subsection{O problema da "nova economia"}

\section{(a) Algumas opiniões}

O ciclo de crescimento dos anos (19)90, de acordo com a maioria dos analistas, esteve calcado nos impactos positivos para a taxa de acumulação causados pelas inovações tecnológicas da assim chamada "tecnologia da informação". Ter-se-ia isto dado em parceria 
com a manutenção de um baixo crescimento dos salários e com um bom desempenho das exportações no período (como se vê na análise empírica abaixo). Todas foram financiadas com recursos do governo norte-americano para o sistema de defesa, e esperavam por um ambiente propício à sua aplicação na economia civil. ${ }^{209}$ Este "passado sujo" dizia muito aos que elogiavam as supostas virtudes de uma suposta economia baseada primordialmente na disputa em mercados livres.

Num discurso na Universidade de St. Thomas, assim falou Alan Greenspan sobre estes eventos:

“A economia norte-americana está passando por um processo de reestruturação no modo pelo qual se fazem negócios, quer dizer, no modo pelo qual se cria riqueza e aumento dos padrões de vida. $\mathrm{O}$ advento das tecnologias baseadas nos computadores tornou obsoletas antigas atividades produtivas de diversos grupos de trabalhadores, principalmente os administrativos. A arquitetura de prancheta, por exemplo, foi largamente computadorizada e, mais genericamente, grandes segmentos do trabalho de escriturários foram retirados das organizações corporativas. Claramente, o trabalho de chão de fábrica [factory floor] não esteve imune. Há uma geração, por exemplo, a laminação aço era feita principalmente por um grande número de operadores manuais. As operações baseadas no computador eliminaram a maior parte de suas tarefas e hoje poucas operações manuais são vistas." 210

Joseph Stiglitz, que também fazia parte da administração de Clinton, assim caracterizou estes acontecimentos, adotando por sua vez o mencionado conceito de "Nova Economia":

"No centro do moderno capitalismo americano estava o que veio a ser chamado de Nova Economia, simbolizada pelas empresas 'ponto-com' que estavam revolucionando a forma de fazer negócios na América - e no mundo -, alterando o ritmo da própria mudança tecnológica e elevando a taxa de crescimento da

\footnotetext{
${ }^{209}$ Como notou o Economic Report of the President de 1994 (o primeiro da Administração Clinton) à página 93: "And enduring American approach to promoting technology development and diffusion evolved just after the Second World War. [...] The Federal Government supported the development and diffusion of jet aircraft and engines, semiconductor microeletronics, computers and computer-controlled machine tools, pharmaceuticals and biotechnology, advanced energy and environmental technologies, advanced materials, and awhole host of other commercially successful technologies."

210 "The American Economy is undergoing a major restructuring in the way we do business, that is, in the way we create wealth and augment standards of living. The advent of computer-based technologies has rendered obsolescent the heretofore productive activities of significant groups of our workers, most prominently those in the middle management. Architectural drafting, for example, has been largely computerized and, most generally, major segments of clerical work have been stripped from business organizations. Clearly, the factory floor has not been immune. A generation ago, for example, steel rolling mills were run by seemingly vast numbers of operating personnel. Computer-based operations have eliminated many of their tasks and today, few hands-on people are visible." Remarks by Alan Greenspan, Chairman, Board of Governors of the Federal Reserve System. 17 de Novembro de 1993, p.01.
} 
produtividade a níveis não vistos em um quarto de século ou mais. $\mathrm{O}$ mundo experimentara uma revolução econômica dois séculos antes, a Revolução Industrial, quando as bases da economia passaram da agricultura para a manufatura. A Nova Economia representava uma mudança de proporções igualmente significativas: uma mudança de produção de bens para a produção de ideias, acarretando o processamento de informações, não de pessoas ou de estoques. Em meados dos anos 90, a manufatura havia, de fato, se retraído, aproximando-se de $14 \%$ do produto total e de proporção ainda menor do emprego total. A Nova Economia também prometia o fim do ciclo econômico, os altos e baixos da economia que, até então, haviam feito parte do capitalismo, na medida em que novas tecnologias da informação permitiam que as empresas controlassem melhor seus estoques. ( $O$ excesso de investimento em estoques que mais tarde tinham de ser cortados fora uma das maiores fontes das quedas de atividades econômicas na era do pósguerra)." 211

Houve descrições menos laudatórias, sem que se negasse o papel das novas tecnologias para o aumento das inversões. Isto significava ver tais novas tecnologias como pertencentes a mais uma etapa da relação entre ciclos e inovações das técnicas de produzir (teares de algodão, lâmpadas elétricas, bombas de gasolina etc.). E não, justamente, como uma alteração que ia separar uma suposta época de "produção" e outra de "informação". Por exemplo, José Luis Fiori comentou que "é verdade que as novas tecnologias têm permitido, até aqui [meados de 1990], economias de escala crescentes e aumentos contínuos de produtividade. Mas o mesmo ocorreu com o aparecimento do telégrafo, do telefone, do rádio, da televisão, só para citar exemplos no campo das comunicações." Porém, completou:

"Por outro lado, não se pode esquecer que a Internet só é virtual até a venda da mercadoria, mas sua produção e sua entrega se dão no campo da 'velha economia'. Não deixa de ser irônico que o grande sucesso das vendas da Internet tenha sido, até recentemente, de uma livraria, a Amazon, cuja expansão de vendas tem se dado no campo dos brinquedos e das ferramentas - coisas muito antigas. $\mathrm{O}$ fato de mudar a distribuição dos bens não altera nem a produção nem a sua natureza." 212

Robert Brenner foi um dos que melhor abordou o problema: descreveu em $O$ boom e a bolha o ambiente macroeconômico em que se deu tais inovações, assim como a própria natureza delas e os impactos da nova tecnologia. Ele não nega o papel desta, mas o situa dentro de um contexto macroeconômico que estimulou sua aplicação. Este ambiente mais propício seria

${ }^{211}$ Os exuberantes anos 90, p.34.

${ }^{212} 60$ lições dos 90, p. 48. 
composto pelos estímulos que a recessão de 1990-91 causou, tal como aumento da concorrência oligopolística, juros baixos, e inflação estável. Destaca o aumento do endividamento externo traduzido em aumento de liquidez no mercado acionário, facilitando o financiamento de novos projetos.

"Tecnologias poderosas vinham surgindo por um bom tempo, e parece bem claro que a maioria, se não todas, das técnicas cruciais implicadas no boom dos anos 1990 há muito estavam disponíveis. Isso é verdade, é claro, no caso do computador pessoal e da internet, ao cerne da revolução da tecnologia da informação, da produção e do desenho auxiliados por computadores em indústrias como a automotiva, ou do varejo e do atacado, das minifábricas de aço [sic!], e assim por diante. Em face de taxas de lucro marcadamente reduzidas, taxas de lucros reais em altas recordes, níveis recordes de endividamento corporativo e desacelerado crescimento da demanda agregada que prevaleceram durante por toda a maior parte da década de 19(80), as empresas haviam hesitado em investir em tais tecnologias. Mas, então, quando a taxa de lucro por fim começou a subir de forma significativa, enquanto as taxas reais de juros e o endividamento corporativo começaram a desmoronar, as empresas foram capazes de fazer rápido uso delas, elevando suas taxas de investimento." ${ }^{213}$

Quanto ao ciclo, os pontos de vista menos laudatórios e mais pessimistas revelaram-se depois mais verdadeiros, quanto à capacidade das novas tecnologias em permitir expansões cada vez mais ascendentes. Neste sentido, para avaliar os impactos do processo, importa pensar todo o alcance de uma ascensão cíclica facilitada por uma vaga de inovações. A tecnologia centrada na microeletrônica e no computador altera o modo como se fazem os bens, e a própria natureza dos bens fabricados. Dado um ambiente favorável, como pensar então a relação entre o ciclo econômico e a inovação tecnológica centrada nas tecnologias de informação? Ao se verificar o espectro atual dos ciclos, em que eles se diferem dos ciclos precedentes?

\section{(b) Ciclo e inovação}

No capítulo 2, tentou-se esboçar uma conexão entre a lei tendencial da queda da taxa de lucros teorizada por Marx e Engels e a reprodução do capital social global nos termos em que Kalecki a colocou. O argumento dado é o de que os efeitos da lei tendencial são em parte cancelados pelo aumento do nível de endividamento externo, sem que este, no entanto, consiga eliminar fundamentalmente as origens da queda relativa das taxas de lucro no setor produtivo norte-americano face aos outros setores (principalmente financeiros). E, num nível mais global, face a outras economias com taxas de lucro mais favoráveis. Isto explica o fato de que os Estados Unidos importem cada vez mais recursos externos, ao mesmo tempo em que conhecem

${ }^{213}$ O boom e a bolha, p. 309. 
uma baixa absoluta da acumulação de capital fixo. Neste ambiente, o consumo vai substituindo cada vez mais a produção local como elemento determinante da demanda efetiva.

Porém, não se enfatizou ali o problema dos ciclos. O que estava posto era, justamente, o comportamento decrescente do produto norte-americano no longo prazo, independentemente das flutuações cíclicas. Quer dizer, enfatizou-se a determinação do processo estrutural subjacente à desaceleração no longo prazo. Assumiu-se, com Kalecki, que as flutuações dependem do nível de inversão, explicadas por: (i) taxa de poupança das empresas; (ii) gastos com amortização, (iii) utilização de capacidade instalada, além (iv) dos efeitos ad hoc da política econômica. Deste modo, buscou-se abordar as flutuações num nível empírico nos capítulos que se sucederam, pressupondo-se como tácita a atuação determinante da taxa de inversão privada para o nível de flutuações, e dentro dos determinantes desta taxa, a política econômica. O explicitamento do fator estrutural, assim, não impediu que se destacassem as reviravoltas, ou as ascensões conjunturais, do movimento econômico. Logo, notou-se empiricamente como tal comportamento estrutural decrescente foi, assim, perpassado por altos e baixos, explicados fundamentalmente pelos determinantes do comportamento das inversões privadas. Persiste, portanto, um comportamento cíclico.

Ocorre porém que o movimento ascendente a partir do início da década de (19)90 esteve atrelado a um ciclo de aplicações de tecnologias inovadoras fundamentalmente fora do setor da economia de guerra. Neste sentido, poder-se-ia perguntar, já subentendendo a origem histórica de tais novas tecnologias (financiamento pelo Estado, complexo industrial-militar etc.): como relacionar, dentro do arcabouço teórico deste trabalho, ciclo e inovação tecnológica?

George Feiwel, em seu extenso estudo da obra de Kalecki - "The Intellectual Capital of Michal Kalecki - A study in Economic Theory and Policy" ${ }^{214}$ - explica que, para Kalecki...

"Evidentemente, a atividade inovadora não está confinada ao desenvolvimento de nova tecnologia, ainda que induza a atividade relacionada com ela, como a introdução de novos produtos, que requerem a formação de capital para sua produção; [ela se refere também à] conquista de novas fontes de abastecimento de matériasprimas, o que implica em novas inversões em instalações produtivas e transporte." 215

Na nota de rodapé a este trecho, pode-se ler: "As inovações, num sentido de um ajuste gradual do produtor ao estado atual da tecnologia, são incluídas na categoria de inversões 'ordinárias', determinadas pelos 'fatores normais' na equação dos determinantes da inversão." ${ }^{216}$ Isto é, na ausência de um boom de novas tecnologias, as melhorias graduais do estado técnico são aproximadas aos custos de amortização do capital fixo. Assim, para Kalecki, o

${ }^{214}$ Traduzido pela Editora Fundo de Cultura Econômica pelo título de "Michal Kalecki: Contribuciones a la teoría de la política econômica", cuja edição de 1981 é aqui utilizada. Estas citações correspondem à seção "Os fatores de desenvolvimento e o ciclo econômico", no capítulo "Flutuações cíclicas e mudanças no longo prazo". As traduções são de minha autoria.

${ }^{215}$ Michal Kalecki: Contribuciones..., p.183.

${ }^{216}$ Michal Kalecki: Contribuciones..., p.183. 
volume de inversões relaciona-se com os lucros obtidos e com o excesso de capacidade instalada das empresas, mas o fator de inovação pode representar um outro elemento no processo na elevação do volume de inversões, desde que ele seja diferente de tais inversões ordinárias. Neste sentido, Feiwel explica o efeito que a inovação - no sentido de invenções que possibilitam um "salto qualitativo" no modo de produzir e/ou do que se produz - tem para Kalecki:

"Kalecki demonstrou como os fatores de desenvolvimento econômico transformam o sistema 'estático' em outro submetido à tendência de crescimento. Sua proposição central reaparece explicando-se a função econômica da inovação com fator de desenvolvimento. A invenção (o progresso técnico) que tem lugar no curso do processo dado faz mais atrativas certas realizações de inversão, dando lugar ao surgimento de novas decisões de investir. $\mathrm{O}$ efeito da inovação proporciona mais estímulos para investir e assim sucessivamente. E isso porque as novas invenções influem na inversão ao fazer a rentabilidade de certos tipos de investimento maior do que teria sido na ausência de inovações (mudança na função de inversão). Ceteris paribus [isto é, na manutenção da taxa de poupança das empresas e na capacidade instalada - V.E.S], a inovação implica uma inversão superior ao nível que de outra forma se obteria. O fluxo das inversões tem um impacto sobre a inversões similar ao do crescimento contínuo dos lucros na teoria endógena dos determinantes das decisões de investir; ou, expressando-se de outro modo, a aparição de inovações tem um efeito similar, dentro da esfera da atividade investidora, a uma alta dos lucros agregados atuais." 217

A inovação exige portanto a inclusão de um elemento adicional na função-investimento. A partir disto, a inovação pode ser considerada como um processo de alteração das condições da fabricação e distribuição de bens, que podem gerar ou não novos bens - alterando ou não de forma qualitativa sua (dos bens) oferta.

Esquematicamente, poder-se-ia derivar daí duas situações das quais pode dizer que há inovação tecnológica:

(a) Uma firma pode alterar métodos de produção e distribuição pela inovação, mas manter fundamentalmente os mesmos bens fabricados. Este é o caso por exemplo da distribuição de bens a partir da internet. Neste caso, numa linguagem marxista, a inovação do processo produtivo está ligada à diminuição dos gastos com capital variável (salários) ou à economia com capital constante, o que leva a um aumento da taxa de lucros dos setores fabricantes. No caso de um melhor controle da oferta, a insegurança diminui porque ela pode ser mais bem administrada a partir da produção feita em respostas mais imediatas ao comportamento da demanda. Ou seja, a inovação no processo de distribuição pode alterar o 
modo como as mercadorias são realizadas, diminuindo a produção excedente por uma fabricação que atende mais de perto os pedidos da demanda, com diminuição de custos fixos e/ou de perdas irrecuperáveis. Este aumento da taxa de lucros pela melhoria do processo produtivo quase sempre é acompanhado por uma queda dos valores dos bens produzidos, mas não necessariamente. ${ }^{218}$

(b) Uma firma pode alterar os métodos de produção elou distribuição, e alterar também os bens fabricados. Neste caso, os ganhos envolvem, além de uma taxa de lucro mais alta, o deslocamento dos gastos dos compradores rumo aos produtos mais novos, em detrimento de bens mais antigos. Isto envolve toda a produção típica dos bens desta nova vaga tecnológica; no caso do consumo das famílias, envolve por exemplo o consumo de processadores de computador cada vez mais rápidos, impressoras de uso doméstico com tecnologias mais refinadas (da impressão a jato de tinta para a laser etc.), substituição das máquinas fotográficas tradicionais pelas atuais máquinas digitais etc.. O mesmo padrão se dá para os bens de produção, cuja taxa de obsolescência aumenta mais rapidamente. Neste caso, dado um aumento das vendas, mesmo que a relação capital/trabalho permaneça constante, há um aumento da realização das mercadorias que identifica uma maior taxa de lucro das firmas (o excedente cresce sobre os custos fixos). $\mathrm{O}$ aumento dos ganhos corporativos advindos do expediente da alteração daquilo que se produz poder-se-ia dar mesmo com uma relação capital/produto constante.

Podem ainda ser introduzidas novas mercadorias que não exijam novos procedimentos produtivos, caso no qual se as condições de produção corrente são mantidas, fundamentalmente. Este caso visa, pela diversificação apenas aparente das mercadorias vendidas, aproveitar ao máximo a amortização do capital instalado. Aí é a propaganda - exterior ao processo de produção - que leva a maiores ou menores vendas. Este processo é menos explicativo do comportamento das inversões privadas, já que não leva a alterações no processo de produção e/ou nos bens fabricados, mas sim apenas no seu volume. Os efeitos da propaganda não podem alterar, em última instância, o comportamento tecnológico das decisões de inversão privadas. Neste caso, a maior parte das atividades de propaganda sempre atende aos procedimentos (a) e (b).

Sob o conceito dos impactos na taxa de lucro, é importante ressaltar a natureza interconexa entre as novas técnicas de produzir e os novos bens produzidos entre as firmas como um todo. A introdução de novos produtos no mercado por uma firma pode ser, em outros setores produtivos a que ela serve, o início subseqüente de um novo modo de produzir. O que para um pode ser o lançamento de novos bens que vão permitir elevar as vendas pela substituição paulatina de produtos antigos (sem alterar sua própria taxa de produtividade, mas sim apenas o volume de vendas), para outros vai propiciar a elevação da taxa de lucro - mas não necessariamente a introdução de novas mercadorias no mercado, ou o próprio aumento do

${ }^{218}$ Se o que diminui no novo processo de trabalho são os gastos com salário, mas com manutenção da mesma quantidade de trabalho por cada mercadoria produzida, o valor dos bens permanece inalterado. 
volume de vendas. Novos métodos de produção podem alterar as condições de trabalho mas manter fundamentalmente o mesmo tipo de mercadoria produzida, e vice-versa. Estes mecanismos tornam o processo de inovação muito dinâmico e sempre interligado entre as firmas, do ponto de vista dos procedimentos de produção. ${ }^{219}$

Porém, assim como a inovação pode significar benefícios aos produtores de um bem ou àqueles que dele dependem em seu próprio processo de produção, a partir de seu barateamento e/ou aumento de eficiência, o acirramento das disputas entre as firmas pode derrubar as mais lentas e/ou deslocar e por fim extinguir setores inteiros. Exemplos: a extinção da produção de máquinas de escrever, impressoras matriciais, aparelhos de toca-fitas e discos de vinil etc.. Dado um ciclo de inovações, as corporações têm de reorganizar constantemente seus processos produtivos, num processo de falências de muitas e surgimentos a partir de uma pequena produção inicial de outras. Tal torna frenético o comportamento do sistema. Uma visão meramente otimista de tais impactos do processo pode levar, portanto, a mascararem-se outros aspectos mais desagradáveis. Tais fatos incluem desaparecimento de cadeias produtivas inteiras e de saberes-fazer de muitas profissões, com conseqüente aumento do desemprego, desindustrialização de regiões inteiras e rápido crescimento desordenado de outras.

Todavia, reconhece-se que o processo de inovação relaciona-se com uma pendente ascendente do ciclo mediante um comportamento semelhante a um processo descrito numa curva de tipo "S". A etapa inicial é feita pelas descobertas, a etapa de expansão é formada pelas aplicações e difusão das novas técnicas, e a última pela saturação das oportunidades de renovação e colocação de mercadorias sob o novo paradigma produtivo. Quer dizer, o processo está sujeito a uma estagnação do ponto de vista da capacidade vertical e horizontal de aprofundamento, depois de expandir-se e irradiar suas positividades para as firmas, quanto às taxas de lucro e novas oportunidades de inversão. Verticalmente, os ganhos de produtividade e de criação estão sujeitos a uma impossibilidade de renovar constantemente os métodos produtivos; quer dizer, a uma incapacidade de obter sempre mais saltos qualitativos. Este é um resultado daquilo que Marx definiu como um aumento da difusão das novas técnicas por todos os concorrentes, cujo corolário, no fim do processo, é um aumento da composição orgânica dos capitais a pressionar a taxa de lucros para baixo. ${ }^{220}$

${ }^{219}$ Para uma discussão do modo como operam tais interconexões, o estudo de Joan Robinson, Acumulação de Capital, é essencial.

${ }^{220}$ Harry Dent Jr. previu a saturação desta etapa, nascida no início dos anos Clinton, para 2008 e 2009. Para além do acerto exato da data e de sua distinta matriz teórica em relação àquela aqui esboçada, vale citá-lo: "Em meados de 2008 ou meados de 2009, a economia norte-americana estará saturada com as futuras infra-estruturas [das tecnologias] da nova informação, justamente [numa situação similar à de] entre 1928 e 1929. Portanto, estas indústrias tecnológicas de alto crescimento vão diminuir e nós veremos o próximo crash liderado por ações de tecnologia começarem na segunda metade de 2009. Os índices da Nasdaq poderiam voltar a níveis mais baixos do que a marca de 1,108 de $2002 \mathrm{em}$ fins de 2010 ou meados de 2012." "By late 2008 or late 2009 at the latest, the U.S. economy will likely be saturated with the new information infrastructures of the future, just as it was between 1928 and 1929. Thus, these high growth tech industries will slow down and we will see the next crash led by tech stocks begin by mid-tolate 2009. The Nasdaq could be back or below its 2002 low of 1,108 by late 2010 or mid-2012." DENT JR., Harry. The Great Depression Ahead, p.58. Conferir o capítulo 2 desta obra para uma interessante (e alternativa) visão sobre os elementos que causam os ciclos, para o autor calcados no crescimento 


\subsection{A readequação da indústria de guerra}

Entrementes, outra importante transformação histórico-econômica estava se desenrolando na economia norte-americana desde 1990-1991: a diminuição das inversões na indústria de guerra, como resultado da viragem para baixo dos gastos federais com defesa. Este foi um dos reflexos mais imediatos do fim da Guerra Fria. A queda das inversões na indústria de guerra iria atingir mais duramente nos estados da Califórnia, Maryland, Connecticut, New Jersey, Massachussets e outros (ver quadro abaixo), onde a presença da produção de artigos bélicos era forte. É interessante acompanhar primeiramente a opinião do governo Bush sobre esta questão.

Os relatórios oficiais do governo Bush, à época, argumentavam ser relativamente ameno à economia norte-americana o processo de "reconversão" para a economia civil. Evidentemente, queriam disfarçar, no nível do discurso oficial, a importância do setor militar para a acumulação. Ignorando, no plano do discurso, como a política anticíclica centrou-se na indústria de guerra na década passada - num cinismo incrível -, o Economic Report of the President de 1991 preferia tratar da questão sob um outro ponto de vista: "a experiência histórica referente às flutuações nos gastos com defesa mostra que a economia norte-americana tem pouca dificuldade em responder a mudanças nos gastos com defesa". ${ }^{221}$

A reconversão envolvia dificuldades, e tais dificuldades não podiam ser tomadas apenas como oscilações de cancelamentos ou perdas de contratos por estas ou aquelas empresas. O contexto sinalizava com uma queda sustentada para todo o setor. A primeira dificuldade relacionava-se à grande especialidade que as firmas e sua mão-de-obra tinham para o desenvolvimento e produção de artigos bélicos. Os impactos seriam grandes, na verdade, para todas as regiões onde a presença de tais indústrias era importante. Os gastos do governo federal eram parte dos recursos correntes que as empresas consideravam como entradas para financiar a pesquisa em desenvolvimento de novas armas e equipamentos; uma diminuição das vendas levaria a menores pesquisas, com conseqüências diretas também para as empresas para a produção civil.

demográfico e no desenvolvimento de etapas tecnológicas:"The fundamental trends that drive our economy: demographics and technology cycles".

221 "The historical experience with flutuations in defense expedinture shows that the U.S. economy has little difficulty responding to shifts in defense spending." Economic Report of the President de 1991, p.148. 
Tabela 1. Estados Unidos. Principais empresas norte-americanas produtoras de artigos bélicos, suas sedes (cidade e estado), número de empregados e faturamento em dólares em 2008.

Principais empresas produtoras de armamento bélico nos Estados Unidos, suas sedes (cidade e estado), número de empregados e faturamento em dólares em 2008

\begin{tabular}{|c|c|c|c|}
\hline Companhia & Cidade e Estado & $\begin{array}{l}\text { Número de funcionários } \\
\text { em } 2008\end{array}$ & $\begin{array}{l}\text { Faturamento em } \\
2008\end{array}$ \\
\hline AAI Corporation & Hunt Valley, Maryland & não disponível & não disponível \\
\hline BAE Systems Inc. & Rockville, Maryland & 44000 & não disponível \\
\hline Boeing & Chicago, Illinois & 162000 & 60910 milhões \\
\hline Carlyle Group & Washington D.C. & 415000 & não disponível \\
\hline $\begin{array}{l}\text { Colt's Manufacturing } \\
\text { Company }\end{array}$ & Hatford, Connecticut & não disponível & não disponível \\
\hline General Atomics & San Diego, California & 328000 & não disponível \\
\hline General Electric & Fairfield, Connecticut & não disponível & 182515 milhões \\
\hline General Dynamics & Falls Church, Virginia & não disponível & 27240 milhões \\
\hline Honeywell & $\begin{array}{l}\text { Morristown, New } \\
\text { Jersey }\end{array}$ & 122000 & 36000 milhões \\
\hline Lockheed-Martin & Bethesda, Maryland & 140000 & 41862 milhões \\
\hline $\begin{array}{l}\text { Northrop Grumman } \\
\text { Corporation }\end{array}$ & Los Angeles, California & 122600 & 32108 milhões \\
\hline Raytheon Corporation & $\begin{array}{l}\text { Cambridge, } \\
\text { Massachussets }\end{array}$ & 72000 & 21300 milhões \\
\hline United Technologies & Hatford, Connecticut & 222000 & 54759 milhões \\
\hline
\end{tabular}

Fonte: endereços eletrônicos das respectivas companhias.

Dada a estrutura oligopólica, tais pesquisas financiadas no setor da economia de guerra terminavam por encontrar aplicações na economia civil, tornando difícil separar, para o caso norte-americano, a pesquisa por si mesma da pesquisa bélica propriamente dita. Daí que a queda nas inversões da indústria de guerra aparecia como uma ameaça à supremacia não só militar, mas tecnológica. ${ }^{222}$ O sistema de "livre empresa", "concorrência" e "liberdade individual" norte-americano aparecia assim, sob a própria avaliação do governo norte-americano, como um sistema centrado, em verdade, na produção de tecnologia para a guerra, financiada com gastos do Estado. Numa época do suposto desaparecimento dos interesses nacionais pela "globalização", a opinião do governo era franca, e era diferente daquela empurrada nos discursos da ONU, OMC, Banco Mundial e outras instâncias, para os países periféricos. "A vantagem que os Estados Unidos têm nas tecnologias de defesa deveriam ser protegidas mediante o continuado investimento em pesquisa, embora algumas prioridades tenham de ser

${ }^{222}$ Como afirmou Carlos Aguiar de Medeiros em seu interessante artigo: "O Departamento de Defesa (DOD) não se limitou a prover amplo financiamento e encomendas aos produtores de armas, mas influenciou o processo de seleção, difusão e indução das modernas tecnologias no pós-guerra. A velocidade do progresso técnico foi, por seu turno, fortemente influenciada pela competição pelas armas." Este artigo, "O desenvolvimento tecnológico americano no pós-guerra como um empreendimento militar”, traz informações preciosas. In: José Luis FIORI, O poder americano, p.230. 
mudadas". ${ }^{223}$ Uma das respostas seria relaxar as regulamentações que impediam a transferência de tecnologia do setor militar para o não-militar.

Como se vê no quadro acima, as maiores empresas de armamentos empregam hoje, em média, duzentos mil funcionários, uma marca que não deve ser tão distinta de quinze anos atrás (não há dados para 1993). Somados a suas famílias, tais trabalhadores geravam uma base social de milhões de indivíduos. Tratava-se então de o quê fazer com os eventuais desempregados. Algumas vozes dentro do governo defendiam que o mesmo deveria auxiliar todos os trabalhadores afetados com programas específicos de auxílio, já que ele (governo) era de fato a única ou maior fonte da demanda para a produção da maior parte. Outros argumentavam que a liberalização de capital iria provocar aumento de inversões em outros setores, de modo que "naturalmente" - pelas mãos do "livre mercado" - as mudanças não iriam alterar o nível de emprego, depois de transcorrido o tempo necessário para tais ajustes. Esta era a postura com mais adeptos no governo Bush: incluir os trabalhadores demitidos nos programas tradicionais de auxílio e re-inserção, que atendiam todos os desempregados.

As perdas principais atingiriam principalmente os produtores de aeronaves, equipamentos de comunicação para TV e rádio, mísseis e veículos espaciais, e firmas que serviam à marinha norte-americana. "Por causa da extensa dispersão geográfica da produção para a defesa" (p.152), as perdas no volume de emprego seriam amplamente distribuídas. Quer dizer, o governo primeiro negava mas depois terminava reconhecendo a importância do setor para a economia como um todo, inclusive no que toca ao recrutamento militar, cuja demanda esperava-se que fosse diminuir: "não se sabe bem ainda que os serviços militares são um dos maiores provedores individuais de treinamento vocacional nos Estados Unidos". ${ }^{224}$

Mas qual era a opinião da equipe de economistas da administração Clinton? Fundamentalmente, não era muito distinta. Reconhecia-se como inevitável a queda do orçamento militar, no curto prazo. Buscou-se então desenvolver programas de auxílio para os trabalhadores e para as firmas atingidas pela queda do orçamento militar, tal como a administração anterior propunha. E enfatizava que o governo deveria continuar com o financiamento das pesquisas que eram antes de responsabilidade do complexo industrial-militar, ainda que a demanda por bens fosse cair. O problema da demanda podia ser contornado; mas não o da supremacia tecnológica. Tratava-se agora de desviar a produção de tecnologias do uso militar para o uso civil, mas sem abandonar o apoio do governo em forma de recursos. $\mathrm{O}$ discurso era similar ao da administração republicana. No Economic Report de 1994, o primeiro escrito pela administração Democrata, podia-se ler:

\footnotetext{
223 "The advantage the United States has in defense technology should be protected through continued investment in research, although some of the priorities may be shifted." Economic Report... de 1993, p. 151.

224 "It is not widely known that the military services are one of the largest single providers of vocational training in the United States". Economic Report... de 1993, p.153.
} 
"O desenvolvimento e organização de novas tecnologias de guerra [deployment] têm sido de interesse do governo há muito tempo. A política tecnológica é especialmente crítica num período de grandes cortes no orçamento de defesa, porque mais da metade do apoio do governo Federal para Pesquisa e Desenvolvimento tem tradicionalmente sido dirigido para a defesa nacional. Com menor necessidade para pesquisa militar, o governo Federal precisa agora fazer uma escolha. Vamos reduzir o apoio total à pesquisa, ou mudar os dólares gastos em pesquisa para tecnologias civis? O Presidente crê que a segunda opção é mais sábia, sendo o porquê de o governo estar orientando as capacidades de pesquisa do Departamento de Defesa e dos laboratórios nacionais em direção a parcerias de Pesquisa e Desenvolvimento com a indústria." 225

\subsection{A política econômica}

(a) O Omnibus Budget Reconciliation Act of 1993 (OBRA93)

Uma das pautas da campanha de Clinton havia sido, novamente, o tema dos déficits fiscais do governo federal. O presidente mostrava certa determinação adicional em zerar o déficit, mas tal determinação - "a redução do déficit foi essencial à minha estratégia econômica" ${ }^{226}$ - ia ser facilitada porque, pela primeira vez em quase quatorze anos (1980-1993) a economia norte-americana parecia crescer de modo sustentado com base especificamente nas inversões privadas. Isto, justamente, sem fazer depender tal crescimento do setor ligado à economia de guerra. Viu-se como planos anteriores foram feitos para equacionar os déficits, sem sucesso. As tentativas de ajustar o orçamento eram sempre malogradas por uma nova viragem nos indicadores, de modo que o tema se arrastava. Entre o déficit e a recessão, a escolha era sempre óbvia. Porém, agora parte importante dos impostos podia crescer às custas dos lucros corporativos.

De fato, era uma marca do sistema político norte-americano discutir eternamente aspectos da política econômica que, pelos motivos estruturais aqui investigados, não podiam ser modificados. As conjunturas passadas, com muitos picos e fendas na taxa de acumulação, aliadas à política do reaganomics, haviam levado as administrações republicanas a sucessivas manipulações deficitárias do orçamento. Todavia, como mostrava a história recente, tais manipulações orçamentárias rumo a déficits sempre ocorriam em períodos de queda da atividade econômica, independentemente do partido no comando. Deste modo, a redução do

225 "The development and deployment of new technology have long been of interest to the government. But technology policy is specially critical in a period of large-scale defense cutbacks, because more than a half of total Federal support of $R \& D$ has traditionally been related to national defense. With less need for research on weaponry, the Federal Government must now make a choice. Will we reduce total research support, or will we shift the research dollars into civilian technologies? The President believes that the latter is the wiser course, which is why the Administration is reorienting the research capabilities of the Defense Department and the national laboratories toward R\&D partnerships with industry." Economic Report of the President de 1994, p. 45.

${ }^{226}$ CLINTON, Bill. Minha Vida, p.491. 
déficit iria surgir menos como um efeito da determinação do presidente e sua equipe do que pelo resultado de variáveis não sob o poder de indução da política econômica - no caso, a taxa de investimentos privados. É claro que o público iria entender isto como um mérito pessoal dos que estavam no comando.

Tudo isto, decerto, não eliminava todas as diferenças entre as visões democratas e republicanas. Classificá-los como parte da "elite do poder" não significa ignorar nuances importantes. O plano para o orçamento de Clinton e equipe foi chamado - similarmente ao modo como Bush o fizera em 1990 - de Omnibus Budget Reconciliation of 1993. Depois de alguma contenda nas duas casas do Congresso, foi aprovado em Agosto de 1993. Sua principal diferença para com os típicos planos orçamentários republicanos era o foco no aumento dos impostos sobre as faixas mais ricas. Tal trazia um acento teórico contrário - no nível do discurso oficial e da orientação particular dos economistas da equipe do governo - à já velha orientação do "lado da oferta". Citando-se mais uma vez Clinton: "Eu promulguei a lei no dia 10 de Agosto. Ela reverteu os doze anos em que a dívida nacional quadruplicou com os déficits criados com base em previsões de receitas exageradamente otimistas e numa crença quase teológica de que impostos baixos e gastos altíssimos conseguem promover crescimento suficiente para equilibrar o orçamento." 227

O Economic Report, cuja redação é de responsabilidade do Council of Economic Advisers, formado em 1993 pelos economistas Laura D'Andrea Tyson, Alan S. Blinder e Joseph E. Stiglitz, assim definiu as metas principais do OBRA93:

"Diversos princípios guiaram a formulação do OBRA93. Primeiro e mais importante, a redução do déficit tinha de ser grande, real [genuine], e crível. Para isto, a administração propôs centenas de cortes específicos e aumentos de impostos. Em segundo lugar, o pacote tinha de ser balanceado entre cortes nos gastos e aumento dos impostos. Especificamente, a redução de 146 bilhões de dólares no ano fiscal de 1998 consiste em 87 bilhões de dólares em cortes líquidos - incluindo-se 25 bilhões numa queda no serviço da dívida - e 59 bilhões em receitas adicionais. Terceiro, os aumentos de taxas são fortemente progressivos - pesadamente desenhados para os que mais podem pagar e que mais se beneficiaram dos grandes cortes de taxas no início dos anos (19)80. Os aumentos de imposto de renda foram elevados apenas para os $1,2 \%$ dos contribuintes. Mais ou menos $90 \%$ das novas taxas do OBRA93 vão ser sustentados pelos $6,5 \%$ dos contribuintes mais bem posicionados na distribuição da renda. Quarto, mesmo quando cortando o déficit, dever-se-ia ter achado espaço no orçamento para uma variedade de investimentos públicos decisivos." 228

\footnotetext{
${ }^{227}$ Minha Vida, p.509.

228 "Several principles guided the design of OBRA93. First and foremost, the deficit reduction had to be large, genuine, and credible. To this end, the Administration proposed hundreds of specific spending cuts and increases in revenue. Second, the package had to be balanced between expenditures cuts and taxa increases. Specifically, the $\$ 146$ billion of deficit reduction in fiscal 1998 consists of $\$ 87$ billion in net
} 
O plano, então, era o politicamente mais avançado que os Estados Unidos tinham tido desde o início da década de 1980, por balancear as contas do governo às custas dos setores mais ricos da população. E, mais importante, porque não elegia o complexo industrial-militar como o elemento principal da indução da acumulação. As vantagens do plano residiam no fato de que desviar as despesas do setor militar auxiliaria a manter baixa a inflação e a diversificar as exportações. O plano também teria um impacto mais favorável no consumo das famílias dos que os planos "pró-ricos" anteriores, não podendo deixar de ser considerado um dos elementos que facilitaria a expansão dos efeitos multiplicadores a partir dali. Como mostra a tabela abaixo, os impostos de renda foram elevados de 31 para $36 \%$ e de $31 \%$ para $39,6 \%$ sobre a renda dos que ganhavam, respectivamente, entre 140 mil e 250 mil dólares ao ano, e para os que ganhavam mais de 250 mil dólares ao ano. Por outro lado, a pequena diferença entre as duas faixas não deixava de ser ainda muito favorável aos milionários e bilionários.

Tabela 2. Mudanças nas taxas marginais de impostos de renda sob o OBRA93 para indivíduos casados vivendo juntos.

\begin{tabular}{ccc}
\hline Renda tributável (dólares) & \multicolumn{2}{c}{ Taxa marginal (porcentagem) } \\
$0-36900$ & Lei antiga & OBRA93 \\
$36900-89150$ & 15 & 15 \\
$89150-140000$ & 28 & 28 \\
$140000-250000$ & 31 & 31 \\
Mais de 250000 & 31 & 36 \\
\hline
\end{tabular}

Fonte: Economic Report of the President de 1994. Capítulo 1, A strategy for growth and change, p.34.

(b) O NAFTA

A administração Clinton, embora lançando mão de tais tipos de medidas, aplicou extensamente políticas liberais, locais e externas. O discurso oficial continuou abordando a necessidade - em sua perspectiva - do aumento da competição entre as firmas, da diminuição da regulação do Estado, e de um comércio internacional com barreiras tarifárias cada vez menores.

Isto demonstrava uma ligação com o discurso republicano bastante próxima, afinal. Tal era percebido pela atenção com que a administração Clinton se envolveu não só na formulação de um tratado de livre comércio com o México e o Canadá, mas também pelo modo como

spending cuts - including \$25 billion in lower debt service - and \$59 billion in additional net revenue. Third, the tax increases were highly progressive - heavily skewed toward the people who are most able to pay and who benefited most from the large tax cuts of the early 1980s. Income tax rates were raised for only about the 1,2 percent of taxpayers. Some 90 percent of the new taxes in OBRA93 will be borne by the upper 6,5 percent of the income distribution. Fourth, even while cutting the deficit, room had to be found in the budget for a variety of critical investments." Economic Report of the President de 1994, p.32. 
tentou levar a proposta a seu paroxismo, com a criação de uma ALCA - Área de Livre Comércio das Américas. Isso era visto na posição norte-americana durante a Rodada do Uruguai da Organização Mundial do Comércio em 1994; no programa de desregulamentação do sistema de telecomunicações (O Telecom Reform Act de 1996); e, em sua segunda administração, pela extinção da própria lei Glass-Steagall, que separava bancos de investimento e comerciais. A lei Gramm-Leach-Bliley Act extirpou tal separação, em 1999.

A formulação do NAFTA - North American Free Trade Agreement - esteve sob responsabilidade do governo George Bush. Visava uma queda das barreiras de importação nos três países da América do Norte. Estava refletindo primeiramente os interesses das empresas que se interessavam nos Estados Unidos por um acordo de livre-comércio: as empresas cujas mercadorias produzidas podiam concorrer no mercado mexicano e no mercado canadense, e as empresas norte-americanas no México e Canadá, que ampliariam suas vendas para o amplo mercado dos Estados Unidos. Como o tratado partia dos Estados Unidos, é evidente que estes eram os interesses primários por detrás do acordo. Por outro lado, as corporações norteamericanas que concorressem com a produção de fora teriam de se adequar à nova situação.

Foi Clinton que levou o NAFTA à frente, até sua aprovação. Segundo a primeira parte do acordo, implementado em 1993, visava-se "estabelecer uma área de livre comércio" cujos objetivos eram, de acordo com o documento original de formulação do Tratado...

“a) eliminar barreiras ao comércio, e facilitar o movimento de bens e serviços nas fronteiras dos três países;

b) promover condições de competição justa em tal área;

c) aumentar substancialmente as oportunidades de investimento nos territórios dos três países;

d) promover proteção adequada e efetiva e reforçar os direitos de propriedade em cada país;

e) criar procedimentos efetivos para a implementação e aplicação deste tratado, para sua administração conjunta e resolução de disputas;

f) estabelecer uma base de trabalho para cooperação trilateral, regional e multilateral para expandir os benefícios deste tratado." 229

\footnotetext{
229 " 1 . The objectives of this Agreement, as elaborated more specifically through its principles and rules, including national treatment, most-favored-nation treatment and transparency, are to: a) eliminate barriers to trade in, and facilitate the cross-border movement of, goods and services between the territories of the Parties; b) promote conditions of fair competition in the free trade area; c) increase substantially investment opportunities in the territories of the Parties; d) provide adequate and effective protection and enforcement of intellectual property rights in each Party's territory; e) create effective procedures for the implementation and application of this Agreement, for its joint administration and for the resolution of disputes; and f) establish a framework for further trilateral, regional and multilateral cooperation to expand and enhance the benefits of this Agreement." Todo o tratado está disponível no endereço eletrônico http://www.sice.oas.org /, respectivo ao Foreign Trade Information System.
} 
Não é necessário enfatizar este tratado de livre mobilidade de fatores não incluía o trânsito de trabalhadores, porque o objetivo expresso era o de, justamente, diminuir a imigração mexicana aos Estados Unidos. Além disso, em seus objetivos gerais previa-se, de modo subentendido, a extensão do livre comércio para o resto da América (item f). Mais especificamente, o tratado visava oficialmente (i) sustentar as exportações de bens e serviços norte-americanos ao Canadá e ao México; e (ii) com o aumento das importações vindas do Canadá e México, rebaixar os custos de importação para a economia norte-americana. $\mathrm{O}$ acordo introduzia uma diminuição geral de barreiras para uma ampla lista de artigos presente no anexo do documento de fundação, além de eliminar barreiras legais para que empresas dos três países pudessem atuar nos outros mercados domésticos. Proibia-se um aumento futuro de barreiras tarifárias para os produtos listados em tal anexo. Seguia-se depois, no documento original, uma ampla gama de restrições, exceções e deveres que os departamentos de comércio exterior de cada país deveriam seguir.

No entanto, os resultados do NAFTA não dependiam apenas dos interesses corporativos. A política econômica não se resumia a isto; já havia um déficit comercial consolidado há muitos anos. E a valorização do dólar no cenário externo, conjugada com a liberalização do comércio e com o endividamento externo, poderia elevar muito o déficit comercial, com as virtuais conseqüências previstas. $\mathrm{O}$ aumento do endividamento externo no período moldava um pano de fundo que permitia esperar um aumento dos déficits.

Quer dizer, com a manutenção de saldos comerciais negativos como expressão da continuidade da captação de poupança externa, o período subseqüente poderia assistir na verdade um crescimento mais rápido das importações vindas do México e do Canadá, em relação às exportações norte-americanas a ambos. Isto estaria em contradição aparente com os objetivos oficiais da política macroeconômica, mas não com os interesses das corporações. Tal era um bom exemplo das dificuldades que tinha Clinton em administrar interesses divergentes. Atender aos interesses de exportação para os Estados Unidos das empresas da Ford instaladas na região mexicana das maquiladoras era o tipo de interesse por trás do NAFTA, que Clinton aprovava em nome da liberdade de comércio. Mas isto significaria mais desemprego nos setores industriais dos Estados Unidos, mais manifestações de sindicatos, menor capacidade produtiva doméstica e aumento dos déficits comerciais. Dar-se-ia também um aumento das dificuldades jogadas sobre a responsabilidade do Fed e de outras instituições responsáveis pela política macroeconômica, em caso de aumento dos déficits comerciais.

Neste sentido, a visão oficial otimista de que o livre comércio podia beneficiar a todos, trazendo uma situação ótima indiscriminada, simplesmente era errada. Havia interesses discrepantes em jogo, e, para além do modelo de crescimento sob a dívida, os custos domésticos norte-americanos já não eram tão favoráveis como no passado a ponto de converter todo e qualquer tratado de livre comércio em uma fonte de vantagens totais para as empresas, trabalhadores e política econômica dos Estados Unidos. E, como se vê à frente, foi o que de fato ocorreu. Liberado o comércio na América do Norte, os saldos comerciais dos Estados Unidos 
com os dois outros países da região deram lugar a déficits crescentes. Assim, (i) o modelo de crescimento da dívida, (ii) os interesses das corporações norte-americanas instaladas nos outros dois países, e (iii) os interesses das empresas norte-americanas que podiam concorrer num comércio mais aberto, sobrepujaram (i) os interesses das empresas e trabalhadores nos Estados Unidos. Para estes, a concorrência com o exterior poderia aumentar objetivamente suas dificuldades, além de (ii) terem sobrepujado também os interesses de uma política externa centrada preponderantemente na defesa de saldos comerciais positivos com aquelas duas nações.

Portanto, a situação concreta determinava que o discurso liberal de livre comércio, aparentemente absolutizante em sua argumentação que buscava desenhar vantagens a todos, na verdade representava apenas algumas forças, obscurecendo outras.

(c) A continuidade das desregulamentações

O governo Clinton apresentou também na política de regulação da atuação dos oligopólios uma continuidade com a administração passada. A lei de desregulamentação e aumento da concorrência no setor de comunicações e eletricidade representava um auxílio do governo às empresas que lançavam novos produtos, derivados da revolução tecnológica, em relação às empresas que ocupavam espaços que agora deveriam ser repartidos $\mathrm{e}$ "modernizados". Literalmente, neste campo a política democrata era a simples continuação da onda liberalizante que o país tinha desde a década de (19)70. Sabe-se como estas decisões iriam impactar inclusive fora dos Estados Unidos, constituindo o que poder-se-ia chamar de a "visão de mundo" típica dos economistas e dos líderes políticos dali ao longo da década.

De acordo com tal visão moderada do novo-liberalismo, ao invés de reforçar o papel do Estado e evitar com que um excesso de capacidade se instalasse em todos os setores, a política de intervenção deveria ser "refinada". Claramente, como quase tudo em uma economia capitalista, a contrapartida de estimular no curto prazo o aumento dos investimentos devido a favorecimentos rápidos à oferta era obter, no médio prazo, justamente um excesso de oferta, que levaria a uma posterior queda das inversões etc.. As escolhas eram óbvias, independentemente de um discurso menos crítico ao papel do Estado. O tom democrata declarava que a desregulação dos setores da economia permitia a "governos e empresas trabalharem juntos", ao invés de simplesmente criticar a participação do Estado. Isso ao invés de simplesmente se admitir que se buscava repartir com as empresas privadas os eventuais ganhos para o Estado nas áreas onde este atuava. Sem a intenção aqui de penetrar na análise específica do comportamento dos setores de energia e comunicações, vale a pena pelo menos citar o trecho do Economic Report de 1996, que expressava a posição liberalizante do governo Clinton nestas questões: 
"Qual o papel apropriado do governo, se ele existe, em regular a manufatura, a distribuição, os preços, e a qualidade dos produtos na economia norte-americana? Grande parte do século XX viu uma expansão do papel do governo como regulador. Mas desde os anos (19)70 o papel regulador declinou em muitos setores. Os primeiros esforços deram-se na aviação, trens, transporte rodoviário, bancos e gás natural. A desregulamentação dos serviços públicos tradicionais, como eletricidade e telefonia, tem já um longo caminho. Entretanto, ambos têm sido objeto de significativas políticas pró-competição no ano passado. Em 16 de Fevereiro, o presidente assinou a lei o amplamente aguardado Telecommunications Act of 1996. Dois meses e meio depois a Comissão para a Regulação da Energia (Energy Regulatory Commission - FERC) autorizou as ordens de número 888 e 889 , que colocaram as bases para a abertura das transmissões interestaduais para todos os geradores e revendedores de energia." 230

\subsection{Uma checagem empírica}

(a) $\mathrm{O}$ ambiente macroeconômico

O bom estado do ambiente macroeconômico durante a primeira e a segunda administração Clinton foi objeto de amplo estudo pela literatura. ${ }^{231}$ Ele foi marcado por um crescimento da taxa de investimentos privados sobre o PIB; por taxas de inflação mais ou menos estáveis, de média de $4 \%$ ao ano; por taxas de juros que oscilaram entre 4,5\% e 5,5\%, acompanhando o crescimento moderado da inflação; por uma queda do desemprego; por um crescimento rápido do mercado acionário; e ainda por um comportamento estável dos agregados monetários. Os comentários do presidente do Fed sobre o desempenho econômico acompanharam este bom desenvolvimento.

No início de 1994, Greenspan observava satisfeito um panorama que perdurou sobre todo o período: "Parcialmente por causa de nossos ajustes estruturais, as fundações da expansão econômica parecem estar bem encaminhadas. O PIB aumentou a uma taxa anual de

\footnotetext{
230 "What is the appropriate role, if any, of government in regulating the manufacture, distribution, prices, and quality of products in the U.S. economy? Much of the 20th century has seen an expansion of the role of government as regulator. But since the late 1970s the regulatory tide has ebbed in many important respects. The first major deregulatory efforts were in industries such as airlines, railroads, trucking, banking, and natural gas. (Box 6-1 illustrates some of the benefits of deregulation.) Deregulating the traditional utilities, particularly telephones and electricity, has taken a slower course. However, both of those industries have been the object of significant procompetitive policy initiatives in the past year. On February 8, 1996, the President signed into law the longawaited Telecommunications Act of 1996. Two and a half months later the Federal Energy Regulatory Commission (FERC) issued its Orders No. 888 and No. 889, which set rules for opening up interstate transmission networks to all generators and resellers of electricity." Economic Report of the President de 1996, p.189.

${ }^{231}$ Conferir: BRENNER, Robert. O boom e a bolha; NUNES, João Marcus Marinho, $O$ vôo da Águia; STIGLITZ, Joseph, Os exuberantes anos 90; BATRA, Ravi, Greenspan, a fraude; KRUGMAN, Paul. A desintegração americana.
} 
aproximadamente 3\% no terceiro trimestre de 1993, e a estimativa para o quarto indicou crescimento de $6 \%$. O mercado de trabalho mostrou também sinais de notável crescimento." 232

Tabela 3. Estados Unidos. Dados selecionados. 1993-1996.

\begin{tabular}{lccccc}
\hline & \multicolumn{2}{c}{ Preços $(1982=100)$} & \multicolumn{3}{c}{ Taxas de Juros (\% ao ano) } \\
1993 & CPI-U & Energia & US Treasury Securities & Fed Funds Rate & Moody's \\
1994 & 144,5 & 104,2 & 3,02 & 3,02 & 6,59 \\
1995 & 148,2 & 104,6 & 4,29 & 4,21 & 7,37 \\
1996 & 152,4 & 105,2 & 5,51 & 5,83 & 6,88 \\
1997 & 156,9 & 110,1 & 5,02 & 5,3 & 6,71 \\
& 160,5 & 111,5 & 5,07 & 5,46 & 6,61
\end{tabular}

Mercado Acionário

NY Exchange Dow Jones Industrial Index Average

\section{Stand\&Poor's}

451,41

460,33

541,64

670,83

872,72
S\&P

earningsprice

ratio

(centavos de US\$)

$\begin{array}{ll}4,46 & 2,8 \\ 5,83 & 5,4 \\ 6,09 & 5,6 \\ 5,24 & 6,0 \\ 4,57 & 6,2\end{array}$

1997 456,54

3522,06
3793,77
4493,76
5742,89
7441,15

Meios de Pagamento (\% de ano a ano) M1

10,3

1,8

$-2,1$

$-4,1$

$-0,7$

1997

\begin{tabular}{lr} 
M2 & M3 \\
1,5 & 4,9 \\
0,4 & 4,7 \\
4,1 & 5,4 \\
4,8 & 5,4 \\
5,7 & 5,5 \\
& \\
\multicolumn{2}{c}{ Horas-extra na } \\
\multicolumn{2}{c}{ indústria por } \\
\multicolumn{2}{c}{ semana (horas) }
\end{tabular}

1993

1994

1995

1996

M3

4,9

4,7

5,4

5,4

5,5
Base Monetária (milhões de US\$)
386510
418166
434307
451712
479466

Total de benefícios pagos a desempregados (milhões US\$) 26460 22950 22844 22386 22915
Empregados no setor produtor de bens (indústria)

23231

23352

23908

24265

Fonte: apêndice estatístico do Economic Report of the President, vários números. Para preços, ver tabela "Consumer prices indexes for major expedintures classes"; para taxa de juros, ver tabela "Bond yields and interest rates"; para mercado acionário, "Historical stock prices and yields"; para meios de pagamento e base monetária, ver "Money stock and debt measures"; para desemprego, ver "Unemployment by demographic characteristic"; para horas-extra e benefícios pagos, ver "Unemployment and insurance programs, selected data"; para empregados no setor de bens, ver tabela "Employees on nonagricultural payrolls, by major industry".

232 "Testimony by Alan Greenspan. Chairman. Board of Governors of Federal Reserve, before the Joint Economic Committee. United States Congress.” 31 de Janeiro de 1994. 
As declarações seguiram otimistas durante todos os três anos seguintes, com flutuações que não mudaram a crença das autoridades na inevitabilidade de um bom desempenho consolidado. O componente M1 variou negativamente a partir de 1995. O componente M2 dos agregados variou $1,5 \%, 0,4 \%$ e depois 4,1\% entre 1993 e 1995 . Tal era o indício de como o bom desempenho aparente do PIB se relacionava com uma colocação cada vez maior da renda das famílias no mercado acionário. O centro das atenções era ele neste frenético período. Por outro lado, dado o panorama de equacionamento dos déficits fiscais, o crescimento da base monetária também esteve estável, com seu crescimento acompanhando o próprio produto. Estas variáveis indicavam o crescimento moderado da inflação. O índice Dow Jones mais que dobrou no período; os outros indicadores do mercado acionário também apresentaram crescimento bastante forte. Os lucros por dólar vendido, e os ganhos por ação, tiveram um comportamento em média ascendente. Tal explica as retro-alimentações do mercado financeiro. Esses dados podem ser observados nas tabelas acima.

O desempenho do produto interno bruto no quadriênio da primeira administração Clinton foi menor do que o de sua segunda administração. Foi porém foi bastante positivo, comparado ao cenário herdado anterior. Ele está abaixo traçado. O perfil de flutuações está dividido em quatro conjunturas principais: (a) ascensão inicial, abarcando o primeiro que vai do trimestre de 1993 ao segundo trimestre de 1994, com média de 3,3\% de variação; (b) descenso até o segundo trimestre de 1995, com média de 2,8\% de crescimento; (c) nova pendente ascendente, até o terceiro trimestre de 1996; (d) novo descenso a partir do terceiro trimestre. A média de crescimento total no período atingiu 3,3\%, formando marca bastante razoável, vista sob o desempenho exclusivo do produto interno bruto.

Gráfico 1. Estados Unidos. Variações trimestrais (\%) do Produto Interno Bruto. 1993-1996.

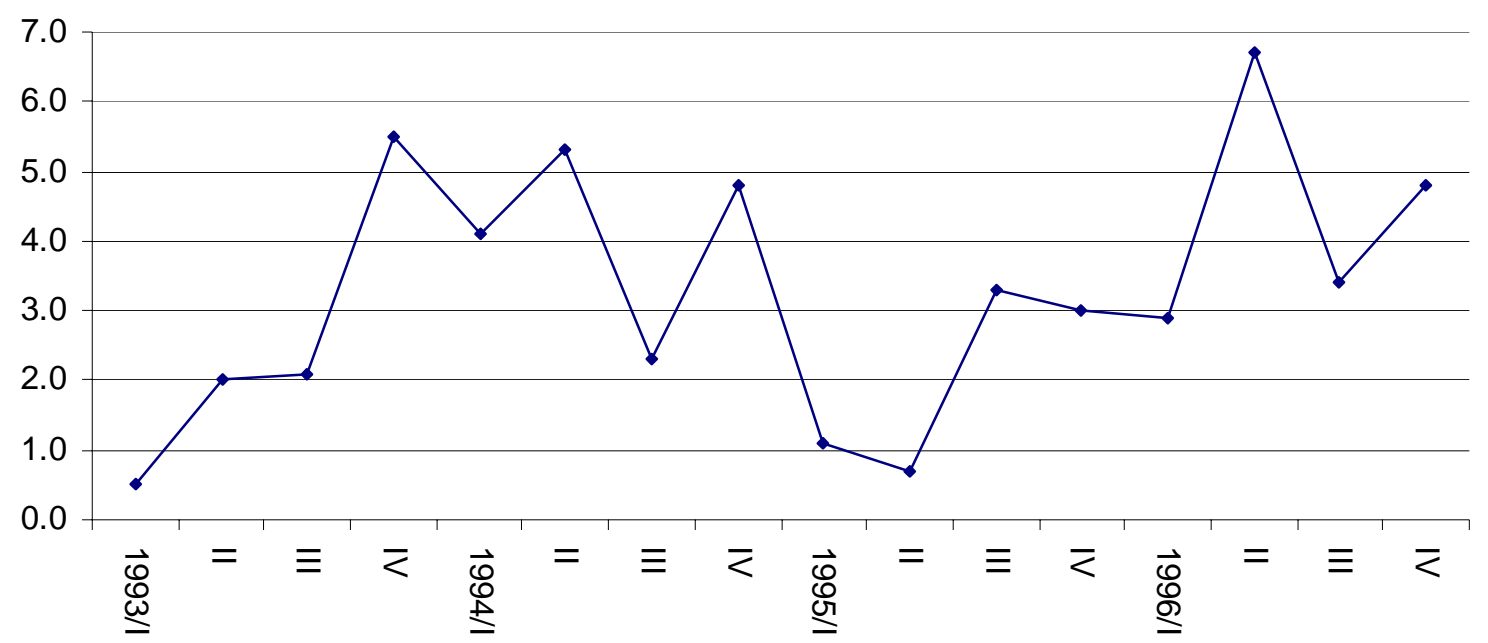

Fonte: NIPA-BEA. Seção 1, Domestic Product and Income, Tabela 1.1.1, Percent Change From Preceding Period in Real Gross Domestic Product. 
Esse comportamento atribui-se, entre outros, aos seguintes fatores: (a) uma política tributária expansiva, com aumento de impostos sobre as faixas mais ricas dos contribuintes; (b) um desempenho crescente da taxa de investimentos privados; (c) um aumento concomitante da taxa de endividamento externo; (d) os favorecimentos, no curto prazo, à livre concorrência, com investimentos sendo feitos em áreas de recém-liberalização que apresentavam boas perspectivas de lucratividade.

Tabela 4. Estados Unidos. Orçamento do governo federal: impostos sobre os lucros corporativos e sobre as famílias, e impostos indiretos sobre as empresas; orçamento destinado à defesa e déficits orçamentários. 1996-1993. Em bilhões de dólares correntes.

\begin{tabular}{|c|c|c|c|c|c|}
\hline (1) & (2) & (3) & (4) & (5) & (6) \\
\hline & $\begin{array}{l}\text { Impostos sobre } \\
\text { os lucros }\end{array}$ & $\begin{array}{l}\text { Impostos sobre } \\
\text { as famílias }\end{array}$ & $\begin{array}{l}\text { Impostos indiretos } \\
\text { sobre as empresas }\end{array}$ & $\begin{array}{l}\text { Orçamento de } \\
\text { Defesa }\end{array}$ & $\begin{array}{c}\text { Déficits } \\
\text { do Orçamento }\end{array}$ \\
\hline 1993/I & 24,1 & 161,6 & 438,0 & 312,1 & $-278,2$ \\
\hline II & 26,9 & 166,5 & 440,4 & 314,6 & $-249,0$ \\
\hline III & 26,3 & 168,4 & 448,5 & 311,5 & $-250,6$ \\
\hline IV & 30,4 & 172,9 & 455,5 & 301,3 & $-224,6$ \\
\hline 1994/I & 26,1 & 170,8 & 458,7 & 303,4 & $-209,1$ \\
\hline II & 29,4 & 176,1 & 466,8 & 313,3 & $-163,2$ \\
\hline III & 31,3 & 178,3 & 473,8 & 304,9 & $-187,6$ \\
\hline IV & 32,9 & 182,0 & 480,4 & 299,9 & $-186,8$ \\
\hline 1995/I & 30,6 & 185,1 & 484,6 & 299,8 & $-189,6$ \\
\hline II & 30,4 & 187,0 & 487,1 & 303,2 & $-177,9$ \\
\hline III & 32,0 & 191,3 & 490,4 & 291,6 & $-176,9$ \\
\hline IV & 31,5 & 194,0 & 495,1 & 298,2 & $-153,0$ \\
\hline 1996/I & 34,1 & 195,0 & 502,3 & 307,8 & $-150,1$ \\
\hline II & 35,0 & 198,9 & 508,9 & 309,3 & $-112,6$ \\
\hline III & 34,9 & 201,7 & 509,4 & 307,6 & $-100,1$ \\
\hline IV & 34,0 & 205,1 & 515,1 & 306,4 & $-78,3$ \\
\hline
\end{tabular}

Fonte: Economic Report of the President, vários números. Ver tabelas "Federal and State and local government receipts and expenditures, national income and product accounts, by major type".

A política orçamentária do governo Clinton pôde levar à frente uma redução do déficit federal basicamente devido (i) ao crescimento da taxa de investimento privado, com seu conseqüente aumento de arrecadação e (ii) aumento do financiamento externo das contas do governo (ver abaixo). Neste ínterim, o governo pôde prescindir dos gastos de defesa justamente por assistir a um desempenho conjuntural favorável dos investimentos corporativos, de modo que a própria redução do orçamento militar facilitou a diminuição do déficit. A tarefa foi ajudada também pelo aumento dos tributos sobre as duas faixas mais ricas dos contribuintes, no sentido de equacionar ainda mais as contas federais. Acima se pode notar, na tabela sobre as contas do governo federal, a (1) queda das despesas militares - ainda que moderada e sujeita a flutuações que a elevaram -; (2) o grande aumento na captação de impostos sobre as famílias e sobre as corporações; e (3) a progressiva queda dos déficits. A diminuição dos gastos militares mais da metade do orçamento total do governo, até então - conjugada com um crescimento da 
taxa de inversão privada, explicam, portanto, a queda do déficit orçamentário. Ele ia se transformar em superávit em 1998 (68 bilhões de dólares).

Por sua vez, menção deve ser feita ao nível de endividamento doméstico, que se elevou bastante em todo o período. Na tabela abaixo, construída com dados do documento Flow of Funds Accounts, de responsabilidade da Reserva Federal, percebe-se como a política econômica sancionou a enorme taxa de crescimento do endividamento de todos os setores da economia no período, principalmente os das corporações financeiras - um dos pilares do "modelo norteamericano". Por exemplo: a dívida total das famílias norte-americanas, somadas às hipotecas e crédito ao consumo, era de quase 4 trilhões de dólares em 1992. Então, o PIB atingia 6,6 trilhões; em termos percentuais, isto dava $60 \%$ do PIB.

Tabela 5. Estados Unidos. Aumentos anuais de empréstimos por setor e dívida remanescente de tais setores em fim de período. 1990-1996. Em bilhões de dólares.

\begin{tabular}{|c|c|c|c|c|}
\hline \multicolumn{5}{|c|}{ Empréstimos por setor: aumento anual } \\
\hline \multirow[t]{2}{*}{ (1) } & $(2)$ & (3) & (4) & $(5)$ \\
\hline & $\begin{array}{l}\text { Hipotecas às } \\
\text { famílias }\end{array}$ & $\begin{array}{l}\text { Crédito ao } \\
\text { consumo }\end{array}$ & $\begin{array}{c}\text { Endividamento } \\
\text { corporativo } \\
\text { (excluídas } \\
\text { empresas } \\
\text { financeiras) }\end{array}$ & Setores financeiros \\
\hline 1990 & 198,6 & 15,1 & 136,4 & 211,2 \\
\hline 1991 & 174,1 & 8,8 & 52,9 & 156,0 \\
\hline 1992 & 171,3 & 9,2 & 24,3 & 238,9 \\
\hline 1993 & 156,8 & 61,4 & 32,5 & 291,5 \\
\hline 1994 & 167,1 & 134,8 & 227,3 & 462,0 \\
\hline 1995 & 153,8 & 147,9 & 183,7 & 439,4 \\
\hline 1996 & 205,5 & 104,9 & 291,5 & 513,8 \\
\hline 1997 & 216,1 & 71,1 & 396,9 & 572,1 \\
\hline \multirow[t]{3}{*}{ (6) } & (7) & $(8)$ & (9) & $(10)$ \\
\hline & \multicolumn{3}{|c|}{ Dívida remanescente total por setor } & \\
\hline & $\begin{array}{l}\text { Hipotecas às } \\
\text { famílias }\end{array}$ & $\begin{array}{l}\text { Crédito ao } \\
\text { consumo }\end{array}$ & $\begin{array}{c}\text { Endividamento } \\
\text { corporativo } \\
\text { (excluídas } \\
\text { empresas } \\
\text { financeiras) }\end{array}$ & Setores financeiros \\
\hline 1990 & 2503,7 & 824,4 & 2535,8 & 2613,6 \\
\hline 1991 & 2681,4 & 815,6 & 2480,7 & 2769,6 \\
\hline 1992 & 2852,7 & 824,8 & 2506,6 & 3024,1 \\
\hline 1993 & 3011,9 & 886,2 & 2551,6 & 3321,0 \\
\hline 1994 & 3178,9 & 1021,1 & 2684,5 & 3791,1 \\
\hline 1995 & 3332,7 & 1168,8 & 2911,3 & 4233,2 \\
\hline 1996 & 3538,2 & 1273,8 & 3095,0 & 4746,9 \\
\hline
\end{tabular}

Fonte: Flow of Funds Accounts of the United States - Federal Reserve Statistical Release. Primeiro Trimestre de 2007. Para empréstimos, p.7. Para dívida remanescente, p.8.

Em 1996, a dívida das famílias chegava a 5,4 trilhões, para um PIB de 7,8 trilhões, tendo crescido em termos percentuais, sobre o PIB, para 70\%. O endividamento das instituições financeiras pulou de 47\% do PIB em 1992 para 60\% do PIB. Quanto ao endividamento das 
famílias, ele acompanhado por uma correlata queda em suas taxas de poupança, como se demonstra na seqüência. Tal era a outra face da moeda do alto nível de endividamento. Ora, porque as famílias se endividariam se a taxa de poupança estivesse crescendo?

(b) Taxa de investimento

A taxa de investimento em capital fixo não-residencial cresceu em proporção do PIB, indo de $9 \%$ para $10 \%$, durante o quadriênio. Esta elevação veio depois de uma queda constante ao longo da década passada. Em 1980, estava em 12\%; em 1985, na mesma marca. Em 1990 caíra a 10\%, e depois a $9 \%$ em 1991. Como se viu anteriormente, a relação consumo das famílias/investimento crescera ao longo da década anterior, com o consumo das famílias saindo de $62 \%$ sobre o PIB em 1980 para 64\% em 1985 e para $66 \%$ em $1990 .{ }^{233}$ O quadriênio 1993 1996 conhecia assim uma inversão, e representaria um hiato, nesta queda consolidada de longo prazo que a taxa de investimento tinha tido e teria, depois que o boom acabasse.

Tabela 6. Estados Unidos. PIB, investimentos privados em capital fixo não-residenciais, e poupança das empresas. 1993-1996. Em bilhões de dólares.

\begin{tabular}{cccccc}
\hline (1) & $\begin{array}{c}(2) \\
\text { Produto Interno } \\
\text { Bruto }\end{array}$ & $\begin{array}{c}(3) \\
\text { Poupança das } \\
\text { empresas }\end{array}$ & $\begin{array}{c}(4) \\
\text { Investimentos } \\
\text { privados } \\
\text { em capital } \\
\text { fixo não- } \\
\text { residenciais }\end{array}$ & $\begin{array}{c}(5) \\
\text { Poupança das } \\
\text { empresas dividida } \\
\text { pelos investimentos } \\
\text { em capital fixo }\end{array}$ & $\begin{array}{c}(6) \\
\text { Investimentos em } \\
\text { proporção do PIB } \\
(3 / 1)\end{array}$ \\
1993/I & 6444,5 & 782,5 & 580,5 & 1,35 & 0,09 \\
II & 6509,1 & 726,2 & 598,8 & 1,21 & 0,09 \\
III & 6574,6 & 759,5 & 606,4 & 1,25 & 0,09 \\
IV & 6704,2 & 724,1 & 630,6 & 1,15 & 0,09 \\
1994/I & 6794,3 & 880,3 & 634,6 & 1,39 & 0,09 \\
II & 6911,4 & 785,7 & 652,9 & 1,20 & 0,09 \\
III & 6986,5 & 793,7 & 667,4 & 1,19 & 0,10 \\
IV & 7095,7 & 795,0 & 687,5 & 1,16 & 0,10 \\
1995/I & 7170,8 & 883,4 & 713,6 & 1,24 & 0,10 \\
II & 7210,9 & 782,9 & 728,1 & 1,08 & 0,10 \\
III & 7304,8 & 799,1 & 729,5 & 1,10 & 0,10 \\
IV & 7391,9 & 812,9 & 739,5 & 1,10 & 0,10 \\
1996/I & 7495,3 & 799,5 & 759,1 & 1,05 & 0,10 \\
II & 7629,2 & 818,6 & 774,8 & 1,06 & 0,10 \\
III & 7703,4 & 855,0 & 801,1 & 1,07 & 0,10 \\
IV & 7818,4 & 880,8 & 816,8 & 1,08 & 0,10 \\
\hline
\end{tabular}

Fonte: Economic Report of the President, vários números. Para PIB e investimentos em capital fixo, ver Tabela 1, Gross Domestic Product; para poupança das empresas ("gross business saving"), ver Tabela Gross Saving and Investment.

De acordo com as hipóteses aqui adotadas, a taxa de desempenho dos investimentos privados foi realmente privilegiada pela inundação de capital farto do exterior. Entretanto, teve

${ }^{233}$ Hoje, 2009, está a 70\%. Conferir o capítulo final. 
desta vez o componente do surto de inovações que a tornou mais expansiva do que teria sido na ausência delas. Isto torna a primeira administração de Clinton um ponto de inflexão: o crescimento estava se dando em bases de um novo padrão produtivo, com crescimento da produtividade na maior parte dos setores. Este é o elemento que deu à expansão norte-americana desde 1993 um caráter não-belicista e centrado na manufatura para a produção civil, diferentemente dos períodos das anteriores administrações republicanas.

Com efeito, tais inovações, fruto da aplicação das cumulativas descobertas da microeletrônica e dos microprocessadores à produção e distribuição, estiveram em estado germinativo, sob o ponto de vista de sua aplicação à economia civil, ao longo do início da década de (19)80. Quando sua utilização se acelerou, tais mudanças passaram a se traduzir em aumento das taxas de lucro, de produtividade, deslocamento na pauta de gastos das famílias e na pauta de exportações norte-americanas, com decorrências positivas também para os ganhos no item de rendas e exportação de bens high tech no balanço de pagamentos.

Para perceber isto de modo mais acurado, é interessante observar o comportamento dos investimentos desagregados num prazo mais longo que o da própria primeira administração de Clinton. Isto leva a perceber o momento exato em que a viragem trazida pelos investimentos nas tecnologias de informação iniciaram uma trajetória ascendente. O gráfico abaixo, fornecido com dados do BEA, permite ver isto de modo claro. Aí se mostram os investimentos, em bilhões de dólares correntes, em diversos ramos dos setores privados norte-americanos. A série de "manufatura" nesta figura refere-se especificamente aos produtores de artigos de consumo final. Pode-se ver bem o aumento muito acima da média dos investimentos nos setores ligados às tecnologias de informação, softwares, informática etc., a partir de 1991. Tais setores crescem rapidamente e tal crescimento durou aproximadamente até 2001, referente à saturação dos investimentos dada a queda da taxa média de lucro. A queda conduziu à readequação entre valores acionários e lucros reais das firmas que mais tinham captado no Dow e no NASDAQ. ${ }^{234}$ Porém, durante o momento que lhes foi favorável, tais investimentos nas novas tecnologias distanciaram-se da média dos outros investimentos referentes a outros componentes dos gastos das firmas, que não deixaram ver um perfil acumulativo em escala crescente naquele período.

O gráfico número 3 abaixo também mostra as mesmas decorrências da aplicação de tais novas tecnologias sobre a taxa de investimento, sob outra perspectiva. Mais uma vez fornecidos pelo Bureau of Economic Statistics, estes dados formulados por tal órgão oficial mostram a contribuição de cada tipo de investimento privado para a variação da taxa total de investimento privado nos Estados Unidos. De fato, a contribuição dos equipamentos de processamento de informação já permanecia bastante acima dos outros tipos de investimento desde a década de (19)80. Todavia, este movimento tende a dobrar na década seguinte, situando-se na casa de $8 \%$

\footnotetext{
${ }^{234}$ Este movimento foi extensamente analisado por Robert Brenner, de modo que se pode referir a $O$ boom e a bolha para uma apreciação mais detalhada, inclusive de como tais investimentos levaram a um enorme excesso de capacidade instalada. Ver especialmente os capítulos 9 e 10 desta obra, intitulados respectivamente "Os contornos e a natureza do boom americano" e "Do término da bolha ao término do boom".
} 
aproximadamente entre 1994 e 2000, explicitando justamente as impressões e verificações de todos os comentaristas.

Gráfico 2. Estados Unidos. Investimentos em setores selecionados. 1990-2001. Em bilhões de dólares.

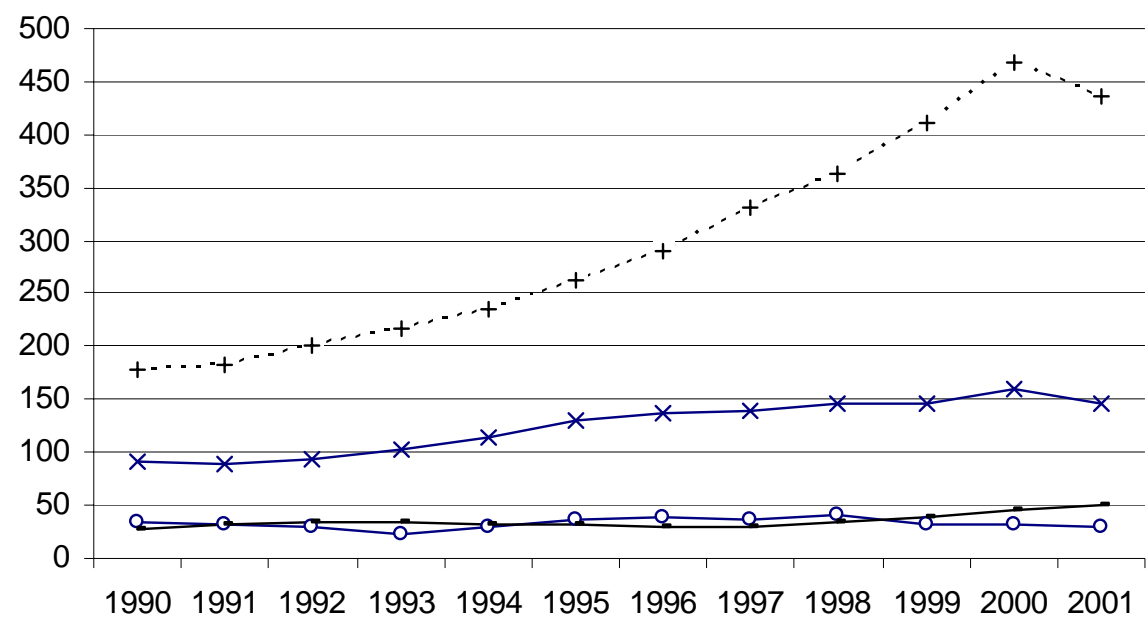

$$
\begin{aligned}
& \text { —_ Manufatura } \\
& \hline \text { Energia e comunicação } \\
& \ldots+\cdots \text { Equipamento de processamento de informações e software } \\
& \ldots \text { Equipamento industrial }
\end{aligned}
$$

Fonte: NIPA-BEA. Seção 5, Saving and Investment; Tabela 5.3.5, Private Fixed Investment by Type.

Gráfico 3. Estados Unidos. Contribuição para a mudança percentual nos investimentos fixos em equipamento e software por tipo. 1980-2001.

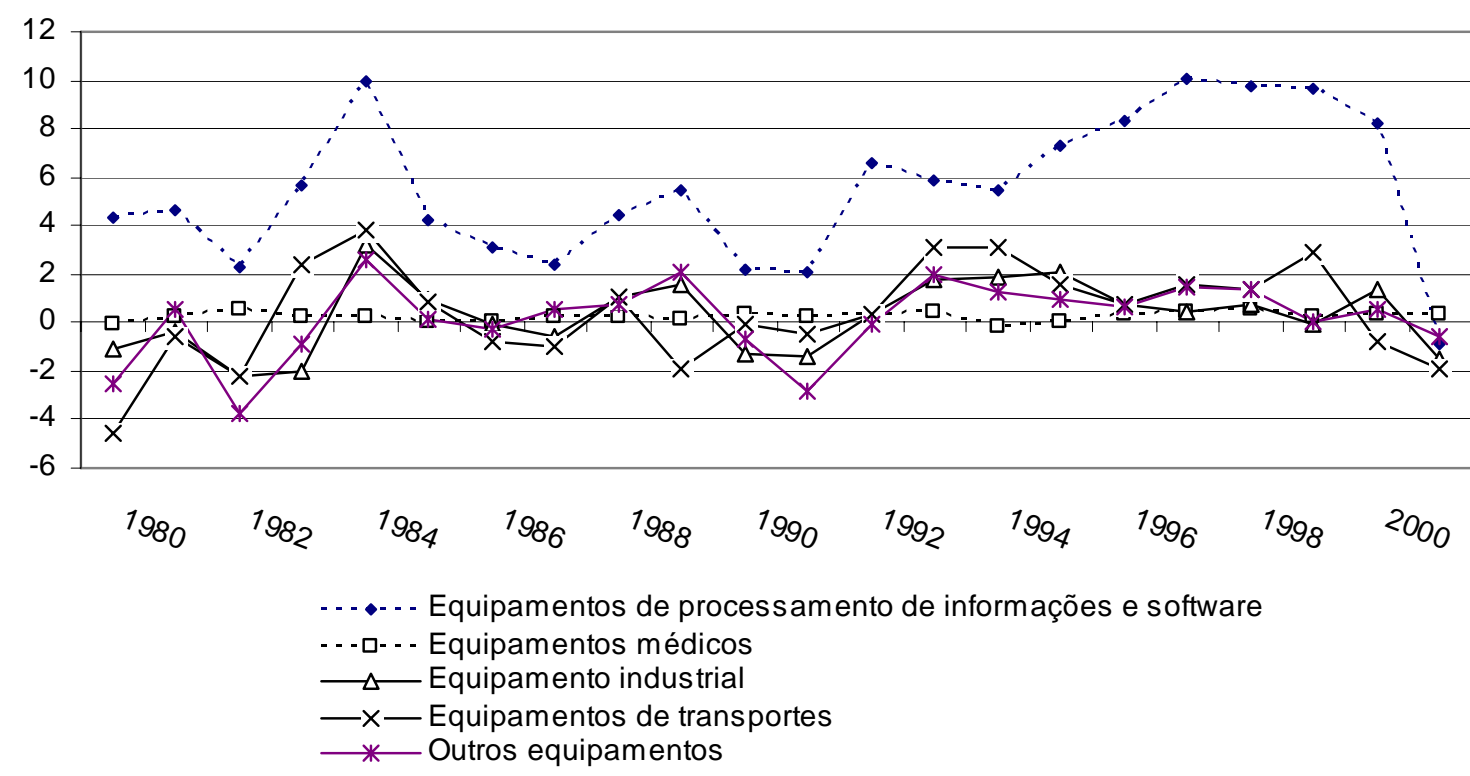

Fonte: NIPA-BEA. Tabela 5.5.2, Contributions to Percent Change in Real Private Fixed Investment in Equipment and Software by Type. 
(c) Produtividade e pauta de consumo das famílias

No que toca à produtividade, ao longo da primeira administração Clinton, seguindo-se depois até o fim da década, a produção por hora elevou-se, como era de se esperar quando da adoção dos procedimentos produtivos acima definidos. É claro que a elevação da taxa de produtividade não teve um caminho que justificasse a alcunha de "revolução" dada aos novos procedimentos produtivos. Porém, a média anual entre 1990 e 2002 foi 2,22\% de variação percentual, ao passo que a média entre 1980 e 1992 foi de apenas 1,68\%. Tal de qualquer modo justifica a noção de que os procedimentos alteraram substancialmente a relação capital/produto.

Interessa notar também, como se pode notar na figura na seqüência, como os salários passaram por uma inversão - regredindo, em termos reais - durante todo o período da primeira administração, para depois ingressarem numa situação de crescimento rápido entre 1996 e 2000. A figura, fornecida pela Tabela B-50 do Economic Report de 2006 (Changes in productivity and related data, business sector), permite ver o espaço havido entre o início do crescimento e o aumento posterior dos salários, com a diminuição da taxa de desemprego. Ela foi de aproximadamente três anos. De qualquer modo, nota-se como, numa estrutura econômica desenvolvida, a introdução de mais produtividade é acompanhada por um aumento dos salários e queda do desemprego - e não de eliminação do volume de mão-de-obra empregada e queda dos salários, como nas economias subdesenvolvidas que conheceram estes mesmos processos de revolução dos modos-de-fazer, mas sob as condições de importação de tecnologia. Mostravase aí a permanência das diferenças entre o centro produtor de tecnologia, e as decorrências contraditórias entre importação de bens de produção mais modernos e barateadores e elevação da taxa de desemprego das economias que não produziam as novas tecnologias. Este problema "macro", porém, não era importante para os defensores da abertura irrestrita do comércio exterior e para os fanáticos das taxas de produtividade, tanto nos Estados Unidos como naqueles que administravam tais políticas na América Latina, Leste Europeu etc.. 
Gráfico 4. Estados Unidos. Variação anual (\%) da produção por hora dos salários reais, nos setores não-agrícolas. 1980-2002.

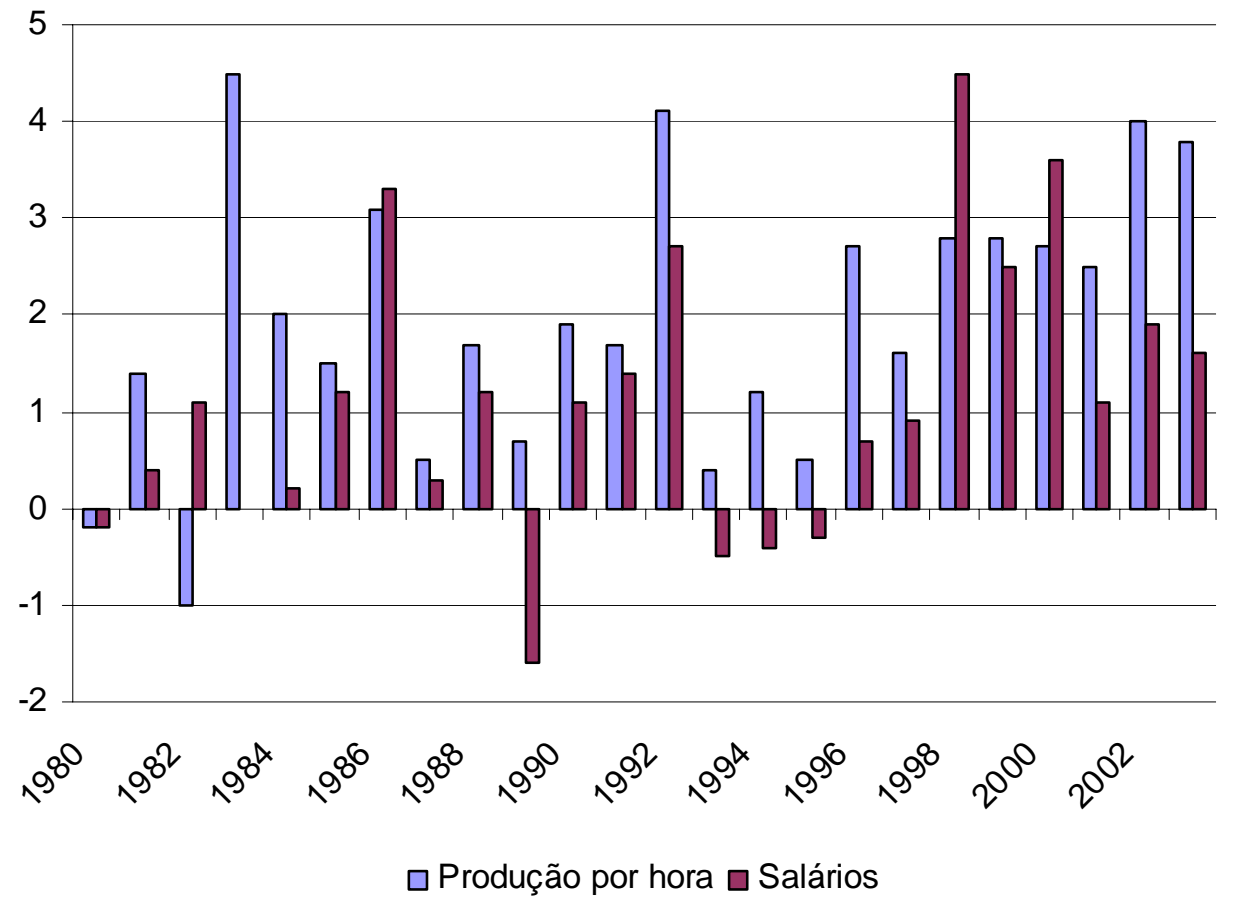

Fonte: Economic Report of the President, 2006. Tabela B-50, Changes in Productivity and related data, business sector, 1959-2005.

$\mathrm{Na}$ seção sobre o processo de inovação, ressaltou-se como ela implica em novos métodos de produção e/ou em novos bens fabricados. Sob outra maneira de ver, isto quer dizer a existência de novos métodos de produção e novos produtos finais, consumidos respectivamente pelas firmas e famílias. No caso das tecnologias de informação, os dois aspectos estiveram presentes; do mesmo modo como elas impulsionaram a taxa de investimentos, elas significaram mudanças na composição de gastos das famílias.

Isto é exatamente o que se pode inferir a partir das figuras abaixo, que mostram um rápido crescimento da importância do computador e todos os periféricos (softwares, impressoras etc.) na composição de gastos do consumo das famílias, a partir de 1991. De fato foi o momento onde estes artigos passaram a ser cada vez mais barateados, tornando-se ao mesmo tempo mais complexos e de usos mais diversificados. Vê, pelo contrário, como tais produtos, em seu crescimento, ganharam uma trajetória bastante rápida e ascendente, em detrimento de outros artigos da pauta de consumo das famílias. ${ }^{235}$

${ }^{235}$ Esta tabela é a de Número 2.4.3. no conjunto de tabelas do BEA, e seu título é Real Personal Consumption Expenditures by Type of Product, Quantity Indexes. 
Gráfico 5. Estados Unidos. Gastos pessoais reais com consumo por tipo de produto, em números-índices $(2000=100)$. 1989-2006.

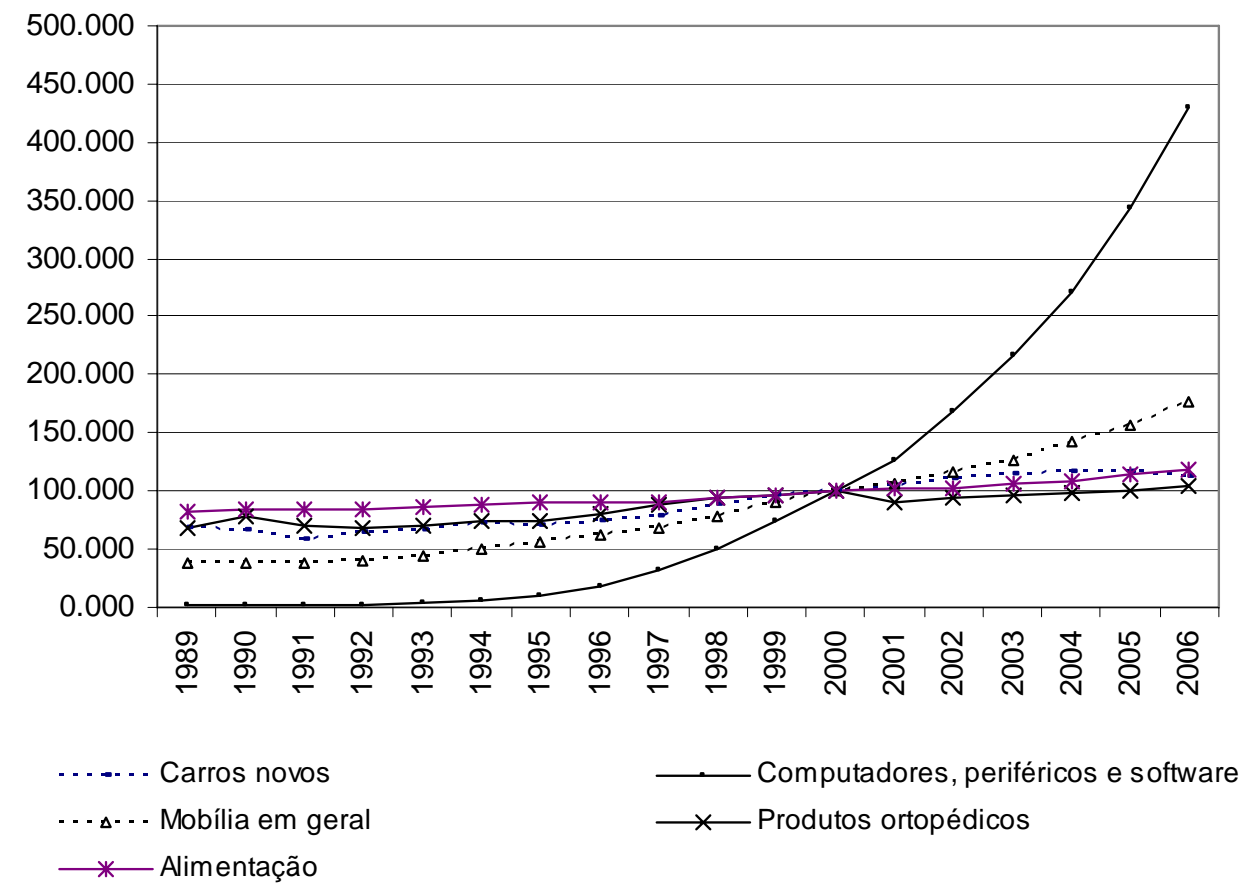

Fonte: NIPA-BEA. Seção 2, Personal Income and Outlays, Tabela 2.4.3, Real Personal Consumption Expenditures by Type of Product, Quantity Indexes.

(d) Crescimento e endividamento externo

São claros os efeitos que as novas tecnologias imprimiram sobre a taxa de investimento das firmas. Isto conduz a duas perguntas, de acordo com o que se está investigando neste estudo. Em primeiro lugar: o aumento da taxa de investimentos produtivos - o aumento da taxa de acumulação produtiva - conseguiu eliminar as desvantagens relativas face aos investimentos financeiros? E, em segundo: o aumento da taxa de investimento produtivo conduziu o país a uma diminuição da atração de recursos externos?

A resposta à primeira pergunta é sim. Todo crescimento real da economia funda-se em oportunidades lucrativas nos setores responsáveis pela acumulação produtiva. Se há crescimento depois de anos de predomínio das finanças, é porque temporariamente as vantagens relativas às inversões financeiras se tornaram menores do que em momentos onde o setor industrial se vê diante de pressões para a baixa da taxa de lucro. Foi o que ocorreu nesta primeira metade da década de (19)90. Os lucros nos setores não-financeiros, e em especial na manufatura, tiveram um desempenho superior aos lucros financeiros, confirmando assim o aumento da acumulação produtiva. Estes resultados podem ser vistos abaixo. Como deixa ver a coluna 4 da tabela abaixo, a relação dos lucros do setor manufatureiro sobre os lucros financeiros saiu de 1,25 no início de 1993 para pular para 2,0 no fim de 1994 e 2,04 no fim do ano seguinte; no quarto trimestre de 1996, a relação chegara 2,30. 
Tabela 7. Estados Unidos. Lucros setoriais: setores financeiros (inclui bancos da Reserva Federal), não-financeiros, e dentre estes os da manufatura. 1993-1996.

\begin{tabular}{ccccc}
\hline (1) & \multicolumn{4}{c}{ Estados Unidos: lucros financeiros e não-financeiros } \\
& $(2)$ & $(3)$ & $(4)$ & $(5)$ \\
1993/I & 76.6 & 263.1 & Manufatura & $\begin{array}{c}\text { Lucros da manufatura/ } \\
\text { Lucros financeiros }\end{array}$ \\
II & 84.7 & 289.8 & 95.8 & 1.25 \\
III & 79.4 & 303.3 & 115.1 & 1.36 \\
IV & 91 & 344.2 & 113.8 & 1.43 \\
1994/I & 44.1 & 354.7 & 142.2 & 1.56 \\
II & 72.3 & 365.6 & 149.7 & 3.38 \\
III & 81.3 & 379.5 & 138.8 & 1.91 \\
IV & 80 & 405.3 & 151.6 & 1.86 \\
1995/I & 89.5 & 387.3 & 166.2 & 2.00 \\
II & 96.3 & 390.4 & 161.9 & 1.80 \\
III & 107.1 & 433.8 & 170.3 & 1.77 \\
IV & 97.4 & 444.7 & 194.5 & 1.81 \\
1996/I & 110.4 & 458.3 & 198.4 & 2.04 \\
II & 111.5 & 472 & 197.1 & 1.79 \\
III & 104 & 480.7 & 204.8 & 1.83 \\
IV & 88.1 & 487.8 & 210.5 & 2.01 \\
& & & 209.7 & 2.30 \\
\hline
\end{tabular}

Fonte: Economic Report of the President, 1998. Tabela B-91, Corporate profits by industry.

Gráfico 6. Estados Unidos. Relação entre os lucros não distribuídos e o consumo de capital fixo, para as empresas domésticas norte-americanas. 1993-1996.

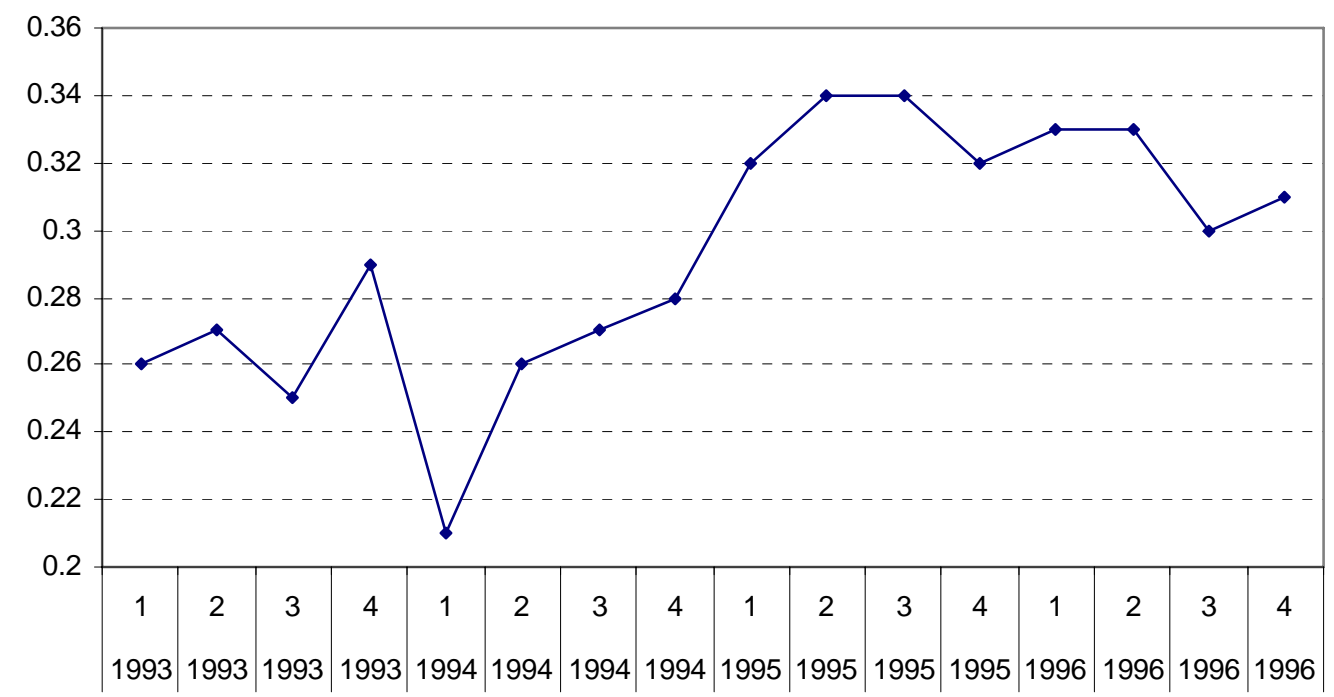

Fonte: cálculo do autor a partir dos dados do NIPA-BEA. Seção 6, Income and Employment by Industry. Para lucros não distribuídos, ver Tabela 6.21A, Undistributed Corporate Profits by Industry; para consumo de capital fixo, ver Tabela 6.22A, Corporate Capital Consumption Allowances by Industry.

Outra maneira de ver isto é sob o ponto de vista da relação entre os investimentos em capital fixo e os lucros obtidos pelas empresas. Neste sentido, a eficiência dos investimentos do capital produtivo também aumentou, no período: acima está traçada a relação entre os lucros 
não-distribuídos pelas empresas domésticas e os investimentos em capital fixo, pelas empresas domésticas. O cálculo é o mesmo que aparece no capítulo de análise empírica (capítulo 4), na seção "A relação investimento-poupança", inclusive com as mesmas séries. ${ }^{236}$ Mas contrariamente à tendência geral de queda vista ali, vinda desde a década de (19)80, aqui a série tem tendência ascendente.

Neste momento, surge então a questão: qual foi o comportamento da atração de recursos externos? O aumento da acumulação produtiva conduziu a uma queda relativa? Vejam-se as inferências que se pode traçar a partir da tabela com a estrutura do endividamento externo disposta abaixo.

Do ponto de vista do governo, as autoridades não se mostraram dispostas a estabilizar o nível de endividamento externo. Por conseqüência, deu-se rápido crescimento do endividamento do governo federal com relação ao exterior, elemento não destacado pela maior parte da literatura quando da discussão sobre a queda dos déficits fiscais. Boa parte dos analistas prefere enfatizar apenas os aumentos dos impostos sobre os lucros corporativos, como se a política de Clinton não tivesse outra estratégia que não esta mesma. Teve, e esta foi a elevação do endividamento externo do governo federal: a quantidade de papéis que o governo havia emitido ao exterior chegara a nada menos do que $80 \%$ do total de impostos arrecadados domesticamente. Isto significa afirmar que a economia mundial - e entre elas as economias periféricas -, transformando seus saldos de balança comercial em papéis norte-americanos, estava financiando cada vez mais o sistema de saúde e militar norte-americano com tais excedentes. Mantinha-se o status quo em ambas pontas do sistema, via o sistema dólar-dólar. Eis um elemento, dentre os outros conhecidos, da reiteração do subdesenvolvimento num pólo do sistema econômico internacional, e do desenvolvimento no outro, pelo mecanismo dos caminhos que os excedentes nacionais adotam.

Interessa destacar também os investimentos diretos aos Estados Unidos em forma desagregada, entre (a) compra de ações e bonds e (b) ampliação da capacidade. Este, que aparece na tabela sob a forma simplesmente de investimentos diretos, manteve-se estagnado durante todo o período, diferentemente da emissão de papéis ao exterior, cuja variação esteve acima da média da própria taxa de atração total de recursos do exterior. Tal elemento é outro a explicar a incapacidade do mero aumento da taxa de lucro doméstica, sozinha, em induzir a um crescimento sem endividamento. $\mathrm{O}$ que aparece pela tabela, cujos dados têm pouca atenção da literatura, é que, juntos, o volume de capitais estrangeiros na economia superou o próprio investimento agregado.

\footnotetext{
${ }^{236} \mathrm{Na}$ Tabela 5.1 das Contas Nacionais do BEA: "Undistributed corporate profits with inventory valuation and capital consumption adjustments" e "Consumption of fixed capital, domestic business".
} 
Tabela 8. Estados Unidos. Estrutura do endividamento externo. Em bilhões de dólares correntes. 1993-1996.

(1)

Títulos norte-americanos em mãos de estrangeiros

Taxa de crescimento do

endividamento externo face ao ano anterior

$\%$ da dívida externa face ao PIB

a) Compra de papéis do governo norte-americano 237

a.1) Por agentes oficiais (Bancos Centrais)

a.2) Por agentes privados

a.3.) Outros títulos em mãos de estrangeiros

a.4) Total

Total arrecadado pelo governo com impostos domésticos $\%$ dos empréstimos externos totais (a.4) sobre arrecadação doméstica

b) Depósitos nos bancos dos EUA

b.1.) Por agentes oficiais

b.2) Por agentes privados

Total

Taxa de variação de (b) face ao ano anterior

c) Compras de ações e bonds de corporações dos EUA

c.1) Ações

c.2) Bonds

Variação de (c) face ao ano anterior

d) Investimento direto nos EUA Variação do investimento direto face ao ano anterior

Investimento agregado
(2)

1993

3112,6

1,11

$47 \%$

388,3

253,9

22,1

665

1154

$57 \%$

69,7

675,5

744

1,05

340,6

389,9

1,17

338,9

413,9

1,03

73,4

783,3

856

1,15

3)

1994

(4)

1995

(5)

1996

4591,3

3960,4

1,19

1,15

$54 \%$

$60 \%$

$7 \%$

415,0

498,9

610,2

266,7

389,4

530,6

25,2

25,9

912

1165

1453

1351

$80 \%$

$67 \%$

107,4

813,4

920

819,9

931

1,07

1,01

1,11
876

585,0

654,5

729,1

1,11

1,11

1007

1038

1165

Fonte: Economic Report of the President, 1999. Tabela B-107, International investment position of the United States at yearend, 1989-97.

${ }^{237}$ Repetindo-se o que está nos capítulos anteriores: no Apêndice Estatístico do Economic Report of the President a linha (a) corresponde - na tabela "International Investment Position of the United States at year-end" da Seção "International Statistics" - à seção "Foreign Official Assets in the United States U.S.government securities"; a linha (b) corresponde a "US treasury securities", em "Other Foreign Assets in the United States"; e a linha (c) corresponde a "Other foreign official assets", de novo em "Foreign Official Assets in the United".

${ }^{238}$ Correspondem respectivamente a ambas linhas "U.S. Liabilities reported by U.S. Banks, not included elsewhere", estando uma na sub-seção "Foreign Official Assets in the United States" e outra na sub-seção "Other Foreign Assets in the United States". 
Para uma compreensão adequada disto, pode causar certa confusão o argumento de que a economia norte-americana é aberta e também investe e compra do exterior, o que supostamente anularia as vantagens do endividamento externo. Realmente, a economia norteamericana também exporta capital, e com esta exportação, recebe direitos de renda e dividendos. $\mathrm{O}$ resultado disto anula em parte o a atração dos recursos externos ao mercado norte-americano. Porém, o aumento do endividamento externo implica que o país receba mais recursos do que exporta, e que importe mais mercadorias do que exporte. A partir desta noção, de endividamento líquido dos Estados Unidos (o resultante crescentemente positivo dos valores da conta de capitais do balanço de pagamentos subtraídos aos da conta corrente do B.P.), percebe-se que a economia elevou as captações líquidas ao exterior durante a administração Clinton. Isto é: diminuiu a proporção (1) de recursos que o país paga ao exterior em forma de importações de mercadorias e remessas de renda face à (2) quantidade similar que o país recebe do mundo. Tal como aparecia antes, define-se que o aumento mais rápido de (2) face a (1) dá a taxa de endividamento externo líquido.

Gráfico 7. Estados Unidos. Endividamento líquido com o exterior. Em bilhões de dólares. Resultados positivos indicam haveres líquidos contra o exterior.

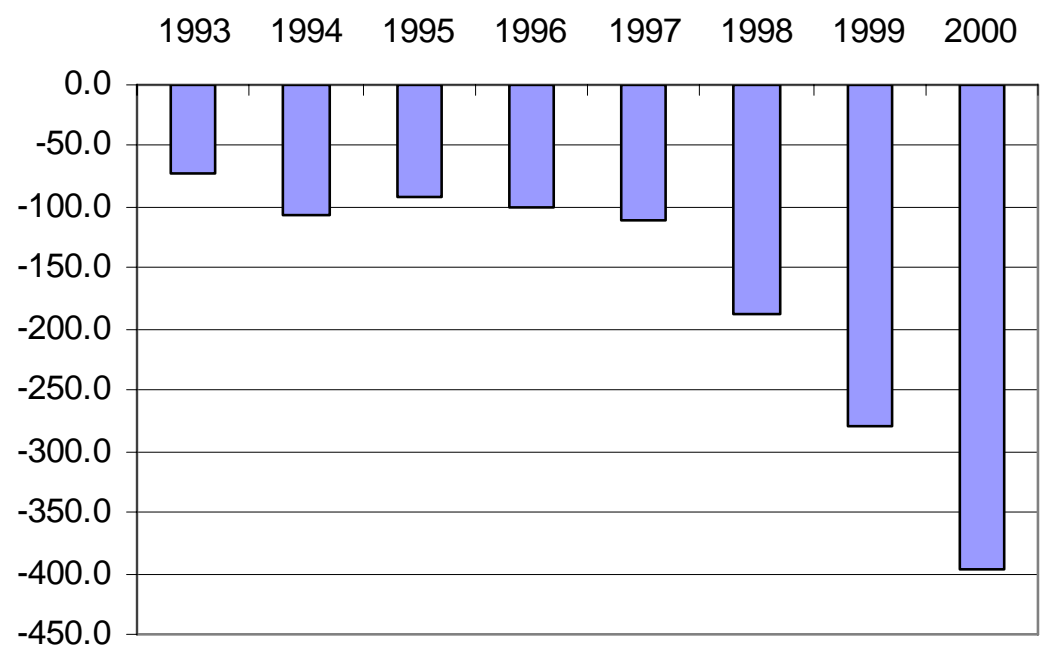

Fonte: NIPA-BEA. Seção 4, Foreign Transactions, Tabela 4.1, Foreign Transactions in the National Income and Product Accounts.

Tal como se vê acima, o crescimento da economia entre 1993 e 1996 resultou num estancamento da taxa de crescimento do endividamento externo, sem no entanto eliminá-lo. Por definição, a economia recebeu por ano uma média de 100 bilhões de dólares a mais pela conta de capitais do que importou em mercadorias e pagou em rendas, pelo lado da conta corrente do B.P. O que isto quer dizer? Isto quer dizer que, sendo o balanço de pagamentos do mundo um jogo de soma zero, o fato de que os Estados Unidos estiveram cada vez mais apresentando resultados positivos em sua conta de capitais - isto é, que o endividamento sobre o PIB tenha crescido ano a ano - significa, pela velha (e verdadeira) lição dos determinantes 
macroeconômicos, que o mundo esteve financiando parte de seus investimentos e seus gastos, em troca de papéis. E automaticamente renunciando temporariamente ao consumo e a ao investimento que poderia ter. Sob outro modo de ver, o aumento do endividamento externo se traduz num maior aumento dos saldos positivos na conta de capitais do que os negativos na conta corrente do balanço de pagamentos. E se alguém está financiando parte dos investimentos e dos gastos, estes investimentos e consumo não podem ser desvencilhados do endividamento, mesmo em períodos de ascensão com base na lucratividade do capital, que passa a ser confundida com a situação de endividamento. Ora, a mera contraposição entre o aumento do endividamento no entre 1990 e 2000 e o aumento das importações deixa isto claro: enquanto a dívida externa aumentou em 5.353 trilhões, o aumento das importações totais dos Estados Unidos somou 533 bilhões no mesmo período, segundo o Economic Report. ${ }^{239}$

Tal como nos capítulos passados, a plotagem dos resíduos das séries de poupança agregada e de aportes de capital externo permite ver o mesmo mecanismo do endividamento externo funcionando como estabilizador inclusive de curto prazo das flutuações da formação de poupança doméstica (gráfico 8 abaixo). A atração de recursos se eleva nos momentos em que a poupança agregada está caindo de modo consolidado - isto é, com exceção do endividamento e vice-versa. Isto significa dizer que o componente externo da poupança agregada aumentou quando a poupança doméstica (poupança agregada menos o componente externo) caiu.

A atração de recursos funcionou como um estabilizador perfeito, simétrico, no curto prazo, para as flutuações que se expressam em menor formação de poupança agregada, pelo sobe e desce da taxa de inversão. É curioso notar a periodicidade da simetria compensadora entre aumento da dívida e necessidade de financiamento no curto prazo. É possível ver também na figura 8 que tal simetria entre dívida e flutuações locais não foi modificada pela expansão da economia. Não obstante não se poder ver na figura, pois ela traça apenas os resíduos com suas tendências eliminadas, não se deve esquecer que o momento é de crescimento das inversões privadas. Tal crescimento, porém, deu-se ele mesmo sobre a base de altas e baixas. Em suas baixas, de curtíssimo prazo, o aumento da dívida externa surge como uma resposta automática. Vê-se aqui, portanto, a equivalência entre o princípio regulador entre a poupança e a dívida já acima estabelecido, e a prática efetiva da economia ao longo do tempo, mesmo quando a tendência geral é de crescimento. As fendas na poupança, no interior desta tendência geral de crescimento, levaram a aumentos esporádicos da dívida.

\footnotetext{
${ }^{239}$ Conferir as tabelas "US international trade in goods by principal end-use category" e "International investment position of United States" nos Economic Reports recentes (principalmente a partir de 2001).
} 
Gráfico 7. Estados Unidos. Resíduos de poupança agregada líquida e de empréstimos externos. Em bilhões de dólares correntes. 1993-1996.

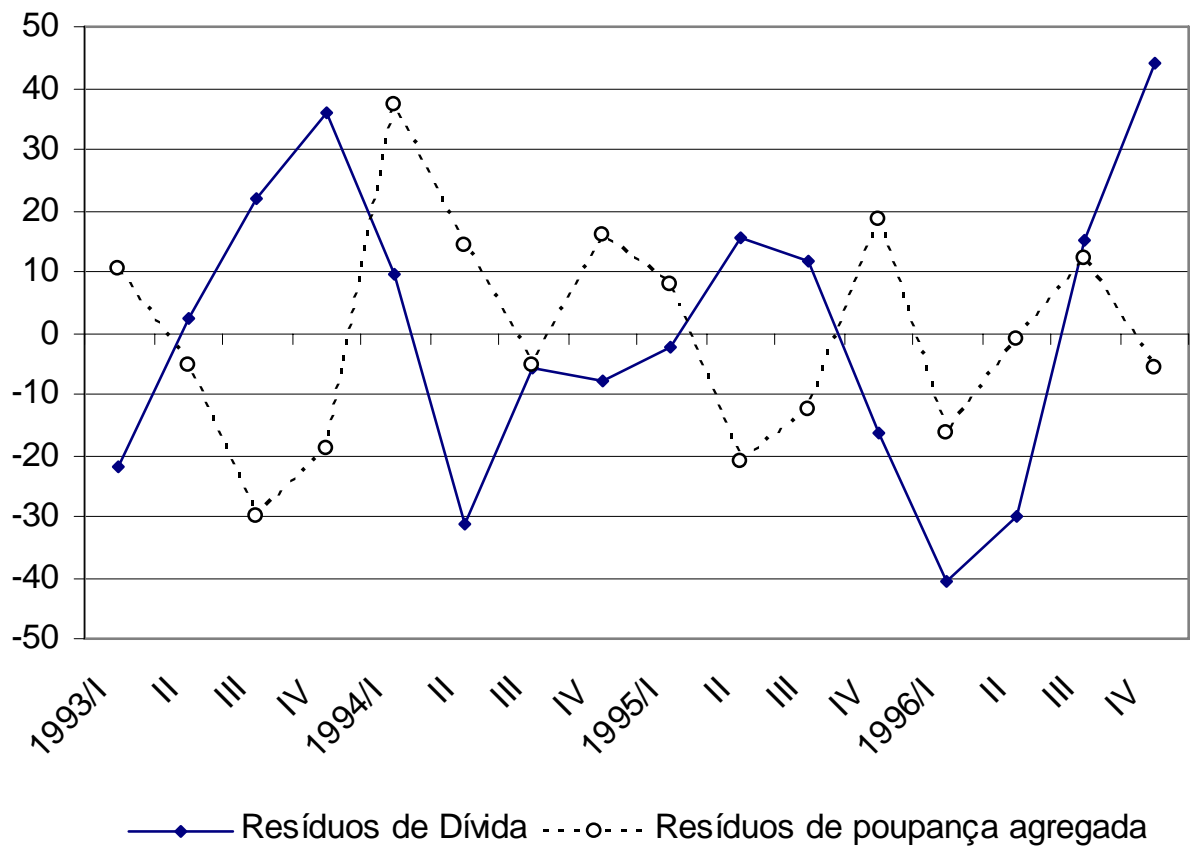

Fonte: Economic Report of the President de 1997 e 1998. Para poupança, ver Tabelas Gross Saving and Investment; para dívida externa (ativos estrangeiros na economia norte-americana) ver U.S. International Transactions, primeira tabela da Seção International Statistics do Economic Report, na seção Foreign Assets in the U.S., net.

A tabela com os valores que geraram a plotagem dos dados acima está disposta na seqüência.

Tabela 9. Estados Unidos. Poupança agregada, poupança doméstica e ativos estrangeiros na economia norte-americana, em base trimestral. 1993-1996.

(1)

Ansos

Poupança Agregada

1993/I

II

III

IV

1994/I

II

III

IV

1995/I

II

III

IV

1996/I

II

III

IV
(2)

932

942

943

980

1062

1065

1071

1118

1136

1133

1167

1224

1215

1256

1295

1303
(3) Empréstimos externos

19,8

51,2

77,9

99,4

80,3

46,5

79,7

84,7

97,6

122,7

125,8

105,1

88,2

106,1

158,6

194,5
(4)

Poupança

doméstica

912.2

890.8

865.1

880.6

981.7

1018.5

991.3

1033.3

1038.4

1010.3

1041.2

1118.9

1112.8

1149.9

1136.4

1108.5
(5)

Empréstimos sobre a poupança

0,02

0,05

0,08

0,10

0,07

0,04

0,07

0,07

0,08

0,10

0,10

0,08

0,07

0,08

0,12

0,14

Fonte: ver gráfico 7 acima. 
Torna-se então necessário perguntar: porque então aumentou o endividamento externo da economia? A resposta está no comportamento dos outros agregados, que consumiram a poupança doméstica (isto é, a poupança agregada menos o endividamento externo) fornecida pela acumulação produtiva em aumento.

Tabela 10. Estados Unidos. Poupança bruta total, poupança das famílias, e saldo em conta corrente. 1993-1996. Em bilhões de dólares.

\begin{tabular}{|c|c|c|c|c|c|}
\hline (1) & (2) & (3) & (4) & (5) & (6) \\
\hline Trimestres & Poupança Agregada Bruta & $\begin{array}{l}\text { Empréstimos } \\
\text { externos } \\
\text { líquidos }\end{array}$ & $\begin{array}{c}\text { Poupança } \\
\text { agregada } \\
\text { menos } \\
\text { empréstimos } \\
\text { líquidos } \\
\text { (doméstica) }\end{array}$ & Poupança das Famílias & $\begin{array}{l}\text { Saldo em Conta de } \\
\text { Conta Corrente }\end{array}$ \\
\hline (1) & (2) & & & (3) & (4) \\
\hline 1990/I & 929.7 & -79.5 & 850.2 & 292.6 & -79.4 \\
\hline II & 963.1 & -69.5 & 893.6 & 307.2 & -70.2 \\
\hline III & 935.0 & -80.4 & 854.6 & 297.8 & -81.1 \\
\hline IV & 934.0 & -77.0 & 857.0 & 300 & -49.5 \\
\hline 1991/I & 1017.2 & 52.9 & 1070.1 & 320.4 & 56.7 \\
\hline II & 954.6 & 18.3 & 972.9 & 317.7 & 18.0 \\
\hline III & 932.1 & -25.3 & 906.8 & 313.7 & -10.2 \\
\hline IV & 952.5 & -10.0 & 942.5 & 344.7 & -10.7 \\
\hline $1992 / \mathrm{I}$ & 959.0 & -11.2 & 947.8 & 359.4 & -10.7 \\
\hline II & 971.1 & -35.3 & 935.8 & 373.8 & -34.6 \\
\hline III & 942.3 & -42.4 & 899.9 & 350.1 & -41.9 \\
\hline IV & 920.5 & -60.9 & 859.6 & 380.9 & -60.5 \\
\hline 1993/I & 954.2 & -46.9 & 907.3 & 272.4 & -43.9 \\
\hline II & 970.8 & -68.8 & 902.0 & 304.3 & -68.2 \\
\hline III & 943.5 & -71.6 & 871.9 & 264.5 & -70.7 \\
\hline IV & 981.3 & -99.5 & 881.8 & 295.1 & -98.8 \\
\hline 1994/I & 1040.4 & -80.1 & 960.3 & 203.3 & -79.5 \\
\hline II & 1064.1 & -106.1 & 958.0 & 258.8 & -102.1 \\
\hline III & 1070.7 & -114.8 & 955.9 & 256.3 & -113.2 \\
\hline IV & 1107.7 & -126.7 & 981.0 & 279.4 & -126.1 \\
\hline 1995/I & 1166.1 & -101.4 & 1064.7 & 302.9 & -100.7 \\
\hline II & 1161.3 & -107.3 & 1054.0 & 253 & -107.1 \\
\hline III & 1187.1 & -89.5 & 1097.6 & 230.3 & -86.9 \\
\hline IV & 1223.7 & -69.6 & 1154.1 & 217.6 & -69.3 \\
\hline 1996/I & 1238.9 & -84.0 & 1154.9 & 236.5 & -83.3 \\
\hline II & 1273.8 & -98.4 & 1175.4 & 223 & -97.8 \\
\hline III & 1308.3 & -123.1 & 1185.2 & 234.9 & -122.4 \\
\hline IV & 1346.3 & -98.4 & 1247.9 & 219.2 & -97.8 \\
\hline
\end{tabular}

Fonte: NIPA-BEA. Para poupança bruta e das famílias, ver Seção 1, Saving and Investment, Tabela 5.1, Saving and Investment; para saldo em conta corrente, ver a tabela "U.S. International Transactions Accounts Data" disponível no endereço do BEA. Para empréstimos líquidos externos, ver Seção 4, Foreign Transactions, Tabela 4, Foreign Transactions in the National Income and Product Accounts, linha 30, Net lending or borrowing. (O sinal negative implica em aumento do endividamento externo.) 
Num nível mais abrangente, deu-se uma desproporção entre a dimensão da formação da poupança agregada pelo setor responsável pela acumulação produtiva, face às necessidades do produto como um todo, dentro do padrão de crescimento vigente.

Acima estão dispostos a poupança agregada total, a poupança doméstica (com exceção do endividamento externo), a poupança das famílias, os saldos em conta corrente do balanço de pagamentos. A necessidade do endividamento externo pode ser percebida pela contraposição do aumento da poupança doméstica (coluna 6) com o comportamento dos outros agregados. Por um lado, a poupança doméstica, dada pela poupança agregada sem o endividamento externo, depois da queda absoluta até meados de 1992, somou crescimento de aproximadamente 388 bilhões entre o quarto trimestre de 1992 e o último de 1996. Mas como se comportaram os outros agregados?

Quanto às importações totais de bens e serviços, apesar de o dólar ter apresentado contínua desvalorização desde o período face ao iene e marco, os saldos negativos em conta corrente do balanço de pagamentos elevaram-se bruscamente, à medida que a economia apresentava bom crescimento. Do ponto mais alto da série de resultados comerciais, o (efêmero) saldo positivo de 18 bilhões, até o ponto mais baixo dela, de 126 bilhões, tem-se crescimento aproximado de 108 bilhões. Isto expressava a contínua queda do poder exportador da economia, principalmente em bens finais, mesmo face às mudanças da base tecnológica. Restariam 280 bilhões aproximados de poupança doméstica. Pois bem: a poupança das famílias caiu 163 bilhões, no mesmo intervalo (1992/IV - 1996IV), deixando à poupança doméstica (sem endividamento externo) uns 117 bilhões. Se o déficit do orçamento federal apresentou declínio de aproximadamente 200 bilhões no mesmo momento, ao passo que o governo elevou a emissão de títulos externos que somou a captação de aproximadamente 500 bilhões como modo de permitir o ajuste doméstico, pode-se entender facilmente como o crescimento do período não eliminou a dívida externa. ${ }^{240}$ Neste caso, a poupança do governo foi suprida desde fora.

Vê-se com isto que não foram apenas o ajuste do orçamento, juntamente com a queda da taxa de poupança das famílias, os únicos elementos responsáveis pela anulação dos efeitos do aumento da acumulação produtiva. Diferentemente da segunda administração Reagan, além de o governo ter ajustado suas contas mediante o estratagema, as exportações não cresceram mais rapidamente que as importações, e a taxa de poupança das famílias despencou ainda mais rapidamente, o que pôs um peso adicional na necessidade de importar capital e assim aumentar o endividamento. $\mathrm{O}$ endividamento externo aumentou com o crescimento, o que indica que a nova economia não estava levando a uma situação nova, em termos qualitativos, na relação do investimento e do consumo sobre a poupança. Isto implica dizer que o aumento da acumulação produtiva não foi suficiente para que o modelo de crescimento baseado no padrão "dólar-dólar" desse lugar a um outro no qual se prescindisse do crescimento da taxa de endividamento

\footnotetext{
${ }^{240}$ Em termos exatos, a porcentagem da arrecadação doméstica coberta pela emissão de títulos ao exterior saiu de $57 \%$ para chegar a $80 \%$. Estes dados podem ser vistos na tabela sobre a estrutura da dívida acima.
} 
externo. O aumento dos gastos das famílias e das importações, e o esforço do governo federal em diminuir o déficit, cancelaram o aumento da poupança doméstica necessária para diminuir o endividamento externo. $\mathrm{O}$ endividamento externo aumentou mesmo diante de um crescimento dos setores responsáveis pela acumulação produtiva. Os investimentos produtivos e as exportações teriam de ter crescido a uma taxa muito mais veloz para eliminar a dívida externa. Seu desempenho mostrava como as dificuldades que conduziram a economia à dívida externa na década anterior ainda estavam presentes.

Tabela 11. Estados Unidos. Consumo das famílias, poupança agregada nacional, investimentos privados não-residenciais e ativos estrangeiros nos Estados Unidos. 1993-1996. Em bilhões de dólares correntes.

\begin{tabular}{|c|c|c|c|c|c|c|}
\hline (1) & (2) & (3) & (4) & (5) & (6) & (7) \\
\hline Trimestres & $\begin{array}{l}\text { Consumo } \\
\text { das famílias }\end{array}$ & $\begin{array}{c}\text { Poupança } \\
\text { Agregada } \\
\text { nacional }\end{array}$ & $\begin{array}{c}\text { Investimentos } \\
\text { privados não- } \\
\text { residenciais }\end{array}$ & $\begin{array}{c}\text { Consumo/ } \\
\text { Investimentos } \\
(1 / 2)\end{array}$ & $\begin{array}{c}\text { Ativos } \\
\text { estrangeiros } \\
\text { nos EUA }\end{array}$ & $\begin{array}{c}\text { Ativos } \\
\text { estrangeiros } \\
\text { nos EUA/taxa } \\
\text { de } \\
\text { investimentos } \\
\text { privados não- } \\
\text { residenciais }\end{array}$ \\
\hline 1993/I & 4367 & 982.2 & 580.5 & 7,50 & 19.8 & 0,03 \\
\hline II & 4424 & 955.1 & 598.8 & 7,30 & 51.2 & 0,08 \\
\hline III & 4481 & 964.3 & 606.4 & 7,30 & 77.2 & 0,12 \\
\hline IV & 4543 & 956.2 & 630.6 & 7,40 & 99.4 & 0,15 \\
\hline 1994/I & 4599 & 1014 & 634.6 & 7,25 & 80.3 & 0,12 \\
\hline II & 4665 & 996 & 652.9 & 7,15 & 46.5 & 0,07 \\
\hline III & 4734 & 1001 & 667.4 & 7,09 & 79.7 & 0,11 \\
\hline IV & 4796 & 1012 & 687.5 & 6,98 & 84.7 & 0,12 \\
\hline $1995 / \mathrm{I}$ & 4836 & 1078 & 713.6 & 6,78 & 97.6 & 0,13 \\
\hline II & 4871 & 1064 & 728.1 & 6,69 & 122.7 & 0,16 \\
\hline III & 4934 & 1098 & 729.5 & 6,76 & 125.8 & 0,17 \\
\hline IV & 4990 & 1130 & 739.5 & 6,75 & 105.0 & 0,14 \\
\hline 1996/I & 5105 & 1119 & 759.1 & 6,72 & 88.2 & 0,11 \\
\hline II & 5189 & 1106 & 774.8 & 6,70 & 106.1 & 0,13 \\
\hline III & 5227 & 1145 & 801.1 & 6,52 & 158.6 & 0,19 \\
\hline IV & 5308 & 1131 & 816.8 & 6,50 & 194.5 & 0,23 \\
\hline
\end{tabular}

Fonte: Economic Report of the President, 1996 e 1998. Para consumo e investimentos, ver tabela B-1, Gross Domestic Product, 1959-98; para poupança agregada, ver Tabela B-32, Gross Saving and Investment, 1959-98; para ativos estrangeiros, tabela B-107, "International investment position of the United States at yearend, 1989-97'.

Com efeito, mesmo depois de levar-se em conta o aumento da lucratividade e das inversões produtivas, a comparação entre o aumento dos investimentos domésticos em capital fixo não-residencial e o aumento do endividamento externo (aqui em base trimestral) não deixa de ser surpreendente. Isto mesmo para os critérios adotados neste trabalho. Para o período 19931996, a atração de recursos externos pela economia norte-americana cresceu quase dez vezes 
(9,8 vezes), ao passo que os investimentos privados apenas 1,4 vezes. É um resultado muito significativo para ser ignorado. ${ }^{241}$

A tabela acima traz (i) o consumo das famílias, (ii) os investimentos privados nãoresidenciais e a relação entre eles, e (iii) os recursos estrangeiros entregues aos Estados Unidos, em base trimestral. Percebe-se que, durante a expansão destes quatro anos, o componente do consumo caiu com relação aos investimentos, indicando o desvio de uma maior parte da renda nacional para a acumulação, o que traduz a própria atratividade dos investimentos reais. A relação consumo das famílias/investimentos em capital fixo apresentou queda constante, que saiu de 7,50 no início de 1993 para chegar a 6,5 em 1996. Por outro lado, a relação entre os ativos estrangeiros entregues aos Estados Unidos e a taxa de investimento tem um comportamento ascendente, indo de 0,12-13, em média no início do período, para 0,23 no fim dele.

(e) Os resultados do NAFTA e a continuidade da exportação de capital produtivo

O papel oficial do NAFTA era aumentar o comércio na América do Norte, mas evidentemente sob auspícios norte-americanos. A manutenção, ou mesmo aumento das exportações da economia norte-americana às duas áreas, não podia ser desconsiderada como um dos objetivos do Tratado. Rigorosamente, o comportamento da balança comercial é elemento decisivo, junto da acumulação local, para uma estabilização dos níveis de endividamento externo. Todavia, o modelo de crescimento baseado no padrão dólar-dólar submeteu o delineamento geral dos resultados, de modo que as importações cresceram muito mais rapidamente para os Estados Unidos. As exportações ao México dos Estados Unidos cresceram 1,44 vezes, ao passo que as importações vindas do país latino cresceram 1,78 vezes entre $1994 \mathrm{e}$ 1998. No mesmo período, as importações vindas do Canadá cresceram 1,77 vezes, ao passo que as exportações ao Canadá 1,33 vezes.

Abaixo se pode ver como o resultado líquido de exportações de bens e serviços ao México e ao Canadá inverteu-se nos anos subseqüentes ao início do NAFTA, e, em menor medida, com o resto da América Latina. Isto é, o acordo teve como um resultado final um aumento das importações líquidas dos Estados Unidos para com estas duas áreas, e não, justamente, um aumento das exportações líquidas norte-americanas. O modelo de crescimento norte-americano levava o NAFTA a privilegiar custos de importação menores e aumento das exportações de bens de capital - impactando positivamente na inflação doméstica e mantendo o desnível qualitativo da economia face ao México, principalmente - mas não conduzia a um

\footnotetext{
${ }^{241}$ Para uma análise laudatória e otimista, conferir por exemplo os artigos "Um desastre esperando por acontecer ou uma economia invejável?" e "A economia americana continua surpreendendo", de João Marcus Marinho Nunes em $O$ vôo da águia. O autor, por exemplo, reiterou seguidamente que não havia bolha no mercado acionário.
} 
superávit comercial consolidado. ${ }^{242} \mathrm{Na}$ ausência do papel dominante do dólar, que permitia um aumento do endividamento externo e a manutenção dos déficits comerciais, não teria havido um desempenho tão desfavorável, do ponto de vista do cômputo global das exportações norteamericanas. Os déficits comerciais teriam que ser diminuídos, vis à vis uma queda dos saldos em conta de capital, a troco de uma crise cambial. Em suma: os resultados do NAFTA nos anos que se seguiram foram expressão de uma condição mais geral dentro do qual se inseria o comércio exterior dos Estados Unidos dentro da situação de endividamento externo. Eles culminaram em favorecer uma inflação baixa e as empresas norte-americanas no México. Por isso os Estados Unidos se preocuparam em estimular processos de abertura comercial sem que houvesse uma contrapartida direta da abertura do mercado norte-americano, nestes anos (19)90. A sempre intransigente postura dos negociadores norte-americanos nas Rodadas do Gatt mostrava que a posição face ao Canadá e ao México não podia ser sempre a regra.

Gráfico 9. Estados Unidos. Saldos líquidos em transações de bens e serviços com Canadá, México e outros países da América Latina. Em milhões de dólares correntes.

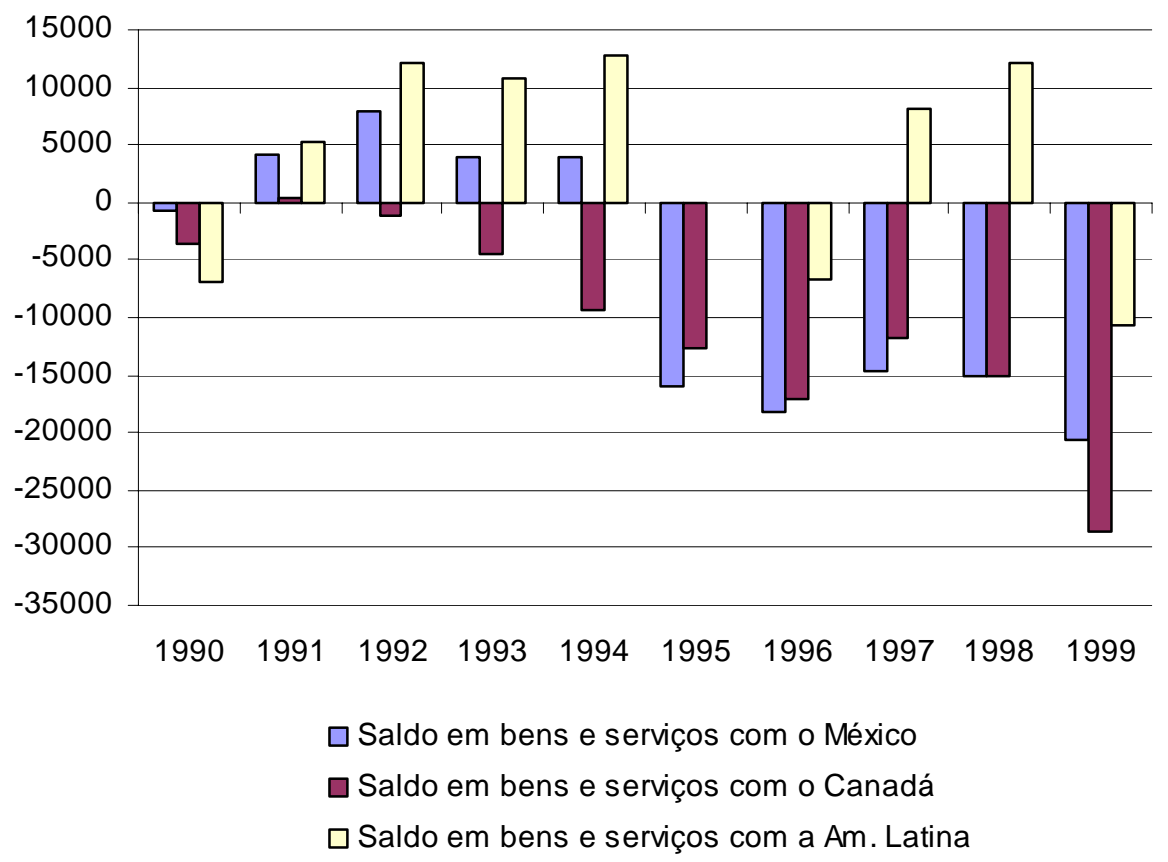

Fonte: NIPA-BEA. Estes dados bilaterais podem ser acessados no endereço do BEA, na Seção International Transactions Accounts Data, Detailed Estimates. ${ }^{243}$

\footnotetext{
${ }^{242}$ Enrique Rajchenberg observou no verbete "México" da Enciclopédia Contemporânea da América Latina e do Caribe, à página 775: "Ao término do século XX, 90\% das exportações mexicanas eram dirigidas para [os Estados Unidos], quando em 1982 os Estados Unidos representavam 50\% dos intercâmbios comerciais. De maneira repentina [depois do NAFTA], a indústria mexicana, habituada ao protecionismo alfandegário, enfrentou a competitividade de mercadorias estrangeiras de igual ou menor preço, e, em algumas ocasiões, de melhor qualidade e com o prestígio de uma marca desejada por certas faixas do mercado. Os elos produtivos foram rompidos e a indústria de bens de capital, certamente pequena, foi varrida. A indústria de montagem ou maquiladora, cujas exportações representavam quase a metade do total, adquiria 3\% apenas de seus insumos no mercado nacional, enquanto $42 \%$ das exportações não maquiladas continham $30 \%$ de conteúdo nacional, incluindo o salário pago aos trabalhadores."

${ }^{243}$ Conferir (http://www.bea.gov/international/index.htm /).
} 
Por outro lado, mesmo com crescimento dos anos (19)90, que expressava ganhos relativos maiores para a produção, e aumento dos investimentos produtivos externos nos Estados Unidos, a relação geral entre a exportação e a importação de capital produtivo mantevese, a favor da primeira. Os IED's aqui envolvem investimentos em ampliação da capacidade e compras de ativos produtivos, separados da compra de ações e títulos corporativos no exterior, que têm uma seção específica na tabela fornecida pelo Economic Report, chamada especificamente de compras de bonds e stocks. ${ }^{244}$ Aqueles que saem dos Estados Unidos pertencentes a companhias norte-americanas, fundamentalmente - são maiores do que os que o país atrai, fato que perfaz a expressão mais direta de que os investimentos produtivos no país ainda eram menos favoráveis, em termos relativos, do que os investimentos em ampliação da capacidade no exterior. Como se vê no gráfico 9, os Estados Unidos continuaram exportadores líquidos de capital produtivo para áreas onde tais investimentos encontravam taxas de lucro maiores durante a década de (19)90.

Gráfico 10. Estados Unidos. Fluxos de Investimento Estrangeiro Direto. 1989-1997. Em bilhões de dólares correntes.

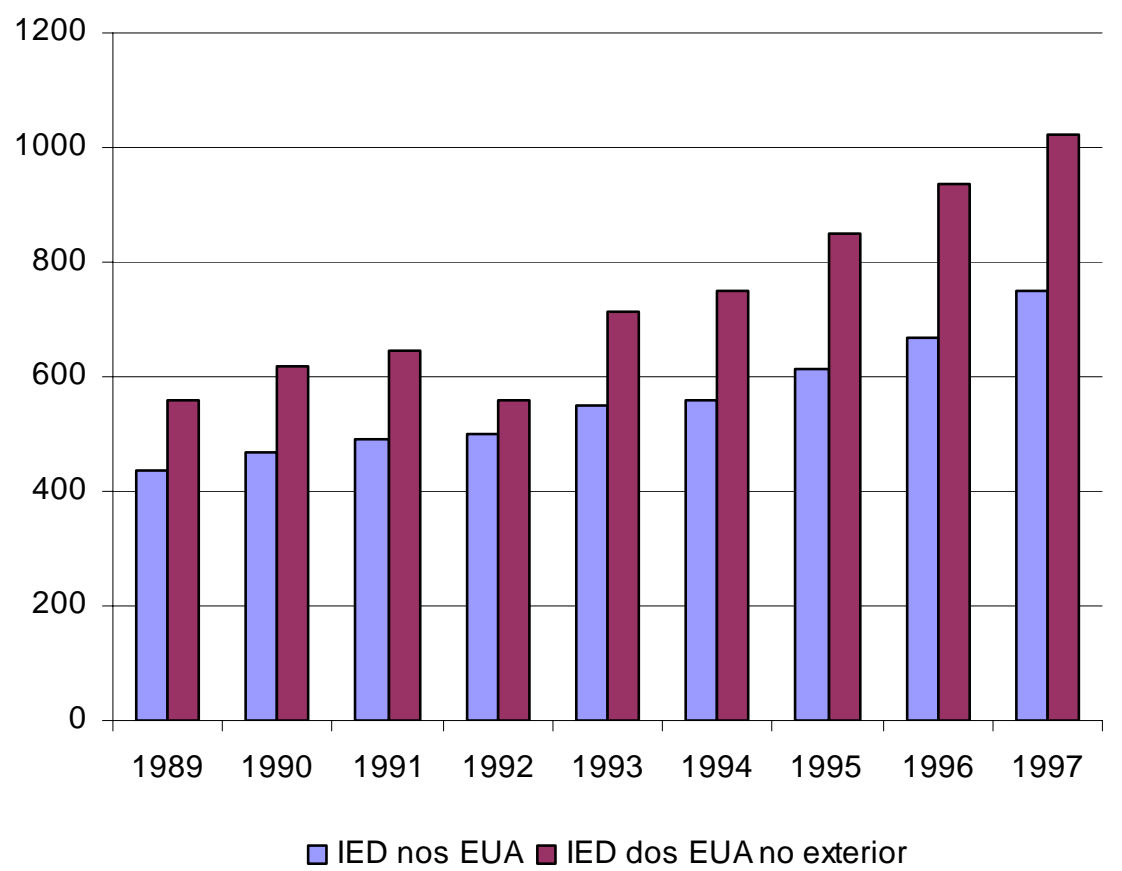

Fonte: ver a tabela "U.S. International Transactions Accounts Data" disponível no endereço do BEA.

De fato, é verdade, como escreveram Duménil e Lévy, que "foram, simultaneamente, o aumento excepcional do fluxo de investimento direto proveniente do exterior e o recurso ampliado ao endividamento que deram ao boom sua amplitude e sua duração". ${ }^{245}$ Dado que o aumento da taxa de lucro nos Estados Unidos foi maior que no Japão e Alemanha no mesmo

\footnotetext{
${ }^{244}$ Esta tabela é intitulada "International Investment Position of United States, end od year", no Apêndice Estatístico.

${ }^{245}$ DUMÉNIL, Gerard, e LÉVY, Dominique. O neoliberalismo sob a hegemonia norte-americana. In: CHESNAIS, François (org.) A finança mundializada, p.99.
} 
período, ${ }^{246}$ houve, tal como se vê na tabela abaixo, uma maior atração de investimento direto pelos Estados Unidos em relação a Japão e Alemanha, do que o oposto. Porém, fora da área das economias mais industrializadas, a taxa de lucro permaneceu mais alta que nos Estados Unidos, o que conduziu à exportação líquida de capital para estas áreas e em termos globais, tal como deixa ver o gráfico acima e a tabela com dados desagregados abaixo, para China, Índia e México.

Vejam-se os dados da tabela a seguir, cujas séries se estendem de fato até 2008 (bem depois do fim da primeira administração Clinton, portanto). Analise-se o caso de cada país por separado, começando-se pelo México.

Tabela 12. Estados Unidos. Investimento Estrangeiro Direto com países selecionados. Em milhões de dólares.

\begin{tabular}{|c|c|c|c|c|c|c|c|c|c|c|}
\hline \multicolumn{11}{|c|}{ Estados Unidos: remessas e recebimentos de investimento direto } \\
\hline \multirow{3}{*}{ (1) } & \multicolumn{5}{|c|}{ IED dos EUA no exterior } & \multicolumn{5}{|c|}{ IED do exterior nos EUA } \\
\hline & (2) & (3) & (4) & $(5)$ & (6) & (5) & (6) & $(7)$ & (8) & (9) \\
\hline & México & China & Índia & Japão & Alemanha & México & China & Índia & Japão & Alemanha \\
\hline 1986 & -340 & - & - & -464 & -1203 & 322 & - & - & 7031 & 2186 \\
\hline 1987 & -393 & - & - & -1222 & -805 & 22 & - & - & 8806 & 4591 \\
\hline 1988 & -750 & - & - & -1114 & -1882 & 38 & - & - & 17205 & 2245 \\
\hline 1989 & -1652 & - & - & -299 & -2522 & 107 & - & - & 18653 & 3738 \\
\hline 1990 & -1926 & - & - & -984 & -1626 & 224 & - & - & 18754 & 585 \\
\hline 1991 & -2321 & - & - & -203 & -4831 & 167 & - & - & 12782 & 2160 \\
\hline 1992 & -1320 & - & - & -683 & -1754 & 647 & - & - & 4245 & 1307 \\
\hline 1993 & -2516 & - & - & -1625 & -4622 & 110 & - & - & 2949 & 7802 \\
\hline 1994 & -4457 & - & - & -1867 & -2863 & 1058 & - & - & 5487 & 6116 \\
\hline 1995 & -2983 & - & - & -2335 & -3349 & 263 & - & - & 8118 & 7908 \\
\hline 1996 & -2405 & - & - & -281 & -1956 & 47 & - & - & 13338 & 19616 \\
\hline 1997 & -5596 & - & - & -339 & -2464 & 331 & - & - & 10186 & 11110 \\
\hline 1998 & -4593 & - & - & -6428 & -3051 & 871 & - & - & 8024 & 42986 \\
\hline 1999 & -8164 & -1946 & -270 & -10605 & -5657 & 1273 & 39 & 14 & 11555 & 23479 \\
\hline 2000 & -4203 & -1817 & -92 & -4295 & -3811 & 5062 & 7 & 6 & 7816 & 14053 \\
\hline 2001 & -14226 & -1911 & -214 & -4732 & -11823 & 716 & 246 & 162 & 7816 & 40206 \\
\hline 2002 & -7656 & -875 & -919 & -8710 & -2416 & 2349 & 121 & 16 & 3131 & 1989 \\
\hline 2003 & -3664 & -1273 & -355 & -867 & -4376 & 2173 & 61 & 125 & 6499 & 12281 \\
\hline 2004 & -8435 & -4499 & -1138 & -12787 & -9073 & 629 & 150 & 277 & 8543 & 7079 \\
\hline 2005 & -9596 & -1955 & -721 & -5940 & -7978 & 19 & 146 & 868 & 17489 & 12101 \\
\hline 2006 & -8777 & -3920 & -1815 & -10115 & -5361 & 1886 & 347 & 443 & 14200 & 40419 \\
\hline 2007 & -8815 & -5710 & -3726 & -15586 & -8291 & 63 & 123 & 1523 & 15668 & 5316 \\
\hline 2008 & -7499 & -16289 & -2423 & -4218 & -7098 & 2200 & 362 & 1943 & 28775 & 1881 \\
\hline
\end{tabular}

Fonte: NIPA-BEA. Estes dados bilaterais podem ser acessados no endereço do BEA, na Seção International Transactions Accounts Data, Detailed Estimates. ${ }^{247}$

\footnotetext{
${ }^{246}$ Ver também Brenner (O boom e a bolha) e Chris Harman, "The rate of profit and the world today", no em International Socialism, A quarterly journal of socialist theory. $\mathrm{O}$ endereço é: http://www.isj.org.uk/?id=340.

${ }^{247}$ Conferir (http://www.bea.gov/international/index.htm /.)
} 
O fluxo de investimentos diretos norte-americanos ao México (coluna 2) é crescente desde o fim da década de (19)80. Ele avançou sem interrupção em sua tendência até 2001, aproximadamente. A crise eleva o nível de incertezas e o fluxo cai, a partir de então. A partir daí, o fluxo de investimento estrangeiro no México a partir dos Estados Unidos se estabilizou num patamar mais ou menos grande. Por outro lado, o nível de investimento produtivo do México aos Estados Unidos (5) foi muito menor, durante todo o período assinalado pelo gráfico, e permanece sempre no mesmo patamar, em tendência assinalada. Constitui o México um dos casos clássicos onde a taxa de lucro é maior mas o desenvolvimento não se obtém pela presença dos conhecidos entraves estruturais.

Quanto à China, o BEA não fornece dados setoriais para o país para o período anterior a 1999, no que tange ao investimento direto. Uma análise dentro do recorte deste capítulo (1993-96) se vê difícil, assim. Mas se pode notar que desde os anos (19)90 a exportação de capital à China foi muito maior do que o movimento oposto. Para o período posterior a 1999, o contraste entre as exportações de capital dos Estados Unidos e as chinesas tornou-se ainda mais evidente. Assim, desde 1999, a China exportou pouquíssimo capital produtivo aos Estados Unidos, ao passo que o movimento inverso foi crescente, em escala rápida. Só entre 2000 e 2008 o movimento de colocação de empresas norte-americanas no país oriental cresceu quase 9 vezes $(8,9$ vezes $)$.

As colunas referentes à Índia (4 e 7) deixam ver um movimento um pouco diferente. A saída de capitais dos Estados Unidos superaram, a partir de 1999, do mesmo modo que para com os outros países, as entradas. Realmente o recebimento de capitais pela Índia nunca ultrapassou em montante as saídas para os Estados Unidos. Mas a partir de 2004 as exportações de capital da Índia aos Estados Unidos iniciaram um crescimento, não visto para China. Está fora do escopo deste trabalho analisar em que setores na economia norte-americana estes investimentos têm se dado. Provavelmente se localizaram na área de produção da microeletrônica, onde algumas firmas indianas atuam com certo pioneirismo. Isto mostra, de todo modo, que a força do movimento acumulador indiano é bem menor que a da China. Vale para a Índia, então, o que se disse sobre o México. A taxa de lucro maior do que a norteamericana se viu e se vê bloqueada em suas potencialidades por outros impedimentos estruturais, no âmbito doméstico. Daí o investimento fora do país.

Caso oposto se dá entre as economias desenvolvidas. A comparação dos movimentos acima assinalados para Japão e Alemanha deixa ver que, em termos gerais, ambos os países caracterizaram por uma exportação de capitais aos Estados Unidos bem superior ao que os Estados Unidos exportam a ambos. Mas há nuances importantes.

Quanto ao Japão: o nível de investimento nos Estados Unidos no fim da década de (19)80 era alto, muito maior do que o movimento oposto. A crise de 1991-92 nos Estados Unidos desestimulou a continuidade, com a contração no mercado norte-americano. Após a crise, e durante o boom dos (19)90, a exportação de capital japonês aumentou de novo. Isto refletia as menores oportunidades de inversão doméstica do que em comparação com as norte- 
americanas. A exportação de capital dos Estados Unidos ao Japão no período todo foi estável, num patamar baixo, de aproximadamente 2,3 bilhões de dólares anuais. A crise de 2001 nos Estados Unidos fez o fluxo de IED japonês cair, e estimulou o movimento oposto. Após a crise, e durante a nova expansão dos anos 2000, prevaleceu a regra de um maior movimento exportador a partir do Japão. Apesar disto, cresceram as colocações norte-americanas no país asiático desde 2002.

Por fim, para a Alemanha o contraste é maior: durante a expansão norte-americana nos (19)90, foi enorme a exportação de capital produtivo alemão para os Estados Unidos. O movimento oposto (Estados Unidos para Alemanha) foi muito menor, e num patamar estagnado; ficou em 3 bilhões, aproximadamente, até 2000. A colocação de capital alemão nos Estados Unidos caiu depois de 2001, data depois da qual se inicia nova ascensão. A exportação de capital norte-americana para a Alemanha cresceu um pouco depois de 2000, mas foi muito menor.

Portanto, se México, Índia e China receberam todos muito mais capital produtivo do que exportaram aos Estados Unidos, pode-se dizer que de modo geral a taxa de lucro em seus setores industriais cresceu mais do que nos Estados Unidos. Mesmo diante do boom, a exportação de capital produtivo dos Estados Unidos foi maior do que sua importação de capital produtivo, para as nações periféricas. Dentro deste contexto, é interessante explicitar um elemento crucial: para este desempenho relativamente menos atrativo dos investimentos em capital fixo nos Estados Unidos face às economias periféricas, durante o período, contribuiu também a rodada de privatizações dos países periféricos. Quando da abertura dos mercados da maior parte dos países cujas elites aceitaram o discurso da "globalização", os ativos produtivos que os grupos norte-americanos compraram estavam em geral muito sub-valorizados, tornando muitos deles mais lucrativos do que os ativos presentes nos próprios Estados Unidos. Empresas com enormes relações de capital/trabalho, em todos os países de mercados abertos durante aquele período de "globalização" - principalmente América Latina e Europa Oriental -, foram adquiridas a preços muito atrativos para compensar tal relação desfavorável. Isto contribuiu ainda mais para a migração de capital dos Estados Unidos para tais regiões. Muitas destas regiões, como no Leste Europeu, eram dotadas de mão-de-obra muito preparada. Isto elevava ainda mais a atratividade de tais inversões externas e os desfavorecimentos relativos aos investimentos domésticos norte-americanos. Mas tal migração de capital era, ressalte-se de novo, formada por capital produtivo, cuja aplicação doméstica não era tão lucrativa como a feita nestes países. Tratava-se então de uma maneira de as autoridades compensarem a necessidade de os Estados Unidos obterem dinheiro internacional pelo aumento dos ativos do país no exterior. Além, é claro, de ocupar o antigo reduto do socialismo mundial.

O movimento oposto se deu com Alemanha e Japão. Os Estados Unidos continuaram oferecendo oportunidades produtivas mais lucrativas, e seguiram importando mais capital produtivo. De fato, há problemas específicos a Japão e Alemanha, no que se refere à política econômica, à proteção aos trabalhadores, dentre outros fatores que influem sobre os diferenciais 
de taxa de lucro nos setores produtivos face aos Estados Unidos. Porém, não se pode negar que foram globais os impactos da crise da lucratividade dos (19)70, e as decorrências das transformações produtivas via aplicação da microeletrônica. Os movimentos de capitais entre os três países são e sempre foram abertos. Isto favoreceria a formação de uma taxa de lucro mais ou menos uniforme entre as três potências. Mas isto foi modificado devido à posição dos Estados Unidos no sistema financeiro internacional. O endividamento externo contribuiu para contornar a assinalada tendência à equalização da taxa de lucros, permitindo um desempenho superior nos Estados Unidos, dentre os países desenvolvidos.

O relato de James Kynge sobre a situação da Boeing em meados de 2006 é elucidativo de uma situação geral:

"A Boeing tinha calculado que poderia economizar muito dinheiro mandando algumas de suas funções de fabricação para a China e outros países de baixo custo. Ela precisava fazer isto para maximizar os ganhos de seus acionistas. Mas, ao fazêlo, ameaçava acabar com os negócios de muitos de seus fornecedores pequenos, de muito tempo [...]. O processo era um ciclo vicioso. Quanto mais a Boeing terceirizava, mais rapidamente as companhias de máquinas operatrizes que a supriam iam à falência, dando oportunidade aos concorrentes chineses para que eles comprassem a tecnologia que precisavam para aprimorar seus fornecimentos para companhias como a Boeing." 248

\subsection{A permanência das dificuldades}

O aumento da acumulação produtiva não levou então à queda do endividamento externo nos Estados Unidos. Mostrou-se difícil reverter o comportamento das outras variáveis que compõem o tipo de crescimento atual, principalmente os déficits comerciais e fiscal, e a taxa decrescente de poupança das famílias. Revertida temporariamente a situação fiscal do governo federal, o aumento da renda agregada conduziu a um aumento das importações - principalmente mediante o recém criado NAFTA - e de rebaixamento ainda maior de gastos das famílias. Tal expressava a incapacidade da recuperação do setor industrial para compatibilizar-se com o tipo de crescimento que nascera alguns anos antes, com vistas justamente a compensar sua própria queda.

Isto porque o crescimento da acumulação produtiva e das exportações do período não foram suficientes para diminuir os níveis de endividamento externo. Durante todos os quatro anos, o aumento líquido do endividamento externo para todos agentes indicou a continuidade dos limites relativos aos investimentos privados e do setor exportador em conduzir a um tipo de crescimento que prescindisse dos empréstimos externos. Assim, mesmo durante o início do boom, e na verdade durante toda a década e até o presente momento (2009), o aumento do

${ }^{248}$ A China sacode o mundo, p.152. 
endividamento externo será a contrapartida do crescimento das inversões, a ponto de não se poder separar exatamente o crescimento de tal taxa da própria atração contínua de recursos do exterior.

Assim, diante do comportamento das outras "variáveis" que compuseram o padrão de crescimento norte-americano neste momento - a saber, (1) a exigência de um volume de consumo ascendente das famílias como elemento necessário à utilização da capacidade instalada; (2) a presença consolidada dos déficits no comércio exterior; e (3) o ajuste das contas do governo federal - o aumento da acumulação produtiva baseado numa maior lucratividade propiciada pelas tecnologias da informação não foi suficiente para que, vista de um modo agregado, a economia pudesse diminuir a dependência dos empréstimos do exterior para financiar parte de seus gastos. Os lucros cresceram, e com eles a poupança nacional. Mas a maior parte desta poupança agregada adicional foi cancelada pela continuidade dos gastos das famílias, pelo aumento das importações e pela captação adicional de recursos no exterior pelo governo federal, como parte da política de cancelamento dos déficits. Neste caso último, o governo só conseguiu impedir o seu processo de despoupança sem aumentar numa mesma proporção os tributos locais mediante a enxurrada de dinheiro vindo de uma economia mundial que agora via os Estados Unidos como o porto mais seguro do mundo, seja pelos resultados do boom seja pelo fim da guerra fria. Em suma: o volume agregado de investimento, de consumo das famílias e os ajuste das contas do governo federal foram maior do que poderiam ser, na ausência de crescentes superávits na conta de capitais.

Consoante as hipóteses adotadas no início deste trabalho, poder-se-ia notar, em segundo lugar, que a dependência norte-americana dos maciços gastos deficitários e do complexo industrial-militar apenas diminuiu quando um ciclo assentado primordialmente no aumento da taxa de lucro das inversões privadas passou a conduzir a economia a um patamar superior de produção e emprego - e tais momentos, como se está acompanhando para a história recente dos Estados Unidos, não tinham sido mais comuns a partir da década de (19)70 - momento depois do qual o sistema entra num período de retomada das inversões militares. E, para corroborar como o complexo industrial-militar faz parte da natureza das regras do jogo, a guerra voltaria a ocupar o centro da política norte-americana quando o boom se desfizesse em bolha, depois de 2001. O período democrata seria assim uma exceção dentro das condições de permanência da estagnação e da guerra como motor do crescimento, de novo em cena após 2001.

Nos Economic Reports, as autoridades oficiais afirmavam que a economia norteamericana podia facilmente se ajustar à economia civil, e que este ajuste estava sendo feito desde o pós-1945. O argumento era baseado numa perspectiva de longo prazo. Afirmava-se que desde o pós-Segunda Guerra Mundial (1945) a importância do setor de armamentos vinha caindo. Evidentemente, a comparação era espúria, porque o marco comparativo usado no documento fora o período da maior guerra já feita pelos Estados Unidos. Um período de exceção tal como da Segunda Guerra Mundial não era, simplesmente, um referencial válido a partir do qual se medir os investimentos na economia de guerra ao longo dos anos subseqüentes. 
Qualquer período posterior a ela iria aparecer como tendo tido uma queda absoluta e relativa das inversões deste tipo. Mas isso diminuiria a importância e a influência do setor para a economia norte-americana neste tempo transcorrido? É claro que não, porque a Segunda Guerra teria sido, à luz posterior, o ponto mais alto que desencadeou, pela criação do poder do complexo industrial-militar, a necessidade da permanência de muitas guerras locais.

Isto é, a criação do complexo industrial-militar levou à necessidade da guerra como normalidade, que assumia dentro do papel da política econômica o papel de ser um dos elementos contra-cíclicos mais funcionais à disposição do governo. Colocar o problema de acordo com a perspectiva de que "mesmo os aumentos de meados dos anos (19)80 causaram apenas uma pequena e temporária alteração na tendência de queda" ${ }^{249}$ era argumento racionalmente ruinoso, pelo próprio tamanho do orçamento militar norte-americano, maior do que o PIB da maior parte das nações do mundo subdesenvolvido. O desdobramento lógico da perspectiva era, como sempre para o governo norte-americano, "não há chances de uma inversão distinta" do excedente social nos Estados Unidos, e muito menos fora dele. Uma vez terminado o ciclo da tecnologia da informação, os investimentos na economia de guerra voltariam a crescer, revelando uma perenidade que ultrapassou a própria guerra-fria.

As vantagens da hegemonia do dólar no mundo podem então ser listadas como segue: (1) mediante a possibilidade de comportamento deficitário continuado da balança comercial, os preços no mercado doméstico norte-americano puderam ser mantidos baixos, dada a abundante oferta de importados. (2) $\mathrm{O}$ aumento do endividamento externo possibilitou um maior ajuste das contas do governo norte-americano, com queda do déficit e um conseqüente menor pagamento de juros. Isto significa dizer que o volume de consumo das famílias pôde ser mantida devido à menor pressão relativa dos impostos cobrados pelo governo norte-americano. O hiato entre as necessidades de gasto do governo e as receitas cobriu-se pela emissão de títulos ao exterior. (3) O aumento dos depósitos internacionais no sistema financeiro contribuiu para a manutenção de capital farto e baixas taxas de juros, elementos do sistema de financiamento essenciais para a abertura de um ciclo expansivo baseado no teste de novas tecnologias de produção e consumo. Entrementes, as inversões no setor bélico puderam diminuir, com o aumento da acumulação produtiva. Como dito, esta não permitiu uma diminuição dos níveis de endividamento externo devido à incapacidade do setor exportador e das inversões produtivas em conduzir a um crescimento suficiente para atender ao nível efetivo de importações, de necessidades de financiamento do governo federal, e indiretemente de consumo das famílias.

Aí o papel da abertura do comércio exterior de outros países, sem uma contrapartida direta de uma abertura proporcional do mercado norte-americano - isto é, um aumento per se dos mercados exteriores - tinha uma importância grande. Quanto menores os déficits, menor a dependência dos fluxos de recursos externos para fechar transações correntes. Mas o problema do comércio exterior dependia não só da influência dos oligopólios na esfera da política

249 "...even the increases of the early 1980 s made only a small, temporary bump in the downward trend." Economic Report of the President de 1993, p.149. 
econômica. Seus resultados estavam na dependência também - e em primeiro lugar - do tipo de crescimento em voga. Particularmente quanto ao NAFTA, é necessário tecer algumas considerações. Em primeiro lugar, havia uma contradição entre os interesses das corporações no acordo, com seus lobbies na administração Clinton, e a necessidade de a política econômica não permitir que os déficits comerciais aumentassem em demasia. Isto porque os interesses dos oligopólios interessados na queda das barreiras comerciais não eram exatamente os mesmos que supostos interesses "nacionais", inclusive os norte-americanos, ou da política econômica. Muitas corporações no México queriam vender aos Estados Unidos, e elas eram norteamericanas, não se preocupando em primeira instância com o déficit comercial de seu país de origem. Por outro lado, se a continuidade da importação de capital eximia a administração norte-americana de manter saldos comerciais, eles não podiam crescer desmensuradamente. $\mathrm{E}$ uma vez liberado o comércio, esta tendência teria a se agravar, nas condições de contínuo superávit na conta de capitais, marca característica do modelo de crescimento. Em suma: havia uma contradição entre o agravamento dos déficits comerciais e os interesses subjacentes ao NAFTA.

As conseqüências do NAFTA eram diferentes para Canadá e México. Para o Canadá, o NAFTA não implicava alteração fundamental acerca de seu futuro econômico, já que o país tinha uma economia industrial com os mesmos padrões de desenvolvimento que os norteamericanos. Na verdade, a história de seu desenvolvimento industrial se confundia com o dos Estados Unidos. Tratava-se de uma relação mais horizontal: havia muitas empresas norteamericanas em seu território e vice-versa. Mas com o México não era assim. Por mais que o México se tornasse um exportador superavitário aos Estados Unidos, o NAFTA iria reduzi-lo de facto a: (i) uma região econômica de colocação de bens de capital, bens finais e serviços de tipo moderno vindos Estados Unidos; (ii) um vendedor aos Estados Unidos de produtos primários petróleo, principalmente - e produtos fabricados pelas empresas norte-americanas instaladas em seu território, principalmente o do norte. A mão-de-obra não podia imigrar. A uma política de desenvolvimento econômico de nada valia participar do Acordo em tais condições: os superávits comerciais com o parceiro rico do norte eram tão-somente a expressão da dependência. Não havia, porém, forças políticas que pudessem conduzir o país a um outro rumo.

Por conseqüência, o NAFTA obscurecia qualquer anseio de industrialização de veio nacional no México - no limite, qualquer possibilidade de que o México pudesse desenvolver uma economia integrada sobre si mesma. O NAFTA mostrava que as corporações no México interessavam-se primordialmente pelo mercado norte-americano, independentemente do estado do mercado doméstico. Evidentemente, este interesse era subordinado, de um ponto de vista da divisão do trabalho, às condições dominantes das empresas norte-americanas que mais se privilegiariam com o acordo. Abrir o comércio entre uma economia industrial e uma subdesenvolvida resultaria numa situação simples: o México venderia bens primários, ou bens industriais fabricados por enclaves industriais, sem antes ter se desenvolvido sob um modelo de 
privilégio do mercado doméstico. Parecia evidente que se o México não tinha se desenvolvido com seu mercado interno protegido, não iria nunca fazê-lo sob o comércio liberalizado.

Mas um acordo sancionado entre oligopólios não visa a industrialização de um país periférico; realmente, boa parte das empresas que atuava no México era de propriedade norteamericana. Seu volume de vendas iria crescer e os custos na economia norte-americana cairiam, sem que maiores questões fossem postas à mesa. Às empresas mexicanas cujos bens eram similares aos que o México iria passar a importar de modo mais barato restava a sorte de concorrer, com perspectivas ruins. Tais empresas, que no Terceiro Mundo são médias ou pequenas, e amiúde familiares, não tinham, porém, uma base de apoio que pudesse representar seus interesses nas instâncias maiores do poder político, face aos bem armados oligopólios por detrás do acordo. Aumentar-se-ia a desnacionalização, extinguir-se-iam frações da burguesia nacional etc.. Em suma: o México desaparecia como região econômica nacional. Na crise cambial de 1994, resultado da conjunção do programa de abertura comercial com a financeira, teve de ser socorrido com a dinheiro dos próprios Estados Unidos. Era um período triste para a teoria do desenvolvimento. ${ }^{250}$ Tão longe do desenvolvimento, e tão perto dos Estados Unidos, era a marca do aprofundamento da estrutura da dependência, cujo novo rótulo agora era o de "globalização".

Com efeito, e vistos num prazo maior do que os anos da administração Clinton, pode-se notar que a diferença absoluta existente entre os setores produtivos e os improdutivos foi desaparecendo cada vez mais, de um ponto de vista do cômputo dos lucros agregados abocanhados face ao produto nacional. Os setores financeiros cresceram pari passu com os setores produtivos, passando a deter uma parcela dos lucros na renda nacional praticamente idêntica à dos setores produtivos, no fim desta década de expansão. Quando observado de um prazo um pouco maior, tal expansão foi simplesmente uma interrupção conjuntural numa tendência de queda consolidada. "É um exagero dizer que houve um 'apogeu' nesta década. A tendência de crescimento da produção só representou três quartos da velocidade dos anos sessenta", afirmaram corretamente Taylor e Eatwell. ${ }^{251} \mathrm{Na}$ tabela abaixo, a relação dos lucros não-financeiros com os financeiros cresce em meados da década de (19)90 apenas para decrescer de novo, no início do século atual.

Isto marca um flagrante contraste com a década de (19)70, e, em menor medida, com a de (19)80. Mostra, na verdade, um caminho de longo prazo de fortes desestímulos ao investimento produtivo, depois de passados os efeitos expansivos do boom e depois de a bolha estourar. Como chamou atenção Brenner, o "maior crescimento conhecido do pós-guerra", como muitos diziam, na verdade não estava fundado numa recuperação do setor produtivo que tivesse eliminado a tendência à financeirização e à necessidade do endividamento externo. Isto

\footnotetext{
${ }^{250}$ Para uma análise detalhada para os casos de Brasil e Argentina das crises engendradas pelas políticas de abertura ao longo da década, conferir as análises de Luiz Eduardo Simões de Souza em A arquitetura de uma crise: história e política econômica na Argentina, 1989-2002, e de Marcos Cordeiro Pires, em Dependência de importações e a crise da mundialização: crescimento e flutuações da economia brasileira - 1980-2000. Ambas são teses de doutoramento pela Universidade de Paulo (ver bibliografia).

${ }^{251}$ Finanzas globales en riesgo, p. 148.
} 
não significa dizer que tal aumento das oportunidades de colocação de capital produtivo não tivessem existido. Elas existiram, mas a economia continuou assistindo uma ascensão dos ganhos financeiros, o que deixa ver que aquilo o que tinha havido era um ciclo de aumento das inversões produtivas, ciclo que, como tal, teria início, meio e fim.

Tabela 13. Estados Unidos. Lucros corporativos financeiros e não-financeiros, e a relação entre eles. 1964-2004. Em bilhões de dólares.

\begin{tabular}{cccc}
$(1)$ & $(2)$ & $(3)$ & $(4)$ \\
& $\begin{array}{c}\text { Lucros corporativos } \\
\text { Financeiros }\end{array}$ & $\begin{array}{c}\text { Lucros corporativos } \\
\text { não-financeiros }\end{array}$ & $2 / 1$ \\
1964 & 8.8 & 55.4 & 6,2 \\
1969 & 13.6 & 65.3 & 4,8 \\
1973 & 20.5 & 79.9 & 3,8 \\
1978 & 39.5 & 160 & 4,0 \\
1982 & 26 & 132.4 & 5,0 \\
1985 & 45.9 & 173.5 & 3,7 \\
1989 & 77.9 & 222.3 & 2,8 \\
1992 & 129.8 & 255.4 & 1,9 \\
1995 & 162.2 & 401 & 2,4 \\
1998 & 165.9 & 469.6 & 2,8 \\
2000 & 200.2 & 413.4 & 2,0 \\
2001 & 227.6 & 322 & 1,4 \\
2004 & 300.6 & 534.2 & 1,7 \\
\hline
\end{tabular}

Fonte: Economic Report of the President, 2006. Tabela B-91, Corporate profits by industry, 1959-2005.

Não é necessário enfatizar, dadas as outras análises que a literatura já realizou, como a desregulamentação do mercado e a posição do Fed em não levar em conta os constantes avisos de que havia uma bolha no mercado financeiro, levariam à enorme capacidade instalada e às perdas no mercado acionário para 2001. Além disso, teriam contribuído para a atual crise (2009), cujos fundamentos se davam no grau de desregulamentação das finanças. Atualmente (2009), assiste-se à maior taxa de desemprego desde 1982-1983, atingindo 9,5\%. O baixo crescimento, a sucessão de solavancos e a dimensão da dívida externa norte-americana indicam que o outono chegou, com flutuações e recuperações cada vez menores. A posição dominante no mercado mundial tende a cair, para os Estados Unidos, e as bases da hegemonia parecem corroerem-se.

O hiato entre 1993 e 2001 deveria ser encarado mais ou menos como algo similar a alguma flutuação ascendente da economia inglesa em meados da primeira década do século XX. Um tipo de flutuação que não impediria a ultrapassagem pela então veloz economia norteamericana e que não seria suficiente para retirar a Inglaterra do caminho de suas perdas relativas de posição. E muito menos tal período poderia ser visto como um momento de transformações supostamente qualitativas no comportamento de vai-e-vem da economia norte-americana. Vista num prazo um pouco maior do que sete anos, sua importância é pequena, de um ponto de vista do crescimento econômico. É claro que a importância das transformações da tecnologia da 
informação (internet) não se limita à produtividade e a novas oportunidades de inversão. Mas o que se discute aqui é o problema das bases do crescimento econômico norte-americano do ponto de vista dos macroindicadores econômicos. Neste sentido, a expansão do setor financeiro indica que mesmo diante do crescimento da acumulação produtiva, as aplicações financeiras continuavam em média representando boas oportunidades de inversão, com a correlata queda relativa dos recursos destinados ao aumento da produção física. Deste momento, o que de mais marcante se viu foram apenas as palavras dos doutores Pangloss e seu misticismo sobre o "fim do ciclo econômico" e a "sapiência absoluta dos mercados acionários", diante de uma tendência decrescente marcada pelas flutuações cíclicas. 
Um comentário final: a brecha entre PIB e PNB e a economia na última década (2000-2009)

"Desde que o juro nada mais é que a parte do lucro pago
pelo capitalista industrial ao capitalista que empresta
dinheiro, o máximo limite do juro é o próprio lucro, caso no
qual a parcela embolsada pelo capitalista produtivo seria
igual a zero."

Karl Marx, O Capital, V.IIIO processo global de produção capitalista

\subsection{Uma última análise empírica}

Este capítulo fecha a análise empírica do trabalho, tendo os seguintes objetivos: (1) analisar o hiato entre PNB e PIB norte-americano no período referente ao estudo; (2) traçar um comentário rápido sobre a evolução da economia nos últimos dez anos (2000-2008), a fim de sugerir a permanência das dificuldades para além do período que este estudo efetivamente abarcou, terminado no primeiro governo Clinton.

\subsection{PIB $\times P N B$}

Atualmente, a categoria de Produto Nacional Bruto não é a preferida pelas autoridades dos Estados Unidos, e mesmo pela Organização das Nações Unidas, órgão responsável pela sistematização dos métodos de Contabilidade Nacional. De fato, tende-se hoje a privilegiar-se a noção de PIB - Produto Interno Bruto -, e de RNB - Rendimento Nacional Bruto. Segundo o Manual de Introdução Prática à Contabilidade Nacional da ONU, “o PIB não é um conceito que represente rendimentos". ${ }^{252}$ Por isso, segundo tal manual da ONU, aa subtração ao PIB da remuneração de assalariados e rendas de propriedades enviadas ao exterior, mais a adição ao PIB da remuneração de assalariados e rendas de propriedades enviadas pelo exterior ao país, gera a noção de Rendimento Nacional Bruto. Assim, a própria noção de PNB não é mais considerada uma categoria oficial segundo tal manual.

Realmente, num momento anterior da análise feita neste trabalho, observou-se que as contas nacionais norte-americanas abandonaram a utilização do conceito de produto nacional bruto como categoria de medição convencional de riqueza nacional. ${ }^{253}$ Cabe investigar-se então o porquê desta troca mais de perto. O motivo parece ser o fato de que sua utilização já não convém aos interesses políticos da elite dirigente norte-americana, no que se refere à manipulação com fins políticos da nomenclatura econômica.

${ }^{252}$ Cuentas Nacionales, uma introducción práctica, p.37.

${ }^{253}$ Ver nota 65 do capítulo 3. 
Vamos relembrar a antiga definição de PNB, que se obtinha se a partir da relação acima indicada:

PNB = PIB + remuneração de assalariados e rendas de propriedades enviadas pelo exterior ao país - remuneração de assalariados e rendas de propriedades enviadas ao exterior pelo país

Por convenção, definia-se antes que havia a identidade RNB $\equiv \mathrm{PNB}$, assim como havia a identidade PIB $\equiv$ RIB, hoje não mais usadas pelo motivo assinalado acima. ${ }^{254}$ Mantendo-se a definição antiga, convencionava-se que o PNB representava a soma da produção doméstica (PIB) menos (1) a parte da produção doméstica, em termos monetários, enviada ao exterior, e mais (2) a parte da produção do exterior que, convertida em dinheiro, é enviada a este país. As rendas eram aí definidas como (i) lucros corporativos e (ii) juros sobre papéis, assim como (iii) outros recebimentos a partir de direitos sobre títulos diversos, como ações, e (iv) salários pagos. $\mathrm{O}$ valor expressado pelo PNB era assim mais realista. Dito isto, passe-se à análise.

Os saldos líquidos de remessas e envio de rendas em relação ao exterior, nos Estados Unidos, decaíram a partir de 1980. Isto foi expressão do aumento mais rápido do (1) pagamento de rendas ao exterior, oriundo do aumento dos haveres estrangeiros contra o país, do que (2) o aumento do recebimento de rendas oriundo da elevação de propriedades norte-americanas no mundo. A figura abaixo deixa ver esta transformação.

Percebe-se um crescimento dos saldos líquidos em rendas estável entre os anos (19)60 e (19)80, que pode ser dividido nos seguintes sub-períodos: (a) um crescimento moderado entre 1960 e 1970, e (b) uma intensificação dos saldos líquidos, até 1980. O período referente à década de (19)80 expressa uma queda dos saldos líquidos, o que denota o processo de aumento dos pagamentos ao exterior assinalado. No fim desta década, o endividamento externo da economia caiu, como resultado do aumento das exportações norte-americanas (Acordo do Plaza de 1985); assim, a relação de rendas com o exterior voltou a crescer favoravelmente. O aumento do endividamento externo durante os anos (19)90 torna novamente a relação de rendas desfavorável com o exterior. No fim da década de 2000, a relação voltou a ser favorável, mas, com exceção de 2002, estava nos mesmos patamares de trinta anos atrás (1980). O aumento das remessas em dólar para os Estados Unidos a partir de suas corporações no mundo, como resultado da preferência destas pelo aumento da retirada de recursos dos países periféricos atingidos pelos impactos da crise de 2001, explica em parte porque a relação tenha tomado esta feição. O aumento das propriedades norte-americanas no mundo, como resultado das políticas de abertura adotadas nos países periféricos e nos ex-países socialistas, explica a nova retomada do aumento das rendas recebidas do exterior pelos Estados Unidos.

${ }^{254}$ Ver por exemplo o manual de Leda Paulani e Márcio Bobik Braga, A Nova Contabilidade Social, especialmente o capítulo 1. 
Gráfico 1. Estados Unidos. Rendas recebidas do exterior menos rendas enviadas ao exterior (saldo líquido em rendas). Em milhões de dólares correntes.

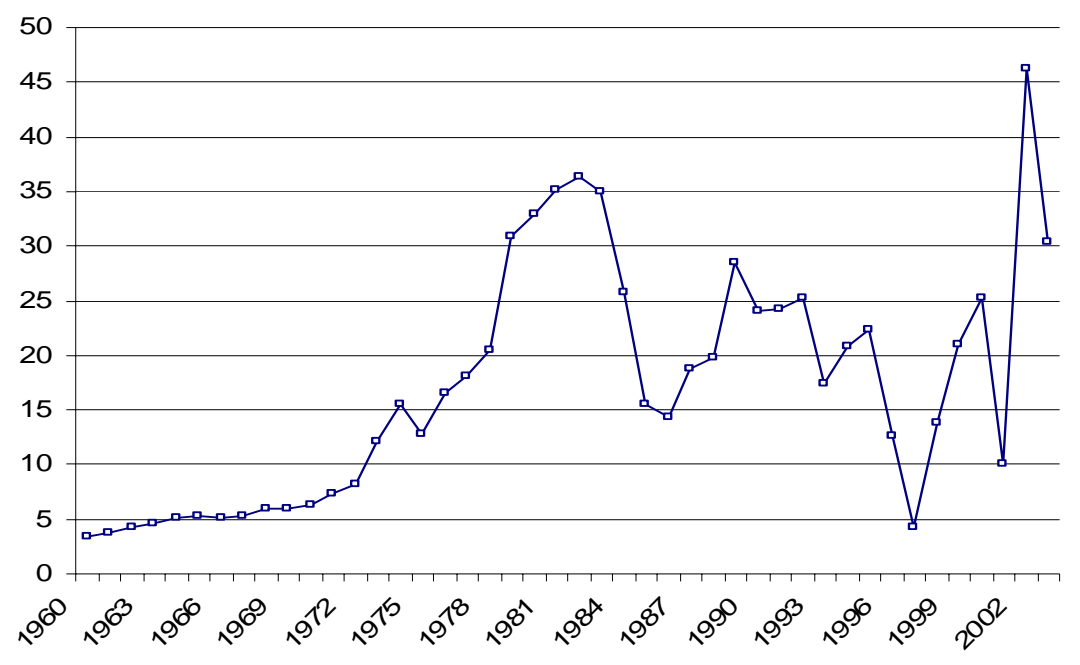

Fonte: Tabela B-103, U.S. International Transactions, 1946-2005, na coluna Balance on Income Receipts and Payments.

Importa então traçar um comparativo da evolução do que seria o PNB norte-americano face à evolução do PIB norte-americano, nas condições do endividamento externo, para perceber porque interessou às autoridades a mudança conceitual. Em tese, sendo o PNB nada mais do que a soma do PIB com o resultado líquido de rendas com o exterior, interessa à óptica oficial do país desenvolvido a utilização do primeiro conceito (PNB), assim como aos administradores dos países subdesenvolvidos a perspectiva de PIB é mais interessante. Isto porque ao país desenvolvido o resultado líquido das rendas é quase sempre positivo, e, ao subdesenvolvido, negativo. Assim, para a nação industrializada, o resultado líquido de rendas quase sempre é uma soma ao PIB, o que gera um PNB maior que o PIB, assim como para a nação periférica o resultado quase sempre negativo em rendas representa uma subtração ao PIB, o que torna o PNB menor que o PIB. Os cálculos de PIB e PNB estão na seqüência.

Tabela 1. Estados Unidos. PIB, resultado de rendas líquidas com o exterior, e PNB, calculado pela soma de PIB e rendas líquidas. PIB e PNB em bilhões dólares. Rendas em milhares de dólares.

\begin{tabular}{cccc}
$(1)$ & $(2)$ & $(3)$ & $(4)$ \\
Anos & PIB & $\begin{array}{c}\text { Rendas líquidas } \\
\text { (em milhares de US\$) }\end{array}$ & $\begin{array}{c}\text { PNB } \\
\text { (em bilhões de US\$) }\end{array}$ \\
1960 & 526.4 & 3.379 & 529.8 \\
1961 & 544.7 & 3.755 & 548.5 \\
1962 & 585.6 & 4.294 & 589.9 \\
1963 & 617.7 & 4.596 & 622.3 \\
1964 & 663.6 & 5.041 & 668.6 \\
1965 & 719.1 & 5.350 & 724.5 \\
1966 & 787.8 & 5.047 & 792.8 \\
1967 & 832.6 & 5.274 & 837.9 \\
1968 & 910.1 & 5.990 & 916.1 \\
1969 & 984.6 & 6.044 & 990.6 \\
1970 & 1038.5 & 6.233 & 1044.7 \\
1971 & 1127.1 & 7.272 & 1134.4 \\
\hline
\end{tabular}




\begin{tabular}{|c|c|c|c|}
\hline \multicolumn{4}{|c|}{ [Continução] } \\
\hline 1972 & 1238.3 & 8.192 & 1246.5 \\
\hline 1973 & 1382.7 & 12.153 & 1394.9 \\
\hline 1974 & 1500.0 & 15.503 & 1515.5 \\
\hline 1975 & 1638.3 & 12.787 & 1651.1 \\
\hline 1976 & 1825.3 & 16.603 & 1841.9 \\
\hline 1977 & 2030.9 & 18.137 & 2049.0 \\
\hline 1978 & 2294.7 & 20.408 & 2315.1 \\
\hline 1979 & 2563.3 & 30.873 & 2594.2 \\
\hline 1980 & 2789.5 & 32.903 & 2822.4 \\
\hline 1981 & 3128.4 & 35.164 & 3163.6 \\
\hline 1982 & 3255.1 & 36.386 & 3291.5 \\
\hline 1983 & 3536.7 & 35.063 & 3571.8 \\
\hline 1984 & 3933.2 & 25.723 & 3958.9 \\
\hline 1985 & 4220.3 & 15.494 & 4235.8 \\
\hline 1986 & 4462.8 & 14.293 & 4477.1 \\
\hline 1987 & 4739.5 & 18.687 & 4758.2 \\
\hline 1988 & 5103.8 & 19.824 & 5123.6 \\
\hline 1989 & 5484.4 & 28.550 & 5513.0 \\
\hline 1990 & 5803.1 & 24.131 & 5827.2 \\
\hline 1991 & 5995.9 & 24.235 & 6020.1 \\
\hline 1992 & 6337.7 & 25.316 & 6363.0 \\
\hline 1993 & 6657.4 & 17.416 & 6674.8 \\
\hline 1994 & 7072.2 & 20.891 & 7093.1 \\
\hline 1995 & 7397.7 & 22.318 & 7420.0 \\
\hline 1996 & 7816.9 & 12.609 & 7829.5 \\
\hline 1997 & 8304.3 & 4.265 & 8308.6 \\
\hline 1998 & 8747.1 & 13.888 & 8761.0 \\
\hline 1999 & 9268.4 & 21.054 & 9289.5 \\
\hline 2000 & 9817.1 & 25.183 & 9842.3 \\
\hline 2001 & 10128.0 & 10.016 & 10138.0 \\
\hline 2002 & 10469.0 & 46.304 & 10515.3 \\
\hline 2003 & 10971.0 & 30.439 & 11001.4 \\
\hline
\end{tabular}

Fonte: para PIB, Tabela B-1 do Apêndice Estatístico do Economic Report of the President, Gross Domestic Product, 1959-2005, e para Rendas Líquidas Tabela B-103, U.S. International Transactions, 1946-2005, na coluna Balance on Income Receipts and Payments.

Para os administradores dos Estados Unidos, como o resultado das contas de renda são sempre positivos (apesar da modificação do padrão de comportamento das séries), conviria, à primeira vista, continuar utilizando a notação de PNB. Porém, quando se observa o produto sob a perspectiva da variação (e esta é a mais utilizada em termos políticos), o PNB vai tender a variar menos que o PIB se os resultados em rendas com o exterior passar a variar menos. Isto pode ser mostrado a partir das variações em porcentagem das duas variáveis, assim como por análise de regressão simples.

Acima estão traçados os dados de PIB, PNB e resultados líquidos das transações de rendas com o exterior. As séries de PIB (coluna 1) e saldos em rendas com o exterior (coluna 2) foram fornecidas pelo Economic Report of the President de 2006, e estão em dólares correntes, 
e não deflacionadas. ${ }^{255} \mathrm{O}$ Economic Report deixou de publicar o produto sob formato "PNB" desde 1991. Para efeitos de comparação do desempenho das duas formas de medir a riqueza nacional, deve-se contrapor PIB e PNB. Para obter o PNB a partir do PIB e dos saldos líquidos de rendas com o exterior, deve-se somar ao PIB tais resultados líquidos de renda. Obtém-se assim a coluna 4, de PNB. As variações de ambas as séries, em porcentagem de ano após ano, estão na tabela a seguir.

As somas totais das variações de PNB e PIB para os períodos de 1960-1980 e 19802000 estão assinaladas na última linha. Pode-se notar como, além da (1) já assinalada diminuição progressiva das taxas de variação de crescimento, mesmo sem descontar-se a inflação, como (2) a soma das variações de PIB é menor que a de PNB no primeiro período, e maior no segundo período, tal como estabelecido na observação acima. Isto mostra como a adoção da categoria de PNB foi preterida em função da de PIB pelas autoridades norteamericanas.

Tabela 2. Estados Unidos. Variações percentuais de PIB e PNB.

\begin{tabular}{cccccc}
\hline$(1)$ & $(2)$ & $(3)$ & $(4)$ & $(5)$ & $(6)$ \\
& PIB & PNB & & PIB & PNB \\
1960 & - & - & 1980 & - & - \\
1961 & 3.5 & 3.5 & 1981 & 12.15 & 12.09 \\
1962 & 7.5 & 7.5 & 1982 & 4.05 & 4.04 \\
1963 & 5.5 & 5.5 & 1983 & 8.65 & 8.52 \\
1964 & 7.4 & 7.4 & 1984 & 11.21 & 10.84 \\
1965 & 8.4 & 8.4 & 1985 & 7.30 & 6.99 \\
1966 & 9.6 & 9.4 & 1986 & 5.75 & 5.70 \\
1967 & 5.7 & 5.7 & 1987 & 6.20 & 6.28 \\
1968 & 9.3 & 9.3 & 1988 & 7.69 & 7.68 \\
1969 & 8.2 & 8.1 & 1989 & 7.46 & 7.60 \\
1970 & 5.5 & 5.5 & 1990 & 5.81 & 5.70 \\
1971 & 8.5 & 8.6 & 1991 & 3.32 & 3.31 \\
1972 & 9.9 & 9.9 & 1992 & 5.70 & 5.70 \\
1973 & 11.7 & 11.9 & 1993 & 5.04 & 4.90 \\
1974 & 8.5 & 8.6 & 1994 & 6.23 & 6.27 \\
1975 & 9.2 & 8.9 & 1995 & 4.60 & 4.61 \\
1976 & 11.4 & 11.6 & 1996 & 5.67 & 5.52 \\
1977 & 11.3 & 11.2 & 1997 & 6.24 & 6.12 \\
1978 & 13.0 & 13.0 & 1998 & 5.33 & 5.44 \\
1979 & 11.7 & 12.1 & 1999 & 5.96 & 6.03 \\
1980 & 8.8 & 8.8 & 2000 & 5.92 & 5.95 \\
SOMA & $\mathbf{1 7 4 . 4 3}$ & $\mathbf{1 7 5 . 0 2}$ & SOMA & $\mathbf{1 3 0 . 2 8}$ & $\mathbf{1 2 9 . 2 8}$ \\
\hline
\end{tabular}

Fonte: calculados com os dados da Tabela B-1 do Apêndice Estatístico do Economic Report of the President, Gross Domestic Product, 1959-2005.

Há também uma maneira econométrica de expor a questão. Veja-se:

A regressão simples em função do tempo dos valores de PIB e PNB, da tabela 1, dão os seguintes valores preditivos:

\footnotetext{
${ }^{255}$ Aqui não importa saber qual é a taxa de inflação, pois ela é de qualquer maneira a mesma para ambas as séries em comparação, para cada um dos períodos (1960-1980 e 1980-2000).
} 
Produtos em função do tempo $(y=a+b x)$

Onde:

$y=\mathrm{PIB}$ ou PNB

$x=$ tempo

Regressões

a)

1960-1980 (Período 1 = T1)

$P N B_{1}=103.86+106.71 x_{1}$

$P I B_{1}=106.31+105.49 x_{1}$

b)

1980-2000 (Período 2 = T2)

$\mathrm{PNB}_{2}=2198.5+338.43 x_{2}$

$P I B_{2}=2167.1+339.23 x_{2}$

A diferença de crescimento assinalada, maior para PNB entre 1960 e 1980, e maior para PIB entre 1980 e 2000, pode ser obtida pela relação dos regressores "b" de cada expressão. Os regressores medem a taxa de crescimento de cada variável, e a comparação (1) da divisão do regressor "b1" de PNB pelo regressor "b2" de PNB com (2) a divisão do regressor "b1" de PIB com o regressor "b2" de PIB mostra qual das séries cresceu mais rapidamente no segundo período (1980-2000). A divisão do regressor do segundo período pelo primeiro dá um resultado maior para PIB do que para PNB, o que nos fornece uma outra maneira de expressar as inferências acima traçadas.

\begin{tabular}{ccc}
\hline Tipo de Produto & $\begin{array}{r}\text { Divisão entre os regressores } \\
\text { " } \mathrm{b}_{2} \text { " } \mathrm{e} \text { " } \mathrm{b}_{1} \text { " }\left(\mathrm{b}_{2} \div \mathrm{b}_{1}\right)\end{array}$ & Resultado \\
PNB & $338.43 \div 106.71$ & 3.17 \\
PIB & $339.23 \div 105.49$ & 3.21 \\
\hline
\end{tabular}

As perdas relativas no saldo de rendas com o exterior explica então as maiores variações do PIB norte-americano em relação a seu PNB, mostrando assim porque passou a haver um interesse das autoridades na mudança categorial. Tal é adequado à ênfase dada para a noção de crescimento econômico nominal, em detrimento de outras abordagens. $\mathrm{O}$ abandono da ênfase na categoria de PNB pelas autoridades norte-americanas não é então um fato desimportante. É um modo de sugerir que não se lembre de que o país é hoje a nação com a maior dívida externa do mundo.

10.3. A economia entre 2000 e 2008

É interessante comentar também, a título de resumo, como se comportaram os agregados fundamentais nos últimos dez anos. A narração das políticas econômicas até o presente momento tornaria este trabalho demasiado extenso, com a desvantagem de que não 
acrescentaria muito à defesa das hipóteses estabelecidas. Além disso, uma análise minuciosa somar-se-ia à enorme quantidade de material disponível hoje sobre as políticas econômicas mais recentes, inclusive publicadas e apresentadas por este autor em periódicos e eventos. Tais episódios já fazem parte de um novo capítulo da história recente do país, história de menor crescimento, novos aumentos dos gastos com economia de guerra e nova rodada de endividamento do Estado, e queda ainda maior da massa de lucros do setor produtivo face à renda nacional. Merecem então num outro estudo que possa investigá-los com o devido tempo. Diferentemente do período 1993-2000, onde havia esperanças de que a economia norteamericana pudesse "surpreender", as dificuldades estruturais assumiram a devida faceta desmitologizada.

O comentário abaixo visa corroborar, pela última vez, as hipóteses sobre o longo prazo adotadas neste trabalho, a saber: o aumento do endividamento externo como mecanismo compensador da queda relativa da taxa de acumulação produtiva na economia norte-americana. Queda esta que, segundo o argumento aqui presente, liga-se ao crescente desfavorecimento dos setores industriais face aos financeiros, e, num nível global, aos desfavorecimentos dos investimentos produtivos domésticos em relação às áreas de maior taxa de lucro na economia mundial.

Em primeiro lugar, nota-se na tabela abaixo que o PIB per capita apresentou variações positivas desde 2000, saindo de 46.000 mil dólares neste ano para 59.000 dólares em 2007 . Porém, isto ocorreu basicamente devido a um crescimento da população de 1,09 vezes, ao passo que o produto interno bruto cresceu 1,4 vezes. Por sua vez, para que se desse este crescimento do PIB, o comportamento do endividamento externo da economia foi tal que a dívida total acumulada, em proporção do PIB, saltou de 77\% em 2000 para nada menos de 145\%, em 2007. Ou seja, o endividamento cresceu, em relação a 2000, 2,65 vezes, comparado com um crescimento do produto de 1,4 vezes. Um outro modo de ver como se elevou o endividamento é compará-lo com a trajetória dos saldos negativos em bens e serviços: estes cresceram aproximadamente 1,8 vezes entre 2000 e 2007; já o aporte total de recursos externos, 2,85 vezes. Tal não poderia ser chamado de um desempenho sadio ou satisfatório. O movimento indica um agravamento das pressões comentadas ao longo deste estudo. 
Tabela 3. Estados Unidos. População, PIB, PIB per capita e dívida externa acumulada com o exterior no fim de período. População em milhares, PIB per capita em dólares, e PIB e dívida em bilhões de dólares correntes.

\begin{tabular}{|c|c|c|c|c|c|}
\hline (1) & (2) & (3) & (4) & (5) & (6) \\
\hline Anos & $\begin{array}{r}\text { População } \\
\text { (milhares) }\end{array}$ & $\begin{array}{l}\text { PIB (bilhões } \\
\text { de US\$) }\end{array}$ & $\begin{array}{c}\text { PIB per } \\
\text { capita } \\
\text { (unidades de } \\
\text { US\$) }\end{array}$ & $\begin{array}{c}\text { Endividamento } \\
\text { externo (bilhões } \\
\text { de US\$) }\end{array}$ & $\begin{array}{c}\text { Déficits em bens } \\
\text { e serviços } \\
\text { (bilhões de } \\
\text { US\$) }\end{array}$ \\
\hline 2000 & 211577 & 9817 & 46000 & 7569 & -379 \\
\hline 2001 & 215092 & 10128 & 47000 & 8177 & -365 \\
\hline 2002 & 217570 & 10469 & 48000 & 8687 & -423 \\
\hline 2003 & 221168 & 10960 & 49000 & 9724 & -469 \\
\hline 2004 & 223357 & 11685 & 52000 & 11586 & -607 \\
\hline 2005 & 226082 & 12421 & 54000 & 13886 & -711 \\
\hline 2006 & 228815 & 13178 & 57000 & 16607 & -753 \\
\hline 2007 & 231867 & 13807 & 59000 & 20081 & -700 \\
\hline
\end{tabular}

Fonte: Economic Report of the President de 2009. Para PIB, Tabela B-1, Gross Domestic Product; para população, Tabela B-34, Population by Age and Group, 1929-2007; para endividamento externo, Tabela B-107, International Investment Position of the United States; para déficits em bens e serviços, Tabela B-103, U.S. International Transactions.

Este comportamento do produto atende aos mesmos delineamentos traçados acima: uma queda da taxa de acumulação produtiva compensada em parte por um aumento, de fato cada vez mais rápido, da taxa de atração de recursos do exterior, que nos Estados Unidos toma a forma de substituição do investimento pelo consumo. $\mathrm{O}$ endividamento externo não evitou a queda da acumulação produtiva, mas a contornou, pelo aumento dos gastos em forma de consumo na economia. A permanência da queda da taxa de inversão produtiva pode ser observada na tabela a seguir, onde se vê a relação dos lucros industriais e dos financeiros (com inclusão dos bancos da Reserva Federal) com os lucros totais da renda nacional, tal como fornecidos pela Tabela B9, Corporate Profits by Industry, 1959-2008, do Economic Report of the President de 2009. Uma menor taxa de inversão leva ao longo do tempo à queda dos lucros realizados.

$\mathrm{O}$ aumento da taxa de endividamento externo relaciona-se com a radical queda dos investimentos após a crise de 2001 - uma maneira de postergar a crise, assegurando o fluxo de demanda agregada e um crescimento do PIB per capita que não teriam base nos recursos que a própria economia gerou. Note-se que a queda da inversão no setor industrial levou a um aumento mais que proporcional dos ganhos financeiros sobre os lucros totais, que em 2002 chegam aos enormes $40 \%$ dos ganhos totais. Por outro lado, mesmo depois da recuperação após 2003 , os lucros industriais não tinham voltado ao patamar mais alto de 2000 . De fato, "os rentistas gozam de uma vida muito mais cômoda numa economia estagnada (sempre que seus lucros não levem ao extremo de causar bancarrotas) do que numa economia de crescimento rápido." 256

${ }^{256}$ Joan Robinson, A Acumulação de Capital, p.277. 
Tabela 4. Estados Unidos. Lucros da indústria e lucros do setor financeiro (inclui bancos da Reserva Federal) em relação aos lucros totais da renda nacional.

\begin{tabular}{ccc}
\hline & Lucros da indústria sobre lucros totais & Lucros financeiros sobre lucros totais \\
$(1)$ & $(2)$ & $(3)$ \\
1980 & 0,36 & 0,16 \\
1985 & 0,32 & 0,17 \\
1990 & 0,28 & 0,31 \\
1995 & 0,26 & 0,24 \\
2000 & 0,18 & 0,26 \\
2001 & 0,07 & 0,31 \\
2002 & 0,06 & 0,36 \\
2003 & 0,08 & 0,35 \\
2004 & 0,13 & 0,29 \\
2005 & 0,15 & 0,28 \\
2006 & 0,16 & 0,26 \\
2007 & 0,17 & 0,24 \\
\hline
\end{tabular}

Fonte: Cálculo a partir dos dados da Tabela B-91, Corporate profits by industry, 1959-2007, do Economic Report of the President de 2009.

Gráfico 2. Estados Unidos. Gastos agregados como porcentagens do PIB. 2000-2006.

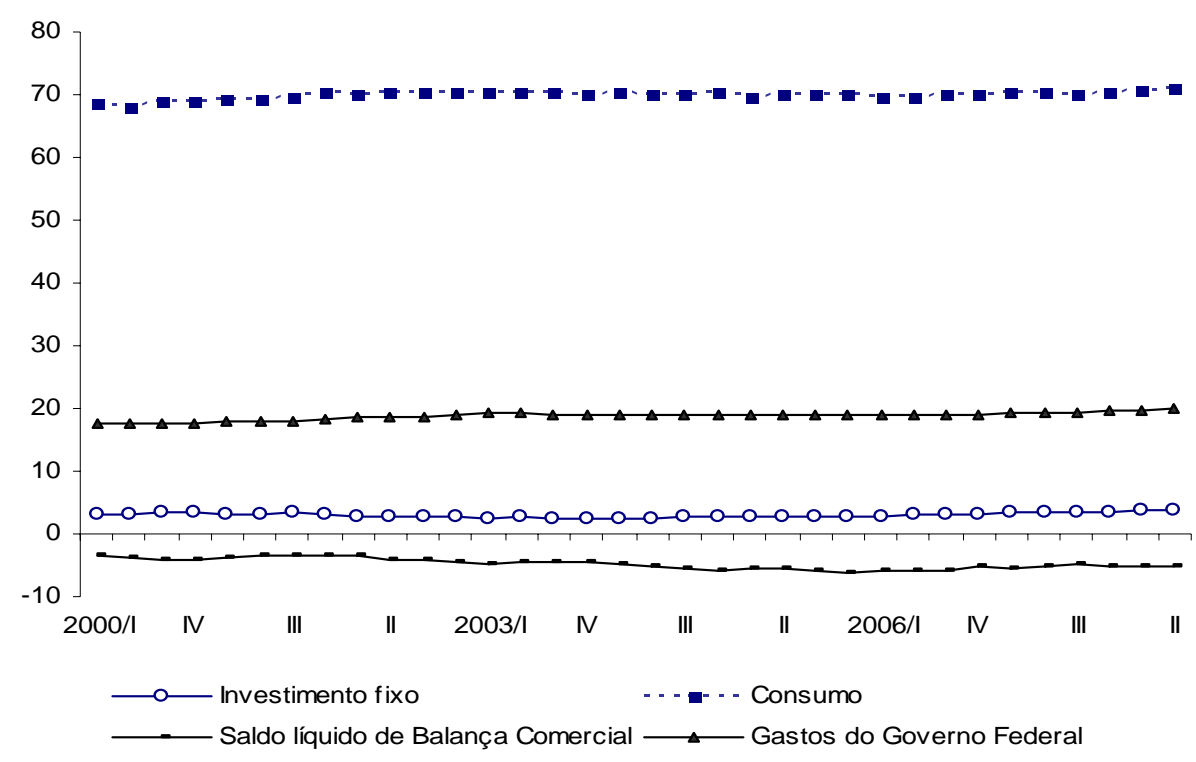

Fonte: NIPA-BEA. Ver Seção 1, Domestic Product and Investment, Tabela 1.1.10, Percentage Shares of Gross Domestic Product.

Acima está disposta a divisão do produto interno bruto em seus componentes agregados principais, desde 2000. Percebe-se uma manutenção, em proporção do produto, do elevado nível de consumo das famílias, estacionado em $70 \%$ do PIB. Os gastos do governo federal permanecem um pouco abaixo de $20 \%$; e o investimento fixo, estável, a aproximadamente 3\% do PIB. Os saldos negativos na balança comercial, por sua vez, saltam de um consumo da renda nacional de 3,6\% em 2000 para 5\% em 2009. Em suma: existe a continuidade, nos últimos dez anos, do que já anteriormente chamamos de "reprodução simples do capital social", pela baixa taxa de investimento da renda nacional. A explicação de o porquê de a taxa de investimento não 
crescer, tendo assim de ser compensada pelo consumo, está dentro das leis que comandam no longo prazo as decorrências da assim chamada "eficiência marginal do capital".

Uma observação sobre as contas do orçamento do governo federal também é elucidativa. Abaixo se percebe que a contrapartida da queda dos impostos praticados pela administração Bush entre 2001 e 2008 - favorecendo principalmente ricos e o capital - viu-se compensada por um aumento dos déficits orçamentários. Ao mesmo tempo, com o fim do ciclo de crescimento da "nova economia" depois de 2001, e a entrada num patamar de crescimento menor, deram-se aumentos dos gastos com defesa, que evoluíram de um patamar de $14 \% \mathrm{em}$ 2000 para $24 \%$ do orçamento federal total em 2004. Estes aumentos dos gastos com defesa vieram acompanhados de duas agressões militares à periferia: Iraque e Afeganistão, com um número de mortos que ultrapassa a casa do milhão. A dívida acumulada em dólares do governo federal - interna e com credores internacionais - chegava a quase $70 \%$ do produto interno bruto. A militarização da economia tem continuado a ser a resposta preferida pelas autoridades.

Tabela 5. Estados Unidos. Contas selecionadas do orçamento federal. Em bilhões de dólares correntes.

\begin{tabular}{ccccccc}
\hline$(1)$ & $\begin{array}{c}(2) \\
\text { Orçamento do } \\
\text { governo } \\
\text { federal }\end{array}$ & $\begin{array}{c}(3) \\
\% \text { do } \\
\text { orçamento } \\
\text { sobre o PIB }\end{array}$ & $\begin{array}{c}\text { Déficits } \\
\text { federais }\end{array}$ & Defesa & $\begin{array}{c}(6) \\
\text { \% dos gastos de } \\
\text { Defesa sobre } \\
\text { orçamento }\end{array}$ & $\begin{array}{c}(7) \\
\text { Dívida } \\
\text { Federal } \\
\text { acumulada }\end{array}$ \\
2000 & 2025 & 0.20 & 236 & 294 & $14 \%$ & 5628 \\
2001 & 1991 & 0.19 & 128 & 304 & $15 \%$ & 5769 \\
2002 & 1853 & 0.17 & -157 & 348 & $18 \%$ & 6198 \\
2003 & 1782 & 0.16 & -377 & 404 & $22 \%$ & 6760 \\
2004 & 1880 & 0.16 & -412 & 455 & $24 \%$ & 7354 \\
2005 & 2153 & 0.17 & -318 & 495 & $22 \%$ & 7905 \\
2006 & 2407 & 0.18 & -248 & 521 & $21 \%$ & 8451 \\
2007 & 2568 & 0.18 & -162 & 552 & $21 \%$ & 8950 \\
$2008{ }^{1}$ & 2552 & - & -454 & 624 & $24 \%$ & 9623 \\
\hline
\end{tabular}

Fonte: Economic Report of the President de 2009. Tabela B-78, Federal receipts, outlays, surplus or deficit, and debt, fiscal years, 1940-2009.

${ }^{1}$ Estimativa.

E este comportamento se deu diante de um alto nível de endividamento doméstico, de todos setores. A dívida total de mercado dos setores domésticos não financeiros - incluindo-se os governos federal, locais e estaduais, assim como todos os setores privados não-financeiros era em 2007 de 31 trilhões de dólares, e de 32 trilhões em Maio de 2008. A poupança líquida das famílias em 2007 era de apenas 57 bilhões de dólares, uma fração irrelevante da poupança nacional. De fato, o Economic Report marcava -0,5 de poupança privada em 2005. Ao mesmo tempo, as autoridades passaram a conduzir a crise aberta desde 2008 não apenas com um aumento do endividamento do governo face ao público, mas sim com uma própria monetização da dívida para dar conta da gigantesca liberalização e garantia de recursos a praticamente todos os agentes da economia: corporações, sistema financeiro, e por decorrência, famílias endividadas. Isto é, o Fed literalmente passou a emitir dólares franca e abertamente, depois de 
um período de crescimento estável, que acompanhava o produto. Em um trimestre, a base monetária simplesmente quase dobrou. Está se dando portanto um correlato aumento da dívida do Tesouro, a fim de socorrer empresas e bancos falidos, e indiretamente bloquear uma piora dos índices de despejo de famílias com suas hipotecas em xeque. Particularmente, este é um traço diferente da crise atual, à luz do passado recente, tal como se viu neste trabalho: o déficit orçamentário eleva-se a uma proporção inédita, a base monetária cresceu de forma rápida e a propriedade privada tornou-se, literalmente, pública. O grande grau de intervenção do Estado revela um nível de piora do comportamento econômico certamente de grau qualitativo. Todos os artifícios, mantida intacta a estrutura de divisão dos rendimentos, são utilizadas para postergar a estagnação.

Em suma: a economia encontra-se numa difícil situação na qual a maximização do consumo das famílias, do déficit orçamentário e da dívida pública, assim como a volta às pulsões militaristas e o aumento veloz do endividamento externo, não são capazes de levar o produto a novas expansões significativas. A dívida externa é o recurso de última instância, assim, que permite postergar o problema, criando outro (o crescimento dos encargos). Este aparece então, justamente, como o recurso de última instância de manutenção do crédito e da demanda agregada, assim como o lastro pelo qual o governo norte-americano pode aumentar sua dívida mais rapidamente do que o produto doméstico.

Gráfico 3. Estados Unidos. Base monetária. Em bilhões de dólares.

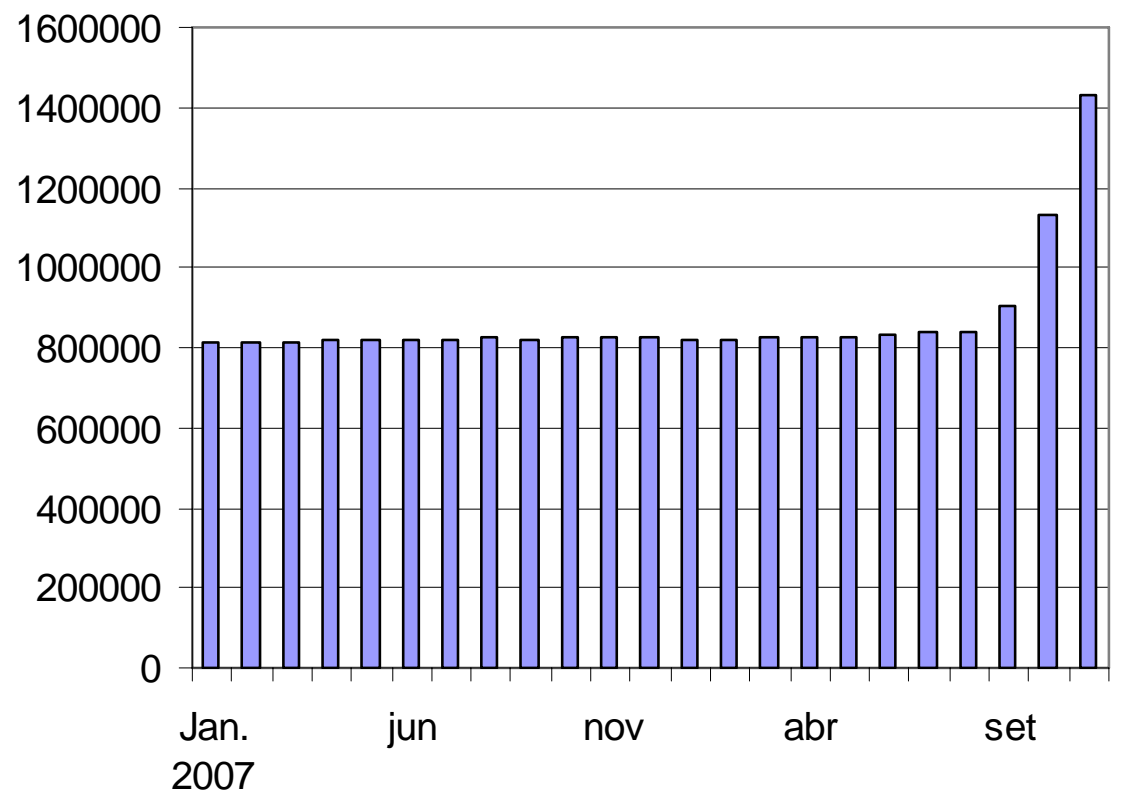

Fonte: Economic Report of the President de 2009, Tabela B-69, Money stock and debt measures, 1965-2007.

Por fim, tal situação de crise nos mercados de crédito atual é o resultado direto de anos de liberalização do sistema financeiro, e num grau superior, resultado da percepção dos administradores de que o nível de endividamento dos agentes deve ser permitido ao máximo 
para que a economia apresente, sempre no curto prazo, um crescimento maior. Essa é a maneira perversa com que os liberais - inclusive da equipe de Clinton - incorporaram as intuições $a d$ hoc do keynesianismo: o lema de "no longo prazo estaremos mortos" significava que as políticas deviam permitir todo tipo de medidas que levassem ao enriquecimento mais rápido das corporações, em detrimento de um crescimento menor porém mais organizado, mediante a regulação da ingerência pública. Não há, porém, a situação ideal onde tudo de melhor é possível. As metáforas democratas, como "um balanço sadio entre a participação do Estado e dos setores privados", agora mostram suas conseqüências mais devastadoras, depois de um período onde se achava que a roda havia sido descoberta.

O conjunto das políticas para dar conta da crise voltaram então, na administração Obama, a uma faceta mais parecida com o keynesianismo, dado o (1) crescimento da base monetária e (2) dos déficits fiscais, déficits estes que, diferentemente dos momentos de crise anterior, não estão sendo dirigidos preponderantemente para a indústria de guerra. $\mathrm{O}$ rápido crescimento da base monetária atualmente mostra também que o controle ad hoc da moeda entrou em cena de modo indiscriminado para lidar-se com a recessão, configurando uma mudança face às posturas mais rígidas do passado recente. 


\section{IV}

Conclusão 


\title{
10
}

\section{Considerações finais}

\author{
"Os dois principais problemas que temos - como manter a \\ liderança [norte-]americana em boa parte do mundo e como \\ lidar com o nosso poderio bélico - não podem ser separados \\ um do outro." \\ "Implicações políticas e segurança financeira: um plano para \\ a América." James K. Galbraith. In: Versus - Revista de \\ Ciências Sociais Aplicadas do CCJE/UFRJ. Ano 1, Edição \\ Zero.
}

$\mathrm{N}$ a esteira de uma base teórica que conecta Marx e Kalecki, e que toma de Keynes e Joan Robinson instrumentos analíticos que não contradizem os postulados gerais da análise baseada na teoria marxista do investimento e distribuição, levando então à construção de um terreno comum de abordagem dos agregados, podem-se retomar as hipóteses deste estudo, para fins de conclusão.

A tese geral foi tentar argumentar como o endividamento externo da economia norteamericana a partir do início da década de (19)80 tem atenuado, mas sem eliminá-las, as decorrências macroeconômicas advindas da tendência para a estagnação do produto. Segundo a primeira hipótese (ver seção 1.3 da introdução), esta tendência para a estagnação origina-se da queda ao longo do tempo da parcela da acumulação produtiva sobre o produto. Ela foi aguçada pelos acontecimentos de meados da década de (19)70, mormente as crises do petróleo e a elevação das taxas de juros. A tendência, por sua vez, deve ser explicada por um crescente diferencial no desempenho das taxas de lucro intersetoriais na economia, onde as desvantagens para os setores industriais explicam-se por suas maiores razões capital/produto e conseqüentes menores taxas de lucro. O crescimento da financeirização é então o outro lado do desenrolar deste processo de crescente queda da acumulação produtiva. A segunda hipótese argumentava que a tendência ao declínio das taxas de lucro nos setores industriais seria aguçada pelos seguintes fatores: (i) pela atuação dos preços relativos; (ii) pelos déficits comerciais; (iii) pela exportação de capital produtivo. Buscou-se problematizar estas duas hipóteses no capítulo 4.

Logo, além haver-se tentado, neste trabalho, investigar as causas das flutuações em tendência decrescente do produto no período, buscou-se demonstrar porque a recuperação das taxas de lucro industriais, em conjunção com as positividades decorrentes da dívida externa, a partir do final da década de (19)80, não levaram à queda da dívida. Os investimentos produtivos, ainda que em recuperação e colher as benesses da fartura de recursos do exterior, continuaram a ver sua lucratividade atrás daqueles financeiros, que cresceram ainda mais. Isto significava, tal como expresso na terceira hipótese, uma queda ao longo do tempo da propensão marginal a investir e a uma elevação dos ganhos financeiros. A terceira hipótese do trabalho tentou-se demonstrar tanto no capítulo 4 (principalmente na seção 4.8), como nos capítulos 
referentes às diferentes conjunturas. Isto significava dizer que os investimentos produtivos, raízes de todo o crescimento econômico, estavam em queda relativa. O consumo então substituiu aos poucos o investimento como parcela determinante da demanda efetiva, ainda que os investimentos produtivos tenham se beneficiado também do endividamento externo, com juros menores no sistema bancário e financiamento através de papéis emitidos ao exterior.

A partir da queda relativa dos investimentos produtivos, a quarta e a quinta hipóteses relacionavam-se mais de perto com o problema da dívida em si. A quarta hipótese estabelecia que durante as flutuações negativas, a economia norte-americana estaria a aumentar o volume de importação de poupança externa, com tal montante da poupança externa aumentando a poupança doméstica total (do qual aquela faz parte). Isto para contrabalançar a flutuação. A análise dos quadros com a estrutura do endividamento externo nos capítulos referentes à conjuntura tentam demonstrar tal quarta hipótese. Para este procedimento valeu-se especificamente da análise de regressão econométrica, especialmente nos capítulos 7, 8 e 9 .

A quinta hipótese referia-se ao poder limitado das descobertas tecnológicas para se contrapor as tendências estagnativas, hipótese referente especialmente ao capítulo 9 . $\mathrm{O}$ interesse deste capítulo residia, entre outros, na verificação desta hipótese. Tentou-se ver porque mesmo o aumento da acumulação produtiva, numa situação de ganhos de fato mais rápidos que os ganhos financeiros, não teria levado à queda do endividamento externo. Isto se deu porque a dimensão da retomada não foi nunca suficiente para gerar os recursos necessários para que os outros componentes da economia nacional pudessem diminuir suas demandas do exterior. Isto implica dizer que o comportamento das variações do produto norte-americano esteve acima da taxa que deveria seguir caso não houvesse o papel dominante do dólar no mundo.

Daí que, em resumo, nas condições do atual tipo de crescimento com base no endividamento externo, somente um aumento muito maior da acumulação poderia, depois de um tempo, fazer com que a relação dívida externa/PIB pudesse cair. Como esta possibilidade é bastante pequena, é claro que os níveis de consumo e investimento teriam de cair, para adequarse melhor às disponibilidade reais de uma economia com quedas sucessivas na taxa de lucro. $\mathrm{O}$ fato de que o cômputo do consumo venha aumentando relativamente cada vez mais significa: (1) que a economia consome e investe endividando-se no exterior; e (2) que o consumo local substitui o investimento como fator expansivo. A diminuição do expediente da dívida seria um caminho doloroso que levaria a um crescimento menor, mas menos instável em suas perspectivas futuras, que envolvem crise em diversos aspectos da regulação da atividade, doméstica e internacional, como hoje se vê com mais clareza. A grande interconexão econômica do mundo hoje padece da dificuldade fundamental de que as decisões que afetam a todos sejam feitas apenas no âmbito particular dos grandes oligopólios norte-americanos e das instâncias de poder político no Fed e na Casa Branca, que atendem a tais interesses corporativos.

Quanto à hipótese 6, poder-se-ia dizer, com base no período Reagan (1981-1988), e depois para os anos 2000, que a indústria de guerra simplesmente faz parte da natureza das regras do jogo capitalista (Joan Robinson) norte-americano. Não se pode entendê-lo sem que se 
explicite a centralidade do complexo industrial-militar para a acumulação, para a política anticíclica. A atenção dada ao complexo industrial-militar nos momentos de flutuação negativa, vistas durante as duas administrações Reagan (e retomada para o período 2001-2008, que está fora do período aqui estudado) deve assim reiterar uma perspectiva bem mais pessimista sobre o comportamento econômico norte-americano do que os modelos cujos princípios básicos são formados pela noção de equilíbrio.

Como corolário do estudo, tem-se que o crescimento depende do endividamento externo, e que a redução do endividamento conduziria a uma redução do crescimento. Poder-seia novamente remeter o leitor principalmente ao capítulo 9 , onde se vê como o crescimento se deu com aumento do endividamento externo, ou ao capítulo 10, onde se mostra, para os anos 2000, como o desempenho da economia, ainda que com um aumento colossal do endividamento externo, foi apenas modesto. Tacitamente se infere que a diminuição da emissão de papéis ao exterior com promessa de pagamento futuro acarretaria num desempenho mais contido.

$\mathrm{O}$ endividamento externo atenua mas não soluciona o problema fundamental atrelado à continuidade do investimento produtivo ao longo do tempo. Ele torna o investimento produtivo mais barato, mas não impede de cair, ao longo do tempo. Buscou-se justamente demonstrar o argumento geral do trabalho em cada uma das subseqüentes conjunturas, de modo a ilustrar como a tese fundamental aparecia em cada momento "particular" da exposição, referente a cada conjuntura determinada: ora a do Reaganomics, com seu acento na indústria de guerra, ora a da liberalizante e desregulamentadora política de Clinton. Sob o argumento kaleckiano/keynesiano aqui apresentado, isto é equivalente a dizer - como se insistiu - que a economia dos Estados Unidos cresceu mais do que poderia ter crescido, na medida em que a poupança externa contribuiu para os investimentos e consumo realizados ao longo do tempo desde o início do endividamento externo nos anos (19)80. A opulência continuou ditando o tom social nos Estados Unidos, mas agora com a diferença de que, de modo totalmente escancarado e não mais sutil (como nas trocas desiguais e na remessa de lucros da política imperialista), a economia mundial estava, porque vigente a política de predomínio do dólar, financiando o consumo e investimento norte-americano.

A economia internacional tem sustentado a centralidade da posição norte-americana na Divisão Internacional do Trabalho como compradora de bens primários e dos bens industriais que o Leste Asiático passou a fabricar. Quer dizer, tem assegurado que suas flutuações continuem a exercer um impacto depressor sobre os preços periféricos. A economia norteamericana, por suas variações decrescentes de acumulação produtiva, deveria estar ajeitando-se a níveis menores de consumo e investimento, como forma de adequá-los a uma situação menos propícia do que no passado; deveria assim, em termos do que pode e do que não pode, estar já dando lugar a uma posição mais parecida com a da Grã-Bretanha na economia mundial: tendencialmente decrescente. Daria lugar, ao mesmo tempo, a crescimentos econômicos de base nacional, que pudessem garantir a subsistência e a reprodução material básica dos países 
periféricos que hoje exportam capital para sustentar os Estados Unidos. O papel do dólar, em última instância de seu poderio militar, permitem assim contornar e adiar o outono.

$\mathrm{O}$ aumento líquido do endividamento externo implica que a diferença entre empréstimos aos Estados Unidos e as importações que os Estados Unidos fazem do exterior é, justamente, igual ao componente da importação de capital que permite aos Estados Unidos manterem uma taxa de consumo e investimento maiores do que a de sua poupança. Significa, em suma, que as nações mais pobres continuam enriquecendo a mais opulenta sociedade da economia mundial. Isto justificaria a substituição das elites periféricas por governos de tipo nacional (Irã, Coreia do Norte, Cuba etc.). Invertendo Pangloss, pode-se dizer que não poderia haver uma situação pior, do ponto de vista dos interesses dos habitantes pobres da maior parte do Terceiro Mundo: seus excedentes continuam sendo canalizados por vias que mantêm a estrutura da dependência intacta.

Os acontecimentos de meados da década de (19)70 não foram decisivos somente porque exacerbaram a tendência para a queda relativa da taxa de lucros no setor industrial. Nas condições do fim do Acordo de Bretton Woods decretado pelas autoridades norte-americanas, instituíram o dólar como a principal divisa de reserva internacional, pondo de lado o ouro e diminuindo ainda mais o papel da libra e do iene. Canalizou-se então em direção a esta moeda, e a todos os ativos nela denominados, o cômputo principal das reservas em moeda externa que não apenas o mundo industrial, mas também as economias subdesenvolvidas, acumularam desde então. Como conseqüência, a economia norte-americana reforçou a condição de importadora líquida de mercadorias e capitais. Estes vindos justamente dos países que passaram a financiar os Estados Unidos. De economia credora, os Estados Unidos passaram então a economia devedora. Situação esta que moldou as relações financeiras e de comércio internacional dentro de uma estrutura na qual os Estados Unidos se mantiveram na ponta do consumo nesta grande cadeia de comércio e dinheiro. A expressão disto foi o correlato aumento líquido das taxas de endividamento externo líquido em proporção do produto.

Portanto, na hipótese da ausência da supremacia do dólar na economia mundial mecanismo último pelo qual a estratégia do crescimento com endividamento é possível - as perspectivas para o crescimento da economia norte-americana seriam ainda mais pessimistas do que efetivamente se apresentaram e se apresentam. Por outro lado, o endividamento externo da economia, na medida em que representa um "desafogo parcial" às condições de consumo e investimento, não logrou levar a um aumento relativo das taxas de acumulação produtiva sobre o produto, o que expressou: (a) a força com que as influências desacumulativas operaram sobre o setor industrial mais especificamente; e (b) a tendência para que a parcela de consumo tenha crescido sem cessar sobre o produto, ao longo do período assinalado. Isto é, o endividamento externo da economia, apesar de facilitar o desempenho dos agregados no curto prazo, não pôde, por si mesmo, conduzir a economia a uma elevação das taxas de acumulação produtiva sobre o produto. 
É claro que a economia poderia, em termos teóricos, ter operado a níveis mais baixos de consumo e investimento, de modo a aproximar-se de uma situação mais próxima do que na teoria marxista se chamaria de "reprodução simples". Isto teria trazido conseqüências menos impactantes para o produto e para a comunidade como um todo nos momentos em que as bases de tal crescimento se deu se vissem erodidas. De fato, adequar a economia à taxa de poupança efetivamente existente teria significado um menor crescimento, e a necessidade de enfrentar todas as conseqüências daí vindas - basicamente, uma diminuição do nível de vida médio. Provavelmente o mercado de capitais não teria se desenvolvido de modo tão rápido como o fez nos últimos anos. Igualmente se daria com todas as outras características de mercado marcantes que são fruto da presença de uma enorme disponibilidade de capitais prontos para serem aplicados a baixas taxas de juro. A economia teria então funcionado em outro patamar.

Porém, uma melhor distribuição do excedente na economia mundial - isto é, menor endividamento da economia norte-americana - teria uma série de outras conseqüências. Positivas, no caso. Em primeiro lugar, teria posto menor pressão sobre o sistema monetário internacional como um todo, no sentido de permitir diversificar mais as opções de acumulação de divisas na periferia. Isso evitaria que as agudas e recorrentes crises cambiais da periferia no período aqui analisado tivessem sempre a conseqüência de uma fuga de capitais para o dólar, realimentando sempre a dessimetria assinalada a favor dos Estados Unidos.

Um outro ordenamento do sistema monetário internacional, com um menor poder do dólar e menor endividamento externo norte-americano, teria também diminuído a relação de dependência que a economia internacional adquiriu das importações dos Estados Unidos. Teria havido mudanças na organização da Divisão Internacional do Trabalho, no sentido de diminuir o grau de importância dos mercados externos nas economias periféricas, com conseqüente readequação de suas estruturas produtivas em função do mercado interno, com impactos positivos do ponto de vista da diversificação da produção e de menor especialização espúria em função dos interesses de consumo do mercado norte-americano. Por fim, uma outra organização do sistema financeiro e monetário internacional teria liberado mais recursos para um maior crescimento propriamente dito das economias periféricas, com conseqüente maior homogeneização do padrão de vida na economia mundial, em benefício do Terceiro Mundo. Por isso aqui se discorda de Franklin Serrano, em $O$ mito do colapso do poder americano, quando insiste que o aumento das importações dos Estados Unidos cancelam as vantagens da dívida. Revela-se aí uma incapacidade de ir além do mero argumento da aparência e repetir que não há crise alguma. Existe uma dificuldade em compreender como há uma crise e uma política de hegemonia pelo dólar ao mesmo tempo, sendo esta um resultado necessário da existência daquela. A posição de Jan Tinbergen parece ser mais razoável:

"[Uma] importante inconsistência nas metas individuais é a falta de preocupação pelo bem estar de outras pessoas, aliás, uma característica da atual civilização, que pode ser parcialmente debitada às doutrinas do liberalismo da Escola 
de Manchester, segundo as quais, para o bem de todos, é suficiente que cada um cuide apenas de seus próprios interesses. Isto vem associado à crença, ou doutrina, de que não há limites para a ganância do homem, de maneira que continua sendo compensador seguir acumulando riqueza pessoal, mesmo quando já foi atingido um nível bastante alto. Na realidade, o aumento da satisfação proveniente das quantidades adicionais de bens, quando ultrapassado certo limite, decresce rapidamente. Entre as conseqüências, destaca-se o conhecido fenômeno da supersaturação observável entre indivíduos ricos, ou até mesmo populações, e caracterizado por um enorme desperdício de recursos, bem como a criação de novas necessidades. A norma de que cada país deve utilizar seus próprios recursos apenas para seu próprio bem-estar é outra manifestação deste estado de espírito que barra o caminho a importantes métodos possíveis de aperfeiçoamento da estabilidade social do mundo.” 257

Neste caso, dá-se uma situação pior do que a descrita por Tinbergen, pois a já mais rica nação do mundo utiliza cada vez mais recursos inclusive das nações mais pobres para manter sua reprodução social.

É claro, todavia, que nas condições realmente existentes hodiernas de derrota das perspectivas "alternativas" às políticas comandadas apenas pelas autoridades norte-americanas e pelos bancos e oligopólios mais poderosos, não se podia esperar que as "regras do jogo" capitalista tenham sido o que elas não podiam ser. No entanto, pode servir de consolo aos que anseiam por mudanças que o fato de que as bases em que se assenta o padrão "dólar-dólar" levarão, cedo ou tarde, à necessidade de uma readequação do sistema como um todo, mudança esta que será feita provavelmente sob o calor de uma crise e não de uma discussão mais ou menos democrática sobre a irracionalidade dos atuais destinos da poupança internacional. Haverá um momento no qual os níveis de endividamento externo da economia norte-americana não poderão mais crescer, assim como o tipo de crescimento baseado nela. Com um aumento da dívida cada vez maior face a um crescimento cada vez menor, mesmo um mercado internacional sempre disposto a deter mais e mais dólares começará a indagar-se sobre alguma séria chance de insolvabilidade. Consumir e produzir cada vez mais com capital alheio enquanto a taxa de crescimento do produto estaciona na marca abaixo de $2 \%$ não poderá ser assim uma estratégia eterna. Lembremos que a libra não há muito já foi a principal divisa de reserva internacional; na sucessão de solavancos e mudanças rápidas pelas quais passa a economia mundial, porque crer que seria diferente com o dólar?

É ocioso especular sobre quando e qual estopim poria a crise na ordem do dia. Basta notar que as perdas acumuladas para os estrangeiros nos Estados Unidos durante a atual crise (2008-2009) constituem fortes elementos desincentivadores à continuidade da compra de títulos norte-americanos, podendo mesmo ser um indício de mudanças estruturais. De qualquer modo, não se podem ignorar as dificuldades de obter cada vez mais crescimento numa economia que já

${ }^{257}$ Política Econômica: princípios e planejamento, p.134. 
apresentou um crescimento enorme ao longo dos últimos duzentos anos. Para além das derivações que a escola marxista sugere, o pensamento econômico sempre chamou atenção para a dialética entre expansão e declínio. Apenas um rechaço radical com a "tradição" pode ignorar completamente as causas estruturais que conduzem ao "outono" da maior economia do mundo.

O caso é que, justamente, este rechaço é bastante marcante para a maior parte dos analistas de economia naquele país, não à toa predominando sempre ali o otimismo mais panglossiano. Tal miopia não conduz a resultados alvissareiros sobre a percepção das verdadeiras causas estruturais que explicam a recessão atualmente em curso, que se avizinha a maior depois da própria crise dos anos (19)30. Porém, não faz muito tempo da quebra da convertibilidade do dólar em ouro, ou seja, de uma situação onde vigorou o peso da força militar dos Estados Unidos em suas relações com o mundo. Poder-se-ia seriamente duvidar de uma crise do dólar e de um calote norte-americano face aos mais fracos, com preservação talvez de gigantes como a China ou Alemanha? Neste caso, a maior parte dos recursos entregues aos Estados Unidos teria sido simplesmente servido aos propósitos norte-americanos, sem que nem ao menos parte dela retornasse aos emprestadores sob a forma de importações. Em suma: predomina hoje uma visão idílica das relações internacionais, visão sem base quando se estuda o que de fato é a história do mundo, sob o predomínio dos Estados Unidos.

Mas - para valer-se pela última vez de uma linguagem estritamente econômica - a discrepância entre as taxas de crescimento cada vez menores da enorme e rica economia norteamericana face ao dinamismo da economia com amplos espaços abertos do Oriente colocará em evidência o contra-senso da hegemonia da moeda internacional de quem entrou no que Steindl chamava de "maturidade". A economia norte-americana terá então que passar a dividir a direção das principais decisões relevantes no mundo com outras nações, incluindo-se aí naturalmente as decisões concernentes à organização do padrão monetário internacional.

Uma vez posto em xeque o papel do dólar, estará posta em xeque também a estratégia de crescimento com base na dívida. Os níveis de crescimento diminuirão ainda mais, e a dependência do comércio com os Estados Unidos diminuirá. A tendência será então que o poderio norte-americano seja aos poucos ofuscado pela ascensão das nações que estão realizando hoje suas radicais políticas industrialização, mormente a China. É somente triste notar como um rearranjo socialista das economias industriais e assim do sistema monetário internacional poderia ter conduzido muito antes, e de modo muito mais planejado e frutífero, esta "horizontalização" e "homogeneização" das relações internacionais que está provocando um tipo de crescimento especificamente capitalista no Oriente. Com isto, mais contradições fundamentais - agora inclusive permeadas pelos problemas ambientais - se avizinham. 


\section{Apêndice: sobre as fontes}

Um comentário particular deve ser feito sobre duas bases cruciais de dados para este estudo. Como visto ao longo deste estudo, as duas principais fontes de documentos oficiais e empíricas utilizadas foram (1) os dados fornecidos pelo Bureau of Economic Analysis, órgão oficial responsável pelas Contas Nacionais, e (2) os dados de praticamente todos os números do Economic Report of the President entre 1979 e 2009, com utilização eventual de números anteriores, principalmente para o capítulo sobre a crise do Acordo de Bretton Woods. Há uma série de outros canais de obtenção de séries, como se vê na parte referente à bibliografia, mas estas duas fontes merecem um comentário à parte, devido à sua centralidade para o estudo da economia norte-americana.

Para uma orientação do leitor, e sua própria verificação de tais dados, dever-se-á consultar os dois seguintes endereços eletrônicos: www.bea.gov e http://fraser.stlouisfed.org/ . O primeiro é o endereço oficial do órgão norte-americano; o segundo é o da filial da Reserva Federal em St. Louis. Veja-se primeiro a orientação para a obtenção dos dados utilizados a partir do fornecimento do BEA.

Logo que acessado o endereço (1), o leitor deveria acessar o link "View all National Accounts Information", que está na parte inicial do endereço. Na próxima página que surge (2), deverá procurar o link "Interactive Tabelas: National Income and Product Accounts Tabelas". Em seguida (3), deve acessar o link "Choose a Tabela from a list of All NIPA Tabelas". (NIPA é a sigla de National Income and Product Accounts Tabelas.) A página aberta conterá todas as tabelas utilizadas neste estudo, divididas em oito seções. Há também uma opção para que se possa fazer o download delas. O leitor poderá, caso opte por consultar os dados sem os copiar para sua máquina, manipular as séries de diferentes maneiras na própria rede, com as opções que este rico endereço dá.

O segundo canal crucial para o estudo da história econômica recente norte-americana é o endereço da seção do Fed de St.Louis, chamado FRASER, Federal Resrrve Archival System for Economic Research, que traz uma massa infinita de documentos oficiais, praticamente desde os anos (19)30. Cada documento oficial, seja ele do Departamento de Comércio, de filiais da Reserva Federal, ou da Casa Branca, traz por sua vez enormes quantidades de séries. Há inclusive anuários estatísticos com dados para o século XIX e para história colonial. Sem uma boa base teórica, o estudioso certamente vai se afogar na quantidade de informações existentes, não sabendo quais usar e quais não.

Os Economic Report of the President trazem a opinião detalhada do presidente e de sua equipe econômica sobre cada aspecto da economia norte-americana. Ele deve ser acessado do seguinte modo: acessado o endereço, deve-se acessar a opção Publications. Ali, escolher-se o Economic Report. Aparecerão as opções sobre o respectivo ano. Cada edição dele refere-se ao ano anterior de seu ano: por exemplo, o Economic Report de 1996 refere-se ao ano de 1995, o de 2000 ao de 1999 etc.. Geralmente a introdução é escrita pelo punho do próprio presidente, e 
os capítulos pelos economistas da equipe econômica e seus encarregados diretos. São documentos anuais extensos, de quatrocentas páginas em média, e que trazem apêndices estatísticos em seu anexo. A utilização deste anexo ou dos dados do BEA é na verdade uma questão de opção ou conveniência e não envolve, naturalmente, auto-exclusão de um ou outro, porque o responsável direto pelo processamento dos dados do Economic Report é o BEA. O apêndice do Economic Report pode ser impresso com mais facilidade, o que facilita o manuseio. Quanto à análise da política econômica, o Economic Report é de fato indispensável, pois ele traz a opinião dos economistas do governo, que visam embasar teoricamente, e com uma extensa base empírica, as visões e opções políticas de cada administração. Geralmente, os relatórios republicanos são mais desonestos e laudatórios que os democratas, tendo aqueles sempre a marca da reação anti-keynesiana da Escola de Chicago, e estes (democratas) um tom "neokeynesiano", porém amplamente abastecido de argumentos liberais ad hoc aqui e ali. Buscou-se traduzir os trechos utilizados e colocar, nas notas de rodapé, os correspondentes trechos no original em inglês.

Este endereço do Fed, o FRASER, também forneceu as declarações e balanços dos sucessivos presidentes do Fed, de modo que tais documentos são bastante valiosos para uma pesquisa sobre a conjuntura. Balanços e avaliações mensais podem ser obtidos pela leitura que os presidentes do Fed faziam a partir das reuniões com os outros economistas e com uma extensa análise dos dados publicados, dentre outros, pelo próprio Fed. Estas declarações devem ser buscadas no link "Federal Reserve History", na página inicial do endereço. Vai abrir-se uma longa página com uma sucessão de números referentes a anos. Há documentos do Federal Open Market Committee e na seqüência documentos referentes aos presidentes do Fed, a partir de William McChesney Martin, em 1929.

Evidentemente, há uma série de outras estratégias de pesquisa e de fontes, de modo que o autor, ao optar por alguma, vai automaticamente excluir outras, pela impossibilidade objetiva de analisar todos os dados que o eficiente aparato estatístico do país produz. O endereço do Bureau of Labor Statistics (www.bls.gov) e do Fed (www.federalreserve.gov e http://www.fedstats.gov) foram também consultados, e dados por eles fornecidos aparecem eventualmente.

Por fim: devo agradecer os funcionários do Fed de St. Louis e do BEA, por prontamente terem respondido todas as dúvidas que encaminhei por correio eletrônico. E, também, por enviarem-me, gratuitamente e direto de Nova York, alguns relatórios impressos do Fed que requisitei por correio a troco de comodidade, porque todos eles estavam de fato disponíveis em formato PDF. Os relatórios foram entregues gratuitamente em minha casa pelo Fedex em uma semana. 


\section{Fontes e Bibliografia}

Fontes

(a) Periódicos

Cambridge Journal of Economics

Business Week

Financial Times

Monthly Review

New Left Review

New Political Economy

Science and Society

The Nova York Times

The Wall Street Journal

The Economist

(b) Séries Numéricas

Governo norte-americano

BEA - Bureau of Economic Analysis: http://bea.gov

BLS - Bureau of Labor Statistics: http://bls.gov

Bureau of the Census: http://censu.gov

Energy Information Administration (EIA): http://www.eia.doe.gov

Fed - http://www.federalreserve.gov e http://www.fedstats.gov

FRASER - Federal Reserve Archival System for Economic Research:

http://fraser.stlouisfed.org/

U.S. Department of Treasure: http://www.ustreas.gov

Federal Reserve of Nova York - http://www.ny.frb.org

Instituições multilaterais

BID - Banco Interamericano de Desenvolvimento: http://iadb.org

BIRD - Banco Mundial: http://worldbank.org

BUNDESBANK - Banco Central da Alemanha: http://bundesbank.de

COMISSÃO ECONÔMICA PARA A AMÉRICA LATINA (CEPAL):

http://websie.eclac.cl/anuario estadistico/anuario 2006/esp/index.asp

FMI - Fundo Monetário Internacional: http://www.imf.org

GATT - General Agreements of Trade and Tariffs: http://gatt.org

MUNK CENTRE FOR INTERNATIONAL STUDIES - Universidade de Toronto (Canadá):

http://www.g8.utoronto.ca

OCDE - Organização para Cooperação e Desenvolvimento Econômico: http://stats.oecd.org 
OMC - Organização Mundial do Comércio: http://wto.org

ONU - Organização das Nações Unidas: http://un.org

SICE - Foreign Trade Information System: http://www.sice.oas.org

UNCTAD - United Nations Conference on Trade and Development: www.unctad.org

(c) Documentos oficiais do governo dos Estados Unidos

Casa Branca: http://www.whitehouse.gov/cea/pubs.html

GPO Acess - Service of the U.S. Government Printing Office: http://www.gpoaccess.gov

Federal Reserve: http://www.federalreserve.gov

Departamento do Estado dos EUA http://state.gov

Federal Reserve Archival System for Economic Research (FRASER):

http://fraser.stlouisfed.org/publications/ERP/.

Census Bureau. Annual Survey of Manufactures. Disponível em:

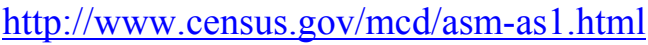

Bibliografia - Livros e Artigos

AGLIETTA, Michel. Macroeconomia financeira. Crises financeiras e regulação monetária. São Paulo: Edições Loyola, 2004.

ALIBER, Robert Z. O jogo monetário internacional. Rio de Janeiro: Editora Jorge Zahar. 1976. AMIN, Samir. Unequal development: an essay on the social formations of peripheral capitalism. Hassocks: Harvester. 1976.

ARRIGHI, Giovani. The geometry of imperialism. Londres: NLB. 1978. . O longo século XX. São Paulo: Contraponto/ Unesp. 2006. . A ilusão do desenvolvimento. Petrópolis: Vozes. 1997. e SILVER, Beverly. Caos e governabilidade no moderno sistema mundial. Rio de Janeiro: Editora Contraponto/UFRJ. 1999.

. The Social and Political Economy of Global Turbulence. In: New Left Review. N.20. Março/Nova de 2003. . Adam Smith em Pequim. São Paulo: Editora Boitempo. 2008.

ARMSTRONG, Philip, GLYN, Andrew e HARRISON, John. Capitalism since 1945. London: Basil Blackwell, Inc. 1991.

BAIROCH, P. The economic development of the Third World since 1900. Berkeley: University of California Press. 1977.

BANDEIRA, Luiz Alberto Moniz. Formação do Império Americano - da Guerra contra a Espanha à Guerra no Iraque. Rio de Janeiro: Editora Civilização Brasileira. 2006.

BARAN, Paul. A economia política do desenvolvimento. São Paulo: Abril Cultural. 1983.

BARAN, Paul e SWEEZY, Paul. El capital monopolista. Buenos Aires: Siglo Veintuno, 1972. 
BARBOSA, Wilson do Nascimento. Uma teoria marxista dos ciclos econômicos. In Marx e Engels na História. São Paulo: Humanitas. 1996. 496 p.

A crise econômico-financeira e o recurso a uma política anti-cíclica.

Universidade de São Paulo. 1986. (Disponível em http://nepheusp.googlepages.com )

. Dominação Imperialista e Globalização da Miséria. São Paulo: Universidade de

São Paulo. (Disponível em http://nepheusp.googlepages.com )

. Globalização: uma péssima parceria. Revista SEADE, 1998.

Econometria. Volumes I, II, III e IV. São Paulo: Universidade de São Paulo.

. Crisálida: aspectos histórico-econômicos do fim da escravidão no Brasil 1850-

1888; introdução a uma análise quantitativa. Tese de livre-docência. Universidade de São

Paulo. 1994.

. Políticas Econômicas do Governo e Estagnação: duas décadas perdidas (1981-

2000). FFLCH-USP. 2004. 252 p.

. O problema da metodologia na pesquisa social. São Paulo: Universidade de São

Paulo. (Fotocopiado) (Disponível em http:/nepheusp.googlepages.com)

. Growth and government economic policies in Brazil. A study on Aggregate

Income Developments (1940-1980). Tese de doutoramento. Universidade de Lund. Lund, Suécia. 1984.

BATRA, Ravi. Greenspan, a fraude. Ribeirão Preto: Editora Novo Conceito, 2006.

. 1990, a grande depressão. São Paulo: Livraria Cultura Editora. 1988.

BELLUZZO, Luiz Gonzaga de Mello. Ensaios sobre o capitalismo no século XX. Campinas: Editora da UNICAMP, 2004.

BEINSTEIN, Jorge. Capitalismo senil. Rio de Janeiro. Ed. Record. 2001.

BERNSTEIN, Michael e ADLER, David. Understanding American Economic Decline. Nova York: Cambridge University Press. 1994.

BETHELL, Leslie. História da América Latina. A América após 1930. São Paulo: Editora Edusp. 2005.

BLAUG, Mark. Teoría Económica en Retrospección. Cidade do México: Fundo de Cultura Econômica. 2001. . Metodologia da Economia. São Paulo: Editora Edusp. 2001.

BLOCK, Fred L. Los Orígenes del desorden económico internacional. Cidade do México: Fondo de Cultura Econômica, 1989.

BOTTOMORE, Tom. Dicionário do Pensamento Marxista. Rio de Janeiro: Jorge Zahar. 1999. e OUTHWAITE, William. Dicionário do Pensamento Social do século XX. Rio de Janeiro: Jorge Zahar. 1996.

BRENNER, Robert. O boom e a bolha - Os Estados Unidos na economia mundial. Rio de Janeiro: Record, 2003.

. The Economics of Global Turbulence. A special report on the world economy, 1950-98. Londres: New Left Review, 1998. 
BUKHARIN, Nikolai I. Economia mundial e imperialismo. São Paulo: Nova Cultural. 1983.

CARSON, Robert B. Economy Issues Today, alternative approaches. Nova York: St. Martin's Press. 1983.

CASTELLS, Manuel. The Economic Crisis and the American Society. Oxford: Basil Blacwell, Publisher. 1980.

CHESNAIS, François. A finança mundializada. São Paulo: Editora Boitempo. 2005. . A mundialização do capital. São Paulo: Xamã. 1996.

CLARK, David. Post-industrial America. A geographical perspective. Nova York: Methuen. 1985.

CLINTON, Bill. Minha vida. São Paulo: Editora Globo. 2004.

COHEN, Benjamin J. American Foreign Economic Policy. Nova York: Harper \& Row. 1968.

DENT Jr., Harry S.. The Great Depression Ahead. Free Press: Nova York. 2009.

DOBBS, Michael. Down with Big Brother. The fall of soviet empire. Nova York: Vintage Books. 1998.

DUNCAN, Richard. The Dollar Crisis. Singapura: John Wiley\&Sons (Asia). 2003.

EATWELL, John, TAYLOR, John. Finanzas Globales em Riesgo - un análisis a favor de la regulación internacional. Buenos Aires: Siglo Veitiuno Editores. 2005.

EINCHENGREEN, Barry. A globalização do capital. São Paulo: Editora 34. 2002.

ELLMAN, Michael. Planejamento Socialista. Rio de Janeiro: Editora Jorge Zahar. 1979. e KONTOROVICH, Vladimir (ed.). The Disintegration of the Soviet Economic

System. Londres: Routledge. 1993.

EMMANUEL, Arghiri. Unequal exchange: a study of the imperialism of trade. Nova York: Monthly Review Press. 1972

ENGELS, Friedich. Anti-Dühring. 5 ed. Rio de Janeiro: Editora Paz e Terra. 2000. . A dialética da natureza. 6 ed. Rio de Janeiro: Editora Paz e Terra. 2000.

FEIWEL, George R. Michal Kalecki: contribuciones a la teoría de la política económica. Cidade do México: Fundo de Cultura Econômica. 1987.

FERRER, Aldo. Economia internacional contemporanea. Texto para latinoamericanos. Cidad del México. 1983.

FIORI, Giuseppe. A vida de Antonio Gramsci. Rio de Janeiro: Editora Paz e Terra. 1979.

FIORI, José Luis TAVARES e Maria da Conceição (orgs). Poder e Dinheiro. Uma economia política da globalização. Petrópolis: Editora Vozes, 1998.

FIORI, José Luis (org). O poder americano. Petrópolis: Editora Vozes, 1998.

. Estados e Moedas no Desenvolvimento das Nações. Petrópolis: Editora Vozes, 2001. . 60 lições dos 90. Rio de Janeiro: Editora Record. 2002. . O poder global e a nova geopolítica das nações. São Paulo: Editora Boitempo. 2006. 
, MEDEIROS, Carlos, e SERRANO, Franklin. O Mito do colapso do poder americano. Rio de Janeiro: Editora Record. 2008.

FMI. Balance of Payments Manual. Quinta Edição. 1993.

FRENCH, Michael. Us Economic History Since 1945. Manchester University Press. 1998.

FRIEDEN, Jeffry e LAKE, David. International political economy. Perspectives on global power and wealth. Londres: Routledge. 1995.

FUNDO MONETÁRIO INTERNACIONAL. World Economic Outlook, Crisis and Recovery. Washington D.C. Abril de 2009.

FURTADO, Celso. A hegemonia dos Estados Unidos e o subdesenvolvimento da América Latina. Rio de Janeiro: Editora Civilização Brasileira, 1975.

. Transformação e crise na economia mundial. Rio de Janeiro: Editora Paz e Terra.

2006.

. A economia latino-americana.. São Paulo: Companhia das Letras. 2007.

. Introdução ao Desenvolvimento. Enfoque histórico-estrutural. Rio de Janeiro:

Editora Paz e Terra. 2000.

. Teoria e Política do Desenvolvimento Econômico. São Paulo: Editora Abril

Cultural. 1983.

GALBRAITH, John Kenneth. A Economia das Fraudes Inocentes. São Paulo: Companhia das Letras, 2004.

. O Novo Estado Industrial. São Paulo: Editora Nova Cultural. 1981.

GLASSMAN, James K. e HASSETT, Kevin. Dow 36.000. Nova York: Times Books. 1999.

GOMES, José Menezes. Acumulação de capital e plano de estabilização. Um estudo a partir da experiência de âncora cambial na América Latina nos anos 90. Universidade de São Paulo, Faculdade de Filosofia, Letras e Ciências Humanas. Tese de doutorado. 2004.

GORBACHEV, Mikhail. O golpe de Agosto - a verdade e as lições. São Paulo: Editora Best Seller. 1991.

. Perestroika. Nuevas ideas para nuestro país y el mundo. Buenos Aires: Ediciones

Emecé. 1987.

GOWAN, Peter. A roleta global. Rio de Janeiro: Editora Record. 2003.

GRAM, Harvey e WALSH, Vivian. Joan Robinson's Economics in Retrospect. In: Journal of Economic Literature. V.XXI. June. 1983.

GRAMSCI, Antonio. Note sul Machiavelli, sulla politica e sullo Stato moderno. Torino: Editori Riuniti. 1975.

Cadernos do Cárcere. (vários volumes). Rio de Janeiro: Editora Civilização Brasileira. 2001.

GRESPAN, Jorge. O negativo do capital. São Paulo: Editora Hucitec. 1999.

GREENSPAN, Alan. The Age of Turbulence - Adventures in a New World. Londres: Penguin Books. 2007.

HARRIS, C. Lowell. The American Economy. Illinois: Richard Irwin. 1956. 
HARRIS, Seymour E.. The Dollar in Crisis. Harcourt, Brace \& World, Inc.: Nova York. 1961.

HICKS, John. A crise na economia keynesiana. São Paulo: Vértice Editora. 1987.

IS-LM: an explanation. In: Journal of Post Keynesianism. Winter. 1980-81. V.III. V.2.

. Mr. Keynes and the Classics. In: Econometrica. V.5. N.2. Abril 1973.

HILFERDING, Rudolf. O capital financeiro. São Paulo: Nova Cultural. 1983.

HILL, Carter, GRIFFITHS, William, e JUDGE, George. Econometria. São Paulo: Editora Saraiva. 2000.

HIRST, Paul. Globalização em questão: a economia internacional e as possibilidades de governabilidade. 3 ed. Petrópolis: Vozes. 2001. 364 p.

HOBSBAWM, Eric. A Era dos Extremos. O breve século XX. 1914-1991. 2 ed. São Paulo: Companhia das Letras. 2000. 598 p.

HOBSON, John Atkinson. Estudio del imperialismo. Madrid: Alianza. 1981.

HUTCHINSON, William K. American economic history: A guide to information sources (Economics information guide series). Nova York: Gale Research Co (1980).

KALECKI, Michal. Ensayos escogidos sobre dinamica de la economia capitalista, 1933-1970. Cidade do México: Fondo de Cultura Econômica, 1984. . Economia socialista e mixta. Madrid: Fondo de Cultura Econômica, 1986. . Teoria de la dinamica capitalista. Ensayo sobre los movimientos cíclicos y a largo prazo da la economia capitalista. Cidade do México: Fondo de Cultura Econômica, 1985. . Crescimento e Ciclo das economias capitalistas. 2 ed. São Paulo: Editora Hucitec. 1983. Economia - Coleção Cientistas Sociais. (Org. Jorge Miglioli.) São Paulo: Editora Ática. 1980.

KAUTSKY, Karl. Imperialism and the war. In: Internacional Socialist Review. Novembro de 1914. . Preparations for Peace. In: Justice. Outubro de 1914, p.2. . Ultra-imperialism. In: Die Neue Zeit. Setembro de 1914.

KENNEDY, Paul. Preparing for the twenty-first century. Nova York: Random House. 1993.

KENNEDY, Peter. Introducción a la econometría. Cidade do México: Fundo de Cultura Econômica. 1997.

KEYNES, John Maynard. A Teoria Geral do Emprego, do Juro e da Moeda. São Paulo: Editora Nova Cultural. 1996. 384 p.

KYNGE, James. A China sacode o mundo. São Paulo: Editora Globo. 2007.

KLEIN, L.R., e GOLDEMBERG, L.S. An econometric model of the United States, 1929-1952. Amsterdã: North-Holland Publishing Company. 1955.

KRUGMAN, Paul. A desintegração americana. Os Estados Unidos perdem o rumo no século XXI. Rio de Janeiro: Editora Record. 2006.

. Pop internationalism. Cambridge: The Mit Press. 1996 
KUZNETS, Simon. Crescimento Econômico Moderno. Ritmo, estrutura e difusão. São Paulo: Editora Nova Cultural. 1986.

LANGE, OSKAR. Ensaios sobre planificação econômica. Coleção Os economistas. São Paulo: Editora Nova Cultural. 1988. . Economia - Coleção Cientistas Sociais. (Org. Lenina Pomeranz.) São Paulo: Editora Ática. 1981.

LACOSTE, Yves. Géographie du sous-développement. Paris: Presses universitaires de France. 1965.

LENIN, Vladimir I. Obras escolhidas. São Paulo: Editora Alfa-Ômega. 1986.

LEWIS, J. Parry Lewis. An introduction to Mathematics. London: MacMillan\&Co.Ltd. 1959.

LUKACS, John. Uma nova república. História dos Estados Unidos no século XX. Rio de Janeiro: Jorge Zahar Editora. 2006.

LUXEMBURGO, Rosa. A acumulação de capital. São Paulo: Nova Cultural. 1983.

MACCIOCCHI, Maria Antonieta. Maria-Antonieta. A favor de Gramsci. Rio de Janeiro: Editora Paz e Terra. 1980.

MANDEL, Ernest. O capitalismo tardio. São Paulo: Nova Cultural. 1983.

MANDEL, Michael. Depressão.com. Rio de Janeiro: Editora Record. 2001.

MAGDOFF, H. Era do imperialismo: a economia da política externa dos Estados Unidos. São Paulo: Hucitec. 1978.

MARX, Karl. Capital. (3 volumes). Moscou: Foreign Languages Publishing House. 1962.

Das Kapital. Dritter Band. Der Gesamtprozeß der Kapitalistischen Produktion. Berlim: Dietz Verlag Berlin. 1964.

MAZOWER, Mark. Continente Sombrio. A Europa no Século XX. São Paulo: Cia. das Letras. 2001.

MILL, John Stuart. Principles of Political Economy, with some of their applications to social philosophy. Toronto: University of Toronto Press. 1965.

MILLS, Wright. The Power Elite. Nova York: Oxford University Press. 1956.

White collar: the American middle classes.Nova York: Oxford University Press, 1953.

MITCHELL, Wesley C.. O ciclo econômico e suas causas. São Paulo: Abril Cultural. 1984.

MORISON, Samuel Eliot, LEUCHTENBURG, William E. e COMMANGER, Henry Seteele. Breve historia de los Estados Unidos. Cidade do México: Fondo de Cultura Econômica. 2003.

NAU, Henry. O Mito da Decadência dos Estados Unidos. A liderança americana na economia mundial na década de 1990. Rio de Janeiro: Editora Jorge Zahar. 1992.

NORTH, Douglas. Growth \& welfare in the American past: a new economic history. New Jersey: Prentice-Hall. 1974.

NUNES, João Marcus Marinho. O vôo da águia. A economia americana no fim do milênio. São Paulo: Editora Saraiva. 2002.

NUSSBAUM, Arthur. Uma história do dólar. Rio de Janeiro: Jorge Zahar Editora. 1967. 
O'CONNOR, James. USA: a crise do Estado capitalista. Rio de Janeiro: Editora Paz e Terra. 1977.

ONU - Organização das Nações Unidas. Cuentas Nacionales: una introducción práctica. Nova York: Departamento de Assuntos Econômicos e Sociais. 2006.

PAULANI, Leda, e BRAGA, Márcio Bobik. A nova contabilidade nacional. São Paulo: Editora Saraiva. 2003.

POMERANZ, Lenina et alii (org.). Dinâmica econômica do capitalismo contemporâneo Homenagem a M. Kalecki. São Paulo: Edusp, 1999.

RATNER, Sidney, SOLTOW, James, SYLLA, Richard. The Evolution of American Economy. Nova York: McMillan Publishing Company. 1993.

RICARDO, David. Princípios de Economia Política e Tributação. São Paulo: Abril Cultural. 1983.

ROBERTS, Richard. Por dentro das finanças internacionais. Rio de Janeiro: Jorge Zahar, 2000. ROBERTSON, William S. América Contemporânea. In: História das Américas. (V.XII.) Org. Pedro Calmon. Rio de Janeiro: Gráfica Editora Brasileira. 1954.

ROSEMBERG, Samuel. American Economic Development Since 1945: Growth, Decline and Rejuvenation. Palgrave Macmillan. 2003.

ROBINSON, Joan. La acumulación de capital. Bogotá: Fundo de Cultura Econômica. 1979. . Economia Marxista. Rio de Janeiro: Editora Fundo de Cultura. 1960. . The second crisis of economic theory. In: American Economic Review, v.62, n.

1/2, Março de 1972 . Ensaios sobre a teoria do crescimento econômico. São Paulo: Abril Cultural. 1983. . The production function and theory of capital. In: Review of Economic Studies. 1954. e EATWELL, John. Introducción a la economía moderna. Cidade do México. 1992.

ROLL, Eric. Historia de las doctrinas económicas. Cidade do México: Fundo de Cultura Econômica. 2003.

ROSDOLSKY, Roman. Gênese e Estrutura de O Capital de Karl Marx. Rio de Janeiro: Editora Contraponto/Ed. UERJ. 2003.

SADER, Emir e JINKINGS, Ivana. Enciclopédia contemporânea da América Latina e do Caribe. São Paulo: Editora Boitempo. 2006.

SANTOS, Milton. Território e sociedade (entrevista com Milton Santos). São Paulo: Editora Perseu Abramo. 2007. . Espaço dividido. São Paulo: Editora Edusp. 2006.

SCHUMPETER, Joseph Alois. Imperialism and social classes. Nova York: A.M.Kelly. 1951. . Teoria do desenvolvimento econômico: uma investigação sobre lucros, capital, credito, juro e o ciclo econômico. São Paulo: Nova Cultural. 1985. 
SCHINCARIOL, Vitor Eduardo. O Brasil sob a crise do fordismo. São Paulo: Editora LCTE. 2007.

. Ensaios sobre a economia dos Estados Unidos. São Paulo: Livraria Ciência e Tecnologia, 2009. v. 600. 160 p.

SEAVOY, Ronald E. An Economic History of the United States: From 1607 to the Present. Nova York: Routledge. 2006.

SECCO, Lincoln. Gramsci e a revolução. São Paulo: Alameda Editorial. 2006.

SHAIKH, Anwar. Valor, acumulación y crisis. Ensayos de economía política. Buenos Aires: Ediciones RYR. 2006.

. Explaining the Global Crisis. New School University. Dezembro de 1999.

Disponível em http://homepage.newschool.edu/ AShaikh/ .

. Explaining the U.S. Trade Deficit. Estados Unidos: The Levy Economics Institute of Bard College. Disponível em: http://homepage.newschool.edu/ AShaikh/

SHAIKH, Anwar M., PAPADIMITRIOU, Dimitri B., DOS SANTOS, Claudio e ZEZZA, Gennaro. How fragile is the U.S. Economy? Estados Unidos: The Levy Economics Institute of Bard College. Disponível em: http://homepage.newschool.edu/ AShaikh/

Is personal debt sustainable? Estados Unidos: The Levy Economics Institute of Bard College. Disponível em: http://homepage.newschool.edu/ AShaikh/

SHILLER, Robert J. Irrational Exuberance. New Jersey: Princeton University Press. 2000.

SMITH, Adam. The Wealth of the Nations. Chicago: William Benton Publisher EncyclopÆdia Britannica, Inc. 1952.

SMITH, David e GEBBIE, Melinda. Reagan para principiantes. Lisboa: Publicações Dom Quixote. 1986.

SOLOMON, Robert. O sistema monetário internacional, 1945-1976. Rio de Janeiro: Editora Jorge Zahar. 1979.

. Dinheiro em Movimento. Rio de Janeiro: Editora Record. 2001.

SRAFFA, Piero. Production of Commodities by means of Commodities. Cambridge: Cambridge University Press. 1960.

STIGLITZ, Joseph E., EDLIN, Aaron S. e De LONG, J. Bradfor. The Economist's Voice - Top economists take on today's problems. Nova York: Columbia University Press. 2008.

Os exuberantes anos 90. São Paulo: Cia. das Letras, 2003.

e BILMES, Linda. The Three Trillion Dollar War. The true cost of the Iraq conflict. Nova York: W.W. Norton\&Company. 2008.

. Globalização: como dar certo. São Paulo: Editora Companhia das Letras. 2008.

STEEDMAN, Ian. Marx after Sraffa. London: NLB. 1977.

STEINDL, Joseph. Maturidade e Estagnação no capitalismo americano. São Paulo: Abril Cultural, 1984.

SWEEZY, Paul. Teoria do desenvolvimento capitalista. São Paulo: Abril Cultural. 1983.

Capitalismo moderno. Rio de Janeiro: Editora Graal. 1977. 
e MAGDOFF, Harry. The End of Prosperity. The American Economy in the 1970s.. Nova York: Monthly Review Press. 1970.

SOUZA, Luis Eduardo Simões de. A arquitetura de uma crise: história e politica econômica na Argentina, 1989-2002. Tese de doutoramento. Universidade de São Paulo - Faculdade de Filosofia, Letras e Ciências Humanas. 2008.

TINBERGEN, Jan. Política Econômica: Princípios e Planejamento. São Paulo: Editora Abril Cultural. 1986.

TRÍAS, Vivian. La Crisis del Dólar y la política norteamericana. La guerra del oro y la diplomacia. Barcelona: Ediciones Península. 1971.

VIANA, Jorge Miguel Pedreira. Estrutura industrial e mercado colonial: Portugal e Brasil (1780-1830). Lisboa: Difel. 1994.

WALLERSTEIN, Immanuel Maurice. Capitalist world-economy. Cambridge: Cambridge University Press. 1979.

Decline of American Power: The U.S. in a Chaotic World. Nova York: New

Press. 2003.

Entering Global Anarchy. In: New Left Review. N.22. Julho/Agosto de 2003.

WOYTINKSY, Emma. Profile of the U.S. Economy. A survey of growth and change. Nova York: Frederick A. Praeger Publishers. 1967.

ZEITLIN, Maurice. American Society, Incl. Chicago: Rand McNally College Publishing Company. 1973. 